\title{
Karla Paresque
}

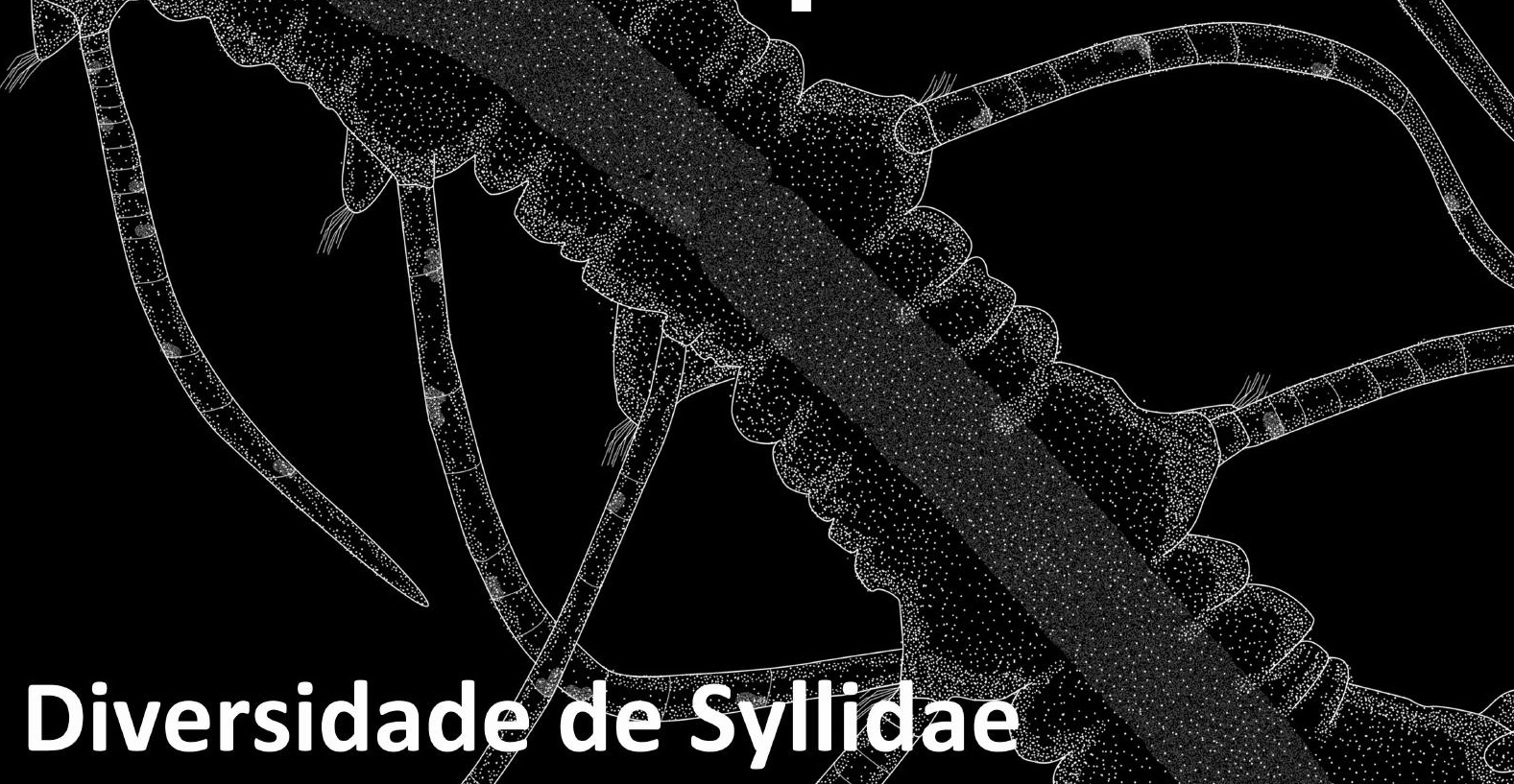

\section{(Polychaeta: Annelida) em substratos consolidados ao longo dos estados da}

Paraíba e Pernambuco, nordeste do Brasil

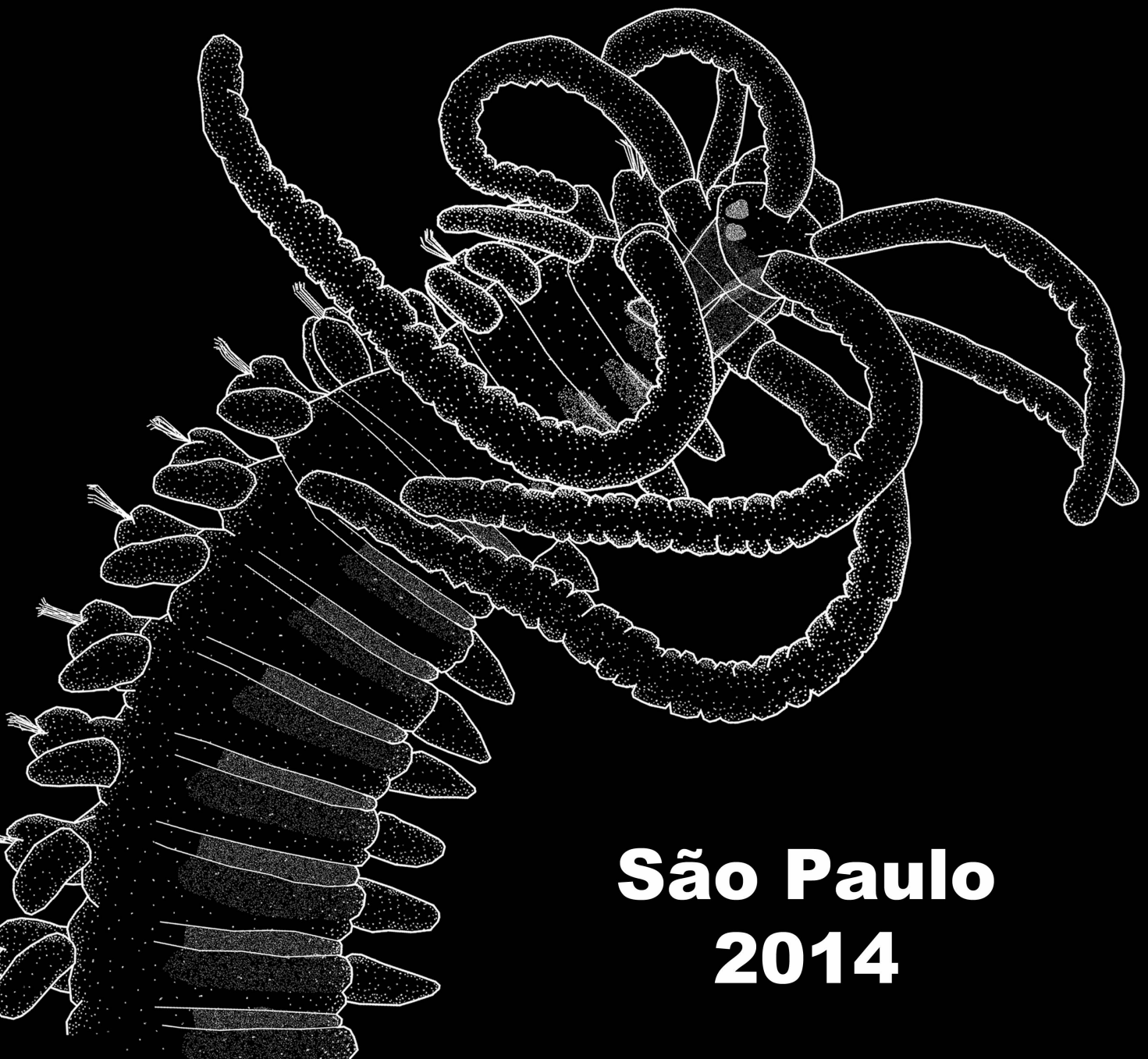


Karla Paresque

Diversidade de Syllidae (Polychaeta: Annelida) em substratos consolidados ao longo dos estados da Paraíba e Pernambuco, nordeste do Brasil

São Paulo

2014 



\section{Karla Paresque}

\section{Diversidade de Syllidae (Polychaeta: Annelida) em substratos consolidados ao longo dos estados da Paraíba e Pernambuco, nordeste do Brasil}

Diversity of Syllidae (Polychaeta: Annelida) on hard substrates off the State of Paraíba and Pernambuco, northeastern Brazil

Tese apresentada ao Instituto de Biociências da Universidade de São Paulo, para a obtenção de Título de Doutor em Ciências, na Área de Zoologia.

Orientador(a): Dr. João Miguel de Matos Nogueira

Co-Orientador: Dr. Marcelo Veronesi Fukuda

São Paulo 

Paresque, Karla

Diversidade de Syllidae (Polychaeta: Annelida) em substratos consolidados ao longo dos estados da Paraíba e Pernambuco, nordeste do Brasil

443 páginas

Tese (Doutorado) - Instituto de Biociências da Universidade de São Paulo. Departamento de Zoologia.

1. Polychaeta 2. Syllidae 3.

Taxonomia 4. Nordeste do Brasil 5.

Biodiversidade. I. Universidade de São

Paulo. Instituto de Biociências.

Departamento de Zoologia.

\section{Comissão Julgadora:}



Esta dissertação não constitui publicação no sentido do artigo 9 do ICZN e portanto quaisquer atos nomenclaturais nela contidos tornam-se sem efeito para princípios de prioridades e de homonímia.

This dissertation should not be considered as a publication in the sense of the article 9 of the ICZN, therefore, any nomenclatural acts herein proposed are considered void for the principles of priority and homonymy. 

Aos grandes amores da minha vida, meus irmãos:

Roberta, Paula e Vitor 

"Learn from yesterday, live for today, hope for tomorrow. The important thing is to not stop questioning."

- Albert Einstein, Relativity: The Special and the General Theory 

Ao Prof. Dr. João Miguel de Matos Nogueira pela orientação e valiosas contribuições para o desenvolvimento deste trabalho. Por confiar no meu potencial, aceitar me orientar e por sempre estar disponível. Por todos os direcionamentos, não só no desenvolvimento desta Tese, mas como um todo no que diz respeito a minha formação taxonômica e científica. Minha gratidão a você é enorme!

Ao Dr. Marcelo Fukuda, por me guiar no mundo dos silídeos desde 2007, quando estive pela primeira vez em contato com a taxonomia do grupo. Por ter feito com que eu entendesse desde o comecinho que nem tudo é exato. Por aceitar me co-orientar, tirar minhas dúvidas nas identificações (e as vezes aumentá-las, sempre me incentivando e promovendo questionamentos que dariam mais meia dúzia de teses), por me acalmar com sua serenidade enquanto minhas "hipóteses" ou meus capítulos me faziam chorar.

Ao Prof. Dr. Guillermo San Martín (Facultad de Ciencias, Universidad Autónoma de Madrid), por todo apoio ao me receber em Madrid, confirmação da maioria das identificações presentes nesta tese, pela amizade e inspiração no trabalho com los pequeños gusanitos.

À FAPESP, pelas bolsas concedidas, de Doutorado (FAPESP proc. 2010/17606-3) e de Pesquisa no Exterior (FAPESP proc. 2011/23211-1); e também por financiar o projeto Biodiversidade de Polychaeta na Zona Entremarés e Infralitoral Raso em Substratos Consolidados no Nordeste do Brasil, Estados da Paraíba e Pernambuco (FAPESP proc. 10/52116-4) no qual se inseriu minha pesquisa.

À CAPES pela Bolsa concedida durante o primeiro mês de doutorado e auxílios concedidos para trabalhos de campo e participação em eventos nacionais e internacionais, através do PROex.

Ao $\mathrm{CNPq}$ por financiar a vinda do Prof. Dr. Guillermo San Martín para o desenvolvimento de projetos em parceria.

À coordenação do Curso de Pós-Graduação em Zoologia do IB/USP, especialmente ao atual coordenador, Prof. Dr. Marcelo Carvalho, por toda a ajuda.

Ao Prof. Dr. Paulo Paiva, Dr. Vasily Radashevsky, Dra. Christine Ruta e Dr. Rômulo Barroso, por serem uns dos primeiros a me incentivarem a estudar os poliquetas taxonomicamente, durante o Curso de Nivelamento sobre Sistemática de Polychaeta em Macaé.

Ao Prof. Paulo Lana, Dra. Rosebel Cunha Nalesso e Dra. Roberta Paresque por sempre me incentivarem e me motivarem cientificamente.

A Javier Sánchez Almazán, do Museo Nacional de Ciencias Naturales, Madrid, e a Stephen Keable, do The Australian Museum, Sydney, por todo apoio logístico durante o período de visita a estas coleções.

Aos técnicos do Depto. de Zoologia Ênio Matos e Phillip Lenktaitis pela preparação e realização das sessões de MEV.

Ao MZUSP, pela utilização do MEV, e à técnica Lara Guimarães, pela operação do equipamento. 
Ao Ênio Matos, por todas as "ideias logísticas", motivação, disposição, preparação de estiletes pra dissecção, ajuda com "as técnicas inovadoras" de preparação de pequenos espécimes. Valheu!

Ao Filipe Gudin pelos desenhos das cerdas nos capítulos 1-3, por todas as dicas e disponibilidade.

A toda equipe do LIPY/UFPB, em especial Rudá e Rafael, e do Laboratório do Dr. José Roberto Botelho de Souza/UFPE, que participaram das coletas e triagens, e ao Ricardo Gama Soares (UFRPE), pelo apoio logístico na coleta em Itamaracá e Goiana.

Aos amigos do LaPol, principalmente aos queridos Orlemir e Marcelo, pela companhia, por todas as conversas e discussões sobre a elaboração da tese, sonhos de trabalhos futuros, risadas, mergulhos, viagens, cafés e outros momentos de descontração, fundamentais para minha vida em São Paulo ao longo desses anos. Muito obrigada por todas correções na versão semifinal/final da tese.

Aos poliquetólogos do Brasil, na minha linha de ascendência, motivadores, inspiradores, admiráveis, Dra. Cecília Amaral (IB/UNICAMP) e Dr. Edmundo Nonato (IO/USP); e a todos os demais tios, tias, e primos, poliquetologicamente falando, por seguirem juntos.

Aos amigos feitos durante estágio em Madrid, dentro e fora da Universidad, por tornarem essa experiência inesquecível, em especial ao amigo Fernando Ángel Fernández-Álvarez, por planejar comigo projetos megalomaníacos, a serem executados um dia... aos professores Dr. Juan Moreira e Dr. Eduardo López; às colegas de laboratório Vívian Brusa, Patricia Álvarez Campos e Aida Verdes; e as compañeras de piso Bruna Azevedo, Mayla Ronacher e Priscila Rossi.

Aos funcionários, técnicos, professores e amigos do Depto. de Zoologia, que proporcionaram um ótimo ambiente de trabalho ao longo destes anos.

Ao Pedro, por todos os conselhos e lições taxonômicas e ajuda nesses últimos anos; e também a toda sua família, pelo carinho.

A toda a minha família, em especial, aos meus pais, Antônio e Italina, meus irmãos Roberta, Paula e Vitor, meu cunhado Leonardo, minhas sobrinhas Ana Clara e Manuela, meus amigos irmãos Cíntia e Pedro, e os pequenos Daniel e João, por me apoiarem incondicionalmente até aqui, e seguirem juntos comigo no caminho da vida.

Muito, muito, muito obrigada! 


\section{ÍNDICE}

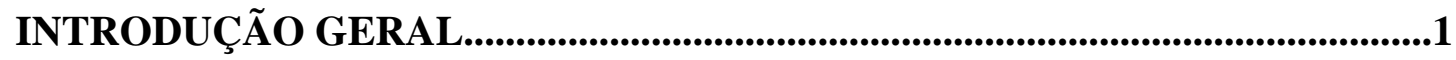

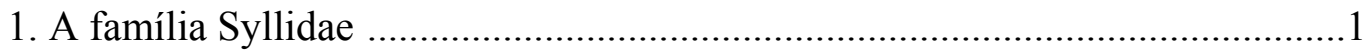

1a. Histórico, classificação e filogenia .......................................................1

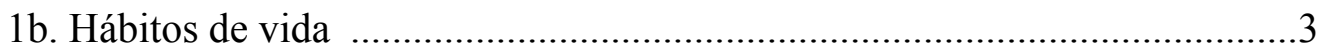

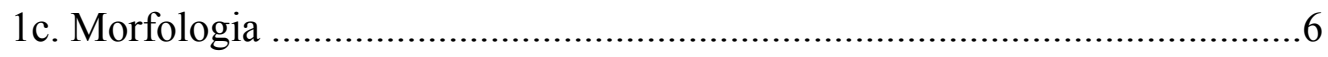

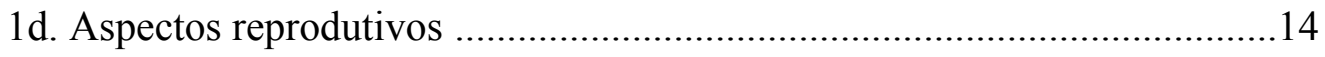

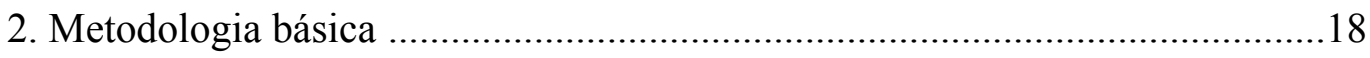

3. Diversidade de Syllidae no nordeste do Brasil .............................................21

4. Organização da Tese ...............................................................................22

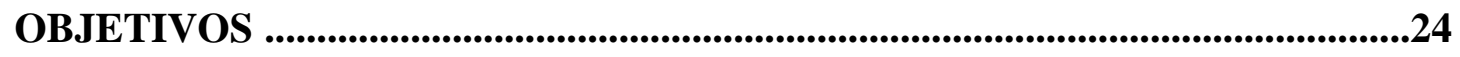

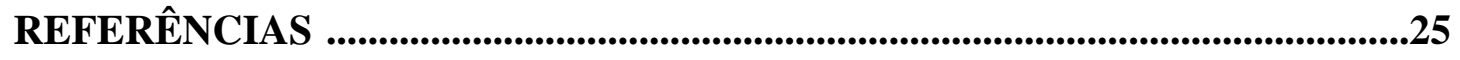

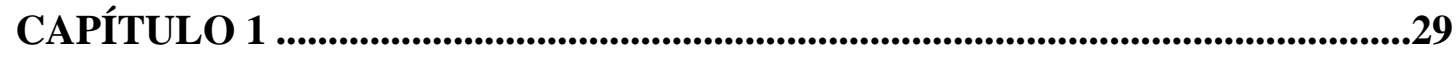

Myrianida Milne Edwards, 1845 and Proceraea Ehlers, 1864 (Polychaeta: Syllidae: Autolytinae) from off northeastern Brazil, with descriptions of three new species

CAPÍTULO 2

New species of Basidiosyllis and Odontosyllis, and new records of Amblyosyllis, Eusyllis and Perkinsyllis (Syllidae:Polychaeta) from off the northeastern Brazilian Coast

CAPÍTULO 3

Branchiosyllis, Megasyllis, Opisthosyllis, Syllis and Trypanosyllis

(Polychaeta: Syllidae: Syllinae) from Brazil, with the description of 7 new species

\section{CAPÍTULO 4}

On some Exogoninae (Polychaeta: Syllidae) from off the northeastern Brazilian coast, with description of a new species

RESUMO .345

ABSTRACT .346 


\section{APÊNDICES}

APÊNDICE 1.

$349-354$

Lista de material analisado provenientes das coleções do Museo Nacional de Ciencias Naturales de Madrid e do The Australian Museum

APÊNDICE 2. $.355-358$

Lista de material examinado no âmbito da presente Tese

APÊNDICE 3. $.359-398$

Artigo aceito para publicação: The genus Exogone (Polychaeta: Syllidae) from the Brazilian coast, with the description of a new species

APÊNDICE 4.

Artigo publicado: The genus Haplosyllis Langerhans, 1879 (Polychaeta: Syllidae) from Northeastern Brazil, with descriptions of two new species

APÊNDICE 5.

Artigo publicado: Species of Odontosyllis Claparède, 1863 (Annelida: Polychaeta: Syllidae) occurring along the Brazilian coast 


\section{INTRODUÇÃO GERAL}

\section{A família Syllidae}

\section{1a. Histórico, classificação e filogenia}

Syllidae Grube, 1850 representa uma das famílias mais complexas e ricas de poliquetas, encontrada em praticamente todos os hábitats marinhos. Atualmente, é formada por 72 gêneros e mais de 700 espécies válidas (San Martín, 2003; Aguado et al., 2012). Este número ainda vem aumentando à medida que novas áreas vêm sendo estudadas. Apesar de a maioria dos representantes de Syllidae ter menos de $5 \mathrm{~mm}$, o reconhecimento destes animais a nível de família é simples, entretanto, a diferenciação de táxons a nível específico, e até mesmo genérico, é considerada bastante difícil.

As primeiras descrições formais de espécies de Syllidae datam da época de Linnaeus, século XVIII; O.F. Müller (1771) foi o autor da primeira descrição de um silídeo de que se tem registro, com a descrição de Nereis armillaris, que posteriormente seria alocada no gênero Syllis Lamarck, 1818. Durante os anos seguintes, outras espécies foram descritas, e também relacionadas ao gênero Nereis. Em 1818, Lamark separou os gêneros Syllis e Nereis, descrevendo a primeira espécie que, posteriormente, daria nome à família: Syllis monilaris Lamarck, 1818. Somente décadas mais tarde, Grube (1850) descreveu a família Syllidea Grube, 1850 em seu trabalho "Die Familien der Anneliden", obra em que o autor fez uma grande revisão de todas as famílias, propondo uma nova classificação para os anelídeos. Essa classificação foi utilizada como base para trabalhos posteriores, e muitas das famílias então propostas continuam válidas até hoje. Posteriormente, Langerhans (1879) dividiu os silídeos em três tribos: 
Syllideae Grube, 1850, Exogoneae Langerhans, 1879, e Autolyteae Langerhans, 1879; complementando essa nova divisão, Malaquin (1893) propôs a tribo Eusylleae Malaquin, 1893. Finalmente, Fauvel (1923) elevou essas tribos ao nível de subfamílias: Syllinae Grube, 1850, Autolytinae Langerhans, 1879, Eusyllinae Malaquin, 1893 e Exogoninae Langerhans, 1879. Apesar da ausência de uma sistematização filogenética, essa classificação, com alguns ajustes, vem sendo utilizada até hoje.

Desde as primeiras análises filogenéticas realizadas com o intuito de verificar as relações de parentesco dentro da família Syllidae, o monofiletismo das subfamílias Syllinae, Autolytinae e Exogoninae vem sendo suportado, Eusyllinae, como até então considerada, aparecendo como um agrupamento não-monofilético (Aguado et al., 2007; Aguado \& San Martín, 2009). Além das quatro subfamílias supracitadas, tradicionalmente utilizadas nas classificações dos silídeos, Aguado \& San Martín (2009), a partir de uma análise filogenética baseada em caracteres morfológicos, propuseram uma quinta subfamília, Anoplosyllinae Aguado \& San Martín, 2009, para um grupamento monofilético incluindo cinco gêneros previamente alocados em Eusyllinae (Tabela 1). Mais recentemente, Aguado et al. (2012) reformularam a subfamília Eusyllinae, alguns gêneros foram excluídos e a diagnose da subfamília, emendada, de forma que, atualmente, também Eusyllinae é considerada monofilética (Figura 1). Neste estudo, os autores combinaram tanto dados morfológicos quanto moleculares, e o consenso estrito da análise suporta o monofiletismo da família Syllidae, assim como o das suas 5 subfamílias (Figura 1).

Finalmente, os gêneros Amblyosyllis Grube, 1857, Anguillosyllis Day, 1963 e Perkinsyllis San Martín, López \& Aguado, 2009 foram incluídos nas análises filogenéticas mas não puderam ser alocados em nenhuma das subfamílias, sendo considerados gêneros independentes com posição incerta na filogenia da família (Figura 
1) (Aguado et al., 2012). Outros gêneros não foram incluídos nas análises, sendo suas relações evolutivas com os demais membros da família ainda desconhecidas (listados na coluna Incertae sedis da Tabela 1) (Aguado et al., 2012).

\section{1b. Hábitos de vida}

Os silídeos são abundantes e comuns em muitos ambientes marinho, ainda que sejam ligeiramente mais raros em grandes profundidades (San Martín, 2003). Assim, estão presentes nos mais variados habitats, incluindo formas intersticiais componentes da meiofauna de praias arenosas (Westheide, 1974; Nogueira et al., 2004; Riera et al., 2007; di Domenico et al., 2009) e da criptofauna de diversos tipos de substratos marinhos, como esponjas, algas, bancos de moluscos e recifes de corais, da zona entremarés ao infra-litoral, e em ambientes de profundidade, em comunidades associadas a fontes hidrotermais (San Martín, 2004). Dada essa alta diversidade e abundância, assim como seus tamanhos reduzidos, é um dos grupos mais difíceis e complexos quando se trata de estudos bentônicos. 
TABELA 1 - Classificação proposta para as subfamílias e respectivos gêneros de Syllidae (modificado de Aguado et al., 2012).

\begin{tabular}{c|c|c|c|c|c}
\hline Autolytinae & Exogoninae & Syllinae & Anoplosyllinae & Eusyllinae & Incertae sedis \\
\hline Epigamia & Brania & Alcyonosyllis & Anoplosyllis & Eusyllis & Acritagasyllis \\
Imajimaea & Cicese & Branchiosyllis & Streptospinigera & Nudisyllis & Amblyosyllis \\
Levidorum & Erinaceusyllis & Dentatisyllis & Astreptosyllis & Odontosyllis & Anguillosyllis \\
Myrianida & Exogone & Eurysyllis & Streptosyllis & Opisthodonta & Basidiosyllis \\
Pachyprocerastea & Parapionosyllis & Haplosyllis & Syllides & Pionosyllis & Bollandiella \\
Paraproceraea & Parexogone & Inermosyllis & & Synmerosyllis & Brachysyllis \\
Paraprocerastea & Prosphaerosyllis & Karroonsyllis & & Brevicirrosyllis \\
Planicirrata & Salvatoria & Megasyllis & & Clavisyllis \\
Proceraea & Sphaerosyllis & Nuchalosyllis & & Dioplosyllis \\
Procerastea & & Opisthosyllis & & & Guillermogonita \\
Virchowia & & Parahaplosyllis & & Haplosyllides \\
& & Paraopisthosyllis & & Lamellisyllis \\
& & Parasphaerosyllis & & Miscellania \\
& & Plakosyllis & & Murrindisyllis \\
& & Rhopalosyllis & & Neopetitia \\
& & Syllis & & Nooralia \\
& & Typosyllis & & Palposyllis \\
& & Tetrapalpia & & Paraehelersia \\
& & Trypanosyllis & & Perkinsyllis \\
& & Xenosyllis & & Psammosyllis \\
& & & & Streptodonta \\
& & & & Westheidesyllis \\
& & & &
\end{tabular}




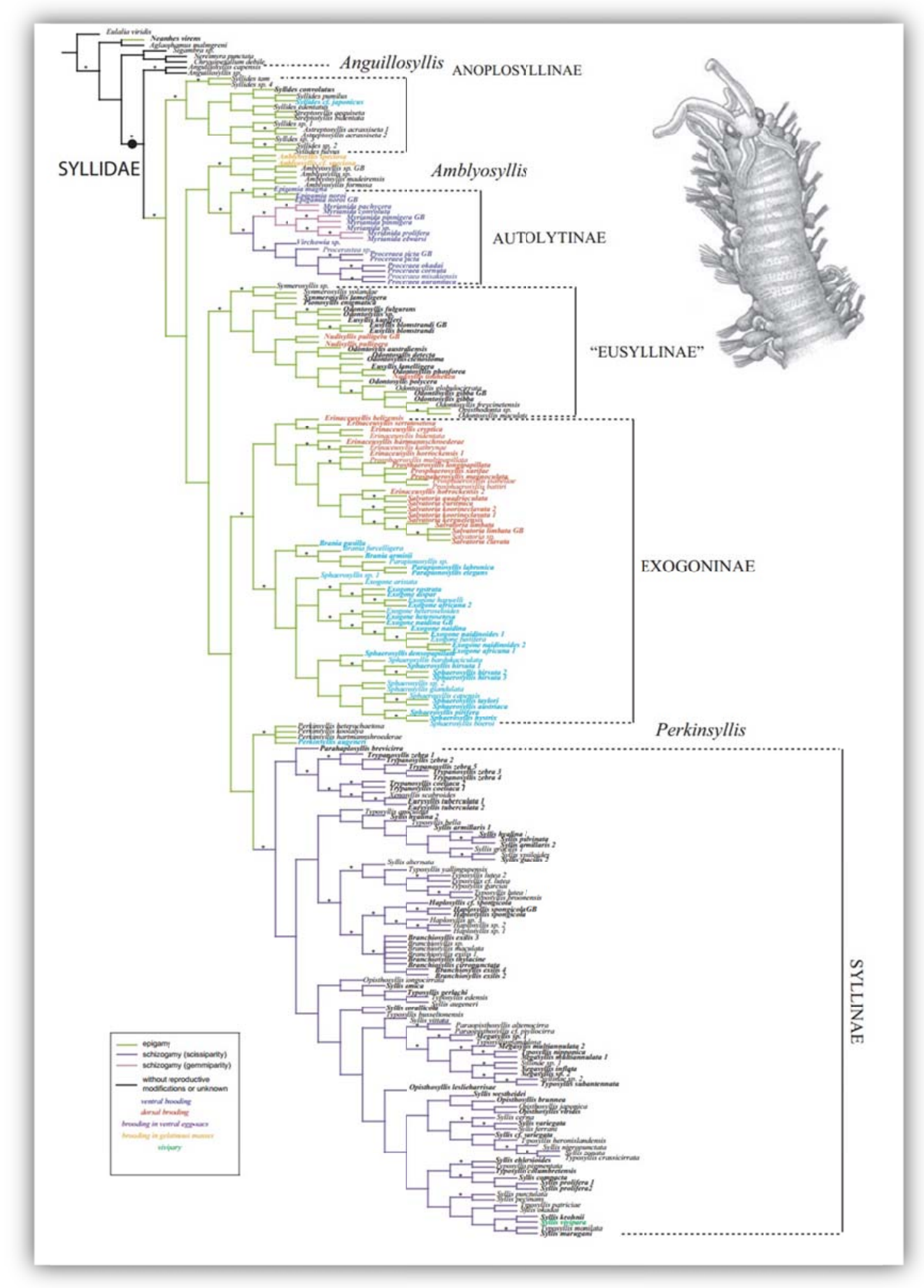

FIGURA 1. Consenso estrito de dados moleculares e morfológicos combinados, analisados por máxima parcimônia. Os nós marcados com “*” representam valores suporte de jackknife $>75 \%$. Em negrito, espécies para as quais são conhecidas a forma de reprodução/incubação. Fonte: Aguado et al., 2012. 
Os silídeos são considerados, em sua maioria, carnívoros ou detritívoros (Fauchald \& Jumars, 1979), mas pouco se sabe a respeito da dieta e dos hábitos alimentares no grupo. Giangrande et al., (2000) comprovaram ainda que algumas espécies são herbívoras, alimentando-se de microalgas e fragmentos de macroalgas, enquanto Lattig et al., (2010) descreveram um possível caso de canibalismo. Existe uma relação entre a armadura da faringe e os hábitos alimentares: detritívoros possuem dente pouco desenvolvido e sugam diretamente os detritos pelo bombeamento do proventrículo, enquanto herbívoros ou carnívoros geralmente possuem dente ou trépano bem desenvolvidos, utilizando-os para perfurar o tecido da presa, para então sugarem o conteúdo com o uso do proventrículo (Lattig et al., 2010). Há ainda diversos outros exemplos de silídeos em associação com outros organismos, como comensais de esponjas e gorgônias (Martin \& Britayev, 1998; Lattig \& Martin, 2009), de briozoários e tunicados (San Martín, 2003; Nygren, 2004) e de ofiuróides (San Martín, 2003). Além disso, o parasitismo também está presente na família, ainda que mais raro, com representantes ecto-parasitas de hidrozoários (San Martín, 2003), crustáceos (Martin et al., 2008) e outros poliquetas (Treadwell, 1909).

\section{1c. Morfologia}

Membros da família Syllidae são poliquetas errantes, de tamanho geralmente relativamente pequeno, embora algumas espécies do gênero Trypanosyllis Claparède, 1864 possam alcançar mais de $13 \mathrm{~cm}$ de comprimento e $7 \mathrm{~mm}$ de largura, com mais de 500 segmentos (Johnson, 1902). A quantidade de segmentos no corpo varia, em geral, com o tamanho dos indivíduos, mas espécies de alguns gêneros, como Amblyosyllis e Brachysyllis Imajima \& Hartman, 1964, possuem número fixo, entre 14-17. O formato 
dos segmentos varia desde muito achatados, como algumas espécies de Trypanosyllis, até muito alongados, como por exemplo, em algumas espécies de Megasyllis San Martín, Hutchings \& Aguado, 2008. Em alguns gêneros ocorre a fusão de segmentos (p. ex., em Murrindisyllis San Martín, Aguado \& Murray, 2007 e Synmerosyllis San Martín, López \& Aguado, 2009). O corpo dos silídeos geralmente é mais largo no nível do proventrículo e afila progressivamente em sentido posterior. A seção corporal normalmente é subcilíndrica, apresentando-se convexa dorsalmente e plana ventralmente. Entretanto, alguns gêneros (Eurysyllis Ehlers, 1864, Plakosyllis Hartmann-Schröder, 1956, Trypanosyllis, e Xenosyllis Marion y Bobretzky, 1875) e algumas espécies de Branchiosyllis Ehlers, 1887 são dorso-ventralmente achatados, enquanto que uma espécie de Branchiosyllis é lateralmente comprimida, com os parapódios direcionados para cima (B. orbiniiformis San Martín, Hutchings \& Aguado, 2008).

O prostômio (Figura 2A) é bem desenvolvido, com formatos variados, desde aproximadamente semi-circular a subpentagonal. A maioria das espécies possui um par de palpos anteriormente (Figura 2A), com formato aproximadamente cônico e voltado para frente na maioria das espécies, com grau de fusão variável, desde totalmente fundidos até totalmente livres um do outro. Quatro olhos relativamente complexos, lenticulados (Verger-Bocquet, 1983) (Figura 2A) estão presentes na maioria das espécies e, por vezes, também há duas manchas ocelares anteriores, sem lentes; excepcionalmente, algumas espécies não apresentam olhos nem manchas ocelares. Em geral, os silídeos possuem ainda três antenas no prostômio (Figura 2A), duas laterais e uma central, sendo que o ponto de inserção, comprimento e forma variam entre espécies. 
O peristômio (Figura 2A), conhecido como segmento tentacular ou bucal, vem imediatamente após o prostômio, circundando a parte posterior do mesmo. Normalmente pode ser visualizado tanto dorsalmente, mais curto do que os setígeros seguintes, quanto ventralmente, onde se encontra bem desenvolvido, formando a boca. Em alguns táxons, o peristômio pode ser recoberto dorsalmente pelo prostômio ou pelo setígero 1 enquanto em outros, o peristômio pode formar um lóbulo nucal e recobrir a parte posterior do prostômio. Assim como o prostômio, o peristômio é aqueto e possui 1-2 pares de cirros peristomiais lateralmente (Figura 2A).

Dorso-lateralmente, entre o prostômio e o peristômio, localizam-se os órgãos nucais, com função quimiorreceptora, dispostos como um par de fendas ciliadas curtas ou como fileiras de cílios densas. Em alguns gêneros (p. ex. Amblyosyllis, Nuchalosyllis Rullier \& Amoureux, 1979, Myrianida Milne Edwards, 1845, Proceraea Ehlers, 1864), os órgãos nucais apresentam-se como projeções nucais (épaulèttes), ovais a digitiformes, estendendo-se em direção posterior, de extensão variável. Outras partes do corpo, como palpos, prostômio, peristômio, apêndices e superfícies dorsal e ventral também podem apresentar ciliação, formando faixas ciliadas ou tufos dispersos.

A segmentação dos silídeos é homônoma, com todos os setígeros apresentando formatos semelhantes (Figura 2A). Características como formato e comprimento dos cirros dorsais, e distribuição de cerdas e acículas por parapódio, geralmente variam entre as regiões do corpo, entretanto, esta variação ocorre gradualmente, de forma que os limites entre as regiões não são claros, além da extensão das mesmas variar de acordo com o tamanho do indivíduo. 


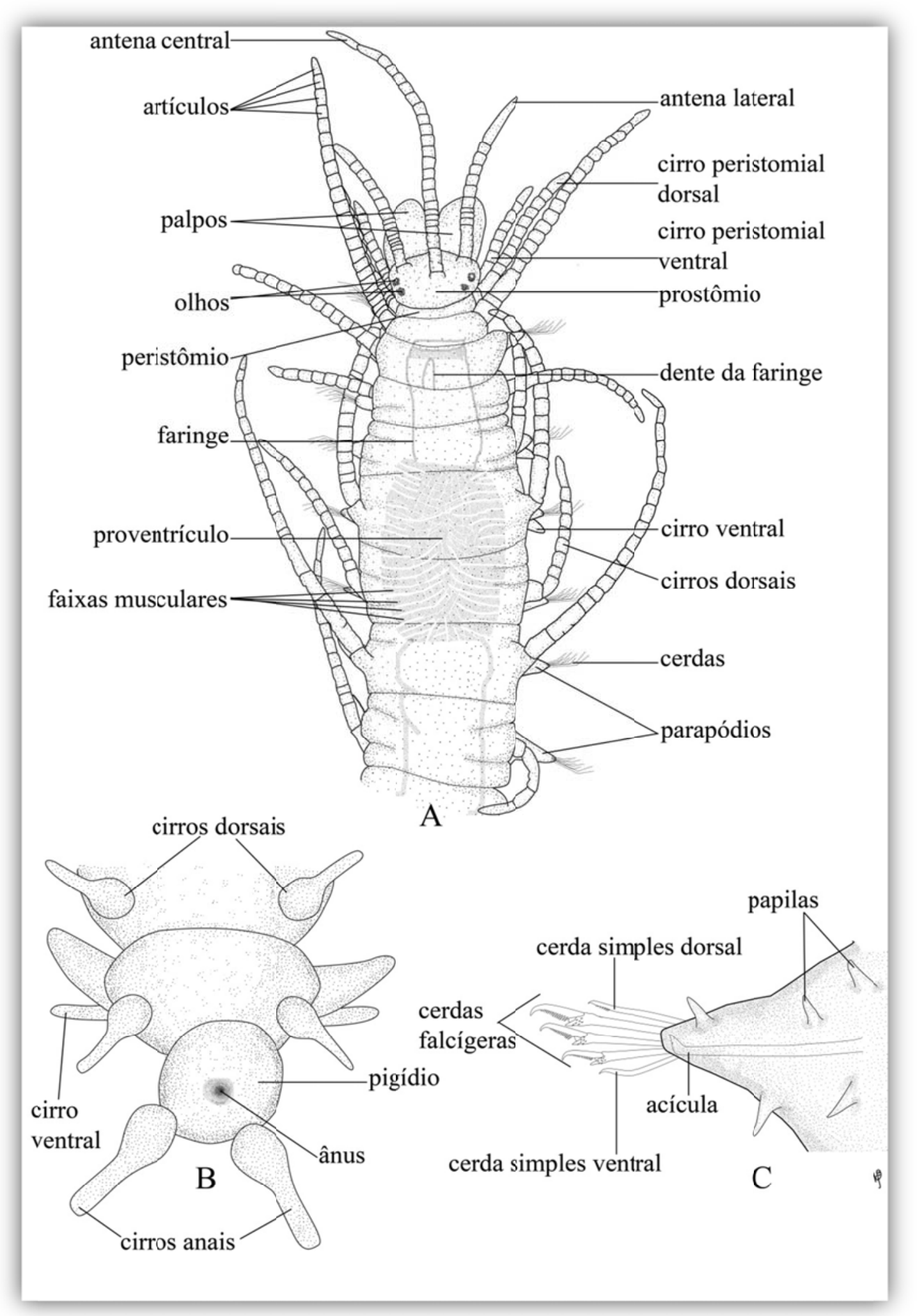

FIGURA 2. Esquemas das principais estruturas morfológicas dos silídeos. (A) região anterior de um Megasyllis (Syllinae), vista dorsal; (B) região posterior de uma Brania (Exogoninae), vista dorsal; (C) parapódio de um Sphaerosyllis (Exogoninae). 
O pigídio normalmente possui um par de cirros anais (Figura 2B) semelhantes aos cirros dorsais posteriores, ou mais longos do que estes, além de, ocasionalmente, uma proeminente papila eles.

A maioria das espécies possui corpo translúcido, embora algumas sejam opacas ou apresentem complexos padrões de pigmentação, como certas espécies da subfamília Autolytinae. Além da pigmentação, as superfícies dorsal e ventral, incluindo palpos, prostômio, peristômio, parapódios e cirros dorsais, podem também ser recobertos por papilas esféricas ou digitiformes (Figura 2C), com um diminuto poro distal, dispostas em faixas ou dispersas, geralmente favorecendo a aglutinação de detritos, o que, frequentemente, prejudica a observação de diversas características dos animais.

Os parapódios são unirremes, com os notopódios reduzidos, sem cerdas ou acículas, apenas portando cirros dorsais, usualmente bem desenvolvidos. Os cirros ventrais (Figura 2A-B) podem ser largos e foliosos, mas geralmente são ovais ou digitiformes, mais curtos do que os lóbulos parapodiais, e não são discerníveis nos Autolytinae. Internamente, os parapódios são sustentados por acículas (Figura 2C), de número e morfologia variáveis. Durante o período reprodutivo, nos segmentos sexuais (epigamia) ou nos estolões (esquizogamia), os parapódios adquirem notoacícula e notocerdas para natação.

As neurocerdas são tipicamente compostas, de articulação heterogonfa (Figuras 2C; 3D-E), mas cerdas simples dorsais e ventrais (Figura 2C) também estão geralmente presentes, ao menos nos setígeros posteriores. Algumas espécies possuem cerdas secundariamente simples robustas, formadas ou pela fusão das hastes e lâminas (Figura 3A, B), ou pela perda secundária da lâmina e alargamento da haste (Figura 3B). Martín \& Britayev, 1998 sugerem que a presença deste tipo de cerda secundariamente simples seja uma adaptação ao modo de vida em associação com outros organismos. 
As cerdas compostas são principalmente falcígeras (Figuras 2C; 3D), embora muitas espécies também apresentem cerdas pseudoespinígeras (Figura 3D), termo proposto por San Martín (1992) para diferenciá-las das típicas cerdas espinígeras encontradas em diversas outras famílias de Polychaeta, com lâminas proporcionalmente mais finas e pontiagudas (Dorsey \& Phillips, 1987). Outra modificação está presente nas cerdas de Branchiosyllis, cujas lâminas são recurvadas, em forma de gancho, e em ângulo de $90^{\circ}$ com as hastes, denominadas úngulas (Góngora-Garza et al., 2011) (Figura 3F). As lâminas das cerdas podem ser unidentadas (Figuras 2C; 3F), subbidentadas ou bidentadas (Figura 3D-E). Tipicamente, as lâminas possuem uma das bordas espinulada (Figuras 2C; 3D-E), com espinhos mais ou menos voltados para cima, proximalmente longos e progressivamente menores em direção distal. As hastes das cerdas compostas geralmente possuem espinulação e alargamento subdistais, com pontas retas ou sigmóides.

As cerdas simples dorsal e ventral (Figura 2C) podem estar presentes desde o primeiro setígero, mas geralmente estão presentes nos setígeros mais posteriores e são mais finas do que as hastes das cerdas compostas no mesmo fascículo. Podem ser unidentadas, bidentadas ou bífidas, com ou sem espinulação subdistal, retas ou sigmoides.

Antenas, cirros peristomiais, cirros dorsais e cirros anais, comumente denominados coletivamente como "apêndices", possuem diferentes formatos, dentre basicamente dois tipos, lisos (Figura 2B) ou articulados (Figura 2A). Os apêndices lisos podem ser papiliformes, subulados, com bases esféricas e pontas afiladas (Figura 2B), ou cilíndricos a filiformes, mais ou menos alongados, sem articulação distinta. Os apêndices articulados, também denominados moniliformes (Figura 2A), são divididos em artículos esféricos, cúbicos ou achatados, o número de artículos não necessariamente 
refletindo o tamanho relativo entre os apêndices, uma vez que o tamanho dos artículos pode variar de acordo com o apêndice e ao longo do mesmo, e, no caso dos cirros dorsais, com a região do corpo. Algumas espécies não possuem articulação ao longo de todo o comprimento dos apêndices, entretanto, também não são totalmente lisos, apresentando-se como que enrugados ou irregularmente constritos, padrão denominado "pseudoarticulado". Os cirros dorsais geralmente estão presentes em todos os setígeros, mas em algumas espécies de Exogoninae estão ausentes no setígero 2.

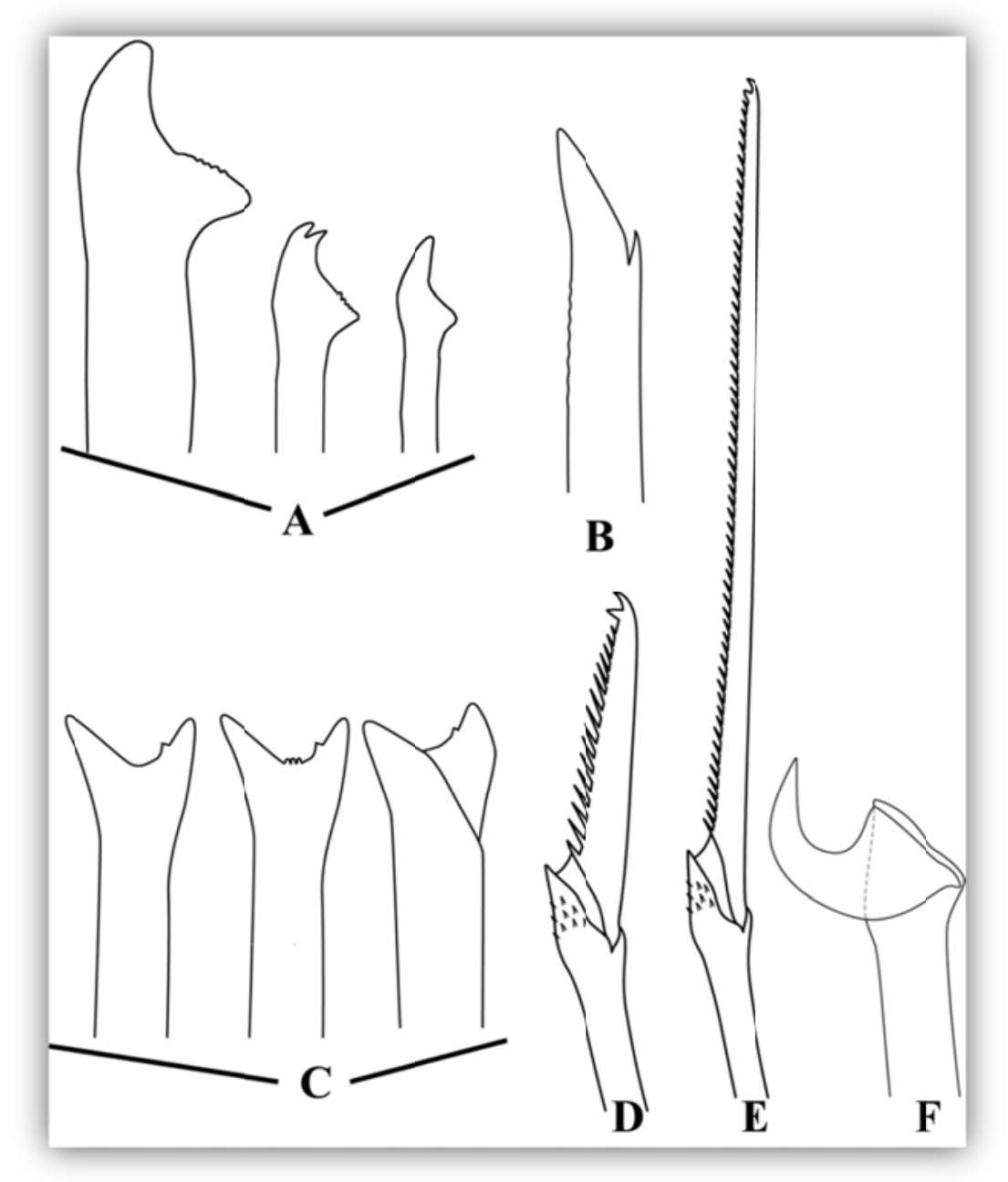

FIGURA 3. Tipos de cerdas em Syllidae. (A) cerda secundariamente simples, derivada da fusão entre hastes e lâminas (B) cerda secundariamente simples, derivada da perda da lâmina; (C) cerda secundariamente simples, derivada da fusão entre hastes e lâminas; (D) cerda composta falcígera; (E) cerda composta pseudoespinígera; (F) úngula. 
Internamente, a faringe estende-se por um número variável de segmentos a partir da boca, esta localizada ventralmente no peristômio. A faringe é um tubo cilíndrico, geralmente reta, ocupando alguns setígeros (Figura 2A), mas em Amblyosyllis e Autolytinae ela se apresenta geralmente fina, alongada, sinuosa, as vezes enrolada, com até diversas voltas. Anteriormente, a margem pode ser circundada por uma coroa de papilas, usualmente 10, e uma densa franja de cílios. Pode ser inerme ou, mais comumente, armada com um dente (Figura 2A), uma coroa completa ou incompleta de dentículos (trépano), ou ambos. A presença de armadura define o clado mais abrangente dentro de Syllidae ("enoplosilídeos"), incluindo todos os silídeos exceto os Anoplosyllinae e Anguillosyllis ("anoplosilídeos") (Aguado et al., 2012).

Associado à porção posterior da faringe localiza-se o proventrículo (Figura 2A), com epitélio glandular interno e robustas fibras musculares externamente. O proventrículo desempenha importante papel endócrino, secretando hormônios relacionados ao controle dos ciclos reprodutivos (Franke, 1999), e digestivo, agindo com uma bomba de sucção (Fauchald \& Jumars, 1979), e é considerado a principal sinapomorfia da família (Glasby, 1993).

Além dos caracteres morfológicos, utilizados para definição de espécies, gêneros e até mesmo subfamílias, os aspectos reprodutivos também são importantes principalmente para classificação das subfamílias, sendo que os sistemas de incubação e tipos de estolões representam valiosas informações filogenéticas (Aguado et al., 2012). 


\section{1d. Aspectos reprodutivos}

Os silídeos apresentam uma espetacular diversidade de fenômenos reprodutivos. O modo primitivo de reprodução é caracterizado pela epitoquia (epigamia e estolonização), enxameamento e fertilização externa (Franke, 1999). Modificações do modo primitivo incluem incubação externa, transferência direta de esperma, fertilização interna, viviparidade, partenogênese e hermafroditismo simultâneo ou sucessivo, sendo que a reprodução assexuada verdadeira é considerada rara e ocorre por fragmentação do corpo seguida de regeneração (arquitomia) (Franke, 1999).

$\mathrm{Na}$ epitoquia, também presente em outros grupos de poliquetas, a forma átoca (bentônica, mais duradoura) dá origem a formas epítocas (planctônicas, de curta existência), cuja função é o transporte e liberação dos gametas. A formação dos epítocos em Syllidae também é diversa, podendo ocorrer de duas maneiras (Franke, 1999). A primeira forma é a epigamia, em que o indivíduo átoco se transforma em epítoco passando por uma série de modificações morfológicas, fisiológicas e comportamentais, como o aumento no tamanho de estruturas sensoriais (olhos, antenas e cirros), desenvolvimento de cerdas natatórias notopodiais, adquirindo uma condição birreme, e desenvolvimento de glândulas genitais em segmentos modificados, para o armazenamento de gametas. Nesta fase, se tornam mais ativos e, em processo desencadeado por diversos fatores, tais como ciclo lunar, duração dia/noite, temperatura da água, etc., nadam para a coluna d'água, formando grandes concentrações de indivíduos, fenômeno conhecido como enxameamento. Machos e fêmeas se reconhecem frequentemente através de feromônios e algumas espécies são capazes de produzir bioluminescência (Zörner \& Fisher, 2007), captada pelos olhos bem desenvolvidos do parceiro reprodutivo, ocorrendo então a liberação dos gametas. 
$\mathrm{Na}$ epigamia, os epítocos (nesse caso, também conhecidos como "epígamos") liberam os gametas por nefridióporos modificados em gametodutos, e frequentemente os indivíduos podem reverter à forma átoca e ao hábito bentônico após o enxameamento, estando aptos a passar novamente por todo o processo na estação reprodutiva seguinte (Daly, 1975; Fischer \& Fischer, 1995). O cuidado parental também está presente em alguns grupos, como nos Exogoninae, em que as fêmeas incubam os embriões ventral ou dorsalmente. Nas espécies com incubação ventral, a prole permanece conectada à forma materna, recebendo nutrientes desta e desenvolvendo-se até um estágio com vários setígeros, quando então são liberados (San Martín, 2005). Diferentemente, a incubação dorsal pode se dá por meio de notocerdas capilares especializadas, ou presos em cirros dorsais, que mantêm os ovos junto ao dorso da forma materna.

O segundo tipo de formação de epítocos é a esquizogamia, processo em que estolões são formados a partir do indivíduo átoco por duas maneiras: cissiparidade, com um estolão sendo formado por vez, na região posterior do corpo; e gemiparidade, com vários estolões sendo formados simultaneamente, formando fileiras de estolões unidos, ou brotando lateralmente na extremidade posterior do indivíduo átoco (Franke, 1999). A esquizogamia é controlada pelo sistema endócrino relacionado ao proventrículo (Durchon, 1957; Franke, 1980; 1983). Os ciclos sexuais promovem mudanças periódicas no funcionamento do sistema, sendo que após o processo de estolonização, o sistema endócrino inibe o desenvolvimento de um novo estolão no átoco e ativa a regeneração dos setígeros perdidos. Embora em muitos casos não haja dimorfismo sexual, a determinação do sexo é fácil, já que as fêmeas possuem relativamente grandes óvulos preenchendo os segmentos, enquanto que os machos apresentam o celoma totalmente preenchido por espermatozoides. 
Na coluna d'água liberam os gametas pela ruptura da parede do corpo, não havendo, portanto, cuidado parental ou incubação. Após a fertilização, ovos permanecem na coluna d'água, onde se desenvolvem em larvas livre natantes ciliadas (San Martín, 2003). Após completar o desenvolvimento, juvenis retornam ao ambiente bentônico, fechando o ciclo.

Na família Syllidae a condição reprodutiva considerada primitiva é a epigamia, presente nos Anoplosyllinae, Eusyllinae, Exogoninae, e nos gêneros Epigamia Nygren, 2004 (Autolytinae), Amblyosyllis e Perkinsyllis. Em Exogoninae, o tipo de incubação dos ovos, dorsal ou ventral, reflete duas linhagens evolutivas, e a esquizogamia aparentemente evoluiu independentemente nos Autolytinae e nos Syllinae (Figura 1) (Aguado et al., 2012).

Aguado et al. (2012) demonstraram que o tipo de epítoco formado em Syllinae também está relacionado a diferentes clados (Figura 4). Os epítocos podem ser classificados em 5 morfotipos segundo Aguado et al. (2012):

1. Ácero ou Tetraglene. Cabeça bilobada; dois pares de olhos; antenas ausentes; com pequeno dimorfismo sexual, estolões masculinos um pouco mais finos e com parapódios mais longos do que os femininos;

2. Pentácero ou Ioida. Cabeça com dois pares de olhos, três antenas moniliformes e dois palpos livres um do outro, robustos;

3. Acéfalo. Cabeça e apêndices cefálicos ausentes; setígeros semelhantes ao longo do corpo, com cerdas natatórias e manchas fotorreceptoras;

4. Tetrácero. Cabeça com um par de olhos, duas antenas moniliformes e dois palpos livres um do outro, finos;

5. Dícero ou Chaetosyllis. Cabeça fortemente bilobada, com um par de olhos dorsal e outro ventral; duas antenas pequenas. 


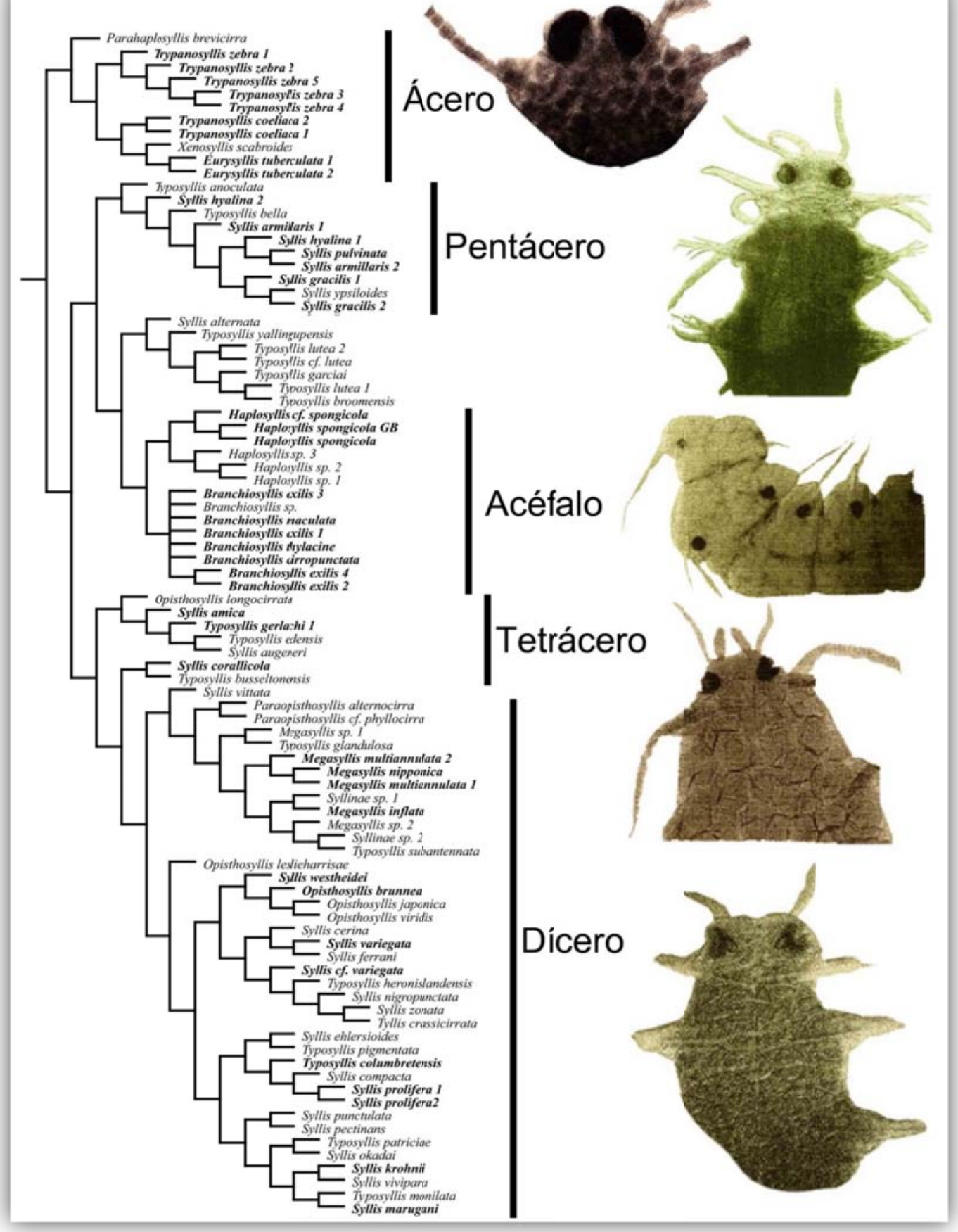

FIGURA 4. Evolução dos tipos de estolões em Syllinae. As relações filogenéticas foram extraídas da Figura 1. Espécies em negrito são aquelas para as quais são conhecidos os tipos de estolão. Figuras de San Martín (2003). Modificado de Aguado et al. (2012). 


\section{Metodologia básica}

No presente estudo foram analisados poliquetas provenientes do nordeste do Brasil, obtidos de coletas dos projetos "Biodiversidade de poliquetas (Annelida, Polychaeta) em substratos consolidados ao longo do estado da Paraíba", e "Biodiversidade de Polychaeta na zona entremarés e infralitoral raso em substratos consolidados no nordeste do Brasil, estados de Pernambuco e Paraíba”.

O litoral raso desses estados caracteriza-se por possuir blocos lateríticos fragmentados, em sua maioria intensamente intemperizados, desde a região entremarés até o infralitoral. Estas concreções lateríticas servem como substrato para formas incrustrantes como algas, colônias de esponjas, cnidários e ascídias, poliquetas tubícolas, crustáceos cirripédios e bancos de bivalves que, por sua vez, promovem o aumento da complexidade ambiental, proporcionando microambientes e oferecendo maior quantidade de recursos para os epibiontes. Esta disponibilidade de recursos torna favorável o desenvolvimento das mais diversas formas de vida, incluindo os silídeos, elevando a biodiversidade nesses ambientes (Edgar, 1983; Gao e McKinley, 1994; Costanza et al., 1997; Spalding et al, 2003).

As coletas foram realizas durante marés baixas em 21 localidades, sendo 12 no Estado da Paraíba e 9 no Estado de Pernambuco (Figura 5). Amostrou-se principalmente a região do entremarés, embora tenham sido feitas algumas amostragens no infralitoral raso, em profundidades não maiores do que $1 \mathrm{~m}$. Foram raspadas pequenas quantidades de diferentes tipos de incrustrantes, como algas, esponjas, ascídias e corais, com o auxílio de espátulas. O material foi acondicionado em tanques aerados com água do mar, para que os animais fossem mantidos vivos e em boas condições, e pequenas porções do material eram retiradas e analisadas sob 
estereomicroscópio. Durante o processo de triagem, algumas características rapidamente perdidas em material fixado, como coloração, puderam ser analisadas e fotografadas com estes animais ainda vivos, de modo a incluir tais características nas respectivas descrições. Os exemplares encontrados foram então anestesiados em solução de mentol, fixados em formalina a $4 \%$ e acondicionados em tubos devidamente identificados. No Laboratório de Poliquetologia (IB/USP), alguns dias depois, os animais eram lavados em água doce e conservados em álcool 70\%. As identificações foram feitas segundo caracteres morfológicos visualizados com o uso de microscópio óptico e, sempre que o número de espécimes e o seu estado de preservação o permitiram, foram analisados exemplares sob microscópio eletrônico de varredura (MEV). Alguns espécimes foram dissecados com o auxílio de estiletes, para análise da faringe e do proventrículo, quando necessário, tendo estas partes sido retiradas dos espécimes e montadas em lâminas permanentes com gel de glicerina ou em stubs para análise sob MEV.

Para a observação ao microscópio eletrônico de varredura, espécimes selecionados foram desidratados em baterias de solução de etanol com concentrações progressivamente maiores, entre 70-100\%, e, em seguida, através do equipamento de Ponto Crítico; os animais foram então montados nos stubs e cobertos com uma camada de ouro de 25-30 nm. A análise do material foi realizada nos equipamentos de MEV dos Laboratórios de Microscopia Eletrônica do Instituto de Biociências da Universidade de São Paulo e do Museu de Zoologia da Universidade de São Paulo.

As ilustrações foram feitas com o auxílio do equipamento de câmara clara, ou com máquina fotográfica digital, acoplados ao microscópio óptico. As imagens foram tratadas com os programas Adobe Photoshop ${ }^{\circledR}$ e/ou Illustrator ${ }^{\circledR}$. 


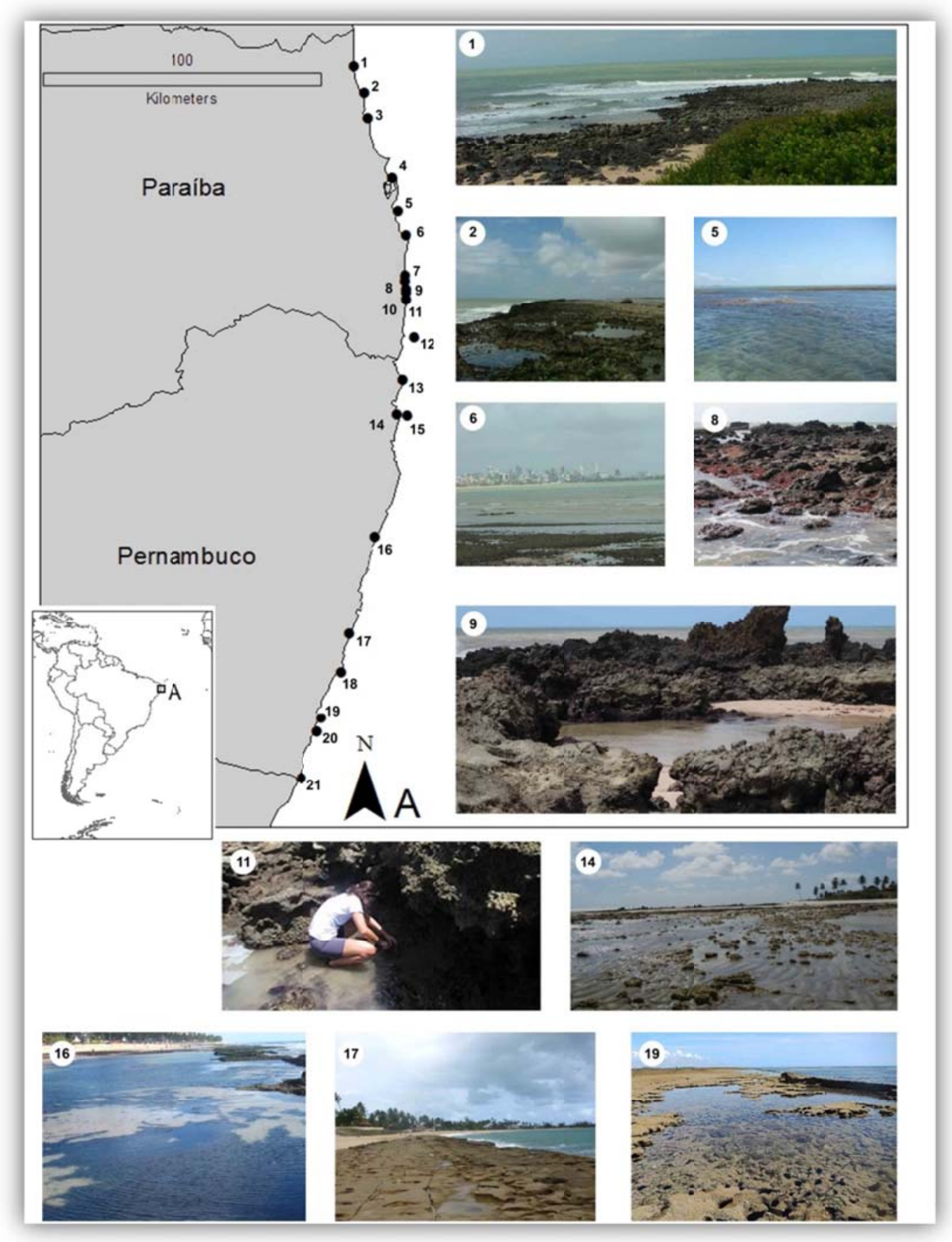

FIGURA 5. Pontos de coleta. Paraíba: 1, Barra de Camaratuba; 2, Ponta da Prainha; Baía da Traição; 3, Barra de Mamanguape; 4, Píer de Cabedelo; 5, Recife do Picãozinho; 6, Praia do Cabo Branco; 7, Praia de Jacumã; 8, Praia de Carapibus; 9, Praia de Tabatinga; 10, Praia do Coqueirinho; 11, Praia de Tambaba; 12, Recife do Farol de Pitimbu. Pernambuco: 13, Praia de Pontas de Pedra; 14, Ponta do Jaguaribe; 15, Recifes de Itamaracá; 16, Praia de Boa Viagem; 17, Recife de Muro Alto; 18, Recife da Barra do Sirinhaém; 19-20, Recife e Praia dos Carneiros; 21, Recife de São José da Coroa Grande. 
Após 2 anos de análise do material de Syllidae da Paraíba e de Pernambuco, as identificações realizadas foram confirmadas/corrigidas durante visita ao Dr. Guillermo San Martín (Universidad Autónoma de Madri, Espanha), considerado a maior autoridade mundial na família. Adicionalmente, para confirmação e comparação com as espécies obtidas, foram analisados espécimes depositados nas coleções do Museo Nacional de Ciencias Naturales de Madrid (Madri, Espanha) e do The Australian Museum, (Sydney, Austrália) (Apêndice 1).

\section{Diversidade de Syllidae no nordeste do Brasil}

O conhecimento atual da diversidade de silídeos ao longo da costa nordestina brasileira é escasso. Apesar de esse litoral ocupar mais da metade da costa brasileira, poucos esforços foram realizados no que diz respeito ao reconhecimento de sua diversidade poliquetológica como um todo. Rullier \& Amoureux (1979) foram os primeiros a registrar representantes dos silídeos para a costa nordestina formalmente, reportando 7 gêneros e 19 espécies, ao amostrarem desde o Atol das Rocas até o sul da Bahia. Recentemente, duas espécies novas foram descritas a partir da análise de material proveniente do Ceará (Nogueira \& Yunda-Guarín, 2008; Fukuda et al., 2009). Considerando os trabalhos formalmente publicados, estes três são os únicos com enfoque taxonômico que trazem descrições e ilustrações dos silídeos no nordeste do Brasil.

No presente estudo, foram realizadas coletas desde ao norte do Estado da Paraíba até ao sul do Estado de Pernambuco, totalizando 21 pontos amostrados em uma extensão de aproximadamente $300 \mathrm{~km}$ de costa (Figura 5). A partir da análise deste 
material, foram registradas 19 espécies novas para a ciência, 14 novas ocorrências de espécies para o Brasil e 18 novas ocorrências de espécies para o litoral nordestino (Apêndice 2).

\section{Organização da Tese}

Além desta "Introdução Geral" e das "Considerações Finais", esta Tese está organizada em quatro capítulos estruturados como artigos científicos e redigidos em inglês. Cada manuscrito está formatado de acordo com os padrões exigidos pela Zootaxa, periódico ao qual pretende-se submetê-los. Embora já estejam em formato para submissão, nenhum deles está aceito, somente um tendo sido submetido até o momento.

O primeiro capítulo, intitulado "Myrianida Milne Edwards, 1845 and Proceraea Ehlers, 1864 (Polychaeta: Syllidae: Autolytinae) from off northeastern Brazil, with descriptions of three new species" apresenta as espécies da subfamília Autolitynae encontradas nas coletas da Paraíba e de Pernambuco. Este manuscrito foi submetido a Zootaxa.

O segundo capítulo, "New species of Basidiosyllis and Odontosyllis, and new records of Amblyosyllis, Eusyllis and Perkinsyllis (Syllidae:Polychaeta) from off the northeastern Brazilian Coast", apresenta espécies da subfamília Eusylinae assim como de alguns dos gêneros incertae sedis de Syllidae.

O terceiro capítulo, intitulado "Branchiosyllis, Megasyllis, Opisthosyllis, Syllis and Trypanosyllis (Polychaeta: Syllidae: Syllinae) from Brazil, with the description of 7 new species", traz as espécies de Syllinae encontradas no presente estudo.

Finalmente, no quarto e último capítulo, são apresentadas as espécies de Exogoninae, exceto Exogone, encontradas ao longo dos estados da Paraíba e de 
Pernambuco, com o título "On some Exogoninae (Polychaeta: Syllidae) from off the northeastern Brazilian coast, with description of a new species".

Todas as espécies incluídas nas sessões "Material examinado" desta Tese, ocorrem nos estados da Paraíba e/ou Pernambuco (Apêndice 2). Adicionalmente, foram analisados espécimes coletados em outros estados, já que muitas espécies haviam sido previamente coletadas por outros projetos realizados ao longo da costa brasileira, mas ainda não haviam sido registradas formalmente (Apêndice 2).

Os capítulos que tratariam dos gêneros Exogone ("The genus Exogone (Polychaeta: Syllidae) from the Brazilian coast, with the description of a new species") e Haplosyllis ("The genus Haplosyllis Langerhans, 1879 (Polychaeta: Syllidae) from Northeastern Brazil, with descriptions of two new species"), foram submetidos e aceitos para publicação na Zootaxa (Apêndice 3) e Marine Biology Research (Apêndice 4) respectivamente. Ambos estão como apêndices por questões de direitos autorais e, futuramente, disponibilização pública desta Tese.

O Apêndice 5 traz o trabalho intitulado "Species of Odontosyllis Claparède, 1863 (Annelida: Polychaeta: Syllidae) occurring along the Brazilian coast", realizado em colaboração com a equipe do Laboratório de Poliquetologia (LaPol) do IB/USP e inclui algumas espécies de Odontosyllis analisadas no âmbito do presente trabalho. 


\section{OBJETIVOS}

O principal objetivo deste trabalho foi realizar um levantamento taxonômico das espécies da família Syllidae presentes no litoral raso dos estados da Paraíba e de Pernambuco e fornecer descrições detalhadas das mesmas, contribuindo para o melhor conhecimento da fauna de poliquetas da região nordeste e do litoral brasileiro como um todo. 


\section{REFERÊNCIAS}

Aguado, M.T. \& San Martín, G. (2009) Phylogeny of the Syllidae (Polychaeta) based on morphological data. Zoologica Scripta, 38, 379-402.

Aguado, M.T., Nygren, A. \& Siddall, M.E. (2007) Phylogeny of Syllidae (Polychaeta) based on combined molecular analysis of nuclear and mitochondrial genes. Cladistics, 23, 552564.

Aguado, M.T., San Martín, G. \& Siddall, M.E. (2012) Systematics and evolution of syllids (Annelida, Syllidae). Cladistics, 27, 1-17.

Costanza, R., d'Arge, R., deGroot, R., Farber, S., Grasso, M., Hannon, B., Limburg, K., Naeem, S., O'Neill, R.V., Paruelo, J., Raskin, R.G., Sutton, P. \& van den Belt, M. (1997) The value of the world's ecosystem services and natural capital. Nature, 387, 253-260.

Di Domenico, M., Lana, P.C. \& Garraffoni, A.R.S. (2009) Distribution patterns of interstitial polychaetes in sandy beaches of southern Brazil. Marine Ecology, 30, 47-62.

Dorsey, J.H. \& Phillips, C.A. (1987) A new species of Syllis (Ehlersia) (Polychaeta: Syllidae) from southern California, and description of the epitoke and atoke variation in $S$. (Ehlersia) heterochaeta Moore, 1909. Bulletin of the Biological Society of Washington, $7,152-161$.

Durchon, M. (1957) Rôle du proventricule dans le déterminisme de la stolonisation chez les Syllidiens. Comptes Rendus Hebdomadaires des Séances de l'Académie des Sciences, $244,1238-1286$.

Edgar, G.J. (1983) The ecology of south-east Tasmania phytal animal communities. I. Spatial organization on a local scale. Journal of Experimental Marine Biology and Ecology, 70, $129-157$.

Fauchald, K. \& Jumars, P.A. (1979) The diet of worms: a study of polychaete feeding guilds. Oceanography and Marine Biology: an Annual Review, 17, 193-284.

Fauvel, P. (1923) Polychètes errantes. In: Faune de France, vol. 5. Le Chavalier. Paris. 486 pp. Franke, H.D. (1980) Zur Determination der zeitlichen Verteilung von Fortflanzungsprozessen in Laborkulturen des Polychaeten Typosyllis prolifera. Helgoländer Meeresuntersuchungen, 34, 61-84.

Franke, H.D. (1983) Endocrine control of reproductive periodicity in male Typosyllis prolifera (Polychaeta, Syllidae). International Journal of Invertebrate Reproduction, 6, 229-238.

Franke, H.D. (1999) Reproduction of the Syllidae (Annelida: Polychaeta). Hydrobiologia, 402, 39-55.

Fukuda, M.V., Yunda-Guarín, G. \& Nogueira, J.M.M. (2009) The genus Prosphaerosyllis (Polychaeta: Syllidae: Exogoninae) in Brazil, with description of a new species. Journal of the Marine Biological Association of the United Kingdom, 89, 1443-1454. 
Gao, K. \& McKinley, K.R. (1994) Use of macroalgae for marine biomass production and $\mathrm{CO}_{2}$ remediation - a review. Journal of Apllied Phycology, 6, 45-60.

Giangrande, A., Licciano, M. \& Pagliara, P. (2000) The diversity of diets in Syllidae (Annelida: Polychaeta). Cahiers de Biologie Marine, 41, 55-65.

Glasby, C.J. (1993) Family revision and cladistic analysis of the Nereidoidea (Polychaeta: Phyllodocida). Invertebrate Taxonomy, 7, 1551-1573.

Glasby, C.J. (2000) Family Syllidae. In: Beesley, P.L., Ross, G.J.B., Glasby, C.J. (Eds.), Polychaetes and Allies: The Southern Synthesis. Fauna of Australia. Vol. 4: Polychaeta, Myzostomida, Pogonophora, Echiura, Sipuncula. CSIRO Publishing, Melbourne, Vic.,pp. 161-167.

Góngora-Garza, G., García-Garza, M.E. \& de León-González, J.A. (2011) Two new species of Branchiosyllis (Polychaeta: Syllidae) from Western Mexico. Proceedings of the Biological Society of Washington, 124, 378-385.

Grube, A.E. (1850) Die Familien der Anneliden. Archiv für Naturgeschichte, 16, 249-364.

Johnson, H.P. (1902). Collateral budding in annelids of the genus Trypanosyllis. The American Naturalist, 36, 295-315.

Lamarck, J.B.P.A. (1818) Histoire Naturelle des animaux sans vertèbres, preséntant les caractères généraux et particuliers de ces animaux, leur distribution, leurs classes, leurs familles, leurs genres, et la citation synonymique des principales espèces qui s'y rapportent; precedes d'une Introduction offrant la determination des caractères essentiels de l'Animal, sa distinction du vegetal et des autres corps naturelles, enfin l'Exposition des Principes fondamentaux de la Zoologie, vol. 5. Deterville, Paris. 612 pp.

Langerhans, P. (1879) Die Wurmfauna von Madeira. Zeitschrift für wissenschaftliche Zoologie, $32,513-592$

Lattig, P. \& Martín, D. (2009) A taxonomic revision of the genus Haplosyllis Langerhans, 1887 (Polychaeta: Syllidae: Syllinae). Zootaxa, 2220, 1-40.

Lattig, P., Martin, D. \& San Martín G. (2010) Syllinae (Syllidae: Polychaeta) from Australia. Part 4. The genus Haplosyllis Langerhans, 1879. Zootaxa, 2552, 1-36.

Malaquin, A. (1893) Recherches sur les syllidiens. Morphologie, Anatomie, Reproduction, Développement. Mémoires de la Société des Sciences, de l'Agriculture et des Arts de Lille, $4^{\text {ème }}$ série, $18,1-477$.

Martin, D. \& Britayev, T.A. (1998) Symbiotic polychaetes: review of known species. Oceanography and Marine Biology: an Annual Review, 36, 217-340.

Martin, D., Marin, I. \& Britayev, T.A. (2008) Features of the first known association between Syllidae (Annelida, Polychaeta) and crustaceans. Organisms, Diversity \& Evolution, 8, 279-281. 
Müller, O.F. (1771) Von Würmern dês süssen und salzigen wassers. H. Mumme \& Faber.

Hof-Buchdrucke, Nicolaus Möller, Copenhague. 200 pp.

Nogueira, J.M.M. \& Yunda-Guarín, G. (2008) A new species of Syllis (Polychaeta: Syllidae: Syllinae) from off Fortaleza, north-eastern Brazil. Journal of the Marine Biological Association of the United Kingdom, 88, 1391-1399.

Nogueira, J.M.M., San Martín, G. \& Fukuda, M.V. (2004) On some exogonines (Polychaeta, Syllidae) from the northern coast of the State of São Paulo, southeastern Brazil - Results of BIOTA/FAPESP/BentosMarinho Project. Meiofauna Marina, 13, 45-78.

Nygren, A. (2004) Revision of Autolytinae (Syllidae: Polychaeta). Zootaxa, 680, 1-314.

Riera, R., Núnez, J. \& Brito, M.C. (2007) A new species of the interstitial genus Neopetitia (Polychaeta, Syllidae, Eusyllinae) from Tenerife, with modified acicular chaetae in males. Helgoland Marine Research, 61, 221-223.

Rullier, F. \& Amoureux, L. (1979) Annélides Polychètes. Annales de l'Institute Oceanographique, 55, 145-206.

San Martín, G. (1992) Syllis Savigny in Lamarck, 1818 (Polychaeta: Syllidae: Syllinae) from Cuba, the Gulf of Mexico, Florida and North Carolina, with a revision of several species described by Verrill. Bulletin of Marine Science, 51, 167-196.

San Martín, G. (2003) Annelida Polychaeta II: Syllidae. In: Ramos, M.A. et al. (eds.), Fauna

Ibérica, vol. 21. Museo Nacional de Ciências Naturales, CSIC, Madrid. 544 pp.

San Martín, G. (2004) Deep sea Syllidae from the Pacific Ocean, collected during cruises with the RV Sonne (Annelida, Polychaeta, Syllidae). Senckenbergiana Biologica, 84, 13-25.

San Martín, G. (2005) Exogoninae (Polychaeta, Syllidae) from Australia with the description of a new genus and twenty-two new species. Records of the Australian Museum, 57, 39152.

Spalding, M., Taylor, M., Ravilious, C., Short, F. \& Green, F. (2003) Global overview. The distribution and status of seagrasses. In: Green, E.P., Short, F.T., Spalding, M.D. (Eds.), World atlas of seagrasses: Present status and future conservation. California Press, Berkeley, 5-26.

Treadwell, A.L. (1909) Haplosyllis cephalata as an ectoparasite. Bulletin of the American Museum of Natural History, 26, 359-360.

Verger-Bocquet, M. (1983) Les organs photorécepteurs des Syllidiens (Annélides Polychètes). L’Année Biologique, 22, 169-185.

Westheide, W. (1974) Interstitielle Fauna von Galapagos. XI. Pisionidae, Pilargidae, Syllidae. Mikrofauna Meeres-bodens, 44, 195-338.

Zörner, S.A. \& Fischer, A. (2007) The spatial pattern of bioluminescent flashes in the polychaete Eusyllis blomstrandi (Annelida). Helgoland Marine Research, 61, 55-66. 


\section{CAPÍTULO 1}

Myrianida Milne Edwards, 1845 and Proceraea Ehlers, 1864

(Polychaeta: Syllidae: Autolytinae) from off northeastern

Brazil, with descriptions of three new species 

Myrianida Milne Edwards, 1845 and Proceraea Ehlers, 1864 (Polychaeta: Syllidae: Autolytinae) from off northeastern Brazil, with descriptions of three new species

\author{
KARLA PARESQUE ${ }^{1 *}$, MARCELO VERONESI FUKUDA ${ }^{1}$, JOÃO MIGUEL DE MATOS \\ NOGUEIRA $^{1} \&$ GUILLERMO SAN MARTÍN $^{2}$ \\ ${ }^{1}$ Laboratório de Poliquetologia, Departamento de Zoologia, Instituto de Biociências, \\ Universidade de São Paulo, R. do Matão, travessa 14, n. 101, 05508-900, São Paulo, SP, \\ Brazil; \\ ${ }^{2}$ Departamento de Biología (Zoología), Facultad de Ciencias, Universidad Autónoma de \\ Madrid, Madrid, Spain.
}

* corresponding author: kparesque@gmail.com

\title{
Table of contents
}

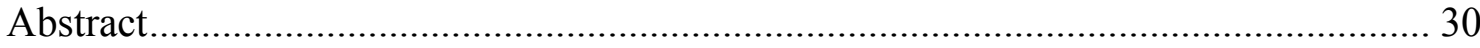

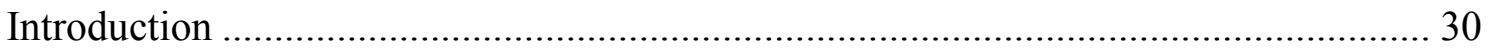

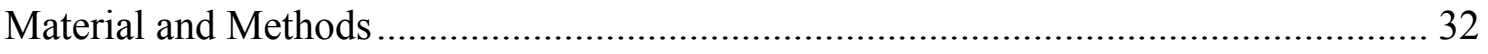

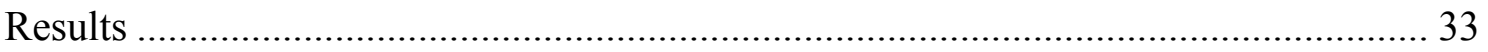

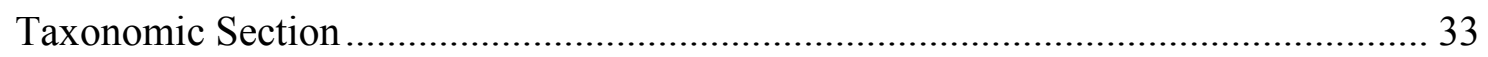

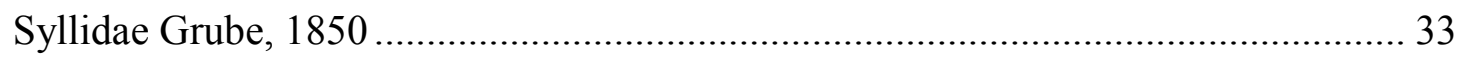

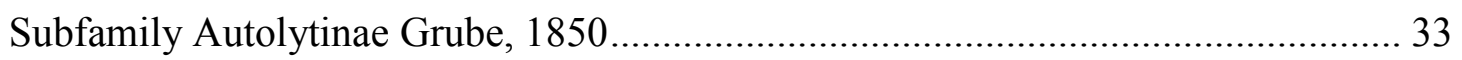

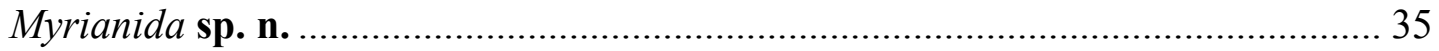

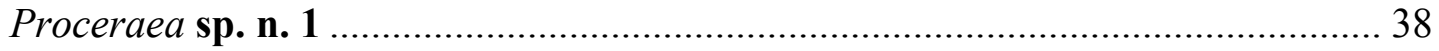

Proceraea madeirensis Nygren, 2004 ............................................................. 42

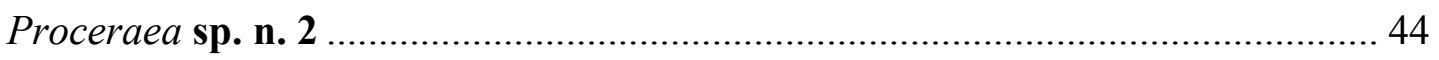

Proceraea rubroproventriculata Nygren \& Gidholm, 2001 ................................. 47

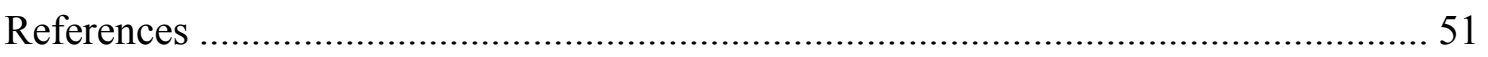

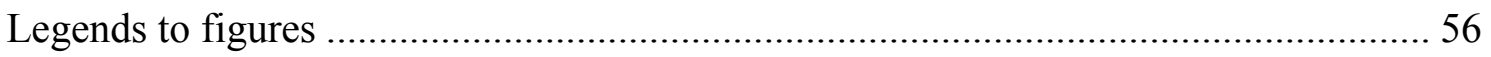




\section{Abstract}

During a study carried out in sandstone reefs off the states of Paraíba and Pernambuco (Brazil), 83 specimens of autolytines, belonging to 5 species, were found. Three species are new to science. Proceraea sp. n. 1 has a long pharynx, through more than 30 chaetigers, a trepan with 22 teeth, and a conspicuous colour pattern, with one black and one orange dorsal bars on each chaetiger. Proceraea sp. n. 2 has transverse dark stripes dorsally on some chaetigers along body, and trepan with 18 teeth, alternating one large and another small, tricuspidate teeth. Myrianida sp. n. has some blue dorsal cirri, transverse orange stripes dorsally, and a trepan with 30 teeth, all about the same size. Proceraea rubroproventriculata is a new reports for the northeastern Brazil and Proceraea madeirensis is a new record from South Atlantic. The Brazilian specimens are compared to the most similar congeners. A key for the species described in this paper is provided.

Keywords: Autolytinae, new species, new occurrence, taxonomy, Southwestern Atlantic, sponge associations.

\section{Introduction}

Autolytines inhabit shallow waters and are mostly associated to sedentary invertebrates (Nygren et al. 2010). They range from 1-60 mm in length and from $0.1-1.2 \mathrm{~mm}$ in width (Nygren \& Pleijel 2010). The Autolytinae Grube, 1850 has been recently studied (Nygren 1999; Nygren \& Gidholm 2001; Nygren \& Sundberg 2003; Nygren 2004; Nygren \& Pleijel 2007, 2010; Nygren et al. 2010) and currently comprises 12 genera 
and more than 100 valid species (Nygren \& Pleijel 2010; Aguado \& San Martín 2009; Aguado et al. 2012), most of them with convoluted pharynx, lacking ventral cirri, and with bayonet-like dorsal simple chaetae (Nygren 2004). According to the reproductive strategies adopted, the Autolytinae are divided three major lineages (Nygren 2004; Nygren \& Pleijel 2007): 1.- Procerini Nygren, 2004, with anterior scissiparity (genus Proceraea Ehlers, 1864), 2.- Epigamia Nygren, 2004 with epigamy, and 3.Autolytini Grube, 1850 with gemmiparity (genus Myrianida Milne Edwards, 1845).

Among the Autolytinae, Myrianida and Proceraea comprise 27 and 26 valid species, respectively. Proceraea rubroproventriculata Nygren \& Gidholm, 2001 is the only representative originally described from Brazil (Nygren \& Gidholm 2001). Some other species have been reported, but not formally published, Proceraea picta Ehlers, 1864 and Myrianida brachycephala (Marenzeller, 1874) (as Autolytus brachycephalus) in Nogueira (2000), Myrianida convoluta (Cognetti, 1953) (as Autolytus (Regulatus) convolutus) and Proceraea cornuta (Agassiz, 1862) (as Autolytus (Regulatus) cornutus) in Nogueira \& Amaral (1997) apud Amaral et al. 2013), and Myrianida dentalia (Imajima, 1966) and Proceraea okadai (Imajima, 1966) (Fukuda 2010). Autolytus prolifer (Müller, 1788), was also cited (Machado 1986), but is no longer valid (Nygren 2004). In addition, the name $A$. prolifer has been erroneously used for many inadequately determined species, as well as for stolons of various taxa. Therefore, the real identity of these specimens cannot be assessed.

We studied the fauna of autolytines from Paraíba and Pernambuco, northeastern Brazil. As a result, we found three species new to Science and two new occurrences for the Southern Atlantic. All these species are fully described and illustrated herein. 


\section{Material and Methods}

The material examined was collected by the project "Diversity of Polychaeta (Annelida) on hard substrates off the states of Paraíba and Pernambuco, northeastern Brazil". Collections were made at neap tide from reefs off Mataraca (Barra de Camaratuba,

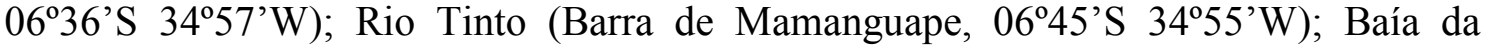
Traição (Ponta da Prainha $06^{\circ} 41^{\prime} \mathrm{S} 3^{\circ} 4^{\circ} 55^{\prime} \mathrm{W}$ ); Cabedelo (Píer de Cabedelo, 06 $58^{\circ} \mathrm{S}$ 34 $50^{\prime} \mathrm{W}$ ), João Pessoa (Praia do Cabo Branco, $07^{\circ} 08^{\prime} \mathrm{S} 34^{\circ} 47^{\prime} \mathrm{W}$ ), Conde (Praia de Carapibus, $07^{\circ} 17^{\prime} \mathrm{S} 34^{\circ} 48^{\prime} \mathrm{W}$; Praia do Coqueirinho, $07^{\circ} 18^{\prime} \mathrm{S} 34^{\circ} 47^{\prime} \mathrm{W}$; Praia de Tabatinga $07^{\circ} 19^{\prime} \mathrm{S} 34^{\circ} 47^{\prime} \mathrm{W}$ ), Goiana (Pontas de Pedra, $7^{\circ} 37^{\prime} \mathrm{S} 34^{\circ} 48^{\prime} \mathrm{W}$ ), Ilha de Itamaracá (Ponta do Jaguaribe, 744’S 3449’W), Sirinhaém (Barra do Sirinhaém, $8^{\circ} 37^{\prime} S 35^{\circ} 2^{\prime} \mathrm{W}$ ) and São João da Coroa Grande (Recifes de São João da Coroa Grande, $\left.8^{\circ} 54^{\prime} \mathrm{S} 35^{\circ} 8^{\prime} \mathrm{W}\right)$. Algae, sponges, ascidians, mussel beds and similar substrates were scrapped from the rocks and examined under stereomicroscope. Syllids were sorted, relaxed in a menthol solution, preserved in $4 \%$ formaline solution and later rinsed in fresh water and transferred to $70 \%$ ethanol.

Further analyses under stereo and light microscopes were made from specimens preserved in ethanol, some of which permanently mounted on slides in glycerine jelly. For the examination under SEM, at least one specimen of each species was dehydrated in a series of progressively increasing concentrations of ethanol solutions, then critical point dried, covered with $25 \mathrm{~nm}$ of gold and examined and photographed under SEM at Laboratório de Microscopia Eletrônica, Instituto de Biociências, Universidade de São Paulo (IB/USP). Line drawings were made with the aid of a drawing tube, from slide mounted specimens. 
For the new species, the entire type-series was measured and comparative tables are provided. Type materials are deposited at the Museu de História Natural (ZUEC), IB-UNICAMP, Brazil; Museu de Zoologia da Universidade de São Paulo (MZUSP), Brazil; and Museo Nacional de Ciéncias Naturales (MNCN), Spain.

\section{Results}

Taxonomic Section

Syllidae Grube, 1850

Subfamily Autolytinae Grube, 1850

Key for the identification of the species of Autolytinae occurring off northeastern

\section{Brazil}

1a. Compound chaetae with large distal tooth, about the same size as subdistal one (Fig. 5C); dorsal cirri oval to digitiform; live specimens lacking blue pigmentation dorsally...2

1b. Compound chaetae with short distal tooth; dorsal cirri elongated (Fig. 2B); live specimens with blue pigmentation dorsally and some dorsal cirri...Myrianida $\mathbf{s p .} \mathbf{n}$.

2a. (1a) Pharynx through $\sim 35$ chaetigers; live specimens with one black and another orange transverse stripes dorsally on each chaetiger...Proceraea $\mathbf{s p . \mathbf { n } . 1}$

2b. (1a) Pharynx through 4-9 chaetigers; live specimens with different colour pattern...3

3a. (2b) Live specimens with colorless proventricle, with $\sim 60$ muscle cell rows, and transverse brown-yellowish stripes dorsally along the body; trepan with 18 unequal teeth...Proceraea madeirensis 
3b. (2b) Live specimens with partially pigmented proventricle, with up to 40 muscle cell rows, and either with reddish-brown transverse stripes dorsally along the body or unpigmented; trepan with 18-24 unequal teeth...4

4a. (3b) Live specimens with orange anterior third of the proventricle and reddishbrown transverse stripes dorsally along the body; trepan with 18 unequal teeth, 9 large and 9 small, arranged in 1 ring, the smaller with tricuspidate...Proceraea $\mathbf{s p .}$ n. 2

4b. (3b) Live specimens with orange anterior and posterior thirds of proventricle and unpigmented body; trepan in chaetigers 1-2, with 22-24 unequal teeth, 11-12 large and 11-12 small, arranged in 2 rings; basal ring present...Proceraea rubroproventriculata

\section{Genus Myrianida Milne Edwards, 1845}

Type species: Myrianida fasciata Milne Edwards, 1845, by monotypy.

Diagnosis (after Nygren 2004). Prostomium rounded to rectangular, four eyes in trapezoid arrangement, pair of anterior eyespots present or not. Palps usually basally fused, completely fused in some taxa, generally ventrally bent, sometimes projecting for little extension in front of prostomium. Nuchal epaulettes of varying length among species, extending from end of peristomium to end of chaetiger 12 (Nygren 2004). Peristomium with two pairs of cirri. Antennae and cirri cylindrical to flattened, with intermediate degrees. Compound chaetae as compound chaetae with bidentate blades. Dorsal simple chaetae bayonet-like. Pharynx with single to multiple sinuations anterior and, sometimes, lateral to proventricle. Trepan arranged in one ring, sometimes with basal ring. Pygidium with one pair of cirri, median papilla absent. 


\section{Myrianida sp. n.}

(Figures 1-2; Table 1)

Material Examined. Type series. State of Pernambuco: Goiana, Pontas de Pedra (7³7'S 344ㅇ' W): holotype and 2 paratype, coll. 13 December 2012 (data of specimens of the type series are provided in Table 1)

Description. Medium-sized body, holotype with 33 segments, $3.3 \mathrm{~mm}$ long, excluding stolons and $0.8 \mathrm{~mm}$ wide. Conspicuous pigmentation in vivo (Fig. 1A-C), orange nuchal epaulettes, one transverse orange stripe dorsally at each $2-4$ segments, beginning from proventricle level, stripes larger on anterior segments; grey-bluish antennae, blue or grey dorsal cirri throughout. Preserved material colorless. Semicircular palps, shorter than prostomium, completely fused to each other. Prostomium rounded to subpentagonal, with two pairs of eyes in trapezoidal arrangement; lateral antennae inserted on anterior margin of prostomium, reaching $\sim$ chaetiger 5 if deflected posteriorly; median antenna inserted on posterior margin of prostomium, between posterior eyes, thicker and almost twice as long as lateral antennae, reaching $\sim$ chaetiger 10 if deflected posteriorly (Fig. 2A); prostomium with paired row of cilia between median and lateral antennae, and scattered tufts of cilia on all antennae. Peristomium slightly shorter than subsequent segments (Fig. 2A); dorsal peristomial cirri slightly longer than lateral antennae, ventral peristomial cirri approximately $1 / 2$ length of dorsal peristomial cirri (Fig. 2A). Nuchal epaulettes extending until end of chaetiger 2 (Fig. 1A). Dorsal cirri of chaetiger 1 blue (Fig. 1A), about same size as median antenna or slightly longer, reaching $\sim$ chaetiger 12 ; dorsal cirri of chaetigers $2,3,5,7$ and 8 grey, short, about same size as dorsal peristomial cirri; dorsal cirri of chaetigers 4 and 6 blue, slightly longer than remaining ones; from chaetiger 9, dorsal cirri alternating grey and 
blue, blue cirri slightly thicker than grey ones; all appendages with cirrophores (Fig. 2A). Parapodial lobes conical, distally blunt (Fig. 1B-C). Anterior parapodia with 18-25 compound chaetae each, midbody parapodia with $12-17$, posterior ones with $10-$ 14 compound chaetae each; shafts of compound chaetae subdistally inflated and spinulated (Fig. 2B-C, F); blades with short spines on margin bidentate, distal tooth shorter than subdistal one (Fig. 2B-C, F); blades with inconspicuous inverse anteroposterior gradation in length and slight progressively longer ventralwards within each parapodium, 8-12 $\mu \mathrm{m}$ long on anterior and midbody chaetigers, 6-10 $\mu \mathrm{m}$ long on stolon chaetigers (Fig. 2B-C, F). Dorsal simple chaetae from chaetiger 11 onwards, thinner than shafts of compound chaetae, bayonet-like, subdistally spinulated (Fig. 2D-E). Anterior parapodia with 2-3 aciculae each, median and posterior parapodia with 1-2 aciculae. Pygidium not seen. Pharynx through 5 chaetigers, with 1 sinuation anterior to proventricle (Figs 1D; 2A), trepan in chaetiger 2, with $\sim 30$ teeth about the same size, arranged in 1 ring, basal ring and infradental spines present (Fig. 1E-F); proventricle through 2 segments (Fig. 2A), with $\sim 27$ muscle cell rows (Fig. 1D).

Reproduction. Schizogamous reproduction by gemmiparity, posteriorly to chaetiger 33 . Holotype with two stolons posteriorly, the fist with 10 chaetigers, $0.8 \mathrm{~mm}$ long, and the second with 19 chaetigers, $2.4 \mathrm{~mm}$ long.

Remarks. Myrianida sp. n. ressembles Myrianida pachycera (Augener, 1913), a wide-spread taxa which, according to molecular data inference, might have been spread by human activity (Nygren 2004). However, M. pachycera has long dorsal cirri, blue dots and some orange stripes on dorsum, eye spots, nuchal epaulettes reaching chaetigers 4-7, and trepan with 37-39 unequal teeth, 11 large and 26-28 small, while Myrianida sp. n. does not have blue dots on dorsal surface, lacks eye spots, its nuchal 
epaulettes do not reach beyond chaetiger 2 , and has trepan with $\sim 30$ teeth of similar size.

Preserved specimens may be confused with M. brachycephala, M. hesperidium (Claparède, 1868), M. juventudensis (San Martín, 1994), M. langerhansi (Gidholm, 1967) and M. quindecimdentata (Langerhans, 1884) by the morphology of chaetae, size of nuchal epaulettes and median antenna, and by the number of muscle cell rows and chaetigers occupied by the proventricle. However, the number of chaetae per parapodium and the morphology of the trepan differ: M. brachycephala has 10-15 chaetae on anterior parapodia and 4-9 on mid- and posterior parapodia, and trepan with 22-29 unequal teeth, 2-10 large alternating with 14-21 smaller; $M$. hesperidium has 714 chaetae on anterior parapodia and 3-8 on mid- and posterior body parapodia, and trepan with 12-13 equal-sized teeth; M. juventudensis has 7 chaetae on anterior parapodia and 3-5 on posterior parapodia, and trepan with 43 equal-sized teeth; $M$. langerhansi has 13-16 chaetae on anterior parapodia and 4-10 on midbody and posterior parapodia, and trepan with 30-43 unequal teeth, 4-5 large alternating with $25-$ 39 small teeth; $M$. quindecimdentata has $7-12$ chaetae on anterior parapodia end 3-6 on mid- and posterior parapodia, and trepan with 12-24 equal-sized teeth (Nygren 2004).

\section{Genus Proceraea Ehlers, 1864}

Type species: Proceraea picta Ehlers, 1864, by monotypy.

Diagnosis. (after Nygren 2004). Body usually long and slender, thread-like. Palps totally fused or with terminal notch, ventrally bent. Prostomium rounded to rectangular, 
with four eyes in trapezoidal arrangement; pair of anterior eyespots present or not. Peristomium with two pairs of cirri. Dorsal cirri of chaetigers 1 and 2 longer than remaining ones, cirri usually of uniform length from chaetiger 3 onwards. Compound chaetae with blades uni- or bidentate, smooth or spinulated. Dorsal simple chaetae usually thick, bayonet-like, distally or subdistally spinulated. Pharynx with one to various sinuations anteriorly and, sometimes, running laterally to proventricle; trepan with two rings of teeth, alternating large and small teeth in different configurations (Nygren 2004); trepan with basal ring, infradental spines absent. Pygidium with one pair of cirri, median papilla absent.

\section{Proceraea sp. n. 1}

(Figures 3-8; Table 2)

Material examined. State of Paraíba: Conde, Praia do Coqueirinho ( $\left.07^{\circ} 18^{\prime} \mathrm{S} 34^{\circ} 47^{\prime} \mathrm{W}\right)$, 1 specimen, coll. 28 August 2011; Praia de Tabatinga (07 $\left.19^{\prime} \mathrm{S} 34^{\circ} 47^{\prime} \mathrm{W}\right)$, associated with Amphimedon viridis Duchassaing \& Michelotti, 1864, 2 specimens, coll. 01 September 2011. State of Pernambuco: Goiana, Pontas de Pedra (7³7’S 34²48’W), 1 specimen, coll. 13 December 2012. Ilha de Itamaracá, Ponta do Jaguaribe $\left(7^{\circ} 44^{\prime} \mathrm{S}\right.$ 34²9'W), 2 specimens, coll. 11 December 2012. Type series. State of Paraíba: Mataraca, Barra de Camaratuba, (06 $\left.36^{\prime} \mathrm{S} 34^{\circ} 57^{\prime} \mathrm{W}\right)$, intertidal: 1 paratype, coll. 12 August 2010; Conde, Praia de Tabatinga, (07 $\left.17^{\circ} \mathrm{S} 34^{\circ} 47^{\prime} \mathrm{W}\right)$, intertidal: holotype, coll. 17 September 2012; 2 paratypes, coll. 01 September. 2011; Praia do Coqueirinho $\left(07^{\circ} 18^{\prime} \mathrm{S} 34^{\circ} 47^{\prime} \mathrm{W}\right)$, intertidal: 1 paratype, coll. 28 August 2011; Praia de Carapibus $\left(07^{\circ} 17^{\prime} \mathrm{S} 34^{\circ} 48^{\prime} \mathrm{W}\right)$, intertidal: 1 paratype, coll. 10 February 2009. (Data of selected specimens of the type series are provided in Table 2). 
Description. Long-sized body, largest specimen with 380 segments, $110 \mathrm{~mm}$ long, $0.6 \mathrm{~mm}$ wide. Conspicuous pigmentation in vivo (Fig. 3A-E), posterior part of prostomium and nuchal epaulettes orange, black longitudinal line between nuchal epaulettes, each segment dorsally with broad black and bright orange to red transverse bars, orange one slightly larger, more conspicuous on anterior and midbody chaetigers; anterior appendages with white iridescent inclusions (Fig. 3A, D), brownish-black dorsal cirri from chaetiger 3 to midbody chaetigers, dorsal cirri from posterior body chaetigers and anal cirri white. Body pigmentation distinctly fainter after preservation, only black bars remaining, brownish, as well as dorsal cirri from anterior and midbody chaetigers (Fig. 4A-B, D). Scattered cilia on dorsal and ventral surfaces, as well as on antennae, dorsal cirri and parapodia throughout (Figs 5C, F, I; 7B, H). Palps semicircular, shorter than prostomium, completely fused to each other or with terminal notch (Figs 5A; 6A), each with a longitudinal row of cilia ventrally (Fig. 7C). Prostomium subpentagonal, with two pairs of eyes in trapezoidal arrangement (Fig.6); lateral antennae inserted on anterior margin of prostomium, reaching $\sim$ chaetiger $6-7$ if deflected posteriorly (Figs 6A; 7A); median antenna inserted on posterior margin of prostomium, between posterior eyes, almost twice as long as lateral antennae, reaching $\sim$ chaetigers $13-14$ if deflected posteriorly (Fig. 6A). Nuchal epaulettes reaching posterior margin of chaetiger 2 (Figs 5B;6A). Peristomium slightly shorter than subsequent segments (Fig. 6A); dorsal peristomial cirri about same length as lateral antennae, ventral peristomial cirri approximately $1 / 2$ length of dorsal peristomial cirri (Fig. 6A). Dorsal cirri of chaetiger 1 similar in size to median antenna or slightly shorter, reaching $\sim$ chaetiger $15-16$ if deflected posteriorly; dorsal cirri of chaetiger 2 shorter, about same size as ventral peristomial cirri; antennae, peristomial and dorsal cirri of chaetiger 1 with cirrophores (Fig. 6A); oval dorsal cirri from chaetiger 3 
onwards, shorter than $1 / 4$ of body width, all about same length (Figs 6A; 7D). Parapodial lobes conical, distally rounded (Figs 6A; 7D-G, I-J; 8D), with numerous pores ventrally (Figs 5I; 8D). Anterior parapodia with 6-19 compound chaetae each, midbody parapodia with $6-18$, posterior parapodia with $2-6$ compound chaetae each; shafts of compound chaetae subdistally inflated and spinulated, with acute tip (Figs 6C, E, G; 8B-D, F, I); blades of compound chaetae smooth and bidentate, teeth about same size (Figs 6C, E, G; 8B, F, I), blades without antero-posterior gradation in length, progressively longer ventralwards within each parapodium, 5-7 $\mu \mathrm{m}$ long on anterior, mid- and posterior body parapodia (Fig. 6C, E, G). Dorsal simple chaetae from chaetiger 1-16, thinner than shafts of compound chaetae, bayonet-like, subdistally spinulated (Fig. 6B, D, F; 8A, E, G-H). Anterior parapodia with 2 aciculae each, midbody and posterior parapodia with 1 acicula each. Pygidium oval with thick pair of anal cirri, with $\sim 2 / 3$ as long as posterior body width (Fig. 7I-J). Pharynx through about 28-43 chaetigers (Fig. 4A), with 1-2 sinuations anterior to proventricle, trepan chaetiger 8-19, with 22 teeth of two sizes, 11 large and 11 small, arranged in 1 ring; basal ring absent (Figs 4C; 5D-E, H); proventricle through 4-7 segments (Fig. 4A, D), with 48-58 muscle cell rows (Fig. 5G).

Reproduction. We found a tube with tree fragments of Proceraea sp. n. 1, including reproductive ones (Fig. 4E-G), which we could not determine if belong to one or more specimens. Anteriormost fragment with head and 48 chaetigers, without any sign of reproductive modifications; second piece, a female stolon with $\sim 65$ chaetigers with two large eyes, carrying eggs along the body (Fig. 4E-F), with natatory chaetae anteriorly; third piece a midbody fragment, without natatory chaetae. In addition, we found some individuals regenerating the anterior and posterior body (Fig. 4B); in both 
cases, the newly formed segments have white dorsal cirri and a single, thin, brown stripe dorsally.

Remarks. Proceraea sp. n. 1 was found in association with the sponge $A$. viridis, very abundant in the studied area. Specimens of Proceraea sp. n. 1 become visible as the "tissues" of the sponge were torn apart in vivo to extract the polychaetes (Fig. 3E). However, our methodology does not allow us to state wheter this species lives exclusively within $A$. viridis or was also present in different substrates, including other species of sponges found close to A. viridis. Another interesting topic about the new species regards the size and posterior position of the proventricle, pharynx and trepan. In the syllids species, since are used in the alimentation, they were on anteriormost chaetigers, and pharynx though few segments. In the specimens analised from northeastern Brazil, all of them in good conditions, the trepan is located between chaetigers $8-19$, the proventricle between the chaetigers $37-51$, the pharynx through 28-43 chaetigers. Complementary analysis of live specimens are needed to understanding how can these work.

Proceraea sp. n. 1 is similar to P. anopla (Monro, 1933), from the Caribbean Sea, in the pigmentation pattern. However, the specimens from Brazil have posterior dorsal cirri white and large pharynx, through $28-43$ chaetigers, with 22 teeth in the trepan, 11 large and 11 small, without basal ring. Proceraea anopla has posterior dorsal cirri reddish-black and shorter pharynx, through about 4-8 chaetigers, with 18 teeth in the trepan, 9 large and 9 small, with basal ring (Nygren 2004). To confirm this last difference, the holotype and others specimens of $P$. anopla should be analysed, because the number of teeth may have been misinterpreted (Arne Nygren, personal communication to KP). 


\section{Proceraea madeirensis Nygren, 2004}

Figures 9-12

Procereaea fasciata Langerhans, 1879: 581, Fig. 33A-C. Junior homonym of Nereis fasciata Bosc, 1802.

?Autolytus (Proceraea) fasciata. Augener 1913: 264-265.

?Proceraea fasciata. Westheide 1974: 323-325, Figs 61-62; Hartmann-Schröder 1987: 44-45, Figs 20-22.

Proceraea madeirensis nom. n. Nygren 2004: 56-57, Fig. 15A-B.

Proceraea madeirensis. Nygren et al. 2010: 45-47, Figs 3B-D, 5C-E.

Material examined. State of Paraíba: Conde, Praia de Tabatinga $\left(07^{\circ} 19^{\prime} \mathrm{S} 34^{\circ} 47^{\prime} \mathrm{W}\right), 1$ specimen, coll. 01 September 2011; Praia de Tambaba (07² $\left.1^{\prime} \mathrm{S} 34^{\circ} 47^{\prime} \mathrm{W}\right), 1$ specimen, coll. 30 August 2011.

Description. Medium-sized body, largest specimen examined with 38 segments, $5.5 \mathrm{~mm}$ long, $0.5 \mathrm{~mm}$ wide. Live specimens with broad, brown transverse bands dorsally on each segment; antennae, dorsal peristomial cirri and dorsal cirri of chaetiger 1 brownish (Fig. 9A-C). Preserved material with brown stripes fainted (Fig. 9D). Palps semi-circular, shorter than prostomium, completely fused to each other. Prostomium rounded to rectangular, with two pairs of eyes in trapezoidal arrangement; lateral antennae inserted on anterior margin of prostomium, reaching $\sim$ chaetigers $3-4$ if deflected posteriorly; median antenna inserted near posterior margin of prostomium, between posterior eyes, almost 3 times longer than lateral antennae, reaching $\sim$ chaetigers $8-9$ if deflected posteriorly (Fig. 9A-C). Peristomium slightly longer than chaetiger 1, about same length as subsequent segments (Fig. 10A-B); dorsal peristomial cirri about same length as lateral antennae or slightly longer, ventral peristomial cirri $\sim 1 / 2$ length of dorsal peristomial cirri (Fig. 10A-C). Dorsal cirri of chaetiger $1 \sim 2 / 3$ length of median antenna, reaching $\sim$ chaetiger 6-7 if deflected posteriorly; dorsal cirri 
of chaetiger $2 \sim 2 / 3$ length of ventral peristomial cirri; antennae, peristomial and dorsal cirri of chaetiger 1 with cirrophores (Fig. 10B); dorsal cirri from chaetiger 3 onwards cylindrical, $\sim 1 / 4$ length of body width at corresponding segment, of uniform length (Figs 10D; 11D); scattered cilia on antennae and cirri (Fig. 10A-B). Nuchal epaulettes reaching end of peristomium, densely ciliated on margins (Fig. 10A-B). Parapodial lobes conical, distally rounded (Figs $10 \mathrm{~A}-\mathrm{D} ; 11 \mathrm{C}-\mathrm{D}, \mathrm{F}$ ). Anterior parapodia with 5-7 compound chaetae each, mid- and posterior body parapodia with 3-5 compound chaetae each; shafts of compound chaetae subdistally inflated and spinulated, with acute, slightly sigmoid tip (Figs 12B, D; 11E); blades of compound chaetae spinulated and bidentate, teeth about same size, close to each other (Figs 12B, D; 11A-B, E, H), blades with inconspicuous antero-posterior gradation in length, progressively longer ventralwards within each parapodium, 4-7 $\mu \mathrm{m}$ long on anterior and midbody parapodia (Fig. 11E, G, H), 5-8 $\mu \mathrm{m}$ long on posterior parapodia. Dorsal simple chaetae from chaetigers 1-5, bayonet-like, subdistally spinulated (Fig. 12A, C), slightly tinner than shafts of compound chaetae on anterior and midbody parapodia (Fig. 12A-D; 11A-B), about same width as shafts of compound chaetae in posterior body chaetigers (Fig. 11H). Anterior and midbody parapodia with 2 aciculae each, posterior parapodia with single acicula each; aciculae straight, with tapering tip. Pygidium semi-circular, with short, cylindrical pair of anal cirri, $\sim 2 / 3$ as long as posterior body width (Fig. 11D). Pharynx through about 5-9 chaetigers, with 1 sinuation anterior to proventricle (Fig. 9D), trepan in chaetigers 1-2, with 18 unequal teeth, 9 large and 9 small, arranged in 2 rings; basal ring present; proventricle through 3-4 segments, with $\sim 61$ muscle cell rows. 
Remarks. Brazilian specimens have blades of compound chaetae with teeth closer to each other than the holotype (Nygren 2004) and newly collected specimens by Nygren et al. (2010), and the dorsal brown bands are narrower in Brazilian material. Preserved specimens are similar to P. penetrans (Wright \& Woodwick, 1977) on the morphology of trepan, teeth of compound chaetae and number of chaetae per parapodium along the body. However, P. penetrans lives associated with Allopora california Verril, 1866, a hydrocoral from California (Wright \& Woodwick, 1997), compound chaetae lacking serration and proventricle has 34 muscle cell rows occupying 2.5 chaetigers while $P$. madeirensis lives on other substrates, its compound chaetae with serration and proventricle with 55-60 muscle cell rows, occupying 3-4 chaetigers.

Type locality. Atlantic Ocean (Madeira Island).

Distribution. Atlantic Ocean (Madeira Island and Northeast of Brazil, first occurrence).

\section{Proceraea sp. n. 2}

(Figures 13-18; Table 3)

Material examined. Type series. State of Paraíba, Baía da Traição, Praia do Farol $\left(06^{\circ} 41^{\prime} \mathrm{S} 34^{\circ} 55^{\prime} \mathrm{W}\right)$, intertidal: 1 paratype, coll. 09 August 2010. Conde, Praia de Tabatinga $\left(07^{\circ} 19^{\prime} \mathrm{S} 34^{\circ} 47^{\prime} \mathrm{W}\right)$, intertidal: 1 paratype, coll. 17 September 2012; Praia do Coqueirinho $\left(07^{\circ} 18^{\prime} \mathrm{S} 34^{\circ} 47^{\prime} \mathrm{W}\right), 1$ paratype, coll. 28 August 2011. State of Pernambuco, Goiana, Pontas de Pedra ( $\left.7^{\circ} 37^{\prime} \mathrm{S} 34^{\circ} 48^{\prime} \mathrm{W}\right), 1$ paratype, coll. 13 December 2012. Data of selected specimens of the type series are provided in Table 3.

Description. Medium-sized body; longest specimen analysed with 68 segments, $9 \mathrm{~mm}$ long, $0.43 \mathrm{~mm}$ wide. Conspicuous pigmentation on living animals, posterior part 
of prostomium and nuchal epaulettes orange; anterior and midbody segments, between chaetigers 3-50, with transverse reddish-brown bands dorsally, intersegmental, at every two segments on anterior body, at every four segments on midbody; anterior third of proventricle orange to red (Fig. 13A-C); median antenna white iridescent (Fig. 13A-C). Preserved material with fainted, brownish dorsal bands. Scattered cilia on dorsal surface along the body (Figs 14A-C; 15A-C, E-H; 16H, K); anterior chaetigers with transverse row of cilia ventrally (Figs 14F; 15D). Semi-circular palps, shorter than prostomium (Fig. 17A), completely fused to each other, each with one row of cilia close to anterior border ventrally (Fig. 14D, F, H). Prostomium subpentagonal (Fig. 14C), with 2 pairs of eyes in trapezoidal arrangement, pair of anterior eyespots absent; semi-circular ciliar trait from each side of base of median antenna to bases of lateral antennae (Fig. 14C); lateral antennae inserted on anterior margin of prostomium, reaching $\sim$ chaetiger $5-6$ if deflected posteriorly; median antenna inserted near posterior margin of prostomium, between posterior eyes, almost 3 times longer than lateral antennae, reaching $\sim$ chaetigers 15-16 if deflected posteriorly (Fig. 17A), antennae with scattered tufts of cilia, mostly on distal third (Figs 14B; 16A-D). Peristomium about same length as subsequent segments (Figs 14B-C; 17A); dorsal peristomial cirri $\sim 2 / 3$ length of lateral antennae, ventral peristomial cirri $\sim 1 / 2$ length of dorsal peristomial cirri (Fig. 17A); peristomial cirri with scattered tufts of cilia (Fig. 16E, M). Dorsal cirri of chaetiger 1 about three times longer than median antenna or slightly shorter, reaching $\sim$ chaetigers $18-19$ if deflected posteriorly; dorsal cirri of chaetiger 2 slightly shorter, $\sim 2 / 3$ length of ventral peristomial cirri, also with scattered tufts of cilia (Fig. 16I); antennae, peristomial and dorsal cirri of chaetiger 1 with cirrophores (Fig. 17A); from chaetiger 3, dorsal cirri digitiform, shorter than $1 / 3$ of body width at corresponding segment, of uniform length (Figs 14A-C; 15A-C, E-H; 17A); dorsal cirri with scattered pores 
(Fig. 16L) and tufts of cilia (Fig. 15A-B, F-G), and ciliated tips (Fig. 16F, I-J, N). Nuchal epaulettes reaching end of chaetiger 1 (Fig. 14B-E). Parapodial lobes conical, distally rounded (Fig. 15B), with scattered pores and tufts of cilia dorsal and ventrally (Fig. 16G). Anterior parapodia with 7-13 compound chaetae each, midbody parapodia with 5-13, posterior parapodia with 2-4 compound chaetae each; shafts of compound chaetae subdistally inflated and spinulated, with acute, slightly sigmoid tip (Figs 17B, D, F; 18B-C, E-G, I, K); blades of compound chaetae with short spinulation, bidentate, distal tooth shorter than subdistal one on anterior parapodia, difference in sizes more conspicuous on dorsalmost chaetae; blades of compound chaetae on mid- and posterior body chaetigers with teeth about same size, or distal tooth just slightly shorter than subdistal one (Fig. 17B, D, F); blades shorter posteriorwards, progressively longer ventralwards within each parapodium, 4-7 $\mu \mathrm{m}$ long along body (Fig. 17B, D, F). Dorsal simple chaetae beginning on chaetigers $3-16$, thinner than shafts of compound chaetae, bayonet-like, subdistally spinulated (Figs 17C, E; 18A, C-F, H-J). Anterior parapodia with 1-2 aciculae each, midbody and posterior parapodia with 1 acicula each. Pygidium as long as posterior chaetigers dorsally, semi-circular and expanded ventrally, with thick, digitiform pair of anal cirri, longer than body width at posterior body (Figs 14A; 160). Pharynx through 4-6 chaetigers, with single sinuation anterior to proventricle; trepan in $\sim$ chaetiger 3 (Fig. 17A), with 18 unequal teeth, 9 large and 9 small, arranged in 1 ring, the smaller with tricuspidate tips (Fig. 17G); basal ring absent; proventricle through 2.5-3.5 segments, with 30-40 muscle cell rows.

Variation. Juveniles with transverse, intersegmental dorsal bands between every segment until chaetiger 9, from chaetiger 10 onwards, bands occur at every 2-4 segments (Fig. 13B); with a red spot on the base of parapodia ventrally. 
Remarks. Proceraea sp. n. 2 ressembles $P$. fasciata in having reddish, transverse stripes along the body, blades of compound chaetae with distal tooth shorter than subdistal one on anterior body chaetigers, teeth about same size from midbody, thick dorsal simple chaetae, and trepan with 18 teeth. However, the short pharyngeal teeth are tricuspidate in the former and monocuspidate in the later. In turn, $P$. fasciata has red spots on the base of parapodia, brown nuchal epaulettes, reaching posterior margin of chaetiger 1 , median antenna reaching $\sim$ chaetigers $8-12$ if deflected posteriorly, dorsal simple chaetae beginning from chaetigers 14-15 (Nygren 2004). Proceraea sp. n. 2 lacks the spots on the base of parapodia, nuchal epaulettes are orange and reach beginning of chaetiger 1 , median antenna reaches $\sim$ chaetigers $15-16$ if deflected posteriorly, dorsal simple chaetae begins from chaetiger 3-16.

Tricuspidate pharyngeal teeth are only known to occur in P. setoensis (Imajima, 1966), which has long teeth tricuspidate, while in Proceraea sp. n. 2 only short teeth are tricuspidate. Moreover, living specimens of $P$. setoensis are orange, without other colour marks, and blades of compound chaetae of anterior chaetigers are unidentate (Nygren 2004).

\section{Proceraea rubroproventriculata Nygren \& Gidholm, 2001}

(Figures 19-22; Table 4)

Proceraea rubroproventriculata Nygren \& Gidholm, 2001: 184-187, Figs 2D-E, 5A-E, 6A-D, 7; Nygren 2004: 74-75, Fig. 27 A-E.

Material examined. State of Paraíba: Rio Tinto, Barra de Mamanguape $\left(06^{\circ} 45^{\prime} \mathrm{S}\right.$ 34 $\left.55^{\circ} \mathrm{W}\right), 3$ specimens, coll. 11 August 2010. Cabedelo, Píer de Cabedelo (06 $58^{\circ} \mathrm{S}$ 
34 $\left.50^{`} W\right), 1$ specimen, coll. 12 February 2009. João Pessoa, Praia do Cabo Branco $\left(07^{\circ} 08^{\prime} \mathrm{S} 34^{\circ} 47^{\prime} \mathrm{W}\right), 2$ specimens, coll. 09 February 2009. Conde, Praia do Coqueirinho (07 $\left.18^{\prime} \mathrm{S} 34^{\circ} 47^{\prime} \mathrm{W}\right), 3$ specimens, coll. 28 August 2011; Praia de Tabatinga (07º $19^{\prime} \mathrm{S}$ $\left.34^{\circ} 47^{\prime} \mathrm{W}\right)$, associated with Amphimedon viridis, 1 specimen, coll. 01 September 2011; 47 specimens, 3 more specimens for SEM, coll. 16 September 2012. Morphological variation among selected specimens in Table 4.

Description. Relatively small-sized body, longest specimen examined with 50 segments, $5.2 \mathrm{~mm}$ long, $0.25 \mathrm{~mm}$ wide (Table 4). Live specimens translucent to pale brownish, colour pattern restricted to orange-red anterior and posterior thirds of proventricle (Fig. 19A-C). Preserved material colorless. Scattered cilia on dorsum, more numerous on anterior and midbody (Fig. 20A-B); peristomium and first 9 segments ventrally with paired oblique bands of cilia, running from mid-line of segment to lateral sides of body, terminating close to posterior boundary of segment (Figs 20CD, F; 21A-B). Palps ovate, distaly rounded, about same size of prostomium, totally fused (Fig. 20A-D); each palp with dense ciliation dorsally on distal third (Fig. 20A-B) and one stripe of cilia latero-ventraly and another ventraly (Fig. 20E), the latter progressively with fewer cilia posteriorwards (Fig. 20C-D, F). Prostomium subpentagonal, with two pairs of eyes in rectangular to trapezoidal arrangement, anterior pair of eyespots absent; lateral antennae inserted on anterior margin of prostomium, reaching chaetigers 4-5 if deflected posteriorly; median antenna inserted near posterior margin of prostomium, between posterior eyes, almost 3 times longer than lateral antennae, reaching chaetigers 16-17 if deflected posteriorly (Figs 20A$\mathrm{B} ; 22 \mathrm{~A})$; prostomium with pair of semicircular rows of cilia, from posterior part of bases of lateral antennae until close to posterior border of the prostomium, laterally to base of median antenna semi-circular ciliar trait from each side of base of median 
antenna to bases of lateral antennae (Fig. 20A-B). Nuchal epaulettes semicircular, reaching posterior border of peristomium (Fig. 20A-B). Peristomium slightly shorter than subsequent segments (Fig. 20A); dorsal peristomial cirri $\sim 2 / 3$ length of lateral antennae, ventral peristomial cirri $\sim 1 / 3-1 / 2$ length of dorsal ones (Fig. 22A). Dorsal cirri of chaetiger 1 as long as median antenna or slightly shorter; dorsal cirri of chaetiger 2 slightly longer than ventral peristomial cirri; remaining dorsal cirri shorter than $1 / 3$ of body width at corresponding segment, with insconspicuous alternation in length (Figs 20B-C; 22A). Antennae, peristomial and dorsal cirri of chaetigers 1 and 2 with cirrophores (Figs 20A-B; 22A); dorsal cirri from chaetiger 3 digitiform, with scattered tufts of cilia arranged in irregular longitudinal rows (Fig. 20A). Parapodial lobes bilobed, distally rounded (Fig. 22A), with longitudinal row of cilia ventrally (Fig. 20C). Anterior parapodia with 4-10 compound chaetae each, midbody parapodia with 5-7, posterior ones with 2-5 compound chaetae each; shafts subdistally inflated and spinulated, with acute, slightly sigmoid tip (Figs 21E-G, K; 22C, E, G); blades spinulated and bidentate, teeth about same size or distal tooth slightly shorter (Figs 21D-H, J-K; 22C, E, G); blades with inconspicuous inverse antero-posterior gradation in length and slight progressively longer ventralwards within each parapodium, 5-7 $\mu \mathrm{m}$ long on anterior and midbody parapodia, 3-5 $\mu \mathrm{m}$ long on posterior parapodia (Fig. 21C, D, H, L). Dorsal simple chaetae beginning on chaetigers 1-14, as thick as shafts of compound chaetae, bayonet-like, subdistally spinulated (Figs 21GI, L; 22B, D, F). Anterior parapodia with 2 straight aciculae each, midbody and posterior parapodia with 1-2 acicula each, aciculae sometimes protruding from parapodial lobes (Fig. 21C-D, H, J). Pygidium with thick, elongate pair of anal cirri, almost twice as long as dorsal cirri of posterior body chaetigers, anal cirri sometimes wrinkled to pseudoarticulated (Fig. 21M). Pharynx through 5-7 chaetigers (Figs 19A- 
B; 22A), with 1-2 sinuations anterior to proventricle (Fig. 22A), trepan in chaetigers 12, with 22-24 unequal teeth, 11-12 large and 11-12 small, arranged in 2 rings; basal ring present; proventricle through 3-4 segments (Fig. 19A-B), with 26-35 muscle cell rows (Fig. 22A).

Host. A great number of specimens were found within the sponge Amphimedon viridis (Fig. 19C).

Remarks. This species is easily identifiable by the color of the proventricle, was described from Florida (USA) and Paraná (Brazil) (Nygren \& Gidholm 2001). In the present paper, we described ciliation patterns along the body, which were not included in the original description. The specimen examined by Nygren \& Gidholm (2001) under SEM was collected in Florida (Arne Nygren, personal communication to KP), and differs from those from northeastern Brazil by having larger cirrophores of the peristomial cirri and more diffused ciliation, not showing the clearly defined ciliary traits described above. Nevertheless, we identified the present material as $P$. rubroproventriculata because we cannot see further differences in other characters that could justify recognizing it as a new species. Molecular tools could to assess whether Brazilian and Floridian material are the same or just two different species.

Type locallity. Atlantic Ocean (USA, Florida, Key Biscaine).

Distribution. Atlantic Ocean (USA: Florida. Brazil: Paraíba, Pernambuco and Paraná). 


\section{Acknowledgements}

The study was carried out within the frame of the Project 'Diversity of Polychaeta (Annelida) on sandstone reefs off northeastern Brazil, states of Paraíba and Pernambuco', funded by the Conselho Nacional de Desenvolvimento Cientifico e Tecnológico - CNPq (proc. 481510/20087) and presently funded by the Fundação de Amparo a Pesquisa do Estado de São Paulo FAPESP (proc. 2010/52116-4). In addition, KP receives a Ph. D. fellowship from FAPESP (proc. 2009/17606-3), MVF receives a post-doc fellowship from FAPESP (proc. 2010/194247), and JMMN receives a productivity grant from CNPq. We are also thankful to Orlemir Carrerette, Rudá Amorin, Rafael Brito, Carmem Alonso Samiguel and all students of Laboratório de Invertebrados Paulo Yang (Universidade Federal da Paraíba - UFPB) for the help with the collections; to Enio Mattos and Phillip Lenktaitis (IB/USP) prepared the specimens and photographed them under the SEM; and to Arne Nygren and an anonymous reviewer for the comments and corrections that will improve this manuscript.

\section{References}

Agassiz, A. (1862) On alternate generation in annelids, and the embryology of Autolytus cornutus. Journal of the Boston Society for Natural History, 7, 384-409.

Aguado, M.T. \& San Martín, G. (2009) Phylogeny of Syllidae (Annelida, Phyllodocida) based on morphological data. Zoologica Scripta, 38, 379-402.

Aguado, M.T., San Martin, G. \& Siddall, M.E. (2012) Systematics and evolution of syllids (Annelida, Syllidae). Cladistics, 28, 234-250.

Amaral, A.C.Z., Nallin, S.A.H., Steiner, T.M., Forroni, T.O. \& Gomes-Filho, D. (2013) Catálogo das espécies de Annelida Polychaeta do Brasil. http://www.ib.unicamp.br/projbiota/bentos_marinho/prod_cien/texto_poli.pdf. (Acessed February 2014).

Augener, H. (1913) Polychaeta 1, Errantia. In: Michaelsen,W. \& Hartmeyer, R. (Eds) Die Fauna Südwest-Australiens. Ergebnisse der Hamburger südwest- 
australischen Forschungsreise 1905, vol 4, Lieferung 5. Gustav Fischer, Jena, 65-304.

Berlandi, R.M., Figueiredo, M.A.D. \& Paiva, P.C. (2012) Rhodolith Morphology and the Diversity of Polychaetes Off the Southeastern Brazilian Coast. Journal of Coastal Research, 28, 280-287.

Bosc, L.A.G. (1802) Histoire naturelle des vers, contenant leur description et leurs moeurs; avec figures dessinés d'àpres nature. Deterville, Paris.

Claparède, E. (1868) Les annélides chétopodes du Golfe de Naples. Mémoires de la Société de physique et d'Histoire naturelle de Genève,19, 313-584.

Cognetti, G. (1953) Osservazioni sulla biologia riproduttiva di una nuova specie di Autolytus del golfo di Napoli. Archivio zoologico italiano, 38, 323-332.

Ehlers, E. (1864) Die Borstenwürmer (Annelida Chaetopoda) nach systematischen und anatomischen Untersuchungen dargestellt. Wilhelm Engelmann, Leipzig. Vol. $1,268 \mathrm{pp}$.

Fukuda, M.V. \& Nogueira, J.M.D. (2006) A new species of Odontosyllis Claparede, 1863 (Polychaeta: Syllidae: Eusyllinae), and description of Brazilian material of Odontosyllis cf. fulgurans (Audouin and Milne Edwards, 1834). Zoological Studies, 45, 223-233.

Fukuda, M.V. (2010) Contribuição ao conhecimento taxonômico dos silídeos (Polychaeta: Syllidae) da região sudeste-sul do Brasil. Ph. D. Thesis, Instituto de Biociências da Universidade de São Paulo, São Paulo, 340 pp.

Fukuda, M.V., Centurion, R., Nogueira, J.M.D. \& San Martin, G. (2012) Two new species of Paraehlersia San Martin, 2003 (Polychaeta, Syllidae) from the Atlantic Coast of South America. Zootaxa, 3264, 38-52.

Fukuda, M.V., Yunda-Guarin, G. \& Nogueira, J.M.M. (2009) The genus Prosphaerosyllis (Polychaeta: Syllidae: Exogoninae) in Brazil, with description of a new species. Journal of the Marine Biological Association of the United Kingdom, 89, 1443-1454.

Gidholm, L. (1967) A revision of Autolytinae (Syllidae, Polychaeta) with special reference to Scandinavian species, and with notes on external and internal morphology, reproduction and ecology. Arkiv för Zoologi,19, 157-213.

Grube, A.E. (1850) Die Familien der Anneliden. Archiv für Naturgeschichte, 16, 249364. 
Hartmann-Schröder, G. (1987) Die Polychaeten der antiborealen Küste von Victoria (Australien) (zwischen Warrnambool im Westen und Port Welshpool im Osten). Teil 13. In: Hartmann-Schröder, G. \& Hartman, G. Zur Kenntnis des Eulitorals der australischen Küsten unter besonderer Berücksichtigung der Polychaeten und Ostracoden. Mitteilungen aus dem Hamburgischen Zoologischen Museum und Institut, 84, 27-66.

Imajima, M. (1966) The Syllidae (Polychaetous Annelids) from Japan (2) Autolytinae. Publications of the Seto Marine Biological Laboratory,14, 27-83.

Langerhans, P. (1879) Die Wurmfauna von Madeira. Zeitschrift für wissenschaftliche Zoologie, 32, 513-592.

Langerhans, P. (1884) Die Wurmfauna von Madeira. 4. Zeitschrift für wissenschaftliche Zoologie, 40, 247-285.

Machado, M.C.S. (1986) Sistema planctônico da região do Emissário Submarino de. Esgotos de Ipanema, Rio de Janeiro - RJ - Populações zooplanctônicas: Annelida Polychaeta. Master Thesis, Universidade Federal do Rio de Janeiro, Rio de Janeiro, 256 pp.

Marenzeller, E. (1874) Zur Kenntniss der adriatischen Anneliden. Sitzungsberichte der Kaiserliche Akademie der Wissenschaften, Wien, MathematischNaturwissenschaftliche Klasse, 69, 1-76.

Milne Edwards, M. (1845) Observations sur le développement des annélides. Annales des sciences naturelles, Paris, 3, 145-182.

Monro, C.C.A. (1933) The Polychaeta errantia collected by Dr. C. Crossland at Colón in the Panamá region and the Galápagos Islands during the expedition of the S. Y. St. George. Part 1. Proceedings of the Zoological Society of London,1933, 1-96.

Morgado, E.H. \& Amaral, A.C.Z. (1985) Anelídeos poliquetos associados ao briozoário Schizoporella unicornis (Johnston). V. Syllidae. Revista Brasileira de Zoologia, 3, 219-227.

Müller, O.F. (1788) Zoologica Danica seu Animalium Daniae et Norvegiae rariorum ac minus notorum. Descriptiones et historia. Havniae.

Nogueira, J.M.D. \& Fukuda, M.V. (2008) A new species of Trypanosyllis (Polychaeta: Syllidae) from Brazil, with a redescription of Brazilian material of Trypanosyllis zebra. Journal of the Marine Biological Association of the United Kingdom, 88, 913-924. 
Nogueira, J.M.D., San Martin, G. \& Amaral, A.C.Z. (2001) Description of five new species of Exogoninae Rioja, 1925 (Polychaeta: Syllidae) associated with the stony coral Mussismilia hispida (Verrill, 1868) in Sao Paulo State, Brazil. Journal of Natural History, 35, 1773-1794.

Nogueira, J.M.M. \& San Martin, G. (2002) Species of Syllis Savigny in Lamarck, 1818 (Polychaeta: Syllidae) living in corals in the state of Sao Paulo, southeastern Brazil. Beaufortia Bulletin Zoological Museum, 52, 57-93.

Nogueira, J.M.M. \& Yunda-Guarin, G. (2008) A new species of Syllis (Polychaeta: Syllidae: Syllinae) from off Fortaleza, north-eastern Brazil. Journal of the Marine Biological Association of the United Kingdom, 88, 1391-1399.

Nogueira, J.M.M. (2000) Anelídeos poliquetas associados ao coral Mussismilia híspida (Verril, 1868) em ilhas do litoral do Estado de São Paulo. Phyllodocida, Amphinomida, Eunicida, Spionida, Terebellida, Sabellida. Ph. D. Thesis, Instituto de Biociências da Universidade de São Paulo, São Paulo, 265 pp.

Nogueira, J.M.M. (2006) Família Syllidae. In: Amaral ACZ, Rizzo AE, Arruda, EP, editors. Manual de Identificação dos Invertebrados Marinhos da Região Sudeste-Sul do Brasil. São Paulo, SP: Editora da Universidade de São Paulo, $134-164$.

Nogueira, J.M.M., San Martin, G. \& Veronesi Fukuda, M. (2004) On some exogonines (Polychaeta, Syllidae, Exogoninae) from the northern coast of the State of Sao Paulo, southeastern Brazil. Results of BIOTA/FAPESP/Bentos Marinho Project. Meiofauna Marina, 13, 45-77.

Nygren A \& Pleijel F. (2007) A new species of Myrianida (Syllidae, Polychaeta) from Belize. Zootaxa, 1595, 17-29.

Nygren, A. \& Gidholm, L. (2001) Three new species of Proceraea (Polychaeta: Syllidae: Autolytinae) from Brazil and the United States, with a synopsis of all Proceraea-like taxa. Ophelia, 54, 177-191.

Nygren, A. \& Pleijel, F. (2010) Redescription of Imajimaea draculai a rare syllid polychaete associated with the sea pen Funiculina quadrangularis. Journal of the Marine Biological Association of the United Kingdom, 90, 1441-1448.

Nygren, A. \& Sundberg, P. (2003) Phylogeny and evolution of reproductive modes in Autolytinae (Syllidae, Annelida). Molecular Phylogenetics and Evolution, 29, $235-249$. 
Nygren, A. (1999) Phylogeny and reproduction in Syllidae (Polychaeta). Zoological Journal of the Linnean Society, 126, 365-386.

Nygren, A. (2004) Revision of Autolytinae (Syllidae: Polychaeta). Zootaxa, 680, 1-314.

Nygren, A., Sundkvist, T., Mikac, B. \& Pleijel, F. (2010) Two new and two poorly known autolytines (Polychaeta: Syllidae) from Madeira and the Mediterranean Sea. Zootaxa, 2640, 35-52.

Paiva, P.C., Young, P.S. \& Echeverría, C.A. (2007) The Rocas Atoll, Brazil: a preliminary survey of the crustacea and polychaete fauna. Arquivos do Museu Nacional, 65, 241-250.

Paresque, K. \& Nogueira, J.M.M. (in press) The genus Haplosyllis Langerhans, 1879 (Polychaeta: Syllidae) from off northeastern Brazil, with descriptions of two new species. Marine Biology Research.

Rullier, F. \& Amoureux, L. (1979) Campagne de la Calypso au large des cotes Atlantiques de l'Amerique du Sud (1961-1962). 1. 33. Annelides polychetes. Annales de l'Institut Oceanographique, 55, 145-206.

San Martin, G. \& Hutchings, P. (2006) Eusyllinae (Polychaeta: Syllidae) from Australia with the description of a new genus and fifteen new species. Records of the Australian Museum, 58, 257-370.

San Martin, G. \& López, E. (2003) A new genus of Syllidae (Polychaeta) from western Australia. Hydrobiologia, 496, 191-197.

San Martín, G. (1994) Autolytinae (Polychaeta, Syllidae) from Cuba and north American Atlantic Ocean. Memoires du Museum National d'Histoire Naturelle, $162,269-277$.

San Martin, G. (2003) Annelida Polychaeta II: Syllidae. In: Ramos Sánchez, M.A., Alba Tercedor J., Bellés i Ros X., Gosalbez i Noguera J., Guerra Sierra A., Macpherson Mayol E., Martin Piera F., Serrano Marino J. \& J., a.T.G. (Eds.) Fauna Ibérica. Museu Nacional de Ciencias Naturales de Madrid. CSIC., Madrid, 554 pp..

San Martin, G. (2005) Exogoninae (Polychaeta: Syllidae) from Australia with the description of a new genus and twenty-two new species. Records of the Australian Museum, 57, 39-152.

San Martin, G., Hutchings, P. \& Aguado, M.T. (2010) Syllinae (Polychaeta: Syllidae) from Australia. Part 3. Genera Alcyonosyllis, Genus A, Parahaplosyllis, and Trypanosyllis (Trypanobia). Zootaxa, 35-48. 
San Martin, G., Hutchings, P. \& Teresa Aguado, M. (2008) Syllinae (Polychaeta: Syllidae) from Australia. Part 1. Genera Branchiosyllis, Eurysyllis, Karroonsyllis, Parasphaerosyllis, Plakosyllis, Rhopalosyllis, Tetrapalpia n.gen., and Xenosyllis. Records of the Australian Museum, 60, 119-160.

Westheide, W. (1974) Interstitielle Fauna von Galapagos 11. Pisionidae, Hesionidae, Pilargidae, Syllidae (Polychaeta). Mikrofauna Meeresbodens, 44, 1-146.

Wright, J.D. \& Woodwick, K.H. (1977) A new species of Autolytus (Polychaeta: Syllidae) commensal on a California hydrocoral. Bulletin of the Southern California Academy of Sciences, 76, 42-48.

\section{Legends to figures}

FIGURE 1. Myrianida sp. n. A-C, living specimen: (A) dorsal view; (B) anterior end, ventral view; (C) posterior end, ventral view; (D) dissected proventricle and pharynx; (E-F) trepan. Scale bars: $A-C=0.3 \mathrm{~mm} ; \mathrm{D}=0.5 \mathrm{~mm}$; $\mathrm{E}-\mathrm{F}=20 \mu \mathrm{m}$.

FIGURE 2. Myrianida sp. n. (A) anterior end, dorsal view; (B-C) anterior and midbody compound chaetae, respectively; (D-E) anterior and midbody dorsal simple chaetae, respectively; $(\mathrm{F})$ compound chaetae of stolon. Scale bars: $\mathrm{A}=0.5 \mathrm{~mm}$; B-F $=$ $10 \mu \mathrm{m}$.

FIGURE 3. Proceraea sp. n. 1, living specimens. (A) anterior end, dorso-lateral view; (B) posterior end; (C) anterior end, dorsal view; (D) prostomium and peristomium, dorsal view; (E) specimen in the sponge Amphimedon viridis. Scale bars: A-E $=1 \mathrm{~mm}$. 
FIGURE 4. Proceraea sp. n. 1, preserved specimens. (A) anterior end, dorsal view; arrow indicating proventricle; (B) newly regenerated anterior end, dorso-lateral view; (C) trepan; (D) proventricle, dorsal view; (E) anterior end of a stolon; (F) anterior end of a stolon with gametes; $(\mathrm{G})$ tube with stolon. Scale bars: A-B, D-G $=1 \mathrm{~mm} ; \mathrm{C}=200$ $\mu \mathrm{m}$.

FIGURE 5. Proceraea sp. n. 1, SEM. (A) prostomium, dorsal view; (B) prostomium and peristomium, dorso-lateral view; arrows indicating left side nuchal epaulette; (C) tip of lateral antenna; (D-E) dissected trepan, lateral and frontal views, respectively (F) detail of prostomium, ventral view; arrows indicating ciliation between palps (pa) and prostomium (pr); (G) dissected proventricle; $(\mathrm{H})$ anterior end of dissected pharynx; (I) detail of parapodium, ventral view. Scale bars: $A, H=50 \mu \mathrm{m} ; \mathrm{B}-\mathrm{E}=20 \mu \mathrm{m} ; \mathrm{F}=10 \mu \mathrm{m}$; $\mathrm{G}=100 \mu \mathrm{m} ; \mathrm{I}=2 \mu \mathrm{m}$.

FIGURE 6. Proceraea sp. n. 1. (A) anterior end, dorsal view; (B) dorsal simple chaeta, anterior parapodium; (C) compound chaetae, anterior parapodium; (D) dorsal simple chaeta, midbody; (E) compound chaetae, midbody; (F) dorsal simple chaetae, posterior parapodium; $(\mathrm{G})$ compound chaetae, posterior parapodium. Scale bars: $\mathrm{A}=0.5 \mathrm{~mm}$; $\mathrm{B}-$ $\mathrm{G}=5 \mu \mathrm{m}$.

FIGURE 7. Proceraea sp. n. 1, SEM. (A) anterior end, dorsal view; (B) anterior end, frontal view; (C) palps and peristomium, ventral view; (D-E) anterior end, dorsal and ventral views, respectively; (F) midbody, dorsal view; (G) anterior body, dorsal view; (H) midbody dorsal cirrus; (I-J) posterior end, dorsal and ventral views, respectively. Scale bars: A-B, D-F, I-J $=100 \mu \mathrm{m} ; \mathrm{C}, \mathrm{G}=50 \mu \mathrm{m} ; \mathrm{H}=20 \mu \mathrm{m}$. 
FIGURE 8. Proceraea sp. n. 1, SEM (A) dorsal simple chaeta, anterior parapodium; (B-D) chaetae, anterior parapodium; (E) dorsal simple chaeta, midbody; (F) dorsalmost falciger, midbody; $(\mathrm{G})$ chaetae, midbody; $(\mathrm{H})$ dorsal simple chaeta, posterior parapodium; (I) falciger, posterior parapodium. Scale bars: A-B, $\mathrm{H}-\mathrm{I}=2 \mu \mathrm{m} ; \mathrm{C}=5$ $\mu \mathrm{m} ; \mathrm{D}=20 \mu \mathrm{m} ; \mathrm{E}-\mathrm{F}=10 \mu \mathrm{m} ; \mathrm{G}=50 \mu \mathrm{m}$.

FIGURE 9. Proceraea madeirensis. A-C, living specimen: (A) entire body, lateral view (B) anterior end, dorsal view; (C) anterior end, lateral view; (D) preserved specimen, pharynx, dorsal view. Scale bars: $A=1 \mathrm{~mm} ; \mathrm{B}-\mathrm{D}=0.5 \mathrm{~mm}$.

FIGURE 10. Proceraea madeirensis, SEM. (A-B) anterior end, dorsal view; (C) entire worm; (D) anterior segments, lateral view. Scale bars: $A, D=100 \mu \mathrm{m} ; \mathrm{B}=40 \mu \mathrm{m} ; \mathrm{C}=$ $400 \mu \mathrm{m}$.

FIGURE 11. Proceraea madeirensis, SEM. (A) chaetae, chaetiger 2; (B) chaetae, chaetiger 3; (C) midbody, ventral view; (D) posterior end, dorsal view; (E) compound chaetae, midbody; (F) posterior end, ventral view; (G) chaetae, midbody; $(\mathrm{H})$ chaetae, posterior end. Scale bars: A-B, E, G-H $=10 \mu \mathrm{m} ; \mathrm{C}-\mathrm{D}, \mathrm{F}=50 \mu \mathrm{m}$.

FIGURE 12. Proceraea madeirensis. (A) dorsal simple chaeta, anterior parapodium; (B) compound chaetae, anterior parapodium; (C) dorsal simple chaeta, midbody; (D) compound chaetae, midbody. Scale bars: A-D $=5 \mu \mathrm{m}$. 
FIGURE 13. Proceraea sp. n. 2, living specimens. (A) two adults, dorsal view; (B) juvenile, dorsal view; $(\mathrm{C})$ adult, anterior end, dorsal view. Scale bars: $\mathrm{A}=1 \mathrm{~mm}$; $\mathrm{B}-\mathrm{C}=$ $0.5 \mathrm{~mm}$.

FIGURE 14. Proceraea sp. n. 2, SEM. (A) entire worm; (B-D) anterior end, dorsal view; (E) close up view of prostomium and peristomium, dorsal view; arrows indicating nuchal epaulettes; $(\mathrm{F}-\mathrm{G})$ anterior body, ventral view; $(\mathrm{H})$ anterior end, frontal view. Scale bars: $A=200 \mu \mathrm{m} ; \mathrm{B}-\mathrm{C}, \mathrm{F}-\mathrm{G}=100 \mu \mathrm{m} ; \mathrm{D}=50 \mu \mathrm{m} ; \mathrm{E}, \mathrm{H}=20 \mu \mathrm{m}$.

FIGURE 15. Proceraea sp. n. 2, SEM. (A) anterior end, lateral view; (B) midbody, dorsal view; (C) anterior end, lateral view; (D) anterior end, ventral view; (E) anterior end, dorsal view; (F) anterior end, lateral view; (G) midbody, dorsal view; (H), (I) posterior end, ventral view. Scale bars: A-B, G-H $=50 \mu \mathrm{m} ; \mathrm{C}, \mathrm{E}-\mathrm{F}=100 \mu \mathrm{m} ; \mathrm{D}, \mathrm{I}=20$ $\mu \mathrm{m}$.

FIGURE 16. Proceraea sp. n. 2, SEM. (A) mid-length of median antenna; (B) median antenna, basal part; (C-D) detail of lateral antenna; (E) detail of peristomial dorsal cirri; (F) tip of dorsal cirri, chaetiger 1; (G) close up view of midbody parapodium, dorsal view; (H) close up view of dorsum, midbody chaetiger; (I) dorsal cirrus, chaetiger 2; (J) dorsal cirrus, midbody chaetiger; (K) close up view of dorsum, posterior chaetiger; (L) close up view of dorsal cirrus, posterior parapodium; (M) tip of dorsal peristomial cirri; (N) dorsal cirrus, posterior parapodium; (O) anal cirri. Scale bars: A-B, H-J, M-O = 20 $\mu \mathrm{m} ; \mathrm{C}-\mathrm{D}, \mathrm{F}-\mathrm{G}, \mathrm{K}-\mathrm{L}=2 \mu \mathrm{m} ; \mathrm{E}=10 \mu \mathrm{m}$. 
FIGURE 17. Proceraea sp. n. 2. (A) anterior end, dorsal view; (B) compound chaetae, anterior parapodium ; (C) dorsal simple chaeta, anterior parapodium; (D) compound chaetae, midbody; (E) dorsal simple chaeta, posterior parapodium; (F) compound chaetae, posterior parapodium; $(\mathrm{G})$ trepan. Scale bars: $\mathrm{A}=0.5 \mathrm{~mm}$; $\mathrm{B}-\mathrm{F}=10 \mu \mathrm{m} ; \mathrm{G}=$ $20 \mu \mathrm{m}$.

FIGURE 18. Proceraea $\mathbf{s p .}$ n. 2, SEM. (A) chaetae, chaetiger 1; (B) ventralmost falciger, anterior parapodium; (C) dorsalmost falciger and dorsal simple chaeta, anterior parapodium; (D) dorsal simple chaeta, anterior parapodium; (E-F) chaetae, midbody; (G) falciger, midbody; (H) dorsal simple chaeta, midbody; (I) chaetae, midbody; (J) dorsal simple chaeta, posterior parapodium; $(\mathrm{K})$ ventralmost falciger, posterior parapodium. Scale bars: A $=20 \mu \mathrm{m} ; \mathrm{B}-\mathrm{D}, \mathrm{G}-\mathrm{H}, \mathrm{J}-\mathrm{K}=2 \mu \mathrm{m}$; E-F, I $=10 \mu \mathrm{m}$.

FIGURE 19. Proceraea rubroproventriculata, living specimens. (A) entire worm, dorsal view; (B) anterior body, dorsal view; (C) specimen (white arrow) on the sponge Amphimedosn viridis. Scale bars: $\mathrm{A}-\mathrm{C}=1 \mathrm{~mm}$.

FIGURE 20. Proceraea rubroproventriculata, SEM. (A), (B) anterior end, dorsal view; (C) anterior end, ventral view; (D) anterior end, ventro-lateral view; (E) detail of palp ciliation; (F) anterior end, ventral view; (G) close up view of limit between chaetigers 1 and $2 ;(\mathrm{H})$ close up view of parapodium of chaetiger 2, ventral view. Scale bars: A-E = $50 \mu \mathrm{m} ; \mathrm{F}=20 \mu \mathrm{m} ; \mathrm{G}=10 \mu \mathrm{m} ; \mathrm{H}=2 \mu \mathrm{m}$. 
FIGURE 21. Proceraea rubroproventriculata, SEM. (A), chaetigers 9-11, ventral view; B, ventral ciliation, detail of gap between rows of cilia within pair, chaetiger 4; (C-D) chaetae, anterior parapodium; (E) ventralmost falciger, anterior parapodium; (F) falciger, midbody; $(\mathrm{G})$ chaetae, midbody; $(\mathrm{H})$ chaetae, posterior body; (I) dorsal simple chaeta, posterior parapodium; $(\mathrm{J})$ chaetae, posterior parapodim; $(\mathrm{K})$ falciger, posterior parapodium; (L) chaetae, posterior parapodium; (M) posterior end, frontal view. Arrows point to protruding aciculae. Scale bars: $A, M=50 \mu \mathrm{m} ; \mathrm{B}, \mathrm{I}=5 \mu \mathrm{m} ; \mathrm{C}=20 \mu \mathrm{m} ; \mathrm{D}, \mathrm{H}$, $\mathrm{J}, \mathrm{L}=10 \mu \mathrm{m} ; \mathrm{E}-\mathrm{G}, \mathrm{K}=2 \mu \mathrm{m}$.

FIGURE 22. Proceraea rubroproventriculata. (A) anterior end, dorsal view; (B) dorsal simple chaeta, anterior parapodium; (C) compound chaetae, anterior parapodium; (D) dorsal simple chaeta, midbody; (E) compound chaetae, midbody; (F) dorsal simple chaeta, posterior parapodium; (G) compound chaetae, posterior parapodium. Scale bars: $\mathrm{A}=0.2 \mathrm{~mm} ; \mathrm{B}-\mathrm{G}=5 \mu \mathrm{m}$. 
TABLE 1. Morphological variation among specimens of the type series of Myrianida sp. $\mathbf{n}$.

\begin{tabular}{|c|c|c|c|}
\hline Myrianida sp. $\mathbf{n}$. & Holotype & Paratype 1 & Paratype 2 \\
\hline Number of chaetigers & $\begin{array}{c}\text { Parental }=33 ; 1 \text { st stolon }=10 \\
\text { 2ndstolon }=19\end{array}$ & Stolon $=28$ & stolon $=26$ \\
\hline Total length (mm) & $\begin{array}{c}\text { Parental }=3.3 ; 1 \text { st stolon }=0.8 \\
\text { 2ndstolon }=2.4\end{array}$ & 1.8 & 1.7 \\
\hline Width at proventricle $(\mathrm{mm})$ & ( & $\begin{array}{l}0.3(4 \mathrm{rd} \\
\text { chaetiger) }\end{array}$ & $\begin{array}{c}0.3(4 \mathrm{rd} \\
\text { chaetiger) }\end{array}$ \\
\hline Length of pharynx (chaetigers) & 5 & - & - \\
\hline $\begin{array}{l}\text { Length of proventricle } \\
\text { (chaetigers) } /(\mu \mathrm{m}) / \text { number } \\
\text { of muscle cell rows }\end{array}$ & $2 / 500 / 27$ & - & - \\
\hline \multicolumn{4}{|l|}{$\begin{array}{l}\text { Number of compound } \\
\text { chaetae per parapodium }\end{array}$} \\
\hline Anterior body & 18-25 (Parental) & $9-12$ & $8-11$ \\
\hline Midbody & 12-17 (Parental) & $7-10$ & $8-10$ \\
\hline Posterior body & 10-14 (Parental) & $2-5$ & $3-5$ \\
\hline 1st stolon & $3-6$ & - & - \\
\hline 2nd stolon (anterior body) & $12-18$ & - & - \\
\hline 2nd stolon (posterior body) & $2-9$ & - & - \\
\hline $\begin{array}{l}\text { Dorsal simple chaetae starting } \\
\text { (chaetiger) }\end{array}$ & 11 & 1 & 3 \\
\hline
\end{tabular}


TABLE 2. Morphological variation among selected specimens of the type series of Proceraea $\mathbf{s p .} \mathbf{n} .1$.

\begin{tabular}{|c|c|c|c|c|c|c|}
\hline Proceraea sp. n. 1 & Holotype & Paratype 1 & Paratype 2 & Paratype 3 & Paratype 4 & Paratype 5 \\
\hline \multirow{3}{*}{ Collection data } & \multicolumn{6}{|c|}{ State of Paraíba } \\
\hline & \multicolumn{3}{|c|}{ Praia de Tabatinga } & Praia do & Praia de & Barra de \\
\hline & 17 Sep 2012 & 01 Sep 2011 & 01 Sep 2011 & $\begin{array}{l}28 \text { Aug } \\
2011\end{array}$ & 10 Feb 2009 & 12 Aug 2010 \\
\hline Number of chaetigers & 230 & 144 (inc.) & 263 & 191 & 257 & 80 (inc.) \\
\hline Total length (mm) & 25 & 30 & 43 & 40 & 50 & 18 \\
\hline Width at proventricle $(\mathrm{mm})$ & 0.3 & 0.5 & 0.4 & 0.45 & 0.5 & 0.7 \\
\hline \multicolumn{7}{|l|}{ Pharynx } \\
\hline Position (chaetigers) & $12-48$ & $8-49$ & $8-51$ & $9-37$ & $12-51$ & $19-44$ \\
\hline Number of chaetigers & 36 & 41 & 43 & 28 & 39 & 28 \\
\hline \multicolumn{7}{|l|}{ Proventricle } \\
\hline Length (chaetigers) / (mm) & $5 / 1$ & $5 / 1.1$ & $7 / 1.4$ & $4 / 1.2$ & $4.5 / 1.45$ & $5 / 1.5$ \\
\hline Number of muscle cell rows & 49 & 48 & 48 & 50 & 58 & 54 \\
\hline \multicolumn{7}{|l|}{$\begin{array}{l}\text { Number of compound chaetae / } \\
\text { parapodium }\end{array}$} \\
\hline Anterior body & $6-8$ & $7-9$ & $12-15$ & 15 & $12-18$ & $11-19$ \\
\hline Midbody & $6-8$ & $6-9$ & 10 & $7-13$ & 9 & $14-18$ \\
\hline Posterior body & $2-4$ & $?$ & $3-6$ & $4-5$ & $2-6$ & $?$ \\
\hline $\begin{array}{l}\text { Dorsal simple chaetae starting from } \\
\text { (chaetiger) }\end{array}$ & 1 & 1 & 2 & 1 & 1 & 1 \\
\hline
\end{tabular}

(inc.)=incomplete specimen; ?=lost data 
TABLE 3. Morphological variation among selected specimens of the type series of Proceraea sp. n. 2.

\begin{tabular}{|c|c|c|c|c|}
\hline Proceraea sp. n. 2 & Holotype & Paratype 1 & Paratype 2 & Paratype 3 \\
\hline \multirow{3}{*}{ Collection data } & $\begin{array}{c}\text { State of } \\
\text { Pernambuco }\end{array}$ & \multicolumn{3}{|c|}{ State of Paraíba } \\
\hline & Pontas de Pedra & $\begin{array}{c}\text { Praia do } \\
\text { Coqueirinho }\end{array}$ & $\begin{array}{l}\text { Praia de } \\
\text { Tabatinga }\end{array}$ & Baía da Traição \\
\hline & 13 Dec 2012 & 28 Aug 2011 & 17 Sep 2012 & 09 Aug 2010 \\
\hline Number of chaetigers & 62 & 16 (inc.) & 39 & 68 (inc.) \\
\hline Total length (mm) & 6 & 4 & 6 & 9 \\
\hline Width at proventricle $(\mathrm{mm})$ & 0.37 & 0.5 & 0.17 & 0.43 \\
\hline Pharynx number of chaetigers & 4 & 6 & 6 & 5 \\
\hline \multicolumn{5}{|l|}{ Proventricle } \\
\hline Length (chaetigers) / (mm) & $3 / 0.46$ & $3.5 / 0.63$ & 2.5 & $3 / 0.57$ \\
\hline Number of muscle cell rows & 39 & 32 & $\sim 30$ & 40 \\
\hline \multicolumn{5}{|l|}{$\begin{array}{l}\text { Number of compound chaetae / } \\
\text { parapodium }\end{array}$} \\
\hline Anterior body & $7-10$ & $10-13$ & $7-8$ & $7-12$ \\
\hline Midbody & $5-8$ & $9-13$ & 5 & $7-9$ \\
\hline Posterior body & $3-4$ & $?$ & $2-4$ & $?$ \\
\hline $\begin{array}{l}\text { Dorsal simple chaetae starting from } \\
\text { (chaetiger) }\end{array}$ & 13 & $?$ & 4 & 16 \\
\hline
\end{tabular}

(inc.) =incomplete specimen; ?=lost data 
TABLE 4. Morphological variation among selected Brazilian specimens of Proceraea rubroproventriculata Nygren \& Gidholm, 2001.

\begin{tabular}{|c|c|c|c|c|c|c|}
\hline Proceraea rubroproventriculata & Ind. 1 & Ind. 2 & Ind. 3 & Ind. 4 & Ind. 5 & Ind. 6 \\
\hline Collection data & \multicolumn{6}{|c|}{ State of Paraíba, Praia de Tabatinga, 17 Sep 2012} \\
\hline Number of chaetigers & 63 & 48 & 50 & 43 & 49 & 37 \\
\hline Total length (mm) & 3.2 & 3 & 5.2 & 3.2 & 4.0 & 2.5 \\
\hline Width at proventricle (mm) & 0.22 & 0.22 & 0.25 & 0.20 & 0.35 & 0.25 \\
\hline Pharynx Number of chaetigers & 5 & 6 & 7 & 7 & 7 & 7 \\
\hline \multicolumn{7}{|l|}{ Proventricle } \\
\hline Length (chaetigers) / (mm) & $3 / 0.39$ & $3 / 0.30$ & $3 / 0.36$ & $3 / 0.27$ & $3 / 0.34$ & $4 / 50$ \\
\hline Number of muscle cell rows & 35 & 26 & 30 & 29 & 32 & 29 \\
\hline \multicolumn{7}{|l|}{$\begin{array}{l}\text { Number of compound chaetae / } \\
\text { parapodium }\end{array}$} \\
\hline Anterior body & $8-10$ & $7-9$ & $8-10$ & 7 & 9 & $4-7$ \\
\hline Midbody & $5-7$ & 6 & $6-7$ & 5 & 5 & 5 \\
\hline Posterior body & $3-5$ & $2-4$ & $2-4$ & $4-5$ & $3-4$ & $2-3$ \\
\hline $\begin{array}{l}\text { Dorsal simple chaetae starting from } \\
\text { (chaetiger) }\end{array}$ & 22 & 1 & 27 & 10 & 4 & 2 \\
\hline
\end{tabular}

Ind=Individual 

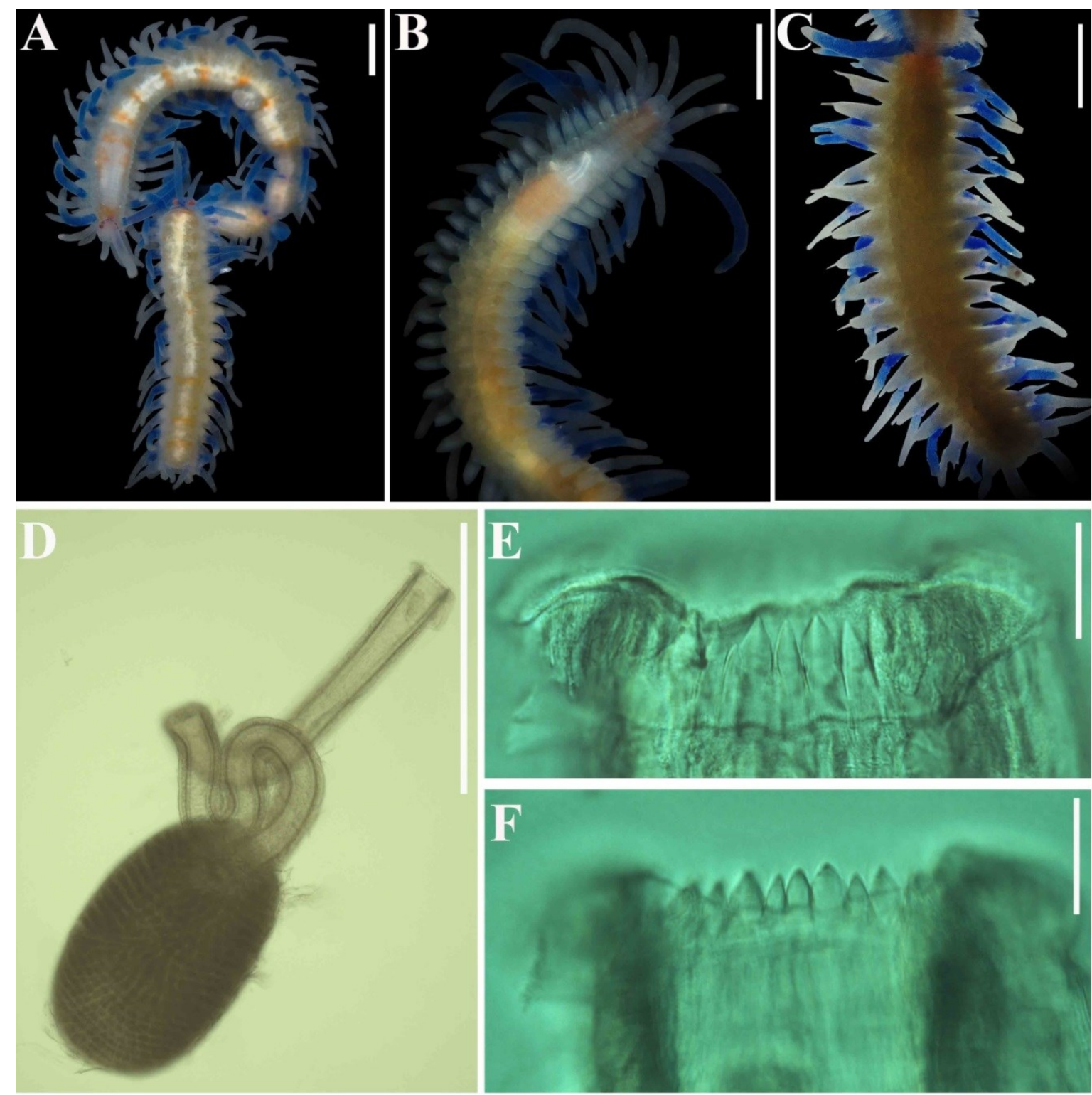

Figure 1 


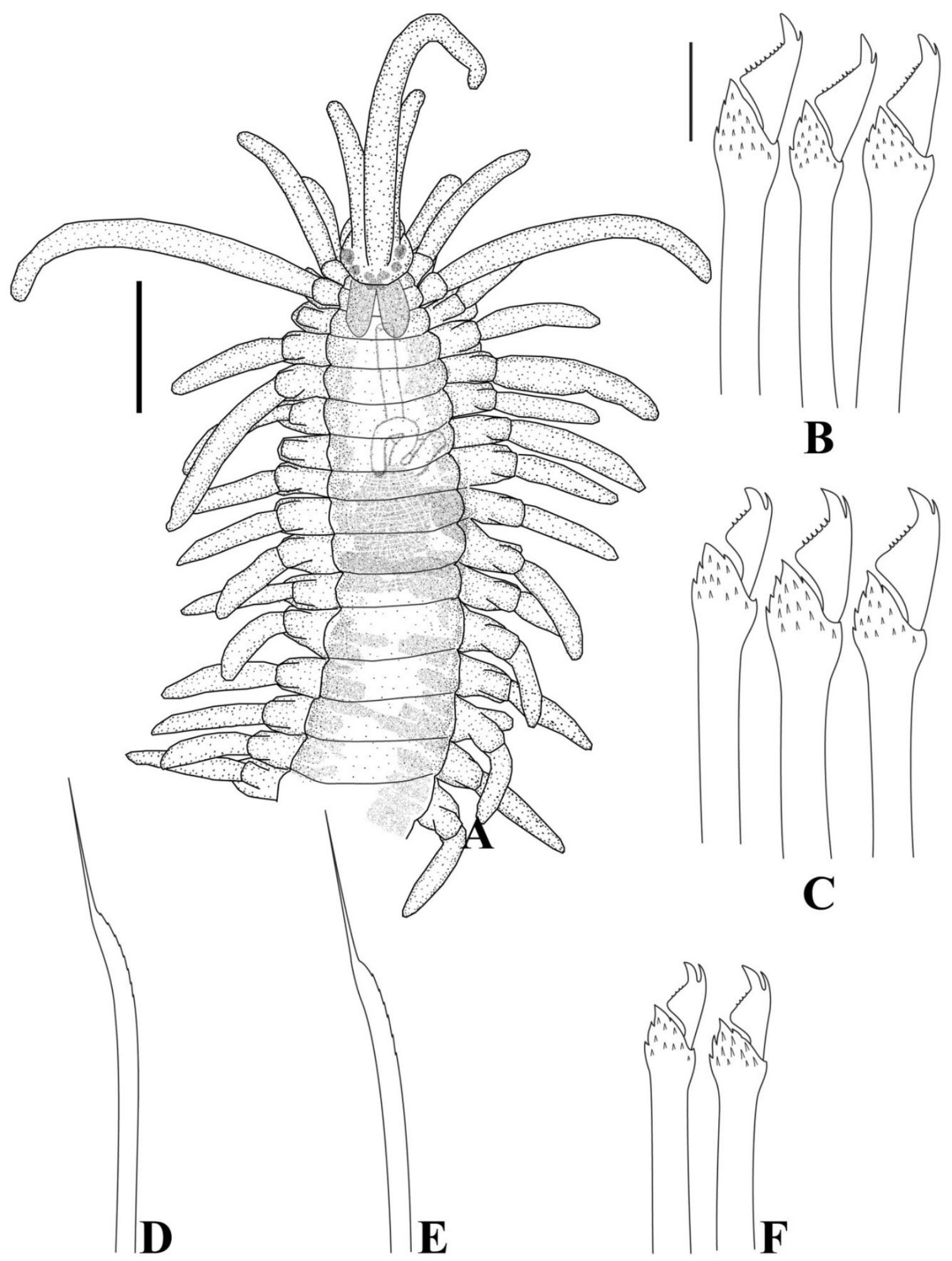

Figure 2 

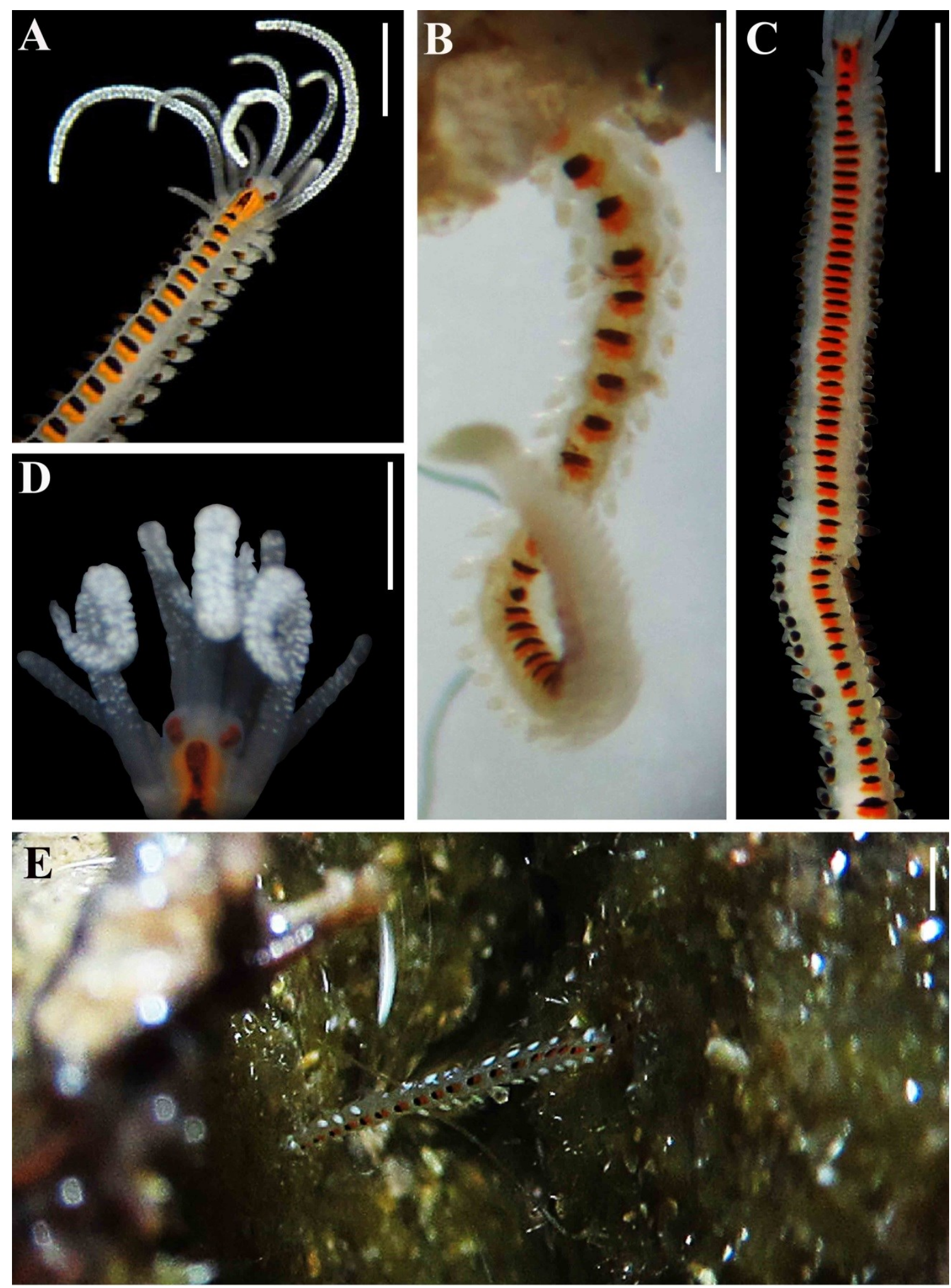

Figure 3 


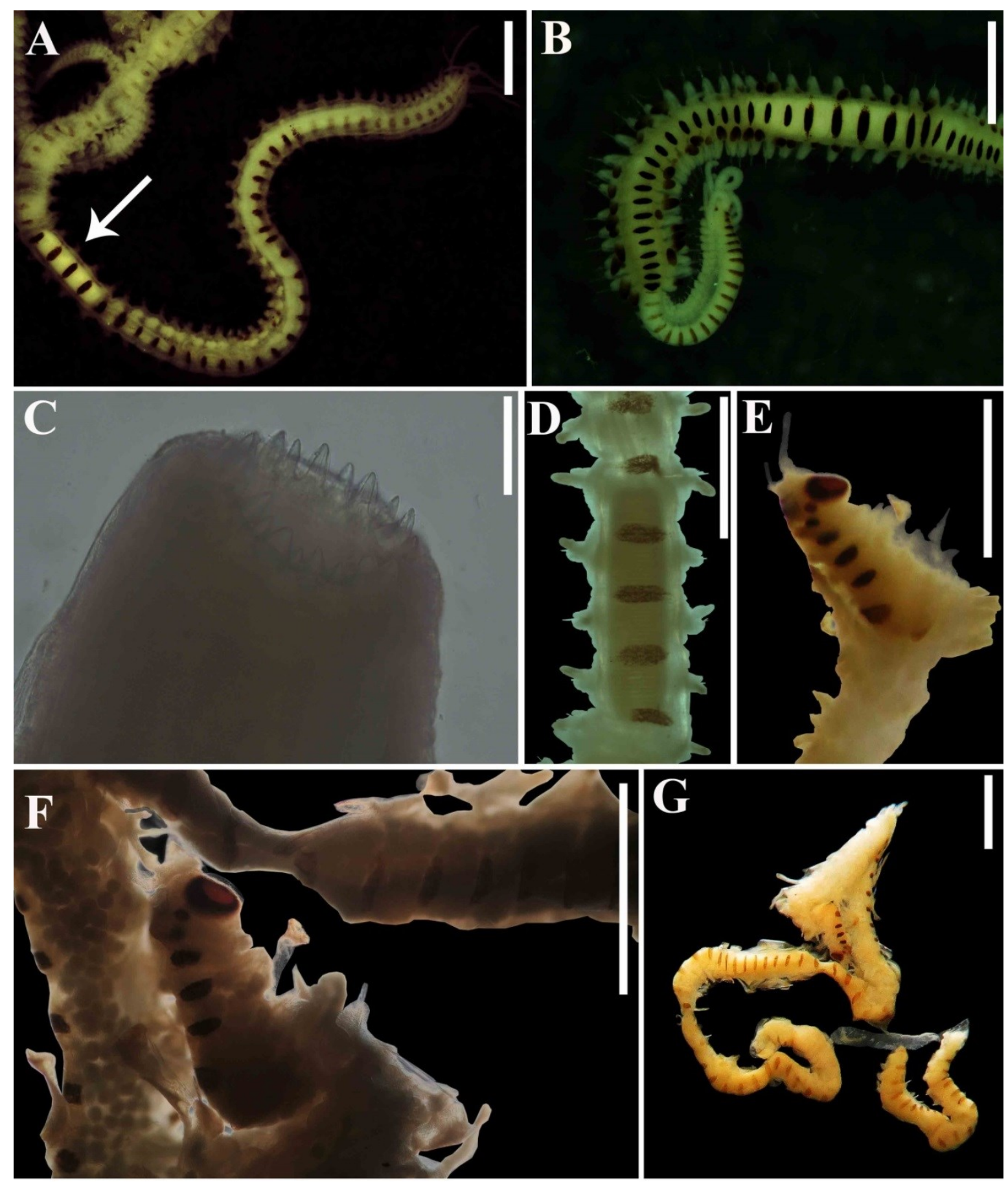

Figure 4 

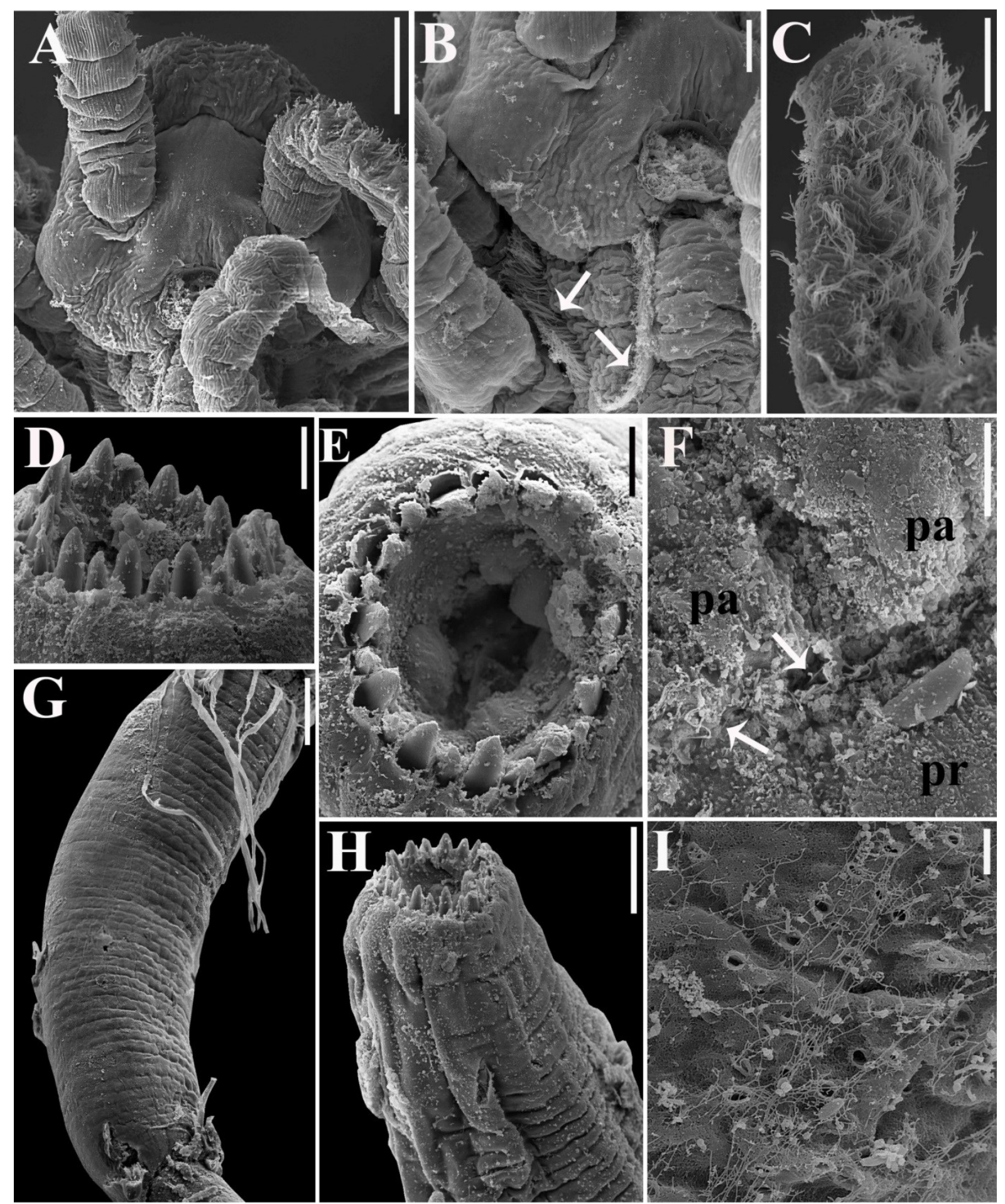

$+2$
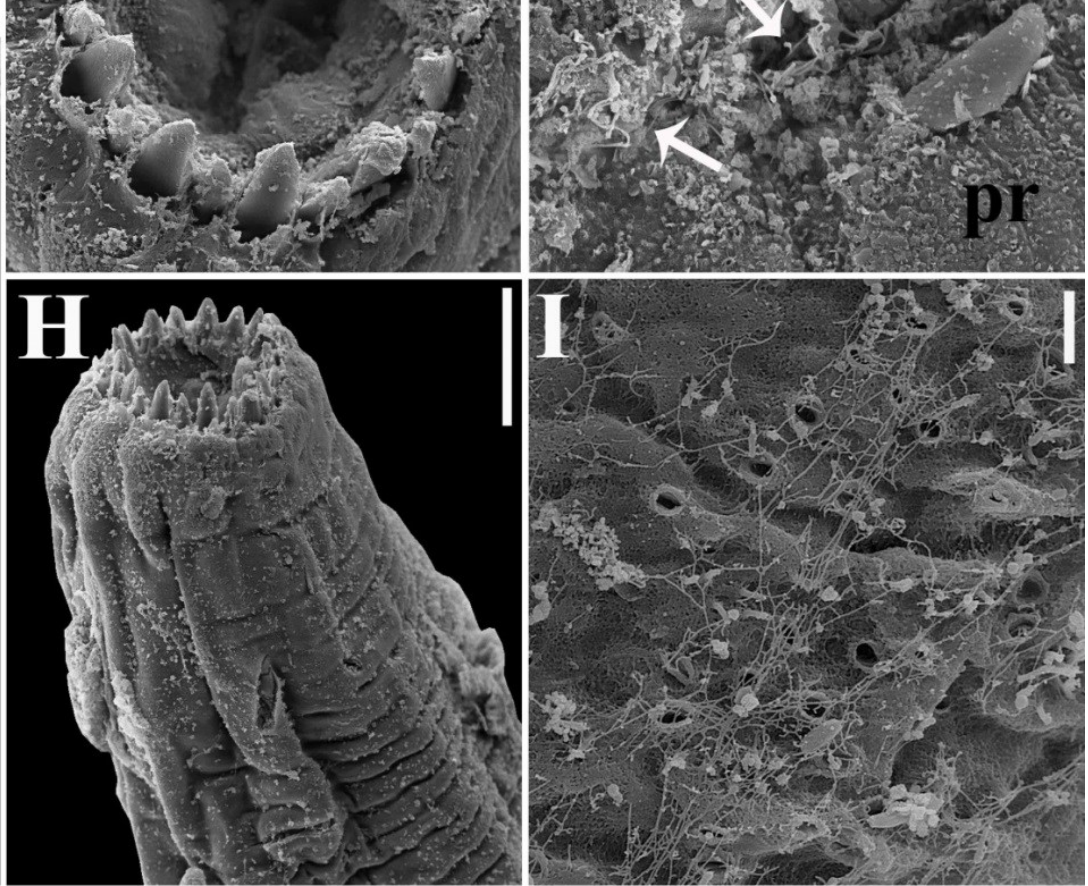

Figure 5 


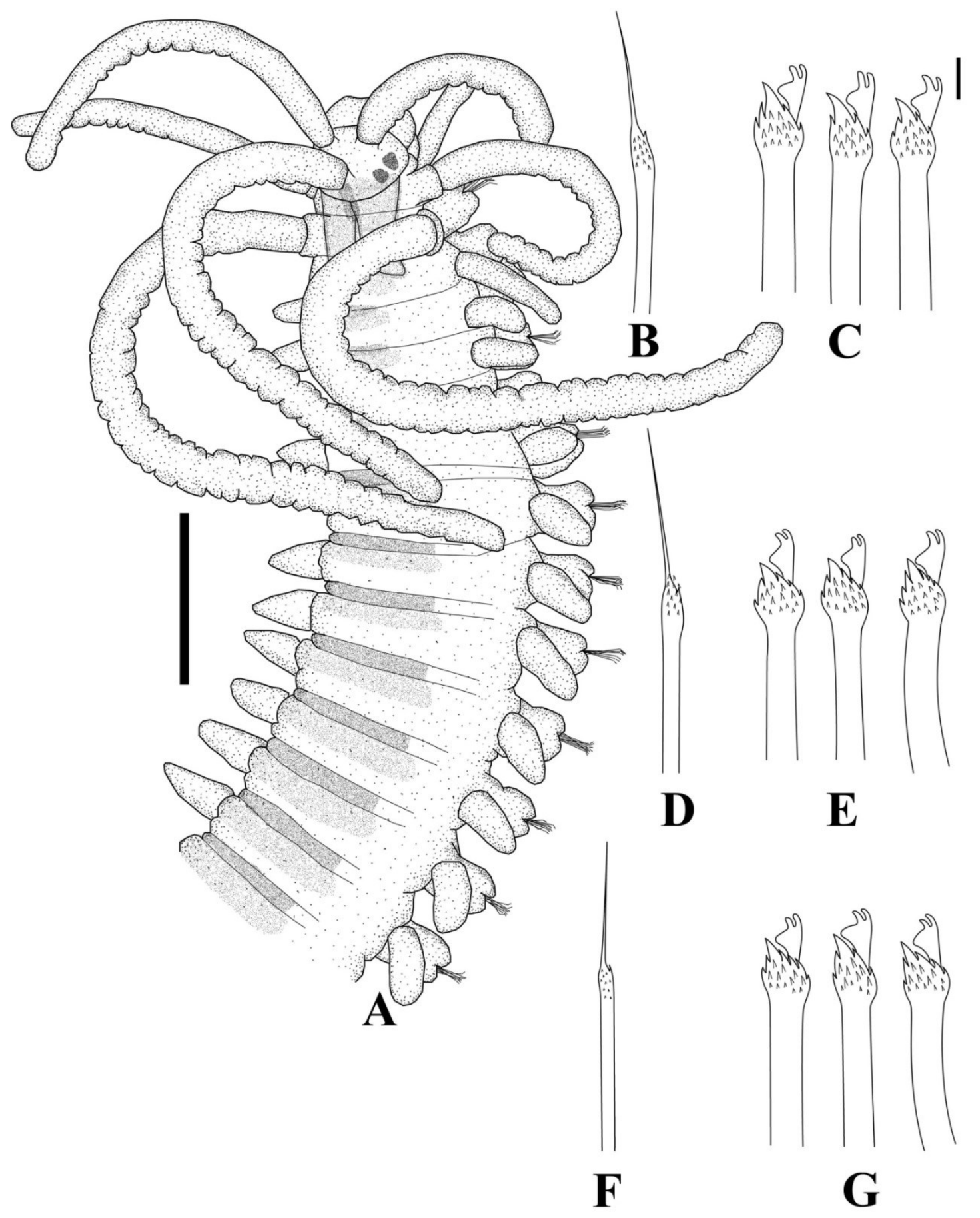

Figure 6 


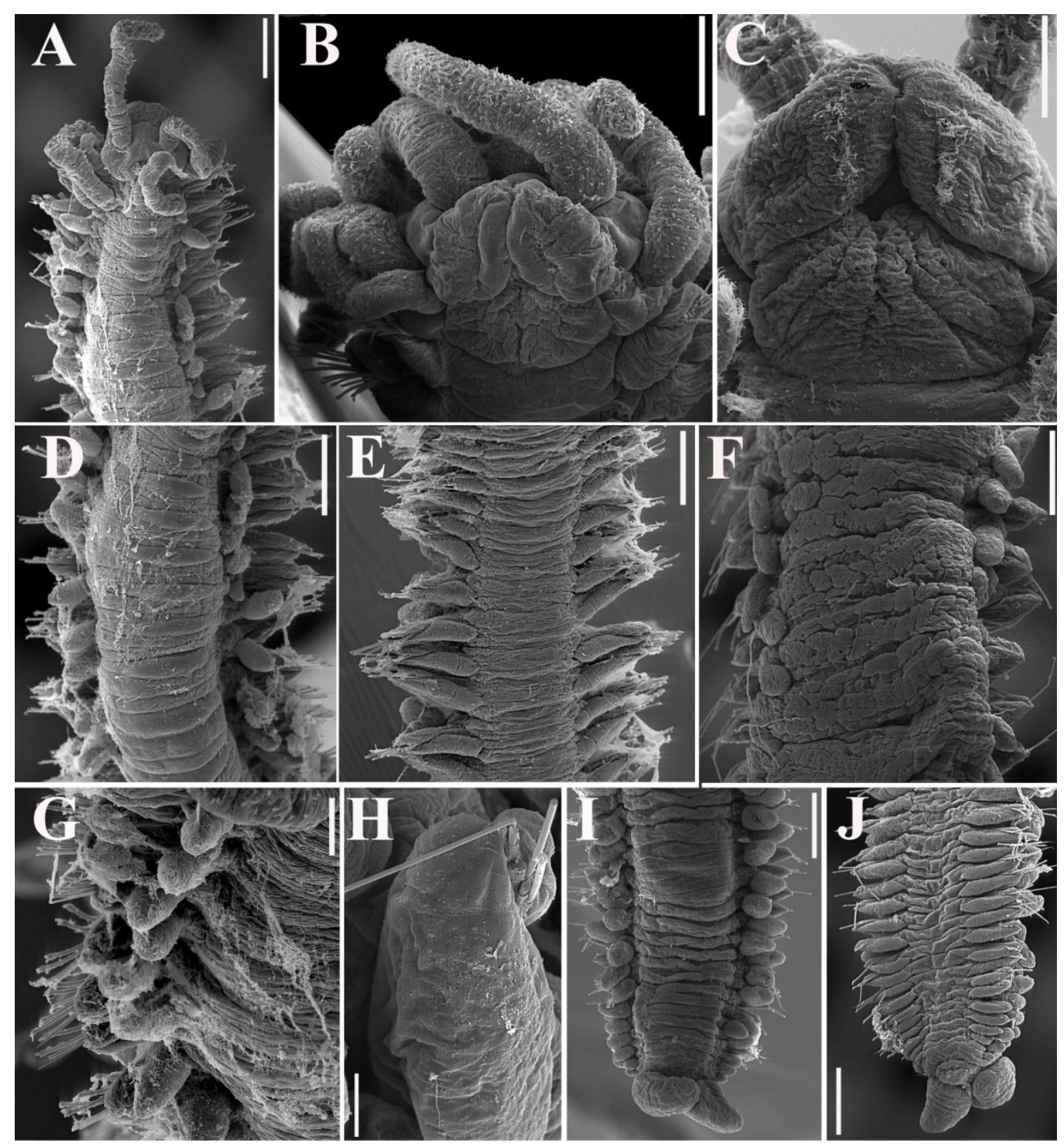

Figure 7 


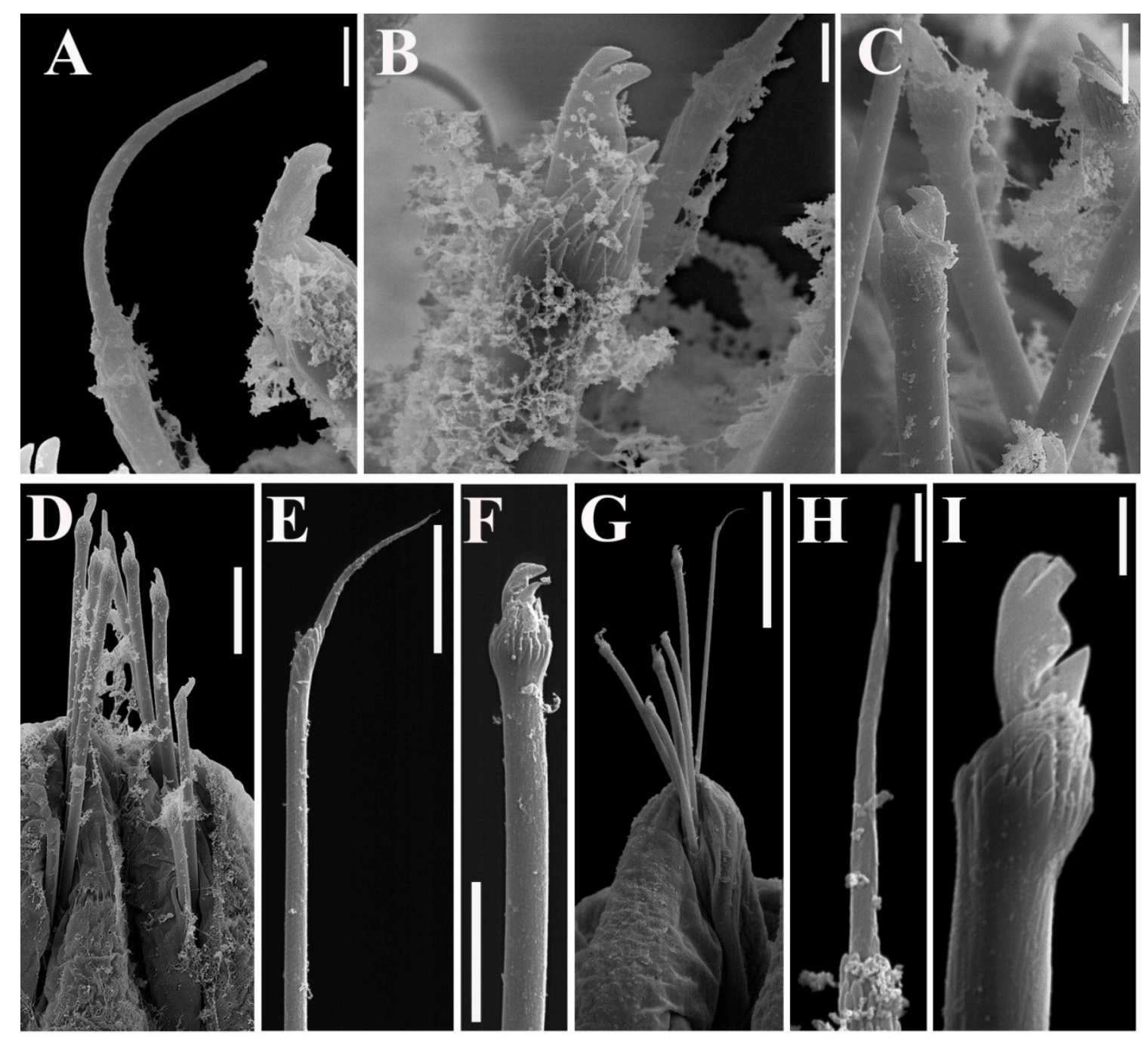

Figure 8
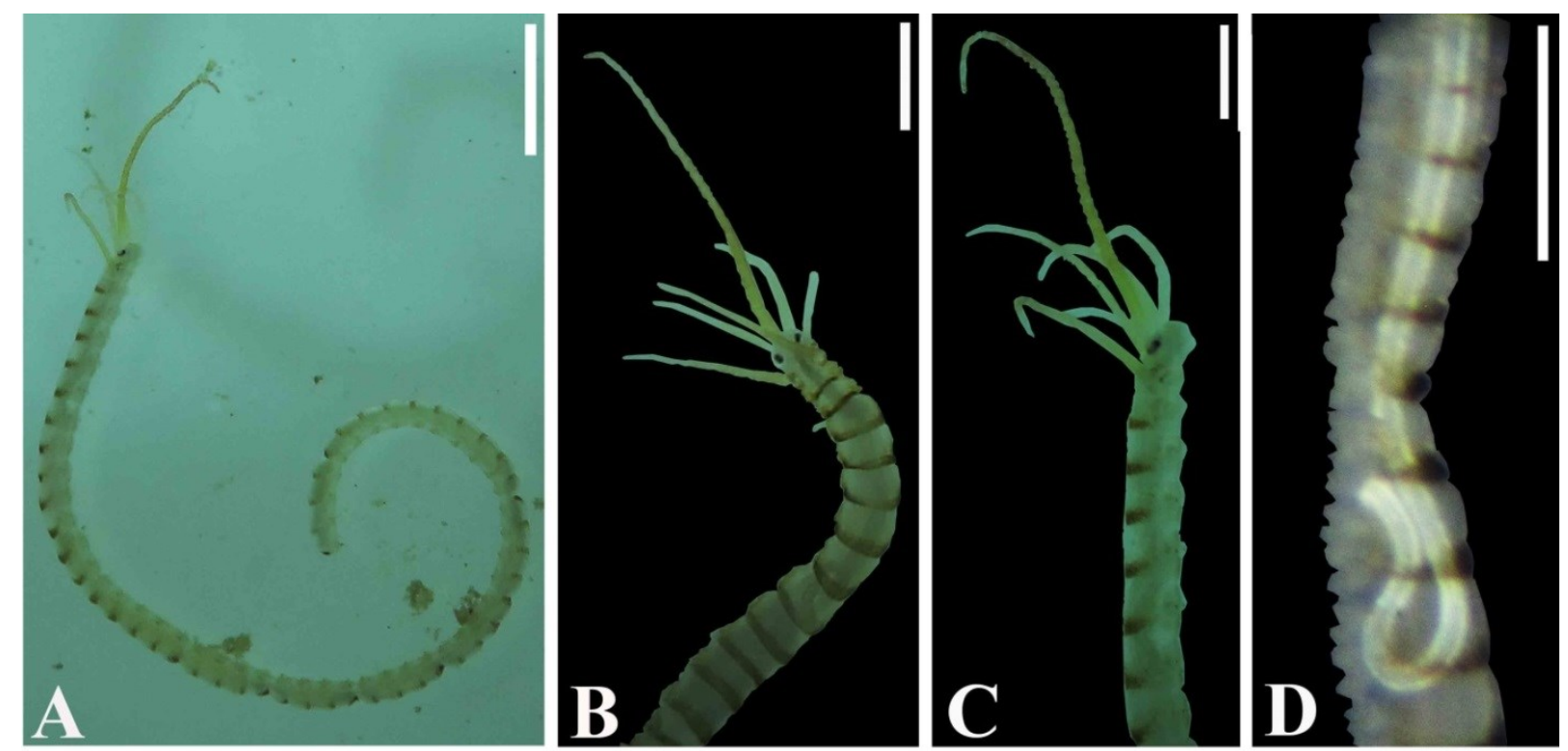

Figure 9 


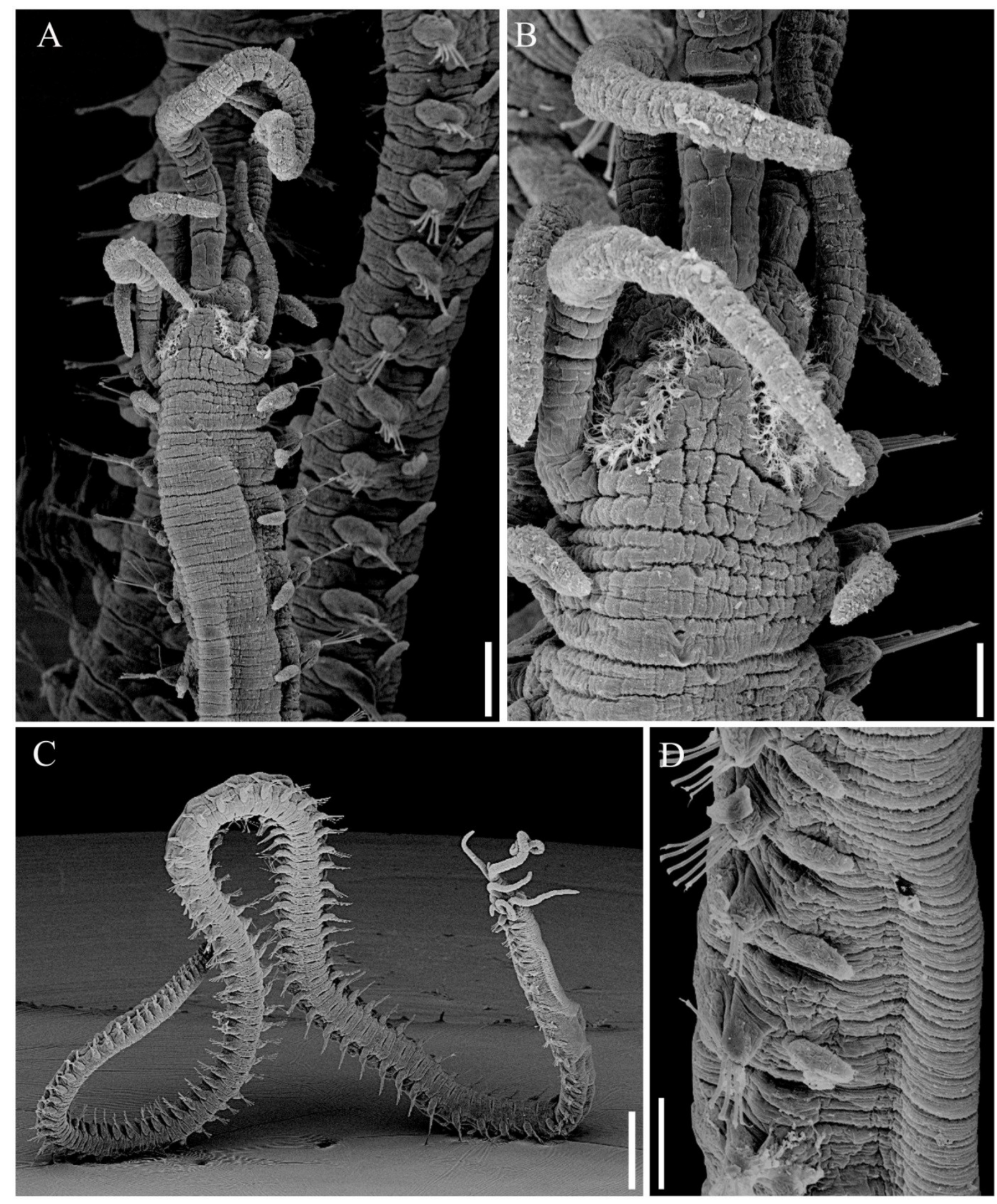

Figure 10 

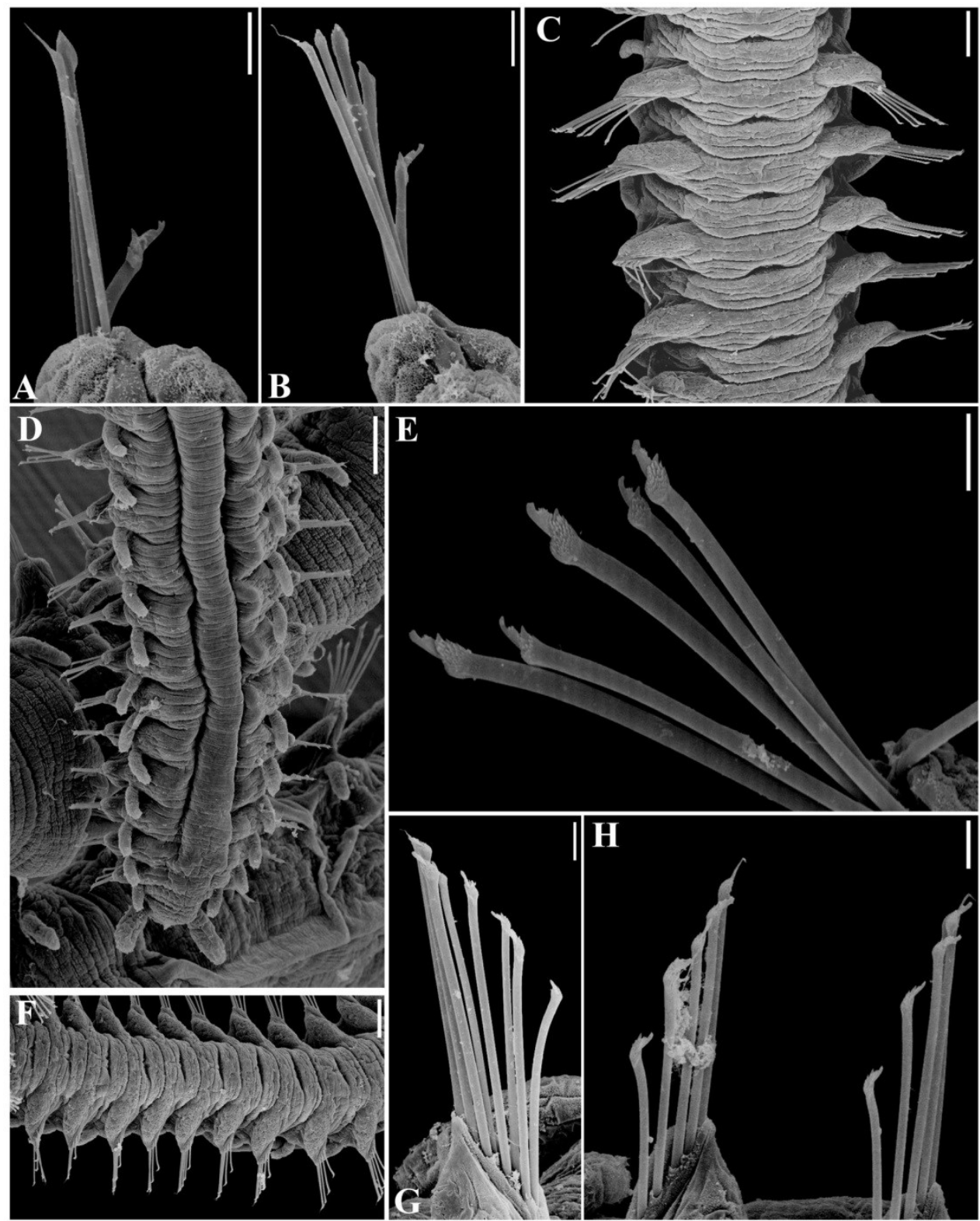

Figure 11

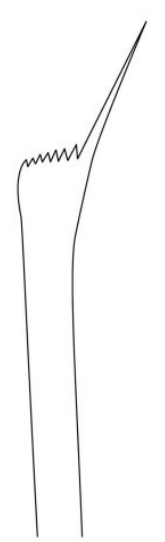

A

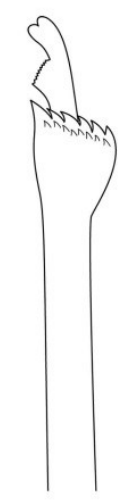

B

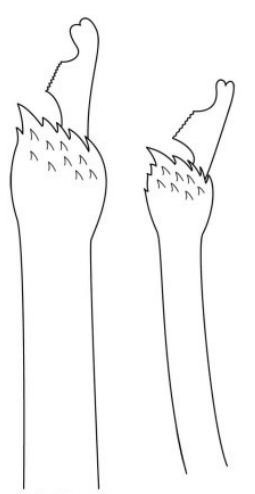

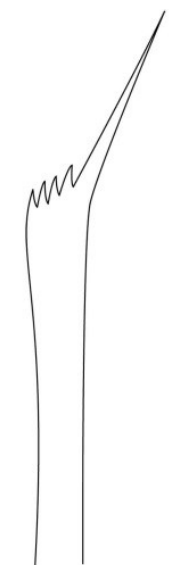

C

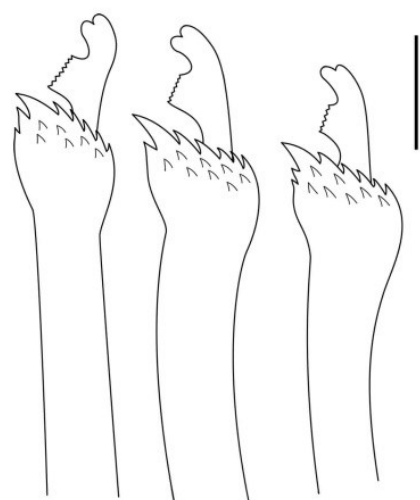

D

Figure 12 

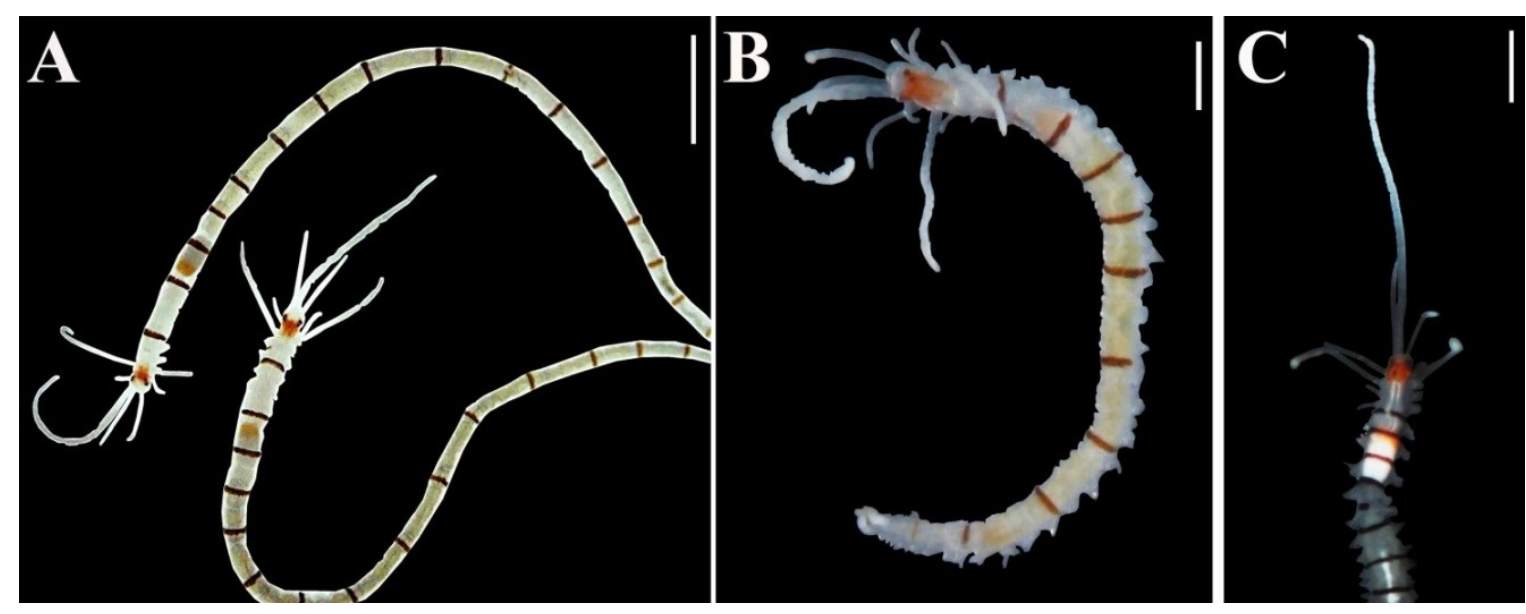

Figure 13
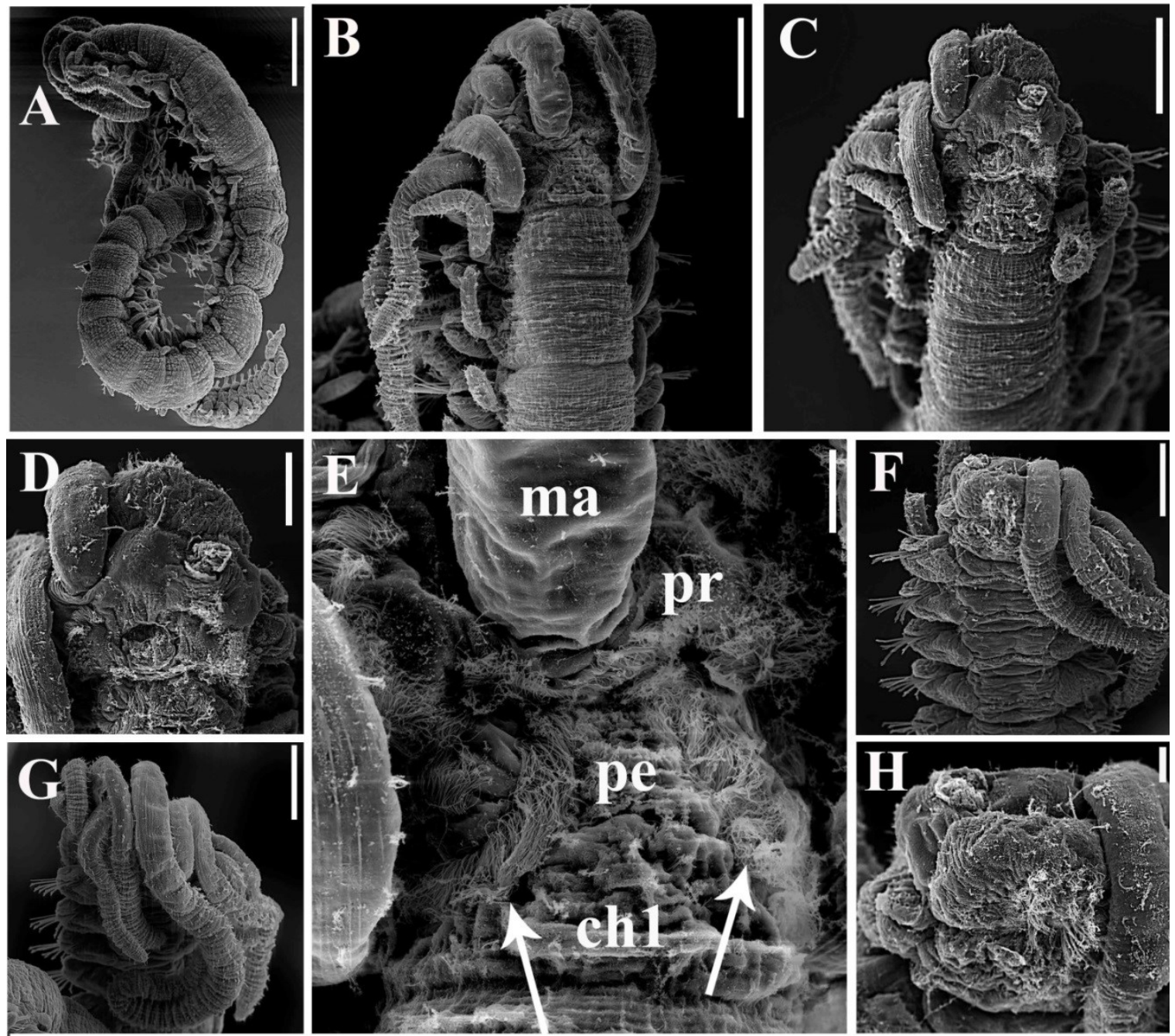

Figure 14 

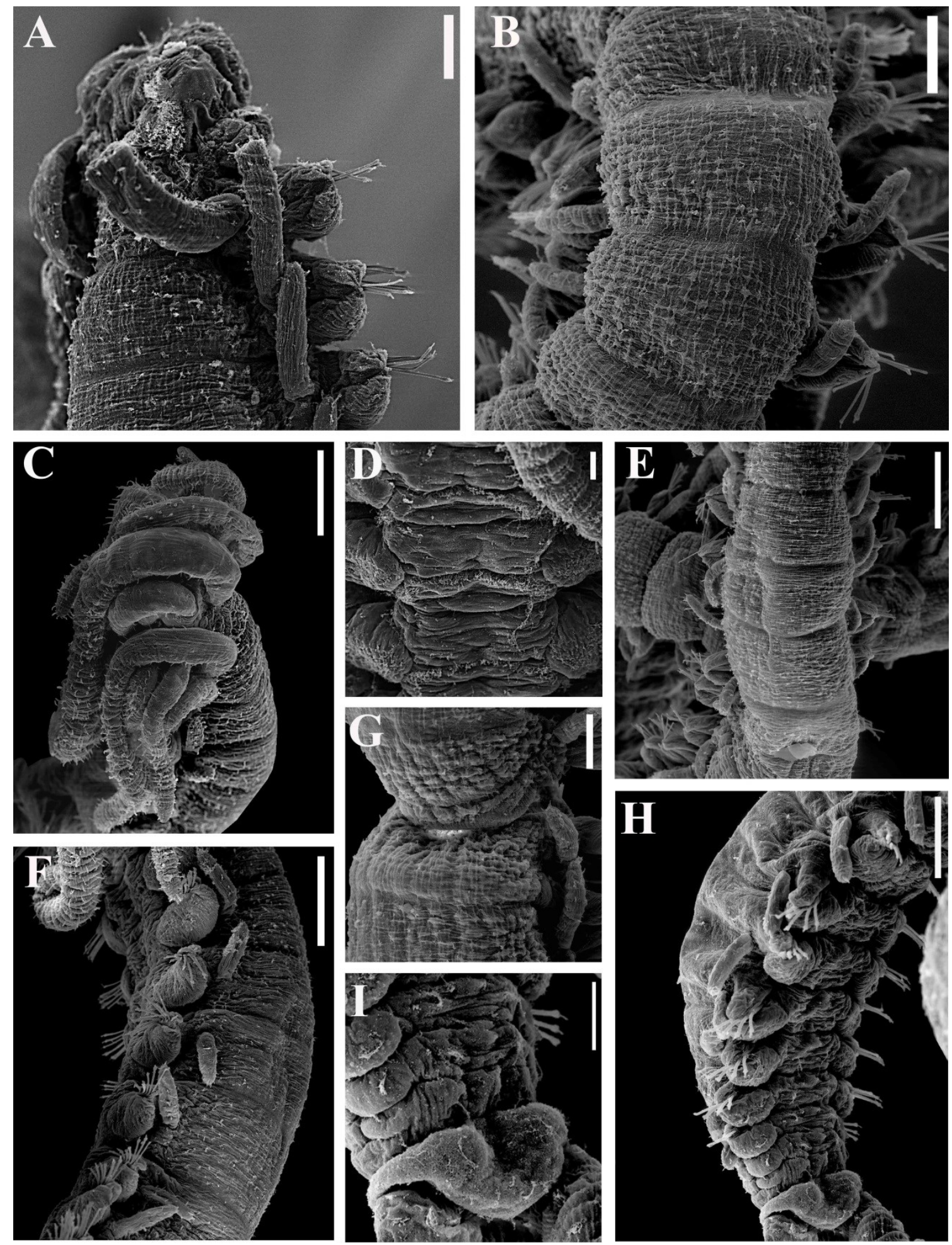

Figure 15 

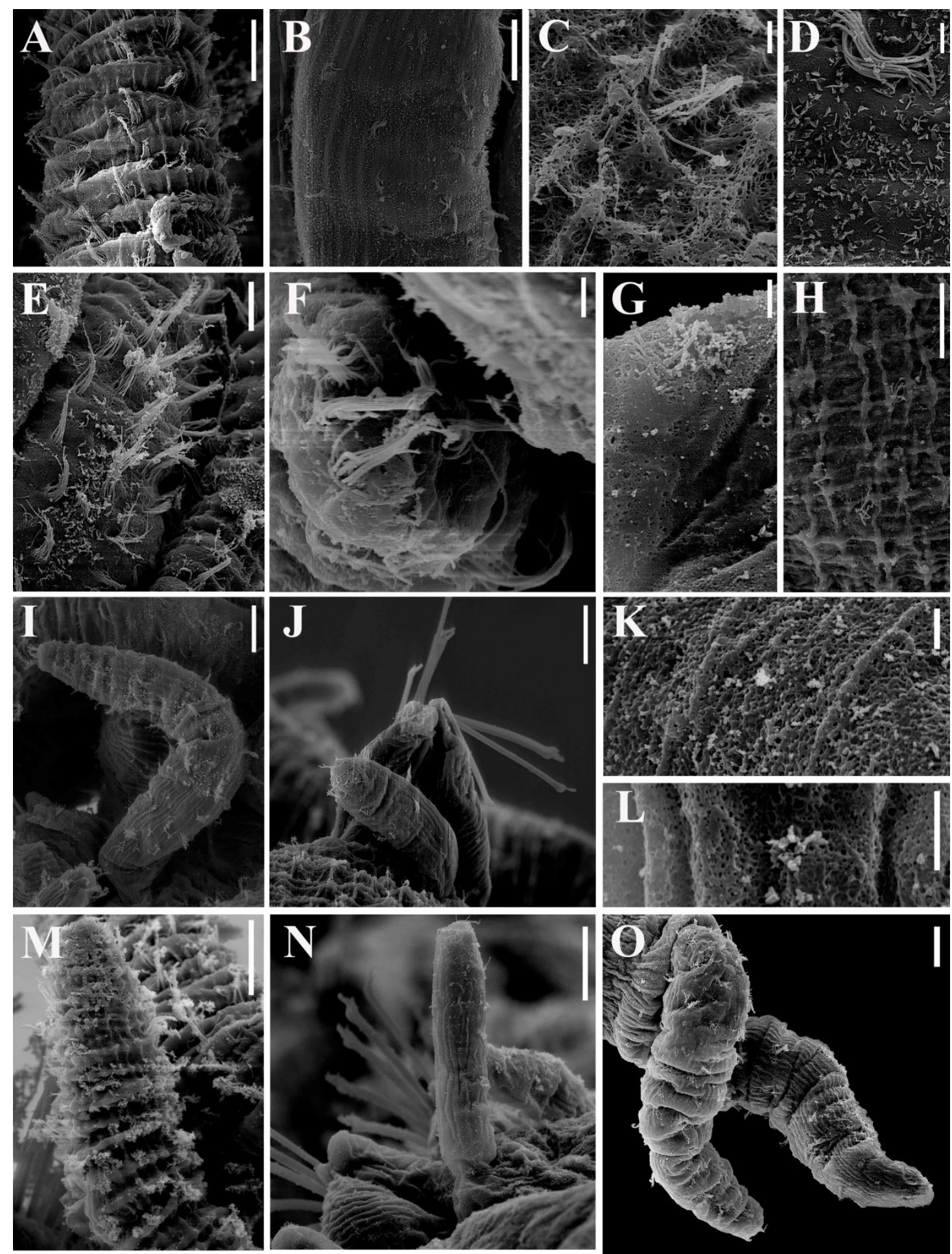

Figure 16 


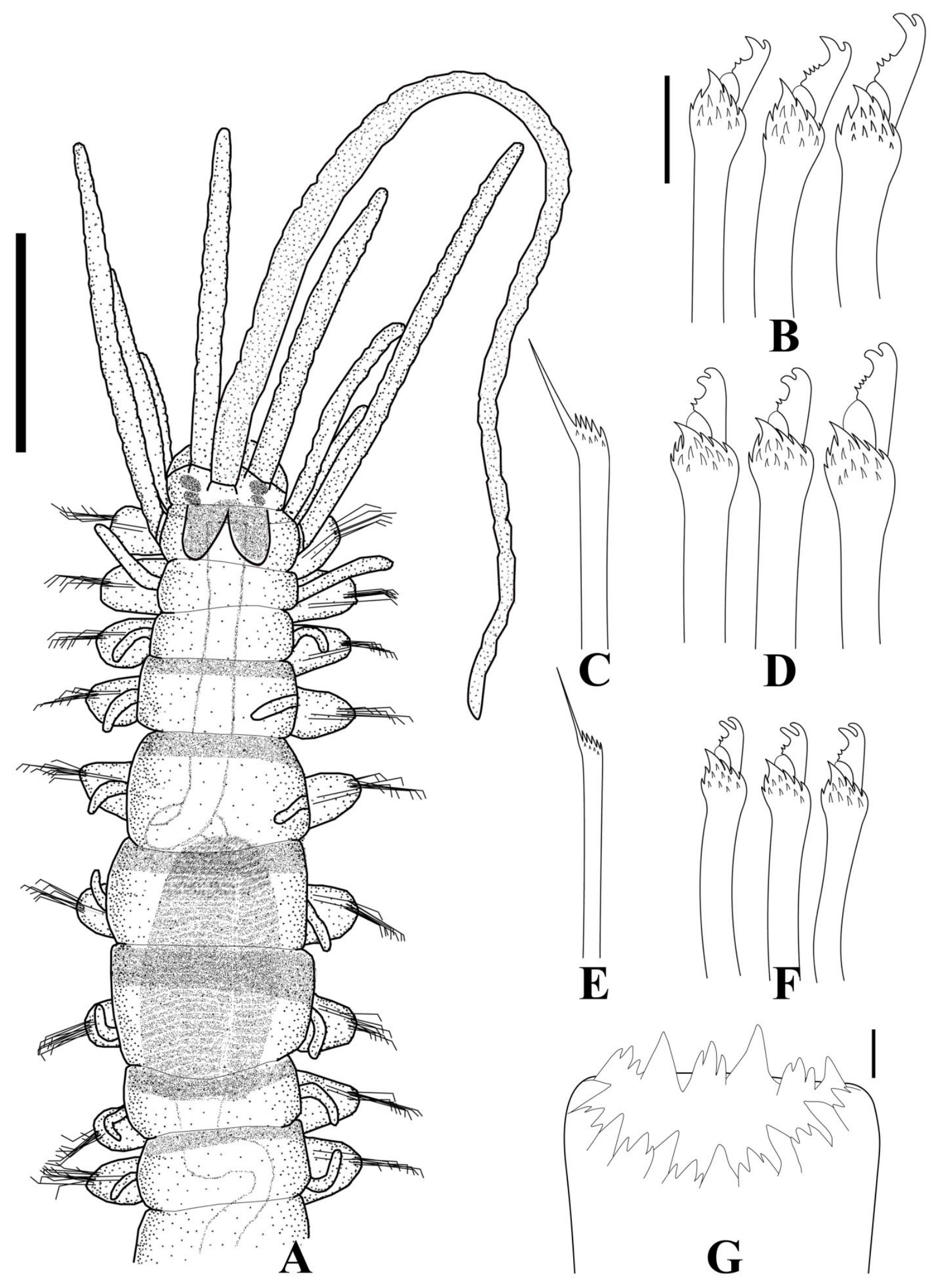

Figure 17 


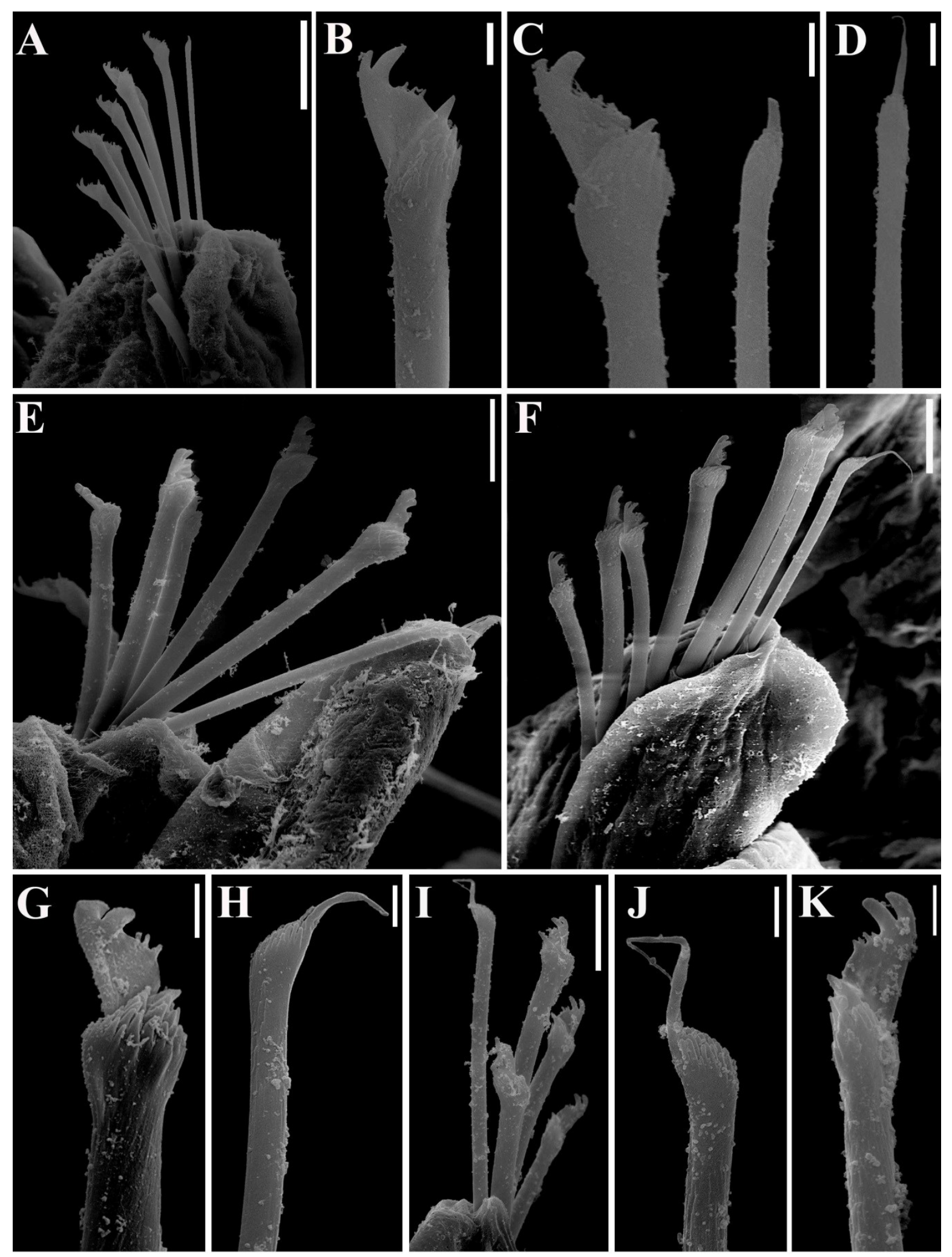

Figure 18 

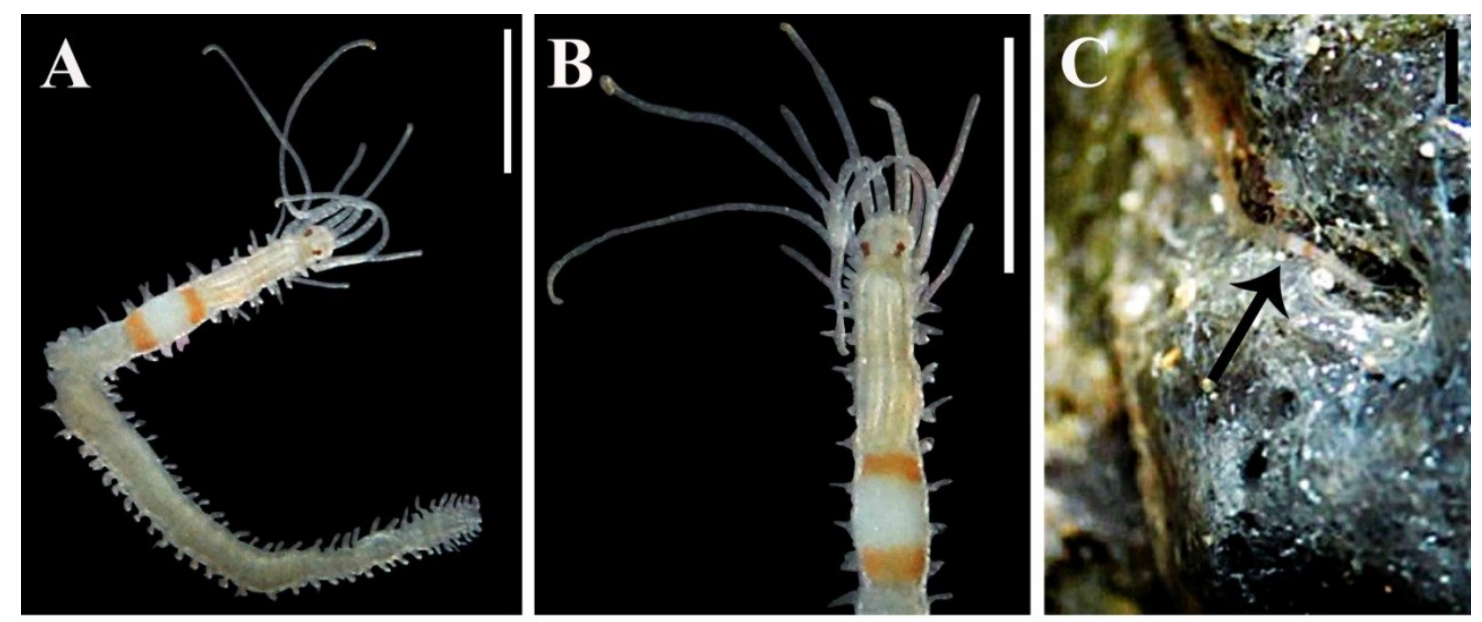

Figure 19

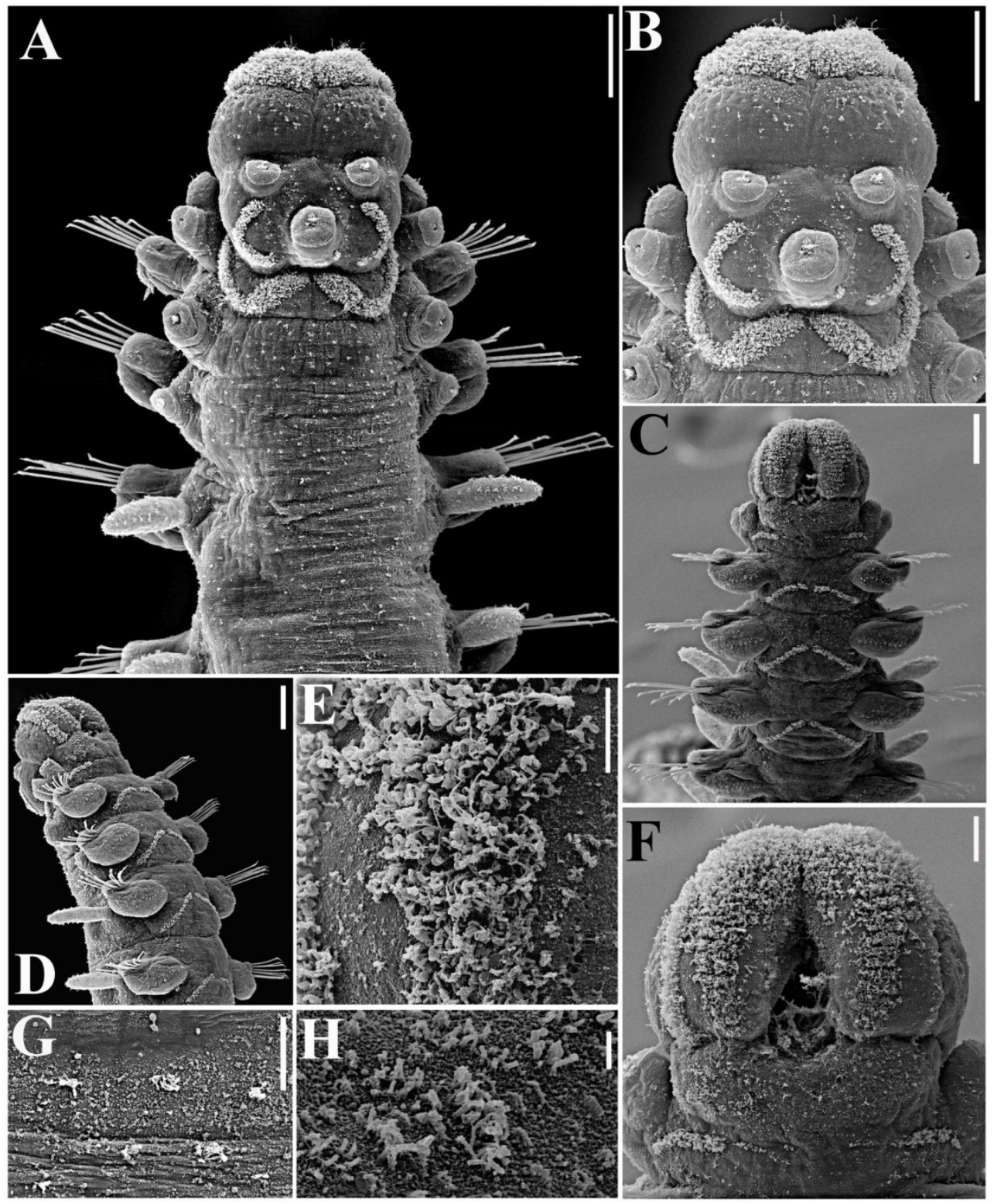

Figure 20 


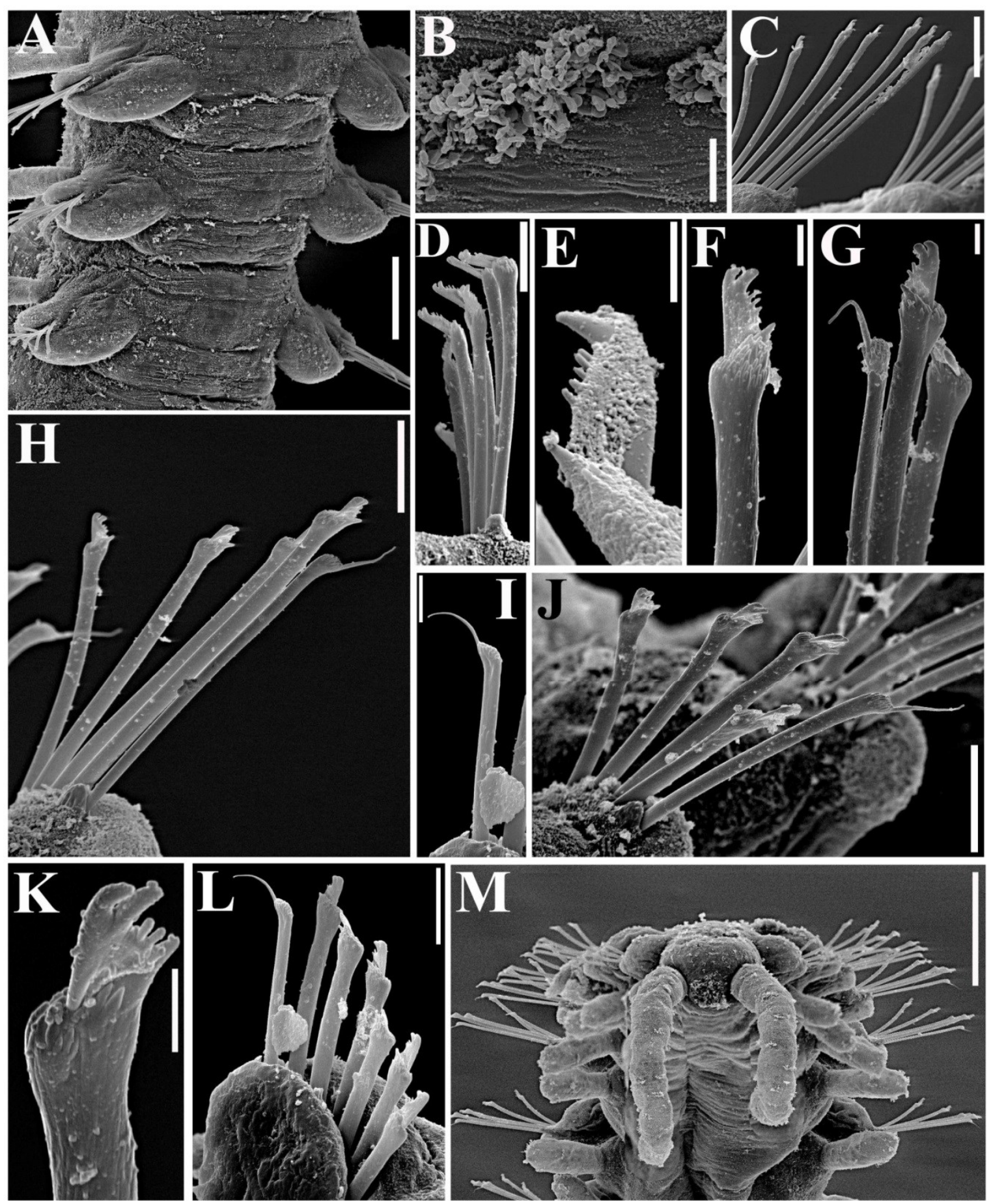

Figure 21 


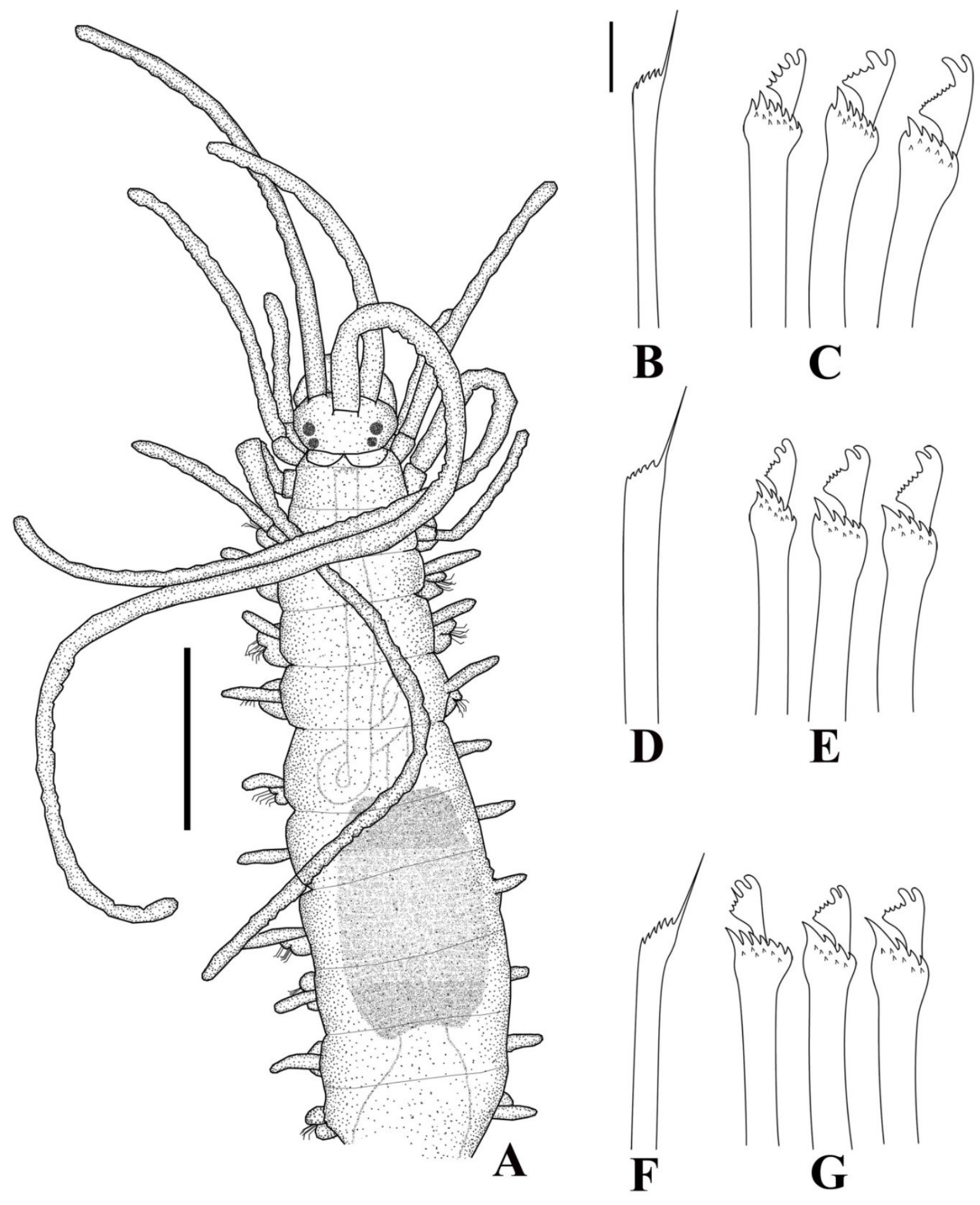

Figure 22 


\section{CAPÍTULO 2}

New species of Basidiosyllis and Odontosyllis, and new records of Amblyosyllis, Eusyllis and Perkinsyllis (Syllidae:Polychaeta)

from off the northeastern Brazilian Coast 



\title{
New species of Basidiosyllis and Odontosyllis, and new records of Amblyosyllis, Eusyllis and Perkinsyllis (Syllidae: Polychaeta) from off the northeastern Brazilian Coast
}

\author{
KARLA PARESQUE ${ }^{1 *}$, MARCELO VERONESI FUKUDA ${ }^{1}$, GUILLERMO SAN MARTÍN ${ }^{2}$ \\ \& JOÃO MIGUEL DE MATOS NOGUEIRA ${ }^{1}$
}

${ }^{1}$ Laboratório de Poliquetologia, Departamento de Zoologia, Instituto de Biociências, Universidade de São Paulo, R. do Matão, travessa 14, n. 101, 05508-900, São Paulo, SP, Brazil;

${ }^{2}$ Departamento de Biología (Zoología), Facultad de Ciencias, Universidad Autónoma de Madrid, Madrid, Spain.

* corresponding author: kparesque@gmail.com

\section{Table of contents}

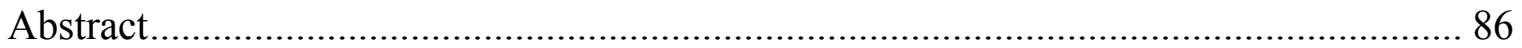

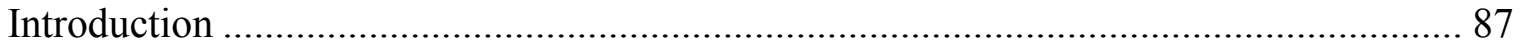

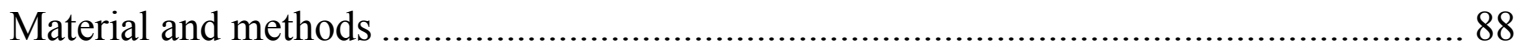

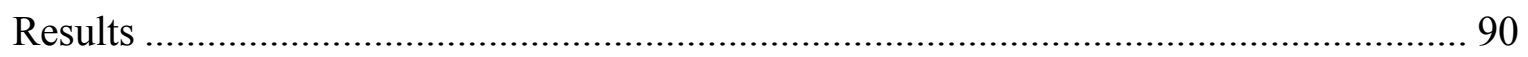

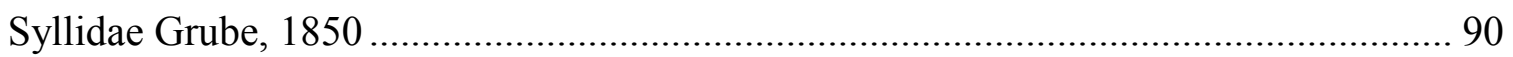

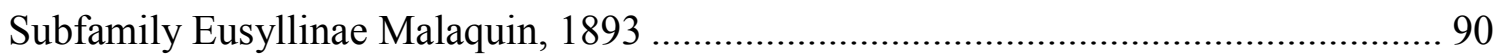

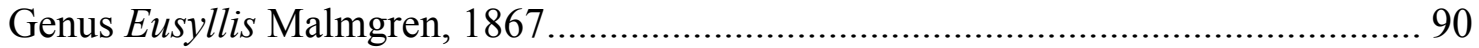

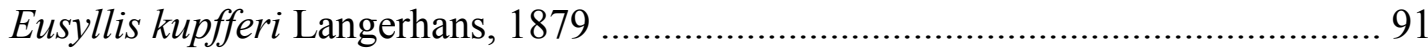

Eusyllis lamelligera Marion \& Bobretzky, 1875 ................................................... 94

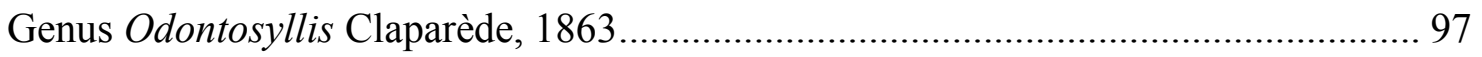

Odontosyllis cf. fulgurans (Audouin \& Milne Edwards, 1833) .............................. 99

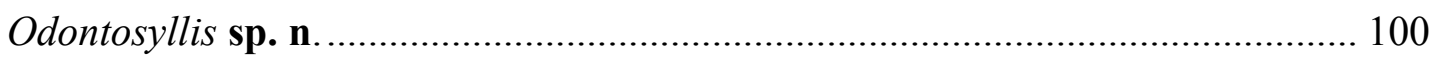

Odontosyllis guillermoi Fukuda \& Nogueira, 2006 ............................................. 104

Odontosyllis aracaensis Fukuda, Nogueira, Paresque \&San Martín 2013 ............. 105

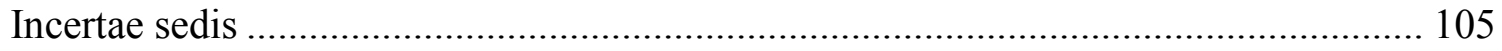

Genus Basidiosyllis San Martín, López \& Aguado, 2009 ....................................... 105

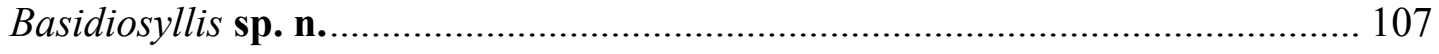

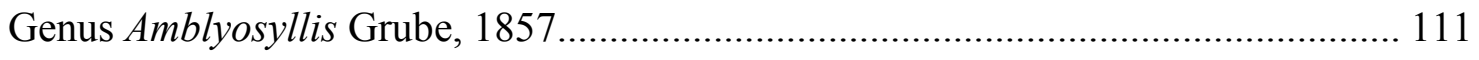


Amblyosyllis sp.

Genus Perkinsyllis San Martín, López \& Aguado, 2009

Perkinsyllis biota Fukuda \& Nogueira, 2013 ....................................................... 116

References

\section{Abstract}

Two new species are herein described, Basidiosyllis sp. n., first occurrence of the genus for the South Atlantic, and Odontosyllis sp. n., also reporting for the first time the genera Amblyosyllis and Eusyllis for the Brazilian coast, previously known only from unpublished $\mathrm{Ph}$. D. thesis, and of Perkinsyllis for the northeartern Brazilian coast. Basidiosyllis sp. n. differs from the other four known species of the genus by having dorsum with red marks, peristomium visible dorsally, dorsal peristomial cirri and dorsal cirri throughout papillate, bidentate falcigers, with teeth of similar size and four aciculae per parapodium. Odontosyllis sp. n. is characterized mostly by having bidentate falcigers, with inverted dorso-ventral gradation in length, shafts of ventralmost falcigers from midbody parapodia onwards inflated subdistally, with sigmoid tip and blades of falcigers of posterior parapodia with subdistal tooth shorter among others chatacters. Descriptions of Amblyosyllis sp., Eusyllis kupfferi and E. lamelligera are also provided, and the Brazilian specimens are compared to the morphologically most similar congeners. Finally, keys for the formally described species of Odontosyllis occurring along the Brazilian coast, and for the currently known species of Basidiosyllis are also provided with the inclusion of the new taxa described herein.

Keywords: Eusyllinae, Syllidae incertae sedis, new occurrence, taxonomy, southeastern Atlantic. 


\section{Introduction}

Syllidae Grube, 1850 is one of the most diverse and systematically challenging families of Polychaeta (Glasby 2000; San Martín 2003, 2005; San Martín \& Hutchings 2006; Aguado \& San Martín 2009), with a high number of genera and species (more than 700 species in more than 70 genera; Aguado \& San Martín 2009), currently divided into 5 subfamilies: Syllinae Grube, 1850; Autolytinae Langerhans, 1879; Exogoninae Langerhans, 1879; Eusyllinae Malaquin, 1893; and Anoplosyllinae Aguado \& San Martín, 2009. The group is easily recognized by the presence of the proventricle, a specialization of the digestive tract, which is often visible through a transparent body. The proventricle is thought to act as a suctorial pump for feeding, also producing hormones involved in the reproductive processes (Heacox \& Schroeder1982; Franke 1983, 1986); it has been considered as a synapomorphy of the group traditionally (Glasby 2000; Pleijel 2001; Aguado 2012), together with the presence of a thickened inner proboscis and dorsal cirri with a regular pattern of alternation (Aguado 2012).

The subfamily Eusyllinae has been considered, for a long time, as a paraphyletic group, although no phylogenetic studies had been performed to investigate the issue. Recently, Aguado et al. (2012) re-arranged the subfamily, and suggested Eusyllinae as a clade joining Odontosyllis Claparède, 1863, Eusyllis Claparède, 1863, Pionosyllis Malmgren, 1867, Opisthodonta Langerhans, 1879, Nudisyllis Knox \& Cameron, 1970, and Synmerosyllis San Martín, López \& Aguado, 2009 although no morphological apomorphies were found.

However, some genera which were previously treated as belonging to the subfamily, such as Basidiosyllis San Martín, López \& Aguado, 2009, Perkinsyllis San Martín, López \& Aguado, 2009, and Amblyosyllis Grube, 1857, are now out of the 
Eusyllinae clade, considered as independent genera, as they could not be allocated in any of the subfamilies, and have been treated as Syllidae incertae sedis (Aguado et al. 2012). In the present paper, we follow this classification.

Recently, an increase in the efforts addressed to assess the diversity of the Syllidae in the southeastern-southern (Nogueira et al. 2001, 2004; Nogueira \& San Martín 2002; Fukuda \& Nogueira 2006, 2012, 2013; Nogueira 2006; Nogueira \& Fukuda 2008; Fukuda et al. 2009, 2012; 2013) and the northeasthern Brazilian coast (Nogueira \& Yunda-Guarin 2008; Fukuda et al. 2013; Paresque \& Nogueira in press; Paresque et al. in press) resulted in several new occurrences and new species described. However, out of the genera treated herein, only Odontosyllis was previously known to occur off the northeastern Brazilian coast (Fukuda et al. 2013).

\section{Material and methods}

The material examined was collected by the project "Diversity of Polychaeta (Annelida) on hard substrates off the states of Paraíba and Pernambuco, northeastern Brazil". Collections were made at neap tide from reefs off Mataraca (Barra de Camaratuba, 06 $36^{\circ} \mathrm{S} 34^{\circ} 57^{\prime} \mathrm{W}$ ); Rio Tinto (Barra de Mamanguape, 06 ${ }^{\circ} 45^{\prime} \mathrm{S} 34^{\circ} 55^{\prime} \mathrm{W}$ ); Baía da Traição (Praia do Farol 06 ${ }^{\circ} 41^{\prime} \mathrm{S} 34^{\circ} 55^{\prime} \mathrm{W}$ ); João Pessoa (Praia do Cabo Branco, $7^{\circ} 08^{\prime} \mathrm{S}$

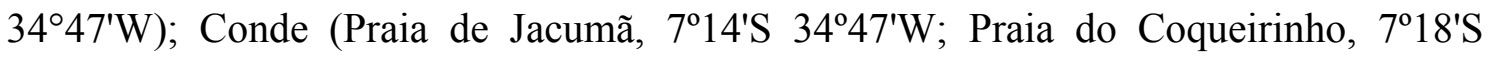
$34^{\circ} 47^{\prime} \mathrm{W}$; Praia de Tabatinga, $7^{\circ} 19^{\prime} \mathrm{S} 34^{\circ} 47^{\prime} \mathrm{W}$; Praia de Tambaba, $\left.7^{\circ} 21^{\prime} \mathrm{S} 34^{\circ} 47^{\prime} \mathrm{W}\right)$; Pitimbu (Farol de Pitimbu $7^{\circ} 28.362^{\prime} \mathrm{S} 34^{\circ} 47.663^{\prime} \mathrm{W}$ ); Goiana (Pontas de Pedra, $7^{\circ} 37^{\prime} \mathrm{S}$ $34^{\circ} 48^{\prime} \mathrm{W}$ ); Ilha de Itamaracá (Ponta do Jaguaribe, $7^{\circ} 44^{\prime} \mathrm{S} 34^{\circ} 49^{\prime} \mathrm{W}$; recifes de Itamaracá, $7^{\circ} 44^{\prime} \mathrm{S} 34^{\circ} 49^{\prime} \mathrm{W}$ ); Sirinhaém (Barra do Sirinhaém, $8^{\circ} 37^{\prime} \mathrm{S} 35^{\circ} 2^{\prime} \mathrm{W}$ ); and São José da Coroa Grande (recifes de São José da Coroa Grande, $8^{\circ} 54^{\prime} \mathrm{S} 35^{\circ} 8^{\prime} \mathrm{W}$ ). In each locality, 
algae, sponges, ascidians, mussel beds and similar substrates were scrapped from the rocks. Additionally, we collected in shallow subtidal $(1 \mathrm{~m})$ in Recife do Picãozinho, João Pessoa, Paraíba $\left(7^{\circ} 4.243^{\prime} \mathrm{S} 34^{\circ} 49.291^{\prime} \mathrm{W}\right)$ and recifes de Itamaracá, Ilha de Itamaracá, Pernambuco $\left(7^{\circ} 44^{\prime} \mathrm{S} 34^{\circ} 49^{\prime} \mathrm{W}\right)$ by snorkeling. In the laboratory, the material was examined alive under a stereomicroscope; polychaetes were sorted, relaxed in menthol solution, preserved in $4 \%$ formaline and, a few weeks later, rinsed in fresh water and transferred to $70 \%$ ethanol.

Further analyses under stereo- and light microscopes were made from specimens preserved in ethanol, some of which were permanently mounted on slides in glycerin jelly. For examination under scanning electron microscope (SEM), at least one specimen of each species was dehydrated in a series of progressively increasing concentrations of ethanol solutions, then critical point dried, covered with $25 \mathrm{~nm}$ of gold and examined and photographed under the SEM at Laboratório de Microscopia Eletrônica, Instituto de Biociências, Universidade de São Paulo (IB/USP). Line drawings were made from slide mounted specimens, with the aid of a drawing tube.

Along the descriptions of new species, measurements were taken from the entire type-series and comparative tables are provided. Data of holotypes are shown between parentheses, after the range of variation for each character. Length of specimens was measured from tip of palps to tip of pygidium, excluding anal cirri; width was measured at proventricular level, excluding parapodia.

The type material is deposited at the Museu de História Natural, IB-UNICAMP (ZUEC), Brazil; Museu de Zoologia da Universidade de São Paulo (MZUSP), Brazil; and Museo Nacional de Ciéncias Naturales (MNCN), Spain. 


\section{Results}

Syllidae Grube, 1850

Subfamily Eusyllinae Malaquin, 1893

\section{Genus Eusyllis Malmgren, 1867}

Type species: Eusyllis blomstrandi Malmgren, 1867.

Diagnosis. Body relatively small to medium sized, with numerous segments. Dorsal ciliary bands in some species. Palps free or fused basally for short extension. Prostomium with four eyes, occasionally also two anterior eyespots, and three antennae. Nuchal organs as two ciliated, semicircular grooves; ciliation usually extending along lateral margins of prostomium. Peristomium with two pairs of peristomial cirri. Antennae, peristomial cirri and dorsal cirri throughout smooth to irregularly articulated. Ventral cirri usually ovate to digitiform; ventral cirri of chaetiger 1 sometimes flattened, laminar. Compound chaetae as falcigers of variable length. Dorsal and ventral simple chaetae present at least on posterior parapodia. Pharynx straight, with mid-dorsal central tooth and usually incomplete trepan, with small denticles in ventral position (Brusa et al. 2012).

Remarks. The genus counts on eight valid species, after a revision by Brusa et al. (2013). To date, four species were informally recorded for Brazilian waters, in unpublished Ph. D. theses (Nogueira 2000; Fukuda 2010), all from off the southeastern coast of the country, including one new species which description will be published elsewhere (Fukuda et al. in prep.). This is the first record of the genus for the northeastern Brazilian coast. 


\section{Eusyllis kupfferi Langerhans, 1879}

(Figures 1-2)

Eusyllis kupfferi Langerhans, 1879: 552, Fig. 14; San Martín 1990: 607, Figs 12, 13; San Martín \& Hutchings 2006: 276-278, Figs 12D-F, 13-14. Fukuda 2010: 38-40, Fig. 8.

Material examined. State of Paraíba: Mataraca, Barra de Camaratuba, intertidal: 3 specimens, coll. 12 August 2010. Baía da Traição, Praia do Farol, intertidal: 93 specimens, coll. 09 August 2010. Rio Tinto, Barra de Mamanguape, intertidal: 27 specimens, coll. 11 August 2010. Conde, Praia de Tabatinga, intertidal: 4 specimens, coll. 01 September 2011. State of Pernambuco: Sirinhaém, Barra do Sirinhaém, $1 \mathrm{~m}: 3$ specimens, coll. 23 June 2013.

Additional material examined. Eusyllis kupfferi. Cuba, Archipiélago de los Canarreos, Punta del Francés, Isla de Pinos, on algae, $4 \mathrm{~m}$ : 11 specs (MNCN 16.01/6764), coll. \& det. G. San Martín. Brazil, state of São Paulo, Ubatuba, Praia da

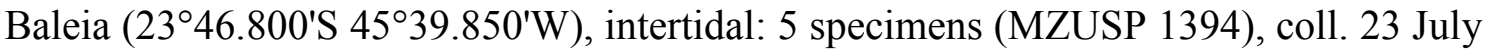
2005; Praia da Fazenda (232 $\left.21.417^{\prime} \mathrm{S} 44^{\circ} 51.917^{\prime} \mathrm{W}\right)$, intertidal: 3 specimens (MZUSP 1397), coll. 16 October 2001; Peruíbe, Praia do Guaraú (2358.729'S 46²2.070'W), intertidal: 7 specimens (MZUSP 1395), coll. 05 March 2007.

Description. Small to medium-sized body, fragile, largest specimen analysed incomplete, $3 \mathrm{~mm}$ long, $0.3 \mathrm{~mm}$ wide, with 21 segments. Pigmentation more evident on anterior body, as two brownish transverse bands per chaetiger, one discontinuous, with wide mid-dorsal gap, other located mid-dorsally, near posterior border of each chaetiger (Figs 1A; 2A), pigmentation frequently dimmed in preserved specimens. Palps rounded, basally fused (Figs 1A; 2A, D). Prostomium subpentagonal to quadrangular (Figs 1C; 2A), with two pairs of eyes in rectangular to trapezoidal arrangement, anterior eyespots 
absent (Fig. 2A); lateral antennae inserted in front of anterior eyes, extending well beyond tip of palps; median antenna inserted slightly posteriorly to lateral antennae (Fig. 1B-C), 2-2.5 times as long as lateral antennae. Nuchal organs not observed. Peristomium inconspicuous dorsally (Fig. 1C), only visible lateral and ventrally; dorsal peristomial cirri slightly shorter than median antenna, ventral peristomial cirri with about same size as lateral antennae or slightly shorter (Fig. 1A-B, D). Dorsal cirri of chaetiger 1 as long as median antenna, 1.5-3 times longer than body width, much longer than remaining dorsal cirri; dorsal cirri of chaetigers $2-3,5,7-8,10$ and shorter dorsal cirri from chaetiger 11 onwards slightly shorter than body width at corresponding segment; dorsal cirri of chaetigers 4, 6 and 9 and longer cirri from chaetiger 11 onwards, about same length as body width at corresponding segment or slightly longer (Fig. 1A-B); from chaetiger 11 onwards, dorsal cirri irregularly alternating in length. Antennae, peristomial and dorsal cirri throughout distally tapered (Fig. 1B, D). Ventral cirri ovate, slightly shorter than parapodial lobes (Fig. 1D). Parapodial lobes conical (Fig. 1B, D). Anterior parapodia with 10-25 falcigers each (Fig. 1E, F), midbody with 7-16, posterior parapodia with 4-7 falcigers each; shafts of falcigers slightly spinulated distally, with straight tips (Fig. 2B, D); blades of falcigers spinulated, unidentate, with rounded tips (Fig. 2B, D); anterior and midbody parapodia with 2-3 dorsalmost falcigers with longer and thinner blades than remaining chaetae (Fig. 1E), ca. 24-30 $\mu \mathrm{m}$ long; remaining falcigers in each fascicle with inverted dorso-ventral gradation in length of blades, dorsalmost blades shorter, ca. 10-15 $\mu \mathrm{m}$ long, ventralmost blades longer, ca. 20-25 $\mu \mathrm{m}$ long (Fig. 1E-F). Dorsal simple chaetae usually from proventricle segments onwards, sometimes present on all segments, bayonet-shaped, subdistally spinulated, (Figs 1G; 2C); ventral simple chaetae not seen. Anteriormost parapodia with up to two aciculae each, one of which distally enlarged, other slightly sigmoid distally, tapered, 
both types apparently with hollow tip (Fig. 2E); remaining parapodia with only single acicula each, distally enlarged, apparently with hollow tip, progressively stouter posteriorwards (Fig. 2F). Pygidium semicircular, with two elongated anal cirri, up to four times longer than posterior dorsal cirri. Pharynx through 4-6.5 segments, trepan with ca. 15 teeth, and large, conical to rhomboidal pharyngeal tooth; proventricle through 3.5-6 segments, with 40-44 muscle cell rows.

Remarks. Brazilian specimens agree with the descriptions provided by San Martín (1990), for Cuban specimens, and San Martín \& Hutchings (2006), for Australian ones, except for the colour pattern, which shows slight differences in the three cases. In Brazilian specimens there are two brownish transverse bands per chaetiger, one discontinuous, more conspicuous dorso-laterally at about half length of each chaetiger, and another mid-dorsal on posterior border of each chaetiger (Fig. 2A); despite San Martín (1990, Fig. 12) have draun a specimen with two similar transverse, mid-dorsal stripes per anterior chaetiger, comparative material analysed from Cuba (MNCN 16.01/6764) was collected in the 80's and unfortunately the colour was not preserved; differently, the Australian specimens have a continuous transverse stripe at about midlenght and two lateral bars posteriorly on each anterior chaetiger (San Martín \& Hutchings 2006, Fig. 13A). Furthermore, San Martín (1990) and San Martín \& Hutchings (2006) did not describe the inverted pattern of gradation in the length of falciger blades observed in Brazilian specimens. This feature, however, is frequently omitted in species descriptions and, although present in many species, it is rarely mentioned. This is the case of the Cuban specimens analysed for comparison with Brazilian specimens, which show similar pattern of length of falcigers, albeit that has not been mentioned before.

Type locality. Madeira Island, Portugal (Atlantic Ocean). 
Distribution. Atlantic Ocean: Portugal (Madeira Island), Spain (Canary Islands), Caribbean (Cuba), Brazil (states of Paraíba, Pernambuco and São Paulo). Indian Ocean: Australia (Western Australia). Pacific Ocean: Australia (Queensland and New South Wales).

\section{Eusyllis lamelligera Marion \& Bobretzky, 1875}

(Figures 3-6)

Eusyllis lamelligera. San Martín, 1984: 83-87, lams. 11, 12D-F; 2003: 117-120, Figs 54-55; San Martín \& Hutchings 2006: 278-280, Figs 15-16. Fukuda 2010: 41-44, Fig. 9.

Material examined. State of Paraíba: Baía da Traição, Praia do Farol $\left(06^{\circ} 41^{\prime} \mathrm{S}\right.$ 34 $55^{\prime} \mathrm{W}$ ), intertidal: 2 specimens, coll. 09 August 2010. Rio Tinto, Barra de Mamanguape, intertidal: 4 specimens, coll. 11 August 2010. João Pessoa, Praia do Cabo Branco, intertidal: 8 specimens, coll. 02 February 2010; Recife do Picãozinho, $1 \mathrm{~m}: 3$ specimens, coll. 15 September 2012. Conde, Praia de Jacumã, intertidal: 1 specimen, coll. 29 January 2010. Pitimbu, Farol de Pitimbu, 1 m: 5 specimens, coll. 18 September 2012. State of Pernambuco: Ilha de Itamaracá, recifes de Itamaracá , 1 m: 2 specimens, coll. 15 December 2012.

Additional material examined. Eusyllis lamelligera. Spain: Baleares, Punta

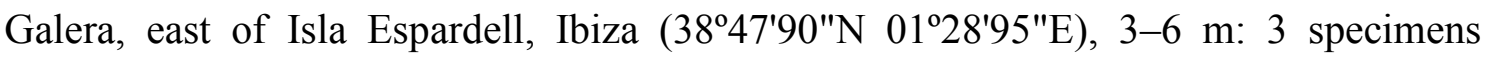
(MNCN 16.01/8680); 25 m: 1 specimen (MNCN 16.01/8684), 06 July 1994, coll. \& det. G. San Martín. Melilla: El Embudo, north of Isla del Congreso, Islas Chafarinas (35'11'01"N 02²6'16"W), 6 m: 3 specimens (MNCN 16.01/8694); west side of Isla de Isabel II, Islas Chafarinas $\left(35^{\circ} 10^{\prime} 59^{\prime \prime} \mathrm{N} 02^{\circ} 25^{\prime} 43^{\prime \prime} \mathrm{W}\right), 9-18 \mathrm{~m}$ : 1 specimen (MNCN 
16.01/8697), coll. 10 September 1991, coll. \& det. E. López. Brazil, Rio de Janeiro, Bacia de Campos $\left(22^{\circ} 19^{\prime} 45.730^{\prime \prime S} 40^{\circ} 1^{\prime} 45.543^{\prime \prime W}\right), 701.7 \mathrm{~m}$ : 1 specimen, 30 January 2009.

Description. Small to medium-sized body, fragile, largest specimen analysed incomplete, $2.2 \mathrm{~mm}$ long, $0.25 \mathrm{~mm}$ wide, with 25 segments. Pigmentation as two dark, transverse dorsal stripes, one close to anterior border, other near posterior border of each chaetiger, more evident on anterior segments; pigmentation frequently lost in preserved material. Palps broad, rounded, free to their bases (Figs 3A-G; 4A-B). Prostomium quadrangular with two pairs of eyes in trapezoidal arrangement, anterior eyespots absent (Fig. 4A); lateral antennae smooth, inserted on anterior margin of prostomium, 2-3 times longer than palps; median antenna inserted slightly posteriorly to lateral antennae (Figs 3A, C, E-F; 4A). Ciliated nuchal organs between prostomium and peristomium (Fig. 3A, C, E, F). Peristomium indistinct dorsally (Fig. 3A, C, E, F); dorsal peristomial cirri slightly shorter than median antenna; ventral peristomial cirri slightly shorter than dorsal peristomial cirri. Dorsal cirri of chaetiger 1 pseudoarticulated, ca. two times longer than lateral antennae, about 1.5 time as long as body width; dorsal cirri of chaetigers 2 and 5 short; dorsal cirri of chaetiger 3 slightly longer than that of chaetiger 2; dorsal cirri of chaetiger 4 longer, about same size as cirri of chaetiger 1; from chaetiger 6 onwards, dorsal cirri irregularly alternating long and short cirri, long cirri longer than body width at corresponding segment, short cirri slightly shorter than body width (Fig. 4C); tufts of cilia between bases of dorsal cirri and corresponding parapodial lobes (Fig. 5I-J) . Antennae, peristomial and dorsal cirri throughout with short cirrophores and distally tapering cirrostyles (Fig. 3C, E). Ventral cirri of chaetiger 1 enlarged, flattened, foliaceous, inserted more ventrally than remaining ventral cirri; ventral cirri from chaetiger 2 onwards ovate to pyriform, 
inserted near bases of parapodial lobes (Fig. 3B, D). Parapodial lobes conical (Fig. 3B, H). Anterior parapodia with 10-18 falcigers each, midbody with ca. 12, posterior parapodia with 3-8 falcigers each; shafts of falcigers slightly spinulated, with straight tips (Figs 5E; 6A-B); blades of falcigers spinulated, bidentate, teeth of similar size, with rounded space in between (Figs 5A-G; 6A-B); blades with dorso-ventral gradation in length (Figs 5A, C, G; 6A-B), dorsalmost falcigers with blades 27-13 $\mu \mathrm{m}$ long, ventralmost with blades $12-8 \mu \mathrm{m}$ long in anterior and midbody parapodia, ca. $12 \mu \mathrm{m}$ long in posterior parapodia. Dorsal simple chaetae present from midbody chaetigers, sigmoid, bidentate, thinner than shafts of falcigers (Figs 5H; 6C); ventral simple chaetae only present in posteriormost parapodia, bidentate, teeth of similar size, subdistally spinulated, and about as thick as shafts of falcigers (Fig. 6D). Anterior parapodia with two aciculae each, midbody and posterior parapodium with single acicula each; aciculae with tricuspidate tip, progressively stouter posteriorwards (Fig. 6E-F). Pygidium semicircular, anal cirri missing in all specimens. Pharynx through 4-5 segments, with anterior margin surrounded by crown of ca. 12 papillae (Fig. 3G); trepan with ca. 20 teeth dorsally and short serration ventrally; pharyngeal tooth large, conical to rhomboidal; proventricle through three segments, with 23-27 muscle cell rows.

Remarks. The specimens from Paraíba and Pernambuco match the descriptions provided for specimens from Mediterranean Sea (San Martín 2003) and Australia (San Martín \& Huchings 2006).

Type locality. France, Gulf of Marseilles (Mediterranean Sea).

Distribution. Atlantic Ocean: English Channel to Canary Islands, Mediterranean Sea, North America (USA), Caribbean (Cuba), Brazil (states of Paraíba, Pernambuco and São Paulo). Pacific Ocean: Japan, Australia (New South Wales, Tasmania). Indian Ocean: Australia (Western Australia). 


\section{Genus Odontosyllis Claparède, 1863}

Type species: Syllis fulgurans Audouin \& Milne Edwards, 1833 designated by Hartman (1959).

Diagnosis. Medium to large sized body. Prostomium with two pairs of eyes, occasionally also with one pair of anterior eyespots, and three antennae; palps free or fused only at bases. Nuchal organs as one pair of ciliated rows extending along posterior border of prostomium. Peristomium with two pairs of cirri and, usually, rounded occipital flap, covering at least posterior part of prostomium. Antennae, peristomial and dorsal cirri throughout smooth to irregularly wrinkled, usually distally tapering. Compound chaetae as uni- or bidentate falcigers. Pharynx usually short, central tooth absent, trepan with teeth directed backwards and, frequently, two lateral plates. Reproduction by epigamy; epigamous frequently bioluminescent.

Remarks. This is the third taxonomic study describing species of Odontosyllis from the Brazilian coast. In the first, Fukuda \& Nogueira (2006) described $O$. guillermoi Fukuda \& Nogueira, 2006 and Brazilian specimens of O. cf. fulgurans. (Audouin and Milne Edwards, 1834) from São Paulo. In the second, Fukuda et al. (2013) described two new species, O. guarauensis Fukuda, Nogueira, Paresque \& San Martín 2013, only found off the coast of São Paulo, and O. aracaensis Fukuda, Nogueira, Paresque \& San Martín 2013, collected off the states of São Paulo (southeastern Brazilian coast) and Paraíba and Pernambuco (northeastern coast). We describe herein the fifth species of the genus occurring off the Brazilian coast, this one only known for the northeastern coast. 


\section{Identification key to the currently known species of Odontosyllis occurring along}

the Brazilian coast (modified from Fukuda et. al. 2013)

1a. Body without colour patterns...2

1b. Body with dorsal pigmentation...3

2a. (1a) Shafts of falcigers similar throughout; blades with teeth about same size... Odontosyllis cf. fulgurans

2b. (1a) Shafts of falcigers larger and more sigmoid ventralwards within each fascicle; posterior falcigers with ventralmost blades with distal tooth larger...Odontosyllis sp. n.

3a. (1b) Blades of falcigers with teeth about same size on anterior body and in dorsalmost chaetae of each fascicle throughout, ventralmost chaetae from midbody onwards with distal tooth larger...Odontosyllis aracaensis

3b. (1b) Blades of falcigers with distal tooth larger throughout ...4

4a. (3b) Two black, transverse, dorsal stripes per chaetiger throughout; prostomial mask as one stripe around posterior border of prostomium, one stripe between eyes of anterior pair and another posterior to posterior pair of eyes. Shafts of posterior body falcigers distally sigmoid, especially those of dorsalmost chaetae of each fascicle. Trepan with six teeth and two lateral plates...Odontosyllis guillermoi

4b. (3b) One roughly triangular patch on prostomium, beneath occipital flap, and one large, dorsal transverse stripe per chaetiger. Shafts of posterior body falcigers with subdistal enlargement, nearly triangular in shape, especially those of dorsalmost chaetae. Trepan with nine teeth and two lateral plates...Odontosyllis guarauensis 
Odontosyllis cf. fulgurans (Audouin \& Milne Edwards, 1833)

Syllis fulgurans Audouin \& Milne Edwards, 1833: 229.

Odontosyllis fulgurans. Fauvel 1923: 274, Figs 103F-I; Gardiner 1975: 135, Fig. 12A-C; San Martín 1984: 93-97, lam. 14; 1990: 618; 2003: 104, Figs 46-47; Nogueira 2000: 89-90, Fig. 20 L-O; 2006: 147.

Odontosyllis cf. fulgurans. Fukuda \& Nogueira 2006: 229-232, Figs 3-4.

Material examined. State of Paraíba: Rio Tinto, Barra de Mamanguape, intertidal: 7 specimens, coll. 11 August 2010. João Pessoa, Praia do Cabo Branco, 3 specimens, col. 02 February 2010. State of Pernambuco: Ilha de Itamaracá, Ponta do Jaguaribe, intertidal: 1 specimen, coll. 11 December 2012; recifes de Itamaracá, 1 m: 3 specimens, coll. 15 December 2012.

Remarks. We noticed a variation in size between specimens of O. fugurans from different localities along the Brazilian coast. In Southeastern Brazil the largest specimen was $5 \mathrm{~mm}$ long, with 50 chaetigers (Fukuda \& Nogueira 2006), whereas in northeastern Brazil we found specimens up to $15 \mathrm{~mm}$ long, incomplete, with 88 chaetigers. San Martín (2003) examined specimens $40 \mathrm{~mm}$ long, with ca. 100 chaetigers, from Spain. Despite the differences in the length, we identified all these Brazilian specimens as $O$. cf. fulgurans following Fukuda \& Nogueira (2006) and Fukuda et al. (2013), because our material matches the description provided by these authors, except for the inverted dorso-ventral gradation in length of the blades of falcigers, which was misinterpreted by Fukuda \& Nogueira (2006).

Type locality. France (Mediterranean Sea).

Distribution. Probably a cosmopolitan species, occurring in tropical and temperate waters (San Martín 2003). 


\section{Odontosyllis sp. n.}

(Figures 7-9; Table 1)

Material examined. Type series. Data of selected specimens of the type series are provided in Table 1. State of Paraíba: Baía da Traição, Praia do Farol, intertidal: 28 specimens, coll. 09 August 2010. Rio Tinto, Barra de Mamanguape, intertidal: 7 specimens, coll. 11 August 2010.

Additional material examined. Odontosyllis australiensis Hartmann-Schröder, 1979. Australia, Western Astralia, Kimberley region: Lafontaine Is. (14 $\left.10^{\prime} \mathrm{S} 125^{\circ} 47^{\prime} \mathrm{E}\right)$, 15 m: 1 specimen (AM W28933), coll. 19 July 1988; reef south of Lucas Is., Brunswick Bay (15¹6'S 124²9'E), 2 m; 1 specimen (AM W28932), coll 24 July 1988; Calliope R., Gladstone (235 $\left.51^{\prime} \mathrm{S} 151^{\circ} 10^{\prime} \mathrm{E}\right)$, silty sand, $5.6 \mathrm{~m}$ : 1 specimen (AM W198074), coll. October 1980.

Description. Small to medium-sized body, largest specimen analysed incomplete, $10.2 \mathrm{~mm}$ long, $0.8 \mathrm{~mm}$ wide, with 58 segments, most specimens shorter (Table 1). Pigmentation absent, body beige after preservation. Palps distally rounded, basally fused (Fig. 7A-D). Prostomium ovate with two pairs of eyes in rectangular to trapezoidal arrangement, anterior eyespots absent (Fig. 8A); lateral antennae inserted on anterior margin of prostomium, about twice as long as combined length of palps and prostomium; median antenna inserted on middle of prostomium, between eyes, 1.5 times length of lateral antennae (Figs 7A-F; 8A); nuchal organs as two pairs of broad semi-circular rows of cilia, one from bases of lateral antennae to lateral borders of prostomium (Figs 7D-F; 8A), and other from base of median antenna to posterior margin of prostomium, then bordering around posterior margin until level of other row (Fig. 7D, F). Peristomium dorsally reduced to semi-circular occipital flap, covering 
central area of posterior prostomium mid-dorsally (Figs 7A-B, D-F; 8A), with fringe of cilia on anterior boarder (Fig. 7A-B, D, F); dorsal peristomial cirri slightly longer than median antenna, ventral peristomial cirri about same size as median antenna, inserted ventro-lateraly, close to mouth (Fig. 7C). Chaetiger 1 with transverse row of cilia extending dorsally for short extent from base of dorsal cirri (Fig.7A); midbody chaetigers with lateral constrictions inbetween, with a tuft of cilia in either side (Fig. 7G-H), and tufts of cilia laterally at bases of cirrophores (Fig. 9O). Dorsal cirri of chaetiger 1 slighly longer than dorsal peristomial cirri (Fig. 7B); dorsal cirri of chaetigers 2 and 3 ca. $1 / 2$ and 2/3, respectively, as long as dorsal cirri 1 , remaining dorsal cirri slightly shorter than dorsal cirri 2 (Fig. 7A). Antennae, peristomial and dorsal cirri throughout with short cirrophores (Figs 7A-G; 9A), cirrostyles distally tapering, alternating between long, similar in length to body width or slightly shorter, and short, ca. $2 / 3$ as long as longer cirri. Ventral cirri round to ovate, slightly shorter than parapodial lobes (Fig. 7C). Parapodial lobes conical, bilobed distally (Fig. 7G). Anterior parapodia with 17-22 falcigers each (Fig. 9C), midbody with 5-16, posterior parapodia with 8-14 falcigers each (Table 1); shafts of falcigers subdistally spinulated, with straight tips in anterior parapodia and in dorsalmost falcigers of each fascicle throughout; from midbody, shafts of ventralmost falcigers subdistally inflated, sigmoid, with short forward directed tip (Figs 8C, E, I; 9B, D, F-G, J, M-N); connective between shafts and blades spinulated, especially on mid- and posterior body chaetigers (Figs 8C, E, I; 9G, J); blades of falcigers spinulated and bidentate, teeth of similar size on anterior and midbody parapodia, falcigers of posterior parapodia with subdistal tooth shorter, difference in length of teeth more conspicuous in ventral chaetae (Figs 8C, E, I; 9B, DL); blades with inverted dorso-ventral gradation in length, 6-17 $\mu \mathrm{m}$ long on anterior chaetigers, 5-16 $\mu \mathrm{m}$ long on midbody, $8-14 \mu \mathrm{m}$ long on posterior chaetigers (Table 1). 
Dorsal simple chaetae beginning on chaetiger 2-24 (Table 1), thin, ca. 1/3 as thick as shafts of falcigers, slightly sigmoid, subdistally spinulated (Figs 8G; 9B) with rounded tips; ventral simple chaetae present only on last chaetigers (Table 1), sigmoid, bidentate, subdistal tooth triangular, sligtly smaller than distal tooth, subdistally spinulated, about $1 / 2$ as thick as shafts of falcigers (Figs $8 \mathrm{H} ; 9 \mathrm{O}$ ); dorsal and ventral simple chaetae present anteriorly in chaetigers newly regenerated. Anterior parapodia with $2-3$ aciculae each, midbody with 1-2, each posterior parapodium with single acicula; newly regenerated chaetigers with single acicula each; aciculae subdistally enlarged, with collar of spines, and short, acute tip (Fig. 8B, D, F). Pygidium not seen. Pharynx through 2-3 segments (Table 1), trepan with six teeth and two lateral plates; proventricle through 6-8 segments, with ca. 60 muscle cell rows (Table 1).

Remarks. The most similar species to Odontosyllis sp. n. is O. australiensis Hartmann-Schröder, 1979, described from Australian material, by having the peristomium reduced to an occipital flap that covers the posterior part of the prostomium (see San Martín \& Huchings 2006, Fig. 19D-E), dorsal cirri with similar pattern of alternation along the body, dorsal and ventral simple chaetae morphologically similar to those of Odontosyllis sp. n., similar number of aciculae per parapodium throughout, and pharynx and proventricle of similar length. However, O. australiensis has a transverse row of cilia dorsally on each chaetiger, extending to parapodial lobes, falcigers with all shafts similar and blades with teeth about same size throughout, and trepan with five teeth (San Martín \& Huchings 2006). On the other hand, Odontosyllis sp. n. has a fringe of cilia on anterior border of peristomium and, except for chaetiger 1, dorsal rows of cilia are absent on chaetigers, falcigers present more sigmoid, subdistaly inflated shafts ventralwards and blades with distal tooth larger on posterior parapodia, and trepan with six teeth. 
Odontosyllis polycera (Schmarda, 1861) shares with Odontosyllis sp. n. the morphology of falcigers and dorsal simple chaetae. Nevertheless, O. polycera is a larger species, with larger occipital flap, covering most of the prostomium; it presents up to 50 falcigers per parapodium on anterior body, blades of falcigers 15-23 $\mu \mathrm{m}$ long, and ventral simple chaetae with short subdistal tooth (San Martín \& Huchings 2006). Contrarily to O. polycera, Odontosyllis sp. n. has shorter occipital flap, 17-22 falcigers per parapodium on anterior body, blades of falcigers 5-16 $\mu \mathrm{m}$ long, and ventral simple chaetae with large subdistal tooth.

Odontosyllis sp. n. can be differentiated from the other species of this genus occurring off the Brazilian coast, $O$. aracaensis, $O$. cf. fulgurans, $O$. guarauensis and $O$. guillermoi by not having colour patterns dorsally. Furthermore, O. guarauensis has longer and ciliate palps; shorter and proportionally stouter antennae and dorsal cirri throughout; roughly rectangular occipital flap, almost as wide as the prostomium, covering posterior and, sometimes, anterior pairs of eyes; shafts of dorsalmost falcigers with subdistal, nearly triangular enlargement and thin, straight tip (see Fukuda et al. 2013, Figs 4C-D; 7E, G); aciculae with different morphology; and trepan with nine teeth (Fukuda et al. 2013). Odontosyllis cf. fulgurans differs from Odontosyllis sp. n. by having longer falcigers bidentate blades throughout, with both teeth similar in length. Odontosyllis aracaensis differs from Odontosyllis sp. n. by having semi-circular occipital flap with smooth anterior margin, without cilia, chaetiger 1, bases of dorsal cirri and constrictions between segments throughout also smooth; shafts of falcigers with straight tips and thinner and elongated blades; and aciculae with different morphology (Fukuda et. al. 2013). Finally, O. guillermoi has 28 and 20 falcigers on each anterior and midbody parapodia, respectively, falcigers with sharp and slightly 
shorter subdistal tooth on anterior chaetigers, much shorter from midbody onwards, and pharynx longer, extending for 9-10 chaetigers (Fukuda \& Nogueira 2006).

Distribution. Atlantic Ocean: only know from off the northern coast of the state of Paraíba, northeastern Brazil.

Etymology. The species epithet refers to the small size of the blades of falcigers.

Odontosyllis guillermoi Fukuda \& Nogueira, 2006

Odontosyllis guillermoi Fukuda \& Nogueira, 2006: 225-229, Figs1-2. Fukuda 2010: $52-56$.

Material Examined. State of Paraíba: Mataraca, Barra de Camaratuba, intertidal: 1 specimen, coll. 12 August 2010. Rio Tinto, Barra de Mamanguape, intertidal: 26 specimens, coll. 11 August 2010. Conde, Praia do Coqueirinho, intertidal: 2 specimens, coll. 28 August 2011; Praia de Tambaba, intertidal: 4 specimens, coll. 30 August 2011. Pitimbu, Farol de Pitimbu, $1 \mathrm{~m}: 1$ specimen, coll. 18 September 2012. State of Pernambuco: Goiana, Praia de Pontas de Pedra, intertidal: 2 specimens, coll. 13 December 2012. Ilha de Itamaracá: Ponta do Jaguaribe, intertidal: 2 specimens, coll. 11 December 2012; recifes de Itamaracá, 1 m: 2 specimens, coll. 15 December 2012.

Type locality. Brazil, São Paulo, Guarujá, Praia Branca (Atlantic Ocean).

Distribution. Atlantic Ocean: off northeastern to southeastern coast of Brazil (states of Paraíba, Pernambuco and São Paulo). 
Odontosyllis aracaensis Fukuda, Nogueira, Paresque \&San Martín 2013

Odontosyllis aracaensis Fukuda, Nogueira, Paresque \& San Martín, 2013: 144-150, Figs 1A, 2-3.

Odontosyllis sp. 1. Fukuda 2010: 56-60, Figs 14-15.

Material examined. State of Paraíba: Baía da Traição, Praia do Farol, intertidal: 1 specimen, coll. 09 August 2010. Conde, Praia de Tambaba, intertidal: 1 specimen, coll. 30 August 2011.

Type locality. Brazil, São Paulo, São Sebastião, Praia do Araçá (Atlantic Ocean).

Distribution. Atlantic Ocean: off northeastern to southeastern coast of Brazil (states of Paraíba and São Paulo).

Syllidae Grube, 1850

Incertae sedis

Genus Basidiosyllis San Martín, López \& Aguado, 2009

Type species. Pionosyllis fusigera Augener, 1913, designated by San Martín et al. 2009.

Diagnosis. Slender, small to medium size body, ciliary bands absent. Palps only fused at bases, roughly triangular to rectangular. Prostomium with four eyes and three antennae; median antenna inserted on anterior half of prostomium. Nuchal organs as 
two ciliated grooves. Peristomium with two pairs of peristomial cirri. Antennae, peristomial cirri and dorsal cirri throughout similar in shape, smooth, club-shaped; some dorsal cirri inflated. Compound chaetae as falcigers only, with bidentate blades. Aciculae distally acuminate or tricuspidate. Parapodia with short prechaetal lobes. Pharynx relatively short with single tooth away from anterior margin; proventricle usually short, of similar in size to pharynx. Reproduction unknown (cf. San Martín et al. 2009).

Remarks. Basidiosyllis was erected after a phylogenetic revision of Pionosyllis, based on morphological characters (San Martín et al. 2009). The genus is supported by one autapomorphy, the presence of inflated dorsal cirri on some segments. This is the first record for this genus to southern Atlantic Ocean, and the genus counts on four known species, including the new species described below.

\section{Key to the current known species of Basidiosyllis (modified from San Martín et al.}

1a. Long, inflated dorsal cirri, with button-shaped tips... Basidiosyllis fusigera

1b. Long, inflated dorsal cirri distally rounded, button-shaped tips absent...2

2a. (1b) Aciculae distally tricuspidate. Blades of falcigers with subdistal tooth somewhat longer. Pigmentation as dorsal transverse black bands. Midbody segments dorsally fused, forming groups of 2-3 segments...Basidiosyllis victoriae

2b. (1b) Aciculae distally acuminate. Blades of falcigers with teeth of similar size. Different colour pattern. Segments not fused...3 
3a. (2b) Anterior segments with numerous red spots dorsally, absent on dorsal cirri; falcigers with blades of similar size within fascicle; two aciculae per anterior parapodium...Basidiosyllis kalimna

3b. (2b) Anterior segments with transverse red stripes dorsally in live material, as red spots on dorsal cirri; falcigers with conspicuous gradation in length of blades within fascicle; up to four aciculae per anterior parapodium ... Basidiosyllis sp. n.

\section{Basidiosyllis sp. $\mathbf{n}$.}

(Figures 10-12; Table 2)

Material examined. Type series. State of Pernambuco: São José da Coroa Grande, recifes São José da Coroa Grande, intertidal: 2 specimens, coll. 25 June 2013. Data of specimens of the type series are provided in Table 2.

Additional material examined. Basidiosyllis kalimna San Martín \& Huchings, 2006. Australia, Western Australia, Exmouth Gulf, Bundegi Reef, north end of beach $\left(21^{\circ} 49^{\prime} \mathrm{S} 114^{\circ} 11^{\prime} \mathrm{E}\right)$, rocky rubble, sediment \& brown algae with epiphytes, $2 \mathrm{~m}, 1$ specimen (AM W28948, holotype), coll. 4 January 1984; Exmouth Gulf, Bundegi Reef, north end of beach $\left(21^{\circ} 49^{\prime} \mathrm{S} 114^{\circ} 11^{\prime} \mathrm{E}\right)$, rocky rubble, coralline algae with green epiphyte, 2 m: 2 paratypes (AM W26779), coll. 4 January.

Description. Medium-sized body, largest specimen analysed $6 \mathrm{~mm}$ long, 0.7 mm wide, with 43 segments. Conspicuous pigmentation on living animals, one large transverse red stripe per chaetiger, across dorsum between dorsal cirri, thinner posteriorly (Fig. 10A-B); some anterior chaetigers additionally with an inverted V anteriorly and a V posteriorly (Figs 10A; 11A). Dorsal and ventral surfaces and dorsal 
appendages with numerous papillae, in higher density on anterior dorsal cirri (Figs 10E; 11A), absent on palps and prostomium. Palps rectangular, basally fused, ventrally bent in paratype. Prostomium sub-quadrangular to ovate, anteriorly ciliated, with red, curved line posterior to each of posterior eyes (Fig. 10C); two pairs of eyes in rectangular to trapezoidal arrangement, anterior eyespots absent; antennae reddish in live specimens (Fig. 10A), brownish in preserved material (Fig. 10C); lateral antennae inserted on anterior margin of prostomium, reaching tip of palps; median antenna thicker, inserted slightly posteriorly, almost transversely aligned with anterior eyes, slightly longer than lateral antennae (Figs 10C; 11A); nuchal organs not visible. Peristomium dorsally short, with a transverse brown stripe (Fig. 10C); dorsal peristomial cirri brown, as long as median antenna (Fig. 11A), ventral peristomial cirri similar to dorsal ones, but slightly shorter and thinner (Fig. 11A). Brown dorsal cirri throughout, those of chaetiger 1 thick, club-shaped, longer than dorsal peristomial cirri, longer than body width at chaetiger 1 (Fig. 11A); dorsal cirri of chaetiger 2 short, digitiform, as long as ventral peristomial cirri, ca. 1/3 of body width; dorsal cirri of chaetigers 3 and 6 club-shaped, ca. 2/3 of body width; dorsal cirri of chaetiger 4 club-shaped, longer and thicker than following cirri, slightly longer than body width (Fig. 11A); remaining dorsal cirri alternating elongated and thick, club-shaped, with short and thin, long and short cirri about 2/3 and 1/3 of body width (Fig. 11A), respectively. Antennae, peristomial and dorsal cirri throughout with short cirrophores (Fig. 11A). Ventral cirri ovate, slightly shorter than parapodial lobes. Parapodial lobes distally bilobed. Anterior parapodia with 15-24 falcigers each, midbody with 14-19, posterior parapodia with 2-12 falcigers each; shafts of falcigers subdistally spinulated, with straight tips (Fig. 12A-C); blades of falcigers faintly spinulated, bidentate, teeth about same size, directed forwards (Fig. $12 \mathrm{~A}-\mathrm{C})$; blades with dorso-ventral gradation in length, 30-15 $\mu \mathrm{m}$ long on anterior 
chaetigers, 28-11 $\mu \mathrm{m}$ long on midbody, 25-10 $\mu \mathrm{m}$ long on posterior chaetigers (Table 2). Dorsal simple chaetae beginning on chaetiger 20-40, thin, about half thickness of shafts of falcigers, slightly sigmoid, with button-shaped tip (Fig. 11E); ventral simple chaetae present only on last chaetigers, sigmoid, bidentate, subdistal tooth triangular, teeth similar in length, with inconspicuous subdistal spinulation, slightly thinner than shafts of falcigers (Figs 10H, 11F). Anterior parapodia with 3-4 aciculae each, midbody with 2-3, posterior parapodia with 1-2 aciculae each; each anterior parapodia with 1-2 aciculae straight, thick, subdistally inflated, distally acuminate, and another 1-2 aciculae distally bent, with acute tips (Fig. 11B); each midbody parapodium with one acicula subdistally bent at $90^{\circ}$, with acute tips, and another straight, subdistally inflated (Fig. 11C); posterior parapodia with acicula subdistally bent at $90^{\circ}$, with acute tip (Fig. 11D). Pygidium squared, anal cirri ovate (Fig. 10F); dorsal ciliated anus. Pharynx through three segments, with a tooth slightly away from anterior border (Fig. 10C-D); proventricle through 2-2.5 segments, with ca. 18 muscle cell rows.

Reproduction. Holotype with posterior stolon. Parental form with 31 chaetigers, stolon with 12 chaetigers (Fig. 10G).

Remarks. The present is the fourth known species in this genus and the first occurring in southern Atlantic. Basidiosyllis fusigera (Augener, 1913) and B. kalimna (San Martin \& Hutchings, 2006) are known from Western Australia, and B. victoriae San Martin, López \& Aguado, 2009 was described from the Caribbean. The pharyngeal tooth in the posterior half of pharynx is a characteristic shared by Basidiosyllis fusigera and B. kalimna and was considered by San Martín et al. (2009) an apomorphy for the genus. However, in Basidiosyllis sp. n. the pharyngeal tooth is located in anterior position, albeit away from anterior margin and in $B$. victoriae its position is uncertain.Therefore, currently the only synapomorphy of the genus seems to be the 
presence of inflated dorsal cirri on some segments (San Martín et al. 2009), once the presence of pre-chaetal lobes is shared with other genera (San Martín et al. 2009).

Basidiosyllis victorae can be differentiated from Basidiosyllis sp. n. by having dorsal and ventral surfaces with black marks, all antennae inserted on anterior margin of prostomium, peristomium not visible dorsally, dorsal peristomial cirri and dorsal cirri throughout smooth, falcigers with bidentate blades, subdistal tooth longer, dorsal simple chaetae bidentate, only two aciculae per parapodium on anterior body, with tricuspidate tip, and proventricle extending through nine chaetigers, with ca. 23 muscle cell rows. On the other hand, Basidiosyllis sp. n. has the dorsum with red stripes, median antennae inserted on middle of prostomium, between the eyes, peristomium dorsally visible, papillate dorsal peristomial cirri and dorsal cirri throughout, falcigers with bidentate blades, teeth about same size, unidentate dorsal simple chaetae, with button-shaped tip, up to four aciculae per parapodium on anterior chaetigers, with acuminate tip, and proventricle extending through $2-2.5$ chaetigers, with ca. 18 muscle cell rows.

Basidiosyllis fusigera was described based in a syntype in poor conditions by San Martín \& Huchings (2006). According to Augener (1913), similarly to the pattern observed in Basidiosyllis sp. n., B. fusigera has dorsal cirri, prostomium and palps with brownish pigmentation, and anterior segments with brown dorsal bands. However, $B$. fusigera has all antennae inserted on anterior margin of prostomium, peristomium not visible dorsally, dorsal peristomial cirri and dorsal cirri smooth throughout, buttonshaped distally, and only two aciculae per parapodium on anterior chaetigers. On the other hand, Basidiosyllis sp. n., has, in addition to what has been said before, papillate dorsal peristomial cirri and dorsal cirri throughout, without button-shaped tips, and up to four aciculae per parapodium on anterior parapodia. 
Finally, B. kalimna can be easily differentiated from Basidiosyllis sp. n. by having parapodia with bilobed prechaetal lobes and trilobed postchaetal lobes, colourless, smooth dorsal cirri throughout, blades of falcigers of similar size within fascicles, about seven chaetae per anterior parapodium, up to two acuminate aciculae par anterior parapodium, dorsal simple chaetae distally bifid, and proventricle with ca. 30 muscle cell rows (San Martin \& Hutchings 2006). Basidiosyllis sp. n., on the other hand, has conical parapodial lobes and about 15-24 falcigers in each anterior parapodium.

Distribution. Atlantic Ocean: only know from off the southern coast of the state of Pernambuco, northeastern Brazil.

\section{Genus Amblyosyllis Grube, 1857}

Type species. Amblyosyllis rhombeata Grube, 1857 by monotypy.

Diagnosis. Body usually short, with few segments, slightly flattened dorsoventrally, with strong intersegmental constrictions. Palps short, usually shorter than prostomium, only basally fused, ventrally bent. Prostomium with three antennae, four eyes, and usually two anterior eyespots, sometimes located ventrally. Peristomium shorter than following segments, with two pairs of peristomial cirri; nuchal organs as one pair of dorsal épaulèttes, usually ciliated, extending above dorsum for variable length. Antennae, peristomial and dorsal cirri throughout longer than body width, usually strongly coiled, smooth to indistinctly articulated. Dorsal and ventral cirri with pigment inclusions. Ventral cirri large, usually inserted away from bases of parapodial lobes. Compound chaetae as heterogomph falcigers only, with bidentate blades; dorsal and 
ventral simple chaetae rarely present. Long and slender, convoluted pharynx; trepan with several teeth, central tooth absent. Proventricle relatively small. Pygidium with one pair of elongate anal cirri (cf. San Martín \& Huchings 2006).

Remarks. This genus was first recorded for Brazilian waters and also for southern Atlantic by Nogueira (2000), in an unpublished Ph. D. Thesis. The autor found A. formosa Claparède, 1863 living in colonies of the scleractinian coral Mussismilia hispida (Verril, 1868) off Ilha dos Alcatrazes, state of São Paulo. Once that part of the thesis was never published, the present is the first formal record of this genus for southern Atlantic and Brazilian waters.

\section{Amblyosyllis sp.}

(Figures 13-15)

Material examined. State of Paraíba, Recife do Picãozinho, intertidal: 1 specimen, coll. 15 September 2012.

Additional material examined. Amblyosyllis enigmatica San Martín \& Huchings, 2006. Australia, New South Wales, Jervis Bay, northwestern corner of Bowen Is. $\left(35^{\circ} 06.81^{\prime} \mathrm{S} 150^{\circ} 46.11^{\prime} \mathrm{E}\right)$, dense bryozoan community under rock ledge, 13 m: 1 specimen (AM W28943, holotype), coll. 8 December 1993. Amblyosyllis multidenticulata San Martín \& Huchings, 2006. Australia, New South Wales: Port Jackson $\left(33^{\circ} 51^{\prime} \mathrm{S} 151^{\circ} 16^{\prime} \mathrm{E}\right)$ : 1 specimen mounted on microscope slide (AM W502, holotype), coll. February 1920, det. G. San Martín. Australia, New South Wales: Port Jackson $\left(33^{\circ} 51^{\prime} \mathrm{S} 151^{\circ} 16^{\prime} \mathrm{E}\right)$ : 1 specimen mounted on microscope slide (AM W25245, 
paratype), id. W.A. Haswell as A. spectabilis. Australia, New South Wales: Ulladulla, Halfway Reef, $200 \mathrm{~m}$ south of Sullivan Reef $\left(35^{\circ} 21.42^{\prime} \mathrm{S} 150^{\circ} 29.31^{\prime} \mathrm{E}\right)$, red algae on rock ledges at base of wall, 13 m: 2 paratypes (AM W28229), coll. 3 May 1997, det. G. San Martín.

Description. Small-sized body, $3.2 \mathrm{~mm}$ long, $0.42 \mathrm{~mm}$ wide, with 13 segments plus some regenerating. Conspicuous pigmentation on living animal, with dorsal dark brown spots along dorsal surface, arranged in 2-3 rows (Figs 13A, D; 14). Palps free, ventrally bent, not visible dorsally (Fig. 13B). Prostomium ovate with two coalescent pairs of red eyes in trapezoidal arrangement, anterior eyespots absent; antennae all about same length, elongate, ca. four times as long as anterior body width; lateral antennae inserted on anterior margin of prostomium, median antenna inserted between anterior pair of eyes; antennae basally smooth to pseudoarticulated, distally tapering, roughly cubic articles from midlenght; two ciliated, elongate nuchal epaulletes, extending to posterior border of chaetiger 2 (Fig. 13A). Peristomium reduced, not visible dorsally, slightly shorter than chaetiger 1 ventrally; dorsal peristomial cirri elongated, slightly longer than antennae, basally smooth to pseudoarticulated, articles elongated from midlenght; ventral peristomial cirri shorter, shorter than body width, smooth to pseudoarticulated (Fig. 13B). Dorsal cirri on chaetiger 1 of approximately same length as antennae, basally smooth to pseudoarticulated, articles elongated from midlenght; dorsal cirri of chaetiger 2 smooth, slightly shorter; remaining anterior dorsal cirri ca. 1.5 times as long as body width at corresponding chaetiger, smooth or pseudoarticulated, articles elongated from midlenght (Fig. 13A); from midbody, dorsal cirri articulated (Fig. 13C), ca. 1.5-2 times as long as body width at corresponding chaetiger. Ventral cirri conical to pyriform, with small pigmentation granules (Fig. 15A-B); on anterior body, ventral cirri inserted on basal half of parapodium, extending 
beyond parapodial lobes (Fig. 15A); on posterior body, ventral cirri inserted approximately at midlength of parapodia, not extending beyond parapodial lobes (Fig. 15B). Parapodial lobes conical, with anterior pre-chaetal lobe (Figs 14; 15A-B). Anterior parapodia with ca. 22 falcigers each, mid- and posterior parapodia with ca. 25 falcigers each; shafts of falcigers slightly inflated and spinulated subdistally (Fig. 15CD); blades of falcigers with low spinulation, distally bidentate, teeth directed forward and of similar size, or subdistal tooth slightly shorter (Fig. 15C-D); blades with dorsoventral gradation in length, 78-42 $\mu \mathrm{m}$ long on anterior chaetigers, 92-55 $\mu \mathrm{m}$ long on midbody, 95-50 $\mu \mathrm{m}$ long on posterior chaetigers. Dorsal and ventral simple chaetae absent. Anterior and midbody parapodia with four aciculae each, posterior parapodia with 3-4 aciculae each; aciculae straight, thick, distally acuminate, with tips protruding from parapodial lobes (Fig. 15E-F). Pharynx through three segments, with one sinuation, trepan not seen; proventricle through two segments, with ca. 15 muscle cell rows.

Remarks. Amblyosyllis sp. is similar to A. speciosa Izuka, 1912 and A. formosa (Claparède, 1863) by having elongated nuchal epauletts, extending to posterior margin of chaetiger 2, parapodia similar throughout, with digitiform pre-chaetal lobe, 20-30 falcigers and 3-4 aciculae each, aciculae straight, thick, distally acuminate, tips protruding, and short proventricle, with up to 15 muscle cell rows (San Martín 2003).

San Martín (2003) noticed variation in the dorsal colouration of some specimens of $A$. formosa, ranging from beige to dark dorsum with some bright spots, which could, perhaps, be compared with the leopard-shaped pattern observed on the Brazilian specimen. Also, A. formosa has smooth to pseudoarticulated dorsal cirri and pharynx with several sinuations (San Martín 2003), while Amblyosyllis sp. has some midbody dorsal cirri conspicuously articulated and pharynx with single sinuation. 
Aguado et al. (2008) described A. speciosa as having ventral cirri with granules, similar to those observed in our Amblyosyllis sp.. However, A. speciosa has falcigers with shorter blades on midbody parapodia (ca. $20 \mu \mathrm{m}$ long; Aguado et al. 2008, Fig. 2H), and anterior appendages articulated, while Amblyosyllis sp. has blades of falcigers 92-55 $\mu \mathrm{m}$ long on midbody, and antennae, peristomial and some anterior dorsal cirri are pseudoarticulated.

Amblyosyllis enigmatica San Martín \& Huchings, 2006 and A. multidenticulata San Martín \& Huchings, 2006 are Australian species which differ from the Brazilian specimen in having shorter nuchal epaulettes, not extending beyond chaetiger 1 , more aciculae per parapodium (6-8 and 5-6, respectively, while Amblyosyllis sp. has 3-4) and pharynx with several sinuations.

Since we did not see the trepan, an important character to differentiate species in this genus, this single specimen should better not be formally named as a new species, until additional material is found.

Distribution. Atlantic Ocean: Brazil (state of Pernambuco). First formal record of the genus for the southern Atlantic.

Genus Perkinsyllis San Martín, López \& Aguado, 2009

Type species. Pionosyllis longisetosa Hartmann-Schröder, 1965 designated by San Martín et al. (2009).

Diagnosis. Medium-sized worms, with 1-2 transverse dorsal bands of cilia per segment. Palps usually fused only at bases. Prostomium with three antennae, two pairs of eyes 
and one pair of eyespots, both eyes and eyespots sometimes absent. Peristomium with two pairs of cirri. Long and slender antennae and cirri throughout, smooth to irregularly articulated. Compound chaetae as falcigers, spiniger-like chaetae usually also present; blades of falcigers spinulated, with spines directed upwards. Distally expanded, bilobed aciculae. Pharynx with single tooth anteriorly; proventricle about same size as pharynx or slightly longer (Fukuda \& Nogueira 2013).

Remarks. This genus was recorded for the first time from Brazilian waters, off southeastern/southern Brazilian coast, by Fukuda \& Nogueira (2013). The authors described two new species, P. biota Fukuda \& Nogueira, 2013 and P. koolalyoides Fukuda \& Nogueira, 2013, and also recorded the presence of $P$. longisetosa (HartmannSchröder, 1965) for the first time in the country.

In the present study, we found P. biota in some collections off the state of Paraíba, enlarging the distribution of this species, and consequently of the genus, to off the northeastern Brazilian coast.

Perkinsyllis biota Fukuda \& Nogueira, 2013

Perkinsyllis biota Fukuda \& Nogueira, 2013: 983-989, Figs 5-8.

Material examined. State of Paraíba: João Pessoa, Praia do Cabo Branco, intertidal: 3 specimens, coll. 02 February 2010; Recife do Picãozinho, intertidal: 1 specimen, coll. 15 September 2009.

Remarks. The specimens match the original description.

Type locality. Brazil, Rio de Janeiro, Campos Basin (Atlantic Ocean). 
Distribution. Atlantic Ocean: Brazil (states of Paraíba, Rio de Janeiro, São Paulo). First record of the genus for the northeastern Brazilian coast.

\section{Acknowledgements}

The Project 'Diversity of Polychaeta (Annelida) on sandstone reefs off northeastern Brazil, states of Paraíba and Pernambuco' was funded by the Conselho Nacional de Desenvolvimento Cientifico e Tecnológico - CNPq (proc. 481510/2008-7), in 2008 2010, and by Fundação de Amparo a Pesquisa do Estado de São Paulo - FAPESP (proc. 2010/52116-4), from 2011 to the beginning of 2014. In addition, KP receives a $\mathrm{Ph}$. D. fellowship from FAPESP (proc. 2009/17606-3), and MVF receives a post-doc fellowship from FAPESP (proc. 2010/19424-7). We are thankful to Orlemir Carrerette, Rudá Amorin, Rafael Brito, Carmem Alonso Samiguel, and all students of Laboratório de Invertebrados Paulo Yang (Universidade Federal da Paraíba/UFPB) for the help with the collections; to Enio Mattos and Phillip Lenktaitis for preparing the specimens and photographing them under the SEM; to Filipe Gudin for drawing the chaetae of Basidiosyllis sp. n., Odontosyllis sp. n., and Amblyosyllis sp. We are also grateful to Javier Sánchez Almazán (MNCN), Tatiana M. Steiner (ZUEC), and Aline Benetti (MZUSP) for collection management, and to Dr Angelika Brandt and the staff of the $\mathrm{ZMH}$ for all the support during a visit of one of us (MVF) to that collection. 


\section{References}

Aguado, M.T. \& San Martín, G. (2009) Phylogeny of the Syllidae (Polychaeta) based on morphological data. Zoologica Scripta 38, 379-402.

Aguado, M.T., San Martín, G. \& Siddall, M.E. (2012) Systematics and evolution of syllids (Annelida, Syllidae). Cladistics, 27, 1-17.

Audouin, J.V. \& Milne Edwards, H. (1833) Classification des Annélides, et description de celles qui habitent les côtes de la France. Annales des Sciences Naturelles, ser. 1, 29, 195-269.

Augener, H. (1913) Polychaeta 1, Errantia. In: Michaelsen,W. \& Hartmeyer, R. (Eds) Die Fauna Südwest-Australiens. Ergebnisse der Hamburger südwest-australischen Forschungsreise 1905, vol 4, Lieferung 5. Gustav Fischer, Jena, 65-304.

Brusa, V.S., Aguado, M.T., San Martín, G. \& Rouse, G. (2013) Revision of the genus Eusyllis Malmgren, 1867 (Annelida: Phyllodocida: Syllidae: Eusyllinae), with the description of a new species from the eastern Pacific Ocean. Zootaxa, 3599(1): 37-50.

Claparède, E. (1863) Beobachtungen über Anatomie und Entwicklungsgeschichte wirbelloser Thiere an der Küste von Normandie angelstellt . Wilhelm Engelmann, Leipzig, 120 pp.

Fauvel, P. (1923) Polychètes errantes. In: Faune de France, vol. 5. Le Chavalier. Paris. 486 pp.

Franke, H.D. (1999) Reproduction of the Syllidae (Annelida: Polychaeta). Hydrobiologia, 402, $39-55$.

Fukuda, M.V. (2010) Contribuição ao conhecimento taxonômico dos silídeos (Polychaeta: Syllidae) da região sudeste-sul do Brasil. Ph. D. Thesis, Instituto de Biociências da Universidade de São Paulo, São Paulo, 340 pp.

Fukuda, M.V. \& Nogueira, J.M.M. (2006) A new species of Odontosyllis Claparède, 1863 (Polychaeta: Syllidae: Eusyllinae), and description of Brazilian material of Odontosyllis cf. fulgurans (Audouin and Milne Edwards, 1834). Zoological Studies, 45, 223-233.

Fukuda, M.V. \& Nogueira, J.M.M. (2012) On a new species of Nuchalosyllis (Polychaeta: Syllidae), a rare syllid genus only known from Brazilian waters. Journal of the Marine Biological Association of the United Kingdom, 93(4): 963-966.

Fukuda, M.V. \& Nogueira, J.M.M. (2013) First occurrence of Perkinsyllis San Martín, López \& Aguado, 2009 (Polychaeta: Syllidae) in Brazil, with descriptions of two new species. Marine Biology Research, 9: 972-989.

Fukuda, M.V., Centurion, R., Nogueira, J.M.D. \& San Martin, G. (2012) Two new species of Paraehlersia San Martin, 2003 (Polychaeta, Syllidae) from the Atlantic Coast of South America. Zootaxa, 3264, 38-52. 
Fukuda, M.V., Nogueira, J.M.M., Paresque, K. \& San Martín, G. (2013) Species of Odontosyllis Claparède, 1863 (Annelida: Polychaeta: Syllidae) occurring along the Brazilian coast. Zootaxa, 3609, 142-162.

Fukuda, M.V., Yunda-Guarín, G. \& Nogueira, J.M.M. (2009) The genus Prosphaerosyllis (Polychaeta: Syllidae: Exogoninae) in Brazil, with description of a new species. Journal of the Marine Biological Association of the United Kingdom, 89, 1443-1454.

Gardiner, S.L. (1975) Errant polychaete annelids from North Carolina. Journal Elisha Mitchell Scient Soc, 91(3), 77-220.

Glasby, C.J. (2000) Family Syllidae. In: Beesley, P.L., Ross, G.J.B., Glasby, C.J. (Eds.), Polychaetes and Allies: The Southern Synthesis. Fauna of Australia. Vol. 4: Polychaeta, Myzostomida, Pogonophora, Echiura, Sipuncula. CSIRO Publishing, Melbourne, Vic.,pp. 161-167.

Grube, A.E. (1850) Die Familien der Anneliden. Archiv für Naturgeschichte, 16, 249-364.

Grube, A.E., (1857) Annulata Örstediana. Enumeratio Annulatorum, quaein itinere per Indian occidentalem et Americam centralem annis 1845-1848 suscepto legit cl. A. S. Örsted, adjectis speciebus nonnulois a cl. H. Kröyero in itinere ad Americam meridionalis collectis. Videnskabelige Meddelelser fra den naturhistoriske Forening, København: $158-186$.

Hartman, O. (1959) Catalogue of the polychaetous annelids of the world. Part 1. Allan Hancock Foundation Publications. Occasional Paper, 23, 1-353.

Hartmann-Schröder, G. (1965) Die Polychaeten des Sublitorals. In: Hartmann-Schröder, G. \& Hartmann G. Zur Kenntnis des Sublitorals der chilenischen Küste unter besonderer Berück-sichtigung der Polychaeten und Ostracoden (Mit bemerkungen über den Einfluss sauerstof-farmer Strömungen auf die Besiedlung von marinen Sedimenten). Mitteilungen aus dem Hamburgischen Zoologischen Museum und Institut, 62, 59-308.

Hartmann-Schröder, G. (1979) Die Polychaeten der tropischen Nordwestküste Australiens (zwis-chen Derby im Norden und Port Hedland im Süden). Teil 2. In : HartmannSchröder, G. \& Hartman, G. Zur Kenntnis des Eulitorals der australischen Küsten unter besonderer Berücksichtigung der Polychaeten und Ostracoden. Mitteilungen aus dem Hamburgischen Zoologischen Museum und Institut, 76, 77-218.

Heacox, A.E. \& Schroeder, P. (1982) The effects of prostomium and proventriculus removal on sex determination and gametogenesis in Typosyllis pulchra (Polychaeta: Syllidae). Development Genes and Evolution, 191, 84-90.

Izuka, A. (1912) The errantiate Polychaeta of Japan. Journal of the College of Science, 30, 1262.

Knox, G.A. \& Cameron, D.B. (1970) Polychaeta from the Snares Islands, New Zealand. Transactions of the Royal Society of New Zealand, 12, 73-85. 
Langerhans, P. (1879) Die Wurmfauna von Madeira. Zeitschrift für wissenschaftliche Zoologie, $32,513-592$

Malaquin, A. (1893) Recherches sur les Syllidiens, morphologie, anatomie, reproduction, développement. Mémoires de la Société des sciences, de l'agriculture et des arts de Lille, 18, 1-477.

Malmgren, A.J. (1867) Annulata polychaeta Spetsbergiae, Grönlandiae, Islandiae et Scandinaviae hactenus cognita. Öfversigt af kongliga vetenskaps-akademiens förhandlingar $n r$. 4. Ex Officina Frenckelliana, Helsingfors.

Nogueira, J.M.M. (2000) Anelídeos poliquetas associados ao coral Mussismilia hispida (Verril, 1868) em ilhas do litoral do Estado de São Paulo. Phyllodocida, Amphinomida, Eunicida, Spionida, Terebellida, Sabellida. Tese de Doutorado - Instituto de Biociências, Universidade de São Paulo. 265 pp.

Nogueira, J.M.M. (2006) Família Syllidae. In: Amaral ACZ, Rizzo AE, Arruda, EP, editors. Manual de Identificação dos Invertebrados Marinhos da Região Sudeste-Sul do Brasil. São Paulo, SP: Editora da Universidade de São Paulo, 134-164.

Nogueira, J.M.M. \& Fukuda, M.V. (2008) A new species of Trypanosyllis Claparède, 1864 (Polychaeta: Syllidae) from Brazil, with a redescription of Brazilian material of Trypanosyllis zebra. Journal of the Marine Biological Association of the United Kingdom, 88, 913-924.

Nogueira, J.M.M. \& San Martín, G. (2002) Species of Syllis Savigny in Lamarck, 1818 (Polychaeta: Syllidae) living in corals in the state of São Paulo, southeastern Brazil. Beaufortia 52, 57-93.

Nogueira, J.M.M., San Martín, G. \& Amaral, A.C.Z. (2001) Description of five new species of Exogoninae (Polychaeta, Syllidae) associated with the stony coral Mussismilia hispida (Verrill, 1868) in São Paulo State, Brazil. Journal of Natural History, 35, 1773-1794.

Nogueira, J.M.M., San Martín, G. \& Fukuda, M.V. (2004) On some exogonines (Polychaeta, Syllidae) from the northern coast of the State of São Paulo, southeastern Brazil Results of BIOTA/FAPESP/BentosMarinho Project. Meiofauna Marina, 13, 45-78.

Nogueira, J.M.M. \& Yunda-Guarín, G. (2008) A new species of Syllis (Polychaeta: Syllidae: Syllinae) from off Fortaleza, north-eastern Brazil. Journal of the Marine Biological Association of the United Kingdom, 88, 1391-1399.

Paresque, K., Fukuda, M.V., Nogueira, J.M.M. \& San Martín, G. (in press) The genus Exogone (Polychaeta: Syllidae) from the Brazilian coast, with the description of a new species. Zootaxa.

Paresque, K. \& Nogueira, J.M.M. (in press) The genus Haplosyllis Langerhans, 1879 (Polychaeta: Syllidae) from off northeastern Brazil, with descriptions of two new species. Marine Biology Research. 
Pleijel, F. (2001) Syllidae Grube, 1850. In: Rouse, G.W. \& Pleijel, F. (Eds), Polychaetes. Oxford University Press, New York, 102-105 pp.

San Martín, G. (1984) Estudio biogeográfico, faunístico y sistemático de los Poliquetos de la família Sílidos (Syllidae: Polychaeta) en Baleares. Publicaciones de la Universidad Complutense de Madrid, 187, Madrid. 581 pp.

San Martín, G. (1990) Eusyllinae (Syllidae, Polychaeta) from Cuba and Gulf of México. Bulletin of Marine Science 46, 590-619.

San Martín, G. (2003) Annelida Polychaeta II: Syllidae. In: Ramos, M.A. et al. (eds.), Fauna Ibérica, vol. 21. Museo Nacional de Ciências Naturales, CSIC, Madrid. 544 pp.

San Martín, G. \& Hutchings, P. (2006) Eusyllinae (Polychaeta: Syllidae) from Australia with the description of a new genus and fifteen new species. Records of the Australian Museum, 58, 257-370.

San Martín, G. López, E. \& Aguado, M.T. (2009) Revision of the genus Pionosyllis (Polychaeta: Syllidae: Eusyllinae), with a cladistics analysis, and the description of five new genera and two new species. Journal of the Marine Biological Association of the United Kingdom, 89, 1455-98.

San Martín, G. (2005) Exogoninae (Polychaeta, Syllidae) from Australia with the description of a new genus and twenty-two new species. Records of the Australian Museum 57, 39 152.

Schmarda, L.K., 1861. Neue wirbellose Thiere beobachtet und gesammelt auf einer Reise um die Erde 1853 bis 1857. I (Turbellarien, Rotatorien und Anneliden) (2). Leipzig: Wilhelm Engelmann, 164 pp.

\section{Legends to figures}

FIGURE 1. Eusyllis kupfferi. (A) live specimen, dorsal view; (B) (C) anterior body, dorsal views; (D) anterior body, ventral view; (E) (F) falcigers, anterior parapodium; arrows point to dorsalmost chaetae; $(\mathrm{G})$ dorsal simpe chaeta, midbody parapodium. Scale bars: A, $0.3 \mathrm{~mm}$; B, $70 \mu \mathrm{m}$; C, $28 \mu \mathrm{m}$; D, $90 \mu \mathrm{m}$; E, $8 \mu \mathrm{m}$; F, $5 \mu \mathrm{m}$; G, $3 \mu \mathrm{m}$.

FIGURE 2. Eusyllis kupfferi. (A) anterior body, dorsal view; (B) falcigers, anterior parapodium; (C) dorsal simple chaeta, midbody parapodium; (D) falcigers, midbody parapodium; (E) (F) aciculae, anterior and midbody parapodium, respectively. Scale bars: A, $100 \mu \mathrm{m}$; B-F, $10 \mu \mathrm{m}$. 
FIGURE 3. Eusyllis lamelligera, SEM. (A) (B) anterior body, dorsal and ventral views, respectively; (C) anterior body, dorsal view; (D) detail of anterior body, ventral view; (E) (F) anterior body, lateral view; (G) everted pharynx, frontal view; (H) midbody, dorso-lateral view. Scale bars: A-C, H, $100 \mu \mathrm{m}$; D-E, $50 \mu \mathrm{m}, \mathrm{F}, 25 \mu \mathrm{m} ; \mathrm{G}, 20 \mu \mathrm{m}$.

FIGURE 4. Eusyllis lamelligera. (A) (B) anterior body, dorsal and ventral views, respectively; (C) midbody, dorsal view. A-B, $0.3 \mu \mathrm{m}$; $\mathrm{C}, 0.2 \mu \mathrm{m}$.

FIGURE 5. Eusyllis lamelligera. (A) falcigers, anterior parapodia; (B) dorsalmost chaeta, anterior parapodium; (C) falcigers, chaetiger 9; (D) falcigers, anterior parapodium; (E) dorsalmost chaetae, midbody parapodium; (F) ventral chaeta, midbody parapodium; (G) falcigers, midbody parapodium; $(\mathrm{H})$ dorsal simple chaeta, posterior parapodium; (I) posterior chaetiger, lateral view; arrow points to tuft of cilia between dorsal cirrus and parapodium; $(\mathrm{J})$ close up view of the tuft of cilia between dorsal cirrus and parapodium, posterior body. Scale bars: A, D, F-G, I, $20 \mu \mathrm{m}$; B-C, E, $10 \mu \mathrm{m}$; H, J, $5 \mu \mathrm{m}$.

FIGURE 6. Eusyllis lamelligera. (A) (B) falcigers, anterior and midbody parapodia, respectively; (C) dorsal simple chaeta; (D) ventral simple chaeta; (E) aciculae, anterior parapodium; (F) acicula, posterior parapodium. Scale bars: A-F, $10 \mu \mathrm{m}$.

FIGURE 7. Odontosyllis sp. n., SEM. (A) (B) (C), anterior end, lateral, dorsal and ventral views, respectively; (D) (E) (F), close up views of prostomium and peristomium, in dorsal, dorsal and lateral views, respectively; $(\mathrm{G})$ ciliation in constrictions between chaetigers, anterior body; $(\mathrm{H})$ detail of ciliation in constriction between chaetigers 3 and 4. Arrows throughout point to ciliation; ch-chaetiger, la-lateral antennae, mamedian antenna, of - occipital flap, pa—palps. Scale bars: A-B, $200 \mu \mathrm{m} ; \mathrm{C}, 100 \mu \mathrm{m}$; D, $\mathrm{F}-\mathrm{G}, 50 \mu \mathrm{m}, \mathrm{E}, 20 \mu \mathrm{m} ; \mathrm{H}, 10 \mu \mathrm{m}$.

FIGURE 8. Odontosyllis sp. n. (A) anterior end, dorsal view; (B) aciculae, anterior parapodium; (C) falcigers, anterior parapodium; (D) aciculae, midbody parapodium; (E) falcigers, midbody parapodium; (F) acicula, posterior parapodium; (G) dorsal simple 
chaeta; $(\mathrm{H})$ ventral simple chaeta; (I) falcigers, posterior parapodium. Scale bars: A, 0.3 $\mathrm{mm} ; \mathrm{B}-\mathrm{I}, 10 \mu \mathrm{m}$.

FIGURE 9. Odontosyllis sp. n., SEM (A) anterior parapodia, dorsal view; (B-F) chaetae, anterior parapodium; (G-L) falcigers, midbody parapodia; (M) shaft of falciger, midbody parapodium; $(\mathrm{N})$ falciger, posterior parapodium; $(\mathrm{O})$ posterior body parapodia: a close up of the ventral simple chaeta on the left box. Scale bars: A, C, 20 $\mu \mathrm{m} ; \mathrm{B}, \mathrm{G}-\mathrm{H}, \mathrm{K}, \mathrm{N}, 5 \mu \mathrm{m}$; D-F, I-J, L, O, $10 \mu \mathrm{m} ; \mathrm{M}, 2 \mu \mathrm{m}$.

FIGURE 10. Basidiosyllis sp. n. (A) (B) whole holotype and paratype, respectively; (C) anterior end, dorsal view; (D) pharynx, dorsal view; (E) detail of dorsal cirri 3 and 4; (F) posterior end, dorsal view; $(\mathrm{G})$ detail of a stolon in formation, between chaetigers 32-44; (H) ventral simple chaeta. Scale bars: A, C, $2 \mathrm{~mm}$; B, 1mm; D, $0.1 \mathrm{~mm}$; E, 0.5 $\mathrm{mm} ; \mathrm{F}-\mathrm{G}, 0.3 \mathrm{~mm} ; \mathrm{H}, 10 \mu \mathrm{m}$.

FIGURE 11. Basidiosyllis sp. n. (A) anterior end, dorsal view; (B) (C) (D) aciculae, anterior, midbody and posterior parapodia; (E) dorsal simple chaeta, detail of tip of chaeta; (F) ventral simple chaeta. Scale bars: A, $0.1 \mathrm{~mm}$; B-F, $10 \mu \mathrm{m}$.

FIGURE 12. Basidiosyllis sp. n. (A) falcigers, anterior, midbody and posterior parapodia. Scale bar: A-C, $30 \mu \mathrm{m}$.

FIGURE 13. Amblyosyllis sp. (A) (B) anterior end, dorsal and ventral view, respectively; (C) dorsal cirrus, midbody; (D) posterior end, dorsal view. Scale bars: A, B, $0.4 \mathrm{~mm}$; C, $0.1 \mathrm{~mm}$; D, $0.3 \mathrm{~mm}$.

FIGURE 14. Amblyosyllis sp. specimen alive, dorsal view. Scale bar: $0.3 \mathrm{~mm}$.

FIGURE 15. Amblyosyllis sp. (A) (B) anterior and posterior parapodia, respectively; (C) (D) falcigers, anterior and posterior parapodia, respectively; (E) (F) aciculae, anterior and posterior parapodia, respectively. Scale bars: A, B, $100 \mu \mathrm{m}$; C, D, $20 \mu \mathrm{m}$; $\mathrm{E}, \mathrm{F}, 10 \mu \mathrm{m}$. 
TABLE 1. Morphological features of the type series of Odontosyllis sp. n.

\begin{tabular}{|c|c|c|c|c|c|c|c|c|c|c|}
\hline $\begin{array}{l}\text { Odontosyllis sp. } \mathbf{n} \text {. } \\
\text { Collection data }\end{array}$ & \multicolumn{10}{|c|}{ State of Paraíba, Baía da Traição, Praia do Farol, coll. 09 August 2010} \\
\hline Number of chaetigers & 38 (inc.) & 26 (inc.) & 21 (inc.) & 16 (inc.) & 17(inc.) & 14 (inc.) & 18 (inc.) & 30 (inc.) & 14 (inc.) & 14 (inc.) \\
\hline Total length (mm) & 5.8 & 3.7 & 1.7 & 1.3 & 1.6 & 1.7 & 2.3 & 3.3 & 1.5 & 1.3 \\
\hline Width at proventricle $(\mathrm{mm})$ & 0.50 & 0.55 & 0.25 & 0.5 & 0.32 & 0.55 & 0.50 & 0.20 & 0.50 & 0.45 \\
\hline Pharynx (number of chaetigers) & 2.5 & 3 & 3 & 3 & 3 & 3 & 3 & 2.5 & 2 & 2 \\
\hline \multicolumn{11}{|l|}{ Proventricle } \\
\hline Length (chaetigers) / (mm) & $7 / 0.98$ & $7 / 0.94$ & $5 / 0.45$ & $5.5 / 0.38$ & $6 / 0.40$ & $7 / 0.85$ & $6 / 0.77$ & $4.5 / 0.45$ & $7 / 0.75$ & $7.5 / 0.60$ \\
\hline Number of muscle cell rows & 67 & $\sim 53$ & $\sim 44$ & $\sim 55$ & $\sim 55$ & $\sim 61$ & $\sim 58$ & $\sim 57$ & $\sim 64$ & $\sim 57$ \\
\hline \multicolumn{11}{|l|}{$\begin{array}{l}\text { Length of blades of falcigers } \\
(\mu \mathrm{m}) \text { / number of falcigers per } \\
\text { parapodium }\end{array}$} \\
\hline $\begin{array}{l}\text { Anterior body (chaetigers 1- } \\
\text { 10) }\end{array}$ & $\begin{array}{c}8-15 / 18- \\
22\end{array}$ & $\begin{array}{c}7-15 / 19- \\
21\end{array}$ & $7-15 / 4-10$ & $\begin{array}{c}7-15 / 10- \\
12\end{array}$ & $6-15 / \sim 10$ & $8-17 / \sim 20$ & $\begin{array}{c}7-15 / 17- \\
20\end{array}$ & $7-15 / \sim 11$ & $7-15 / \sim 22$ & $7-13 / \sim 20$ \\
\hline Midbody (chaetigers 11-25) & $7-12 / 9-13$ & $\begin{array}{c}7-15 / 13- \\
19\end{array}$ & $6-16 / 7-9$ & $6-12$ / 8-9 & $6-13 / \sim 10$ & $5-13 / \sim 16$ & $7-16 / \sim 16$ & $6-13 / \sim 9$ & $5-12 / \sim 15$ & $6-14 / 10$ \\
\hline Posterior body (or 5 last) & $7-12 / 8$ & $\begin{array}{c}7-15 / 11- \\
14\end{array}$ & - & - & - & - & - & $7-12 / 4-6$ & - & - \\
\hline $\begin{array}{l}\text { Dorsal / ventral simple chaetae } \\
\text { starting from (chaetiger) }\end{array}$ & $24 / 35$ & $-1-$ & $3 / 2$ & $6 /-$ & $-/ 8$ & $-1-$ & $-1-$ & $23 / 24$ & $-1-$ & $-1-$ \\
\hline $\begin{array}{l}\text { Number of aciculae (anterior, } \\
\text { mid-, posterior body parapodia) }\end{array}$ & $2,1,1$ & $2-3,2-3,2$ & $1,1,-$ & $1,1,-$ & $1,1,-$ & $3,2,-$ & $2,2,-$ & $1,1,1$ & $2,1,-$ & $2,1,-$ \\
\hline
\end{tabular}


TABLE 2. Morphological features of the type series of Basidiosyllis sp. n..

\begin{tabular}{|c|c|c|}
\hline \multirow[b]{3}{*}{ Collection data } & \multicolumn{2}{|c|}{ Basidiosyllis sp. nov. } \\
\hline & Holotype & Paratype \\
\hline & \multicolumn{2}{|c|}{ State of Pernambuco, recifes de São José da Coroa Grande, coll. 25 June 2013} \\
\hline Numero ACCESS & 1549 & 1586 \\
\hline Number of chaetigers & Total $=43:$ Parental $=31 ;$ stolon $=12$ & 28 \\
\hline Total length (mm) & Total $=7.2:$ Parental $=5.2 ;$ stolon $=2.0$ & 3.2 \\
\hline Width at proventricle (mm) & 0.4 & 0.33 \\
\hline Pharynx Number of chaetigers & 3 & 3 \\
\hline Proventricle & & \\
\hline Length (chaetigers) / (mm) & $2.5 / 0.28$ & $2 / 0.22$ \\
\hline Number of muscle cell rows & $\sim 18$ & $\sim 19$ \\
\hline $\begin{array}{l}\text { Length of blades of falcigers }(\mu \mathrm{m}) / \text { number of } \\
\text { falcigers per parapodium }\end{array}$ & & \\
\hline Anterior body & $18-30 / 15-24$ & $15-25 / 15-18$ \\
\hline Midbody & $11-28 / 16-19$ & $12-22 / 14-16$ \\
\hline Stolon & $15-25 / 10-12$ & $10-13 / 2-6$ \\
\hline Dorsal / ventral simple chaetae starting from (chaetiger) & $40 /-$ & $20 / 20$ \\
\hline Number of aciculae (anterior, mid-, posterior body) & $3-4,2,1$ & $3,2-3,2$ \\
\hline
\end{tabular}




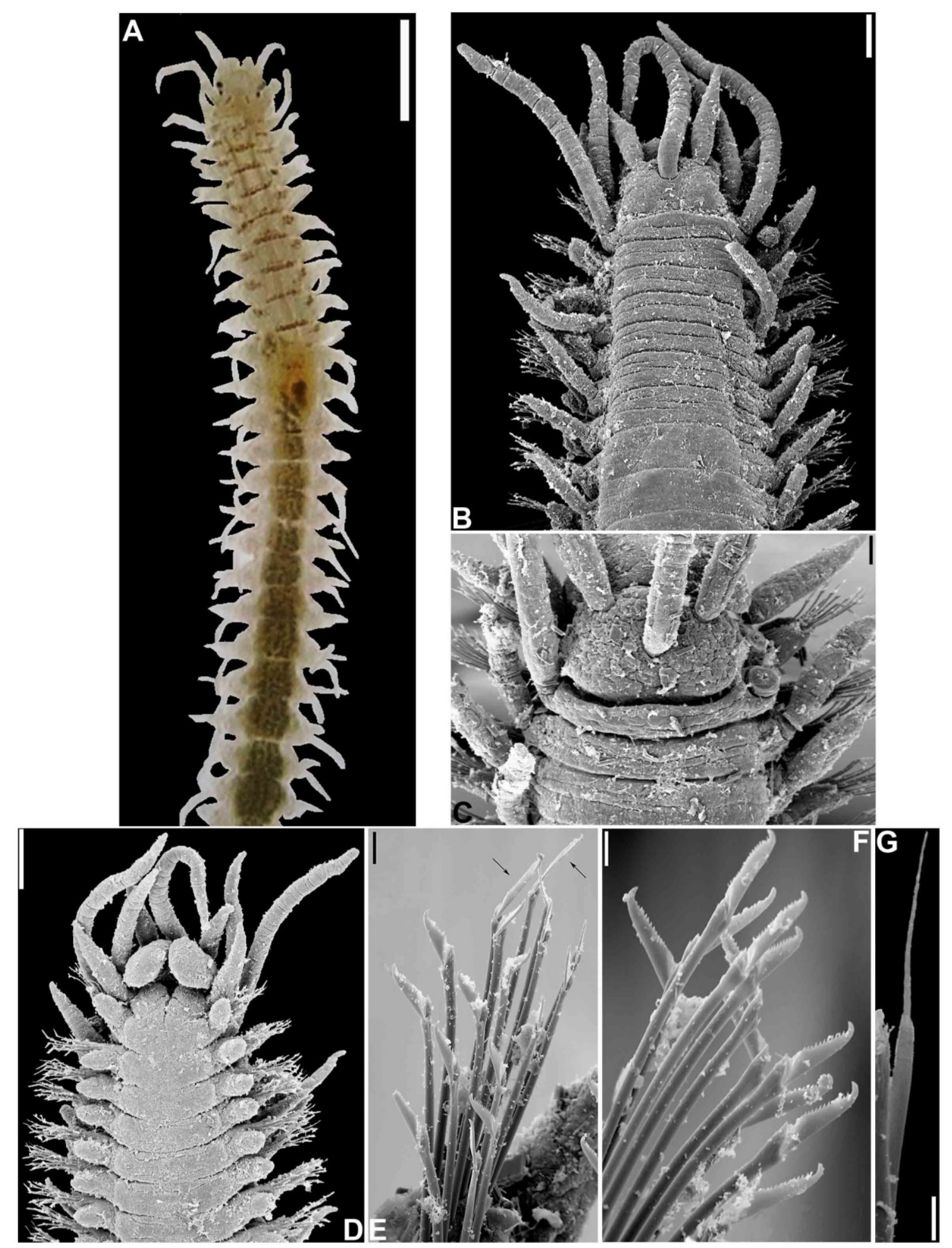

Figure 1 


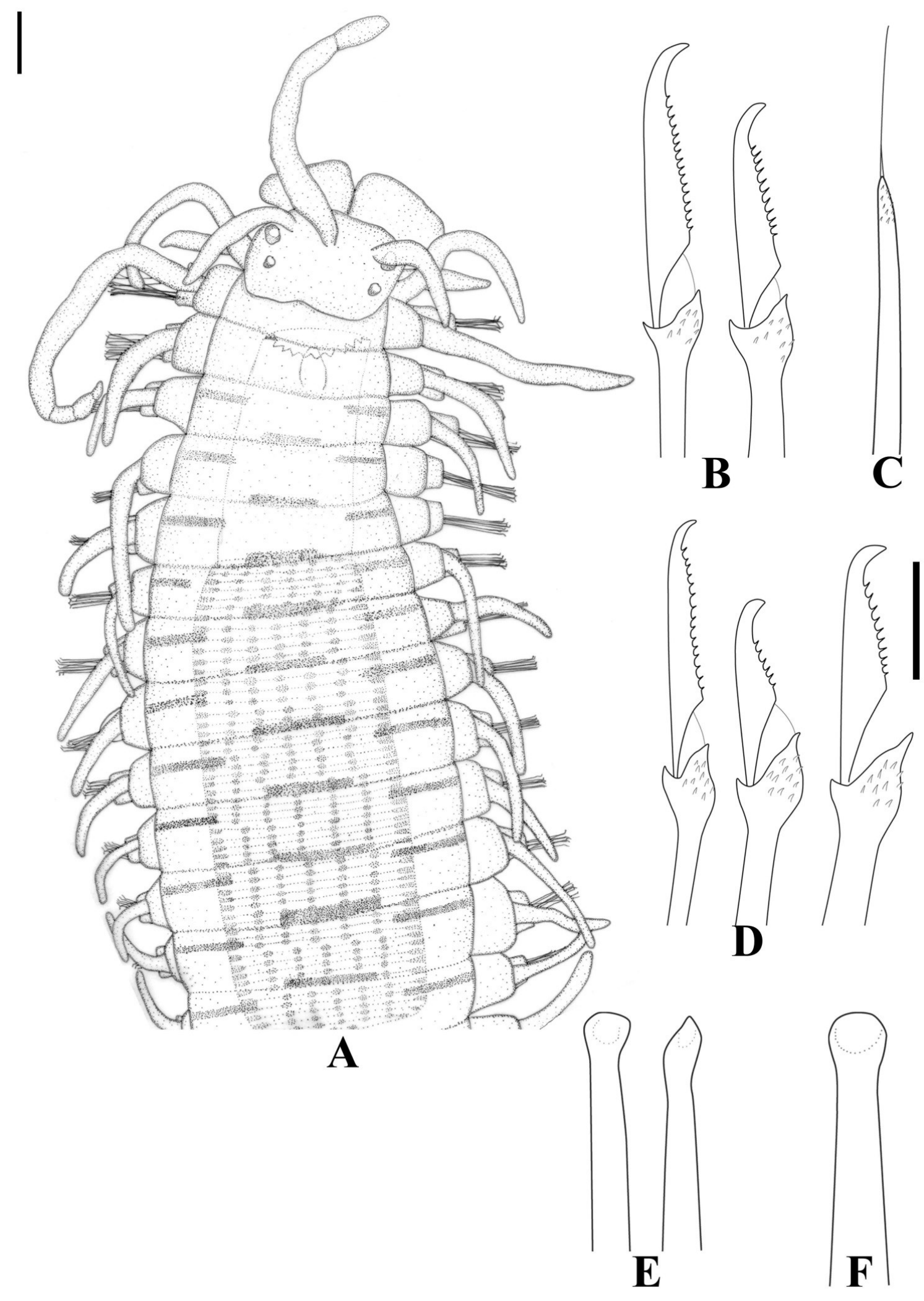

Figure 2 

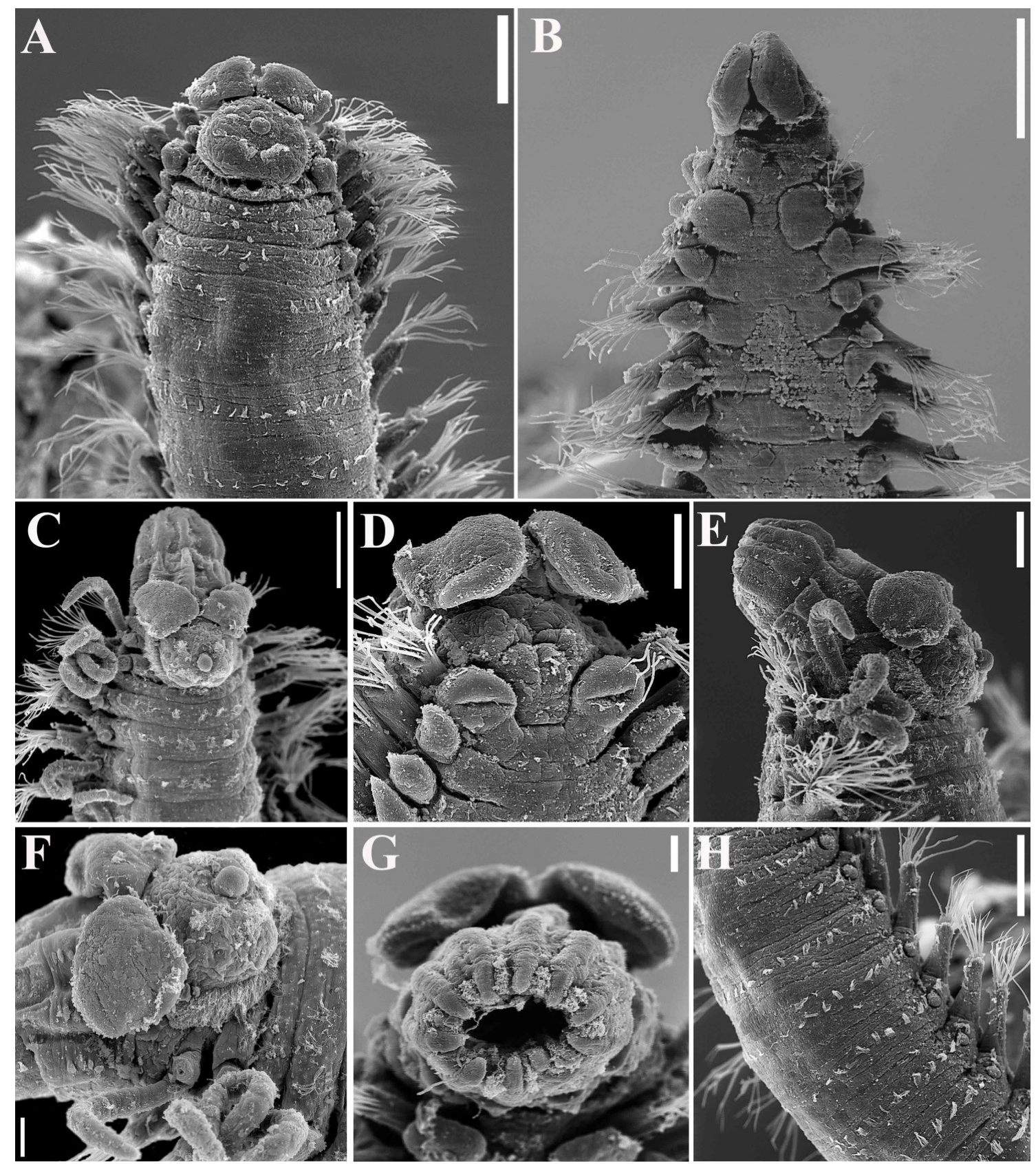

Figure 3 


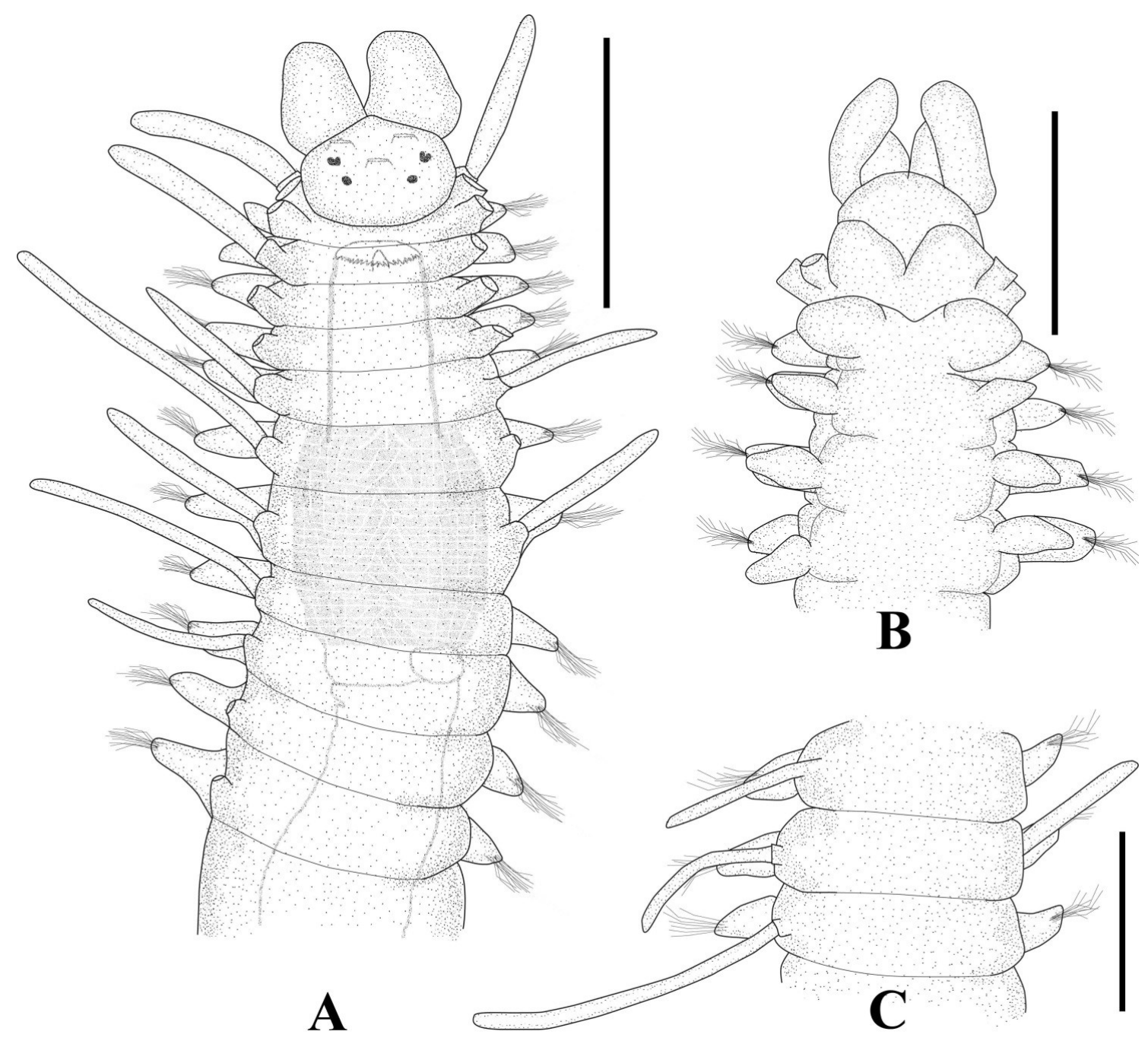

Figure 4 

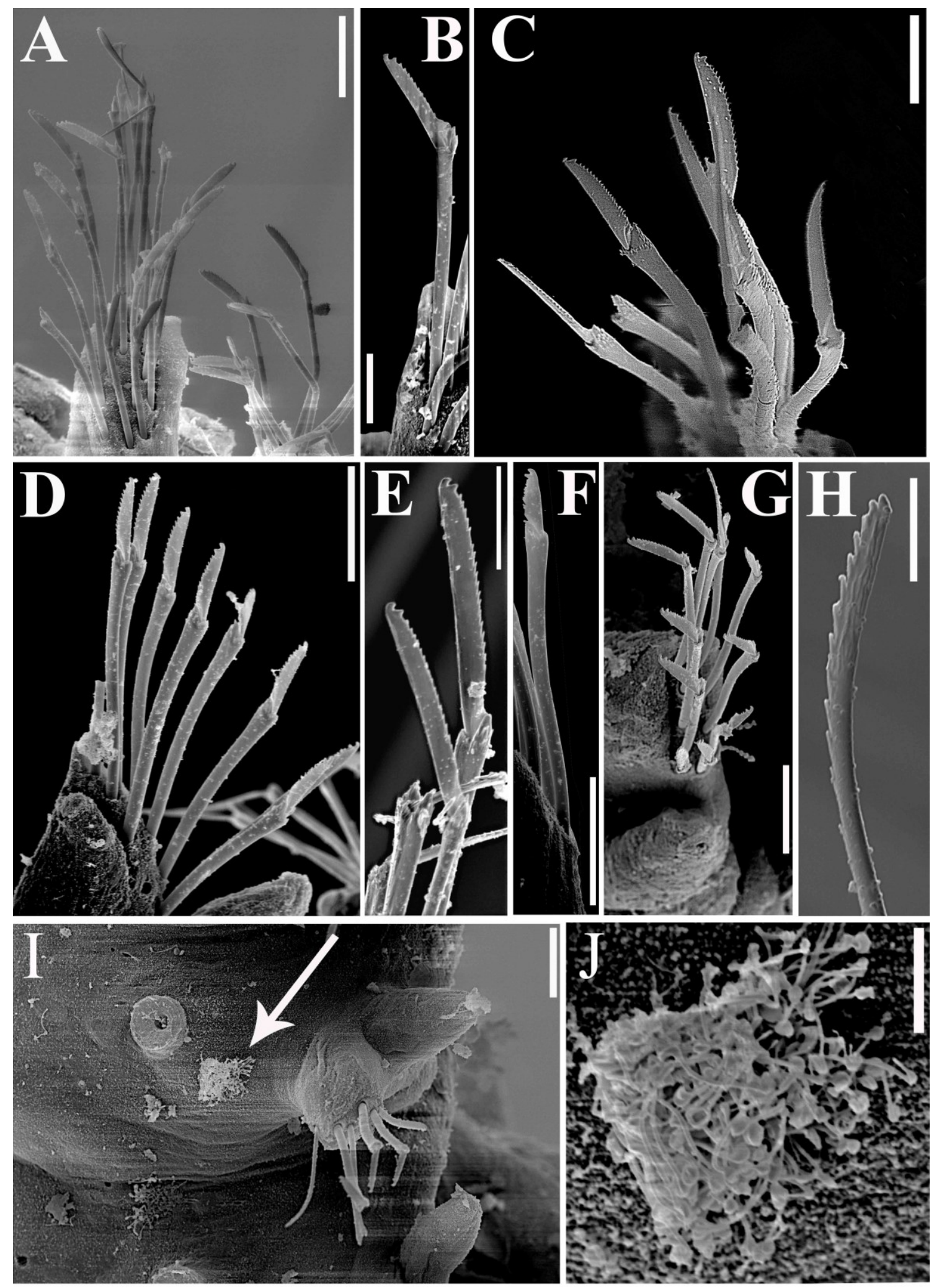

Figure5 

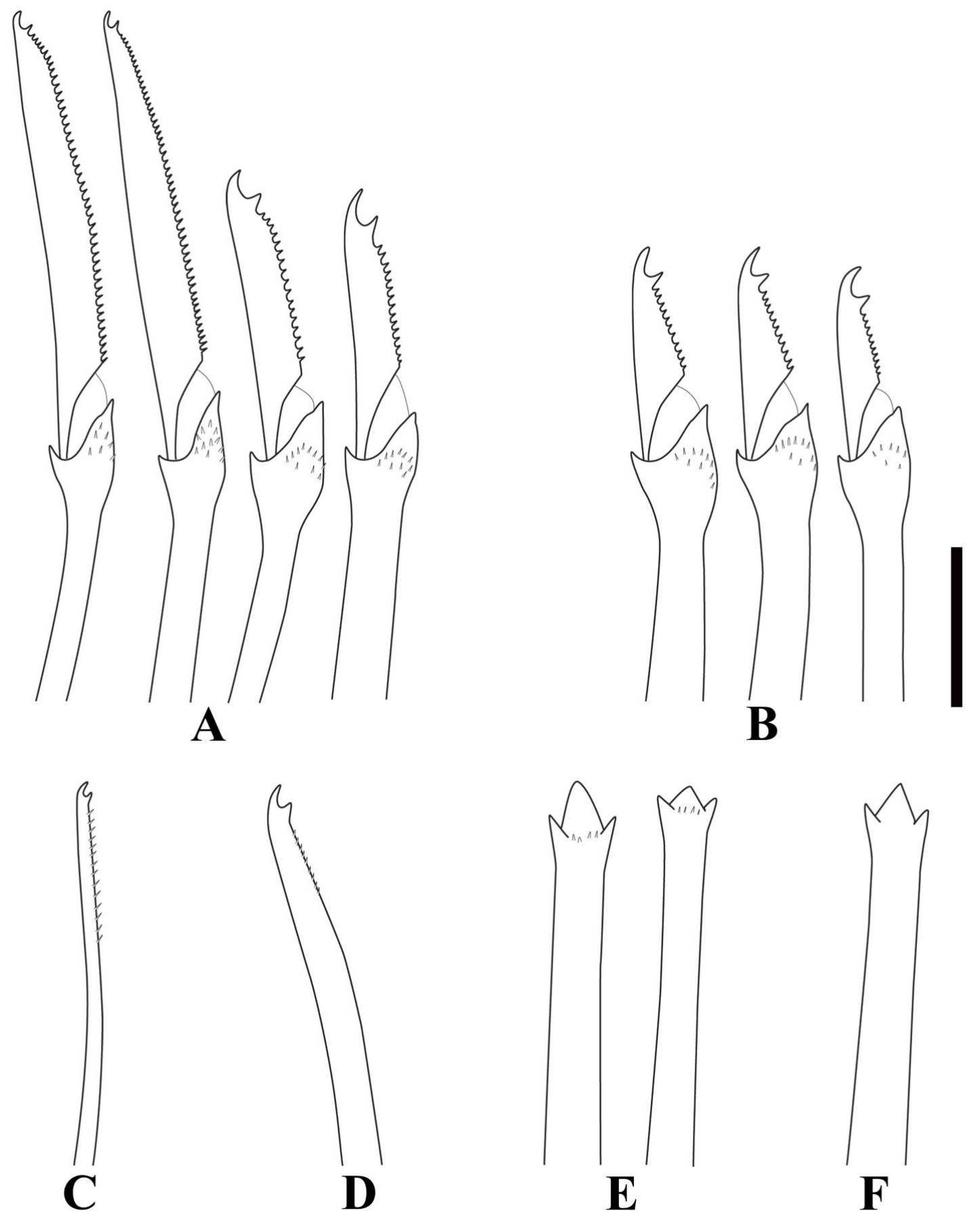

E

F

Figure 6 

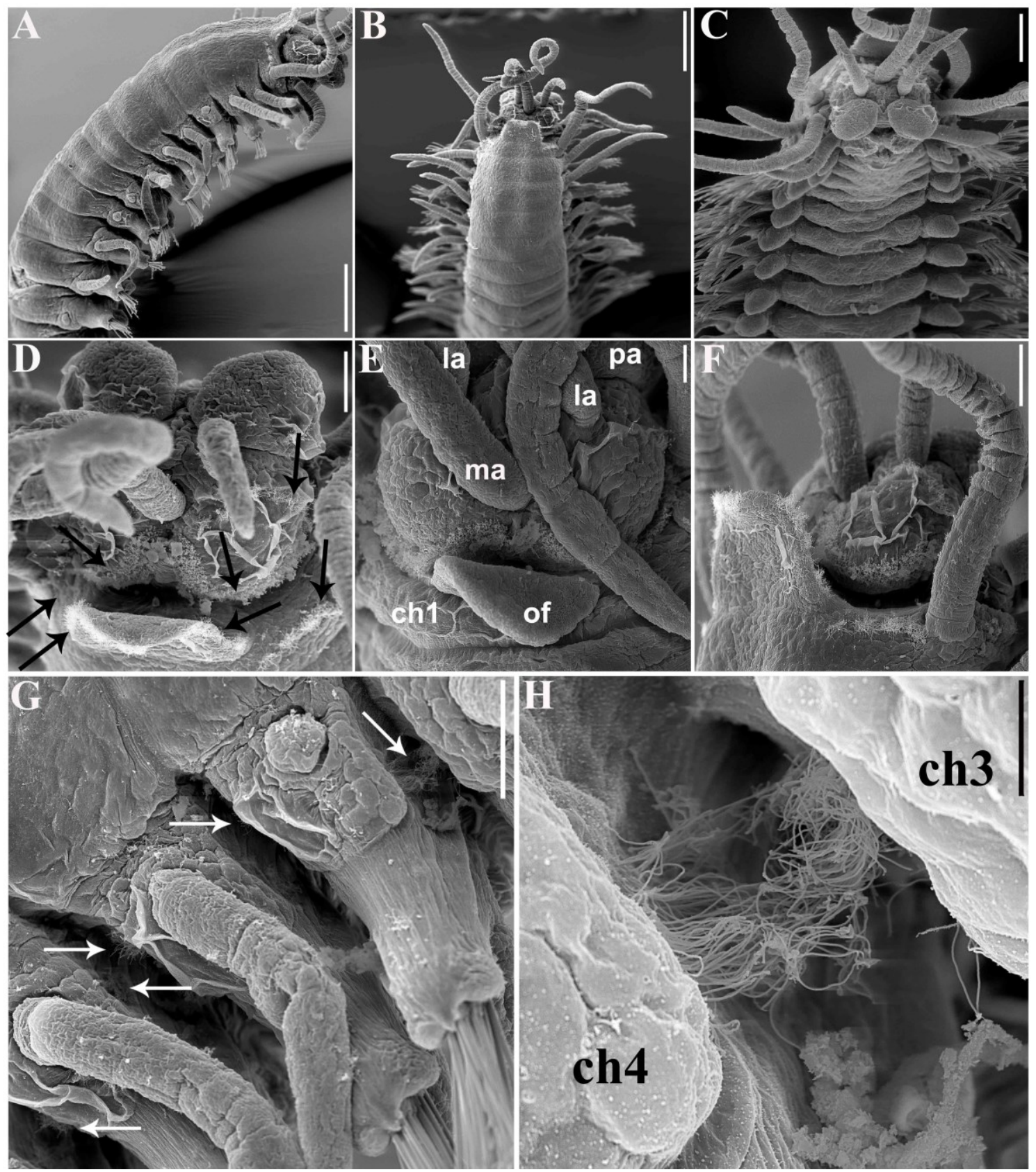

Figure 7 

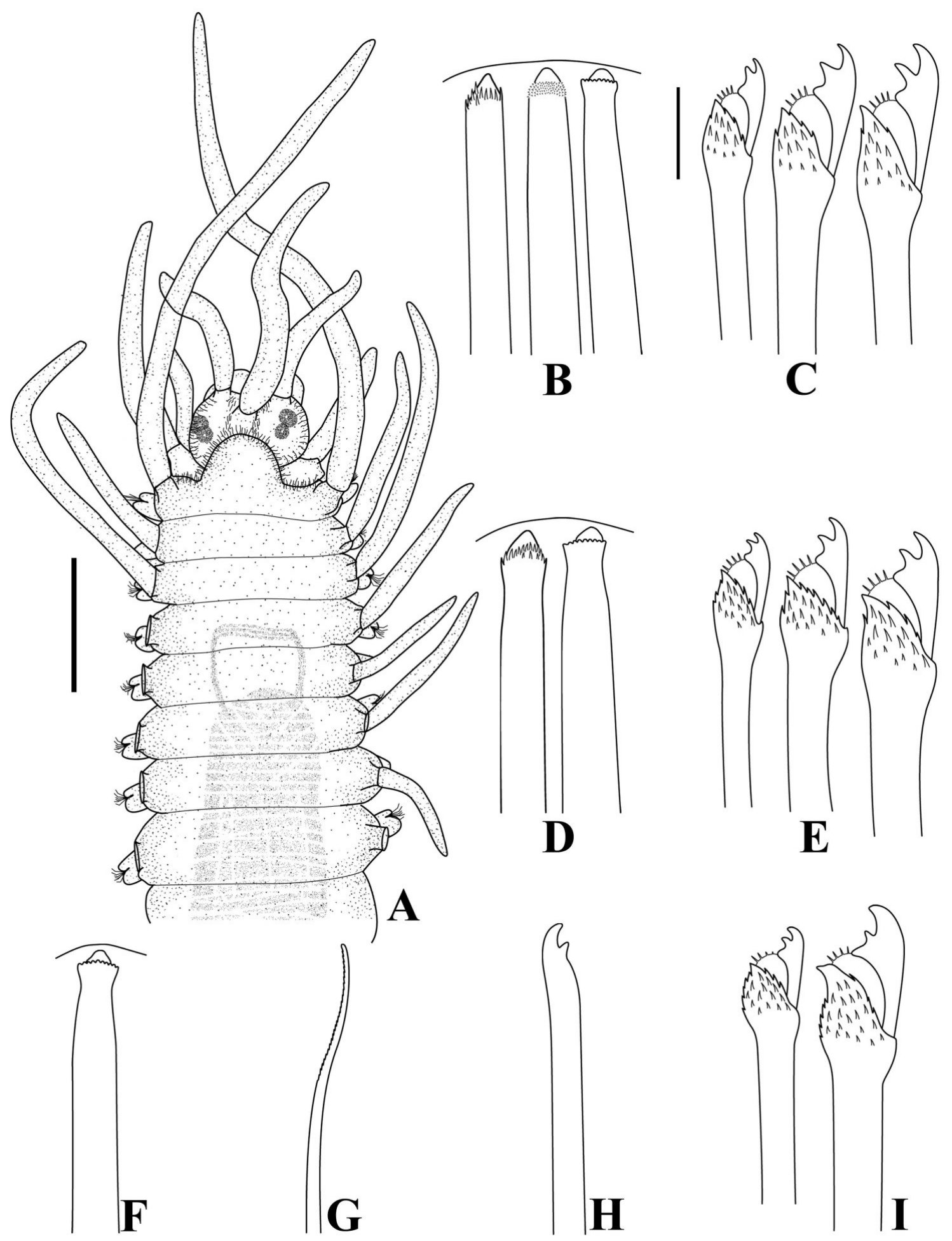

Figure 8 

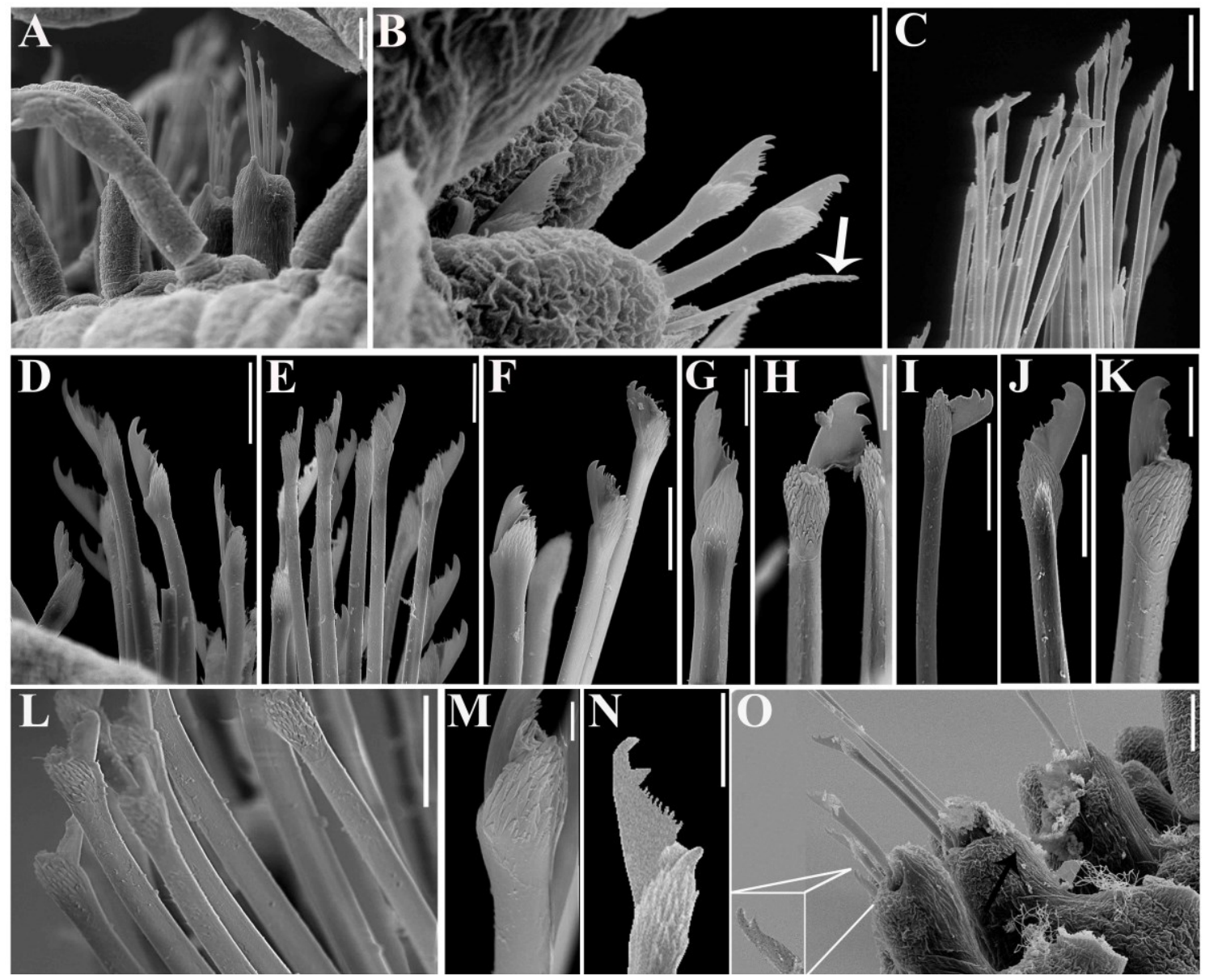

Figure 9 


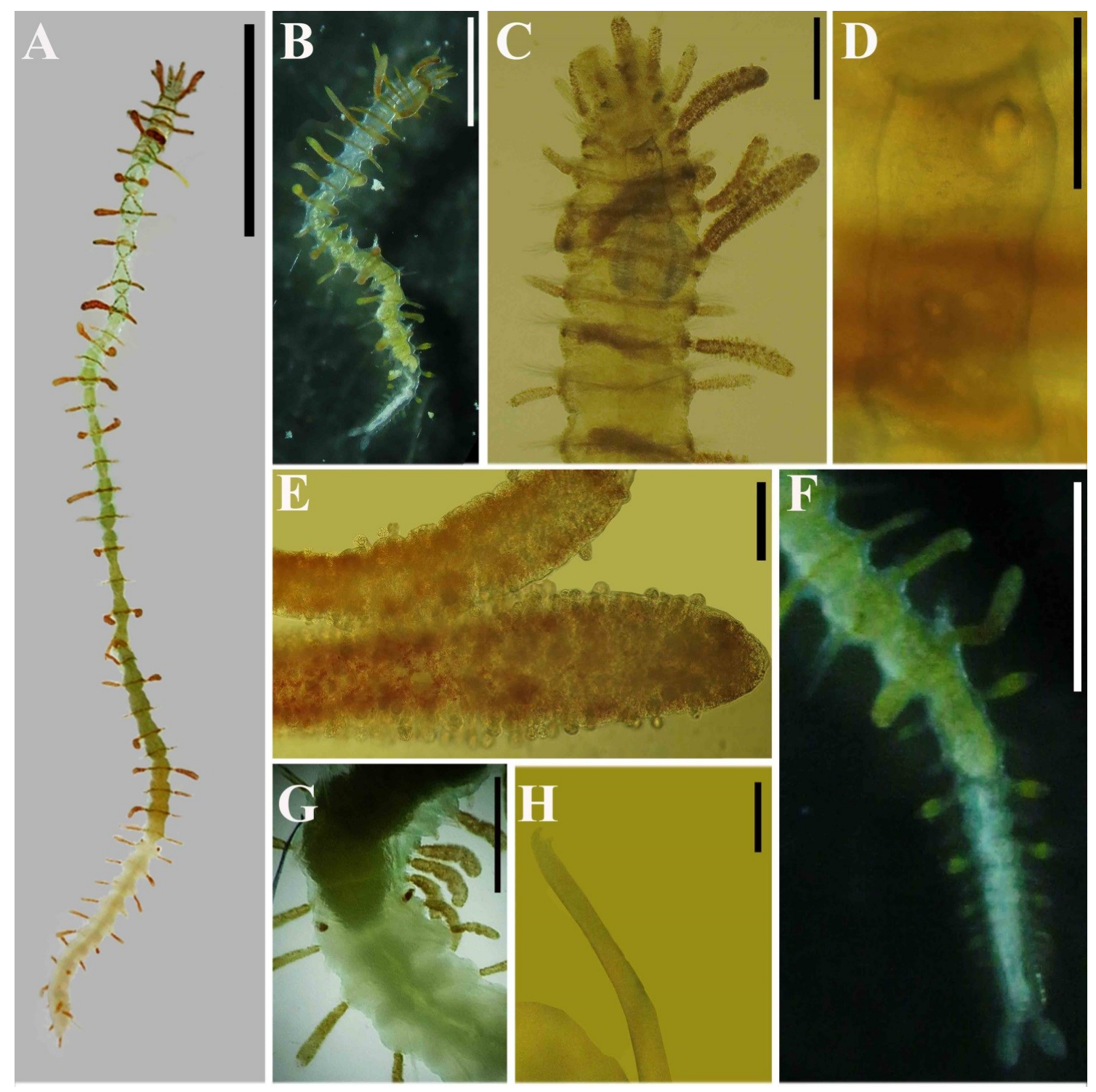

Figure 10 

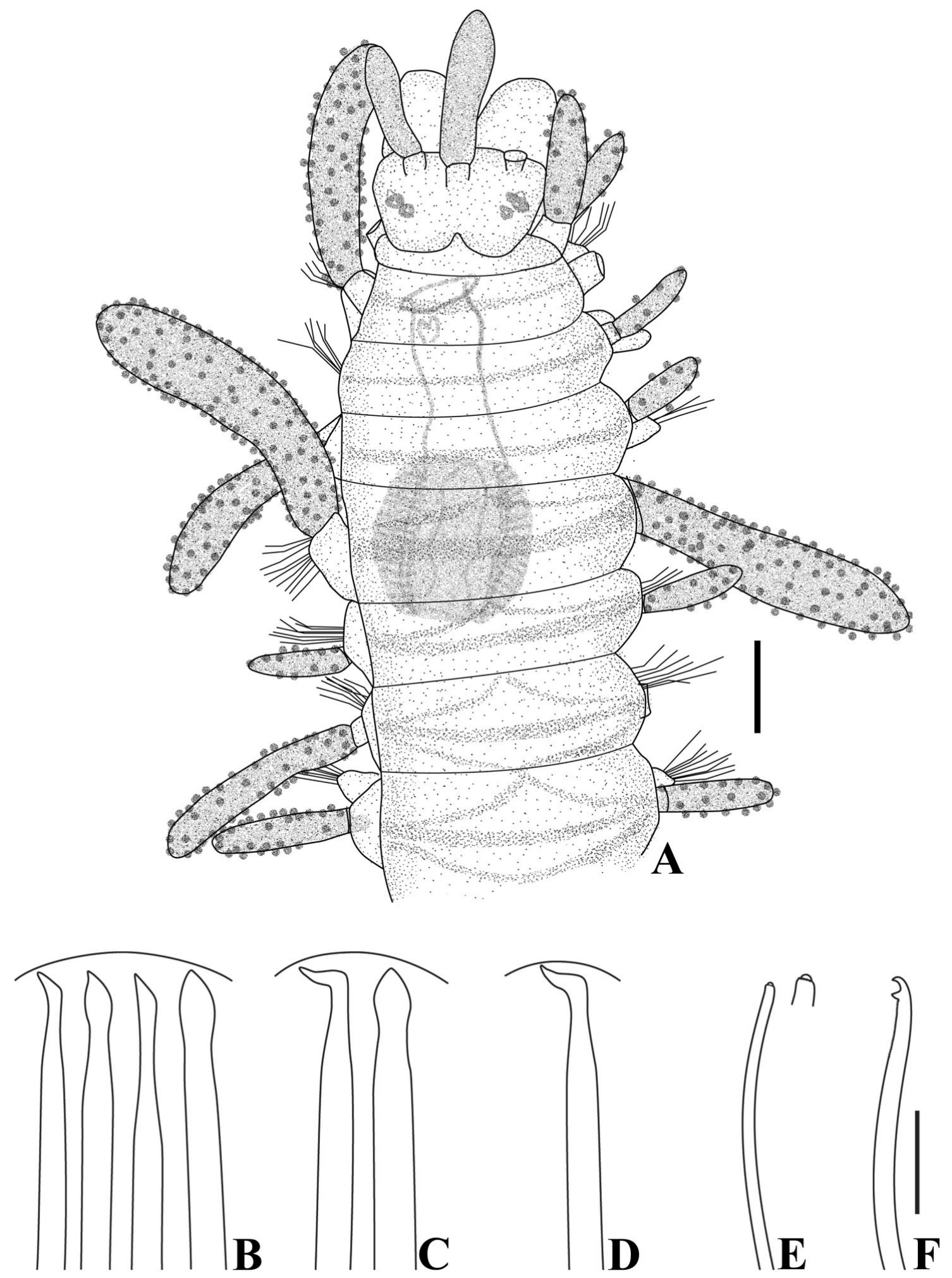

Figure 11 

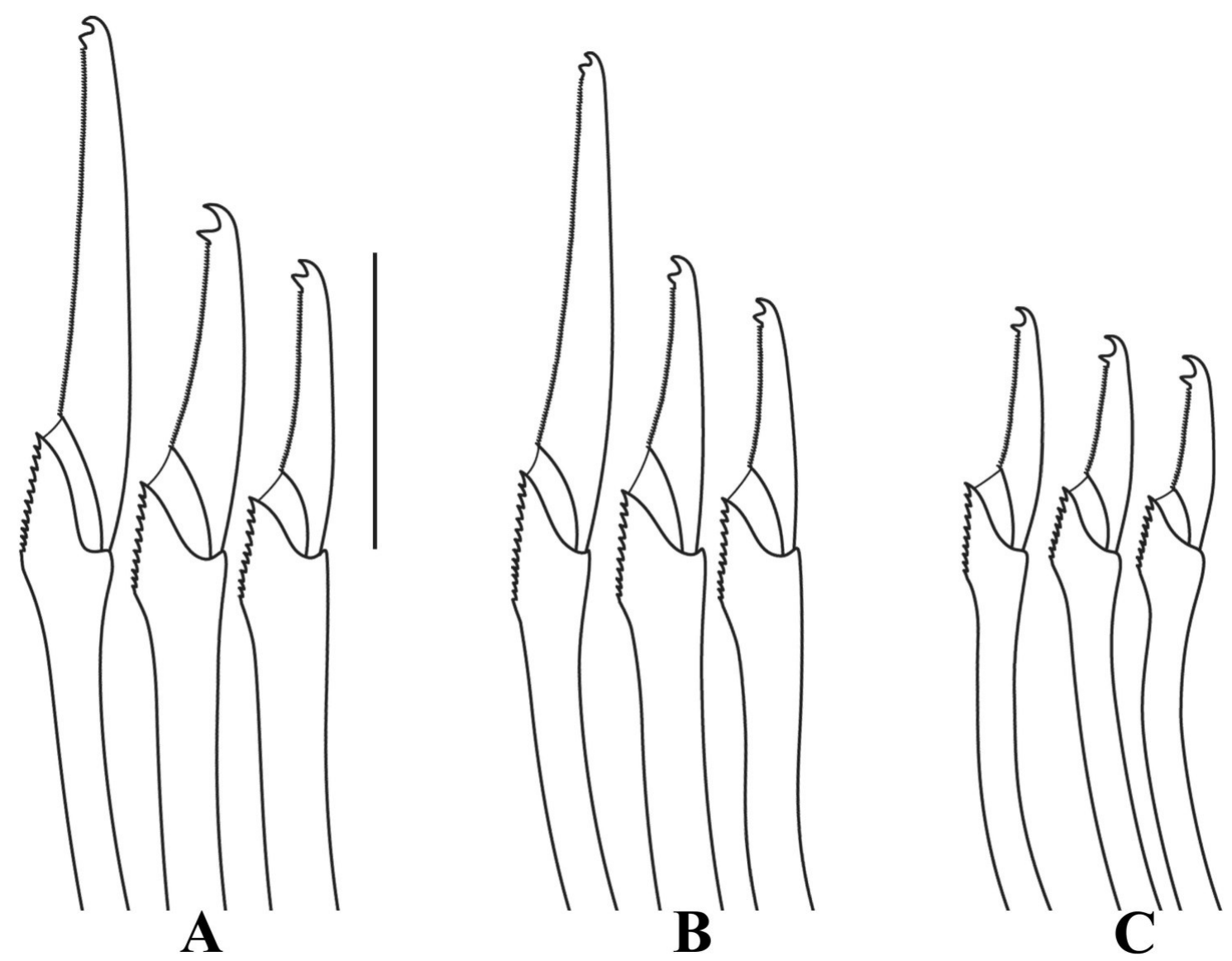

Figure 12 


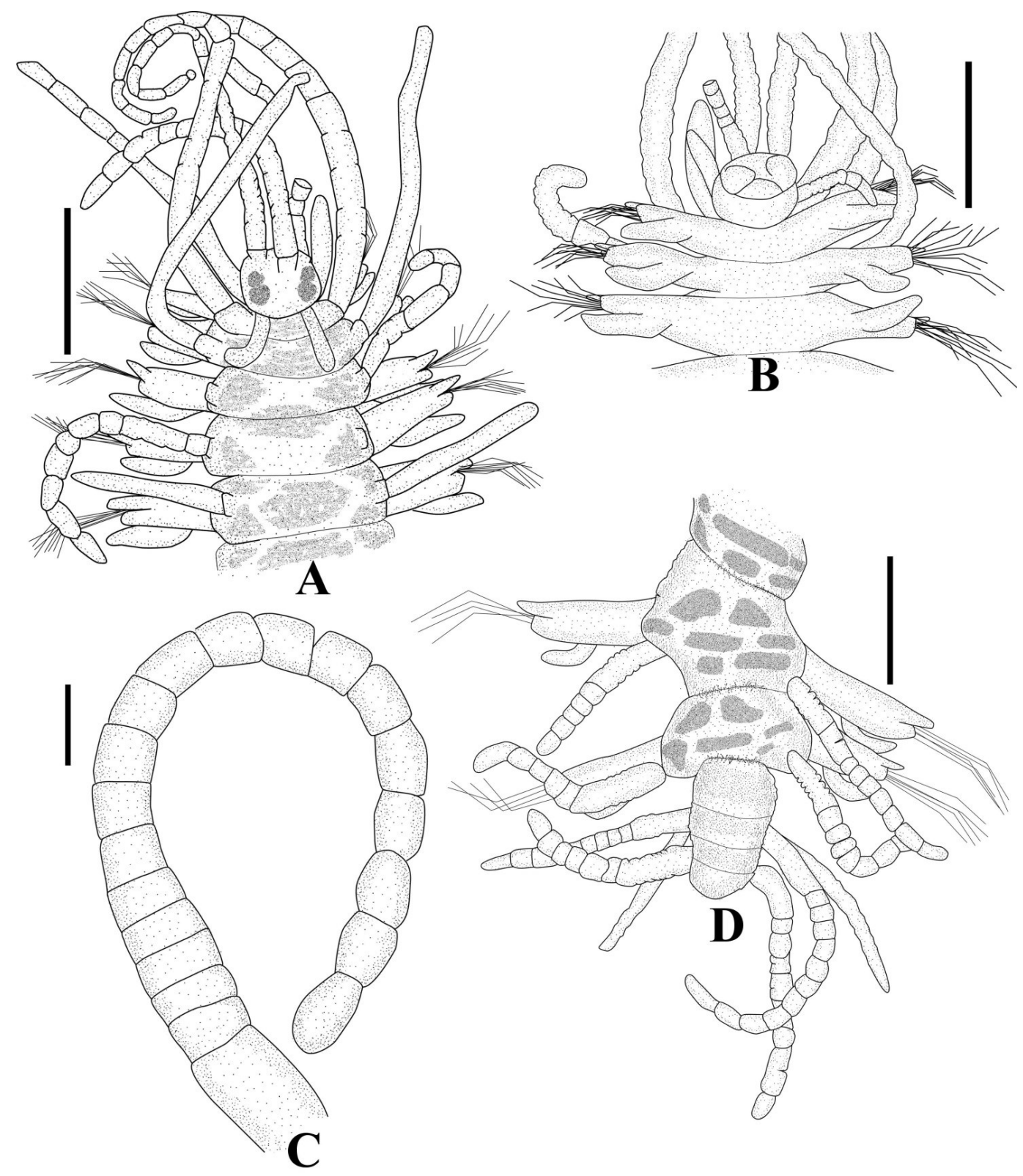

Figure 13

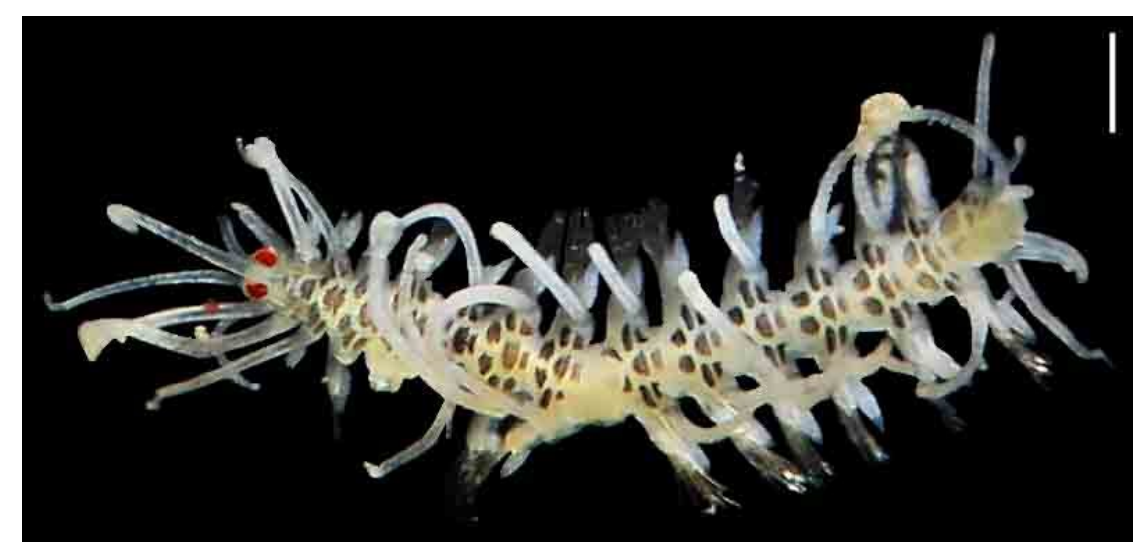

Figure 14 


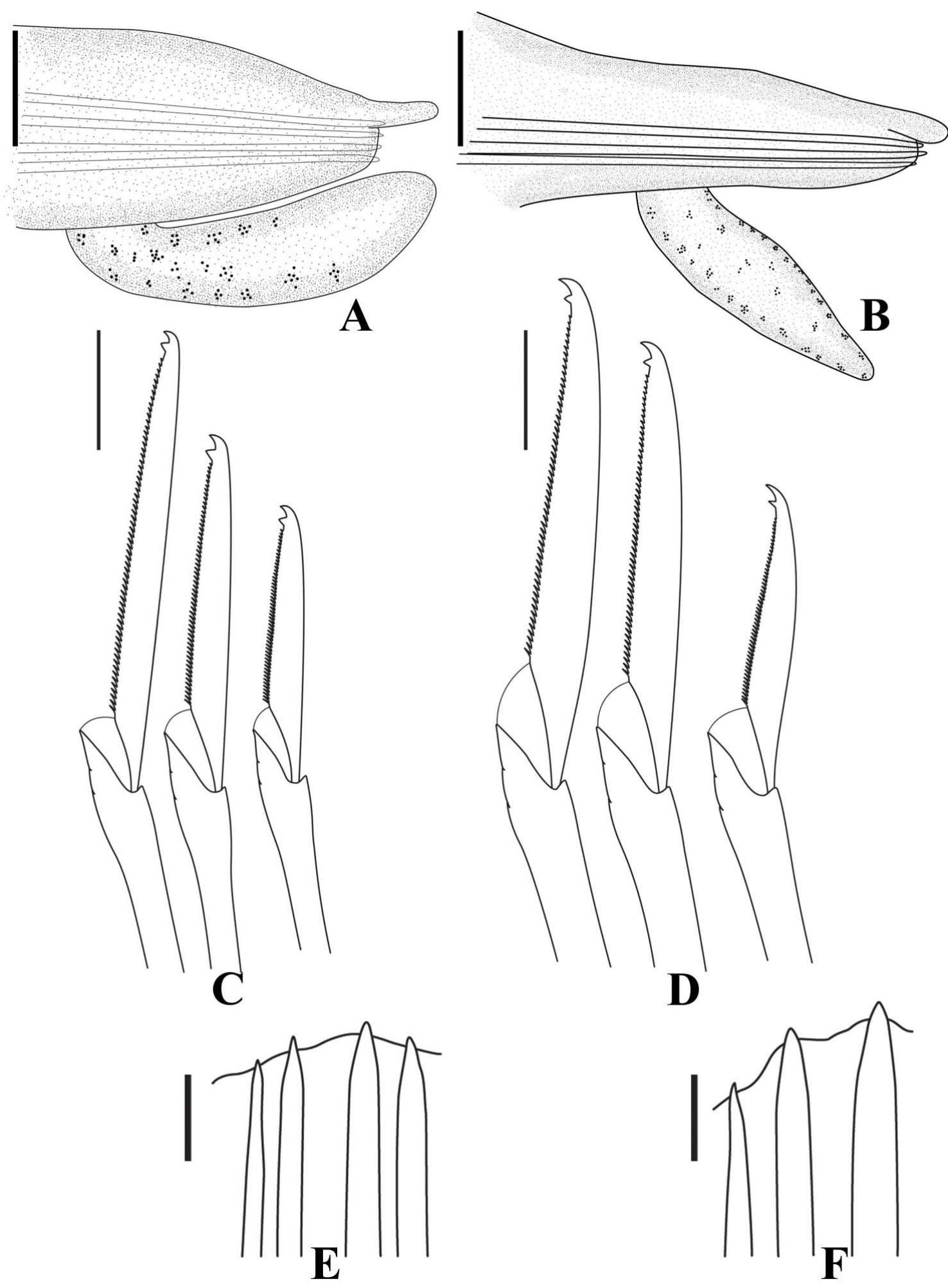

Figure 15 


\section{CAPÍTULO 3}

Branchiosyllis, Megasyllis, Opisthosyllis, Syllis and

Trypanosyllis (Polychaeta: Syllidae: Syllinae) from Brazil, with the description of 7 new species 

Branchiosyllis, Haplosyllis, Megasyllis, Opisthosyllis, Syllis and Trypanosyllis (Polychaeta: Syllidae: Syllinae) from Brazil, with the description of 7 new species

\author{
KARLA PARESQUE $^{1 *}$ MARCELO VERONESI FUKUDA ${ }^{1} \&$ JOÃO MIGUEL DE MATOS \\ NOGUEIRA $^{1}$
}

${ }^{1}$ Laboratório de Poliquetologia (LaPol), Departamento de Zoologia, Instituto de Biociências, Universidade de São Paulo, R. do Matão, travessa 14, n. 101, 05508-090, São Paulo, SP, Brazil

* corresponding author: kparesque@gmail.com

\title{
Table of contents
}

Abstract 142

Introduction 143

Material and methods 144

Results 146

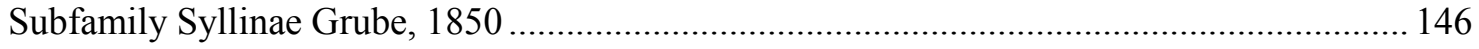

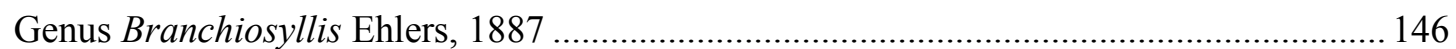

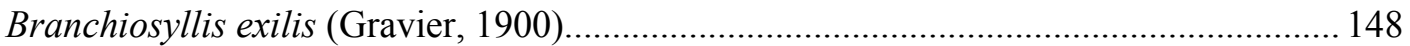

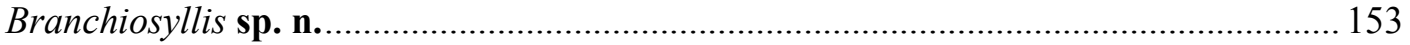

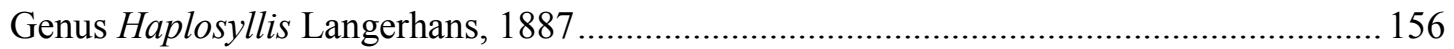

Haplosyllis amphimedonicola Paresque \& Nogueira, 2014 ....................................................159

Haplosyllis rosenalessoae Paresque \& Nogueira, 2014 .............................................................160

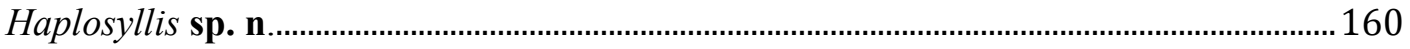

Genus Megasyllis San Martín, Aguado \& Hutchings, 2008 .......................................................164

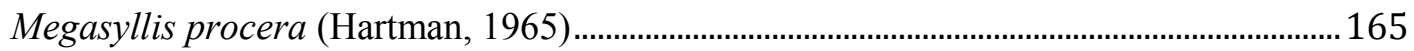

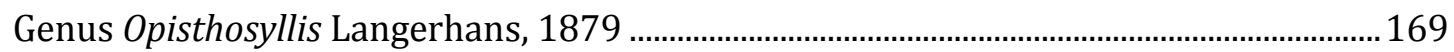

Opisthosyllis brunnea Langerhans, 1879 ................................................................................ 170

Opisthosyllis viridis Langerhans, 1879 .................................................................................173

Genus Trypanosyllis Claparède, 1864 ................................................................................... 178 
Trypanosyllis zebra (Grube, 1860).

Genus Syllis Lamarck, 1818 181

Syllis sp. n. 1 190

Syllis gracilis Grube, 1840. 194

Syllis sp. n. 2 197

Syllis cf. rosea (Langerhans, 1879) 202

Syllis hyllebergi (Licher, 1999). 205

Syllis sp. n. 3 . 206

Syllis beneliahuae (Campoy \& Alquézar, 1982).. 209

Syllis sp. n. 4 210

Syllis lutea (Hartmann-Schröder, 1960) 216

Syllis cf. westheidei San Martín, 1984. 216

Syllis corallicola Verril, 1900 219

Syllis pseudoarmillaris Nogueira \& San Martín, 2002. 220

Syllis prolifera Krohn, 1852 222

Syllis sp. n. 5 223

References. 228

Legends to figures 234

\begin{abstract}
Brazilian specimens of Branchiosyllis exilis, Branchiosyllis sp. n., Haplosyllis sp. n., Megasyllis procera, Opisthosyllis brunnea, O. viridis, Syllis cf. rosea, S. cf. westheidei and 5 new species of Syllis, are described from recently collected material, and illustrated herein. The distributions of Syllis beneliahuae, S. corallicola S. gracilis, S. hyllebergi, S. lutea, S. prolifera and S. pseudoarmillaris are expanded from the southeastern to the northeastern Brazilian coast. Trypanosyllis zebra is recorded for the
\end{abstract}


first time in the state of Paraíba. Additionally, keys to the currently known species of Branchiosyllis, Haplosyllis, Opisthosyllis and Syllis from Brazil is provided.

Keywords: Taxonomy, northeastern Brazil, Syllidae distribution, diversity, sandstones reef.

\section{Introduction}

The family Syllidae Grube, 1850 is one of the most diverse families of polychaetes, with 72 accepted genera and almost 700 species (San Martín 2003; Aguado \& San Martín 2009; Aguado et al. 2012). The family is represented by very abundant animals living epibiontically on various substrata, from hard to soft bottoms, and from intertidal to abyssal depths (San Martín 2003).

The subfamily Syllinae Grube, 1850, with about 270 species and 19 genera, is monophyletic, although the apomorphies that define the group are not known for all the taxa included (Aguado et al. 2012). According to the classification suggested by Aguado et al. (2012), the subfamily is characterized by reproducing schizogamically by scissiparity, lacking stolons and distinct regions. Schyzogamy is also found in the Autolytinae Langerhans, 1879, but originating independently in the two subfamilies (Aguado et al. 2012). An historic approach and a general introduction to the subfamily is given by San Martín et al. (2008a).

Up to the present, 7 genera and 47 species of the subfamily were recorded from Brazil (Fukuda 2010; Amaral et al. 2013): 1 species of Parasphaerosyllis Monro, 1937, 2 of Nuchalosyllis Rullier \& Amoureux, 1979 (genus so far endemic to the country), 3 of Branchiosyllis Ehlers, 1887, 3 of Opisthosyllis Langerhans, 1879, 3 of Trypanosyllis 
Claparède, 1864, 5 of Haplosyllis Langerhans, 1879, and 30 of Syllis Lamarck, 1818. However, most of these records come from unpublished thesis and ecological studies (Amaral et al. 2013), and several have not been found in recent taxonomic studies (e.g., Nogueira \& San Martín 2002; Fukuda \& Nogueira 2006; Nogueira 2006; Nogueira \& Fukuda 2008; Fukuda et al. 2009; Paresque \& Nogueira, 2014; Paresque et al. in press), rendering the real number of occurrences in the country difficult to access.

Brazilian specimens of Branchiosyllis exilis (Gravier, 1900), Branchiosyllis sp. n., Haplosyllis sp. n., Megasyllis procera (Hartman, 1965), Opisthosyllis brunnea (Langerhans, 1879), O. viridis Langerhans, 1879, Syllis cf. rosea (Langerhans, 1879), S. cf. westheidei San Martín, 1984 and 5 new species of Syllis, are herein described, from recently collected material off the northeastern Brazilian coast. The distributions of $S$. beneliahuae (Campoy \& Alquézar, 1982), S. corallicola Verril, 1900, S. gracilis Grube, 1840, S. hyllebergi (Licher, 1999), S. lutea (HartmannSchröder, 1960), S. prolifera Krohn, 1852 and S. pseudoarmillaris Nogueira \& San Martín, 2002, are expanded from the southeastern to the northeastern Brazilian coast. Trypanosyllis zebra (Grube, 1860) is recorded for the first time in the state of Paraíba. Additionally, keys to the currently known species of Branchiosyllis, Haplosyllis, Opisthosyllis and Syllis from Brazil is provided.

\section{Material and methods}

The material for the present study came from six independent studies, the description of each of these projects and a map showing ${ }^{1}$ the points of collections are given by Paresque et al. (in press). Identifications were based on morphological characters.

\footnotetext{
${ }^{1}$ Este mapa encontra-se na FIGURA 1 do APÊNDICE 3 desta Tese (p. 383).
} 
Analyses under stereo- and light microscopes were made of specimens preserved in ethanol, some of which were permanently mounted on slides in glycerin jelly. Blade lengths for compound chaetae are given in dorso-ventral sequence within a fascicle. For examination under scanning electron microscope (SEM), the specimens were dehydrated in a series of progressively increasing concentrations of ethanol solutions (70-100\%), critical point dried, covered with $25 \mathrm{~nm}$ of gold and photographed under the SEM at the Laboratório de Microscopia Eletrônica, IB/USP. Line drawings of slidemounted specimens were made with the aid of a drawing tube attached to an Olympus BX-51 ${ }^{\circledR}$ microscope. Length of the specimens was measured from the tip of palps to the tip of pygidium, excluding anal cirri; width was measured at proventricular level, excluding parapodia.

The nomenclature used for Haplosyllis chaetal morphology follows that suggested by Martin et al. (2003) and Lattig \& Martin (2009). The chaetal characters used here are:

- length of main fang: similar in length or longer than chaetal width;

- upper side of main fang: with or without denticles;

- mid-joining point between apical teeth and main fang: curved (usually short) or straight (at right angle with main fang, short or long);

- proximal and distal apical teeth: equal in size or one of them larger than the other.

The nomenclature used for Branchiosyllis follows Góngora-Garza et al. (2011), in addopting 'ungula' (pl. 'ungulae') to name the modified, claw-shaped falcigers characteristic of the genus.

Type material and voucher specimens will be deposited at the Museu de Zoologia da Universidade Estadual de Campinas, Campinas, Brazil (ZUEC); Museu de Zoologia 
da Universidade de São Paulo, São Paulo, Brazil (MZUSP) and Museo Nacional de Ciéncias Naturales, Madrid, Spain (MNCN). Comparative material was examined from specimens lodged at the MNCN, and The Australian Museum, Sydney, Australia (AM).

\section{Results}

Family Syllidae Grube, 1850

Subfamily Syllinae Grube, 1850

\section{Genus Branchiosyllis Ehlers, 1887}

Type species: Branchiosyllis oculata Ehlers, 1887.

Diagnosis. Relatively medium-sized to large body, subcilindrical to dorso-ventrally, or, more rarely, laterally, flattened. Palps free or fused at bases. Prostomium with four eyes, occasionally also with two anterior eyespots, and three antennae. Peristomium with two pairs of peristomial cirri. Antennae, peristomial, dorsal and anal cirri articulated. Parapodial lobes sometimes with branchiae. Compound chaetae as falcigers only; falcigers of at least one body region with modified blades, claw-shaped, blades arranged in $90^{\circ}$ with shaft ('ungulae'). Simple chaetae not known, apparently altogether absent. Pharynx with single tooth, anteriorly located; proventricle usually of approximate same size as pharynx.

Remarks. The genus Branchiosyllis from the American coasts was recently revised by San Martín et al. (2013), who recognized B. diazi Rioja, 1958 and B. exilis (Gravier, 1900) as occurring off the Brazilian Coast, B. diazi reported especifically from 
the state of Pernambuco, while $B$. exilis was considered as a cosmopolitan species. However, Rullier \& Amoureux (1979) also recorded B. diazi as occurring off the coast of Alagoas, and Nogueira (2006) registered B. exilis off the state of São Paulo. A third species, B. oculata, was recorded by Paiva et al. (2007) and Neves \& Omena (2003) for Rio Grande do Norte, and by Rullier \& Amoureux (1979) and Santa-Isabel et al. (1998) for the state of Bahia. In this study we found two species belong the genus, B. exilis and Branchiosyllis sp. $\mathbf{n}$.

\section{Key for Identification to species of Branchiosyllis currently recorded in Brazilian waters}

1a. Body cilindrical. Branchiae absent...Branchiosyllis exilis

1b. Body dorso-ventrally flattened. Branchia present...2

2a. (1b) Bidentate and unidentate falcigers on anterior part of body, ungulae also present at least posteriorly. Peristomium distinct dorsally...B. diazi*

2b. (1b) Only ungulae throughout, unmodified falcigers absent. Peristomium dorsally reduced...3

3a. (3b) Black body in life. Branchiae with dome form on midbody...Branchiosyllis oculata* $^{*}$

3b. (3b) Yellow to orange body in life. Branchiae with 3-5 lobes on midbody...Branchiosyllis sp. $\mathbf{n}$.

*Species not analysed in the present study, data provided by Álvarez-Campos et al. 2012. 


\section{Branchiosyllis exilis (Gravier, 1900)}

(Figures 1-5)

Branchiosyllis exilis. San Martín 1984: 294-303, lams. 69-72; 2003: 332-336, Figs 184-185; Nogueira 2000: 98-99, Fig. 22J-M; 2006: 148; San Martín et al. 2008a: 127-130, Figs 7, 8B-F.

Material examined. State of Paraíba: Mataraca, Barra de Camaratuba $\left(6^{\circ} 36^{\prime} \mathrm{S}\right.$ 34 $57^{\prime} \mathrm{W}$ ), intertidal: 2 specimens (MZUSP 2410), coll. 12 August 2010. Baía da Traição, Praia do Farol (6 $\left.6^{\circ} 41^{\prime} S 34^{\circ} 55^{\prime} \mathrm{W}\right)$, intertidal: 1 specimen (MZUSP 2139), coll. 09 August 2010. Rio Tinto, Barra de Mamanguape $\left(6^{\circ} 45^{\prime} \mathrm{S} 34^{\circ} 55^{\prime} \mathrm{W}\right)$, intertidal: 1 specimen (MZUSP 2141), coll. 11 August 2010. João Pessoa, Praia de Cabo Branco ( $\left.7^{\circ} 08^{\prime} \mathrm{S} 34^{\circ} 47^{\prime} \mathrm{W}\right)$, intertidal, on sabellariid reefs: 1 specimen (MZUSP 2144), coll. 09 February 2009; 1 specimen (MZUSP 2143) coll. 02 February 2010. State of Pernambuco: Goiana, Pontas de Pedra $\left(7^{\circ} 37^{\prime} \mathrm{S} 34^{\circ} 48^{\prime} \mathrm{W}\right)$, intertidal: 2 specimens (MZUSP 2142), coll. 13 December 2012. Sirinhaém, Barra do Sirinhaém ( $8^{\circ} 36.707 ' S$ 35².450'W), intertidal: 1 specimen (MZUSP 2208), coll. 23 July 2013.

Additional material examined. Branchiosyllis lorenae San Martín \& Bone, 1999. Venezuela, Morrocoy Park, on Thalassia testudinum beds: holotype (MNCN 16.013704).

Description. Middle-sized, subcylindrical, ventrally flattened body (Figs 1C-D; 2A); longest specimen analysed ca. $15.5 \mathrm{~mm}$ long, $0.7 \mathrm{~mm}$ wide, with 66 chaetigers. Live specimens with dark, transverse stripe per chaetiger along body (Fig. 2A), at midlength of broader difuse dark band, and dark spots on antennae, peristomial, anal and dorsal cirri throughout (Fig. 2A, C). Palps triangular, distally rounded, fused at bases (Figs 1A, D-E; 2B-C), each palp with three rows of cilia: longer row beginning 
on prostomium, posteriorly at base of median antenna, running oblique and anteriorly to bases of lateral antennae and then into palps, C-shaped, ventral, on middle third of palps (Figs 1A-B, D-E; 3D); remaining rows transverse, ventral and distinctly shorter, one near posterior margin of palps, laterally to mouth, the other at point of fusion between palps (Fig. 1E). Prostomium subpentagonal, shorter than palps, with two pairs of red eyes in open trapezoidal arrangement, anterior eyespots absent (Fig. 2B-D); median antenna inserted between posterior eyes, elongated, reaching beyond tip of palps, with ca. 17-28 articles (Figs 1A-B; 2B-C; 3D); lateral antennae slightly shorter than median antenna, inserted on anterior margin of the prostomium, with 12-23 articles each (Figs 1A; 2B-D). Ciliated nuchal organs between prostomium and peristomium, only visible under SEM (Fig. 3D). Peristomium slightly shorter than subsequent segments, with small anterior lobe and a row of cilia on anterior margin (Figs 1A-B; 2D; 3D); dorsal peristomial cirri longer than antennae, with 28-34 articles each; ventral peristomial cirri shorter, about as long as lateral antennae, with 14-23 articles each, with tuft of cilia on posterior side of cirrophore, between peristomial cirri (Fig. 3B). Dorsal cirri of chaetiger 1 as long as dorsal peristomial cirri, with $33-47$ articles each; dorsal cirri of chaetigers 2 and 5 about same size, with $21-31$ and 22-35 articles each, respectively; dorsal cirri of chaetiger 3 longer, with $28-41$ articles each; dorsal cirri of chaetiger 4 shorter, with 2945 articles each; following dorsal cirri alternating long, with 24-40 articles each, and short, with 19-38 articles each (Fig. 1G-H); two longitudinal rows of cilia at bases of dorsal cirri, one anteriorly and another posteriorly (Fig. 3E-F), with additional transverse, short row of cilia dorsally (Fig. 3E). Chaetiger 1 with additional pair of tufts of cilia ventrally (Fig. 3A). Ventral cirri ovate to pyriform, inserted at midlength of parapodial lobes, reaching their tips (Figs 1F, H-I; 3C, G; 4A-B). Parapodial lobes elongate, distally bilobed (Figs 1F, H-I; 3C, F-G; 4A-D, G) with digitiform, similar in 
length prechaetal and postchaetal lobes (Fig. 4G); at least three anteriormost parapodia with short, transverse row of cilia dorsally each (Fig. 3A, F), and another ventrally to bases of ventral cirri (Fig. 3C), absent from chaetiger 4-5 (Fig. 3C). Branchiae absent. Anterior parapodia with up to four uni- to subbidentate and 4-12 bidentate falcigers each, ungulae absent (Figs 4A-B; 5A-C); each midbody parapodium with up to six unito subbidentate, six bidentate falcigers, and also up to five ungulae (Figs 4C-F; 5E-G); posterior parapodia with 2-6 ungulae each (Figs $4 \mathrm{H}-\mathrm{J}$; 5I-K), falcigers absent. Shafts of compound chaetae subdistally spinulated (Figs 4E, H; 5A-C, E-F); blades of uniand subbidentate chaetae smooth to slightly spinulated (Figs 4A-B; 5C, G); blades of bidentate falcigers spinulated, teeth similar in length or subdistal tooth slightly shorter (Figs 4A; 5A-B, E-F); blades of ungulae smooth (Figs 4C-F, H-J; 5G, I-K), ventralmost 1-2 ungulae larger than remaining in each parapodium (Fig. 4C-E). Anterior parapodia with up to three aciculae each, one of which irregularly inflated subdistally, remaining aciculae straight with acute tip (Fig. 5D); mid- and posterior body parapodia with up to two aciculae each, subdistally inflated, distally pointed (Fig. $5 \mathrm{H}, \mathrm{L}$ ), tips of aciculae frequently protruding from parapodial lobes throughout (Fig. 4G). Pygidium semicircular, with pair of elongated anal cirri, about same length as posterior dorsal cirri. Pharynx through 4-8 segments; tooth slightly away from anterior border; proventricle extending for 6-8 chaetigers, with ca. 42 rows of muscle cells.

Variation. One specimen (MZUSP 2208) colected from Barra do Sirinhaém has dorsal and ventral surfaces with dark difused pigmentation in anterior body and transverse stripes on dorsum from midbody (Fig. 2E).

Remarks. Branchiosyllis exilis is a cosmopolitan species and was reviewed recently by Álvares-Campos et al. (2012), who analysed morphologically a great number of specimens from around the world, concluding that a molecular approach is 
necessary to determine if there is a single species, with slight differences among populations, or if there are several sibling species grouped together under the name B. exilis. Considering this, Brazilian specimens of $B$. exilis fit the group of the holotype (and material from Australia and Cuba), with slender and elongate cirri (longer than body width, 30-40 articles), blades of falcigers with dorso-ventral gradation in length and both teeth similar in size. About the colour pattern, they noticed this character to be highly variable and thus not useful for identification, at least in preserved specimens. The Brazilian material generally matches Álvarez-Campos et al. (2012) description, although with slightly differences on dorsal pigmentation.

Branchiosyllis lorenae, B. salazari, B. maculata (Imajima, 1966) and B. thylacine San Martín, Hutchings \& Aguado, 2008 are also species lacking branchiae, with ungulae starting from midbody chaetigers and with dark spots on cirri, similar to the pattern found in B. exilis. The first two are from the Caribean Sea and both the last are from the Pacific Ocean (Álvarez-Campos et al. 2012). Branchiosyllis lorenae differs from B. exilis by having three ovate spots on dorsum of each segment, absent on anteriormost chaetigers; peristomium dorsally reduced; falcigers with subdistal tooth shorter than distal tooth; and ungulae present only on posterior parapodia. Brazilian specimens of $B$. exilis have different colour patern dorsally, as a transverse stripe per chaetiger or additionally difused dark pigmentation dorsal and ventrally; peristomium dorsally conspicuous, although shorter than following chaetigers; and ungulae starting from midbody.

Ruíz-Ramirez \& Harris (2008) described B. salazari and also analysed the type material of $B$. exilis. The authors noticed that the holotype of $B$. exilis does not have dorsal pigmentation, however, as already mentioned, this character is extremely variable, especially considering preserved material (Álvarez-Campos et al. 2012). Ruíz- 
Ramirez \& Harris (2008) distinguished B. salazari from B. exilis mostly based on the morphology of anterior and midbody aciculae, and also on the size of teeth of midbody blades of falcigers. According to decription provided by the authors, B. salazari has three aciculae per parapodium anteriorly, two straight, with acute tips, and one subdistally oblique, with acute tip; from midbody, each parapodium with two aciculae, one straight with acute tip and another subdistally oblique, with tip directed upwards (Ruíz-Ramirez \& Harris 2008, Fig. 3B, D); while B. exilis has two aciculae per parapodium anteriorly, one with L shaped and another subdistally oblique, and posterior parapodia with single acicula each, distally tapering and curved. Furthemore, the blades of falcigers on midbody parapodia are bidentate in $B$. exilis, with distal tooth ca. three times larger than subdistal one; and blades of falcigers on midbody of B. salazari are unidentade (Ruíz-Ramirez \& Harris 2008). Brazilian specimens of Branchiosyllis exilis have falcigers with both teeth similar in size, and anterior aciculae different from $B$. salazari (Ruíz-Ramirez \& Harris 2008). Live specimens of B. salazari also have different pattern of dorsal pigmentation when compared with live material of Brazilian B. exilis (Leslie Harris, personal communication to KP). According to a photo taken by LH and kindly shown to us, B. salazari has anterior chaetigers with two brownish dimmed transverse bands per chaetiger, one discontinuous, mid-dorsal with lateral gaps, another near posterior border of each chaetiger.

Branchiosyllis maculata differs from $B$. exilis by having some completely black articles on dorsal cirri throughout, dorsum lacking pigmentation patterns, dorsal cirri throughout and blades of falcigers longer, and ungulae only present on posteriormost parapodia. On the other hand, B. exilis does not have black articles on dorsal cirri, although some scattered black spots are common. Finally, B. thylacine can be differentiated from Brazilian specimens of $B$. exilis by only having ungulae on posterior 
parapodia, all falcigers with unidentate blades and different aciculae, straight and with rounded tips.

Type locality. Acapulco, Mexico (Pacific Ocean).

Distribution. Apparently circumtropical, also present in the warmest regions of the Mediterranean sea (Álvarez-Campos et al. 2012). First record from off the northeastern Brazilian coast.

\section{Branchiosyllis sp. $\mathrm{n}$.}

(Figures 6-12)

Material examined. State of Paraíba: Baía da Traição, Praia do Farol (6 $\left.6^{\circ} 41^{\prime} \mathrm{S} 34^{\circ} 55^{\prime} \mathrm{W}\right)$, intertidal: 1 specimen (MZUSP 2134), coll. 09 August 2010. Rio Tinto, Barra de Mamanguape $\left(6^{\circ} 45^{\prime} \mathrm{S} 34^{\circ} 55^{\prime} \mathrm{W}\right)$, intertidal: 26 specimens, coll. 11 August 2010. João Pessoa, Praia de Cabo Branco $\left(7^{\circ} 08^{\prime} \mathrm{S} 34^{\circ} 47^{\prime} \mathrm{W}\right)$, intertidal: 2 specimens (MZUSP 2136), coll. 02 February 2010; on rhodolith: 1 specimen (MZUSP 2137), coll. 09 February 2009. State of Pernambuco: Goiana, Pontas de Pedra ( $\left.7^{\circ} 37^{\prime} \mathrm{S} 34^{\circ} 48^{\prime} \mathrm{W}\right)$, intertidal: 1 specimen (MZUSP 2138), coll. 13 December 2012. Sirinhaém, Barra do Sirinhaém $\left(8^{\circ} 36.707^{\prime} \mathrm{S} 35^{\circ} 2.450^{\prime} \mathrm{W}\right)$, intertidal: 2 specimens (MZUSP 2133), coll. 23 July 2013. Almirante Tamandaré, Praia dos Carneiros ( $8^{\circ} 42.849^{\prime} \mathrm{S}$ 354.999'W), intertidal, in Tedania ignis (Duchassaing \& Michelotti, 1864): 1 specimen (MZUSP 2132), coll. 22 July 2013.

Additional material examined. Branchiosyllis pacifica Rioja, 1941. Panamá, Coiba National Park: Isla de Uvas $\left(7^{\circ} 49^{\prime} 00^{\prime \prime} \mathrm{N} 81^{\circ} 46^{\prime} 00^{\prime} \mathrm{W}\right)$, coral rubble, $3 \mathrm{~m}$ : 18 specimens (MNCNM 16.01/11585), 11 specimens (MNCN 16.01/11588), coll. 6 
February 1997, coll. \& det. M. Capa; Isla del Canal de Afuera (741'50"N 81³8'25W), 6 m: 10 specimens (MNCN 16.01/11586), coll. 12 February 1997, coll. \& det. M. Capa;

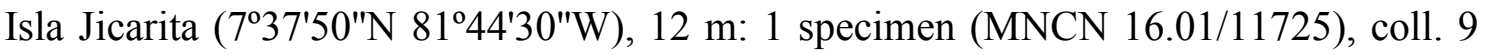
February 1997, coll. \& det. M. Capa.

Description. Relatively small-sized body; dorsoventrally flattened body, ribbonlike (Fig. 6A, 7B); longest specimen analysed ca. $5.5 \mathrm{~mm}$ long, $0.5 \mathrm{~mm}$ wide, with 52 chaetigers; yellow to orange in life (Fig. 7A-F). Reniform, distally rounded palps, fused at bases (Figs 6C; 7E; 8A). Prostomium pentagonal to ovate, about as long as palps, with two pairs of eyes in trapezoidal arrangement, anterior eyespots absent (Figs 7D-F; 8A); median antenna inserted anteriorly to anterior pair of eyes, elongated, reaching beyond tip of palps, with ca. 17 articles (Figs 6B; 7E; 8A); lateral antennae inserted on anterior border, slightly shorter than median antenna, with 15-16 articles each (Figs 6B; 7E; 8A). Peristomium dorsally inconspicuous (Figs 6D, F; 7E; 8A); dorsal peristomial cirri longer than antennae, with 19-32 articles each; ventral peristomial cirri shorter, about as long as lateral antennae, with 12-14 articles each; bases of dorsal peristomial cirri with row of cilia (Fig. 6E). Chaetiger 1 with triangular projection over prostomium at dorsal midline, almost reaching level of posterior pair of eyes (Figs 6D, F; 7E; 8A) and pair of tufts of cilia laterally to this structure (Fig. 6D, F); from midbody, dorsal surface of each chaetiger with rounded protuberance near midlength (Fig. 9C, F). Dorsal cirri of chaetiger 1 shorter than dorsal peristomial cirri, with 19-24 articles each; dorsal cirri of chaetigers 2 and 5 about same size, with 22-26 articles each; dorsal cirri of chaetiger 3 longest, with 24-28 articles each; dorsal cirri 4 shorter, with 16-21 articles each; following dorsal cirri alternating long, with 15-28 articles each, and short, with 15-19 articles each, both longer than body width at corresponding segment (Fig. 9C); bases of dorsal cirri with longitudinal row of cilia posteriorly (Figs 6H; 10B, D). 
Digitiform ventral cirri, inserted at midlength of parapodial lobes or slightly closer to base, reaching their tips (Figs 6C, G; 8B-C; 10A). Parapodial lobes elongate, distally bilobed (Figs 6H; 8B-C; 10A, C) with digitiform prechaetal lobe, distinctly longer than postchaetal lobe (Fig. 6H); single branchia on each parapodium, located dorsally, starting from chaetiger 2; branchiae bi- or trilobed in anterior and posterior parapodia, with up to five lobes in midbody parapodia (Figs $6 \mathrm{H} ; 8 \mathrm{~A}, \mathrm{C} ; 9 \mathrm{~B} ; 10 \mathrm{~B}-\mathrm{D} ; 11 \mathrm{~A}-\mathrm{E}$ ); parapodial lobes with tuft of cilia posteriorly (Fig. 10A-B, D). Anterior parapodia with 4-6 ungulae each; midbody parapodia with four, posterior parapodia with 2-3 ungulae each; falcigers absent throughout. Shafts of ungulae triangular, slightly spinulated subdistally spinulation only visible under SEM (Figs 9A, D-E, G; 12A, C, E); ungulae with smooth, strongly curved, unidentate blades (Figs 9A, D-E, G; 12A, C, E); each parapodium with 1-2 ventralmost chaetae larger than remaining (Fig. 12A, C, E). Anterior parapodia with two aciculae each, straight with acute tip, tips protruding from parapodial lobe (Fig. 12B); mid- and posterior body parapodia with single acicula each, distally slightly sinuous, with acute tip (Fig. 12 D, F). Pygidium semicircular, with two elongated anal cirri, as long as posterior dorsal cirri. Pharynx through ca. five segments; tooth at anterior border (Fig. 8A); proventricle extending for 3.5-4 chaetigers, with ca. 33 rows of muscle cells.

Remarks. Branchiosyllis sp. n. is characterized by having a flattened, ribbon-like body, peristomium dorsally inconspicuous, branchiae and ungulae on all parapodia, and falcigers absent. Other species of the genus with similar characteristics are B. pacifica and B. lamelligera Verrill, 1900. However, B. pacifica differently from Branchiosyllis sp. n., does not have pigmented body and has 2-4 ungulae per anterior parapodium whereas Branchiosyllis sp. n. has 4-6 ungulae per anterior parapodium. 
Branchiosyllis lamellifera, according to the redescription by San Martín et al. (2013), is very similar to Branchiosyllis sp. n., in overall body shape. However, Brazilian specimens have the median antenna inserted more posteriorly in relation to lateral antennae; prostomium slightly broader than long; appendages (i. e. antennae, peristomial and dorsal cirri) more slender and elongated; chaetiger 1 with triangular projection over prostomium; midbody branchiae with up to five lobes; up to six ungulae on anterior parapodia; pharynx through ca. five chaetigers and proventricle through 3.54 chaetigers. On the other hand, B. lamellifera known from Bermuda and Gulf of Mexico, has all antenna inserted nearly in line (San Martín et al. 2013, Fig. 4B, D); stouter appendages (i. e. antennae, peristomial and dorsal cirri); chaetiger 1 with rounded projection over prostomium (San Martín et al. 2013, Fig. 4A-B); midbody branchiae with up to three lobes; up to 3-4 ungulae on anterior parapodia; and pharynx and proventricle through nine chaetigers each.

According to San Martín et al. (2013), B. pacifica occurs in the Eastern tropical Pacific Ocean, while B. lamellifera occurs in Bermuda, Gulf of Mexico, Venezuela and, probably, also Curaçao.

Distribution. Atlantic Ocean: Brazil (states of Paraíba and Pernambuco).

\section{Genus Haplosyllis Langerhans, 1887}

Type species: Syllis spongicola Grube, 1855.

Diagnosis. Body of variable size, usually up to $10 \mathrm{~mm}$ long, with numerous nearly cylindrical segments. Palps robust, fused at bases. Prostomium with four eyes and three 
antennae. Two pairs of peristomial cirri. Antennae, peristomial cirri, anal and dorsal cirri throughout moniliform, the latter sometimes with a single small article on either side on posterior parapodia. Ventral cirri digitiform. Pharynx with anterior tooth surrounded by crown of 10-12 soft papillae and ring of cilia, occasionally with trepan of small teeth. All chaetae simple, with bi- or unidentate tips, 1-12 per parapodia. Simple chaetae not known, apparently altogether absent.

Remarks. A large revision of this genus was recently carried out and descriptions for all known species were provided (Lattig \& Martin 2009); also, a complete comparative table with all currently valid species was recently provided by Paresque \& Nogueira (2014). The last authors described two new species from the norteasthern Brazilian coast, H. amphimedonicola Paresque \& Nogueira (2014), living associated with the sponge Amphimedon viridis Duchassaing \& Michelotti, 1864, and $H$. rosenalessoae Paresque \& Nogueira (2014), both from material collected off the state of Paraíba. Haplosyllis spongicola, considered for a long time as cosmopolitan species, also was reported from the state of Pará, north Brazil, to state of São Paulo, southeastearn Brazil (Amaral et al. 2013). However, the distribution of H. spongicola is limited to Mediterranean and European Atlantic waters (Lattig \& Martin 2009) and the Brazilian reports are considered doubtful here. Besides these species, Fukuda (2010) reported H. loboi Paola, San Martin \& Martin, 2006 occurring in the state of São Paulo. We expanded de distribution of $H$. amphimedonicola and $H$. rosenalessoae from the norh of Paraíba to south of Pernambuco herein. 
Key for Identification to species of Haplosyllis currently recorded in Brazilian waters

1a. Two types of chaetae per parapodium, different in size and shape. Longer chaeta with distal tooth slightly shorter than distal one and narrow angle between teeth; shorter chaetae with proximal tooth shorter, clearly separated...Haplosyllis $\mathbf{s p .} \mathbf{n}$

1b. One type of chaeta per parapodium, differen in size and similar in shape...2

2a. (1b) Long midbody dorsal cirri, longer than body width at corresponding segment...Haplosyllis spongicola

2b. (1b) Short midbody dorsal cirri, shorter than body width at corresponding segment...3

3a. (2b) Midbody dorsal cirri alternating between long, with 3-7 articles, and short, with 1-3 articles each. Body wall of mid- to posterior body chaetigers without dorsal granulation...Haplosyllis amphimedonicola

3b. (2b) Midbody dorsal cirri alternating between long, with 8-13 articles, and short, with 4-8 articles each. Body wall of mid- to posterior body chaetigers with dorsal granulation, as internal iridescent and granulose inclusions, arranged in continuous transverse rows across chaetigers, broader laterally, at base of parapodia, progressively narrowing towards dorsal midline...Haplosyllis rosenalessoae

*Species not analysed in the present study, data provided by Lattig \& Martin (2009) and Lattig et al. (2010) 


\section{Haplosyllis amphimedonicola Paresque \& Nogueira, 2014}

Haplosyllis amphimedonicola Paresque \& Nogueira, 2014: 597-602, Figs 1-4.

Material examined. State of Paraíba: Mataraca, Barra de Camaratuba (6 $6^{\circ} 36^{\prime} \mathrm{S}$ 34 $\left.57^{\prime} \mathrm{W}\right)$, intertidal: 18 specimens, coll. 12 August 2010. Baía da Traição, Praia do Farol (6 $\left.{ }^{\circ} 41^{\prime} \mathrm{S} 34^{\circ} 55^{\prime} \mathrm{W}\right)$, intertidal: 347 specimens, coll. 09 August 2010. Rio Tinto, Barra de Mamanguape $\left(6^{\circ} 45^{\prime} \mathrm{S} 34^{\circ} 55^{\prime} \mathrm{W}\right)$, intertidal: 650 specimens, coll. 11 August 2010. Cabedelo, Píer de Cabedelo (6 $\left.58^{\circ} \mathrm{S} 34^{\circ} 50^{\prime} \mathrm{W}\right)$, intertidal: 21 specimens, coll. 12 February 2009. Conde, Praia de Tabatinga ( $\left.7^{\circ} 19^{\prime} \mathrm{S} 34^{\circ} 47^{\prime} \mathrm{W}\right)$, intertidal: 361 specimens; coll. 17 September 2012; Praia do Coqueirinho ( $\left.7^{\circ} 18^{\prime} \mathrm{S} 34^{\circ} 47^{\prime} \mathrm{W}\right), 294$ specimens, coll. 28 August 2011. State of Pernambuco: Goiana, Pontas de Pedra (7³7'S 34º48'W), 318 specimens, coll. 13 December 2012. Ilha de Itamaracá, Ponta do Jaguaribe $\left(7^{\circ} 44^{\prime} \mathrm{S}\right.$ 3449'W), intertidal: 61 specimens, coll. 11 December 2012. Recife, Praia de Boa Viagem $\left(8^{\circ} 7.420^{\prime} \mathrm{S} 34^{\circ} 53.725^{\prime} \mathrm{W}\right)$, intertidal: 7 specimens, coll. 19 January 2014. Ipojuca, Praia de Muro Alto ( $\left.8^{\circ} 25.787^{\prime} \mathrm{S} 34^{\circ} 58.567^{\prime} \mathrm{W}\right)$, intertidal: 4 specimens, coll. 17 January 2014. Almirante Tamandaré, Praia dos Carneiros ( $\left.8^{\circ} 42.849^{\prime} \mathrm{S} 35^{\circ} 4.999^{\prime} \mathrm{W}\right)$, intertidal: 6 specimens, coll. 22 July 2013.

Type locality. Barra de Mamanguape, Rio Tinto, Paraíba, Brazil (Atlantic Ocean)

Distribution. Atlantic Ocean: Brazil (states of Paraíba and Pernambuco). 


\section{Haplosyllis rosenalessoae Paresque \& Nogueira, 2014}

Haplosyllis rosenalessoae Paresque \& Nogueira, 2014: 603-608, Figs 5-7.

Material examined. State of Paraíba: Mataraca, Barra de Camaratuba (6 $36^{\circ} \mathrm{S}$ 34 $57^{\prime} \mathrm{W}$ ), intertidal: 4 specimens, coll. 12 August 2010. Baía da Traição, Praia do Farol (6 $41^{\circ}$ 'S 345' $\mathrm{W}$ ), intertidal: 32 specimens, coll. 09 August 2010. Rio Tinto, Barra de Mamanguape $\left(6^{\circ} 45^{\prime} \mathrm{S} \quad 34^{\circ} 55^{\prime} \mathrm{W}\right)$, intertidal: 9 specimens, coll. 11 August 2010. Cabedelo, Píer de Cabedelo (6 $\left.6^{\circ} 58^{\prime} \mathrm{S} 34^{\circ} 50^{\prime} \mathrm{W}\right)$, intertidal: 13 specimens, coll. 12 February 2009. Conde, Praia de Tabatinga ( $\left.7^{\circ} 19^{\prime} \mathrm{S} 34^{\circ} 47^{\prime} \mathrm{W}\right)$, intertidal: 15 specimens; coll. 17 September 2012; Praia do Coqueirinho (7º $\left.18^{\prime} \mathrm{S} 34^{\circ} 47^{\prime} \mathrm{W}\right), 11$ specimens, coll. 28 August 2011. State of Pernambuco: Goiana, Pontas de Pedra (7³7'S 34º48'W), 24 specimens, coll. 13 December 2012. Ilha de Itamaracá, Ponta do Jaguaribe $\left(7^{\circ} 44\right.$ 'S 34ำ ${ }^{\prime}$ ), intertidal: 8 specimens, coll. 11 December 2012. Recife, Praia de Boa Viagem $\left(8^{\circ} 7.420^{\prime} \mathrm{S} 34^{\circ} 53.725^{\prime} \mathrm{W}\right)$, intertidal: 4 specimens, coll. 19 January 2014.

Type locality. Praia de Cabo Branco, João Pessoa, Paraíba, Brazil (Atlantic Ocean)

Distribution. Atlantic Ocean: Brazil (states of Paraíba and Pernambuco).

\section{Haplosyllis sp. $\mathbf{n}$.}

(Figures 13-14)

Material examined. State of Paraíba: Mataraca, Barra de Camaratuba (6 $36^{\prime} \mathrm{S}$ 34 $\left.57^{\prime} \mathrm{W}\right)$, intertidal: 2 specimens, coll. 12 August 2010. Baía da Traição, Praia do Farol 
(6 $\left.6^{\circ} 41^{\prime} \mathrm{S} 34^{\circ} 55^{\prime} \mathrm{W}\right)$, intertidal: 3 specimens, coll. 09 August 2010. Rio Tinto, Barra de Mamanguape $\left(6^{\circ} 45^{\prime} \mathrm{S} \quad 34^{\circ} 55^{\prime} \mathrm{W}\right)$, intertidal: 6 specimens, coll. 11 August 2010. Cabedelo, Píer de Cabedelo (6 $\left.6^{\circ} 58^{\prime} \mathrm{S} 34^{\circ} 50^{\prime} \mathrm{W}\right)$, intertidal: 2 specimens, coll. 12 February 2009. State of Pernambuco: Goiana, Pontas de Pedra ( $\left.7^{\circ} 37^{\prime} \mathrm{S} 34^{\circ} 48^{\prime} \mathrm{W}\right), 4$ specimens, coll. 13 December 2012. Ilha de Itamaracá, Ponta do Jaguaribe (744'S 3449'W), intertidal: 2 specimens, coll. 11 December 2012. Sirinhaém, Barra do Sirinhaém ( $\left.8^{\circ} 36.707^{\prime} \mathrm{S} 35^{\circ} 2.450^{\prime} \mathrm{W}\right)$, intertidal: 1 specimen, coll. 23 July 2013. São José da Coroa Grande, recifes São José da Coroa Grande, intertidal: 1 specimen, coll. 25 June 2013. Almirante Tamandaré, Praia dos Carneiros $\left(8^{\circ} 42.849^{\prime} \mathrm{S} 35^{\circ} 4.999^{\prime} \mathrm{W}\right)$, intertidal: 3 specimens, coll. 22 July 2013.

Description. Small-sized body; largest specimen analysed ca. $9 \mathrm{~mm}$ long, $0.4 \mathrm{~mm}$ wide, with 34 chaetigers. Pigmentation absent, specimens beige to light yellow body after preservation. Mid- to posterior body chaetigers with small dorso-lateral papillae close to dorsal cirri (Fig. 13B, D). Triangular, distally rounded palps, totally free from each other (Fig. 13A). Sub-pentagonal prostomium, shorter than palps, with two pairs of red eyes in trapezoidal arrangement, anterior eyespots absent; median antenna inserted between anterior eyes, longer than palps (Fig. 13A), with 19-24 articles; lateral antennae shorter, inserted at anterior margin of prostomium, with 9-14 articles each (Figs 13A; 14A). Ciliated nuchal organs between prostomium and peristomium (Fig. 13A, C), only visible under SEM. Peristomium of similar length or slightly shorter than following chaetigers; dorsal peristomial cirri shorter than median antenna, with 14-19 articles each; ventral peristomial cirri shorter, with 8-11 articles each (Fig. 13A). Anterior dorsal cirri relatively long; dorsal cirri of chaetiger 1 longer than following cirri, with 19-30 articles each, reaching slightly beyond tip of palps; dorsal cirri of chaetiger 2 shorter, with 6-15 articles each; dorsal cirri of chaetiger 3 with 8-17 articles 
each; dorsal cirri of chaetiger 4 longer, with 12-18 articles each; dorsal cirri of chaetigers 5 and 6 with 5-13 and 8-20 articles each, respectively; dorsal cirri on chaetigers 7 and 8 similar to each other, shorter, with 5-11 articles each; following cirri alternating long, with 6-16 articles, and short, with 3-10 articles each, long cirri about twice as long as short cirri and longer than half body width at corresponding segment; alternation between long and short cirri progressively less conspicuous posteriorwards; posterior dorsal cirri short, with 1-3 articles each. Ovate ventral cirri inserted at bases of parapodia, slightly longer than parapodial lobes on anterior body, shorter on posterior body. Parapodial lobes conical, with 1-3 chaetae each; two types of chaetae per parapodium throughout (Fig. 13E, G): long chaetae with distal teeth of same size or distal tooth slightly thinner (Figs 13E, G; 14C, G), teeth with oblique tip, upwardlydirected, main fang shorter than shaft width; mid-joining point straight and relatively long, upper side of main fang with few, short denticles (Fig. 13E, F, I); short chaetae (Fig. 14E) with distal tooth upwardly-directed and proximal tooth thinner, directed forwards, with relatively wide space between teeth (Fig. 13E, G-H); main fang shorter than shaft width; mid-joining point straight and relatively shorter; upper side of main fang with few, short denticles. Anterior and midbody chaetigers with only two aciculae per parapodium, single acicula per parapodium on posterior body; aciculae of two types, one of which subdistally bent at almost right angle, with oblique tip, another distally oblique, upwardly directed (Fig. 14B, D, F); posterior body parapodia with latter type of acicula only. Pygidium semicircular, with ciliated anus dorsally and pair of anal cirri with 1-5 articles each, up to three times as long as posterior dorsal cirri. Pharynx extending for 5-7 chaetigers, tooth at anterior border; anterior margin of pharynx surrounded by fringe of cilia; proventricle 5.2-6.4 $\mathrm{mm}$ long, extending for 3-4.5 chaetigers, with $30-40$ rows of muscle cells. 
Remarks. The most similar species to Haplosyllis sp. n. is H. djiboutiensis Gravier, 1900, by having two types of chaetae per parapodium, body with papillae, and aciculae with similar shape. Material of $H$. djiboutiensis was recently studied by Lattig et al. (2010), who analysed specimens from Australia, while Lattig \& Martin (2011), analyzing individuals collected in Quatar and Abu Dhabi. Haplosyllis djiboutiensis from these three places can be differentiated from Brazilian new species by having the shorter chaetae on midbody thinner, with longer mid-joining point.

Additionally, Haplosyllis sp. n. differs from $H$. djiboutiensis from Australia (Lattig et al. 2010), by having shorter proventricle, through 3-4.5 chaetigers, with 3040 rows of muscle cells, while Australian specimens may have longer proventricle, extending for 3-9 segments, with up to 50 rows of muscle cells. Specimens of $H$. djiboutiensis from Quatar are shorter, only 2-4 mm long; they also have shorter dorsal cirri on chaetigers $5-8$, with $2-9,3-13,2-8$, and $4-8$ articles, respectively; longer proventricle, extending through 5-12 chaetigers, and with fewer rows of muscle cells, 26-36 (Lattig \& Martin 2011) whereas H. djiboutiensis from Abu Dhabi differs from Haplosyllis sp. n. by having longer cirri throughout (Lattig \& Martin 2011). In contrast, Brazilian specimens have larger bodies, 4-9 mm long; dorsal cirri of chaetigers 5-8 with 5-13, 8-20,5-11, and 5-11 articles, respectively; and proventricle extending for $3-4.5$ chaetigers, with $30-40$ rows of muscle cells.

Haplosyllis sp. n. differs from $H$. amphimedonicola and $H$. rosenalessoae mainly by having two types of chaetae per parapodium. Furthermore, different from Haplosyllis sp. n., H. amphimedonicola has a stouter body; papillae absent on dorsum; shorter antennae; shorter midbody cirri; chaetae with distal teeth similar in size to each other; and aciculae with different morphology. Compared to Haplosyllis sp. n., $H$. rosenalessoae is a longer and more robust species; with shorter and stouter antennae; 
chaetae on mid- and posterior body with smooth main fang; indistinct distal teeth of chaetae from midbody; and aciculae with different morphology.

\section{Genus Megasyllis San Martín, Aguado \& Hutchings, 2008}

Type species: Syllis corruscans Haswell, 1885, designated by San Martín et al. (2008).

Diagnosis. Relatively large body, long, subcylindrical, with annelated segments throughout. Palps large, broad, fused at bases. Prostomium with four eyes, anterior eyespots absent, and three antennae; prostomium frequently with two dorso-lateral protuberances. Two pairs of peristomial cirri. Antennae and cirri throughout with distinct cirrophores; antennae, peristomial and dorsal cirri of anterior chaetigers articulated to pseudo-articulated; remaining dorsal cirri irregularly wrinkled to smooth, slender; all cirri either smooth or articulated in some species. Ventral cirri triangular to conical. Parapodia with prechaetal and postchaetal lobes. Compound chaetae as heterogomph falcigers only, blades bidentate, teeth similar in size or distal tooth slightly larger. Dorsal and ventral simple chaetae only present on posterior parapodia. Aciculae distally sinuous, slightly acuminate. Pharynx similar in length or shorter than proventricle, frequently pigmented, with crown of soft papillae surrounding opening and only single tooth close to anterior margin (San Martín et al. 2014).

Remarks. This genus includes species originally described in the genera Pionosyllis Malmgren, 1897, Eusyllis Malmgren, 1897 and Syllis Lamarck, 1818 (San Martín et al. 2008b, 2014). Among the 14 currently known species (San Martín et al. 
2014), only M. procera (Hartman, 1965) was recorded in Brazil (Nogueira 2000, Fukuda 2010, in both cases as Pionosyllis procera).

Megasyllis procera (Hartman, 1965)

(Figures 15-21; Table 1)

Pionosyllis procera Hartman, 1965: 79-80, Fig. 10C-D; San Martín \& Estapé 1993: 227-231, Figs 1-2; Nogueira 2000: 81-82, Fig. 20A-F; Fukuda 2010: 81-84, Fig. 22.

Material examined. (Selected morphological features of Brazilian specimens are provided on Table 1). State of Paraíba: Farol de Pitimbu $\left(7^{\circ} 28.362^{\prime} \mathrm{S} 34^{\circ} 47^{\prime} \mathrm{W}\right)$, intertidal: 8 specimens, coll. 18 September 2012. João Pessoa, recifes do Picãozinho $\left(7^{\circ} 4.243^{\prime} \mathrm{S} 34^{\circ} 49.291^{\prime} \mathrm{W}\right), 1 \mathrm{~m}: 9$ specimens, coll. 15 September 2012. State of Pernambuco: Ilha de Itamaracá, recifes de Itamaracá, (743.944'S 3449.200'W), $1 \mathrm{~m}: 3$ specimens, coll. 15 December 2012.

Additional material examined. Megasyllis mariandreworum San Martín, Aguado \& Álvarez-Campos, 2013. Australia, New South Wales, Botany Bay, 400 m north of Towra Point (3359'50"S 151 $\left.{ }^{\circ} 10^{\prime} 21^{\prime \prime E}\right)$, sand, $2.1 \mathrm{~m}$ : holotype (AMW35406), coll. March 2009, det. G. San Martín.

Megasyllis tigrina San Martín, Aguado \& Álvarez-Campos, 2013: Australia, New South Wales, Jervis Bay $\left(35^{\circ} 07.49^{\prime} \mathrm{S} 150^{\circ} 45.77^{\prime} \mathrm{E}\right)$, small, white sponge with pink lobes, on a seagrass bed, $7 \mathrm{~m}$ : holotype (AM W36503) and 3 paratypes (AM W36504); on rock on sandy bottom covered in bryozoa \& polychaetes, $6 \mathrm{~m}: 2$ paratypes (AM W36505), coll. 8 December 1993, det. G. San Martín. 
Description. Middle-sized body; longest specimen analysed $10 \mathrm{~mm}$ long, $0.3 \mathrm{~mm}$ wide, with 72 chaetigers. Greenish body, with brown spots dorsally, mostly on posterior body (Fig. 15A-E); distinctly slender at midbody, stouter anteriorly and posteriorly (Figs 15A-B; 16A-B). Anterior chaetigers smooth to slightly annulated (Figs 16B, E; 17), chaetigers more markedly annulated from midbody (Figs 18, 19A-B); dorsal surface of posterior chaetigers with short papillae and pores (Fig. 19C-D, F). Palps rounded, close each other, fused at bases (Figs 16G; 17). Prostomium ovate, slightly shorter than palps (Fig. 16C, E), with two pairs of eyes in open trapezoidal arrangement, anterior eyespots absent (Fig. 17); median antenna inserted between eyes, at center of prostomium, 3-4 times longer than palps, with 15-20 articles (Figs 16C-E; 17); lateral antennae shorter, about $2 / 3$ as long as median antenna, inserted on anterior margin of prostomium, with 10-18 articles each; proximal third of antennae weakly articulated (Figs 16C, E; 17), more conspicuously articulated distally, with uneven articles; prostomium with paired row of cilia from bases of lateral antennae to near base of median antennae (Fig. 16C-E); additional row of cillia laterally, on anterior half of prostomium (Fig. 16F). Ciliated nuchal organs between prostomium and peristomium, only visible under SEM (Fig. 16C, E). Peristomium shorter than anterior chaetigers (Figs 16E; 17); dorsal peristomial cirri as long as lateral antennae, with 17-22 articles each; ventral peristomial cirri shorter, with 10-14 articles each. Dorsal cirri with red to brown spots; dorsal cirri of chaetiger 1 longer than dorsal peristomial cirri, with 18-30 articles each; dorsal cirri of chaetigers 2 and 5 shorter, of similar length, with 12-17 articles each; dorsal cirri of chaetigers 3 and 4 with 13-24 and 9-23 articles each, respectively; midbody dorsal cirri longer than body width at corresponding segment, with 11-21 articles each (Fig. 18); posterior body dorsal cirri shorter, with 8-9 articles each, as long as body width at corresponding segment or slight shorter (Fig. 19F-G). 
Ventral cirri digitiform, inserted at bases of parapodial lobes, reaching their tips (Fig. 19B, G). Parapodial lobes conical (Figs 19B; 20; 21D). Anterior parapodia with 9-16 falcigers each; midbody parapodia with 7-14; posterior parapodia with 2-9 falcigers each. Shafts of falcigers thin, with stout subdistal spines (Figs 19E; 22B-C); blades of falcigers bidentate (Figs 19E; 21A-B, F-G; 22B-C), teeth increasing posteriorwards, rounded space inbetween on anterior parapodia, oblique space from midbody; blades with dorso-ventral gradation in length, with 46-17 $\mu \mathrm{m}, 25-15 \mu \mathrm{m}$ and $20-11 \mu \mathrm{m}$ long, on anterior, mid- and posterior body parapodia, respectively. Dorsal simple chaetae only present on posterior parapodia, unidentate, with rounded tips, thinner than shafts of falcigers (Figs 21E; 22D); ventral simple chaetae only present on posteriormost parapodia, slightly sigmoid, bidentate, with similar tip as blades of falcigers, slightly thinner than shafts of falcigers (Figs 21C, G; 22E). Anterior parapodia with up to three aciculae each, 1-2 subdistally inflated, with tapering tip, and one thinner, subdistally bent at near right angle, with oblique tip (Fig. 22F); number of aciculae per parapodium decreasing posteriorwards; midbody with 1-2 aciculae per parapodium, one of each type (Fig. 22G); single acicula in each posteriormost parapodium, subdistally bent at near right angle (Fig. 22H). Pygidium semicircular, with two elongated, weakly articulated anal cirri, longer and stouter than posterior dorsal cirri (Fig. 19G). Pharynx through 2-3 segments, with red stripe on anterior boarder and tooth slightly away from anterior border (Fig. 17); proventricle extending for 2-3 chaetigers, with 22-27 rows of muscle cells (Fig. 17).

Reproduction. Some specimens with posterior stolon with ca. 18 segments, with a pair of eyes (Fig. 15C-D).

Remarks. Megasyllis procera is characterized by having irregularly annulated chaetigers from midbody; long antennae; shafts of falcigers with inflated tips and 
spinulated boarder; blades of falcigers with dorso-ventral gradation in length on anterior parapodia, with teeth shorter than from midbody onwards; dorsal simple chaetae distally rounded; aciculae with curved, oblique tips; pharynx and proventricle similar in length, through 2-3 chaetigers, and proventricle with 22-27 rows of muscle cells. This species can be easily differentiated from M. mariandreworum, from Australia, because the latter has falcigers and ventral simple chaetae with subdistal tooth larger than distal one; aciculae straight; and unarticulated appendages throughout. Megasyllis tigrina San Martín, Aguado \& Álvarez-Campos, 2014, contrarily to M. procera, has two transverse black or red stripes per segment dorsally and another ovate reddish spot at base of each dorsal cirrus; longer blades of falcigers, up to $80 \mu \mathrm{m}$ long on anterior parapodia; midbody chaetigers inconspicuously annulated; and bifid dorsal simple chaetae.

Up to now, Megasyllis procera is the only species of the genus reported for the Atlantic Ocean. Brazilian specimens agree with the original description provided from Hartman (1965) and the redescription provided by San Martín \& Estapé (1993, as Pionosyllis procera).

Type locality. Between Atlantis Canyon and Block Canyon, New England Continental Slope (Atlantic Ocean).

Distribution. Atlantic Ocean: Cape Verde Islands, Southern and south-western Africa, USA, Cuba, Brazil (states of Paraíba and Pernambuco). First record from South Atlantic. 


\section{Genus Opisthosyllis Langerhans, 1879}

Type species: Opisthosyllis brunnea Langerhans, 1879.

Diagnosis. Relatively medium to large-sized body. Palps only basally fused. Prostomium with three antennae, two pairs of eyes and sometimes one pair of anterior eyespots. Two pairs of peristomial cirri; peristomium with occipital flap in some species. Antennae, peristomial and dorsal cirri throughout distinctly articulated; ventral cirri digitiform to ovate. Compound chaetae as falcigers only. Pharynx with opening surrounded by crown of papillae, pharyngeal tooth located away from anterior border, usually on posterior half of pharynx (San Martín et al. 2008b).

Remarks. The genus was first recorded for the Brazilian coast by Morgado \& Amaral (1985), who found O. corallicola Hartmann-Schröder, 1965 associated with the bryozoan Schizoporella unicornis (Johnston in Wood, 1844) in the state of São Paulo. Nogueira (2006) and Fukuda (2010) also recorded O. brunnea from off the state of São Paulo; and Paresque (2008) and Fukuda (2010) found O. viridis Langerhans, 1879 among material from off the states of Espírito Santo and Rio de Janeiro, respectively. Prior to the present study, there was no formal record for Opisthosyllis for the northeastern Brazilian coast. 
Key for Identification to species of Opisthosyllis recorded in northeastern Brazilian waters

1a. Dorsum with numerous papillae. Occipital flap absent...Opistosyllis viridis

1b. Dorsum without papillae. Occipital flap present ... Opisthosyllis brunnea

Opisthosyllis brunnea Langerhans, 1879

Opisthosyllis brunnea Langerhans, 1879: 541, Fig. 7. Augener 1918: 274, Fig. 25. Day 1967: 253, Fig. 12.5 C-E. Cantone 1976: 229, Figs 2-3. Fauvel 1953: 155, Fig. 78. HartmannSchröder 1979: 86; 1980: 48; 1981: 24; 1982: 58; 1991: 25, Fig. 19. San Martín 1984: 311, Figs 75-76; 1991: 230; 2003: 330, Fig. 183. Núñez et al. 1993: 115, Figs 2H, 3F. Capa et al. 2001: 106.

Not Opisthosyllis brunnea. Imajima 1966b: 230, Fig. 42. Lee \& Rho 1994: 135, Fig. 2.

Opisthosyllis nuchalis Verrill, 1900: 620. Monro 1933: 254, Fig. 7A-C.

Opisthosyllis australis Augener, 1913 (in part): 218, pl. 28, Fig. 35.

Material examined. State of Paraíba: João Pessoa, Praia de Cabo Branco ( $7^{\circ} 08^{\prime} \mathrm{S}$ $34^{\circ} 47^{\prime} \mathrm{W}$ ), intertidal: 1 specimen (MZUSP 2147), coll. 09 February 2009; 8 specimens (MZUSP 2146), coll. 02 February 2010. Conde, Praia de Carapibus ( $\left.7^{\circ} 17^{\prime} \mathrm{S} 34^{\circ} 48^{\prime} \mathrm{W}\right)$, intertidal: 9 specimens (MZUSP 2148), on rodholiths: 2 specimens (MZUSP 2149), coll. 10 February 2009; Praia do Coqueirinho ( $\left.7^{\circ} 18^{\prime} \mathrm{S} 34^{\circ} 47^{\prime} \mathrm{W}\right), 2$ specimens (MZUSP 2150), coll. 28 August 2011; Praia de Tambaba ( $\left.7^{\circ} 21^{\prime} \mathrm{S} 34^{\circ} 47^{\prime} \mathrm{W}\right), 1$ specimen (MZUSP 2151), coll. 30 August 2011. State of Pernambuco: Ilha de Itamaracá, recifes de Itamaracá, (743.944'S 3449.200'W), 1 m: 1 specimen (MZUSP 2153), coll. 15 December 2012. State of Espírito Santo: Vitória, Ilha do Boi, Praia da Direita $\left(20^{\circ} 18^{\prime} \mathrm{S}\right.$ $\left.40^{\circ} 17^{\prime} \mathrm{W}\right)$, rocky shore, intertidal: on Arthrocardia gardnerii Manza, 1937: 14 specimens (MZUSP 2199), coll. 21 July 2005; 14 specimens (MZUSP 2205), coll. 01 
November 2005; 13 specimens (MZUSP 2201), coll. 01 March 2006; on Centroceras clavulatum (C. Agardh) Montagne, 1846: 5 specimens (MZUSP 2197), coll. 26 May 2005; 1 specimen (MZUSP 2145), coll. 01 November 2005; 1 specimen (MZUSP 2200), coll. 01 March 2006; on Colpomenia sinuosa (Mertens ex Roth) Derbès \& Solier, 1851: 17 specimens (MZUSP 2206), coll. 01 November 2005; 9 specimens (MZUSP 2204), coll. 01 March 2006; on Hypnea musciformis (Wulfen) J. V. Lamouroux 1813: 13 specimens (MZUSP 2198), coll. 26 May 2005; 4 specimens (MZUSP 2195), coll. 21 July 2005; 2 specimens (MZUSP 2207), coll. 01 November 2005; 8 specimens (MZUSP 2202), coll. 01 March 2006; on Sargassum sp.: 1 specimen (MZUSP 2194), coll. 26 May 2005; 1 specimen (MZUSP 2203), coll. 01 March 2006.

Additional material examined. Opisthosyllis brunnea. Venezuela, Falcón, Tiraya, Península de Paraguaná, 0.5 m: 1 specimen (MNCN 16.01/11025), coll. 10 January 2007, coll. \& det. Díaz \& Vanegas. Cuba, Archipiélago de los Canarreos, Isla de Pinos, Cayo Matías: 1 specimen (MNCN 16.01/750), coll. 18 May 1984, coll. \& det. G. San Martín,

Description. Large-sized body; longest specimen analysed ca. $23.8 \mathrm{~mm}$ long, 1.1 mm wide, with 81 chaetigers. Brownwish green body, especially anteriorly. Palps triangular, distally pointed, totally free from each other. Subpentagonal prostomium, as long as palps, with 2 pairs of eyes in open trapezoidal arrangement, anterior eyespots absent; median antenna inserted between posterior pair of eyes, reaching beyond tip of palps, with 23-26 articles; lateral antennae shorter, inserted anteriorly to eyes, shorter than median antenna, with 13-19 articles each. Ciliated nuchal organs dorsally between prostomium and peristomium, distinctly curved, reaching base of median antenna, under occipital flap, and extending laterally around prostomium/peristomium border. Peristomium shorter than anterior chaetigers, with rounded, nearly semicircular 
occipital flap covering posterior part of prostomium; dorsal peristomial cirri as long as median antennae or slightly longer, with 26-30 articles each; ventral peristomial cirri shorter, with 11-18 articles each. Dorsal cirri of chaetiger 1 longer than dorsal peristomial cirri, with 36-40 articles each; dorsal cirri of chaetigers 2 and 5 shorter, of similar size, with 17-21 articles each; dorsal cirri of chaetigers 3 and 4 with 29-31 and 33-36 articles each, respectively; following dorsal cirri alternating long, with 32-38 articles each, longer than body width at corresponding segment, and short, with 23-29 articles each, shorter than body width on anterior and midbody segments, longer than body width at corresponding segment posteriorly; dorsal cirri with proximal articles wider, distally tapering. Antennae, peristomial and dorsal cirri throughout with short cirrophores. Digitiform ventral cirri, inserted at beginning of middle third of parapodial lobes and reaching their tips. Parapodial lobes distally bilobed, pre-chaetal lobe longer. Anterior parapodia with 10-16 falcigers each; midbody parapodia with 9-13, posterior parapodia with 5-9 falcigers each. Shafts of falcigers slightly spinulated; tip of shafts straight on anterior body and sigmoid on mid- and posterior body, especially on ventralmost chaetae from posterior body; blades of falcigers spinulated, unidentate to subbidentate, in the latter case with subdistal spine more conspicuous than remaining ones; falcigers with subtle gradation in length of blades, with $38-25 \mu \mathrm{m}$ long in anterior parapodia, 34-24 $\mu \mathrm{m}$ and 30-20 $\mu \mathrm{m}$ long in mid- and posterior body parapodia, respectively. Dorsal simple chaetae present from midbody parapodia, truncate, with minute subdistal spines, thinner than shafts of falcigers; ventral simple chaetae only present in posteriormost parapodia, sigmoid, unidentate, subdistally spinulated, about as thick as shafts of falcigers. Anterior parapodia with up to four aciculae each, straight, with hollow concavity; number of aciculae decreasing posteriorwards to single acicula per parapodium on posteriormost chaetigers. Pygidium semicircular, with two elongated 
anal cirri, as long as posterior dorsal cirri. Pharynx through 9-11 segments; pharyngeal tooth near posterior margin of pharynx; proventricle extending for 11-12 chaetigers, with 54-64 rows of muscle cells.

Remarks. Brazilian specimens of $O$. brunnea are similar to those from the Caribbean (Venezuela and Cuba), Iberian Peninsula (San Martín 2003) and Australia (San Martín et al. 2008b) except for the size of the subdistal tooth of the blades of falcigers on anterior body chaetigers, number of aciculae per parapodium and of rows of muscle cells in the proventricle. Brazilian and Australian specimens have up to four aciculae per parapodium anteriorly, while Caribbean and Iberian specimens have only two; Brazilian, Caribbean and Iberian specimens have falcigers with subdistal tooth as a spine, and ca. 60 rows of muscle cells in the proventricle, while Australian specimens have anterior body falcigers with larger subdistal tooth, triangular, similar to distal one (San Martín et al. 2008b, Fig. 17E-F), and ca. 30 rows of muscle cells in proventricle.

Type locality. Madeira Island, Portugal (Atlantic Ocean).

Distribution. Pacific Ocean: Australia (Queensland and New South Wales). Indian Ocean: Australia (Western Australia), Mozambique, South Africa. Atlantic Ocean: Mediterranean Sea (Spain: Baleares and Chafarinas Islands), Portugal (Madeira Island), Brazil (states of Paraíba, Pernambuco, Espírito Santo and São Paulo). First record from off the state of Espírito Santo and northeastern Brazilian coast.

Opisthosyllis viridis Langerhans, 1879

Opisthosyllis viridis Langerhans, 1879: 543, pl. 31, Fig. 9. Monro 1939: 390, Fig. 301. Imajima 1966b: 224, Fig. 39. López \& San Martín 1994: 130, Fig. 1. Lee \& Rho 1994: 135, Fig. 3. 
Opisthosyllis australis Augener, 1913 (in part): 218, pl. 3, Fig. 35, Fig. 28 a-d. HartmannSchröder 1979: 85; 1980: 47; 1981: 24; 1991: 26.

Opisthosyllis papillosa Hartmann-Schröder, 1960: 87, Figs 59-62; 1965: 108, Figs 33-35; 1980: 48; 1981: 24; 1991: 26.

Material examined. State of Pernambuco: Ilha de Itamaracá, Ponta do Jaguaribe (744'S 3449'W), intertidal: 2 specimens (MZUSP 2154), coll. 11 December 2012. State of Espírito Santo: Vitória, Ilha do Boi, Praia da Direita $\left(20^{\circ} 18^{\prime} \mathrm{S} 40^{\circ} 17^{\prime} \mathrm{W}\right)$, rocky shore, intertidal, on Arthrocardia gardnerii: 1 specimen (MZUSP 2192), coll. 26 May 2005; 2 specimens (MZUSP 2158), coll. 21 July 2005; on Centroceras clavulatum: 7 specimens (MZUSP 2193), coll. 26 May 2005; 1 specimen (MZUSP 2159), coll. 01 November 2005; 4 specimen (MZUSP 2189), coll. 01 March 2006; on Hypnea musciformis: 14 specimens (MZUSP 2191), coll. 26 May 2005; 1 specimen (MZUSP 2190), coll. 01 March 2006; on Sargassum sp.: 1 specimen, coll. 26 May 2005; 1 specimen, coll. 01 March 2006. State of São Paulo: Ubatuba, Praia de Picinguaba (2322'31"S 4450'21"W), intertidal: 1 specimen (MZUSP 2160), coll. 08 June 2001.

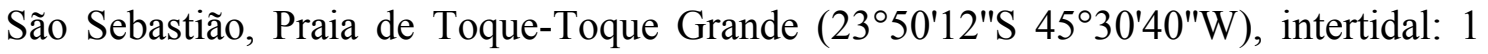
specimen (MZUSP 2161), coll. 10 April 2001; Praia da Baleia (2346.800'S 45³9.850'W), intertidal: 4 specimens (MZUSP 2155), coll. 08 April 2001; 6 specimens (MZUSP 2156), coll. 12 December 2001; 1 specimen (MZUSP 2157), coll. 17 October 2005. Guarujá, Ilha das Palmas $\left(24^{\circ} 00^{\prime} 34^{\prime \prime S} 46^{\circ} 19^{\prime} 25^{\prime \prime W}\right)$, intertidal: 1 specimen (MZUSP 2162), coll. 05 October 2005.

Additional material examined. Opisthosyllis leslieharrisae Aguado, San Martín \& Nygren, 2005. USA, California, Isla de Santa Catalina (33²6.7'N $\left.118^{\circ} 29.1^{\prime} \mathrm{W}\right), 1-4$ m: holotype (MNCN 16.01/10264) and 1 paratype (MNCN 16.01/10266), coll. 15 January 2001, det. M.T. Aguado, G. San Martín and A. Nygren. 
Description. Small-sized body; longest specimen analysed $8 \mathrm{~mm}$ long, $0.6 \mathrm{~mm}$ wide, with 74 chaetigers. Body without colour patterns; dorsal surface of peristomium and chaetigers throughout covered in numerous rounded, small papillae, arranged in irregular transverse row. Palps roughly triangular, distally rounded, fused at bases. Prostomium ovate, shorter than palps, with two pairs of eyes in open trapezoidal arrangement, anterior eyespots absent; median antenna inserted between posterior pair of eyes, near posterior border of prostomium, reaching beyond tip of palps, with 17-21 articles; lateral antennae shorter, inserted on anterior margin of prostomium, with 9-14 articles each. Nuchal organs not seen. Peristomium shorter than anterior chaetigers, sometimes covering posterior part of prostomium, occipital flap absent; dorsal peristomial cirri as long as median antenna or slightly longer, with 19-25 articles each; ventral peristomial cirri shorter, with 11-15 articles each. Dorsal cirri of chaetiger 1 longer than dorsal peristomial cirri, with 23-30 articles each; dorsal cirri of chaetigers 2 and 5 of similar size, shorter, with ca. 11 articles each; dorsal cirri of chaetigers 3 and 4 with 12-18 and 13-18 articles each, respectively; following dorsal cirri alternating long, with ca. 18 articles each, as long as $3 / 4$ of body width at corresponding segment, and short, with ca. 9 articles each, about $1 / 2$ body widthat corresponding segment; posterior dorsal cirri shorter, long and short cirri with 6-9 and 2-6 articles each, respectively, both shorter than $1 / 2$ body width at corresponding segment. Antennae, peristomial and dorsal cirri with short cirrophores. Ventral cirri ovate on anterior body, more digitiform and elongated posteriorwards, shorter than parapodial lobes, inserted at their bases. Parapodial lobes conical, slightly bilobed. Anterior parapodia with 14-17 falcigers each; midbody parapodia with 8-11, posterior parapodia with 4-6 falcigers each. Shafts of falcigers slightly spinulated subdistally; shafts of falcigers on anterior body with straight tips, slightly inflated subdistally, shafts with more sigmoids tips posteriorwards; 
blades of falcigers with minute spines, subbidentate, with subdistal spine more conspicuous than remaining ones; blades of falcigers with dorso-ventral gradation in length, 29-10 $\mu \mathrm{m}$ long on anterior parapodia, 20-15 $\mu \mathrm{m}$ long and 12-10 $\mu \mathrm{m}$ long on mid- and posterior body parapodia, respectively. Dorsal simple chaetae present from midbody parapodia, bifid, with minute subdistal spines, as thick as shafts of falcigers; ventral simple chaetae only present on posteriormost parapodia, sigmoid, bidentate, slightly spinulated subdistally, about as thick as shafts of falcigers. Anterior parapodia with up to two aciculae each, with slightly inflated tip; number of aciculae decreasing posteriorwards to single acicula per parapodium on posteriormost chaetigers. Pygidium semicircular, with two elongate anal cirri, longer than posterior dorsal cirri, with 11-13 articles each. Pharynx through 7-9 segments; pharyngeal tooth near posterior margin of pharynx; proventricle extending for 6-7 chaetigers, with ca. 52 rows of muscle cells.

Remarks. Opisthosyllis leslieharrisae and O. convexa Lee \& Rho, 1994 also have the dorsal surface covered on numerous papillae. Brazilian specimens of $O$. viridis can be differentiated from $O$. leslieharrisae by having rounded papillae, shorter dorsal cirri, distinctly shorter spines on edge of blades of falcigers, and pharyngeal tooth located more posteriorly in pharynx, close to proventricle, while $O$. leslieharrisae has triangular papillae on dorsum and pharyngeal tooth located at $3 / 4$ of pharyngeal length.

Opisthosyllis convexa has longer appendages than Brazilian specimens of $O$. viridis. Furthermore, in $O$. convexa, the subdistal tooth of falcigers is more separated from distal tooth than in $O$. viridis, and pharynx occupies 5-6 chaetigers, while proventricle extends for $10-11$ chaetigers.

San Martín et al. (2008b) analysed four paratypes and three non-type specimens of O. papillosa Hartmann-Schröder, 1960, and three syntypes of O. australis Augener, 1913, concluding that both species are junior-synonymes of $O$. viridis. The authors 
noticed that $O$. viridis, as currently considered, has high intraspecific variability, suggesting that this could be another case of a complex of sibling species. Brazilian specimens of $O$. viridis also present some differences from specimens from others localities, with shorter appendages than the described for Australian (San Martín et al. 2008b) and Japanese material (Imajima, 1966b); bifid dorsal simple chaetae and bidentate ventral simple chaetae; and proventricle with ca. 52 rows of muscle cells. On the other hand, Australian specimens have bidentate dorsal simple chaetae and ventral simple chaetae with acute tip; and proventricle with ca. 32 rows of muscle cells (San Martín et al. 2008b, Fig. 27G). Korean specimens of $O$. viridis have dorsal simple chaetae similar to those of Brazilian specimens (bifid) and ventral simple chaetae similar to those of Australian specimens (with acute tip) (Lee \& Rho 1994). Papillae are absent on prostomium and palps of Brazilian and Australian specimens (San Martín et al. 2008b, Fig. 27), but present in material from Cape Verde (López \& San Martín 1994). Because of this great variability observed in material $O$. viridis from different localities, we agree with San Martín et al. (2008b), that a molecular approach is needed to clarify the diversity of species under this name.

Type locality. Madeira Island, Portugal (Atlantic Ocean).

Distribution. Pacific Ocean: South Korea, Japan, Australia (Queensland and New South Wales). Indian Ocean: Australia (Western Australia). Atlantic Ocean: Portugal (Madeira Island) and Brazil (Pernambuco, Espírito Santo and São Paulo). First record from off the northeastern Brazilian coast. 


\section{Genus Trypanosyllis Claparède, 1864}

Type species: Syllis zebra Grube, 1860, designated by Claparède, 1864.

Diagnosis. Medium to large sized syllines, up to $13 \mathrm{~cm}$ long, with flattened, ribbon-like body. Palps ovate, free from each other. Prostomium with three antennae, two pairs of eyes, sometimes with pair of anterior eyespots. Antennae, peristomial and dorsal cirri throughout moniliform. Peristomium usually dorsally reduced, with two pairs of peristomial cirri. Compound chaetae as falcigers only, sometimes secondarily simple due to fusion between shaft and blade; dorsal and/or ventral simple chaetae present sometimes, on posteriormost parapodia. Pharynx with anterior trepan; central, larger tooth sometimes also present.

Remarks. Three species of Trypanosyllis were recorded from Brazil: $T$. aurantiacus Nogueira \& Fukuda, 2008, originally described from the state of São Paulo; T. parvidentata Perkins, 1981 found in Guanabara Bay, state of Rio de Janeiro (Santi \& Tavares 2009); and T. zebra, recorded to the states of Pernambuco and Bahia by Rullier \& Amoureux (1979); to São Paulo by Morgado \& Amaral (1985) (associated with the bryozoan Schizoporella unicornis, as T. taeniaformis), by Duarte \& Nalesso (1996) (associated with the sponge Zycomycale parishii (Bowerbank A.A.), also as $T$. taeniaformis (Haswell, 1886)) and by Nogueira \& Fukuda (2008); and to Rio de Janeiro by Attolini (1997) and Nogueira (2006). 


\section{Trypanosyllis zebra (Grube, 1860)}

Syllis zebra Grube, 1860: 86, pl. 3, Fig. 7.

Trypanosyllis zebra. Langerhans 1879: 556. Haswell 1920: 101. Fauvel 1923: 269, Figs 101A-E. Day 1967: 256, Figs 12.6. A-B. San Martín 2003: 311, Figs 171-173. Nogueira \& Fukuda 2008: 2-7, Fig. 1. San Martín et al. 2008b: 43-48, Figs 31F, 32-36.

Trypanosyllis krohnii Claparède, 1864: 558, pl. 7, Fig. 2.

Syllis taeniaformis Haswell, 1885: 741, pl. 1, Figs 4-5.

Trypanosyllis taeniaformis Augener 1913: 230. Westheide 1974: 39, Figs 16A-D. Day \& Hutchings 1979: 105.

Trypanosyllis (Trypanedenta) taeniaformis Imajima \& Hartman 1964: 127, Figs 30 H-K. Imajima 1966b: 239, Figs 45 A-I. Hartmann-Schröder 1989: 18.

Trypanosyllis richardi Gravier, 1900: 168, pl. 9, Figs 12-13.

Trypanosyllis vittigera Ehlers, 1887: 151, pl. 40, Figs 1-3. Uebelacker 1984: 30-88, Figs 30-81, 82A-H. Parautolytus luzonensis Pillai, 1965: 123, Figs 5E-I, 6A-C.

Material examined. State of Paraíba: Mataraca, Barra de Camaratuba $\left(6^{\circ} 36^{\prime} \mathrm{S}\right.$ 3457'W), intertidal: 4 specimens (MZUSP 2174), coll. 12 August 2010. Baía da Traição, Praia do Farol (6 $\left.6^{\circ} 41^{\prime} S 4^{\circ} 55^{\prime} \mathrm{W}\right)$, intertidal: 3 specimens (MZUSP 2173), coll. 09 August 2010. Rio Tinto, Barra de Mamanguape $\left(6^{\circ} 45^{\prime} \mathrm{S} 34^{\circ} 55^{\prime} \mathrm{W}\right)$, intertidal: 4 specimens (MZUSP 2175), coll. 11 August 2010. Cabedelo, Píer de Cabedelo (658'S 34 $50^{\prime} \mathrm{W}$ ), intertidal: 1 specimen (MZUSP 2179), coll. 12 February 2009. João Pessoa, Praia de Cabo Branco ( $\left.7^{\circ} 08^{\prime} \mathrm{S} 34^{\circ} 47^{\prime} \mathrm{W}\right)$, intertidal: 1 specimen (MZUSP 2165), coll. 09 February 2009; 1 specimen (MZUSP 2181), coll. 02 February 2010. Conde, Praia de

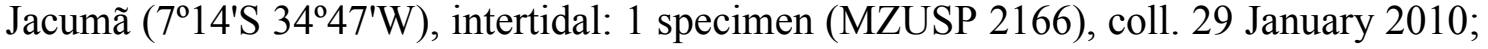
Praia de Tabatinga $\left(7^{\circ} 19^{\prime} \mathrm{S} 34^{\circ} 47^{\prime} \mathrm{W}\right)$, intertidal: 3 specimens (MZUSP 2186), coll. 1 September 2011; on Amphimedon viridis: 1 specimen (MZUSP 2185), coll. 17

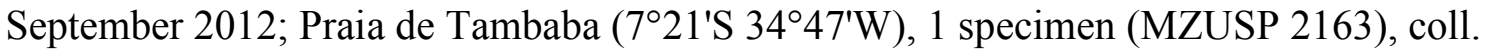

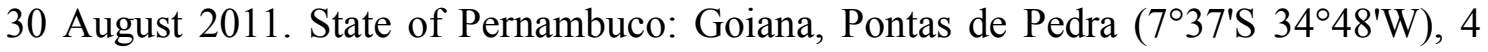
specimens (MZUSP 2170), coll. 13 December 2012. Ilha de Itamaracá, Ponta do Jaguaribe $\left(7^{\circ} 44^{\prime} \mathrm{S} 34^{\circ} 49^{\prime} \mathrm{W}\right)$, intertidal: 1 specimen (MZUSP 2182), coll. 11 December 
2012. State of Espírito Santo: Vitória, Ilha do Boi, Praia da Direita $\left(20^{\circ} 18^{\prime} \mathrm{S} 40^{\circ} 17^{\prime} \mathrm{W}\right)$, rocky shore, intertidal, on Arthrocardia gardnerii: 12 specimens (MZUSP 2172), coll. 21 July 2005; on Hypnea musciformis: 1 specimen (MZUSP 2180), coll. 26 May 2005. State of Rio de Janeiro: Búzios, Praia Azeda, intertidal: 1 specimen (MZUSP 2171), coll. 08 April 2004. State of São Paulo: Ubatuba, Praia de Picinguaba (23²2'31"S 4450'21"W), intertidal: 57 specimens (MZUSP 2183), coll. 08 June 2001; 39 specimens (MZUSP 2169), coll. 18 October 2001; 2 specimens (MZUSP 2188), coll. 17 October 2001. São Sebastião, Praia da Baleia $\left(23^{\circ} 46.800^{\prime} S 45^{\circ} 39.850^{\prime} \mathrm{W}\right)$, intertidal: 20 specimens (MZUSP 2184), coll. 23 July 2005; 1 specimen (MZUSP 2187), coll. 17 October 2005; Praia do Araçá (2348'54"S 45²4'24"W), intertidal: 1 specimen (MZUSP 2164), coll. 20 July 2005. Guarujá, Praia de Pernambuco (2358'20"S $\left.46^{\circ} 11^{\prime} 02 " \mathrm{~W}\right)$, intertidal: 22 specimens (MZUSP 2168), coll. 22 June 2005; 8 specimens (MZUSP 2167), coll. 04 October 2005; Ilha das Palmas, (2400'34"S 46¹9'25"W), intertidal: 1 specimen (MZUSP 2176), coll. 6 March 2004. São Vicente, Ilha Porchat (235' $\left.39^{\prime \prime S} 46^{\circ} 22^{\prime} 08^{\prime \prime} \mathrm{W}\right)$, intertidal: 1 specimen (MZUSP 2177), coll. 18 November 2002.

Remarks. The specimens analysed herein agree with the description of Brazilian material provided by Nogueira \& Fukuda (2008).

Type locality. France (Mediterranean Sea).

Distribution. Atlantic Ocean: Mediterranean Sea, Africa, Brazil (states of Paraíba, Pernambuco, Espírito Santo, Rio de Janeiro and São Paulo). This is the first record of the genus to the states of Paraíba and Espírito Santo. 


\section{Genus Syllis Lamarck, 1818}

Type species: Syllis monilaris Lamarck, 1818

Diagnosis. Medium to large sized body. Palps only basally fused or free from each other. Prostomium with 3 antennae, 2 pairs of eyes and sometimes 1 pair of anterior eyespots. Two pairs of peristomial cirri. Antennae, peristomial and dorsal cirri throughout moniliform. Ventral cirri ovate to slightly digitiform. Compound chaetae as falcigers and, in some taxa, also spiniger-like chaetae; dorsal and ventral simple chaetae usually present. Pharynx with tooth located at anterior border, or close to it; pharynx margin surrounded by crown of soft papillae. Reproduction by stolons.

Remarks. Syllis is a highly heterogeneous group, currently the largest genera of the family, with more than 130 species (San Martín, 2003). Langerhans (1879) divided the genus into three subgenera; Syllis, with secondarily simple chaetae by shafts and blades fusion; Ehlersia, with, pseudoespiniger blades; and Typosyllis, with falciger chaetae only. Recently, Aguado et al. (2012) concluded that the type of chaetae is a homoplastic character. We consider Syllis as valid and the two other genera as its junior synonym herein.

Currently, according to Amaral et al. (2013), 30 species of Syllis occur along the Brazilian coast, from the intertidal zone until $749 \mathrm{~m}$ deep. Among those, S. glandulata Nogueira \& San Martín, 2002, S. pseudoarmillaris Nogueira \& San Martín, 2002, and S. guidae Nogueira \& Yunda-Guarin, 2008 were originally described from Brazilian material, the first two from the State of São Paulo, the last from the State of Ceará. Besides these species, Nogueira \& San Martín (2002) reported other nine species for São Paulo, living in colonies of the scleractinian coral Mussismilia hispida (Verril, 
1868), S. beneliahuae (Campoy \& Alquézar, 1982), S. corallicola Verril, 1900, S. gracilis Grube, 1840, S. hyllebergi (Licher, 1999), S. lutea (Hartmann-Schröder, 1960), S. maryae San Martín, 1992, S. prolifera Krohn, 1852, S. truncata Haswell, 1920, and S. tyrrhena (Licher \& Kuper, 1998). Nogueira \& San Martín (2002) provided detailed descriptions for Brazilian material and speculated about the Brazilian reports of Syllis armilaris (Müller, 1771) and Syllis hyalina Grube, 1863. Rullier \& Amoureux (1979) reported $S$. armilaris and $S$. hyalina (as $T$. armilaris and $T$. hyalina, respectively) from northeasthern Brazil; Nogueira \& San Martín (2002), however, considered these records as doubtful, and sugested that none of these species really occurs in Brazil. Based on the diagnosis provided by Rullier \& Amoureux (1979), Nogueira \& San Martín (2002) indicated that the reports could be, in fact, of S. magellanica Augener, 1918 in the case of $S$. armilaris, and $S$. glandulata, in the case of $S$. hyalina. After Rullier \& Amoureux (1979), other authors also recorded S. hyalina as occurring along off the Brazilian coast but, as also happens with many other records for the country, in ecological papers without a taxonomic approach, usually with no voucher material availabble (see Amaral et al. 2013 for more details).

Nogueira (2006) reported two more species of Syllis for the state of São Paulo, S. amica Quatrefages, 1865 and S. magelanica, while Fukuda (2010) reported and provided detailed descriptions for other nine species, occurring from Rio de Janeiro to Santa Catarina, Syllis cf. aciculigrossa (San Martín, 1990), S. garciai (Campoy, 1982), Syllis cf. gerlachi (Hartmann-Schröder, 1960) S. magellanica S. ortizi San Martín, 1992, S. rosea (Langerhans, 1879), S. sclerolaema Ehlers, 1901, S. westheidei San Martín, 1984, and Syllis sp. 1.

Besides the already mentioned cases of S. hyalina and S. armillaris, other seven species recorded for the Brazilian coast should also be considered as doubtful records, 
since no descriptions were provided for the Brazilian specimens nor there is voucher material available for examination. These species are indicated with * in the Key for Identification and they are S. cornuta Rathke, 1843 (also reported as Syllis (Ehlersia) cornuta and Langerhansia cornuta), S. fasciata Malmgren, 1867 (as Typosyllis fasciata), S. golfonovensis (Hartmann-Schröder, 1962), S. prolixa Ehlers, 1901 (as Syllis (Typosyllis) prolixa), S. ehlersioides japonica Buzhinskaja, 1985 (as Typosyllis ehlersioides), and S. nuchalis (Hartmann-Schröder, 1960).

In the present paper, we provide descriptions for five new to science species. In

addition, S. beneliahuae, S. corallicola, S. gracilis, S. hyllebergi, S. lutea, S. prolifera and S. pseudoarmillaris are recorded for the first time from off the northeastern Brazilian coast.

\section{Key for Identification to species of Syllis currently recorded in Brazilian waters}

1a. Midbody with secondarily simple chaetae by complete (Fig. 25G) or incomplete (Fig. 25J) fusion of shafts and blades or by lacking blades (Fig. 24D-F)...2

1b. Midbody chaetigers with falcigers and frequently dorsal simple chaetae; spiniger-like and ventral simple chaetae may also be present ...7

2a. (1a) Dorsalmost chaetae of midbody parapodia secondarily simple by loss of blades...3

2b. (1a) At least some chaetae of midbody parapodia secondarily simple by fusion of shafts and blades...4 
3a. (2a) Blades of falcigers with thin distal tooth with acute tip, and short subdistal tooth; dorsalmost chaetae of mid- and posterior body parapodia with long, sinuous and narrow tip... Syllis sp. n. 1

3b. (2a) Blades of falcigers with rounded distal tooth, and conspicuous subdistal tooth, slightly shorter than distal one; dorsalmost chaetae of mid- and posterior body parapodia with short, straight and wide tip...Syllis amica ${ }^{1}$

4a. (2b) Blades of falcigers of anterior body parapodia with dorso-ventral gradation in length, 30-15 $\mu \mathrm{m}$ long; midbody with 'ypsiloid' secondarily simple chaetae, with short blades fitted on one side of distal part of shaft ...5

4b. (2b) Blades of falcigers of anterior body parapodia without dorso-ventral gradation in length, $12-10 \mu \mathrm{m}$ long; from midbody, blades completely fused to entire top of shaft, not ypsiloid, resembling chaetae of Haplosyllis...Syllis sclerolaema ${ }^{2}$

5a. (4a) Midbody chaetigers with 2-3 ypsiloid chaetae per parapodium, shafts totally fused to blades, falcigers present on anterior and posterior body chaetigers ... Syllis gracilis

5b. (4a) Ypsiloid chaetae of midbody parapodia with shafts partially to totally fused to blades, falcigers present throughout, or absent on midbody parapodia...6

6a. (5b) Each midbody parapodium with 2 chaetae, one of each type (Fig. 27C), ypsiloid chaetae with shafts totally fused to blades, without scar at fusion line, blades with short spines or smooth, tips of chaetae aligned or blade side slightly shorter (Figs 25G; 27B); and one falciger chaetae with shafts and blades partially fused (Fig. 25J). Anterior parapodia with up to three aciculae each, one of which subdistally inflated with oblique tips and two straight, distally rounded ...Syllis sp. n. 2 
6b. (5b) Each midbody parapodium with up to five chaetae, two of them ypsiloid, with shafts totally fused to blades, with scar at fusion line, blades with short spines or smooth, tips of chaetae with blade side shorter; and 3-4 chaetae with shafts and blades partially fused. Anterior parapodia with up to 4 aciculae each, subdistally inflated with oblique tips...Syllis magellanica ${ }^{2}$

7a. (1b) Spiniger-like chaetae present... 8

7b. (1b) Spiniger-like chaetae absent...15

8a. (7a) Aciculae of posterior body parapodia straight, distally tapering... 9

8b. (7a) Aciculae of posterior body parapodia different from above, distally curved, oblique, subdistally inflated or bent...10

9a. (8a) Anterior parapodia with 12-16 chaetae each. Blades of spiniger-like chaetae bidentate, ca. $80 \mu \mathrm{m}$ long on anterior parapodia (Licher 1999)...Syllis cornuta ${ }^{3}$ 9b. (8a) Anterior parapodia with 25-30 chaetae each. Blades of spiniger-like chaetae $145 \mu \mathrm{m}$ long on anterior parapodia; longer spiniger-like blades unidentate, shorter spiniger-like blades bidentate...Syllis aciculigrossa ${ }^{2}$

10a. (8b) Blades of falcigers and ventral simple chaetae with distal spines similar in length or longer than subdistal tooth; blades of spiniger-like chaetae with subdistal tooth shorter to inconspicuous... Syllis garciai ${ }^{4}$

10b. (8b) Blades of falcigers and ventral simple chaetae with short spines; blades of spiniger-like chaetae clearly bidentate at least on anterior parapodia...11

11a. (10b) Distal tooth of posterior body falcigers shorter than subdistal tooth...Syllis hyllebergi ${ }^{5}$ 
11b. (10b) Distal tooth of posterior body falcigers similar or large than subdistal tooth...12

12a. (11b) Anterior parapodia with $3-4$ aciculae each...13

12b. (11b) Anterior parapodia with 2 aciculae each...14

13a. (12a) Blades of spiniger-like chaetae with 31,48 and $35 \mu \mathrm{m}$ long on anterior, mid- and posterior body parapodia, respectively. Dorsal simple chaetae bidentate... Syllis beneliahuae ${ }^{5}$

13b. (12a) Blades of spiniger-like chaetae with 50,77 and $42 \mu \mathrm{m}$ long on anterior, mid- and posterior body parapodia, respectively. Dorsal simple chaetae uni- to subbidentate... Syllis $\mathbf{s p .} \mathbf{n} . \mathbf{3}$

14a. (12b) Dorsum of two consecutive chaetigers, soon after proventricle level, swelled, dark, with internal granulose appearance. Spiniger-like chaetae bidentate throughout; thin teeth..... Syllis maryae

14b. (12b) Dorsum of chaetiger similar throughout. Spiniger-like chaetae of anterior parapodia bidentate, from midbody spiniger-like chaetae unidentate, with rounded tooth...14

15a. (7b) All falcigers with unidentate blades ... Syllis fasciata $*^{3}$

15b. (7b) Falcigers with at least some blades bidentate ...16

16a. (15b) Blades of posterior body falcigers with distal tooth shorter ...17

16b. (15b) Blades of posterior body falcigers with distal tooth at least as large as sudistal one...20 
17a. (16a) Dorsal simple chaetae bifid...18

17b. (16a) Dorsal simple chaetae subbidentate...19

18a. (17a) Blades of anterior body falcigers short, without dorso-ventral gradation in length, 10-13 $\mu \mathrm{m}$ long; blades of ventralmost falcigers of posterior body parapodia with subdistal tooth slightly larger than distal one... Syllis guidae

18b. (17a) Blades of anterior body falcigers longer, with dorso-ventral gradation in length, 40-20 $\mu \mathrm{m}$ long; blades of ventralmost falcigers of posterior body parapodia with subdistal tooth distinctly larger than distal one ...Syllis ortizi ${ }^{2}$

19a. (17b) Midbody dorsal cirri alternating long, with $40-45$ articles, and short, with ca. 22 articles each. Blades of anterior body falcigers with distal tooth bent at right angle. Ventral simple chaetae with distal teeth similar in length, with oblique space inbetween ...Syllis sp n. 4

19b. (17b) Midbody dorsal cirri alternating long, with $23-25$ articles, and short, with ca. 9 articles each. Blades of anterior body falcigers with distal tooth hooked. Ventral simple chaetae with subdistal tooth larger, teeth at right angle ...Syllis lutea ${ }^{2}$

20a. (16b) Posterior body aciculae subdistally inflated, with short oblique tip...21

20b. (16b) Posterior body aciculae different from above, distally hollow, straight, tapering or bent at right angle ...26

21a. (20a) Long midbody dorsal cirri longer than body width at corresponding segment ...22

21b. (20a) Long midbody dorsal cirri shorter or as long as body width at corresponding segment ...23 
22a. (21a) Blades of falcigers with subdistal tooth shorter. Dorsal simple chaetae bifid; ventral simple chaetae with subdistal tooth shorter than distal one...Syllis cf. westheidei

22b. (21a) Blades of falcigers with distal teeth similar in length. Dorsal simple chaetae subbidentate; ventral simple chaetae with teeth similar in length...Syllis corallicola ${ }^{5}$

23a. (21b) Anterior parapodia with up to $2-3$ aciculae each...24

23b. (21b) Anterior parapodia with up to 4-5 aciculae each... Syllis golfonovensis ${ }^{3}$

24a. (23a) Parapodia with dorsal glands, with granular material. Blades of midbody falcigers with conspicuous dorso-ventral gradation in length... Syllis glandulata ${ }^{5}$ 24b. (23a) Dorsal glands absent. Blades of midbody falcigers similar in length...25

25a. (24b) Blades of midbody falcigers bidentate... Syllis pseudoarmillaris ${ }^{5}$

25b. (24b) Blades of midbody falcigers uni- to subbidentate... Syllis armillaris $*^{3}$

26a. (20b) Aciculae distally inflated, rounded...27

26b. (20b) Aciculae otherwhise... 28

27a. (26a) Blades of falcigers with dorso-ventral gradation in length, bidentate, distal teeth similar in length or subdistal tooth slightly shorter... Syllis prolifera

27b. (26a) Blades of falcigers all about same length, subbidentate... Syllis prolixa $*^{3}$

28a. (26b) Anterior parapodia with up to $4-5$ aciculae each; aciculae of posterior body parapodia straight, tapered, tips protruding from parapodial lobes...29 
28b. (26b) Anterior parapodia with up to 1-2 aciculae each; aciculae throughout slightly curved or bent at right angle; posterior body aciculae not protruding from parapodial lobes...32

29a. (28a) Blades of falcigers subbidentate...30

29b. (28a) Blades of falcigers clearly bidentate...31

30a. (29a) Median antenna with $7-15$ articles; lateral antennae with $11-12$ articles each; longer midbody dorsal cirri with ca. 9 articles each...Syllis hyalina $*^{3}$

30b. (29a) Median antenna with ca. 33 articles; lateral antennae with ca. 25 articles each; longer midbody dorsal cirri with up to 47 articles each...Syllis ehlersioides $*^{3}$

31a. (29b) Midbody dorsal cirri alternating long, 30-35 articles each, longer than body width at corresponding segment, and short, 23-24 articles each, shorter than body width at corresponding segment. Blades of falcigers with conspicuous dorso-ventral gradation in length, 43-18 $\mu \mathrm{m}$ long on anterior and midbody parapodia, 32-12 $\mu \mathrm{m}$ long on posteriorbody. ...Syllis sp. $\mathbf{n} . \mathbf{5}$

31b. (29b) Midbody dorsal cirri alternating long, 16-18 articles each, longer than body width at corresponding segment, and short, ca. 12 articles each, as long as body width at corresponding segment. Blades of falcigers with inconspicuous dorso-ventral gradation in the length, 25-18 $\mu \mathrm{m}$ long on anterior parapodia, 16-12 $\mu \mathrm{m}$ long on posterior parapodia...Syllis variegata $*^{4}$

32a. (28b) Dorsal simple chaetae distally bifid. Aciculae of anterior body parapodia distally curved, slightly thinner than shafts of falcigers; posterior body aciculae similar but stouter, about same width as shafts of falcigers ... Syllis nuchalis ${ }^{3}$ 
32b. (28b) Dorsal simple chaetae distally truncate. Anterior body parapodia with at least acicula bent at right angle each; posterior parapodia with single acicula each, bent at right angle; aciculae throughout conspicuously thinner than shafts of falcigers ... 33

33a. (32b) Body slender. Dorsal cirri short throughout. Blades of falcigers with sharp teeth. Pharynx through 5-6 segments; proventricle occupying 2 chaetigers...Syllis tyrrhena ${ }^{5}$

33b. (32b) Body stout. Dorsal cirri slightly longer than body width at corresponding segment, with dark inclusions. Blades of falcigers with distally blunt teeth. Pharynx through 8-10 segments; proventricle occupying 5-6 chaetigers...Syllis truncata ${ }^{2}$ ${ }^{1-6}$ Species not analysed in the present study, data provided by: ${ }^{1}$ Nogueira $2006 ;{ }^{2}$ Fukuda 2010; ${ }^{3}$ Licher 1999; ${ }^{4}$ San Martín 2003; ${ }^{5}$ Nogueira \& San Martín 2002; ${ }^{6}$ Nogueira \& Yunda-Guarín, 2008.

Species marked with * are considered as doubtful record in Brazilian waters herein.

\section{Syllis sp. n. 1}

(Figures 23-25)

Syllis sp1 sensu Fukuda, 2010: 303-307, Fig. 80.

Material examined. State of Paraíba: Baía da Traição, Praia do Farol (6 $41^{\circ}$ 'S 3455'W), intertidal: 5 specimens, coll. 09 August 2010. Conde, Praia de Tabatinga $\left(7^{\circ} 19^{\prime} \mathrm{S}\right.$ 34 $\left.47^{\prime} \mathrm{W}\right)$, intertidal: 1 specimen coll. 17 September 2012.

Additional material examined. Syllis amica. Spain, Anadalcía, Málaga, Mijas, Los Faroles: 2 specimens (MNCN 16.01/134), det. G. San Martín \& J.M. Viéitez; Cádiz, Chiclana de la Frontera, Playa de La Barrosa: 13 specimens (MNCN 
16.01/6975), coll. February 1983, coll. \& det. G. San Martín; Asturias, Tapia de Casariego, Playa "La Ribeira": 21 specimens (MNCN 16.01/6974), coll. \& det. G. San Martín.

Description. Small-sized body; longest specimen analysed ca. $6 \mathrm{~mm}$ long, 0.3 mm wide, with 65 chaetigers. Beige body. Palps ovate to kidney-shaped, totally free from each other (Fig. 23B-C). Prostomium ovate, as long as palps, with two pairs of eyes in open trapezoidal arrangement, anterior eyespots absent; median antenna inserted between posterior pair of eyes, reaching beyond tip of palps, with 13-15 articles; lateral antennae shorter, inserted anteriorly to eyes, with 8-9 articles each (Fig. 23A-C). Ciliated nuchal organs dorsally between prostomium and peristomium, only visible under SEM (Fig. 23C-D). Peristomium shorter than anterior chaetigers (Fig. 23A); dorsal peristomial cirri as long as median antenna, with 14-18 articles each; ventral peristomial cirri shorter, with $8-13$ articles each. Dorsum of three consecutive chaetigers, near chaetigers 19-21, soon after proventricle level, swelled, dark, with internal granulose appearance (Fig. 23E-G). Dorsal cirri of chaetiger 1 longer than dorsal peristomial cirri, with 16-23 articles each; dorsal cirri of chaetigers 2 and 5 shorter, of similar size, with ca. 12 articles each; dorsal cirri of chaetigers 3 and 4 with 12-16 and 14-18 articles each, respectively; following dorsal cirri alternating long, with 12-15 articles each, as long as body width at corresponding segment; and short, with 712 articles each, shorter than body width at corresponding segment; dorsal cirri distally tapering from proventricle level (Fig. 23E-F). Ventral cirri ovate to digitiform, inserted near to base of parapodial lobes, reaching their tips (Fig. 23B). Parapodial lobes conical (Fig. 23B, E-F). Anterior parapodia with 8-11 falcigers each; midbody and posterior parapodia with 4-6 and 3-4 falcigers each, respectively. Shafts of falcigers subdistally spinulated, with straight tips (Figs 24A-C , G-J; 25A, C-D); blades of falcigers 
spinulated (Figs 24B-C, G-I; 25A, C-D); dorsalmost chaetae of anterior and posterior parapodia bidentate, subdistal tooth shorter (Fig. 24C); midbody falcigers unidentate to subbidentate, spinulated blades; blades decreasing in length ventralwards within each fascicle throughout (Figs 24G; 25A, C-D), to ventralmost falcigers subbidentate to unidentate (Figs 24G, I; 25A, D); blades of falcigers with gradation in length (Figs 24A-B, H; 25A, C-D), 15-8 $\mu \mathrm{m}, 13-10 \mu \mathrm{m}$ and 8-4 $\mu \mathrm{m}$ long on anterior, midbody and posterior parapodia, respectively; on midbody parapodia, dorsalmost chaeta of each fascicle secondarily simple by loss of blade, tip narrow and elongate, slightly curved and distally tapered (Figs 24E-F; 25B). Dorsal and ventral simple chaetae only present on posteriormost parapodia, dorsal chaetae with subdistal spines and rounded tip (Fig. $25 \mathrm{E}$ ), as thick as shafts of falcigers; ventral simple chaetae thinner than falciger shafts, subdistally spinulated, bidentate, subdistal tooth shorter (Figs 24J;25F). Anterior parapodia with up to three aciculae each throughout, subdistally oblique with rounded tips (Fig. 25G); from midbody, a single aciculae per parapodium, distally curved, with rounded tips (Fig. 25H); aciculae progressively stouter posteriorwards. Pygidium bilobed, with two thick anal cirri ventrally, shorter than posterior dorsal cirri (Figs XX), with anal papilla, as long as posterior ventral cirri inbetween. Pharynx through 8 segments; pharyngeal tooth on anterior margin of pharynx; proventricle extending for 6-7 chaetigers, with $37-42$ rows of muscle cells.

Remarks. Syllis sp. n. 1 belongs to a group of species of Syllis with dorsalmost chaetae secondarily simple due to loss of blades, at least on midbody. The most similar species is $S$. amica, a cosmopolitan taxon found in a great variety of substrates that also presents consecutive chaetigers swelled, with internal granulose appearance (named dorsal glands by San Martín 2003). However, the author did not illustrate that. This cited structure is absent in the specimens analysed of $S$. amica from Mediterranean, then 
was not possible to assess whether it has the same appearance as seen in the Brazilian new species. Nevertheless, Syllis sp. n. 1 differs from $S$. amica by having, in general, short appendages: median antenna and lateral antennae with 8-9 and 13-15 articles each respectively; dorsal cirri of chaetiger 2, 3 and 4 with 12, 12-16 and 14-18 articles each, respectively; midbody dorsal cirri alternating between long and short, with 12-15 and 7-12 articles each, respectively. Additionally, the blades of anterior falcigers have thinner and longer teeth, the secondarily simple chaetae have narrower and longer tips, and up to 3 aciculae per anterior parapodium. On the other hand, S. amica by has, longer appendages: median antenna and lateral antennae with 20 and 18 articles each respectively; dorsal cirri of chaetiger 2, 3 and 4 with 17-20, 17-20 and 30 articles each, respectively; midbody dorsal cirri alternating between long and short, with 20-22 and 17 articles each, respectively. The blades of anterior falcigers have rounded and shorter teeth, the secondarily simple chaetae have thicker and shorter tips, and 2 aciculae per anterior parapodium.

The other two species with secondarily simple chaetae by loss of blades are $S$. elongata (Johnson, 1901) and S. ferrani Alós \& San Martín, 1987. Both have the secondarily simple chaetae with different morphology and also in both cases the dorsal glands are absent. Additionally, S. elongata has unidentate blades of falcigers, with rounded tips (Licher, 1999), while S. ferrani presents a conspicuous colour pattern dorsally (San Martín 2003), which is absent in Syllis sp. n. 1.

Distribution. Atlantic Ocean: Brazil (states of Paraíba, Pernambuco and São Paulo). 


\section{Syllis gracilis Grube, 1840}

Syllis gracilis Grube, 1840: 77-78; San Martín 1984: 376-381, lams. 97-98; 2003: 413-416, Figs 226-227; Licher 1999: 289-291, Abb. 10A; Nogueira \& San Martín 2002: 68-72, Figs 7 8. Fukuda 2010: 263-267, Fig. 73.

Syllis (Syllis) gracilis. Fauvel 1923: 259, Fig. 96f-i; Rullier \& Amoureux 1979: 162.

Material examined. State of Paraíba: Mataraca, Barra de Camaratuba (6 $36^{\circ} \mathrm{S}$ 34 $57^{\prime} \mathrm{W}$ ), intertidal: 19 specimens, coll. 12 August 2010. Baía da Traição, Praia do Farol (6 $\left.6^{\circ} 41^{\prime} \mathrm{S} 34^{\circ} 55^{\prime} \mathrm{W}\right)$, intertidal: 10 specimens, coll. 09 August 2010. Rio Tinto, Barra de Mamanguape $\left(6^{\circ} 45^{\prime} \mathrm{S} 34^{\circ} 55^{\prime} \mathrm{W}\right)$, intertidal: 11 specimens, coll. 11 August 2010. Cabedelo, Píer de Cabedelo (6 $\left.6^{\circ} 58^{\prime} \mathrm{S} 34^{\circ} 50^{\prime} \mathrm{W}\right)$, intertidal: 1 specimen, coll. 12 February 2009. João Pessoa, Cabo Branco ( $\left.7^{\circ} 08^{\prime} \mathrm{S} 34^{\circ} 47^{\prime} \mathrm{W}\right)$, intertidal: 1 specimen, coll. 09 February 2009; 1 specimen, coll. 02 February 2010. Conde, Praia de Jacumã (7014'S $\left.34^{\circ} 47^{\prime} \mathrm{W}\right)$, intertidal: 3 specimens, coll. 29 January 2010; Praia de Tabatinga $\left(7^{\circ} 19^{\prime} \mathrm{S}\right.$ 34 $\left.47^{\prime} \mathrm{W}\right)$, intertidal: 30 specimens; on Amphimedon viridis: 1 specimen, coll. 1 September 2011; Praia do Coqueirinho ( $\left.7^{\circ} 18^{\prime} \mathrm{S} 34^{\circ} 47^{\prime} \mathrm{W}\right), 15$ specimens, coll. 28

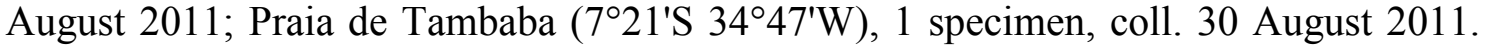
State of Pernambuco: Goiana, Pontas de Pedra ( $\left.7^{\circ} 37^{\prime} \mathrm{S} 34^{\circ} 48^{\prime} \mathrm{W}\right), 12$ specimens, coll. 13 December 2012.

Additional material examined. Syllis gracilis. Cuba, Archipiélago de los Canarreos, Cayo Matías, isla de Pinos, 3 m: 1 specimen (MNCN 16.01/683), coll. \& det. G. San Martín. Spain, Asturias, La Ribeira: 4 specimens (MNCN 16.01/8930), coll. 17 August 1979, det. G. San Martín; Andalúcia, Almería (3555'68"-3555'63"N $\left.3^{\circ} 03^{\prime} 25^{\prime \prime}-3^{\circ} 02^{\prime} 67^{\prime \prime W}\right), 33-49$ m: 1 specimen (MNCN 16.01/8037), coll. 23 July 1996, det. G. San Martín; Andalúcia, Cádiz, Chiclana de la Frontera, Playa de La Barrosa: 1 
specimen (MNCN 16.01/8940), coll. \& det. G. San Martín; Melilla, Islas Chafarinas $\left(35^{\circ} 11^{\prime} 05^{\prime \prime} \mathrm{N} 02^{\circ} 25^{\prime} 43^{\prime \prime} \mathrm{W}\right), 12 \mathrm{~m}: 1$ specimen (MNCN 16.01/8044), coll. 21 February 1991, coll. \& det. E. López. Argentina, Inidep: 6 specimens (MNCN 16.01/8075), coll. 21 October 1982, coll. \& det. G. San Martín. USA, Hawaii, Honolulu, Waikiki beach: 12 specimens (MNCN 16.01/8076), coll. October 1982, det. G. San Martín. Australia,

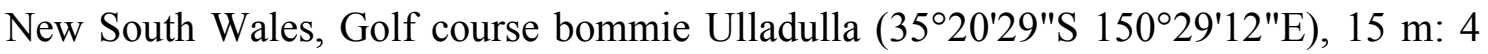
specimens (AM W29511), coll. 02 May 1997.

Syllis gracilis australiensis Hartmann-Schröder, 1979. Australia, Western Australia: Beacon Island, off south end of Long Island (28²8'48"S 113 46'18"E), 4-5 m, dead coral covered in coralline algae: 2 specimens (AM W29477), coll. 25 May 1994, det. G. San Martín; Goss Passage (28²5'30"S 11347'E), 8 m, dead plates of Acropora, covered in coralline algae: 1 specimen (AM W29484), coll. 22 May 1994, det. G. San Martín; Goss Passage, North end of Long Island (28²7'54"S 11346'18"E), $8 \mathrm{~m}$, dead coral, coralline and brown algae: 1 specimen (AM W29486), coll. 22 May 1994, det. G. San Martín; Goss Passage, southeast end of Long Island (28²8'48"S $113^{\circ} 46^{\prime} 30^{\prime \prime E}$ ), 8 m, dead coral covered in coralline algae: 3 specimens (AM W29488), coll. 22 May 1994, det. G. San Martín; Northeast entrance to Goss Passage (28²7'54"S $113^{\circ} 46^{\prime} 42^{\prime \prime E}$ ), $33 \mathrm{~m}$, underneath isolated boulders embedded in coral sand: 1 specimen (AM W29492), coll. 22 May 1994, det. G. San Martín; Kimberleys: Long Reef (1358'S 1253'ㄹ), 25 m: 2 specimens (AM W29539), coll. 17 July 1988, det. K. B. Attwood; west side of Cassini Island (13 $\left.57^{\circ} \mathrm{S} 125^{\circ} 37^{\prime} \mathrm{E}\right)$ : 2 specimens (AM W29540), coll. 18 July 1988, det. K. B. Attwood; south side North Slate Island (15³2'S 124²4'E): 3 specimens (AM W29543), coll. 9 July 1988, det. K. B. Attwood. Northern Territory: Darwin Harbour: off Nightcliff, Old Man's Rock (12²8'30"S 13054'12"E), 5-7 m, on dead coral rubble, lots of sponges and hydroids: 2 specimens (AM W29506), coll. 17 
July 1993, det. K. B. Attwood; Lee Point (12²0'S 13053'48"E), 3 m, on dead coral rubble washings: 3 specimens (AM W29548), coll. 11 July 1993, det. K. B. Attwood; East Point, $\left(12^{\circ} 24^{\prime} 36^{\prime \prime S} 130^{\circ} 39^{\prime} 57^{\prime \prime E}\right)$, 7-10 m, on dead coral rubble and algal washings: 6 specimens (AM W29549), coll. 17 July 1993, det. K. B. Attwood. Queensland: Outer Yonge Reef, Great Barrier Reef (14²36'S $\left.145^{\circ} 38^{\prime} \mathrm{E}\right), 30 \mathrm{~m}$, on coral rubble: 5 specimens (AM W29514), coll. 24 January 1977, det. K. B. Attwood.

Remarks. Syllis gracilis is considered a cosmopolitan species (Nogueira \& San Martín 2002) and a review of material from different localities is needed. Among the material of the "gracilis-Complex" examined, following Licher (1999) (see also additional material examined in Syllis sp. n. 2), from the Atlantic Ocean (Mediterranean Sea, Caribean, Brazil), Pacific Ocean (Peru and Australia) and Indian Ocean (Autralia) some variation in the following characters was found: shape and size of dorsal cirri throughout; length of blades of falcigers of anterior body parapodia; size of subdistal tooth of blades of falcigers; degree of fusion between shafts and blades of midbody ypsiloid chaetae, from totally fused to separate; size of subdistal tooth and morphology of shafts of midbody ypsiloid chaetae; number and shape of aciculae; and size of proventricle.

The Brazilian specimens described by Nogueira \& San Martín (2002) agree with this newly collected material from Paraíba and Pernambuco analysed herein and also with the material examined from Spain and Cuba.

Maltagliati et al. (2000) studied specimens of S. gracilis corresponding morphologically to the original description and noticed the presence of two genetically divergent entities under the name $S$. gracilis, each one living in a different environment, brackish and marine. The authors hipothesized that different habitats could host different cryptic species of the "gracilis-Complex". After analysing the material from 
several localities around the world, we believe several species could be separated only by morphological characters, if a comprehensive and careful review of material from each locality is taken.

Type locality. Mediterranean Sea.

Distribution. Cosmopolitan (San Martín 2003).

\section{Syllis sp. n. 2}

(Figures 26-29)

Material examined. State of Paraíba: Mataraca, Barra de Camaratuba $\left(6^{\circ} 36^{\prime} \mathrm{S}\right.$ 34 $\left.57^{\prime} \mathrm{W}\right)$, intertidal: 18 specimens, coll. 12 August 2010. Baía da Traição, Praia do Farol (6 $\left.6^{\circ} 41^{\prime} \mathrm{S} 34^{\circ} 55^{\prime} \mathrm{W}\right)$, intertidal: 10 specimens, coll. 09 August 2010. Rio Tinto, Barra de Mamanguape (6 $\left.6^{\circ} 45^{\prime} \mathrm{S} 34^{\circ} 55^{\prime} \mathrm{W}\right)$, intertidal: 11 specimens, coll. 11 August 2010. João Pessoa, Cabo Branco (708'S 34 $\left.47^{\prime} \mathrm{W}\right)$, intertidal: 1 specimen, coll. 09 February 2009; 1 specimen, coll. 02 February 2010; Conde, Praia de Tabatinga ( $\left.7^{\circ} 19^{\prime} \mathrm{S} 34^{\circ} 47^{\prime} \mathrm{W}\right)$, intertidal: 30 specimens; coll. 17 September 2012; Praia do Coqueirinho (7º $18^{\prime} \mathrm{S}$ $34^{\circ} 47^{\prime}$ W), 15 specimens, coll. 28 August 2011. State of Pernambuco: Goiana, Pontas de Pedra (7³7'S 3448'W), 1 specimen, coll. 13 December 2012.

Additional material examined. Syllis mayeri Musco \& Giangrande, 2005. Belize, Isla Carrie Bow, 15 m, on sponge Ircinia strobilina (Lamarck, 1816): holotype (MNCN 16.01/10263), coll. July 2001, det. Musco et al. 2005.

Syllis ypsiloides Aguado, San Martín \& Ten Hove, 2008: Australia, New South

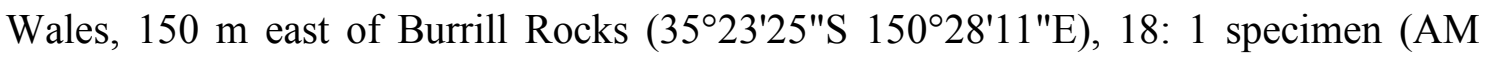
W29509), coll. 01, May 1997. 
Description. Middle-sized body; longest specimen analysed ca. $18 \mathrm{~mm}$ long, 0.3 mm wide, with 116 chaetigers. Pigmentation absent in preserved specimens. Palps ovate, fused at bases (Fig. 26B, E). Prostomium ovate, as long as palps, with two pairs of eyes in open trapezoidal arrangement, anterior eyespots absent; median antenna inserted between posterior pair of eyes, reaching beyond tip of palps, with 14-16 articles; lateral antennae shorter, inserted anterior to eyes, with 11-12 articles each (Fig. 26A-B, F). Nuchal organs not visible. Peristomium about same length as anterior chaetigers (Fig. 26F); dorsal peristomial cirri as long as lateral antennae, with 13-17 articles each, ventral peristomial cirri shorter, with ca. 11 articles each. Ventral surface of posterior body chaetigers with holes in the midline, one per chaetiger (Fig. 27D-E). Dorsal cirri throughout distally tapering, with cubic articles (Figs 26A, E-F; 27A-C ), those of anterior segments elongated, with 10-20 articles each (Fig. 26A, E-F); from proventricle onwards, dorsal cirri broader at midlength, abruptly tapering distally (Fig. 27A, C), with ca. 7 articles on midbody and 3-6 on posterior body segments, shorter than body width at corresponding segment (Fig. 27A-B). Ventral cirri ovate, inserted at bases of parapodial lobes, reaching their tips (Fig. 27B, D-E). Parapodial lobes conical (Figs 26E-F; 27A-C, E). Anterior parapodia with ca. 7 falcigers each; most midbody parapodia with ypsiloid-chaetae only, with shafts and blades completely fused or not; midbody divided in three distinct regions, according to chaetal distribution: after proventricle, each parapodium with dorsalmost chaeta with shaft an blade completely fused (Figs. 26G; 29B) and 2-3 chaetae with blades progressively shorter and more fitted into shaft posteriorwards, but not fused to it (Figs 26D; 29C), followed by parapodia with 1-2 dorsalmost fused chaetae (Figs 28B-D; 29D) and 1-2 chaetae with shafts and blades not fused, usually one of each per parapodium (Figs 28C-D; 29E), and then chaetigers with only 1-2 chaetae with shafts and blades not fused, with blades 
fitted into shaft, not inflated subdistally, and 1-2 bidentate falcigers, fused chaetae absent (Figs 28E; 29F-G); posterior body parapodia with falcigers only, progressively more per parapodium, ypsiloid-chaetae absent, last ones with 4-5 falcigers each (Figs 28A, F; 29H). Shafts of falcigers subdistally slightly inflated and spinulated, with straight tip (Fig. 26C, H-I; 29A, H), or subdistally inflated and slightly sigmoid tip (Fig. 28D, F). Blades of falcigers on anterior parapodia spinulated and bidentate, subdistal tooth shorter, with conspicuous dorso-ventral gradation in length (Figs 26H-I; 29A), 30-15 $\mu \mathrm{m}$ long; from proventricle level through midbody, completely fused ypsiloid chaetae with not visible fusion line (Figs 26G; 28B-D, H; 29B, D) and short spines on blade (Fig. 28C-H), easily eroded (Figs 26G, 28B); not fused ypsiloid chaetae with short bi- to subbidentate blades 16-12 $\mu \mathrm{m}$ long, with conspicuous spines, (Figs 26J; 29C), easily eroded (Figs 26D; 28C; 29E); blades of not fused ypsiloid chaetae of posterior midbody chaetigers $15-12 \mu \mathrm{m}$ long, bi- to subbidentate, falcigers with blades 19-14 $\mu \mathrm{m}$ long, spinulated, bidentate, distal tooth larger (Figs 28E; 29G); falcigers of posterior body chaetigers with thinner, spinulated, bidentate blades, distal tooth larger, subdistal tooth progressively shorter ventralwards, blades with gradation in length (Figs 28F; 29H), 20-12 $\mu \mathrm{m}$ long. Dorsal simple chaetae only present on posteriormost parapodia, thinner than shafts of falcigers, subdistally spinulated, subbidentate (Fig. $28 \mathrm{G}$ ); ventral simple chaetae only present on posteriormost parapodia, thinner than shafts of falcigers, subdistally spinulated, bidentate, distal tooth larger (Fig. 28A). Anterior parapodia with up to three aciculae each, one of which with oblique tip and two straight, with rounded tips (Fig. 29I); from proventricle onwards parapodia with single acicula each, stouter, with tip (Fig. 29J). Pygidium semicircular, with two elongated anal cirri ventrally, with 15-18 articles each; proximal articles cubical, distal articles more elongate (Fig. 27F); anal papilla between anal cirri, as long as posterior 
ventral cirri. Pharynx through 8-14 segments, pharyngeal tooth slightly away from anterior border; proventricle extending for 3.5-6 chaetigers, with 44-49 rows of muscle cells.

Remarks. Syllis sp. n. 2 belongs to the "gracilis-Complex" (sensu Licher 1999), which includes species of Syllis with ypsiloid chaetae formed by complete or incomplete fusion of shafts and blades on midbody parapodia, and with dorsal cirri spindle-shaped. The other species belonging to this group are $S$. magellanica, $S$. gracilis, S. mayeri, and S. ypsiloides. Our analysis of material of other species belonging to this group (see the 'additional material examined') showed variation on the morphology of midbody chaetae, with varying degrees of fusion between shafts and blades, and also on the morphology of shafts, subdistally inflated or not, indented to fit blades or not and on spinulation and size of teeth of blades.

Syllis sp. n. 2 is unique in the "gracilis-Complex" by having the midbody divided in three distinct regions 1-) on anterior midbody, after proventricle, ypsiloid chaetae with shafts and blades completely fused, fusion line not visible, blades smooth or with short spines, tips of blades at same level of tips of shafts or slightly lower and 2-3 chaetae with blades progressively shorter and more fitted into shaft, subdistally inflated, indented to fit blades; 2-) on midbody, 1-2 ypsiloid chaetae with shafts and blades completely fused, fusion line not visible, and 1-2 chaetae with shafts and blades not fused, with blades spinulated or not, bidentate, subbidentate or unidentate subdistally inflated, indented to fit blades; 3-) on posterior midbody, 1-2 chaetae with shafts and blades not fused, with blades fitted into shaft, not inflated subdistally, nor indented to fit blades, and 1-2 bidentate falcigers. Additionally, the number and aciculae shape also featuring the new species. 
Syllis gracilis was reported to the state of São Paulo by Nogueira \& San Martín (2002) and also found in the states of Paraíba and Pernambuco. Differently from Syllis sp. n. 2, $S$. gracilis has all ypsiloid chaetae completely fused, fusion line not visible, blades smooth or with minute spines, bidentate, with short subdistal tooth. Furthermore, the aciculae of $S$. gracilis are subdistally inflated with short, acute tip, while Syllis sp. n. 2 has anterior parapodia with up to three aciculae each, one of which with oblique tip and two straight, with rounded tips; from proventricle onwards parapodia with single acicula each, stouter, with tip.

Syllis magellanica, described by Augener (1918) based from material from Punta Arenas (Chile), with a rich description of the type specimens and also of specimens from Ushuaia (Argentina). Nogueira (2006) and Fukuda (2010) reported this species to the state of São Paulo, providing descriptions and SEM images of the Brazilian specimens. Posteriorly, examining the material collected and described by Augener (1918), one of us (MVF) confirmed the identification Brazilian specimens. Syllis magellanica has blades of anterior dorsalmost falcigers longer and thinner than those of Syllis sp. n. 2. Furthermore, S. magelanica has each midbody parapodium with up to five chaetae, two of them ypsiloid, with shafts totally fused to blades, with scar at fusion line, blades with short spines or smooth, tips of chaetae with blade side shorter; and 3-4 chaetae with shafts and blades partially fused. Anterior parapodia with up to four aciculae each, subdistally inflated with oblique tips.

Syllis mayeri, recently described from material from Belize, also has short and spindle-shaped dorsal cirri from proventricle level, blades of anterior falcigers bidentate, with gradation in length, ypsiloid chaetae with shafts and blades not completely fused on midbody parapodia, and pharynx occupying 14 chaetigers. Syllis mayeri differs from Syllis sp. n. 2, however, by having falcigers with shorter and closer 
to each other distal teeth; by not having ypsiloid chaetae with completely fused shafts and blades; anterior parapodia with up to four aciculae each, with rounded tips; midposterior parapodia with two aciculae, one of them protruding from parapodial lobe; and proventricle though 7 chaetigers, with 33 rows of muscle cells.

Finaly, S. ypsiloides, described from Indonesia, shares with Syllis sp. n. 2 anterior falcigers with bidentate blades, with gradation in length; midbody ypsiloid chaetae, with fused and not fused shafts and blades, and pharynx occupying 10 chaetigers. However, these species can be separated because S. ypsiloides has dorsal cirri thoghout with articles similar in width along the length; anterior parapodia with two aciculae each, both distally curved, with oblique tips; and proventricle through nine chaetigers, with 40 rows of muscle cells.

Distribution. Atlantic Ocean: Brazil (states of Paraíba and Pernambuco).

\section{Syllis cf. rosea (Langerhans, 1879)}

(Figure 30)

Material examined. State of Paraíba: Baía da Traição, Praia do Farol (6 $\left.6^{\circ} 41^{\prime} \mathrm{S} 34^{\circ} 55^{\prime} \mathrm{W}\right)$, intertidal: 1 specimen, coll. 09 August 2010. Rio Tinto, Barra de Mamanguape $\left(6^{\circ} 45^{\prime} \mathrm{S}\right.$ 34 $\left.55^{\prime} \mathrm{W}\right)$, intertidal: 4 specimens, coll. 11 August 2010.

Additional material examined. Syllis rosea. Spain, Andalucía, Cádiz, Chiclana de la Frontera, Playa de La Barrosa: 3 specimens (MNCN 16.01/7025), coll. 27 February 1983, coll. \& det. G. San Martín. Spain, Baleares, Cabo Nati, (4043'00"N 0349'30"E), intertidal: 1 specimen (MNCN 16.01/7020), coll. 28 June 1994, coll. \& det. G. San Martín. 
Description. Short body relatively elongate and slender, largest specimen analysed ca. $7 \mathrm{~mm}$ long, $0.2 \mathrm{~mm}$ wide, with 64 chaetigers. Body not pigmented. Palps ovate, broad, fused at bases. Prostomium subpentagonal, as long as palps, with two pairs of eyes in trapezoidal arrangement, anterior eyespots absent; median antenna inserted between posterior pair of eyes, reaching beyond tip of palps, with 12 articles; lateral antennae slightly shorter, inserted on anterior margin of prostomium, with 10-11 articles each. Nuchal organs not visible. Peristomium shorter than anterior chaetigers; dorsal peristomial cirri nearly same length as median antennae, with 13 articles each; ventral peristomial cirri shorter, with 8 articles each. Dorsal cirri of chaetiger 1 as long as median antennae and dorsal peristomial cirri, with 12-14 articles each; dorsal cirri of chaetigers 2,3 and 5 shorter, all of similar size, with 8-9 articles each; dorsal cirri of chaetiger 4 with 13-16 articles each; following dorsal cirri alternating long, with 8-11 articles, and short, with 7-9 articles, both about as long as body width at corresponding segment; dorsal cirri spindle-shaped, with cubic articles; dorsal cirri from midbody with 1-2 iridescent inclusions per article, except distalmost. Digitiform ventral cirri, inserted at middle third of parapodial lobes, not reching their tips. Parapodial lobes conical. Anterior parapodia with 1-2 dorsalmost spiniger-like chaetae and 8-11 falcigers each; midbody and posterior parapodia with 1-2 spiniger-like chaetae and 4-5 falcigers each. Shafts of compound chaetae subdistally inflated and spinulated (Fig. 30A-C). Blades of falcigers spinulated, spines directed upwards, decreasing in length distally, blades bidentate, distal tooth larger, with rounded space inbetween teeth; blades of falcigers with dorso-ventral gradation in length, 15-10 $\mu \mathrm{m}$ long throughout (Fig. 30A-C). Blades of spiniger-like chaetae spinulated, spines progressively shorter, directed upwards; blades of anteriormost spiniger-like chaetae bidentate, resembling elongated falcigers, progressively increasing in length between chaetigers $1-8,22-52 \mu \mathrm{m}$ long; on midbody, 
blades of spiniger-like chaetae unidentate, with rounded tip, 42-62 $\mu \mathrm{m}$ long; blades of posteriormost spiniger-like chaetae bidentate, similar to those from anteriormost chaetigers, 20-25 $\mu \mathrm{m}$ long (Fig. 30A-C). Dorsal simple chaetae only present on posterior parapodia, thinner than shafts of falcigers, truncate, with short distal spines (Fig. 30D); ventral simple chaetae only present on posteriormost parapodia, thinner than shafts of falcigers, bidentate, with short evenly-sized teeth and short subdistal spinulation (Fig. 30E). Anterior parapodia with up to two aciculae each; mid- and posterior body parapodia with single acicula each; aciculae with oblique tips throughout body (Fig. 30F-H). Pygidium bilobed, with two elongated anal cirri ventrally, longer than posterior dorsal cirri, with 11 articles each; triangular anal papilla between anal cirri, as long as posterior ventral cirri. Pharynx through 7-8 segments, pharyngeal tooth slightly away from anterior border; proventricle extending for three chaetigers, with 25 rows of muscle cells.

Remarks. Brazilian specimens of $S$. cf. rosea differ from $S$. rosea described by Imajima (1966a) and San Martín (2003) by having shorter median and lateral antennae, with 12 and 10-11 articles each, respectively, shorter midbody dorsal cirri, alternating long, with 8-11 articles, and short, with 7-9 articles each; anterior dorsal cirri without iridescent inclusions; pharyngeal tooth slightly dislocated from the pharynx opening; and proventricle extending for 3 chaetigers, with 25 rows of muscle cells. Contrarily, the specimens analysed by San Martín (2003) present longer antennae, median one with 19-25 articles and lateral ones with 12-15 articles each; longer midbody dorsal cirri, alternating long, with 20 articles, and short, with 12-14 articles each; dorsal cirri from chaetiger 1 with iridescent inclusions in articles; and pharyngeal tooth on the pharynx opening. Brazilian specimens also differ from S. rosea described by Licher (1999), by 
having shorter blades of midbody spiniger-like chaetae, $42-62 \mu \mathrm{m}$ long, against $70-75$ $\mu \mathrm{m}$.

Brazilian specimens are much shorter than those from Spain. San Martín (2003) studied specimens up to $16 \mathrm{~mm}$ long and $0.2 \mathrm{~mm}$ wide, with 108 chaetigers, while our largest specimen is $7 \mathrm{~mm}$ long and $0.2 \mathrm{~mm}$ wide, with 64 chaetigers. Since few specimens were herein analysed, we cannot be sure if the differences observed are all size-dependent. Because of these differences, we prefer to identify our material as Syllis cf. rosea.

Type locality. Madeira Island, Portugal (Atlantic Ocean).

Distribution. Atlantic Ocean: Portugal, Spain, Mediterranean Sea, Brazil (Paraíba). Pacific Ocean: Japan. Indian Ocean: Red Sea.

\section{Syllis hyllebergi (Licher, 1999)}

Typosyllis hyllebergi Licher, 1999: 76-78, Abb. 34.

Syllis hyllebergi. Nogueira \& San Martín 2002: 67-68, Figs 5-6. Fukuda 2010: 267-270.

Material examined. State of Paraíba: Mataraca, Barra de Camaratuba (6 $6^{\circ} 36^{\prime} \mathrm{S}$ 34 $57^{\prime} \mathrm{W}$ ), intertidal: 1 specimen, coll. 12 August 2010. State of Pernambuco: Goiana, Pontas de Pedra $\left(7^{\circ} 37^{\prime} \mathrm{S} 34^{\circ} 48^{\prime} \mathrm{W}\right), 2$ specimens, coll. 13 December 2012. Ilha de Itamaracá, Ponta do Jaguaribe $\left(7^{\circ} 44^{\prime} \mathrm{S} 34^{\circ} 49^{\prime} \mathrm{W}\right)$, intertidal: 1 specimen, coll. 11 December 2012.

Remarks. The analysed material matches the description provided by Nogueira $\&$ San Martín (2002) for specimens from São Paulo. 
Type locality. El Kura Lagoon, Dahab, Egypt (Red Sea, Indian Ocean).

Distribution. Indian Ocean: Egypt (Gulf of Aqaba). Atlantic Ocean: Israel, Cyprus, Suez Canal, Brazil (states of Paraíba and São Paulo). First record from off the northeastern Brazilian coast.

\section{Syllis sp. n. 3}

(Figures 31)

Material examined. State of Paraíba: João Pessoa, Cabo Branco ( $\left.7^{\circ} 08^{\prime} \mathrm{S} 34^{\circ} 47^{\prime} \mathrm{W}\right)$, intertidal: 12 specimens, coll. 02 February 2010. Conde, Praia de Tabatinga ( $7^{\circ} 19^{\prime} \mathrm{S}$ $\left.34^{\circ} 47^{\prime} \mathrm{W}\right)$, intertidal: 14 specimens, coll. 17 September 2012; Praia de Tambaba ( $7^{\circ} 21^{\prime} \mathrm{S}$ $\left.34^{\circ} 47^{\prime} \mathrm{W}\right), 4$ specimens, coll. 30 August 2011.

Description. Middle-sized body; largest specimen analysed ca. $17 \mathrm{~mm}$ long, 0.3 mm wide, with 129 chaetigers. Colour pattern absent. Palps ovate, broad, fused at bases. Prostomium subpentagonal, as long as palps, with two pairs of eyes in trapezoidal arrangement, anterior eyespots absent; median antenna inserted between posterior pair of eyes, reaching beyond tip of palps, with 21 articles; lateral antennae slightly shorter, inserted on anterior margin of prostomium, with 16-19 articles each. Nuchal organs not observed. Peristomium shorter than anterior chaetigers; dorsal peristomial cirri longer than median antennae, with 34-37 articles each; ventral peristomial cirri shorter, with 14-19 articles each. Dorsal cirri of chaetiger 1 as long as dorsal peristomial cirri, with 31-35 articles each; dorsal cirri of chaetigers 2 and 5 of similar size, shorter, with 11-15 articles each; dorsal cirri of chaetigers 3 and 4 longer, with 19-24 and 23-28 articles each, respectively; following dorsal cirri alternating long, with 28-32 articles each, as 
long as body width at corresponding segment, and short, with 19-22 articles each, shorter than body width at corresponding segment; dorsal cirri moniliform, with rouded articles throughout; dorsal cirri progressively thicker posteriorwards, with 1-2 gold, elongated and rolled inclusions in each article, more conspicuous in posterior parapodia. Digitiform ventral cirri, inserted at base of parapodial lobes and extending beyond tip of them. Parapodial lobes conical. Anterior parapodia with 1-2 spiniger-like chaetae each and 6-9 falcigers each; midbody and posterior parapodia with 1-2 spiniger-like chaetae and 4-6 falcigers each. Shafts of compound chaetae subdistally inflated and spinulated (Fig. 31A-C). Blades of falcigers with progressively shorter spines directed upwards, bidentate, teeth short, both similar in size, with rounded space inbetween; blades of falcigers with dorso-ventral gradation in length, 23-10 $\mu \mathrm{m}$ long thoughout (Fig. 31AC). Blades of spiniger-like chaetae bidentate, with short spinulation; blades of spinigerlike chaetae of anteriormost prapodia resembling elongated falcigers, blades progressively increasing in length between chaetigers $1-8,27-50 \mu \mathrm{m}$ long; on midbody and posterior parapodia, blades of spiniger-like chaetae 65-77 $\mu \mathrm{m}$ and 40-45 $\mu \mathrm{m}$ long, respectively (Fig. 31A-C). Dorsal simple chaetae only present on posterior parapodia, thinner than shafts of falcigers, unidentate (Fig. 31D); ventral simple chaetae only present on posteriormost parapodia, thinner than falciger shafts, bidentate, with short teeth about same size, subdistally smooth (Fig. 31E). Anterior parapodia with up to four aciculae each, 1-2 of which straight, or slightly curved, with acute tips, and 1-2 inflated subdistally, with oblique tips (Fig. 31F); midbody with two aciculae per parapodium, one of wich straight, with acute tip and another subdistally oblique, with acute tip (Fig. 31G); posterior body with single acicula per parapodioum, with oblique tip (Fig. $31 \mathrm{H}$ ). Pygidium semicircular, anal cirri and papilla inbetween not observed. Pharynx through 
ten segments, pharyngeal tooth near posterior margin of pharynx; proventricle extending for six chaetigers, with 40 rows of muscle cells.

Remarks. Syllis sp. n. 3 is similar to $S$. rosea from Spain and S. cf. rosea from Brazil by having spinulated and bidentated blades of falcigers, with gradation dorsoventral in length, spiniger-like chaetae with longer blades on midbody, and bidentate ventral simple chaetae. However, Syllis sp. n. 3 can be differentiated from both by having longer antennae, peristomial and dorsal cirri throughout, median antennae with 21 articles, lateral antennae with 16-19 articles each; dorsal and ventral peristomial cirri with 34-37 and 14-19 articles each, respectively; midbody dorsal cirri alternating long, with 28-32, and short, with 19-22 articles each. Specimens of S. rosea analysed by San Martín (2003) have median antennae about same length as Syllis sp. n. 3, with 23 articles, but shorter lateral antennae, with 14 articles each; dorsal and ventral peristomial cirri also shorter, with 11-12 and 7 articles each, respectively; midbody dorsal cirri alternating between long, with 20, and short, with 12-14 articles each, while specimens from Brazil, treated here as $S$. cf. rosea, have appendages even shorter, median antennae with 12 articles, lateral antennae with 10-11 articles each; dorsal and ventral peristomial cirri with 13 and 7 articles each, respectively; midbody dorsal cirri alternating between longer, with 8-11 articles, and shorter, with 7-9 articles each, spindle-shaped. Furthermore, differing from Syllis cf. rosea from Brazil, Syllis sp. n. 3 has bidentate blades of spiniger-like chaetae throughout, with short spinulation; aciculae, on anterior body and midbody, with different morphology and number, up to four aciculae per parapodium, 1-2 of which straight, with acute tips, the remaining subdistally inflated, with oblique tips; pharynx and proventricle occupying ten and six chaetigers, respectively, proventricle with 40 rows of muscle cells. Brazilian specimens Syllis cf. rosea described above have unidentate blades of spiniger-like chaetae of 
midbody parapodia, with rounded tips, with longer and stouter spinulation; $1-2$ aciculae per parapodium, subdistally inflated, with oblique to with curved tips; pharynx and proventricle extending through 7-8 and three chaetigers, respectively, and proventricle with 25 rows of muscle cells.

Syllis beneliahuae is another species which also occurs off Brazil and which morphologically resembles Syllis sp. n. 3, by having bidentate blades of spiniger-like chaetae, dorso-ventral gradation in length of falcigers throughout and anterior parapodia with 3-4 aciculae each. Contrarily, specimens of Syllis sp. n. 3 have longer blades of spiniger-like chaetae, up to 50, 77, and $42 \mu \mathrm{m}$ long on anterior, mid- and posterior body, respectively, but with shorter spinulation; and dorsal simple chaetae subdistally spinulated, with rounded tip. On the other hand, $S$. beneliahuae has shorter blades of spiniger-like chaetae, with 31,48 and $35 \mu \mathrm{m}$ long on anterior, mid- and posterior body, respectively; and dorsal simple chaetae bidentate, with both teeth similar in size (Nogueira \& San Martín 2002).

Distribution. Atlantic Ocean: Brazil (states of Paraíba and Pernambuco).

\section{Syllis beneliahuae (Campoy \& Alquézar, 1982)}

Langerhansia beneliahui Campoy \& Alquézar, 1982: 124, Fig. 3.

Syllis beneliahuae. San martín 1984: 360-364; Pls. 90-91; 2003: 405-408, Figs 222-223; Capa et al. 2001: 107. Nogueira \& San Martín 2002: 60-63, Figs 1-2.

Typosyllis beneliahuae. Licher 1999: 47-48, Figs 17B, 22, see also for synonymy.

Material examined. State of Paraíba: Mataraca, Barra de Camaratuba $\left(6^{\circ} 36^{\prime} \mathrm{S}\right.$ 34 57'W), intertidal: 5 specimens, coll. 12 August 2010. Cabedelo, Píer de Cabedelo 
(6 $\left.58^{\prime} \mathrm{S} 34^{\circ} 50^{\prime} \mathrm{W}\right)$, intertidal: 1 specimen, coll. 12 February 2009. João Pessoa, Cabo Branco $\left(7^{\circ} 08^{\prime} \mathrm{S} 34^{\circ} 47^{\prime} \mathrm{W}\right)$, intertidal: 3 specimens, coll. 02 February 2010.

Additional material examined. Syllis beneliahuae. Spain, Baleares, Cala Benimela, N. of isla de Menorca: 6 specimens (MNCN 16.01/6979), coll. 2 August 1979, coll. \& det. G. San Martín. Brazil, São Paulo, Ilha de Alcatrazes (2606'S 45ํํ'W), 3-10 m: 1 specimen (MNCN 16.01/8725), coll. 17 March 1996, det. J.M.M. Nogueira \& G. San Martín.

Remarks. The analysed material matches the description provided by Nogueira $\&$ San Martín (2002) for specimens from São Paulo.

Type locality. Playa del arroz, Spain (Mediterranean Sea).

Distribution. Pacific Ocean: Panamá (Isla de Coiba). Atlantic Ocean: Spain, Canary Islands, Cuba, Brazil (states of São Paulo and Paraíba). First record from off the northeastern Brazilian coast.

\section{Syllis sp. n. 4}

(Figures 32-34)

Material examined. State of Paraíba: Baía da Traição, Praia do Farol (6 $\left.{ }^{\circ} 41^{\prime} \mathrm{S} 34^{\circ} 55^{\prime} \mathrm{W}\right)$, intertidal: 2 specimens, coll. 09 August 2010. João Pessoa, Cabo Branco ( $7^{\circ} 08^{\prime} \mathrm{S}$ $34^{\circ} 47^{\prime} \mathrm{W}$ ), intertidal: 3 specimens, coll. 09 February 2009; 2 specimens, coll. 02 February 2010. Conde, Praia de Tabatinga $\left(7^{\circ} 19^{\prime} \mathrm{S} 34^{\circ} 47^{\prime} \mathrm{W}\right)$, intertidal: 1 specimen, coll. 17 September 2012. State of Pernambuco: Almirante Tamandaré, Praia dos Carneiros ( $\left.8^{\circ} 42.849^{\prime} \mathrm{S} 35^{\circ} 4.999^{\prime} \mathrm{W}\right)$ : 1 specimen, coll. 22 July 2013. 
Additional material examined. Syllis cruzi Núñez \& San Martín, 1991. Spain:

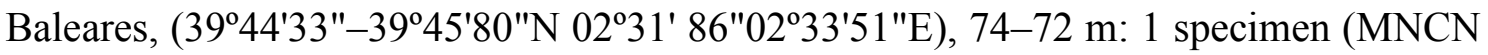
16.01/6745), coll. 25 June 1994, det. G. San Martín; Comunidad Valenciana, Castellón, N. of Columbrete Grande, islas Columbretes, (39 54'02"N 0041'15"E), $47 \mathrm{~m}$ : 1 specimen (MNCN 16.01/6745), coll. 12 July 1994, det. G. San Martín.

Description. Short-sized body; largest specimen analysed ca. $8 \mathrm{~mm}$ long, $0.5 \mathrm{~mm}$ wide, with 72 chaetigers. Body not pigmented. Palps ovate, broad, fused at bases (Fig. 32A-D); palps with 2 pairs of rows of cilia ventrally (Fig. 32C-D). Prostomium subpentagonal, as long as palps or slightly shorter (Fig. 32A), with two pairs of eyes in open trapezoidal arrangement, anterior eyespots absent; median antenna inserted between eyes, at center of prostomium, reaching beyond tips of palps, with 17-19 articles; lateral antennae shorter, inserted anteriorly to eyes, with 14-15 articles each (Fig. 32A). Ciliated nuchal organs between prostomium and peristomium (Fig. 32A, E). Peristomium shorter than anterior chaetigers (Fig. 32A), anterior margin ciliated (Fig. 32A); dorsal peristomial cirri as long as median antenna, with 16-19 articles each, ventral peristomial cirri shorter, with 13-15 articles each. Dorsal cirri of chaetiger 1 longer than dorsal peristomial cirri, with 25-29 articles each; dorsal cirri of chaetigers 2 and 5 shorter, of similar size, with 16-18 articles each; dorsal cirri of chaetigers 3 and 4 with 19-22 and 22-25 articles each, respectively; following dorsal cirri alternating long, 25-30 articles each, 1.5 times as long as body width at corresponding segment, and short, 8-12 articles each, as long as body width at corresponding segment or slightly longer (Fig. 32F-H); dorsal cirri throughout with rectangular proximal articles, slightly wider than long, distalmost articles cubic to slightly longer than wide (Fig. 32A-B). Digitiform ventral cirri inserted at proximal middle third of parapodial lobes, reaching their tips or slightly shorter (Fig. 32B, G, J). Parapodial lobes bilobed (Figs 32I; 33C). 
Anterior parapodia with 9-11 falcigers each; midbody and posterior parapodia with 4-5 and 2-3 falcigers each, respectively (Figs 33C, E-F, H, K; 34A-C). Shafts of falcigers subdistally spinulated (Figs 33A, D; 34A-C), with straight tip on anterior and midbody parapodia (Figs 33A, C-F; 34A-B), and on dorsalmost falcigers of posterior body chaetigers (Fig. 34C); shafts of ventralmost falcigers on posterior parapodia subdistally inflated, roughly triangular (Fig. 34C). Blades of falcigers spinulated, spines progressively shorter, directed upwards, except for 2-3 longer distalmost spines reaching level of subdistal tooth (Figs 33A-J; 34A-C); blades bidentate (Figs 33A, B, D, F-G, I; 34A-C), anterior falcigers with teeth of similar size (Figs 33A-D; 34A); from midbody, blades of falcigers with subdistal tooth larger, difference progressively more conspicuous ventralwards within each fascicle (Figs 33E-F, H-I; 34A-B); blades of falcigers with dorso-ventral gradation in length (Figs 33C, E-F, H; 34A-C), 30-13 $\mu \mathrm{m}, 37-17 \mu \mathrm{m}$ and $25-15 \mu \mathrm{m}$ long on anterior, midbody and posterior parapodia, respectively. Dorsal simple chaetae only present on posterior parapodia, thinner than shafts of falcigers, subbidentate, subdistal tooth only visible under SEM (Figs 33K; 34D); ventral simple chaetae only present on posteriormost parapodia, ca. $2 / 3$ as thick as shafts of falcigers, subdistally spinulated, bidentate, subdistal tooth shorter with oblique space inbetween (Figs 33J; 34E). Anterior parapodia with up to three aciculae each, 1-2 of which straight with rounded or acute tips, and another with oblique tips, protruding from parapodial lobe (Figs 33C; 34F); midbody parapodia with two aciculae each, one distally oblique and other inflated subdistally, with acute tip (Figs 32I; 34G); each posterior parapodium with single straight acicula, inflated subdistally, with acute tip (Fig. 34H). Semicircular pygidium, with two elongated anal cirri ventrally, about same length as posterior long dorsal cirri, with 22-26 articles each (Fig. 32H, J); anal papilla inbetween cirri, same length as posterior ventral cirri (Fig. 32H, J). Pharynx 
through 8-9 segments, pharyngeal tooth in anterior boarder; proventricle extending for six chaetigers, with $40-43$ rows of muscle cells.

Remarks. The most similar species to Syllis sp. n. 4 is $S$. guidae Nogueira \& Yunda-Guarin, 2008, a species described from Brazil, also from off the northeastern coast. Both species have bidentate blades of falcigers, with subdistal tooth larger and long distal spines; pharynx and proventricle with 8-9 and 5-6 chaetigers each, respectively. In the original description of S. guidae, Nogueira \& Yunda-Guarin (2008) noticed a large variation on the length of antennae and cirri along the body, attributing this difference to the body-size variation observed (4-13 mm long). In Syllis sp. n. 4 we did not observe such a variation on length of appendages, as sizes of antennae, peristomial and dorsal cirri throughout are considerable less variable among specimens.

Syllis sp. n. 4 differs from $S$. guidae by having shorter antennae, median and lateral ones with 17-19 and 14-15 articles each, respectively; shorter dorsal peristomial cirri, 16-19 articles; dorsal cirri with cubic articles proximally and rectangular, longer than wide articles distally; blades of dorsalmost falcigers longer, ca. $35 \mu \mathrm{m}$ long on anterior and midbody parapodia; aciculae with different morphology, anterior parapodia with up to three aciculae each, 1-2 of which straight with rounded or acute tips, and another with oblique tips, protruding from parapodial lobe, midbody parapodia with two aciculae each, one distally oblique and other irregularly inflated subdistally, with acute tip, each posterior parapodium with single straight acicula, irregularly inflated subdistally, with acute tip; straight dorsal simple chaetae, with acute tip; ventral simple chaetae bidentate, teeth of similar size, with oblique space inbetween, with minute subdistal spines; and proventricle with up to 43 rows of muscle cells.

Syllis guidae, on the other hand, has longer antennae, median and lateral ones with 34 and 25 articles each, respectively; longer dorsal peristomial cirri, with 26 articles 
each; tapering dorsal cirri, with progressively shorter rounded articles; blades of dorsalmost falcigers ca. $15 \mu \mathrm{m}$ long on anterior and midbody parapodia; anterior parapodia with up to two aciculae each, both thin, subdistally inflated, with short, oblique tip and single acicula per parapodium from midbody, like anterior ones; distally bifid dorsal simple chaetae; bidentate ventral simple chaetae, teeth at right angle (Nogueira \& Yunda-Guarín 2008, Figs 1H; 3G-H), and long subdistal spines; and proventricle with up to 29 rows of muscle cells.

Syllis sp. n. 4 is similar to $S$. cruzi by also having bidentate blades of falcigers, with subdistal tooth larger; and alike dorsal simple chaetae. However, Syllis sp. n. 4 has the dorsal cirri from midbody about 1.5 times as long as body width; blades of falcigers with long spines, directed upwardsy, progressively shorter, except for 2-3 distalmost spines reaching level of secondary tooth; anterior parapodia with up to three aciculae each; and proventricle with up to 43 rows of muscle cells. On the other hand, S. cruzi has midbody long dorsal cirri shorter than body width at corresponding segment; blades of falcigers with short spines, although also with 1-2 longer distalmost spines; anterior parapodia with up to two aciculae each, of different morphology from Syllis sp. n 4 (San Martín 2003, Fig. 217 D); and proventrricle with up to 30 rows of muscle cells (San Martín 2003).

Syllis lutea was reported to the state of São Paulo by Nogueira and San Martín (2002) and Fukuda (2010), and was also found in the present study (see below). These species share similar lengths of median antenna and peristomial cirri, as well as of pharynx and proventricle. Syllis sp. n. 4 differs from S. lutea by having lateral antennae with 14-15 articles each; midbody dorsal cirri alternating long, 25-30 articles, longer than body width at corresponding segment, and short, 8-12 articles, as long as body width at corresponding segment or slightly longer; shafts of falcigers subdistally 
spinulated, with straight tip on anterior and midbody parapodia, and dorsalmost falcigers of posterior parapodia; shafts of ventralmost falcigers of posterior parapodia subdistally inflated with sigmoid tip; bidentate ventral simple chaetae, teeth of similar size; and aciculae different in number and shape. On the other hand, Syllis lutea has lateral antennae with 18-33 articles each; shorter midbody dorsal cirri, alternating long, ca. 22 articles, longer than body width at corresponding segment, and short, ca. ten articles, shorter than body width at corresponding segment; shafts of falcigers all similar throughout, subdistally inflated, straight, with shorter tip (Nogueira \& San Martín 2002, Fig. 13C, H, J); bidentate ventral simple chaetae, subdistal tooth larger, with long subdistal spines; anterior parapodia with up to four thin aciculae each, subdistally inflated, with short and oblique tips (Nogueira \& San Martín 2002, Fig. 13 D-F), not protruding from parapodial lobes.

Syllis jorgei San Martín \& López, 2000, S. magnipectinis Storch, 1967 and S. ortizi are species which share with Syllis sp. n. 4 similar morphology and length of dorsal cirri, blades of falcigers with larger subdistal tooth, and also pharynx and proventricle of similar length. However, S. ortizi differs from Syllis sp. n. 4 by having blades of falcigers with longer and slender spinulation, and subdistal tooth distinctly larger on posterior parapodia; bifid dorsal simple chaetae; bidentate ventral simple chaetae, subdistal tooth larger; and proventricle with ca. 27 rows of muscle cells (Fukuda, 2010). Syllis jorgei differs from Syllis sp. n. 4 in size of subdistal tooth of the blades of falcigers, shorter in the Mediterranean species, about same size as distal one, while the Brazilian species has subdistal tooth larger from midbody parapodia. Finaly, S. magnipectinis is different from Syllis sp. n. 4 by having blades of falcigers with subdistal tooth distinctly larger and more triangular and than that observed in Syllis sp. n. 4. 
Distribution. Atlantic Ocean: Brazil (states of Paraíba and Pernambuco).

\section{Syllis lutea (Hartmann-Schröder, 1960)}

Typosyllis lutea Hartmann-Schröder, 1960: 81-82, Taf. 2, 5, Figs 38-41; Licher 1999: 177-178, Abb. $17 \mathrm{H}, 79$ see also for synonymy.

Syllis lutea. San Martín 1992: 186, Fig. 5I-J; Nogueira \& San Martín 2002: 75-80, Figs 13-14; Fukuda 2010, 270-273.

Non Syllis lutea. San Martín 1984a: 370-373, lams. 94-95.

Material examined. State of Paraíba: Rio Tinto, Barra de Mamanguape $\left(6^{\circ} 45^{\prime} \mathrm{S}\right.$ 34 55'W), intertidal: 4 specimens, coll. 11 August 2010. João Pessoa, Cabo Branco $\left(7^{\circ} 08^{\prime} \mathrm{S} 34^{\circ} 47^{\prime} \mathrm{W}\right)$, intertidal: 3 specimens, coll. 02 February 2010.

Remarks. The analysed material matches the description provided by Nogueira \& San Martín (2002) for specimens from São Paulo.

Type locality. Sarso Island, Saudi Arabia (Red Sea).

Distribution. Circuntropical. First record from off the northeastern Brazilian coast.

Syllis cf. westheidei San Martín, 1984

(Figures 35-37)

Material examined. State of Paraíba: Baía da Traição, Praia do Farol (6 $\left.6^{\circ} 41^{\prime} \mathrm{S} 34^{\circ} 55^{\prime} \mathrm{W}\right)$, intertidal: 3 specimens, coll. 09 August 2010. Rio Tinto, Barra de Mamanguape (6 $6^{\circ} 45^{\prime} \mathrm{S}$ 
34 $\left.55^{\prime} \mathrm{W}\right)$, intertidal: 4 specimens, coll. 11 August 2010. Conde, Praia do Coqueirinho ( $\left.7^{\circ} 18^{\prime} \mathrm{S} 34^{\circ} 47^{\prime} \mathrm{W}\right), 2$ specimens, coll. 28 August 2011. State of Pernambuco: Almirante Tamandaré, Praia dos Carneiros ( $\left.8^{\circ} 42.849^{\prime} \mathrm{S} 35^{\circ} 4.999^{\prime} \mathrm{W}\right)$ : 1 specimen, coll. 22 July 2013.

Additional material examined. Syllis westheidei. Spain: Andalucía, Almería, Los Escullos: 1 specimen (MNCN 16.01/7038), coll. October 1983, coll. \& det. G. San Martím; Cádiz, Chiclana de la Frontera, Playa de La Barrosa: 1 specimens (MNCN 16.01/7028), coll. \& det. G. San Martín.

Description. Middle-sized body; largest specimen analysed incomplete, ca. 10 mm long, $0.4 \mathrm{~mm}$ wide, with 54 chaetigers. Body not pigmented. Palps ovate, broad, fused at bases (Fig. 35A-C). Prostomium subpentagonal, as long as palps, with two pairs of eyes in trapezoidal arrangement, anterior eyespots absent; median antenna inserted between eyes, at center of prostomium, reaching beyond tip of palps, with 20 23 articles; lateral antennae shorter, inserted anteriorly to eyes, with 14-17 articles each; prostomium with paired row of cilia, from bases of lateral antennae to near base of median antenna (Fig. 35B, D). Ciliated nuchal organs between prostomium and peristomium, as paired dorsolateral row of cilia, only visible under SEM (Figs 35D). Peristomium shorter than anterior chaetigers, with transverse row of cilia dorsally near anterior margin (Fig. 35B, D); dorsal peristomial cirri as long as median antennae, with 17-20 articles each; ventral peristomial cirri shorter, with 13-15 articles each. Dorsal cirri of chaetiger 1 longer than dorsal peristomial cirri, with 35-39 articles each; dorsal cirri of chaetigers 2 and 5 shorter, of similar size, with 19-22 articles each; dorsal cirri of chaetigers 3 and 4 with 29-32 and 22-26 articles each, respectively; following dorsal cirri alternating long, with 25-30 articles each, longer than body width at corresponding segment, and short, with 19-26 articles each, as long as body width at corresponding 
segment; anteriormost dorsal cirri with same-sized articles throughout (Fig. 35A, C); remaining dorsal cirri with proximal articles wider (Fig. 35E-F). Digitiform ventral cirri, inserted at middle third of parapodial lobes, reaching their tips (Fig. 35C, E). Parapodial lobes bilobed (Fig. 36A-B). Anterior and midbody parapodia with 9-13 falcigers each, posterior parapodia with 3-6 falcigers each. Shafts of falcigers subdistally spinulated (Fig. 36C, F-G, K), shafts of falcigers slightly subdistally inflated, with straight tips (Figs 36A-F; 37A-C). Blades of falcigers spinulated, spines progressively shorter, directed upwards; blades bidentate, distal tooth larger (Figs 36CG; 37A-C); blades with dorso-ventral gradation in length (Figs 36A-B, E; 37A-C), 33$10 \mu \mathrm{m}, 20-15 \mu \mathrm{m}$ and $20-8 \mu \mathrm{m}$ long on anterior, mid- and posterior body parapodia, respectively. Dorsal simple chaetae only present on posterior parapodia, as thick as shafts of falcigers, distally bifid, rounded under optical microscope (Fig. 37D) with subdistal spines (Figs 36I), sometimes eroded, smooth, with rounded tips (Fig. 36J); ventral simple chaetae only present on posteriormost parapodia, about as thick as shafts of falcigers, bidentate, distal tooth larger, subdistally spinulated (Figs 36H; 37E). Anterior parapodia with up to five aciculae each, 3-4 straight with rounded tips, and 12 with oblique tips (Fig. 37F); midbody parapodia with 2-3 aciculae each, one of which oblique and 1-2 with acute tips (Fig. 37G); number of aciculae per parapodium decreasing posteriorwards to single aciculae on each posteriormost parapodium, with oblique tip. Semicircular pygidium, with paired elongated anal cirri ventrally, longer than posterior dorsal cirri (Figs $35 \mathrm{~F}-\mathrm{G}$ ); anal papilla inbetween cirri as long as posterior ventral cirri (Fig. 35G); anus ciliated (Fig. 35G). Pharynx through 8-9 segments, with pharyngeal tooth near anterior border; proventricle extending for seven chaetigers, with $40-43$ rows of muscle cells. 
Remarks. Brazilian specimens are treated as $S$. cf. westheidei herein because they show small differences compared to specimens from Spain also examined, and to the redescription provided by San Martín (2003).

Brazilian specimens of Syllis cf. westheidei slightly differ from Spanish specimens in the morphology of the blades of falcigers of posterior body, Brazilian specimens presenting dorso-ventral gradation in length, 20-8 $\mu \mathrm{m}$ long, while specimens from Spain have all blades of posterior body falcigers similar in length, $20 \mu \mathrm{m}$ long. The size of the proventricle is also different, through 7 and 11 chaetigers in Brazilian and Spanish material, respectively.

Type locality. Islas Baleares, Spain (Mediterranean Sea).

Distribution. Pacific Ocean: Islas Galápagos. Atlantic Ocean: Spain (Mediterranean Sea), Brazil (Paraíba, Pernambuco, São Paulo).

\section{Syllis corallicola Verril, 1900}

Syllis (Typosyllis) corallicola Verril, 1900: 603.

Typosyllis corallicola. Licher 1999: 116-119, Fig. 54.

Syllis corallicola. Nogueira \& San Martín 2002: 73-75, Figs 11-12; San Martín 2003: 439-443, Figs 242-243; Fukuda 2010: 250-253.

Material examined. State of Paraíba: João Pessoa, Cabo Branco $\left(7^{\circ} 08^{\prime} \mathrm{S} 34^{\circ} 47^{\prime} \mathrm{W}\right)$, intertidal: 3 specimens, coll. 09 February 2009; 1 specimen, coll. 02 February 2010.

Additional material examined. Syllis corallicola. Spain, Andalucía, Almería, Roquetas de Mar, 3 m: 4 specimens (MNCN 16.01/1196), coll. November 1986, det. O. 
Díaz. Cuba, Archipiélago de los Canarreos, Isla de Pinos, Punta Pedernales, 4 m: 1 specimen (MNCN 16.01/768), coll. \& det. G. San Martín. Brazil, São Paulo, Ilha de Alcatrazes, 3-10 m: 1 specimen (MNCN 16.01/8723), coll. 17 March 1996, det. J.M.M. Nogueira \& G. San Martín.

Remarks. The analysed material matches the description provided by Nogueira \& San Martín (2002) for specimens from São Paulo.

Type locality. Bermuda (Atlantic Ocean).

Distribution. Atlantic Ocean: Bermuda, Antillas, Cuba, Mediterranean Sea (San Martín 2003), Brazil (states of Paraíba, Pernanbuco and São Paulo). First record from off the northeastern Brazilian coast.

Syllis pseudoarmillaris Nogueira \& San Martín, 2002

Syllis pseudoarmillaris Nogueira \& San Martín, 2002: 83-85, Figs 17-18; Nogueira 2006: 160. Fukuda 2010: 286-289.

Material examined. State of Paraíba: Mataraca, Barra de Camaratuba (6 $366^{\prime} \mathrm{S}$ 3457'W), intertidal: 13 specimens, coll. 12 August 2010. Baía da Traição, Praia do Farol (6 $\left.41^{\circ} \mathrm{S} 34^{\circ} 55^{\prime} \mathrm{W}\right)$, intertidal: 11 specimens, coll. 09 August 2010. Rio Tinto, Barra de Mamanguape $\left(6^{\circ} 45^{\prime} \mathrm{S}\right.$ 34 $\left.4^{\circ} 55^{\prime} \mathrm{W}\right)$, intertidal: 3 specimens, coll. 11 August 2010. Cabedelo, Píer de Cabedelo ( $\left.6^{\circ} 58^{\prime} \mathrm{S} 34^{\circ} 50^{\prime} \mathrm{W}\right)$, intertidal: 2 specimens, coll. 12 February 2009. João Pessoa, Cabo Branco ( $\left.7^{\circ} 08^{\prime} \mathrm{S} 34^{\circ} 47^{\prime} \mathrm{W}\right)$, intertidal: 1 specimen, coll. 09 February 2009; 23 specimens, coll. 02 February 2010; recifes do Picãozinho (7².243'S 3449.291'W), 1 m: 8 specimens, coll. 15 September 2012. Conde, Praia de Jacumã 
( $\left.7^{\circ} 14^{\prime} \mathrm{S} 34^{\circ} 47^{\prime} \mathrm{W}\right)$, intertidal: 4 specimens, coll. 29 January 2010; Praia de Tabatinga $\left(7^{\circ} 19^{\prime} \mathrm{S} 34^{\circ} 47^{\prime} \mathrm{W}\right)$, intertidal: 3 specimens; coll. 17 September 2012; Praia do Coqueirinho ( $\left.7^{\circ} 18^{\prime} \mathrm{S} 34^{\circ} 47^{\prime} \mathrm{W}\right), 18$ specimens, coll. 28 August 2011; Praia de Tambaba ( $\left.7^{\circ} 21^{\prime} \mathrm{S} 34^{\circ} 47^{\prime} \mathrm{W}\right), 16$ specimens, coll. 30 August 2011. State of Pernambuco: Goiana, Pontas de Pedra $\left(7^{\circ} 37^{\prime} \mathrm{S} 34^{\circ} 48^{\prime} \mathrm{W}\right), 4$ specimens, coll. 13 December 2012. Ilha de Itamaracá, Ponta do Jaguaribe $\left(7^{\circ} 44^{\prime} \mathrm{S} 34^{\circ} 49^{\prime} \mathrm{W}\right)$, intertidal: 1 specimen, coll. 11 December 2012. Almirante Tamandaré, Praia dos Carneiros ( $\left.8^{\circ} 42.849^{\prime} \mathrm{S} 35^{\circ} 4.999^{\prime} \mathrm{W}\right)$, intertidal: 6 specimens, coll. 22 July 2013.

Additional material examined. Syllis pseudoarmillaris. Brazil, São Paulo, Ilha

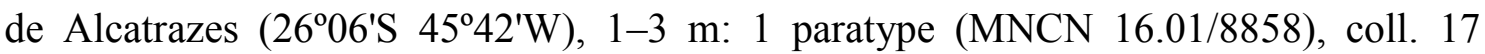
March 1996, det. JMM Nogueira \& G. San Martín. Australia, Queensland, Calliope River (2349'S 151¹3'E): 7 specimens (AM W29391), coll. 1974, det. G. San Martín.

Remarks. The material examined from northeastern Brazil differs from a paratype analysed for the present study, and from specimens described by Nogueira \& San Martín (2002), by having 1-2 anterior black stripes per chaetiger dorsally, similar to that found by Fukuda (2010), also from the State of São Paulo. In material collected for the present study, some specimens kept original pigmentation, although dimmed, after preservation, either in formaline or in ethanol, while others, sometimes from the same samples, did not.

One specimen collected at Cabedelo has three internal structures which apparently correspond to fertilized eggs, indicating occurrence of viviparity in this species (G. San Martín, pers. comm. to KP).

On the other hand, the material analysed from Queensland, Australia, is very different, with up to 4 anterior aciculae, subdistally inflated with oblique tip; falcigers longer than those from Brazilian specimens and unidentate blades. 
Type locality. Laje de Santos, São Paulo, Brazil (Atlantic Ocean).

Distribution. Atlantic Ocean: Brazil (states of Paraíba and São Paulo First record from off the northeastern Brazilian coast.

\section{Syllis prolifera Krohn, 1852}

Syllis prolifera Krohn, 1852: 66-76, Taf. 3, Fig. 1; San Martín 1984a: 331-335, lam. 78-79; 1992: 171-173, Fig. 1E-H; 2003: 344-347, Figs 186-187; Nogueira 2000: 114, Fig. 27G-L; 2006: 159; Nogueira \& San Martín 2002: 72-73, Figs 9-10; Capa 2003: 218-219, Fig.100.

Typosyllis prolifera. Licher 1999: 135-140, Abb. 17S, 61.

Syllis (Typosyllis) bouvieri Gravier, 1900: 163-165, pl. 9, Fig. 10, Figs 31-34.

Material examined. State of Paraíba: Mataraca, Barra de Camaratuba $\left(6^{\circ} 36^{\prime} \mathrm{S}\right.$ 34 $\left.57^{\prime} \mathrm{W}\right)$, intertidal: 7 specimens, coll. 12 August 2010. Baía da Traição, Praia do Farol (6 $\left.{ }^{\circ} 41^{\prime} \mathrm{S} 34^{\circ} 55^{\prime} \mathrm{W}\right)$, intertidal: 4 specimens, coll. 09 August 2010. Rio Tinto, Barra de Mamanguape $\left(6^{\circ} 45^{\prime} \mathrm{S} 34^{\circ} 55^{\prime} \mathrm{W}\right)$, intertidal: 11 specimens, coll. 11 August 2010. João Pessoa, Cabo Branco ( $\left.7^{\circ} 08^{\prime} \mathrm{S} 34^{\circ} 47^{\prime} \mathrm{W}\right)$, intertidal: 3 specimens, coll. 09 February 2009; 14 specimens, coll. 02 February 2010. Conde, Praia de Jacumã ( $\left.7^{\circ} 14^{\prime} \mathrm{S} 34^{\circ} 47^{\prime} \mathrm{W}\right)$, intertidal: 5 specimens, coll. 29 January 2010; Praia de Tabatinga ( $\left.7^{\circ} 19^{\prime} \mathrm{S} 34^{\circ} 47^{\prime} \mathrm{W}\right)$, intertidal: 6 specimens; coll. 17 September 2012; Praia do Coqueirinho (7º $18^{\prime} \mathrm{S}$ $\left.34^{\circ} 47^{\prime} \mathrm{W}\right), 5$ specimens, coll. 28 August 2011; Praia de Tambaba ( $\left.7^{\circ} 21^{\prime} \mathrm{S} 34^{\circ} 47^{\prime} \mathrm{W}\right), 2$ specimens, coll. 30 August 2011. State of Pernambuco: Goiana, Pontas de Pedra ( $7^{\circ} 37^{\prime} \mathrm{S}$ 34ำ $\left.{ }^{\circ} \mathrm{W}\right), 4$ specimens, coll. 13 December 2012. Almirante Tamandaré, Praia dos Carneiros ( $\left.8^{\circ} 42.849^{\prime} \mathrm{S} 35^{\circ} 4.999^{\prime} \mathrm{W}\right)$, intertidal: 2 specimens, coll. 22 July 2013. 
Remarks. The analysed material matches the description provided by Nogueira \& San Martín (2002) for specimens from São Paulo.

Type locality. Villefranche-sur-Mer, France (Mediterranean Sea).

Distribution. Cosmopolitan. First record from off the northeastern Brazilian coast.

\section{Syllis sp. n. 5}

(Figures 38-40)

Material examined. State of Paraíba: Mataraca, Barra de Camaratuba (6 ${ }^{\circ} 36^{\prime} \mathrm{S}$ 34 ${ }^{\circ} 57^{\prime} \mathrm{W}$ ), intertidal: 8 specimens, coll. 12 August 2010. Baía da Traição, Praia do Farol (6 $\left.6^{\circ} 41^{\prime} \mathrm{S} 34^{\circ} 55^{\prime} \mathrm{W}\right)$, intertidal: 4 specimens, coll. 09 August 2010. Rio Tinto, Barra de Mamanguape $\left(6^{\circ} 45^{\prime} \mathrm{S} \quad 34^{\circ} 55^{\prime} \mathrm{W}\right)$, intertidal: 2 specimens, coll. 11 August 2010. Cabedelo, Píer de Cabedelo (6 $\left.58^{\prime} \mathrm{S} 34^{\circ} 50^{\prime} \mathrm{W}\right)$, intertidal: 1 specimen, coll. 12 February 2009. João Pessoa, Cabo Branco $\left(7^{\circ} 08^{\prime} \mathrm{S} 34^{\circ} 47^{\prime} \mathrm{W}\right)$, intertidal: 5 specimens, coll. 09 February 2009; 1 specimen, coll. 02 February 2010. Conde, Praia de Jacumã (7º $14^{\prime}$ S 34 $47^{\prime} \mathrm{W}$ ), intertidal: 1 specimen, coll. 29 January 2010; Praia de Tabatinga ( $7^{\circ} 19^{\prime} \mathrm{S}$ $\left.34^{\circ} 47^{\prime} \mathrm{W}\right)$, intertidal: 2 specimens, coll. 17 September 2012; Praia de Tambaba ( $7^{\circ} 21^{\prime} \mathrm{S}$ 34 ${ }^{\circ} 47^{\prime} \mathrm{W}$ ), intertidal: 1 specimen, coll. 30 August 2011. State of Pernambuco: Goiana,

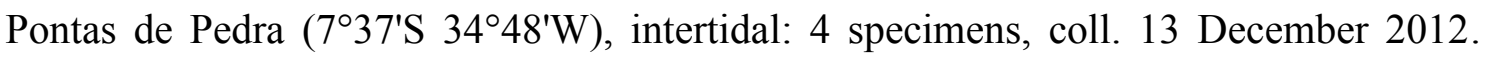
Ilha de Itamaracá, Ponta do Jaguaribe $\left(7^{\circ} 44^{\prime} \mathrm{S} 34^{\circ} 49^{\prime} \mathrm{W}\right)$, intertidal: 2 specimens, coll. 11 December 2012. Almirante Tamandaré, Praia dos Carneiros (842.849'S 354.999'W) intertidal: 2 specimens (MZUSP XX), coll. 22 July 2013. 
Additional material examined. Syllis castroviejoi Capa, San Martín \& López, 2001. Panamá, Isla de Coiba, Arrecife de Granito de Oro ( $\left.7^{\circ} 39^{\prime} 20^{\prime \prime} \mathrm{N} 81^{\circ} 42^{\prime} 20^{\prime \prime} \mathrm{W}\right), 4.5$ m: holotype (MNCN 16.01/6100); 1 paratype (MNCN 16.01/9215); 2 paratypes (MNCN 16.01/9207), coll. 16 November 1997.

Description. Middle-sized body; largest specimen analysed ca. $15 \mathrm{~mm}$ long, 0.5 mm wide, with 110 chaetigers. Dorsal surface with internal granulose inclusions in midand posterior body chaetigers; ventral surface of anterior body segments with several pores (Fig. 38H). Palps conical, distally rounded, fused at bases, with paired of row of cilia ventrally (Fig. 38B-D, F). Prostomium subpentagonal, shorter than palps, with two pairs of eyes in trapezoidal arrangement, anterior eyespots absent; median antenna inserted between posterior pair of eyes, reaching beyond tip of palps, with 32-34 articles; lateral antennae shorter, inserted anterior to eyes, about $3 / 4$ of median antenna length, with 20-24 articles each; prostomium with pair of rows of cilia, from bases of lateral antennae to near base of median antenna (Fig. 38C, F, I). Ciliated nuchal organs between prostomium and peristomium, only visible under SEM (Fig. 38G). Peristomium shorter than anterior chaetigers (Fig. 38C), covering posterior margin of prostomium (Fig. 38C); anterior margin of peristomium with transverse row of cilia dorsally (Fig. 38C, F-G); dorsal peristomial cirri as long as median antenna, with 32-35 articles each; ventral peristomial cirri shorter, 16-18 articles each. Dorsal cirri of chaetiger 1 as long as dorsal peristomial cirri, with 30-34 articles each; dorsal cirri of chaetigers 2 and 5 shorter, of similar size, 20-22 and 23-25 articles each, respectively; dorsal cirri of chaetigers 3 and 4 longer, 33-35 and 36-40 articles each, respectively; following dorsal cirri alternating long and short, long cirri with 30-35 articles each, as long as body width at corresponding segment, short cirri with 23-24 articles each, shorter than body width at corresponding segment (Figs. 38A, 39J); on posterior body, 
long cirri with 23-26 articles each, as long as body width at corresponding segment, short cirri with 15-18 articles each, shorter than body width at corresponding segment (Fig. 39F, L). Antennae, peristomial and dorsal cirri throughout, with proximal articles wider, distally tapering (Figs 38E; 39F, J, L), and 1-2 granular inclusions per article. Digitiform ventral cirri inserted at middle third of parapodial lobes, reaching their tips (Figs 38B, E; 39A, D-F, J-L). Parapodial lobes bilobed (Fig. 39A). Anterior parapodia with 13-17 falcigers each, midbody with $7-10$, posterior parapodia with $3-6$ falcigers each. Shafts of falcigers slightly spinulated, with straight tips (Figs. 40A-C); ventralmost falcigers of posterior body chaetigers with shafts slightly more inflated subdistally (Figs 39H, 40C). Blades of falcigers spinulated, bidentate, teeth of similar size (Figs 39G-H, 40A-C); blades of falcigers with dorso-ventral gradation in length (Figs. 39A-E; 40A-C), 43-18 $\mu \mathrm{m}$ long on anterior and midbody parapodia, 32-12 $\mu \mathrm{m}$ on posterior parapodia. Dorsal simple chaetae only present on posterior parapodia, thinner than shafts of falcigers, with blunt tip under optical microscope (Fig. 40D), bifid under SEM (Fig. 39G) with minute subdistal spines (Fig. 39G); ventral simple chaetae only present on posteriormost parapodia, thinner than shafts of falcigers, straight, bidentate, subdistally spinulated (Figs 39I; 40E). Anterior parapodia with up to 5 aciculae each, 2-3 of which straight with rounded tip and 1-2 slender, with oblique tips, and one curved (Fig. 40F); number of aciculae decreasing posteriorwards; midbody parapodia with two straight aciculae each, one with rounded tip and another with oblique tip, the last one protruding from parapodial lobe; posterior parapodia with a single acicula each, progressively stouter, straight, with acute tips, protruding from parapodial lobes (Figs 39D, G; 40F-H). Semicircular pygidium, with paired elongated anal cirri, same length as posterior long dorsal cirri (Fig. 39F), with 30-33 articles each; anal papilla inbetween same length as posterior ventral cirri (Fig. 39F, K); anus ciliated 
(Fig. 39K). Pharynx through 9-11 segments, with pharyngeal tooth near anterior margin; proventricle extending for six chaetigers, with 32-35 rows of muscle cells.

Remarks. Syllis castroviejoi was described originally from Coiba, Panamá, Pacific Ocean and is the most similar species to Syllis sp. n. 5. Both species share similar lengths of median and lateral antennae, as well as ventral peristomial cirri; and proventricle through 6 chaetigers with about 36 rows of muscle cells. The differences between these species are subtle: the dorsal surface of $S$. castroviejoi has transverse orange stripes; parapodia with internal granules; appendages and articles of appendages stouter; shorter dorsal peristomial cirri, ca. 23 articles; shorter midbody dorsal cirri, alternating between 22 and 11 articles each, respectively; and aciculae inflated subdistally, with acute tip, not protruding from parapodial lobes. Mid- and posterior body segments of Syllis sp. n. 5 have internal dorsal granules, but stripes as such of $S$. castroviejoi are absent. Furthermore, Syllis sp. n. 5 does not have granules in parapodia; the appendages are slender, with distal articles longer than those of $S$. castroviejoi; midbody dorsal cirri are longer, alternating between 30-35 and 23-24 articles each, respectively; there are more aciculae in each anterior parapodium, protruding from parapodial lobes, and of different morphology.

Among the groups suggested by Licher (1999), Syllis sp. n. 5 is more similar to the species belonging to the "variegata-complex", characterized by having compound chaetae as falcigers only (spiniger-like chaetae absent), with spinulated blades; 3-5 aciculae in each anterior parapodia, aciculae straight, with acute sometimes oblique tip, and 1-2 aciculae in each posterior parapodium, with acute tips, stouter than anterior ones. This group comprehends S. aciculata (Treadwell, 1945), S. bella (Chanberlin, 1919), S. macrodentata (Hartmann-Schröder, 1982), S. remanei (Hartmann-Schröder, 
1960), S. taiwanensis (Licher, 1999), S. variegata Grube, 1860, and $S$. warrnamboolensis (Hartmann-Schröder, 1987).

However, the appendages of $S$. aciculata, S. remanei, S. taiwanensis and $S$. warrnamboolensis are shorter than those of Syllis sp. n. 5. Furthermore, S. aciculata has blades of falciger shorter than in Syllis sp.n. 5, with inconspicuous gradation in length, and distinctly shorter subdistal tooth in ventralmost chaetae of anterior body parapodia. $S$. remanei has blades of falcigers with shorter spinulation, as progressively shorter spines in dorsalmost and intermediary chaetae within each fascicle, while ventralmost falcigers have minute, nearly inconspicuous spines. S. taiwanensis, $S$. macrodentata, $S$. warrnamboolensis, and $S$. bella have falcigers with shorter blades, with inconspicuous dorso-ventral gradation in length. Syllis variegata is different from Syllis sp. n. 5 by having a peculiar colour pattern dorsally, as a dark, transverse " 8 " on each chaetiger; shorter blades of falcigers, $25-18 \mu \mathrm{m}$ long on anterior parapodia, and 16-12 $\mu \mathrm{m}$ long on posterior parapodia; and aciculae with straight, rounded tips on anterior body (Licher 1999; San Martín 2003). Differently from S. variegata, Syllis sp. n. 5 does not have dorsal pigmentation; has longer falcigers blades, with conspicuous dorso-ventral gradation in length, 43-18 $\mu \mathrm{m}$ long on anterior parapodia, and 32-12 $\mu \mathrm{m}$ long, on posterior parapodia; and anterior parapodia with up to five aciculae. 


\section{References}

Aguado, M.T. \& San Martín, G. (2009) Phylogeny of the Syllidae (Polychaeta) based on morphological data. Zoologica Scripta 38, 379-402.

Aguado, M.T., San Martín, G. \& Siddall, M.E. (2012) Systematics and evolution of syllids (Annelida, Syllidae). Cladistics, 27, 1-17.

Aguado, M.T., San Martín, G. \& Ten Hove, H.A. (2008) Syllidae (Annelida: Polychaeta) from Indonesia collected by the Siboga (1899-1900) and Snellius II (1984) expeditions. Zootaxa, 1673, 1-48.

Álvarez-Campos, P., San Martín, G. \& Aguado, M.T. (2012) The genus Branchiosyllis Ehlers, 1887 from Philippines Islands, with the description of two new species. Zootaxa, 3542, $49-68$.

Amaral, A.C.Z., Nallin, S.A.H., Steiner, T.M., Forroni, T.O. \& Gomes-Filho, D. (2013) Catálogo das espécies de Annelida Polychaeta do Brasil. http://www.ib.unicamp.br/projbiota/bentos_marinho/prod_cien/texto_poli.pdf. (Acessed February 2014).

Attolini, F.S., Flynn, M.N. \& Tararam, A.S. (1997) Influence of Spartina alterniflora and tide level on the structure of polychaete associatons in an euryhaline salt marsh in Cananéia lagoon estuarine region (SE Brazil). Revista Brasileira de Oceanografia, 45, 25-34.

Augener, H. (1913) Polychaeta I, Errantia. Die Fauna Südwest-Australiens. Ergebnisse des Hamburger Südwest-australischen Forschungreise, 1905, 4 (5), 65-304.

Augener, H. (1918) Polychaeta. In: Michaelsen W. (Ed.), Beiträge zur Kenntnis der Meeresfauna Westafrikas, II Lief. 2. L. Friedrichsen \& Co., Hamburg, pp. 67-225.

Augener, H. (1927) Polychaeten von Südost- und Süd-Australien. Papers from Dr. Th. Mortensen's Pacific Expedition 1914-16. Videnskabelige Meddelelser fra Dansk Naturhistorisk Forening København, 83, 71-275.

Campoy, A. \& Alquezar, E. (1982) Anelidos poliquetos de las formaciones de Dendropoma petraeum (Monterosato) de las costas del Sureste de Espana. Actas do II Simposio Iberico de Estudos do Benthos Marinho, Liboa, 2, 121-137.

Cantone, G. (1976) Ricerche sul litorale della Somalia. Anellidi Policheti der Bender MTONI e sar UANLE. Italian Journal of Zoologysuppl. VIII, 9, 223-254.

Capa, M. (2003) Estudio de la criptofauna coralina y de los Anélidos Poliquetos (Annelida: Polychaeta) de sustratos duros del Parque Natural de Coiba, Panamá. Ph. D. Universidad Autónoma de Madrid, unpublished, 382 pp. 
Capa, M., San Martín, G. \& López, E. (2001) Autolytinae, Eusyllinae and Exogoninae (Syllidae: Polychaeta) from Coiba National Park, Panamá. Revista De Biologia Tropical, 49(2), 621-627.

Claparède, E. (1864) Glanures zootomiques parmi les Annélides de Port-Vendres (Pyrenées Orientales). Mémoires de la Societé de Physique et d'Histoire Naturelle de Géneve, 17 (2), 463-600.

Day, J.H. (1967) A Monograph on the Polychaeta of Southern Africa, 1. Errantia, 2. Sedentaria. Brit Mus (Nat Hist) London Publ, (656), 1-458, 459-878.

Day, J.H. \& Hutchings, P.A. (1979) An Annotated Check-list of Australian and New Zealand Polychaeta, Archiannelida and Myzostomida. Records of the Australian Museum, 32 (3), 80-161.

Duarte L.F.L \& Nalesso, R.C. (1996) The sponge Zygomycale parishii (Bowerbank) and its endobiotic fauna. Estuarine, Coastal and Shelf Science, 42, 139-51.

Ehlers, E. (1887) Report on the annelids of the dredging expedition of the U. S. coast survey steamer "Blake". Memoirs of the Museum of Comparative Zoology at Harvard College, $15,1-335$.

Fauvel, P. (1923) Faune de France 5. Polychètes Errantes. Le Chevalier Eds., Paris 486 pp.

Fukuda, M.V. (2010) Contribuição ao conhecimento taxonômico dos silídeos (Polychaeta: Syllidae) da região sudeste-sul do Brasil. Ph. D. Thesis, Instituto de Biociências da Universidade de São Paulo, São Paulo, 340 pp.

Giangrande, A., Licciano, M. \& Pagliara, P. (2000) The diversity of diets in Syllidae (Annelida: Polychaeta). Cahiers de Biologie Marine, 41, 55-65.

Góngora-Garza, G., García-Garza, M.E. \& de León-González, J.A. (2011) Two new species of Branchiosyllis (Polychaeta: Syllidae) from Western Mexico. Proceedings of the Biological Society of Washington, 124 (4), 378-385.

Gravier, Ch. (1900) Contribution à l'étude des Annélides Polychètes de la Mer Rouge. Nouvelles Archives du Muséum d'Histoire Naturelle, Ser. 4, 137-282.

Grube, A. E. (1840) Actinien, Echinodermen und Würmer des Adriatischen und Mittelmeers. J. H. Bon, Königsburg, 19pp.

Hartman, O. (1965) Catalogue of the polychaetous annelids of the world. Supplement 19601965 and index. Allan Hancock Foundation Publications. Occasional Paper, 23, 1-197.

Hartmann-Schröder, G. (1960) Polychaeten aus dem Roten Meer. Kieler Meeresforschungen, $16,69-125$.

Hartmann-Schröder, G. (1979) Teil 2. Die Polychaeten der tropischen Nordwestküste Australiens (zwischen Port Samson im Norden und Port Hedland in Süden). Mitteilungen aus dem Hamburgischen Zoologischen Museum und Institut, 76, 75-218. 
Hartmann-Schröder, G. (1980) Teil 4. Die Polychaeten der tropischen Nordwestküste Australiens (zwischen Port Samson im Norden und Exmouth im Süden). Mitteilungen aus dem Hamburgischen Zoologischen Museum und Institut, 77, 41-110.

Hartmann-Schröder, G. (1981) Teil 6. Die Polychaeten der tropisch-subtropischen Westküste Australiens (zwischen Exmouth im Norden und Cervantes im Süden). Mitteilungen aus dem Hamburgischen Zoologischen Museum und Institut, 78, 19-96.

Hartmann-Schröder, G. (1982) Teil 8. Die Polychaeten der subtropischen-antiborealen Westküste Australiens (zwischen Cervantes im Norden und Cape Naturaliste im Süden). Mitteilungen aus dem Hamburgischen Zoologischen Museum und Institut, 79, $51-118$.

Hartmann-Schröder, G. (1989) Teil 14. Die Polychaeten der antiborealen und subtropischtropischen Küste Südost-Australien zwischen Lakes Entrance (Victoria) im Süden und Maclean (New South Wales) im Norden. Mitteilungen aus dem Hamburgischen Zoologischen Museum und Institut, 86, 11-63.

Hartmann-Schröder, G. (1991) Teil 16. Die Polychaeten der subtropisch-tropischen bis tropischen Ostküste Australiens zwischen Maclean (New South Wales) und Gladstone (Queensland) sowie von Heron Is (Großes Barriere-Riff). Mitteilungen aus dem Hamburgischen Zoologischen Museum und Institut, 88, 17-71.

Haswell, W.A. (1885) Observations on some Australian Polychaeta. Proceedings of the Linnean Society of New South Wales, 10, 733-756.

Haswell, W.A. (1920) Australian Syllidae, Eusyllidae and Autolytidae. Journal of the Linnean Society of London, 24, 90-112.

Imajima, M. \& Hartman, O. (1964) The Polychaetous Annelids of Japan. Part I. Allan Hancock Foundation Publication Occasional Paper 26 I, 237 pp.

Imajima, M. (1966a) The Syllidae (Polychaetous Annelids) from Japan. IV. Syllinae (1). Publications of Seto Marine Biological Laboratory 14 (3), 219-252.

Imajima, M. (1966b) The Syllidae (Polychaetous Annelids) from Japan. (V). Syllinae (2). Publications of Seto Marine Biological Laboratory, 14, 253-294.

Krohn, A. (1852) Ueber die Erscheinungen bei der Fortpflanzung von Syllis prolifera und Autolytus prolifer. Archiv für Naturgeschichte18: 66-76.

Langerhans, P. (1879) Die Würmfauna van Madeira. Zeitschrift für wissenschaftliche Zoologie, $33,513-592$.

Lattig, P. \& Martín, D. (2009) A taxonomic revision of the genus Haplosyllis Langerhans, 1887 (Polychaeta: Syllidae: Syllinae). Zootaxa, 2220, 1-40. 
Lattig, P. \& Martin, D. (2011). Two new endosymbiotic species of Haplosyllis (Polychaeta: Syllidae) from the Indian Ocean and Red Sea, with new data on $H$. djiboutiensis from the Persian Gulf. Italian Journal of Zoology 78, 112-23.

Lattig, P., Martin, D. \& San Martín G. (2010) Syllinae (Syllidae: Polychaeta) from Australia. Part 4. The genus Haplosyllis Langerhans, 1879. Zootaxa 2552, 1-36.

Lee, J. W. \& Rho, B. J. (1994) Two New Species of Syllidae (Annelida, Polychaeta) from Korea. The Korean Journal of Systematic Zoology, 10, 55-60.

Licher, F. (1999) Revision of Gattung TyposyllisLangerhans, 1879 (Polychaeta: Syllidae). Morphologie, Taxonomie und Phylogenie. Abhandlungen der Senckenbergischen Natursforchenden Gesellschaft, 551, 1-336.

López, E. \& San Martín, G. (1994) Syllidae (Polychaeta) recolectados en las Islas de Cabo Verde por la I Expedición Ibérica. Revista de Biología Tropical, 42, 129-139.

Maltagliati, F., Peru, A.P., Casu, M., Rossi, F., Lardicci, C., Curini-Galletti, M. \& Castelli, A. (2000). Is Syllis gracilis (Polychaeta: Syllidae) a species complex? An allozyme perspective. Marine Biology, 136, 871-879.

Martin, D., Britayev, T.A., San Martín, G. \& Gil, J. (2003) Inter-population variability and character description in the sponge-associated Haplosyllis spongicola complex (Polychaeta: Syllidae). Hydrobiologia, 496, 145-62.

Monro, C.C.A. (1933) The Polychaeta errantia collected by Dr. C. Crossland at Colón in the Panamá region and the Galápagos Islands during the expedition of the S. Y. St. George. Part 1. Proceedings of the Zoological Society of London, 1933, 1-96.

Monro, C.C.A. (1939) On some tropical Polychaeta in the British Museum, mostly collected by Dr. C. Crossland at Zanzibar, Tahiti and the Marquesas (II. Families Syllidae and Hesionidae). Novitates Zoologicae, 41, 383-393.

Morgado, E.H. \& Amaral, A.C.Z. (1985) Anelídeos poliquetos associados ao briozoário Schizoporella unicornis (Johnston). V. Syllidae. Revista Brasileira de Zoologia, 3, 219227.

Neves, G. \& Omena, E.P. (2003) Influence of sponge morphology on the composition of the polychaete associated fauna from Rocas Atoll, northeast Brazil. Coral Reefs, 22, 123129.

Nogueira, J.M.M. (2000) Anelídeos poliquetas associados ao coral Mussismilia híspida (Verril, 1868) em ilhas do litoral do Estado de São Paulo. Phyllodocida, Amphinomida, Eunicida, Spionida, Terebellida, Sabellida. Tese de Doutorado - Instituto de Biociências, Universidade de São Paulo. 265 pp. 
Nogueira, J.M.M. (2006) Família Syllidae. In: Amaral ACZ, Rizzo AE, Arruda, EP, editors. Manual de Identificação dos Invertebrados Marinhos da Região Sudeste-Sul do Brasil. São Paulo, SP: Editora da Universidade de São Paulo, 134-164.

Nogueira, J.M.M. \& Fukuda, M.V. (2008) A new species of Trypanosyllis Claparède, 1864 (Polychaeta: Syllidae) from Brazil, with a redescription of Brazilian material of Trypanosyllis zebra. Journal of the Marine Biological Association of the United Kingdom, 88, 913-924.

Nogueira, J.M.M. \& San Martín, G. (2002) Species of Syllis Savigny in Lamarck, 1818 (Polychaeta: Syllidae) living in corals in the state of São Paulo, Southeastern Brazil. Beaufortia, 52, 57-93.

Nogueira, J.M.M. \& Yunda-Guarín, G. (2008) A new species of Syllis (Polychaeta: Syllidae: Syllinae) from off Fortaleza, north-eastern Brazil. Journal of the Marine Biological Association of the United Kingdom, 88 (7): 1391-1399.

Núñez, J., San Martín, G. \& Brito, M.C. (1993) Syllinae (Polychaeta, Syllidae) de las Islas Canarias. Revista de la Academia Canaria de Ciencias, 4, 109-129.

Paiva, P.C., Young, P.S. \& Echeverría, C.A. (2007) The Rocas Atoll, Brazil: a preliminary survey of the crustacea and polychaete fauna. Arquivos do Museu Nacional, Rio de Janeiro $65,241-250$.

Paresque, K. (2008) Influência das características do hábitat na comunidade macrobentônica associada a diferentes fitais no entre-marés da Ilha do Boi, Vitória, Espirito Santo. Dissertação de Mestrado, Universidade Federal do Espírito Santo. 47 pp.

Paresque, K., Fukuda, M.V. \& Nogueira, J.M.M. (in press) The genus Exogone (Polychaeta: Syllidae) from the Brazilian coast, with the description of a new species. Zootaxa.

Paresque, K. \& Nogueira, J.M.M. (2014) The genus Haplosyllis Langerhans, 1879 (Polychaeta: Syllidae) from off northeastern Brazil, with descriptions of two new species. Marine Biology Research, 10, 554-576.

Pillai, T.G. (1965) Annelida Polychaeta from the Philippines and Indonesia. Ceylon Journal of Science, $5,112-177$.

Ruiz-Ramírez, J.D. \& Harris, L. (2008) Branchiosyllis salazari sp. n. (Polychaeta, Syllidae) del Caribe noroccidental y comentarios sobre el material tipo de B. exilis (Gravier, 1900). Animal Biodiversity and Conservation, 31 (2): 1-9.

Rullier, F. \& Amoureux, L. (1979) Annélides Polychàetes. Annales de l'Institute Oceanographique, 55, 145-206.

San Martín, G. (1984) Estudio biogeográfico, faunístico y sistemático de los Poliquetos de la família Sílidos (Syllidae: Polychaeta) en Baleares. Publicaciones de la Universidad Complutense de Madrid, 187, Madrid. 581 pp. 
San Martín, G. (1991) Syllinae (Polychaeta: Syllidae) from Cuba and the Gulf of México. Bulletin of Marine Science, 48, 236-241.

San Martín, G. (1992) Syllis Savigny in Lamarck, 1818 (Polychaeta: Syllidae: Syllinae) from Cuba, the Gulf of Mexico, Florida and North Carolina, with a revision of several species described by Verrill. Bulletin of Marine Science, 51, 167-196.

San Martín, G. (2003) Annelida Polychaeta II: Syllidae. In: Ramos, M.A. et al. (eds.), Fauna Ibérica, vol. 21. Museo Nacional de Ciências Naturales, CSIC, Madrid. 544 pp.

San Martín, G., Álvarez-Campos, P. \& Aguado, M.T. (2013) The genus Branchiosyllis Ehlers, 1887 (Annelida, Syllidae, Syllinae) from off the American coasts, with the description of a new species from Venezuela. Pan-American Journal of Aquatic Sciences 8, 166179.

San Martín, G., \& Estapé, S. (1993) Redescription of Pionosyllis procera Hartman, 1965 (Syllidae: Polychaeta), and comments about its reproduction and its systematic position. Revista de Biología Tropica, 141, 227-231.

San Martín, G., Hutchings, P. \& Aguado, M.T. (2008a) Syllinae (Polychaeta, Syllidae) from Australia. Part. 1. Genera Branchiosyllis, Eurysyllis, Karroonsyllis, Parasphaerosyllis, Plakosyllis, Rhopalosyllis, Tetrapalpia n. gen., and Xenosyllis. Records of Australian Museum, 60(2), 119-160.

San Martín, G., Hutchings, P. \& Aguado, M.T. (2008b) Syllinae (Polychaeta, Syllidae) from Australia. Part. 2. Genera Inermosyllis, Megasyllis n. gen., Opisthosyllis, and Trypanosyllis. Zootaxa, 1840, 1-53.

San Martin, G. \& López, E. (2000) Three new species of Syllis (Syllidae: Polychaeta) from Iberian coasts. Cahiers de Biologie Marine, 41, 425-434.

Santa-Isabel, L.M., Aguiar, M.P., Jesus, A., Kelmo, F. \& Dutra, L. (1998) Biodiversity and spatial distributoion of the Polychaeta (Annelida) communities in the sediment of an area of coral-algal buildups, northern coast of the State of Bahia, Brazil. Revista de Biologia Tropical, 46, 111-120.

Santi, L. \& Tavares, M. (2009) Polychaete assemblage of an impacted estuary, Guanabara Bay, Rio de Janeiro, Brazil. Brazilian Journal of Oceanography, 57, 287-303.

Storch, V. (1967) Neue polychaeten aus der sandfauna des Roten Meeres. Zoologischer Anzeiger, 178, 102-110.

Uebelacker, J.M. (1984) Family Syllidae Grube, 1850. In: Uebelacker, J. M. \& Johnson, P. G. (Eds.) Taxonomic guide to the polychaetes of the northern Gulf of Mexico, vol. IV. Barry A. Vittor and Associates, Mobile, pp. 1-151. 
Verrill, A.E. (1900) Additions to Turbellaria, Nemertina and Annelids of the Bermudas, with revisions of some New England genera and species. Transactions of the Connecticut Academy of Arts and Sciences, 10, 595-670.

Westheide, W. (1974) Interstitielle Fauna von Galapagos. XI. Pisionidae, Pilargidae, Syllidae. Mikrofauna Meeres-bodens, 44, 195-338.

\section{Legends to figures}

FIGURE 1. Branchiosyllis exilis, SEM. (A) (B) anterior body, dorsal view; (C) anterior body, lateral view; (D) (E) anterior body, ventral view; (F) parapodium, midbody; (G) midbody, dorsal view; $(\mathrm{H})$ midbody, rear view of end of fragment (incomplete specimen); (I) parapodium, midbody. Scale bars: A, C-D, G, $200 \mu \mathrm{m}$; B, E, I, $50 \mu \mathrm{m}$; F, $20 \mu \mathrm{m} ; \mathrm{H}, 100 \mu \mathrm{m}$.

FIGURE 2. Branchiosyllis exilis, live specimen. (A) complete specimen, dorsal view; (B) (C) Anterior body, dorsal view, a light and a dark specimens, respectively; (D) prostomium, dorsal view; (E) midbody. Scale bars: A, B, $1 \mathrm{~mm}$; C, $0.5 \mathrm{~mm}$; D-E, 0.2 $\mathrm{mm}$.

FIGURE 3. Branchiosyllis exilis, SEM. (A) chaetigers 1-2, ventral view, white arrows indicate tufts of cilia on chaetiger 1 and on parapodia of chaetigers 1 and 2; (B) detail of peristomium and chetiger 1 , white arrows indicate tufts of cilia posteriorly, on ventral peristomial cirri and on ventral surface of chaetiger 1; (C) chaetigers 1-4, ventral view, white arrows indicate tufts of cilia on the base of parapodia of chaetigers 1-3; (D) detail of prostomium and peristomium, dorsal view, white arrow indicates row of cilia on 
prostomium, black arrow indicates row of cilia on peristomium; (E) chaetigers 1-3, dorsal view, white arrows indicate tufts of cilia on dorsal side of base of dorsal cirri; (F) anterior body, right lateral view, white arrows indicate tufts of cilia on the dorsum of parapodium of chaetiger 2 and between dorsal cirri of chaetigers 4 and 5; (G) midbody, ventral view. ch1-4-chaetigers 1-4; dc1-dorsal cirri, chaetiger 1; dpc-dorsal peristomial cirri; la-lateral antenna; no-nuchal organ; p1-2-parapodia 1-2; peperistomium; pr-prostomium; vpc_-ventral peristomial cirri. Scale bars: A, B, $20 \mu \mathrm{m}$; C-E, $50 \mu \mathrm{m} ; \mathrm{F}, 100 \mu \mathrm{m} ; \mathrm{G}, 200 \mu \mathrm{m}$.

FIGURE 4. Branchiosyllis exilis, SEM. (A) falcigers, parapodium 2, ventral view; (B) chaetae, parapodium 18; (C) chaetae, midbody; (D) chaetae, parapodium 28; (E) (F) chaetae, midbody; (G) detail of parapodium, dorsal view, white arrows indicating protruding aciculae; (H) (I) (J) ungulae, mid- to posterior body. Scale bars: A, $200 \mu \mathrm{m}$; B, $50 \mu \mathrm{m} ; \mathrm{C}-\mathrm{F}, \mathrm{J}, 20 \mu \mathrm{m} ; \mathrm{G}, \mathrm{I}, 10 \mu \mathrm{m} ; \mathrm{H}, 5 \mu \mathrm{m}$.

FIGURE 5. Branchiosyllis exilis. (A) (B) (C) dorsal, intermediate and ventral falcigers, respectively, anterior body; (D) aciculae, anterior body (E) (F) (G) dorsal, intermediate and ventral falcigers, respectively, midbody; (H) aciculae, midbody (I) (J) (K) dorsal, intermediate and ventral chaetae, respectively, posterior body; (L) aciculae, posterior body. Scale bars: $30 \mu \mathrm{m}$.

FIGURE 6. Branchiosyllis sp. n., SEM. (A) complete specimens, ventro-lateral view; (B) (C) anterior end, dorsal and ventral view, respectively; (D) detail of anterior body, dorsal view; (E) detail of peristomial ciliation, dorsal view; (F) detail of the chaetiger 1, dorsal view; $(\mathrm{G})$ anterior parapodia, lateral view; (H) anterior parapodia, dorsal view, 
white arrows indicating tufts of cilia on the posterior side of base of dorsal cirri. ch15-chaetigers 1-5; dc1-2-dorsal cirri, chaetiger 1-2; dpc-dorsal peristomial cirri; ma-median antenna; pr-prostomium; vc-ventral cirri; vpc-ventral peristomial cirri. Scale bars: A, $1 \mathrm{~mm}$; B-C, $200 \mu \mathrm{m}$; D-F, $20 \mu \mathrm{m}$; G, $50 \mu \mathrm{m} ; \mathrm{H}, 100 \mu \mathrm{m}$.

FIGURE 7. Branchiosyllis sp. n., live specimen. (A) complete specimen, dorsal view; (B) (C) specimens inside the sponge Tedania ignis; (D) (E) (F) specimens collected in undetermined substrates. Scale bars: A-B, D, F, $1 \mathrm{~mm}$; C, $0.5 \mathrm{~mm}$; E, $200 \mu \mathrm{m}$.

FIGURE 8. Branchiosyllis sp. n.. (A) anterior body, dorsal view; (B) parapodium 1, lateral view; (C) parapodium, midbody, lateral view. Scale bars: A, $300 \mu \mathrm{m}$; B-C, 50 $\mu \mathrm{m}$.

FIGURE 9. Branchiosyllis sp. n., SEM. (A) ungulae, parapodium 5; (B) parapodia, midbody, dorsal view; (C) midbody, dorsal view; (D) (E) ungulae, midbody; (F) posterior body, dorsal view; (G) ungulae, posterior body. Scale bars: $A, 10 \mu \mathrm{m} ; \mathrm{B}, 100$ $\mu \mathrm{m} ; \mathrm{C}, 200 \mu \mathrm{m} ; \mathrm{D}, 2 \mu \mathrm{m} ; \mathrm{E}, 20 \mu \mathrm{m} ; \mathrm{F}, 5 \mu \mathrm{m} ; \mathrm{G}, 100 \mu \mathrm{m}$.

FIGURE 10. Branchiosyllis sp. n., SEM. (A) parapodium 1, dorso-lateral view; (B) parapodium 3, dorso-lateral view; (C) anterior parapodia, dorso-lateral view; (D) anterior parapodia, dorsal view; continuous white arrows indicating tufts of cilia on posterior side of parapodia, red arrows indicating tufts of cilia on posterior side of base of dorsal cirri. br-branchia; p1-p5-parapodium 1-5; vc-ventral cirri. Scale bars: $\mathrm{A}-\mathrm{D}, 20 \mu \mathrm{m}$. 
FIGURE 11. Branchiosyllis sp. n., SEM. (A) branchiae, parapodia 4-5; (B) branchia, midbody, white arrows indicating tufts of cilia on posterior side of base of dorsal cirri; (C) (D) (E) branchia, midbody, white arrows in E indicating tufts of cilia on posteriorior side ofparapodia. Scale bars: A-E, $20 \mu \mathrm{m}$.

FIGURE 12. Branchiosyllis sp. n.. (A) (C) (E) ungulae, anterior, mid- and posterior body, respectively; (B) (D) (F) aciculae anterior, mid- and posterior body, respectively. Scale bar: $15 \mu \mathrm{m}$.

FIGURE 13. Haplosyllis sp. n., SEM. (A) anterior end, dorsal view; (B) midbody, lateral view, white arrows indicating dorso-lateral pappilae; (C) detail, nuchal organ; (D) detail, dorsal pappilae; (E) chaetae, anterior body; (F) chaeta, detail of denticles on upper side of main fang, anterior body; $(\mathrm{G})$ chaetae, parapodium 11; (H) chaeta, midbody; (I) chaeta, posterior body. Scale bars: $A=100 \mu \mathrm{m} ; \mathrm{B}=50 \mu \mathrm{m} ; \mathrm{C}=10 \mu \mathrm{m}$; $\mathrm{D}$ $=2 \mu \mathrm{m} ; \mathrm{E}, \mathrm{G}-\mathrm{I}=5 \mu \mathrm{m} ; \mathrm{F}=1 \mu \mathrm{m}$.

FIGURE 14. Haplosyllis sp. n.. (A) anterior end, dorsal view; (B) (D) (F) anterior, mid- and posterior body aciculae, respectively; (C) (E) (G) anterior, mid- and posterior body chaetae, respectively. Scale bars: $A=200 \mu \mathrm{m} ; \mathrm{B}-\mathrm{G}=5 \mu \mathrm{m}$.

FIGURE 15. Megasyllis procera, live specimens. (A) (B) anterior body, dorsal view; (C) (D) stolon, dorsal view, arrows indicating the eyes; (E) posterior body, dorsal view. Scale bars: A, $400 \mu \mathrm{m}$; B-C, $200 \mu \mathrm{m}$; D-E, $200 \mu \mathrm{m}$. 
FIGURE 16. Megasyllis procera, SEM. (A) complete specimen; (B) anterior body, lateral view; (C) prostomium and peristomium, dorsal view, white arrows indicating the nucal organ; (D) detail of prostomium showing tuft of cilia between median and lateral antennae, and ciliated nuchal organ; (E) anterior body, dorsal view; (F) detail of ciliation between palps and prostomium, lateral view; $(G)$ anterior body, ventral view. la-lateral antennae; ma-median antenna; no-nucal organ; pa-palp; peperistomium; pr-prostomium. Scale bars: A, $500 \mu \mathrm{m}$; B, $200 \mu \mathrm{m}$; C-D, $20 \mu \mathrm{m}$; E, G, $100 \mu \mathrm{m} ; \mathrm{F}, 5 \mu \mathrm{m}$.

FIGURE 17. Megasyllis procera, anterior body, dorsal view. Scale bar: $0.3 \mathrm{~mm}$.

FIGURE 18. Megasyllis procera. (A) midbody, dorsal view. Scale bar: $0.2 \mathrm{~mm}$

FIGURE 19. Megasyllis procera, SEM. (A) midbody, dorsal view; (B) midbody, ventro-lateral view; (C) posterior body, dorsal view; (D) detail of posterior body, dorsolateral view; (E) dorsalmost falciger, porterior parapodia; (F) posterior body, dorsal view; (G) posterior body, ventral view. Scale bars: A, C-D, $50 \mu \mathrm{m}$; B, $20 \mu \mathrm{m}$; E, $5 \mu \mathrm{m}$; F, $200 \mu \mathrm{m} ; \mathrm{G}, 100 \mu \mathrm{m}$.

FIGURE 20. Megasyllis procera, parapodium, midbody. Scale bar: $20 \mu \mathrm{m}$.

FIGURE 21. Megasyllis procera, SEM. (A) (B) falcigers, parapodium 2; (C) tip of ventral simple chaetae, posterior body; (D) parapodium, midbody; (E) dorsal simple chaeta, posterior body; (F) falcigers, midbody; (G) chaetae, posterior body. Scale bars: A, F-G, $10 \mu \mathrm{m} ; \mathrm{B}, \mathrm{D}, 20 \mu \mathrm{m} ; \mathrm{C}, \mathrm{E}, 2 \mu \mathrm{m}$. 
FIGURE 22. Megasyllis procera. (A) (B) (C) anterior, mid- and posterior body falcigers; (D) dorsal simple chaeta; (E) ventral simple chaetae; (F) (G) (H) aciculae, anterior, mid- and posterior parapodia. Scale bar: $20 \mu \mathrm{m}$.

FIGURE 23. Syllis sp. n. 1, SEM. (A) (B) anterior body, dorsal and ventral view, respectively; (C) anterior body, dorsal view, white arrows indicating ciliated nuchal organs; (D) detail of nuchal organ; (E) (F) midbody, dorso-lateral and dorsal view, respectively, white arrows indicating dorsal glands; (F) complete specimen, lateral view, white arrows indicating dorsal glands. Scale bars: A-B, E-F, $200 \mu \mathrm{m} ; \mathrm{C}, 100 \mu \mathrm{m}$; $\mathrm{D}, 10 \mu \mathrm{m} ; \mathrm{G}, 500 \mu \mathrm{m}$.

FIGURE 24. Syllis sp. n. 1, SEM. (A) (B) falcigers, anterior body; (C) dorsalmost falciger, anterior body; (D) (E) (F) secondarily simple chaetae, midbody; (G) ventralmost falcigers, midbody; $(\mathrm{H})$ chaetae, midbody; (I) (J) chaetae, posterior body, white arrow indicating ventral simple chaeta. Scale bars: A-B, H, $20 \mu \mathrm{m}$; C, E, $5 \mu \mathrm{m}$; $\mathrm{D}, \mathrm{F}-\mathrm{G}, \mathrm{I}-\mathrm{J}, 10 \mu \mathrm{m}$.

FIGURE 25. Syllis sp. n. 1. (A) falcigers, anterior parapodia; (B) secondarily simple chaeta, midbody parapodia; (C) (D) falcigers, mid- and posterior body parapodia; (E) dorsal simple chaeta; $(F)$ ventral simple chaeta; $(\mathrm{G})(\mathrm{H})$ aciculae, anterior and posterior parapodia, respectively. Scale bar: $20 \mu \mathrm{m}$.

FIGURE 26. Syllis sp. n. 2, SEM. (A) anterior body, dorsal view; (B) detail of prostomium, dorso-lateral view; (C) ventralmost falciger, parapodium 2; (D) falciger, midbody, with partial fusion between shaft and blade; (E) anterior body, ventral view; 
(F) anterior body, dorso-lateral view; (G) ypsiloid chaeta, midbody; (H) chaetae, parapodium 2; (I) chaetae, parapodium 11; (J) ypsiloid chaetae with incomplete fusion between shaft and blade, midbody. Scale bars: A, $200 \mu \mathrm{m} ; \mathrm{B}, \mathrm{H}, 20 \mu \mathrm{m} ; \mathrm{C}, \mathrm{J}, 5 \mu \mathrm{m} ; \mathrm{D}$, $\mathrm{G}, \mathrm{I}, 10 \mu \mathrm{m} ; \mathrm{E}-\mathrm{F}, 100 \mu \mathrm{m}$.

FIGURE 27. Syllis sp. n. 2, SEM. (A) (B) midbody, dorsal and ventral views, respectively; (C) posterior body, dorsal view; (D) detail of posterior body, ventral view, white arrows indicating ventral holes; (E) posterior body, ventral view, white arrows indicating ventral holes; (F) anus and anal cirri, frontal view. Scale bars: A-C, E, 100 $\mu \mathrm{m} ; \mathrm{D}, \mathrm{F}, 50 \mu \mathrm{m}$.

FIGURE 28. Syllis sp. n. 2, SEM. (A) chaetae, posterior body, white arrow indicating ventral simple chaeta; (B) ypsiloid chaeta, midbody; (C) (D) chaetae, midbody; (E) chaetae, mid- to posterior body; $(\mathrm{F})$ chaetae, posterior body; $(\mathrm{G})$ dorsal simple chaeta, posterior body; (H) ypsiloid chaeta, frontal view. Scale bars: A-D, $10 \mu \mathrm{m}$; E-F, $20 \mu \mathrm{m}$; $\mathrm{G}, 5 \mu \mathrm{m} ; \mathrm{H}, 2 \mu \mathrm{m}$.

FIGURE 29. Syllis sp. n. 2. (A) anterior facigers; (B) fused chaeta, anterior midbody; (C) partially fused chaetae, anterior midbody; (D) fused chaeta, medium midbody; (E) partially fused chaetae, medium midbody; (F) partially fused chaetae, posterior midbody; (G) falcigers, posterior parapodia; (I) aciculae, midbody parapodia; (J) acicula, posterior parapodia. Scale bar: $20 \mu \mathrm{m}$. 
FIGURE 30. Syllis cf. rosea. (A) (B) (C) chaetae, anterior, mid- and posterior body, respectively; (D) dorsal simple chaeta; (E) ventral simple chaeta; (F) (G) (H) aciculae, anterior, mid- and posterior body, respectively. Scale bars: $20 \mu \mathrm{m}$.

FIGURE 31. Syllis sp. n. 3. (A) (B) (C) chaetae, anterior, mid- and posterior body, respectively; (D) dorsal simple chaeta; (E) ventral simple chaeta; (F) (G) (H) aciculae, anterior, mid- and posterior body, respectively. Scale bars: $20 \mu \mathrm{m}$.

FIGURE32. Syllis sp. n. 4 SEM. (A) (B) anterior body, dorsal view, red arrow indicating ciliated anterior boarder of peristomium; (B) anterior body, ventral view; (C) detail of prostomium and peristomium, ventral view; (D) palps, ventral view; (E) left side of border between prostomium and peristomium, dorsal view, pointed white arrow indicating nuchal organ, red arrow indicating anterior boarder of peristomium; (F) (G) midbody, dorsal and ventral views, respectively; $(\mathrm{H})$ posterior body, dorsal view; (I) midbody parapodium, arrows indicating protruding aciculae; $(\mathrm{J})$ posterior body, frontal view, white arrow indicating anal papilla. ac - anal cirri, pa-palps, pe-peristomium, pr-prostomium. Scale bars: A-B, G-H, $200 \mu \mathrm{m}$; C, J, $100 \mu \mathrm{m}$; D-E, $40 \mu \mathrm{m}$; F, 400 $\mu \mathrm{m} ; \mathrm{I}, 20 \mu \mathrm{m}$.

FIGURE 33. Syllis sp. n. 4, SEM. (A) (B) dorsalmost falcigers, anterior body; (C) falcigers, anterior body, white arrows indicating protruding aciculae; (D) ventralmost falcigers, parapodium 3; (E) (F) chaetae, midbody; (G) dorsalmost falcigers, midbody; (H) falcigers, mid- to posterior body; (I) dorsalmost falciger, posterior body; (J) ventral simple chaeta; (K) parapodia, posterior body, white arrows indicating dorsal simple chaetae. Scale bars: A, D, G, I, $10 \mu \mathrm{m} ; \mathrm{B}, 5 \mu \mathrm{m}$; C, E-F, H, $20 \mu \mathrm{m} ; \mathrm{J}, 2 \mu \mathrm{m}$. 
FIGURE 34. Syllis sp. n. 4. (A) (B) (C) falcigers, anterior, mid- and posterior body, respectively; (D) dorsal simple chaeta; (E) ventral simple chaeta; (F) (G) (H) aciculae, anterior, mid- and posterior body, respectively. Scale bars: $10 \mu \mathrm{m}$.

FIGURE 35. Syllis cf. westheidei, SEM. (A) (B) anterior body, dorsal view, white arrows indicating pair of rows of cilia between median and lateral antennae, red arrows indicating transverse row of cilia on peristomium; (C) anterior body, ventral view; (D) detail of prostomium and peristomium, dorsal view, white arrows indicating pair of rows of cilia between median and lateral antennae, black arrow indicating transverse row of cilia on peristomium; (E) midbody, ventral view; (F) posterior body, dorsal view; (G) close up of pigidium, anus and anal papilla, frontal view. ap-anal papilla, la-lateral antenna, ma-median antennae, no-nuchal organ, pdc- dorsal peristomial cirri,pe-peristomium, pr-prostomium. Scale bars: A, $500 \mu \mathrm{m}$; B-C, 200 $\mu \mathrm{m} ; \mathrm{D}, 40 \mu \mathrm{m} ; \mathrm{E}, \mathrm{G}, 20 \mu \mathrm{m} ; \mathrm{F}, 400 \mu \mathrm{m}$.

FIGURE 36. Syllis cf. westheidei, SEM. (A) (B) anterior parapodia, dorsal and ventral views, respectively; (C) ventralmost falciger, anterior parapodium; (D) dorsalmost falciger, anterior parapodium; (E) (F) falcigers, midbody; (G) falcigers, posterior body; (H) ventral simple chaeta; (I) (J) dorsal simple chaetae; (K) falcigers, posterior body. Scale bars: A-B, E, $20 \mu \mathrm{m}$; C, H, $2 \mu \mathrm{m}$; D, K, $10 \mu \mathrm{m}$; F-G, I-J, $5 \mu \mathrm{m}$.

FIGUE 37. Syllis cf. westheidei. (A) (B) (C) falcigers, anterior, mid- and posterior body, respectively; (D) dorsal simple chaeta; (E) ventral simple chaeta; (F) (G) (H) aciculae, anterior, mid- and posterior body, respectively. Scale bars: $20 \mu \mathrm{m}$. 
FIGURE 38. Syllis sp. n. 5, SEM. (A) complete specimen, dorsal view; (B) (C) anterior body, ventral and dorsal view, respectively; (D) prostomium, ventral view, white arrow indicating row of cilia on palp; (E) anterior body, ventro-lateral view; (F) anterior body, dorsal view; white arrow indicating rows of cilia between median and lateral antennae, black arrows indicating transverse row of cilia on anterior boarder of peristomium; $(\mathrm{G})$ close up of nuchal organ and row of cilia on peristomium, white arrow indicating nuchal organ, black arrow indicating the peristomial ciliation; $(\mathrm{H})$ close up of ventral surface, anterior body, white arrows indicating pores; (I) close up of of ciliation between median and lateral antennae. la-lateral antenna, pa-palps, pr-prostomium, peperistomium,. Scale bars: A, $1 \mathrm{~mm}$; B, E, $200 \mu \mathrm{m}$; C, F, $100 \mu \mathrm{m}$; D, $50 \mu \mathrm{m}$; G, I, $10 \mu \mathrm{m}$; $\mathrm{H}, 5 \mu \mathrm{m}$.

FIGURE 39. Syllis sp. n. 5, SEM. (A) (B) (C) falcigers, anterior body; (D) (E) falcigers, midbody, white arrow indicating protruding acicula; (F) posterior body, ventral view, white arrow indicating anal papilla; (G) chaetae, posterior body, white arrow indicating protruding acicula; $(\mathrm{H})$ ventralmost falciger, posterior body; (I) ventral simple chaeta; (J) midbody, ventral view; (K) pygidium, frontal view, white arrow indicating anus, red arrow indicating anal papilla; (L) posterior body, ventral view. dsc — dorsal simple chaeta. Scale bars: A-E, $20 \mu \mathrm{m} ; \mathrm{F}, \mathrm{J}, 100 \mu \mathrm{m} ; \mathrm{G}-\mathrm{H}, 5 \mu \mathrm{m} ; \mathrm{I}, 2 \mu \mathrm{m}$; $\mathrm{K}, 10 \mu \mathrm{m}$.

FIGURE 40. Syllis sp. n. 5. (A) (B) (C) falcigers, anterior, mid- and posterior body, respectively; (D) dorsal simple chaeta; (E) ventral simple chaeta; (F) (G) (H) aciculae, anterior, mid- and posterior body, respectively. Scale bars: $10 \mu \mathrm{m}$. 
TABLE 1. Selected morphological features of Megasyllis procera specimens from Brazil.

\begin{tabular}{|c|c|c|c|c|c|c|}
\hline Megasyllis procera & Specimen 1 & Specimen 2 & Specimen 3 & Specimen 4 & Specimen 5 & Specimen 6 \\
\hline Collection data & \multicolumn{6}{|c|}{ State of Paraíba, Farol de Pitimbu $\left(7^{\circ} 28.362^{\prime} \mathrm{S} 34^{\circ} 47^{\prime} \mathrm{W}\right)$, intertidal, coll. 18 September 2012} \\
\hline $\begin{array}{l}\text { Number of chaetigers }+ \text { posterior achetous segments / Total } \\
\text { length } \mathrm{x} \text { width at proventricle }(\mathrm{mm})\end{array}$ & $\begin{array}{l}52+4 / 8.5 \times \\
0.32\end{array}$ & $35+3 / 7 \times 0.35$ & $61+1 / 10 \times 0.34$ & $\begin{array}{l}56+1 / 6.8 \times \\
0.32\end{array}$ & $72+1 / 1 \times 0.3$ & $67 / 1 \times 0.3$ \\
\hline Length of pharynx (chaetigers) & 3 & 2 & 2.5 & 3 & 3 & 3 \\
\hline $\begin{array}{l}\text { Length of proventricle (chaetigers) / length / number of } \\
\text { muscle cell rows }\end{array}$ & $2.5 / 0.35 / 27$ & $3 / 0.41 / 23$ & $2 / 0.3 / 23$ & $3 / 0.42 / 23$ & $2.5 / 0.3 / 24$ & $3 / 0.33 / 22$ \\
\hline \multicolumn{7}{|l|}{ Number of articles } \\
\hline Central antennae & 20 & $\begin{array}{l}4 \text { (elongated } \\
\text { articles) }\end{array}$ & $?$ & 17 & 15 & 15 \\
\hline Lateral antennae & 12,11 & 17,18 & 13,15 & 12,14 & 10,11 & 12,10 \\
\hline Peristomial dorsal / ventral cirri & $21,21 / 11.11$ & $18,22 / 14,11$ & $17,22 / 13,10$ & $19,22 / 12,11$ & $18,17 / 10,10$ & $19, ? / 13, ?$ \\
\hline Dorsal cirri $1 / 2$ & $?, 19 / 14,11$ & $18, ? / 16,15$ & 30,29 & 17,19 & 22,23 & 22,25 \\
\hline Dorsal cirri 3 / 4 & $16, ? / 15,23$ & $24,23 / 9,12$ & $11, ?$ & 11,14 & 9,9 & 10,10 \\
\hline Dorsal cirri 5 & 17,14 & 15,16 & 14,16 & 17,24 & 13,13 & $?, ?$ \\
\hline Long cirri, midbody & $15-16$ & $18-21$ & $13-15$ & $16-22$ & $17-21$ & $12-13$ \\
\hline Short cirri, midbody & $11-13$ & $14-17$ & $9-11$ & $14-17$ & $9-14$ & $9-11$ \\
\hline \multicolumn{7}{|l|}{$\begin{array}{l}\text { Length of blades of falcigers }(\mu \mathrm{m}) / \text { number of falcigers } \\
\text { per parapodium }\end{array}$} \\
\hline Anterior body & $20-45 / 12-15$ & $20-45 / 9-16$ & $20-46 / 12-14$ & $25-40 / 13-14$ & $17-35 / 10-14$ & $22-42 / 9-13$ \\
\hline Midbody & $12-15 / 11-14$ & $15-25 / 9-14$ & $15-20 / 10-14$ & $17-27 / 7-12$ & $12-15 / 7-10$ & $12-15 / 7-12$ \\
\hline Posterior body & $15-20 / 2-13$ & $11-17 / 2-16$ & $15-20 / 2-9$ & $15-18 / 2-12$ & $12-17 / 2-9$ & $15-20 / 2-12$ \\
\hline Dorsal / ventral simple chaetae starting from (chaetiger) & $22 / 40$ & $27 / 29$ & $24 / 32$ & $42 / 42$ & $16 / 52$ & $35 / 54$ \\
\hline $\begin{array}{l}\text { Number of aciculae in anterior, medium, posterior } \\
\text { parapodia }\end{array}$ & $2,2,1$ & $3,2,1$ & $3,2,1$ & $3,1-2,1$ & $2-3,1,1$ & $2,1,1$ \\
\hline
\end{tabular}



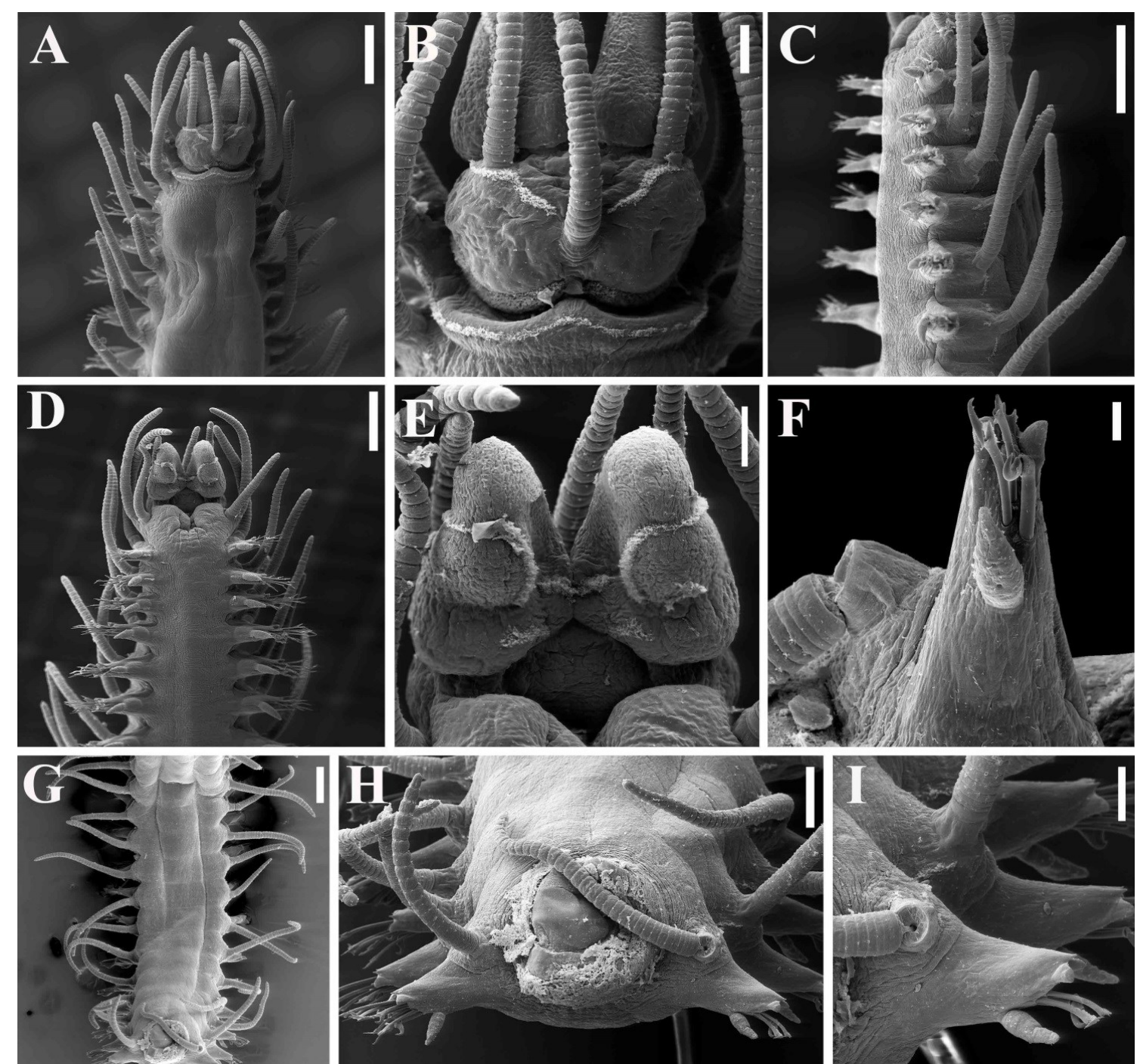

Figura 1 


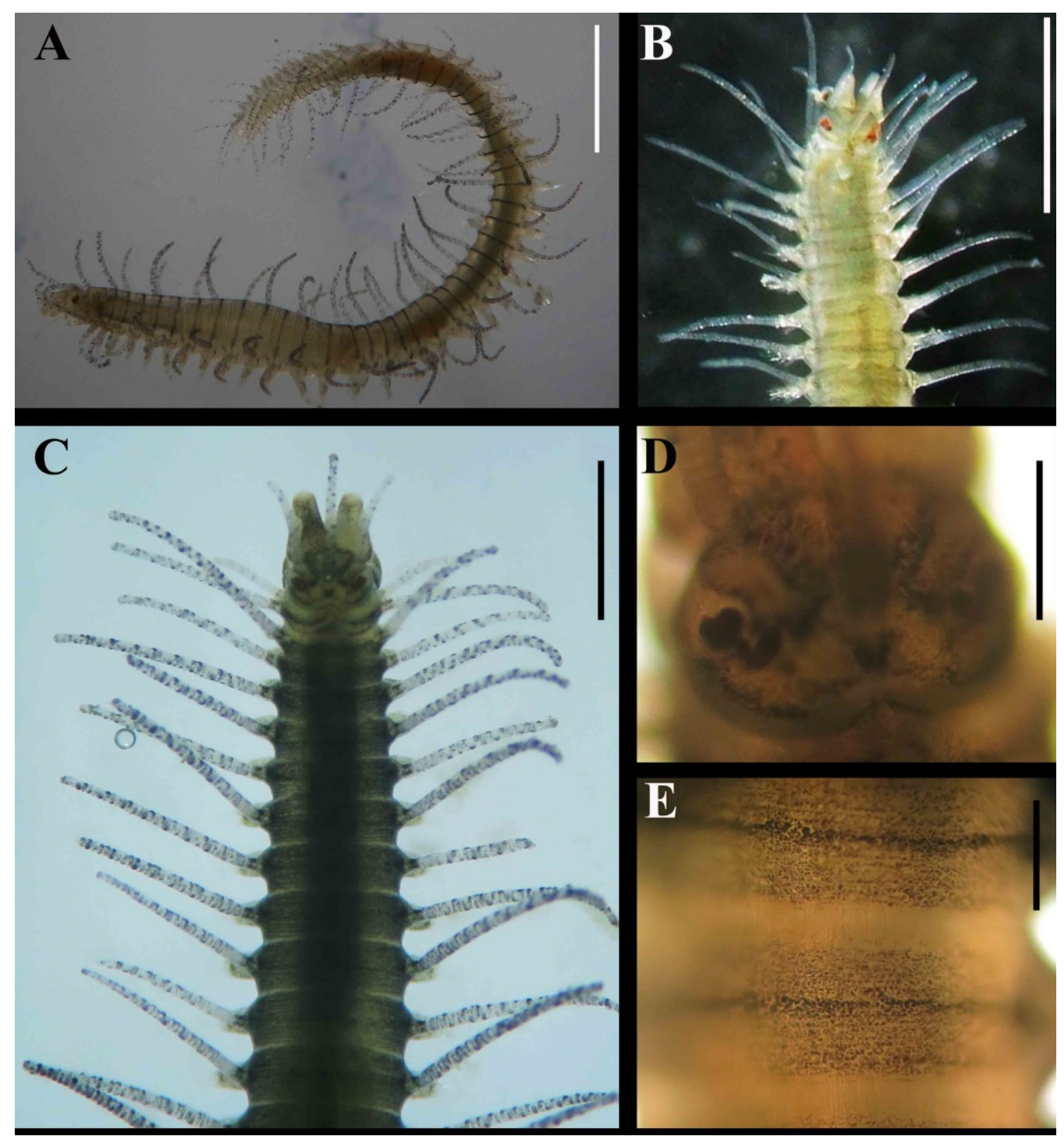

Figura 2 

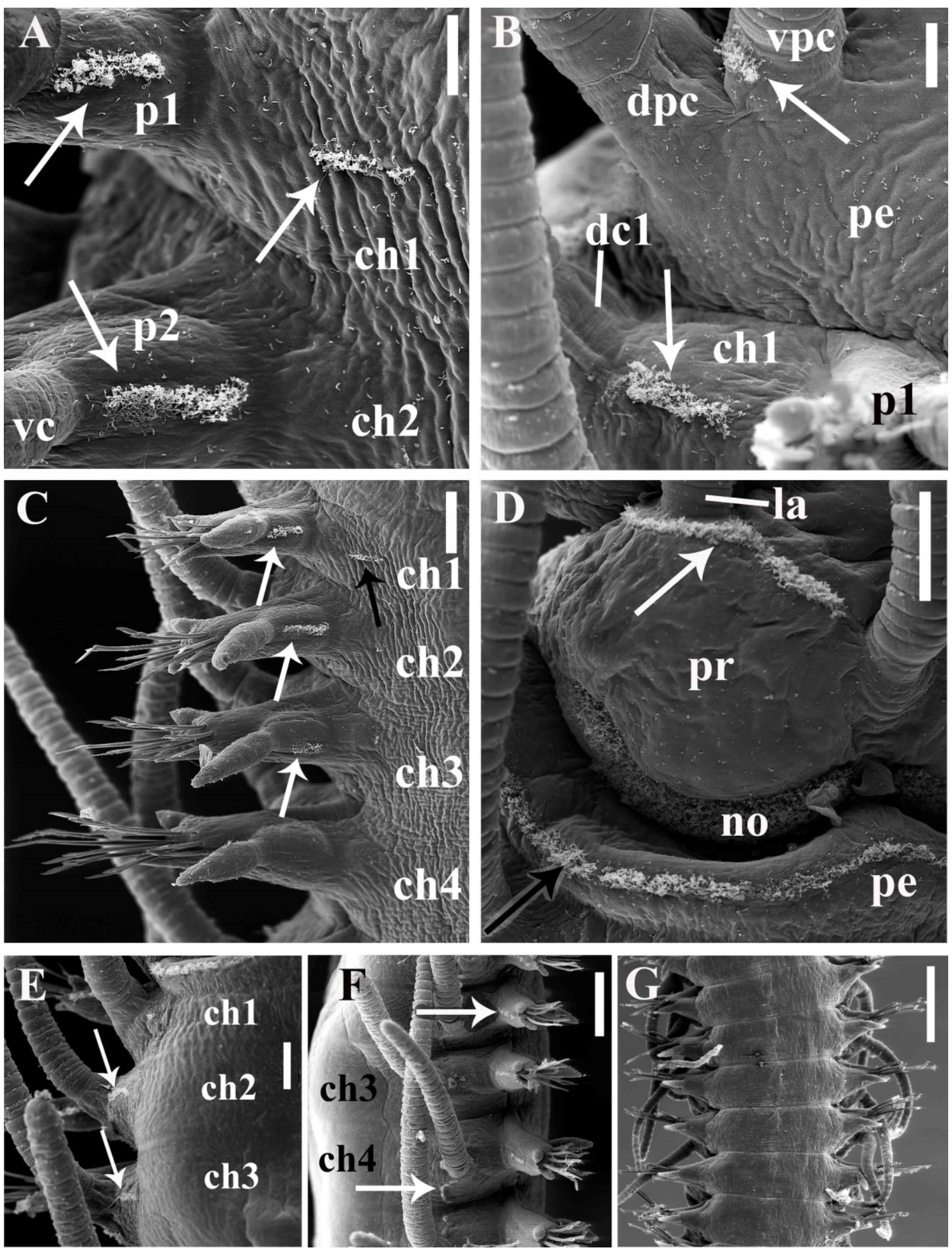

Figura 3 

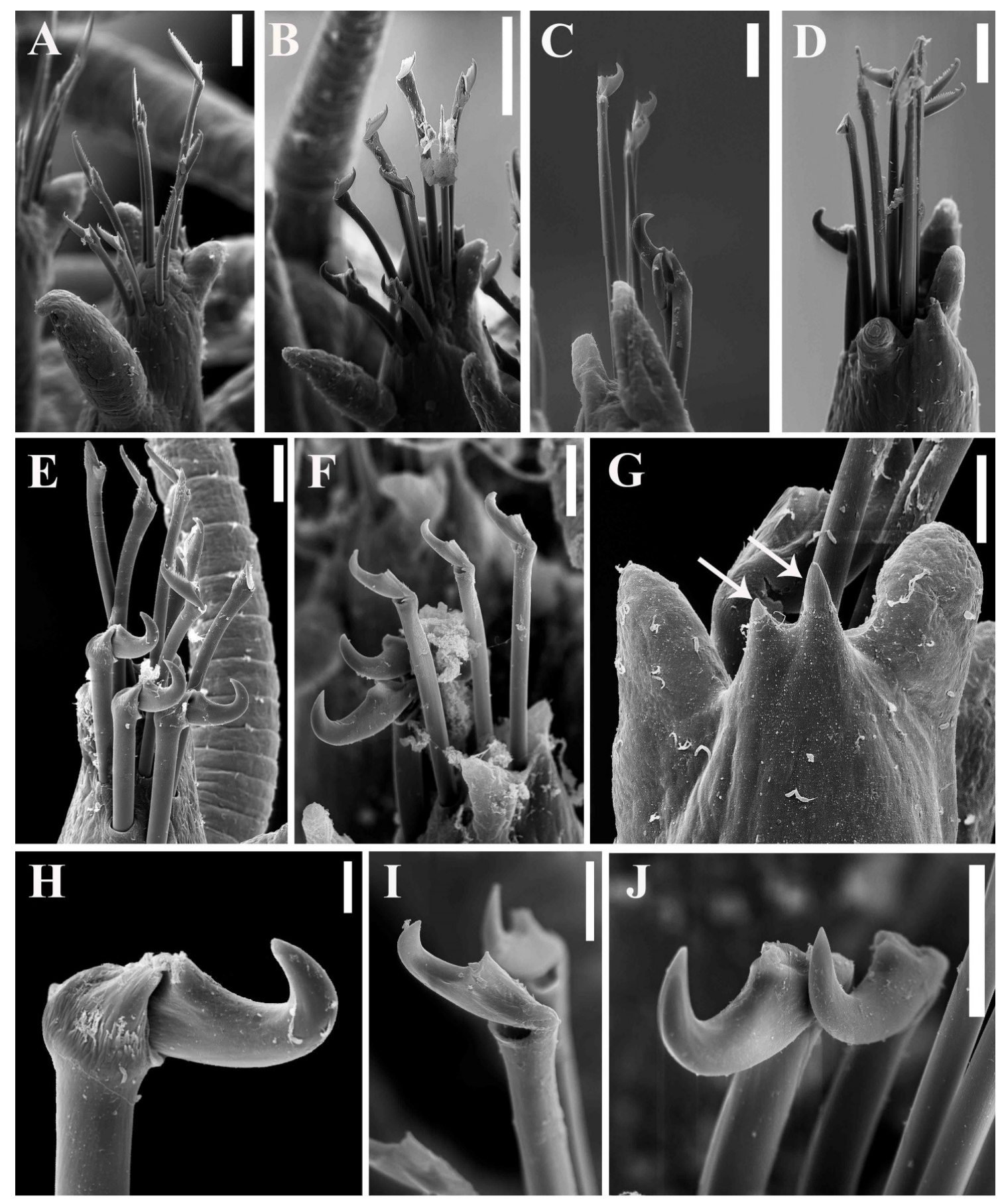

Figura 4 


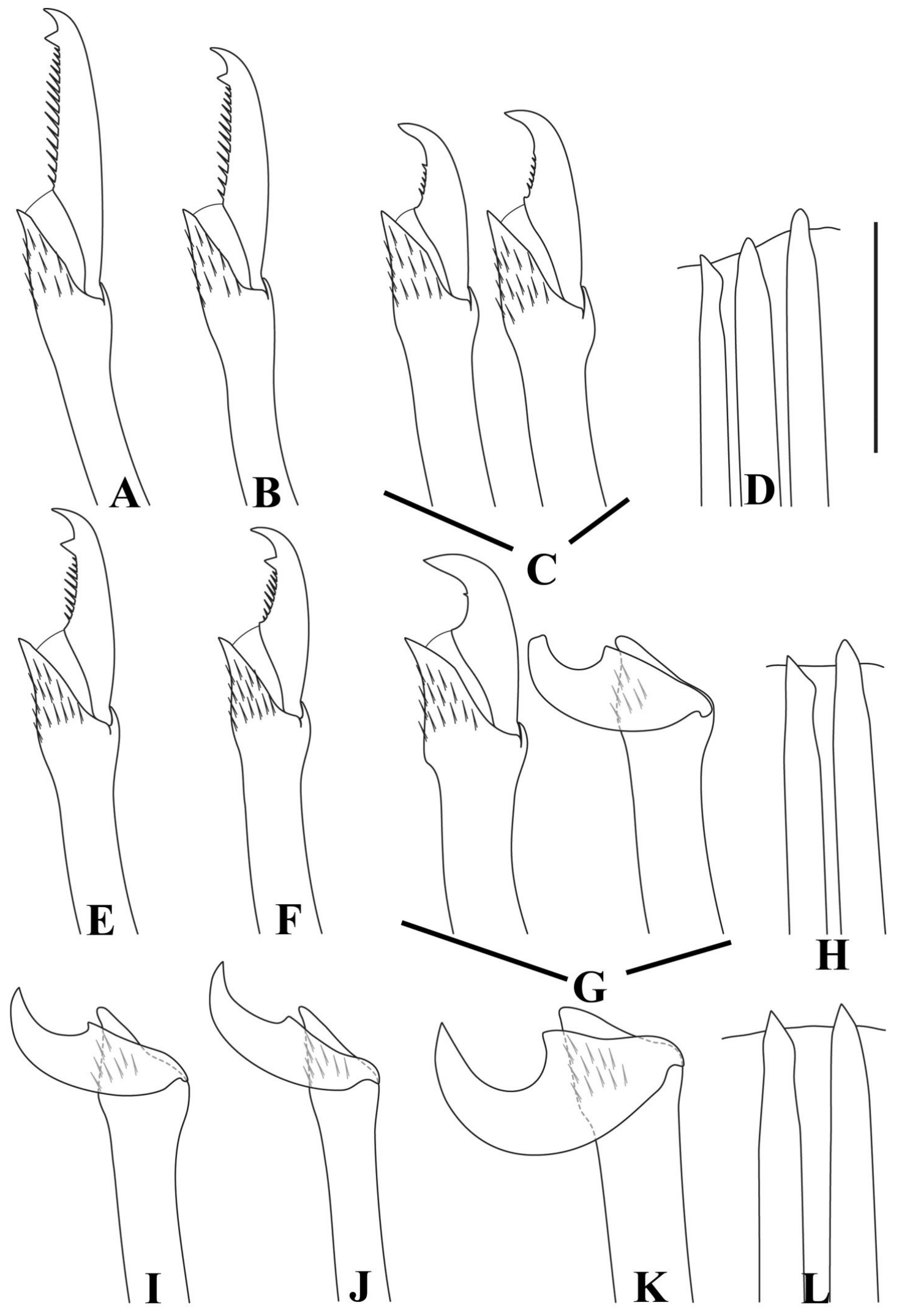

Figura 5 


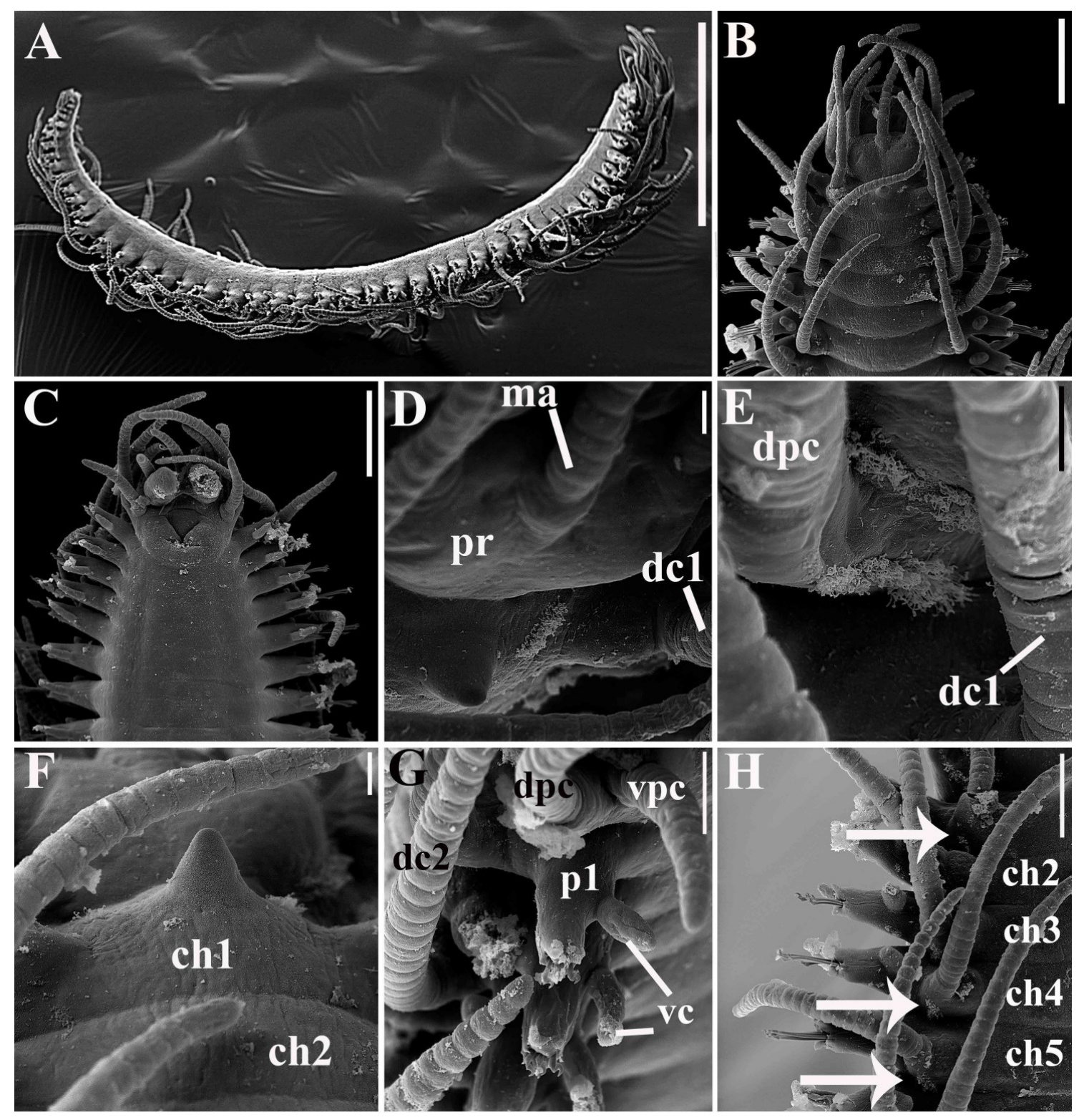

Figura 6 

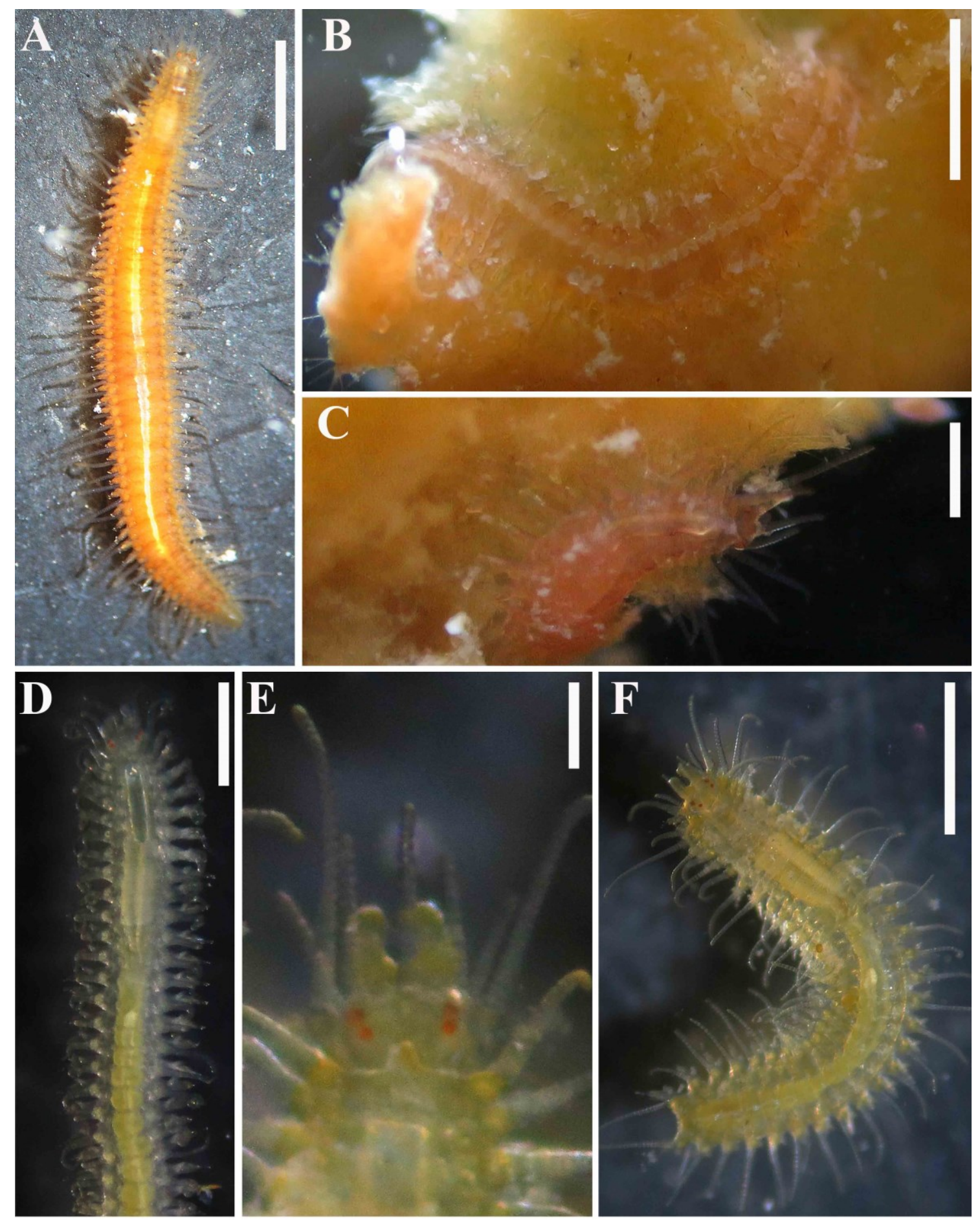

Figura 7 


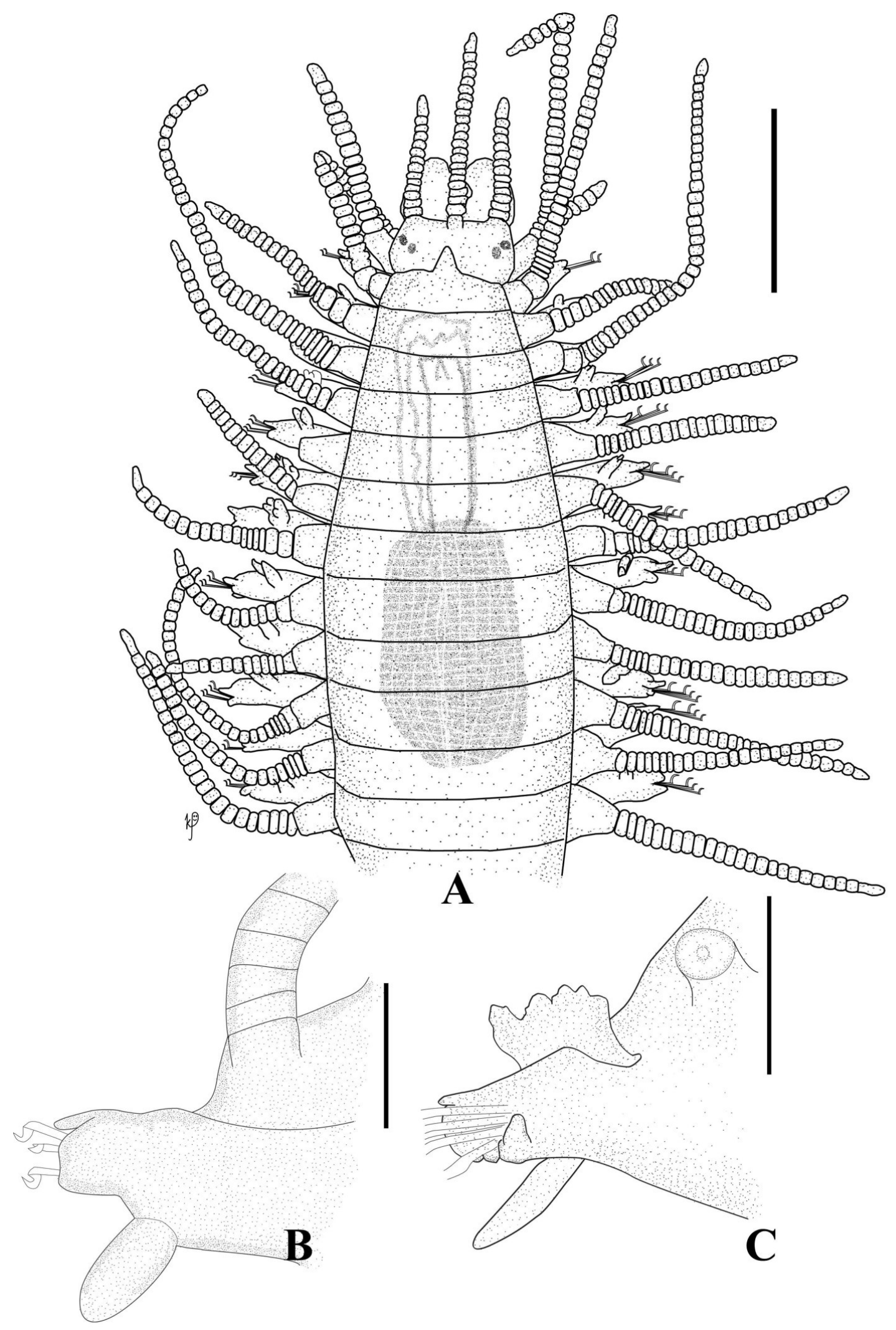

Figura 8 


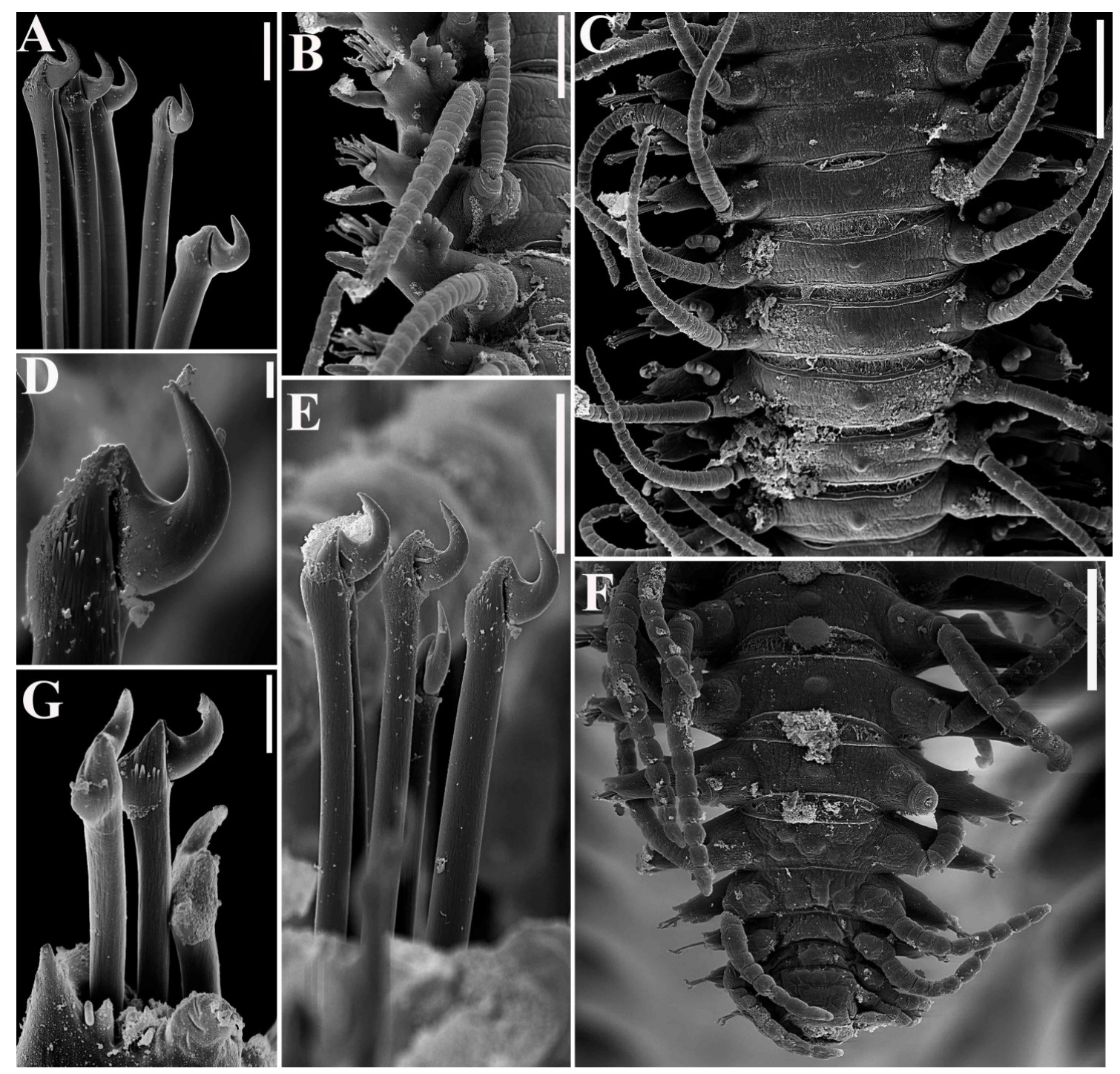

Figura 9 


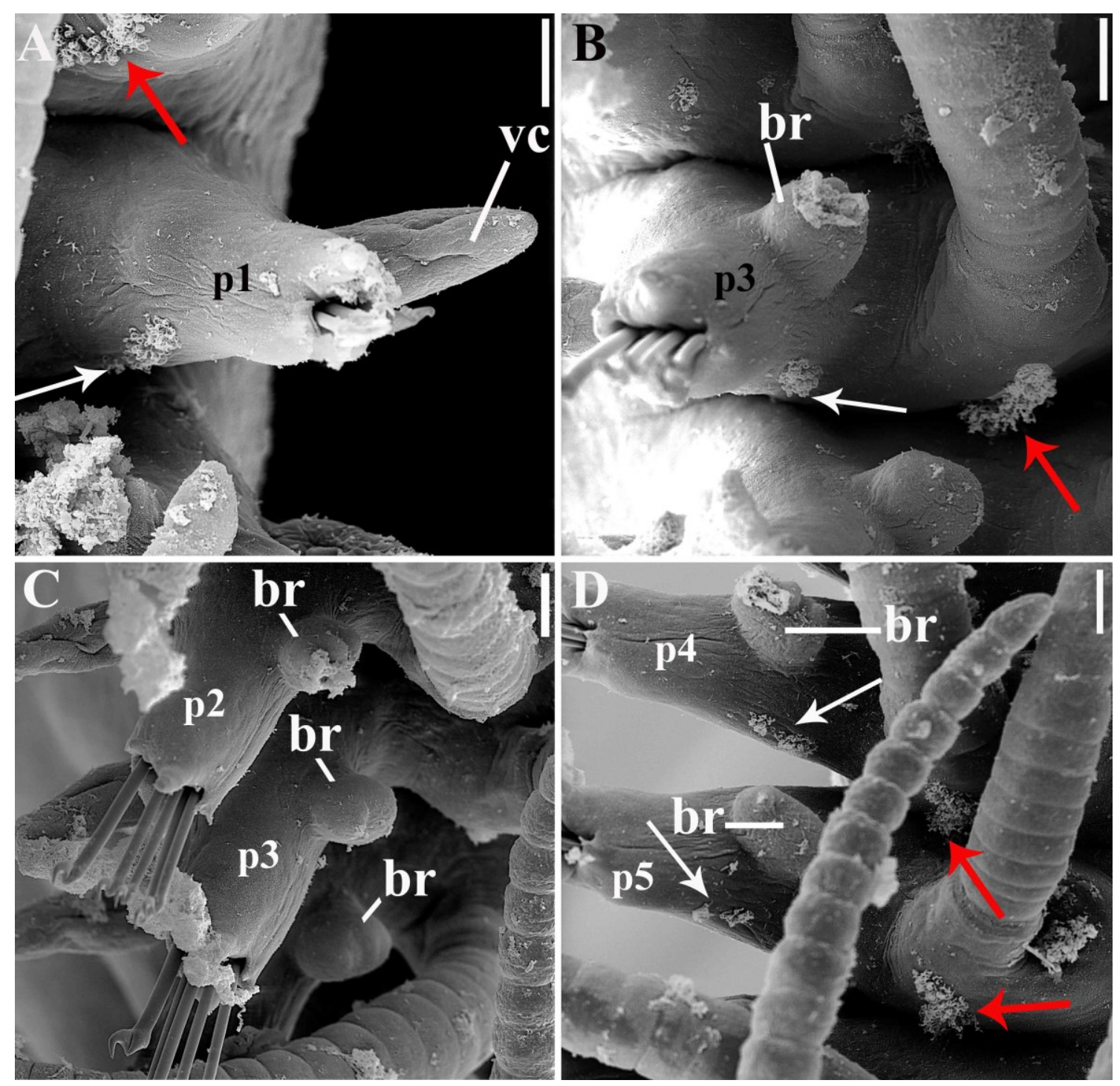

Figura 10 


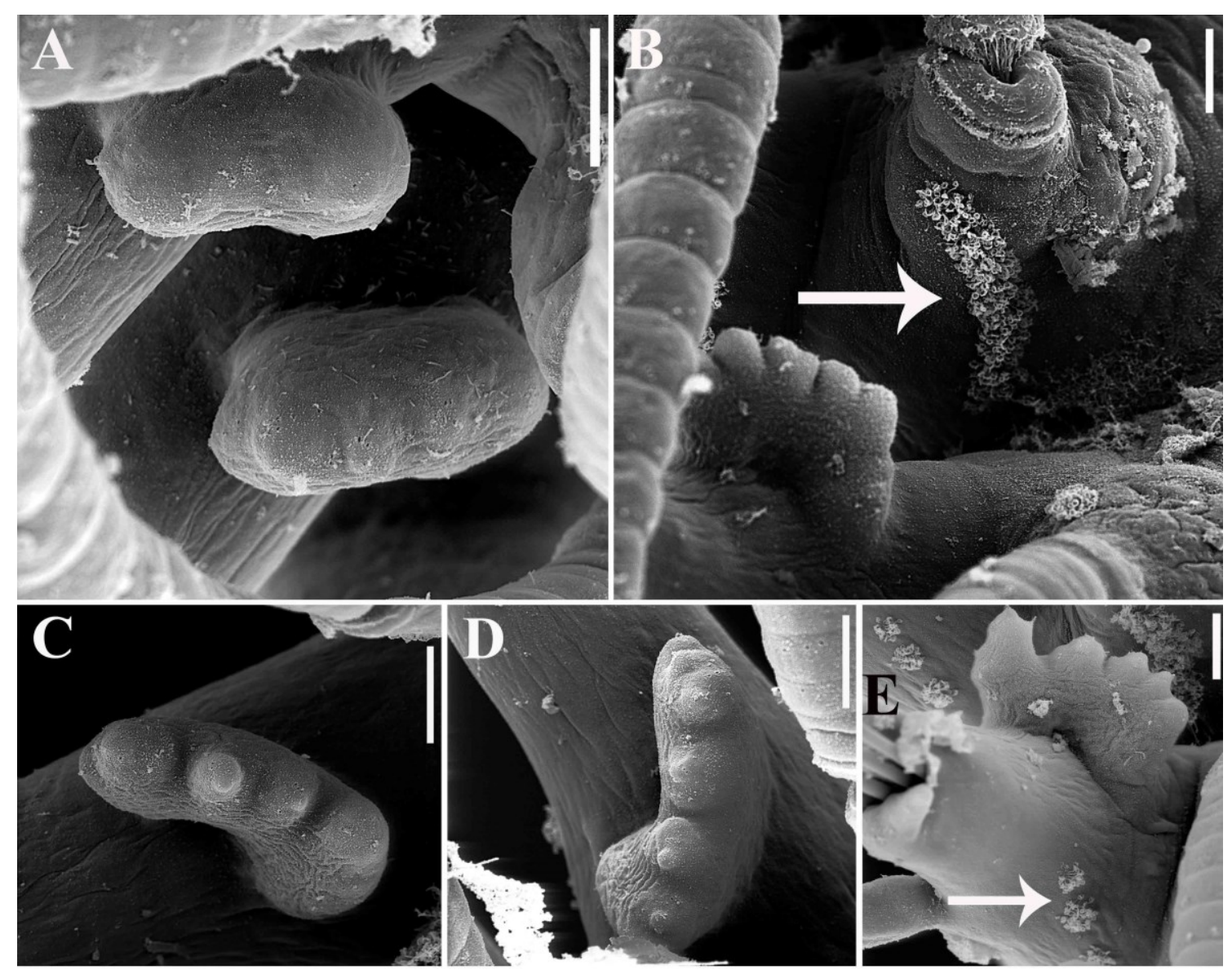

Figura 11 

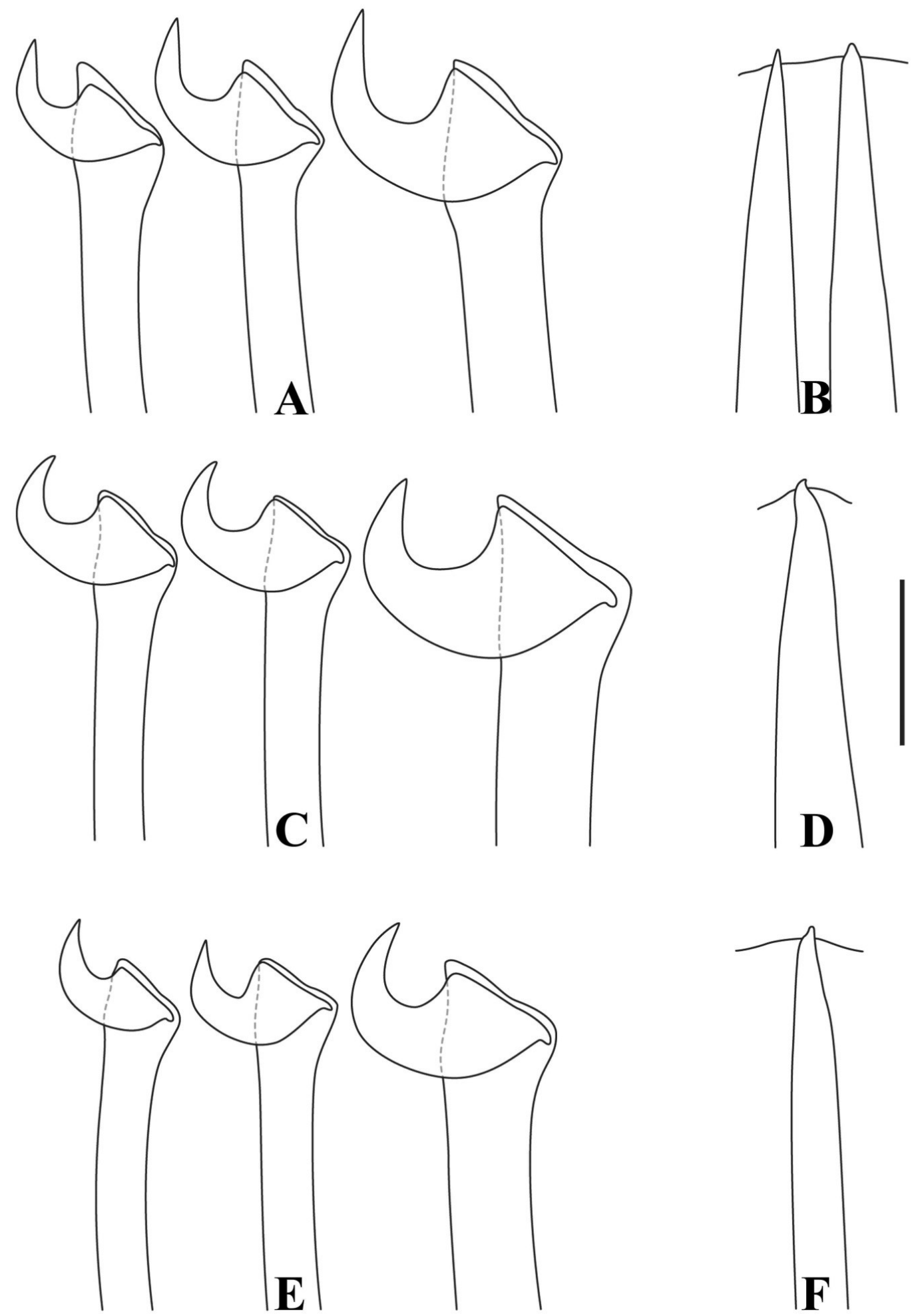

Figura 12 


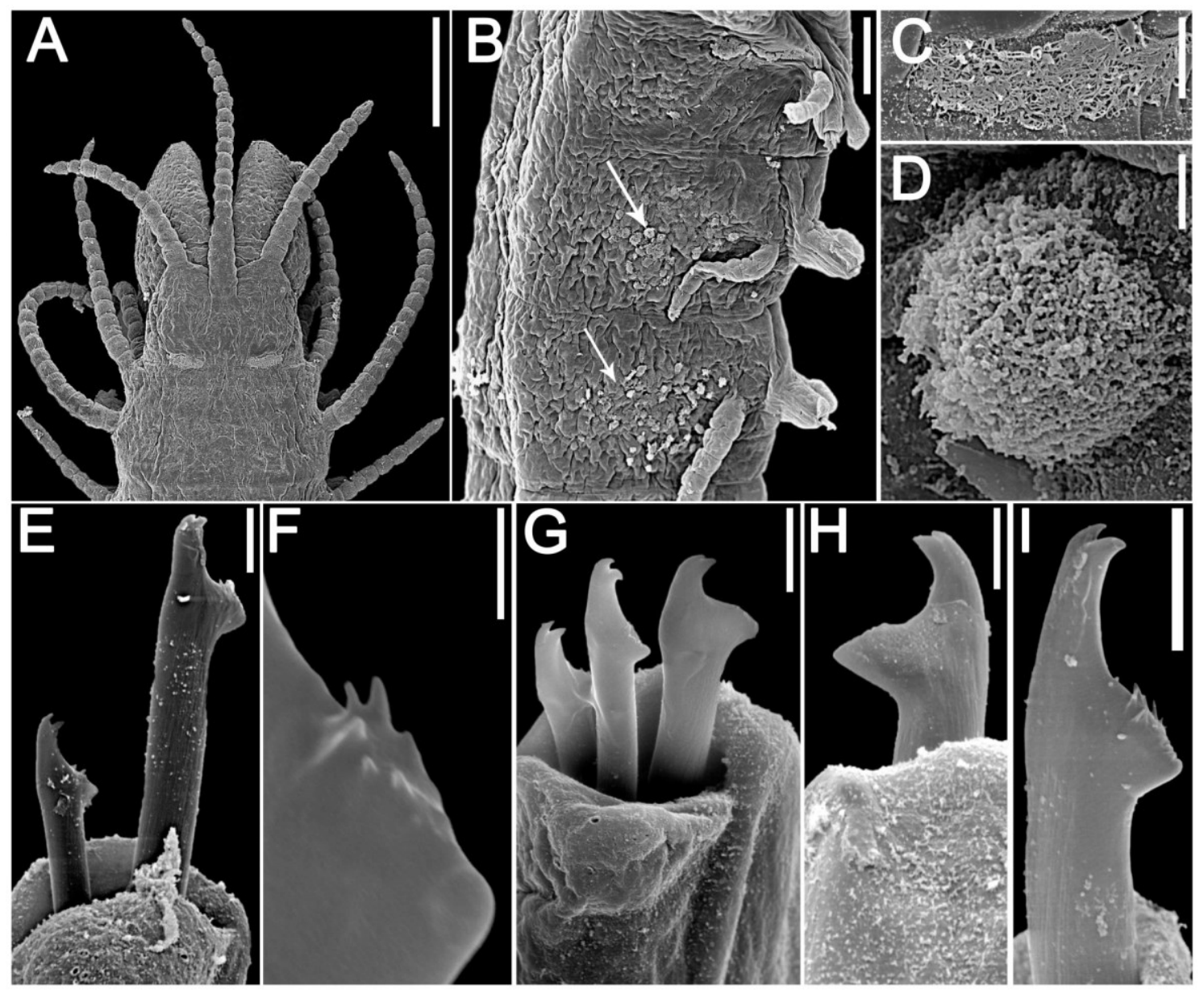

Figura 13 


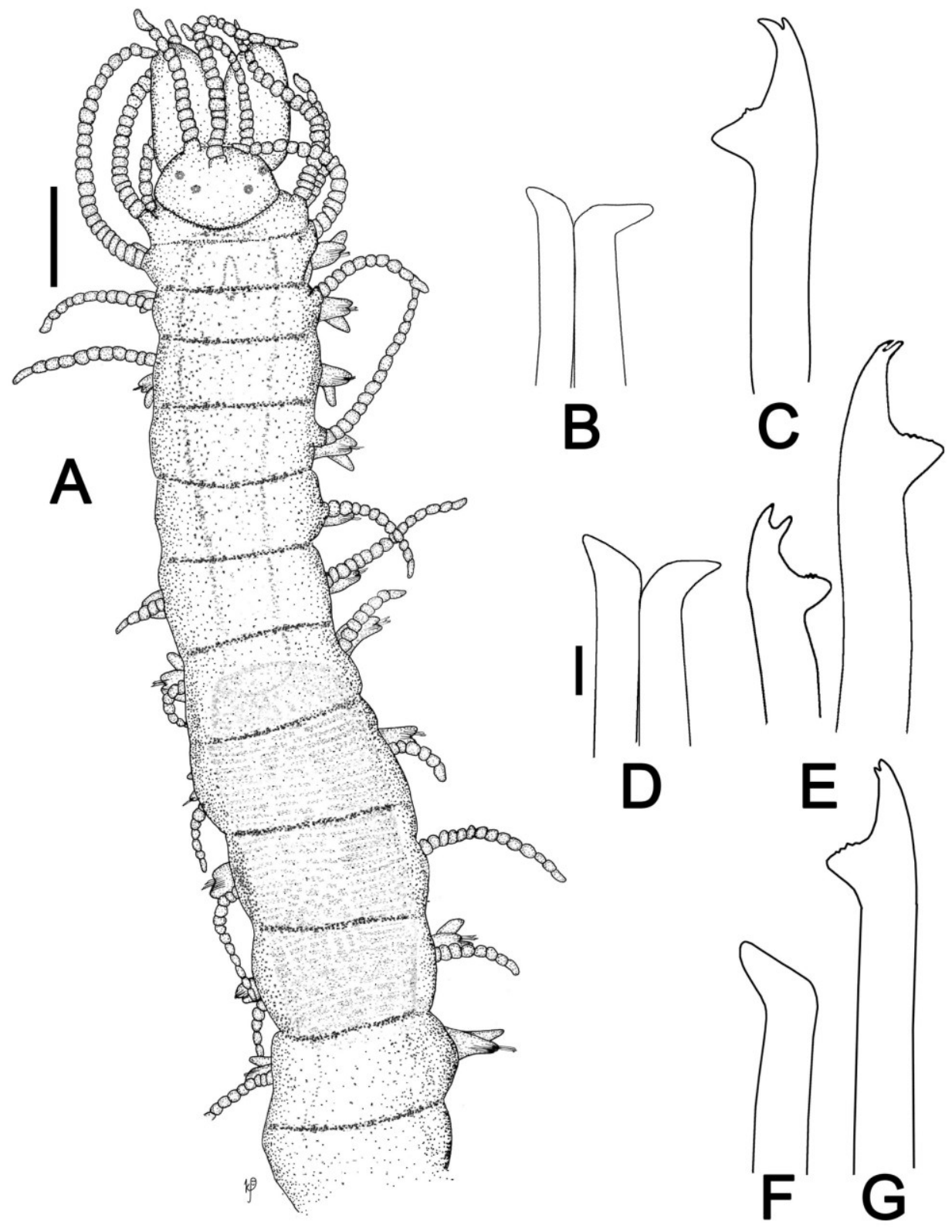

Figura 14
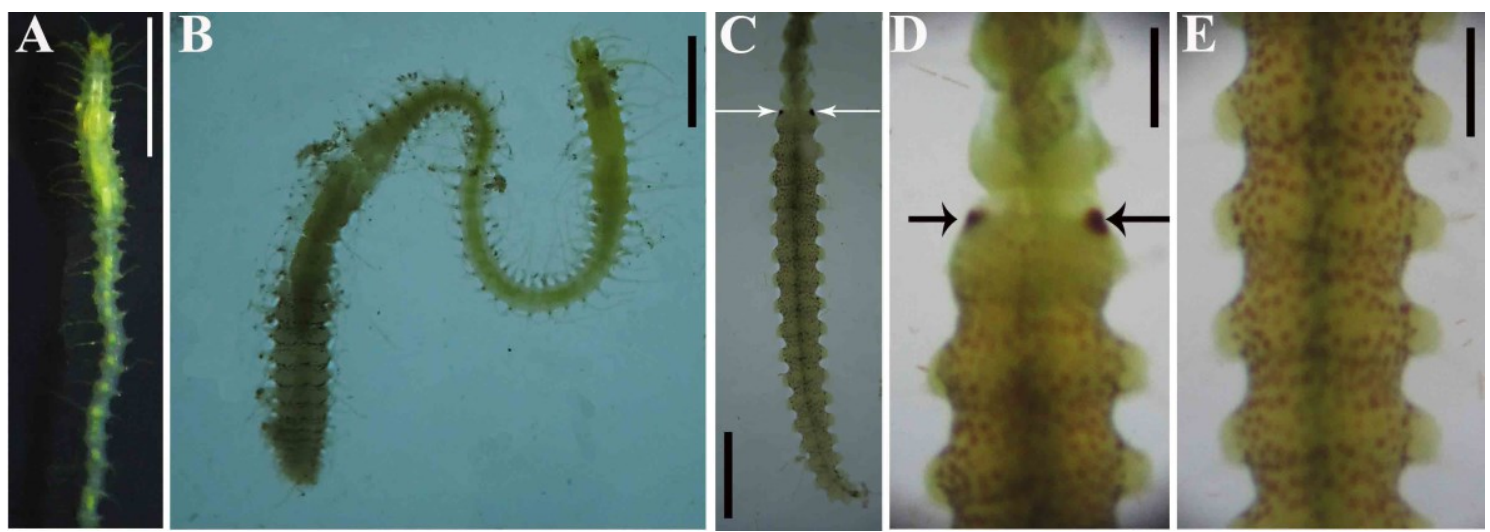

Figura 15 

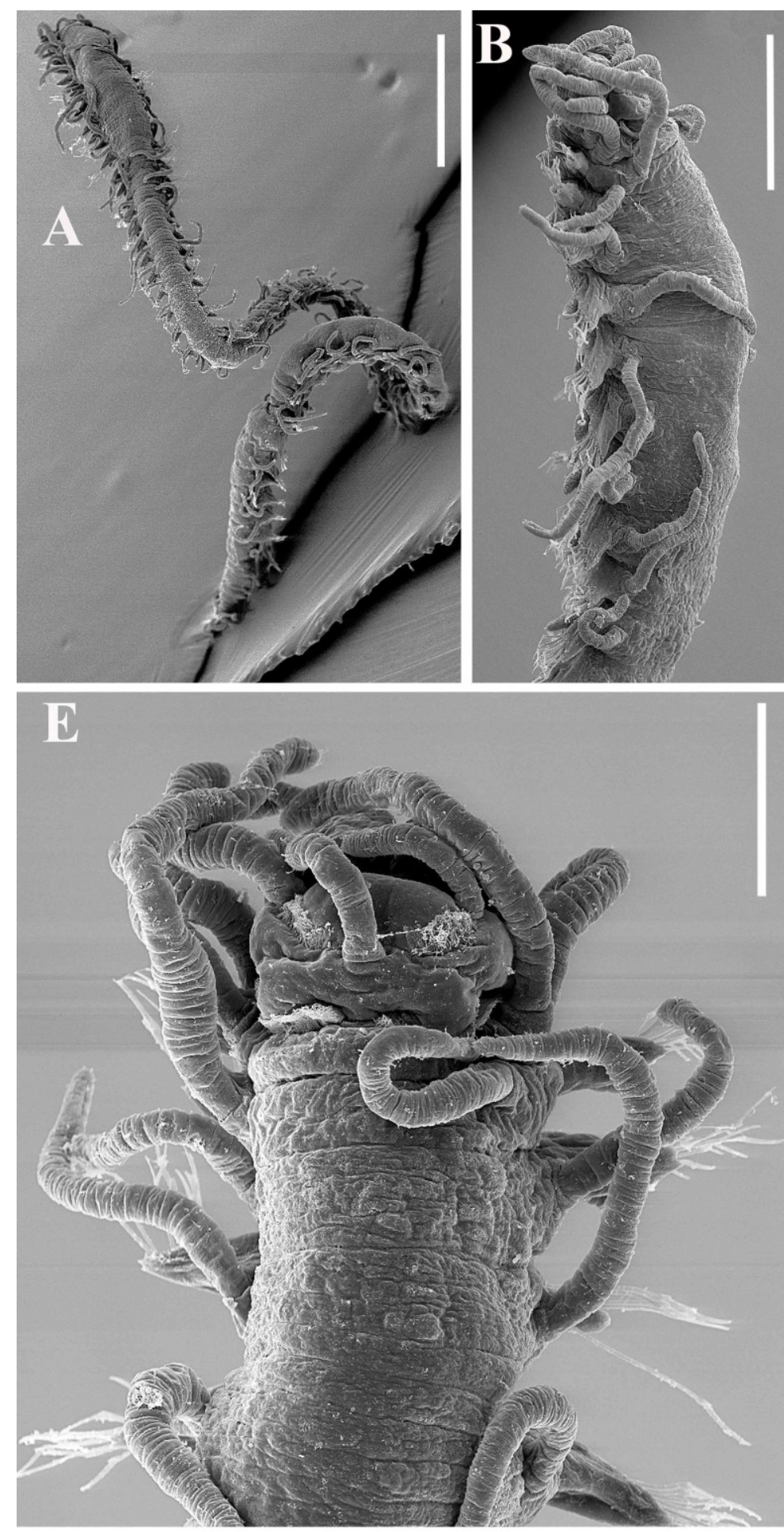
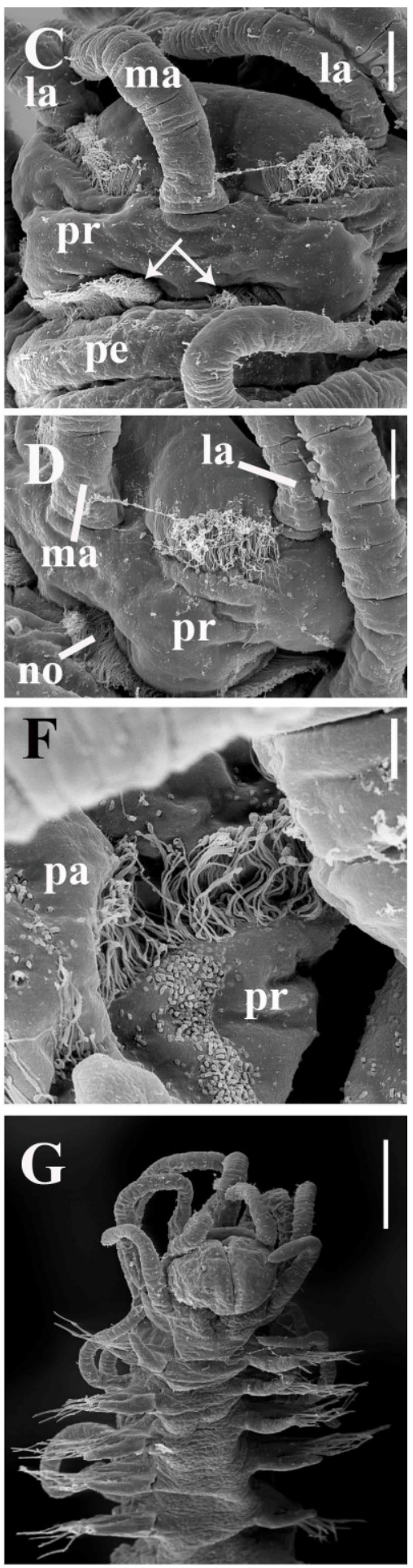

Figura 16 


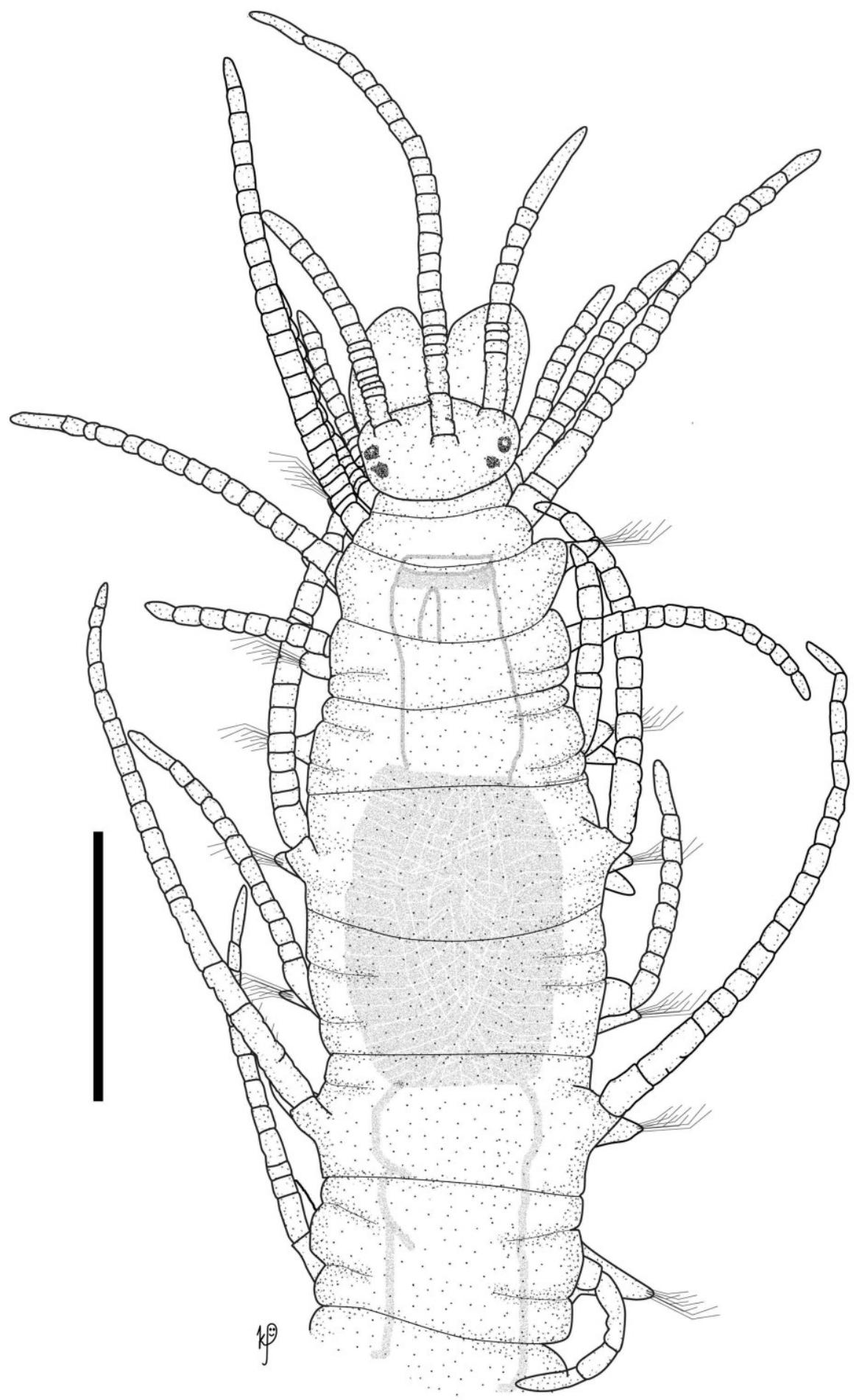

Figura 17 


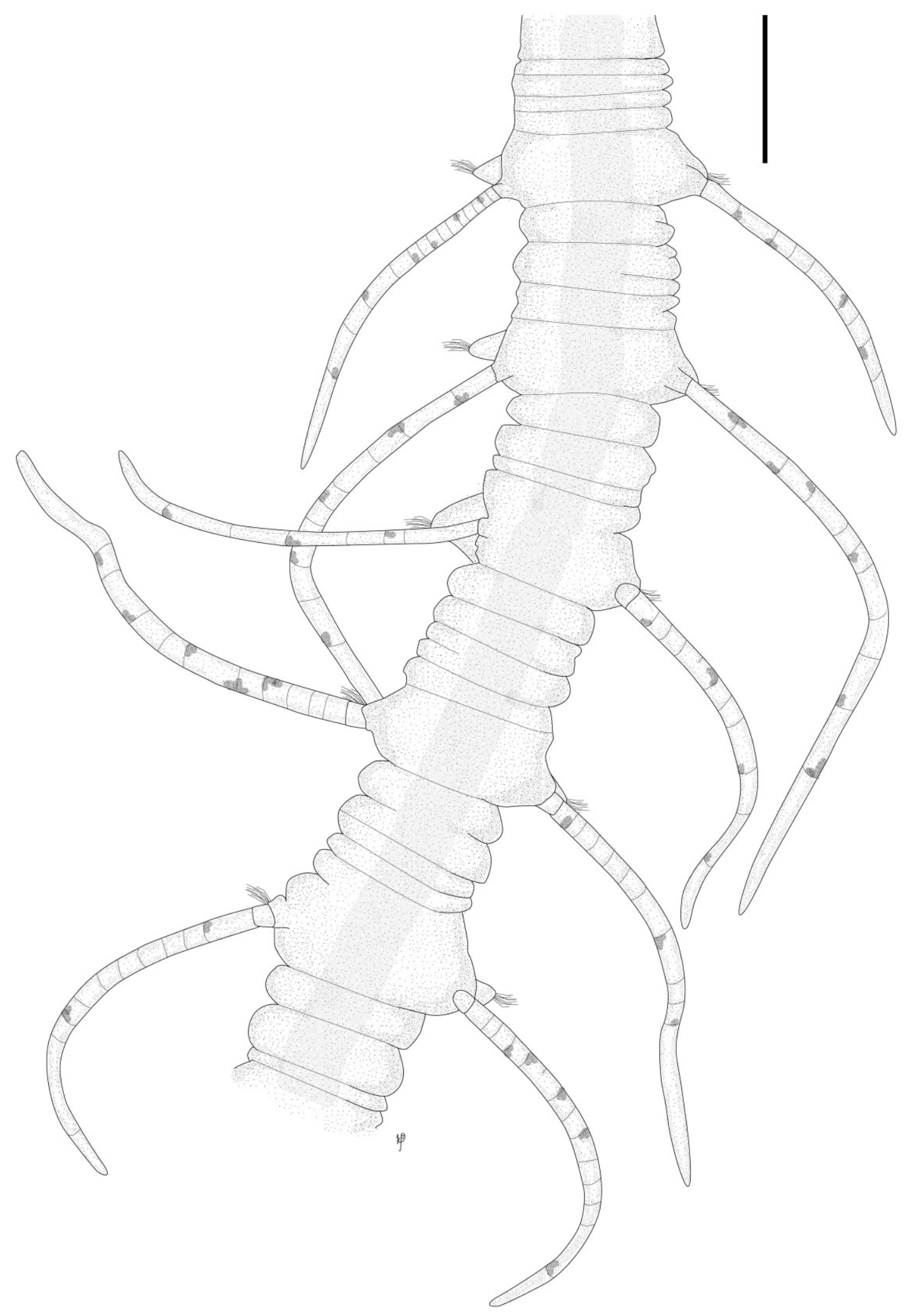

Figura 18 

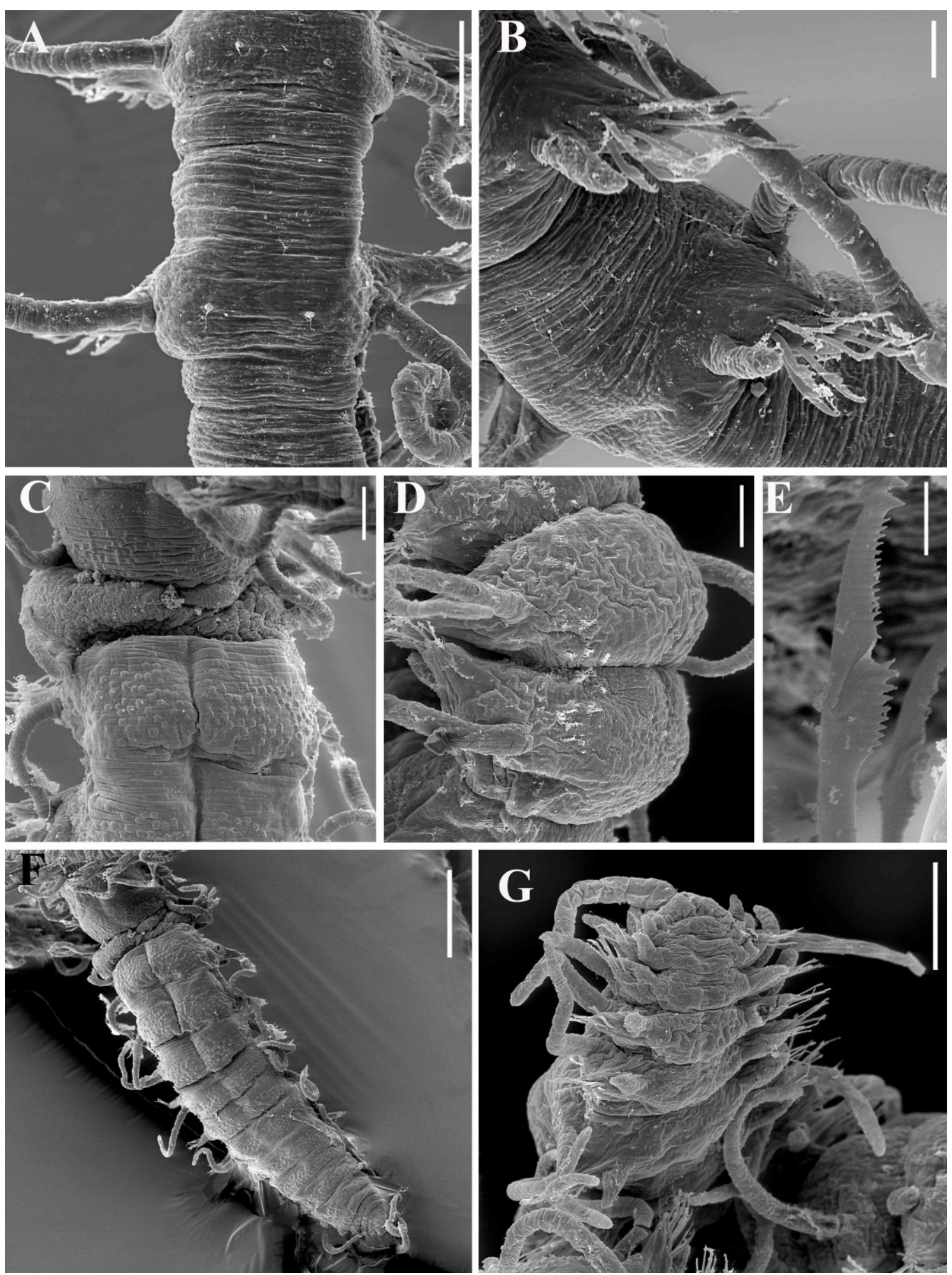

Figura 19 


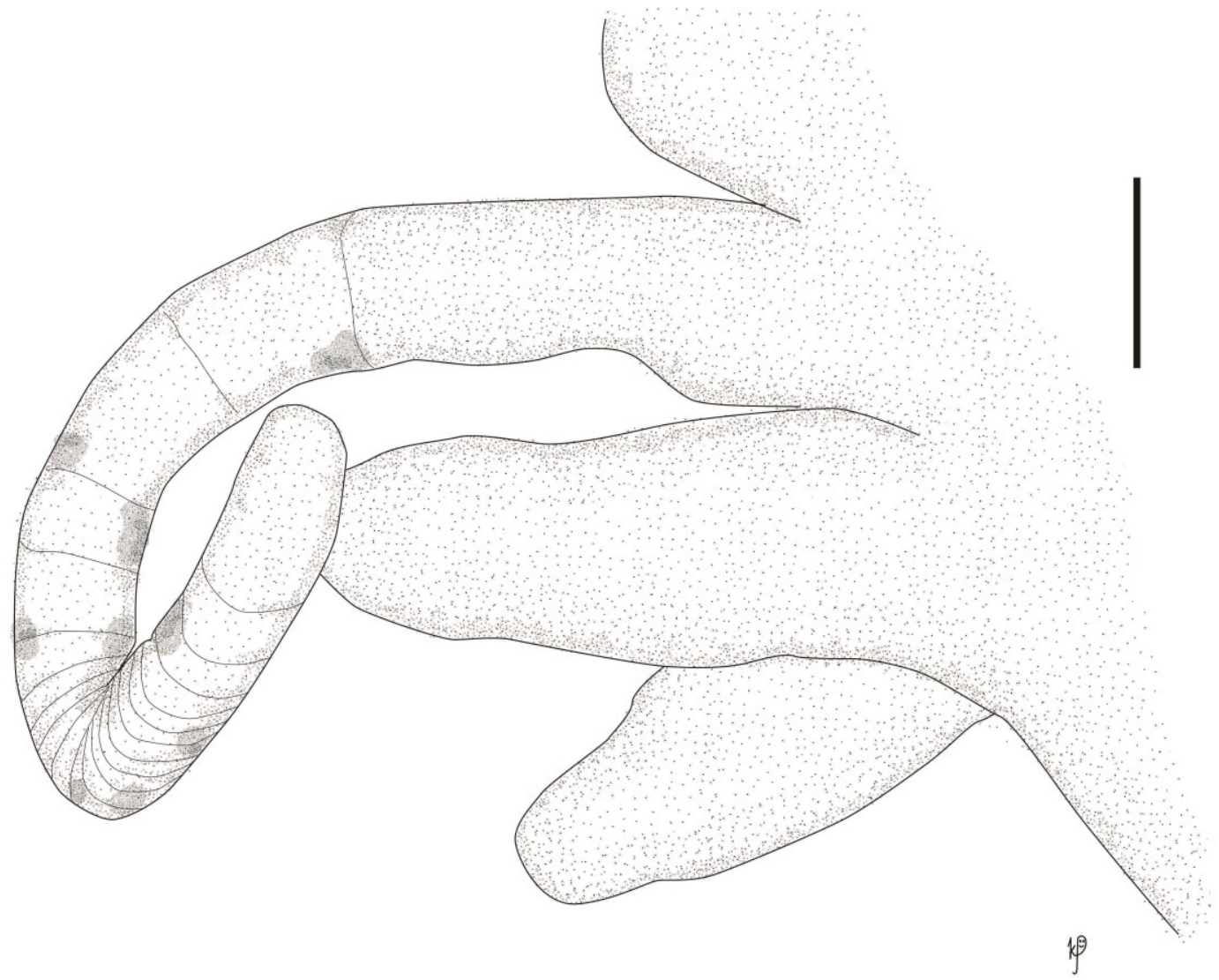

Figura 20 


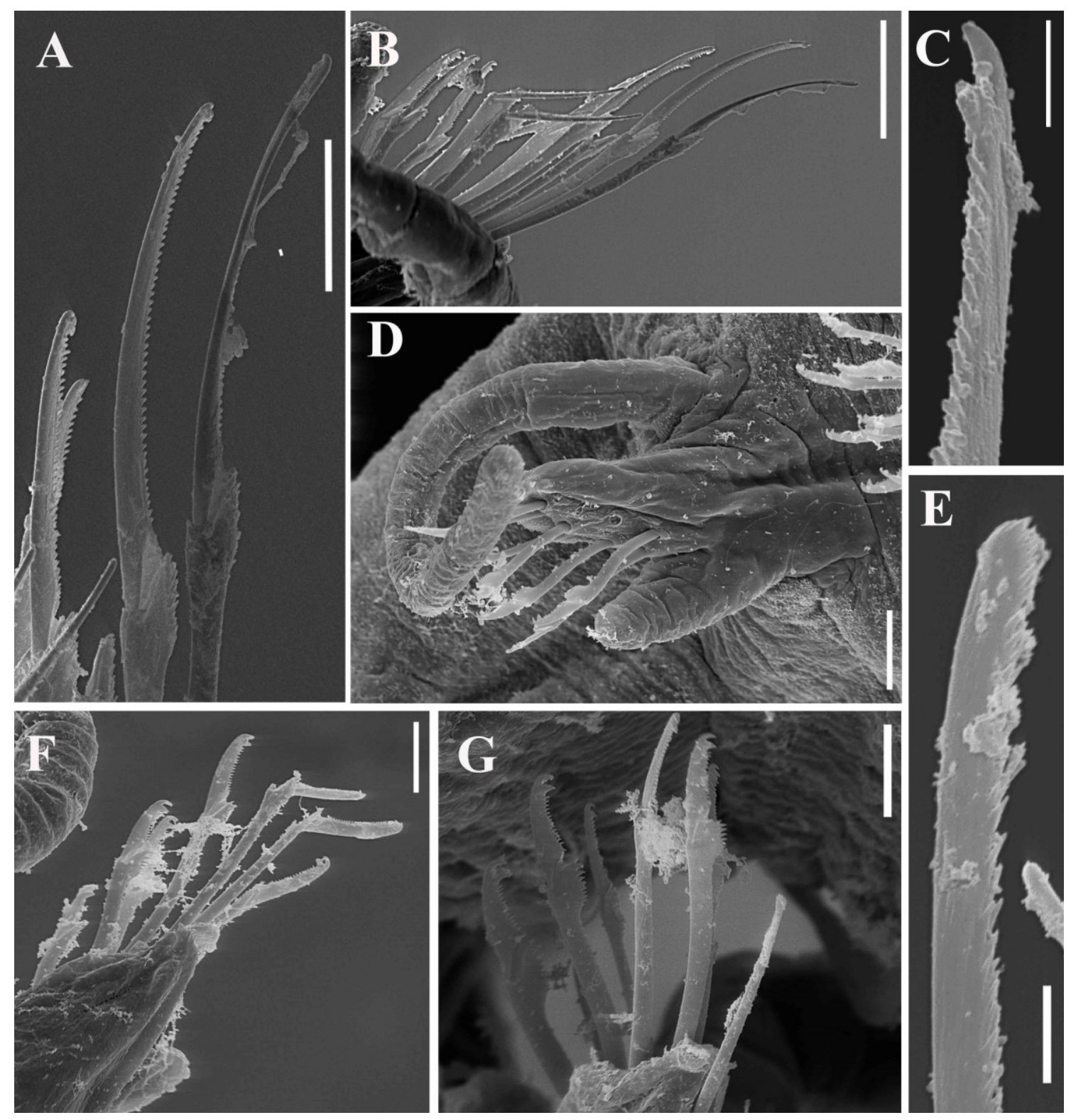

Figura 21 


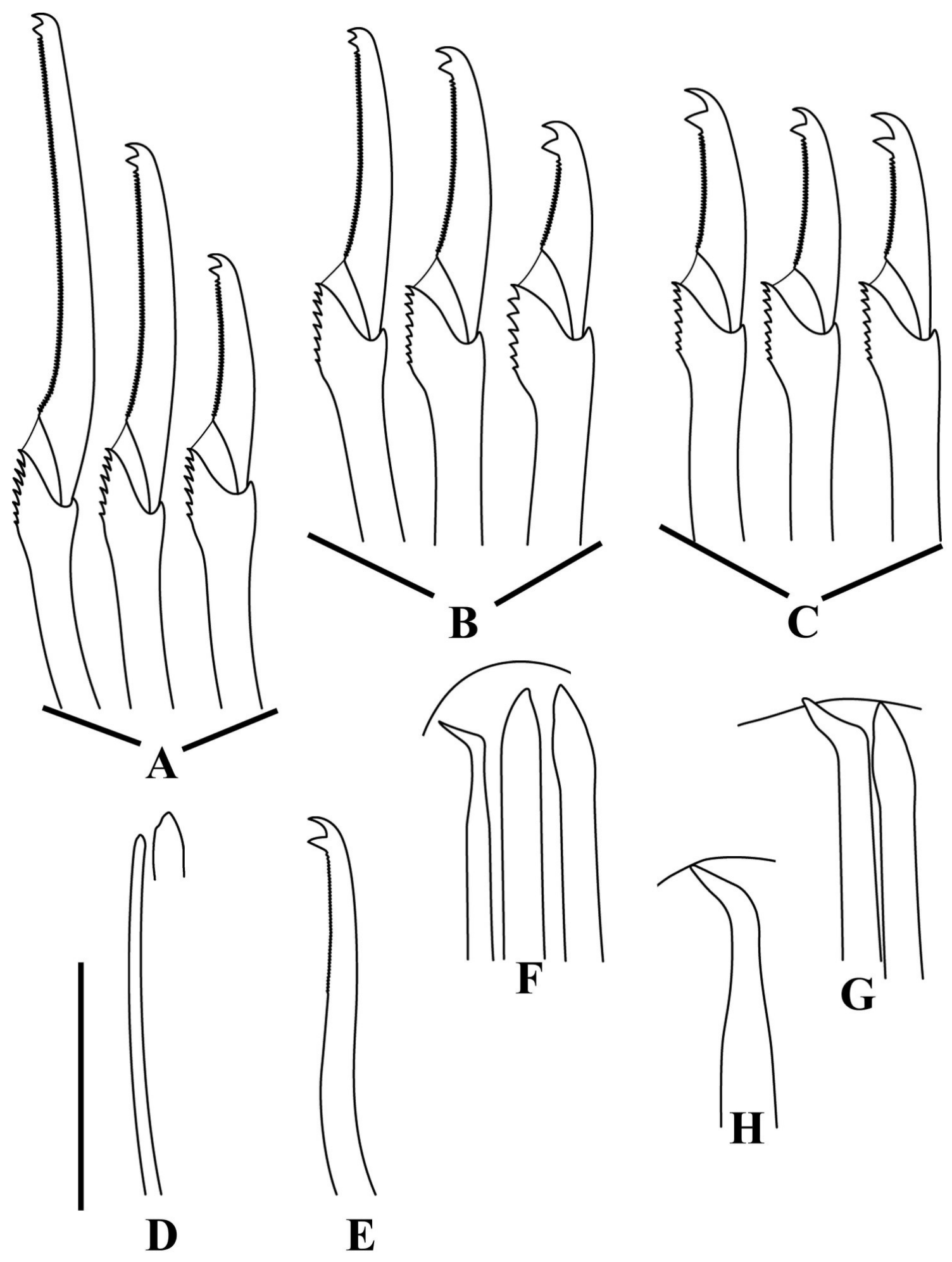

Figura 22 

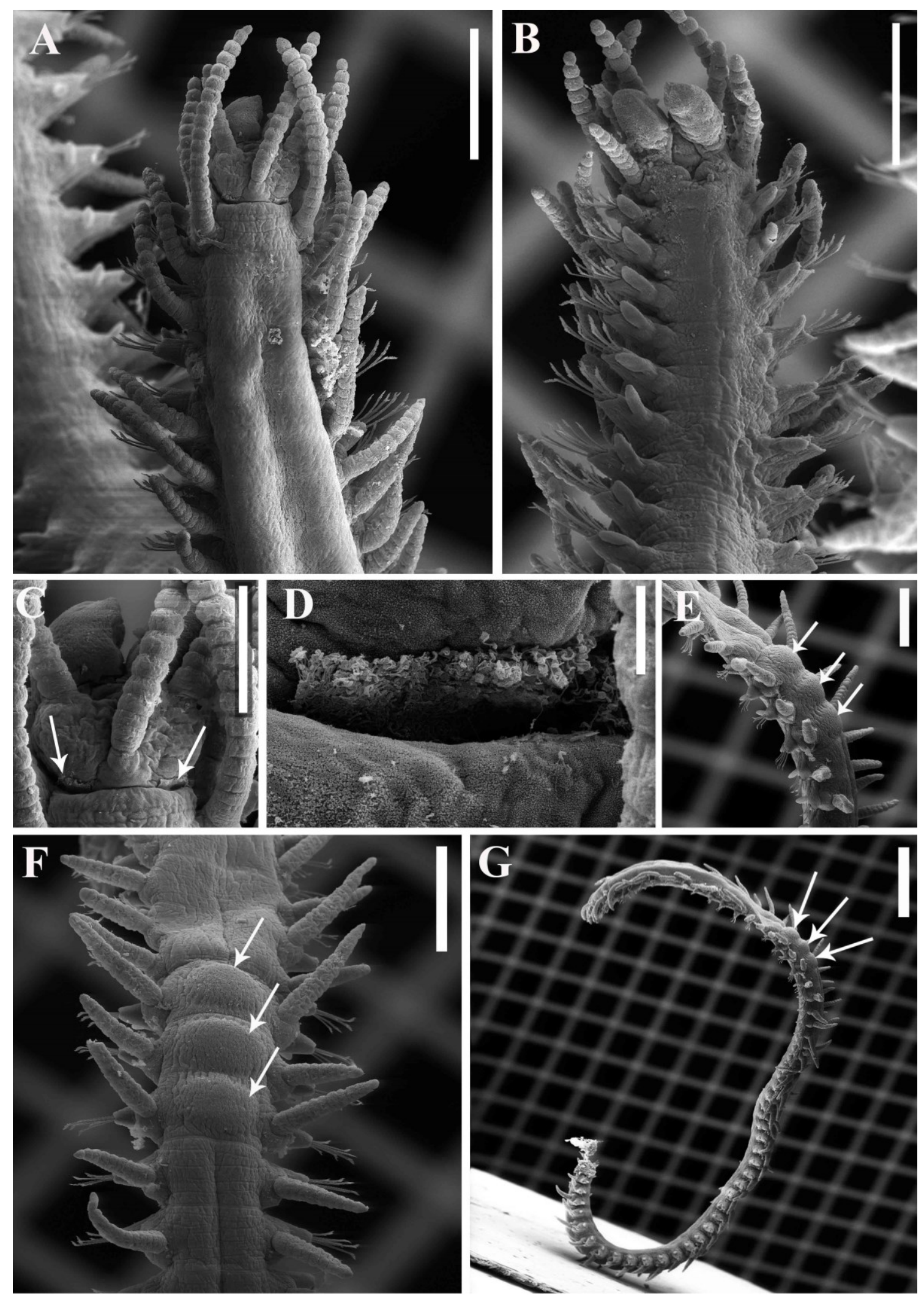

Figura 23 

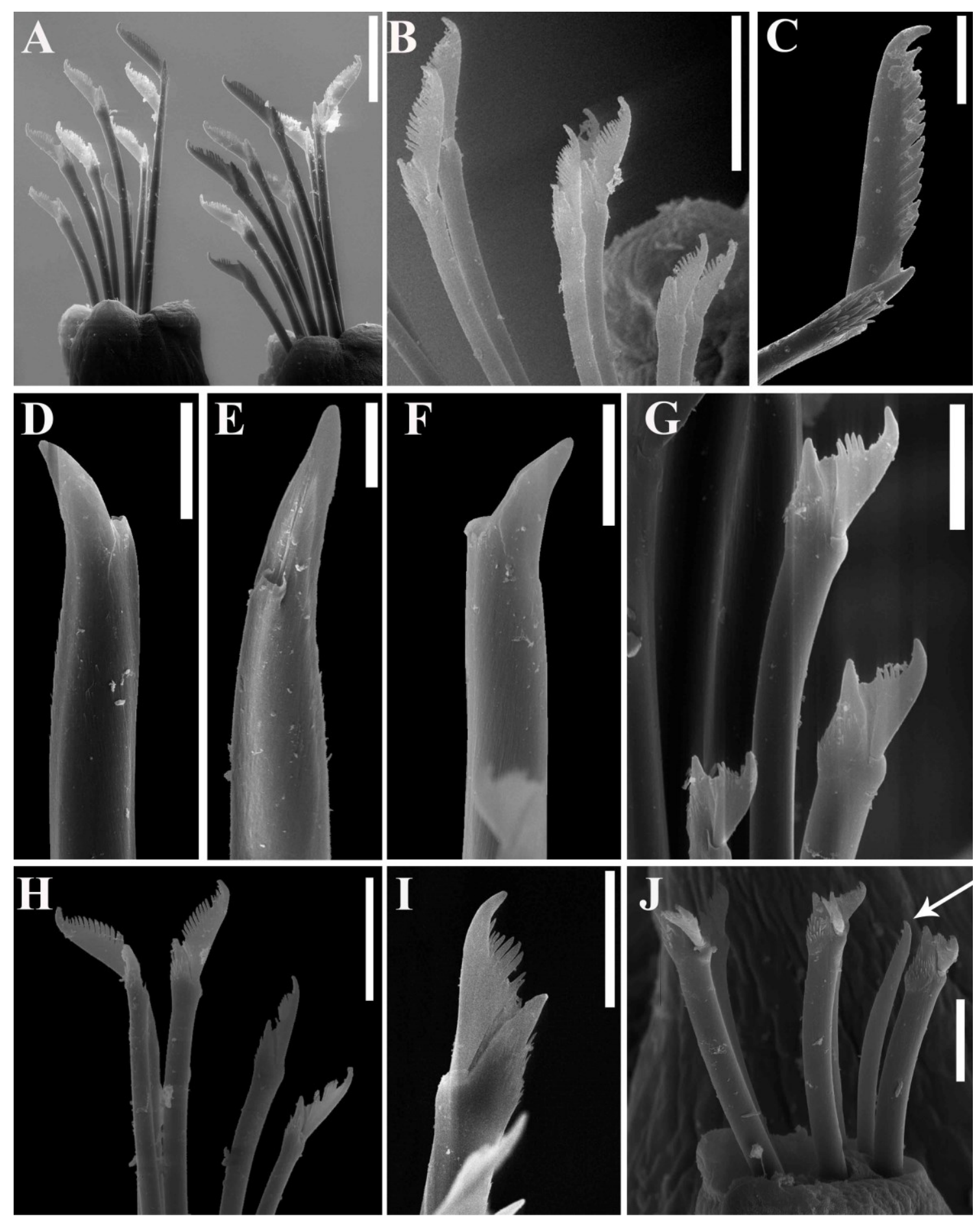

Figura 24 

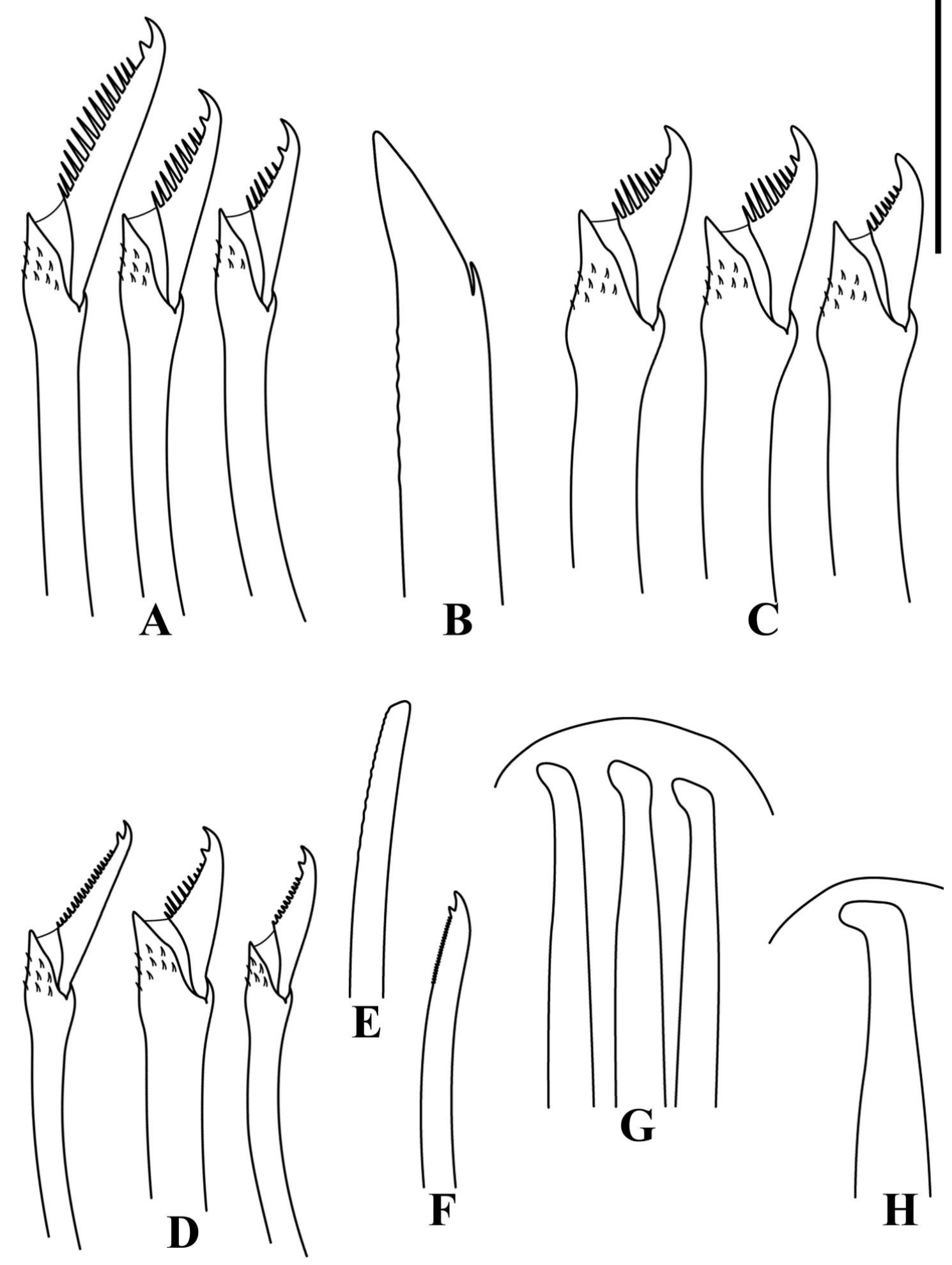

Figura 25 

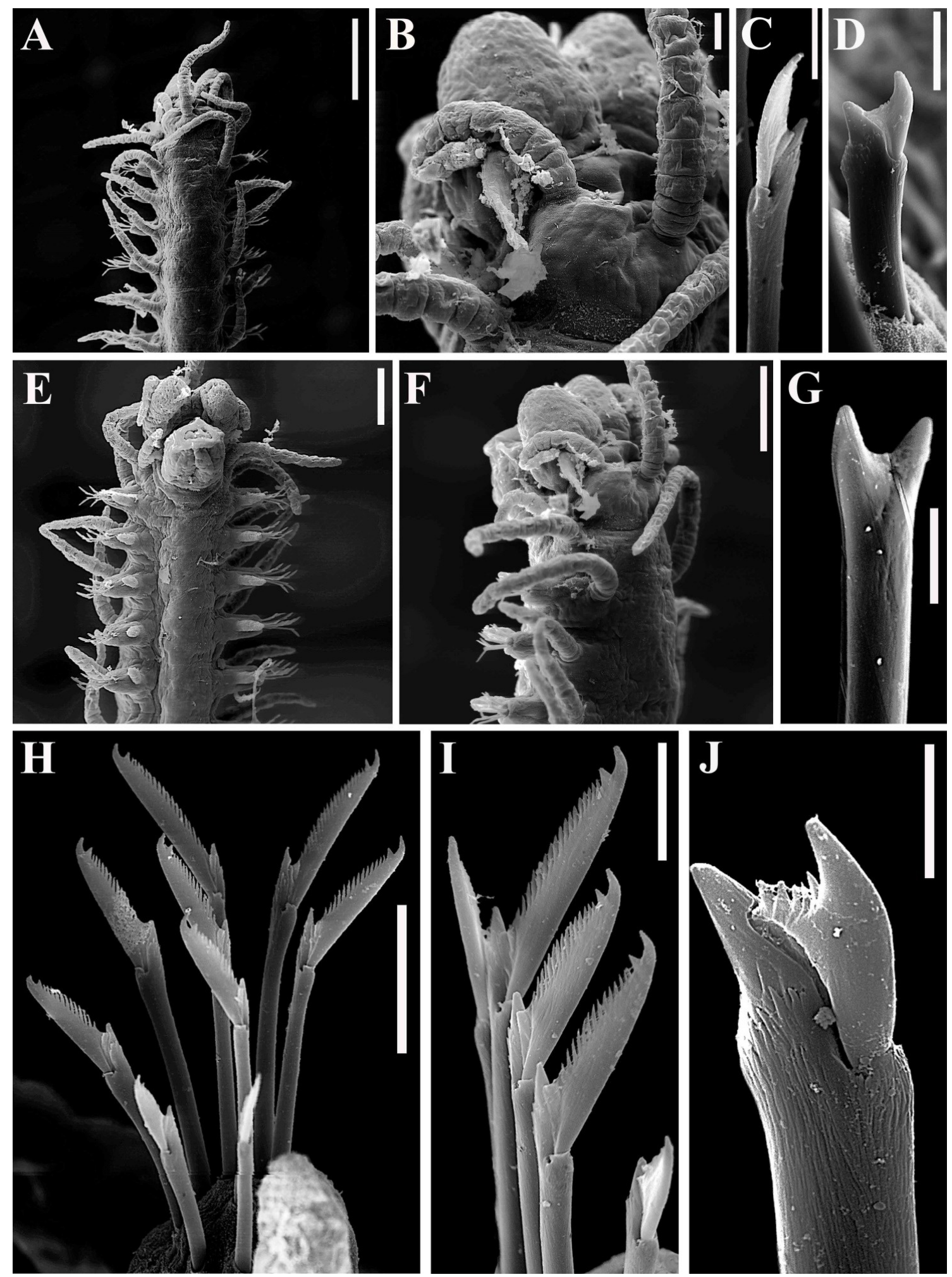

Figura 26 


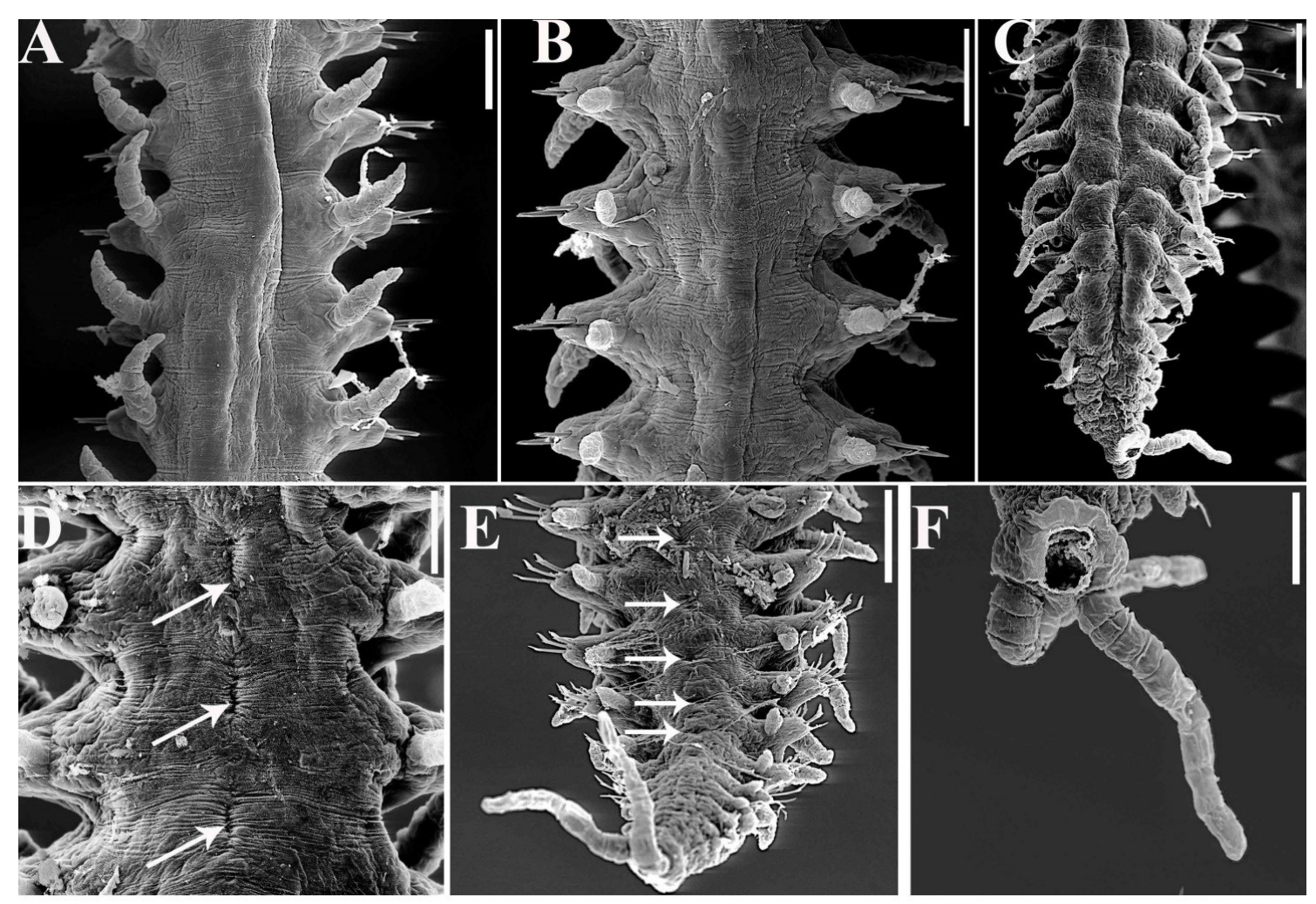

Figura 27 


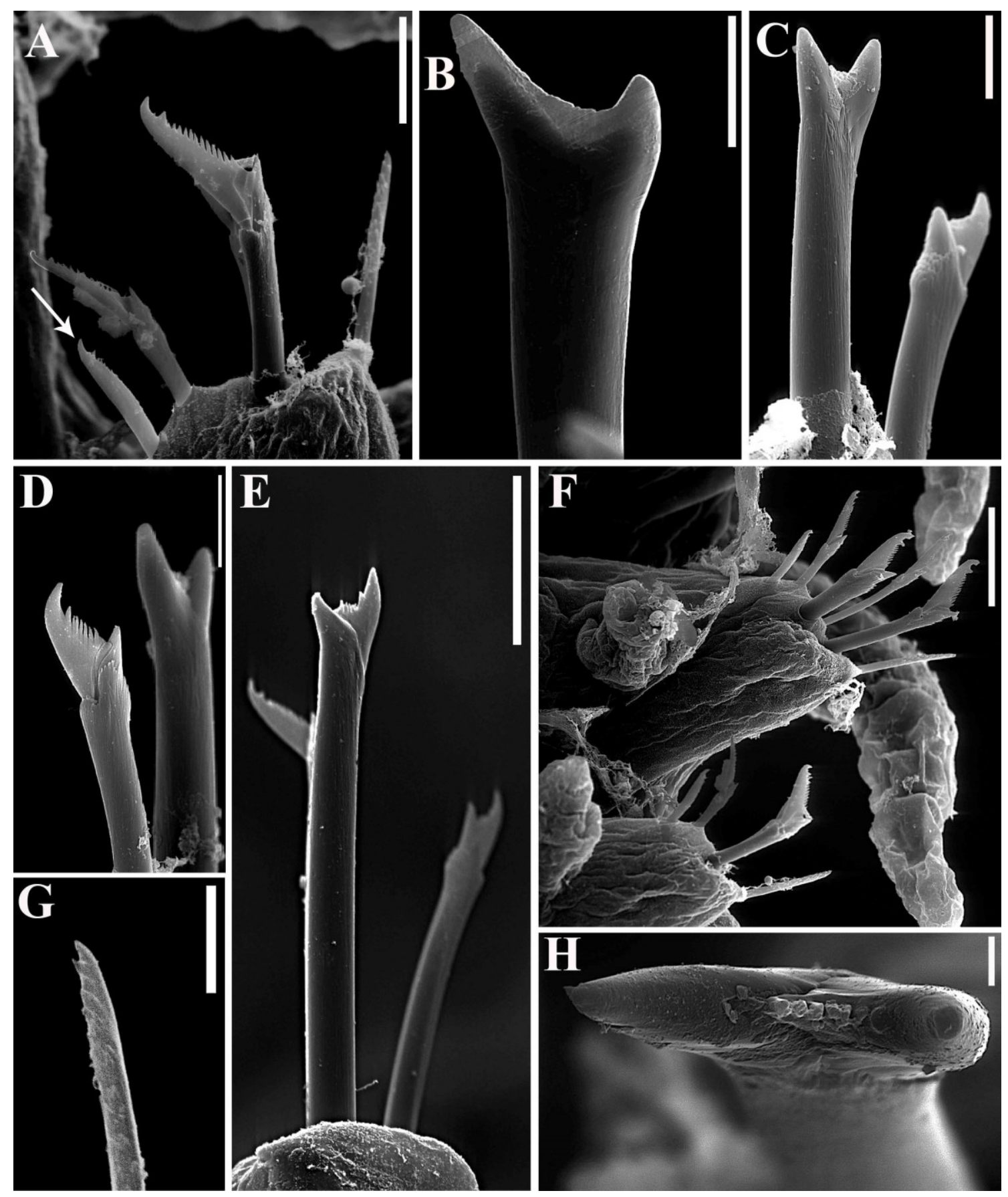

Figura 28 


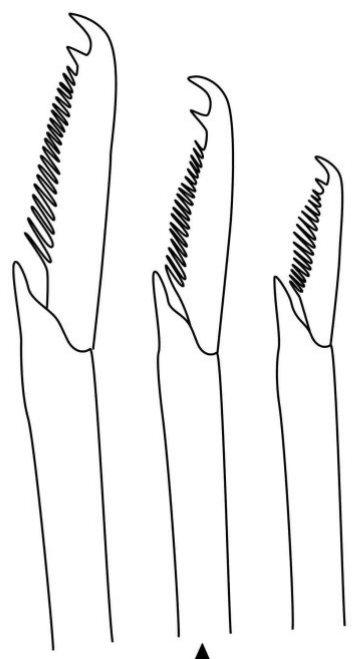

A
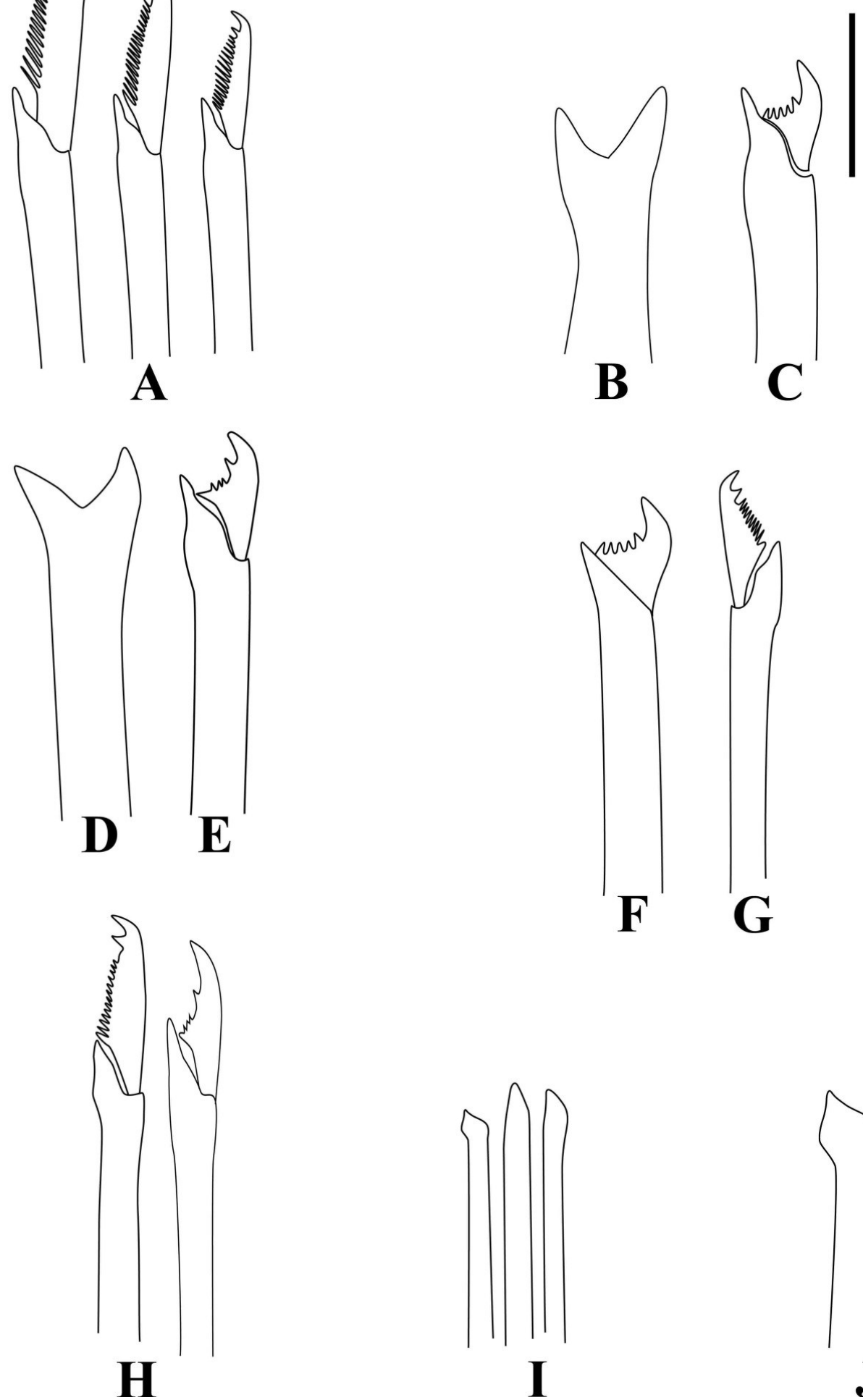

H

I

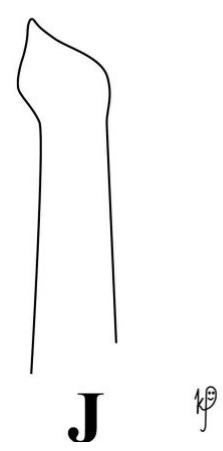

Figura 29 

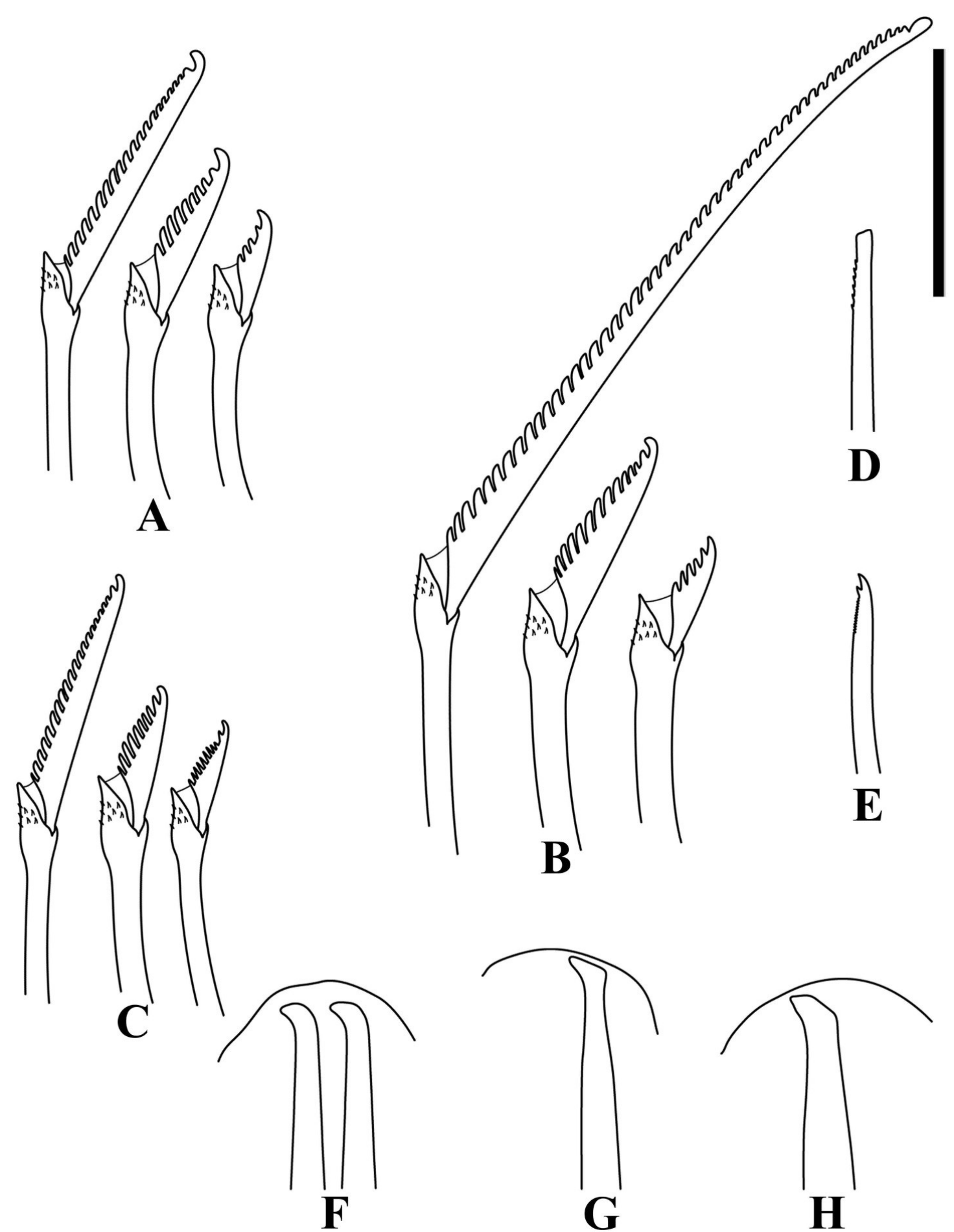

Figura 30 

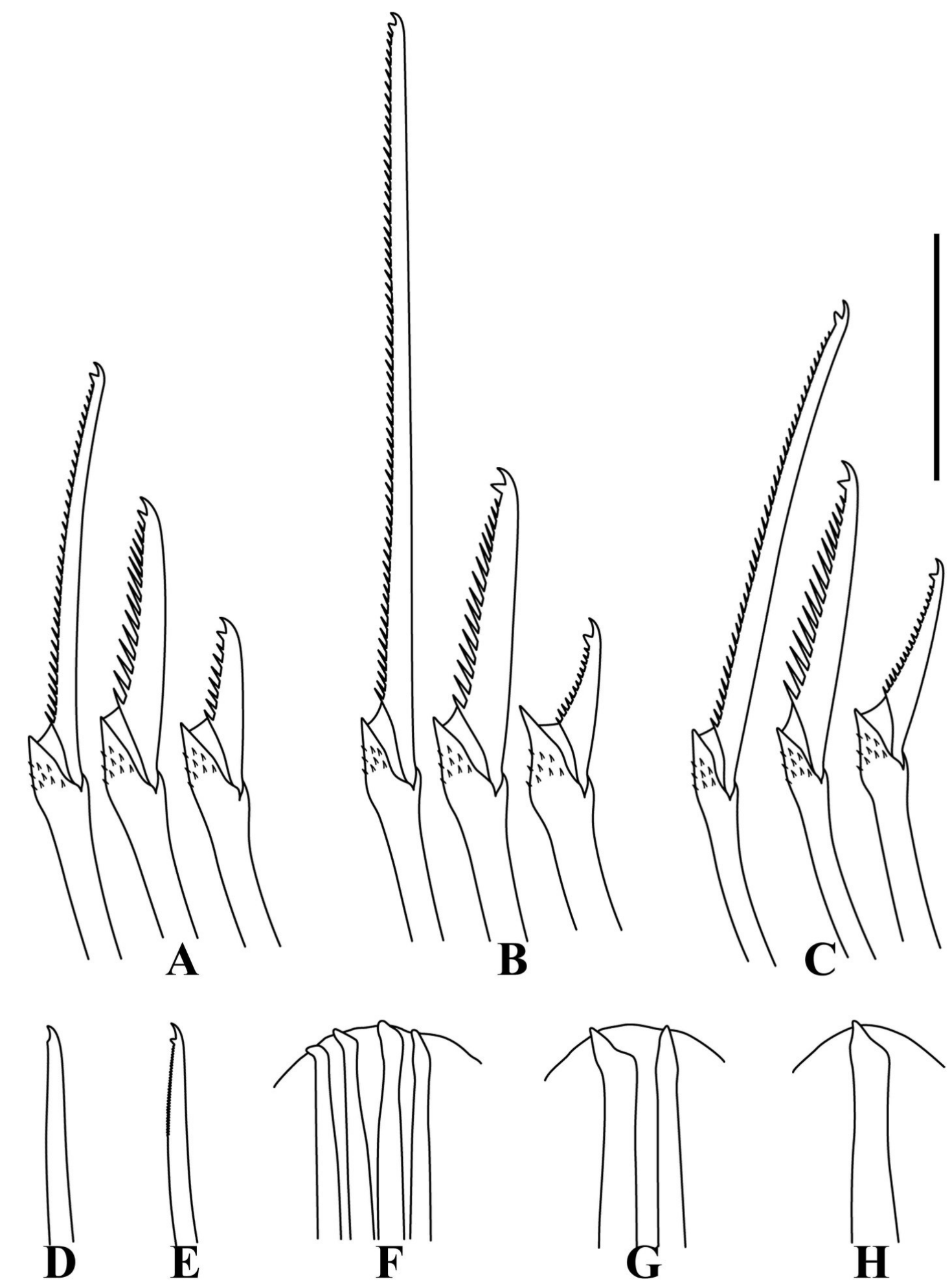

Figura 31 

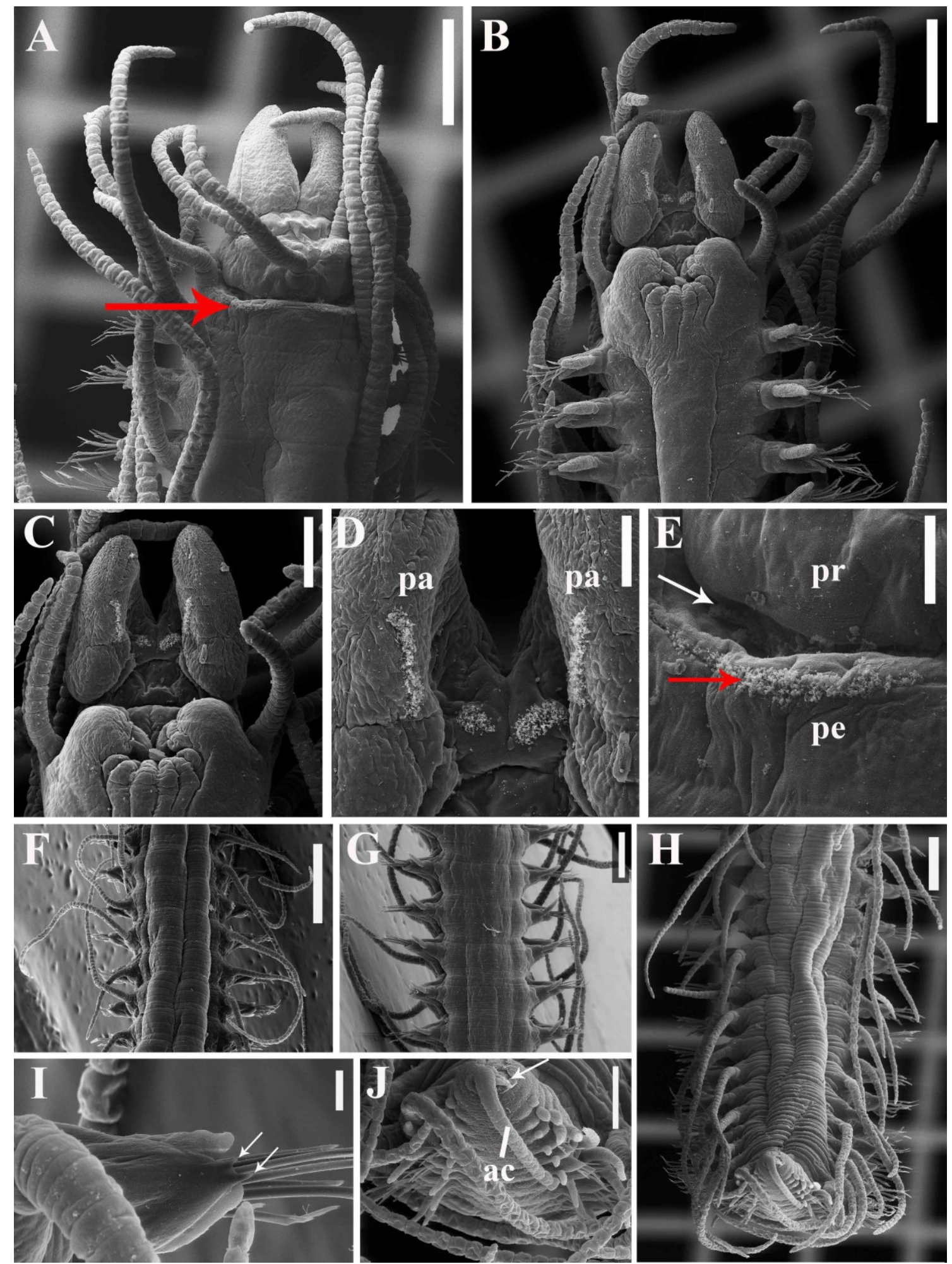

Figura 32 

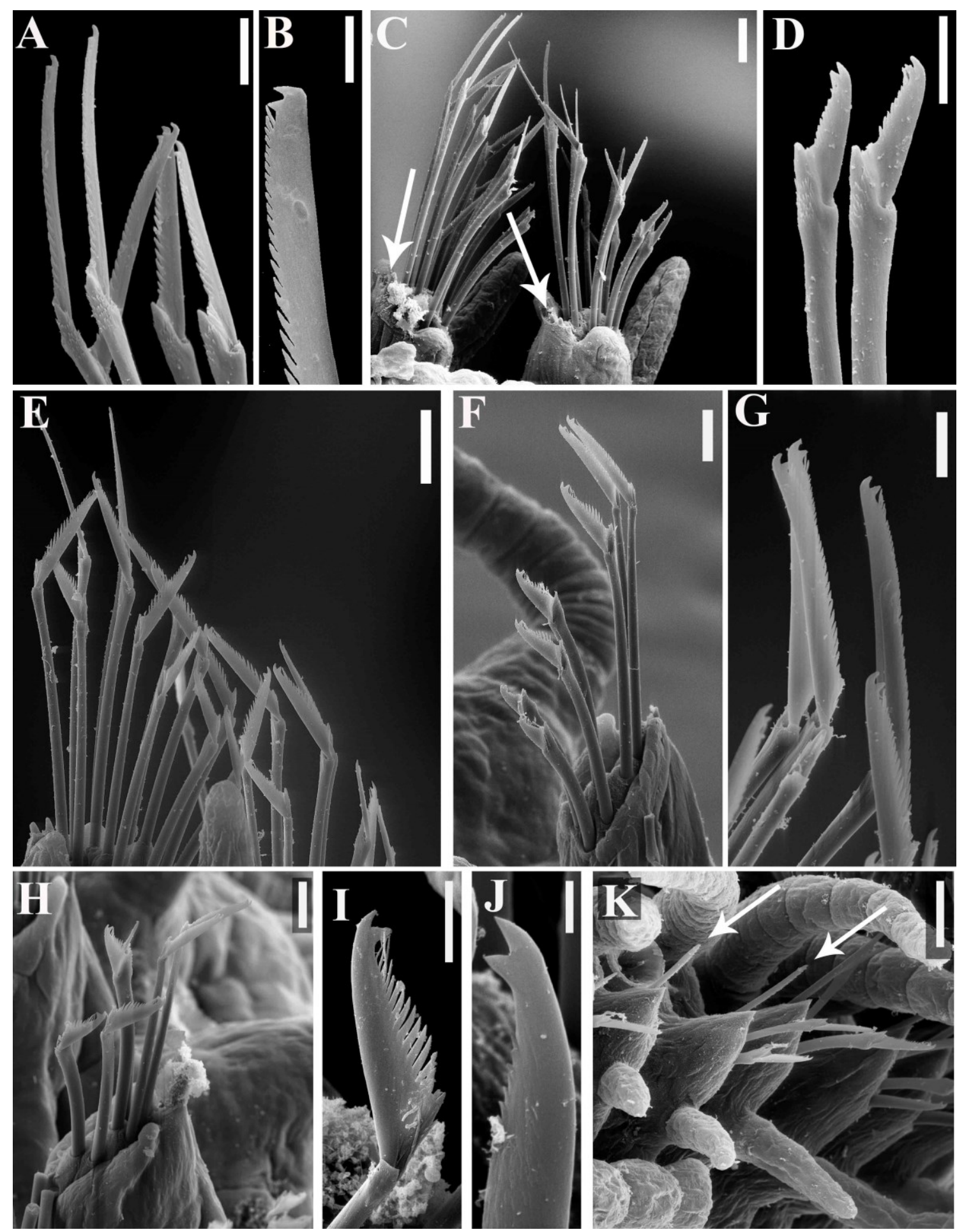

Figura 33 

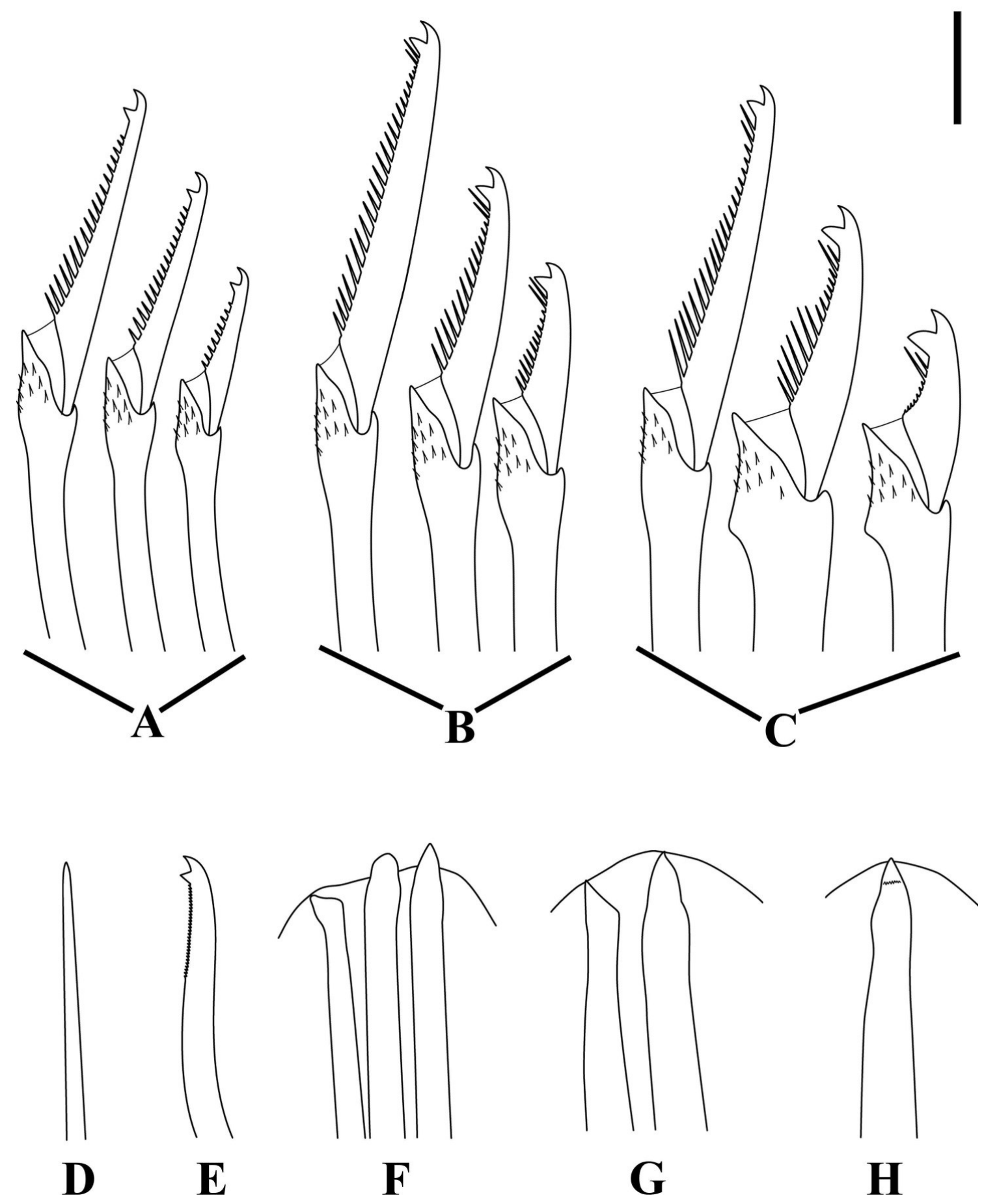

F

G

H

Figura 34 

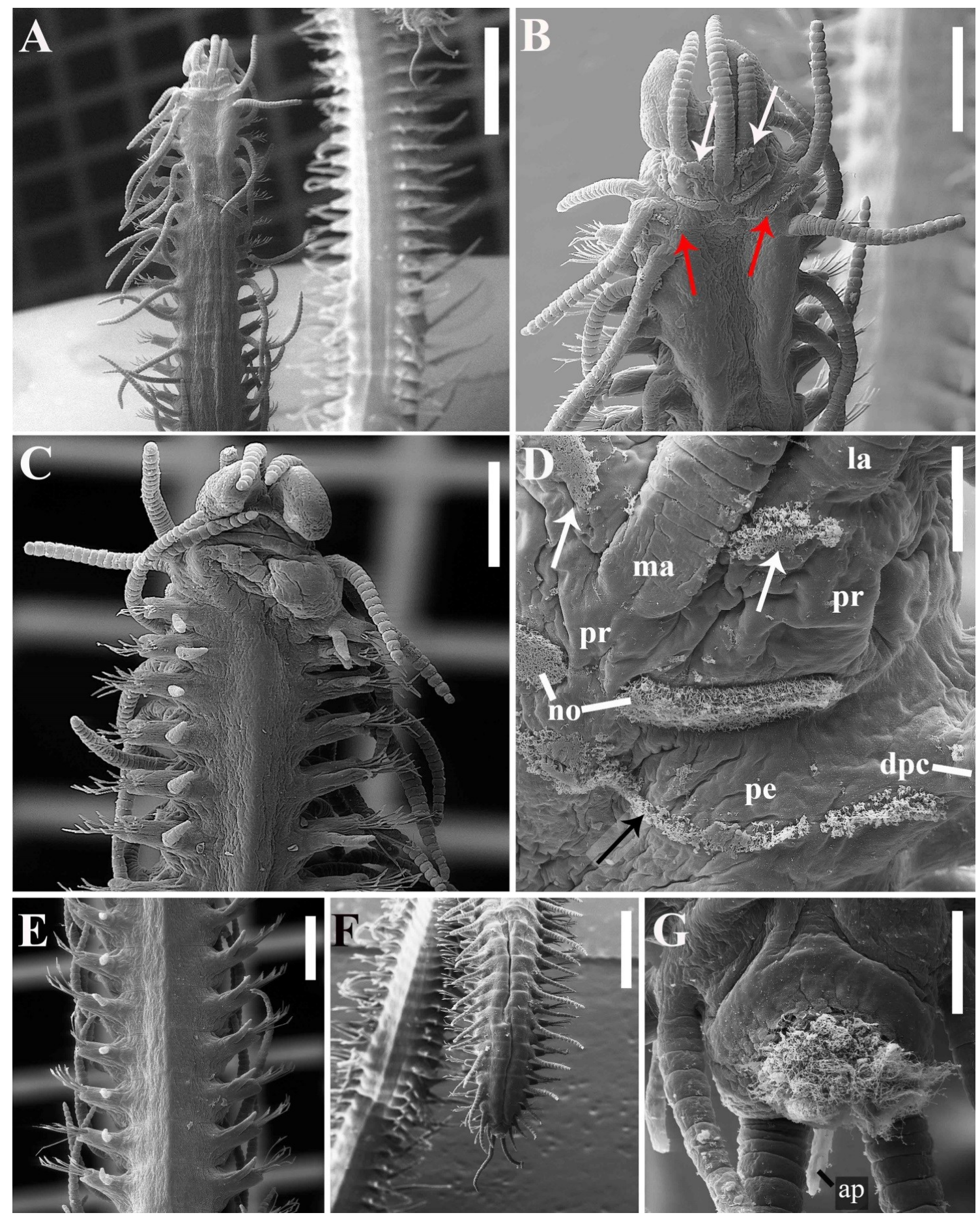

Figura 35 


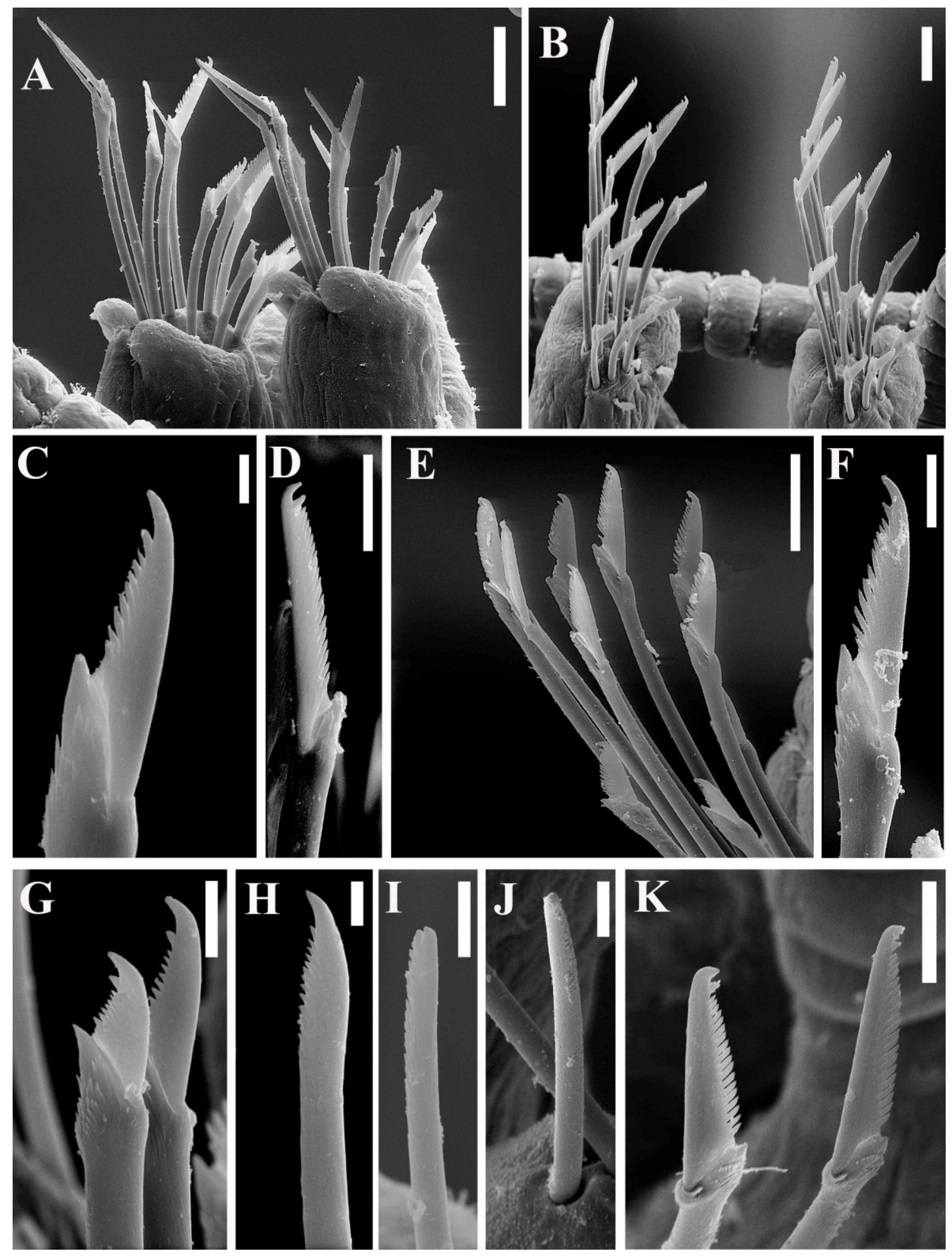

Figura 36 


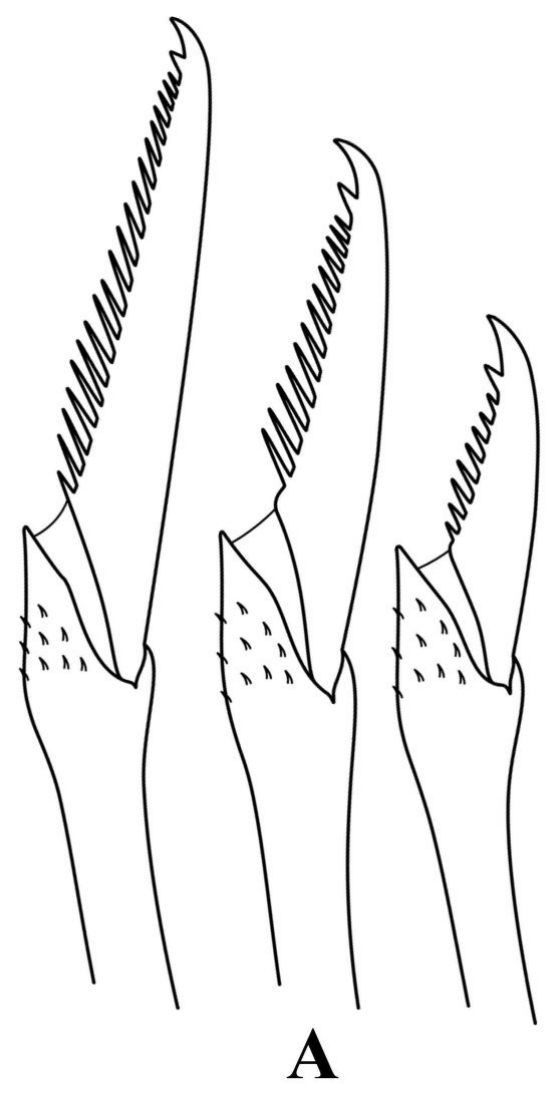

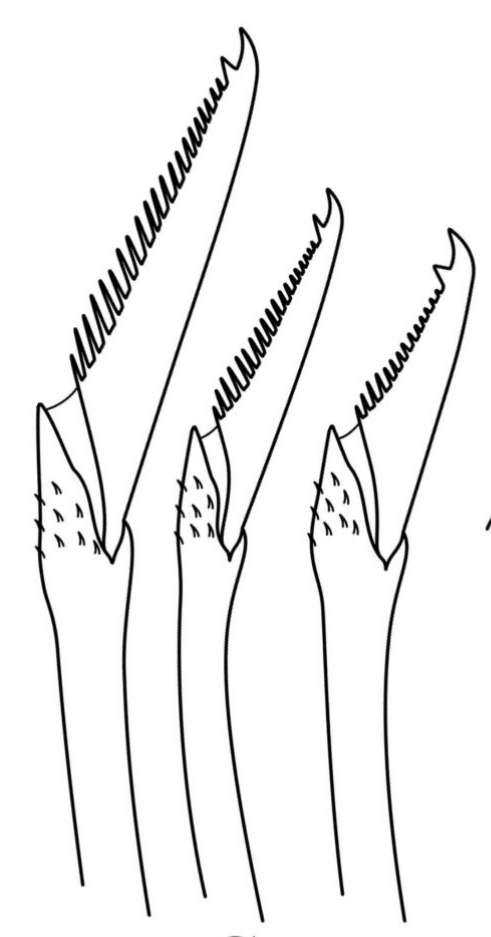

C
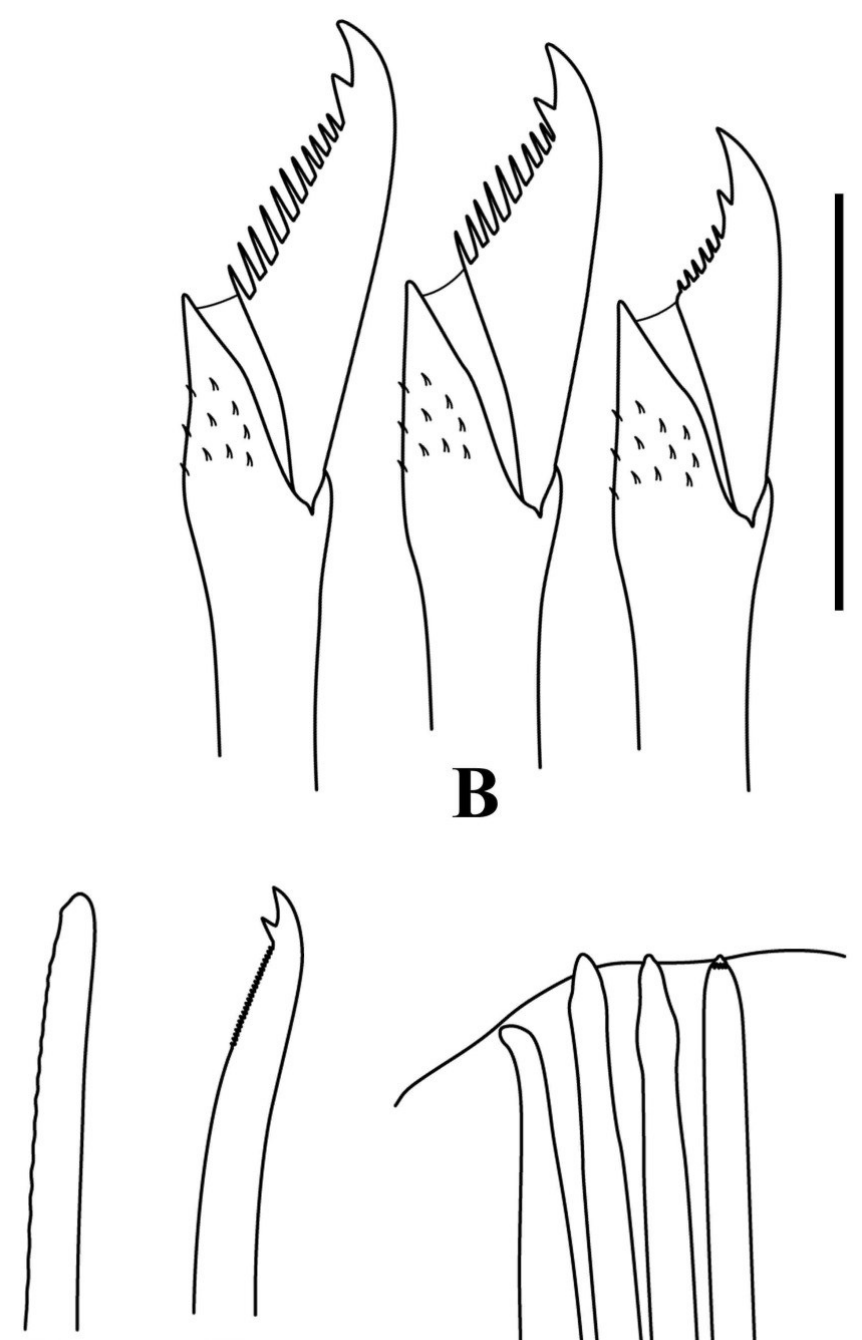

D $\mathbf{E}$

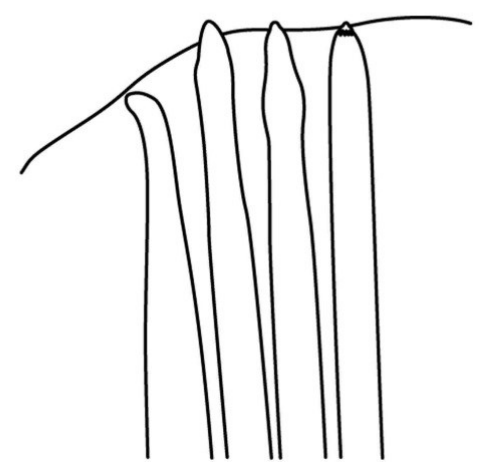

F

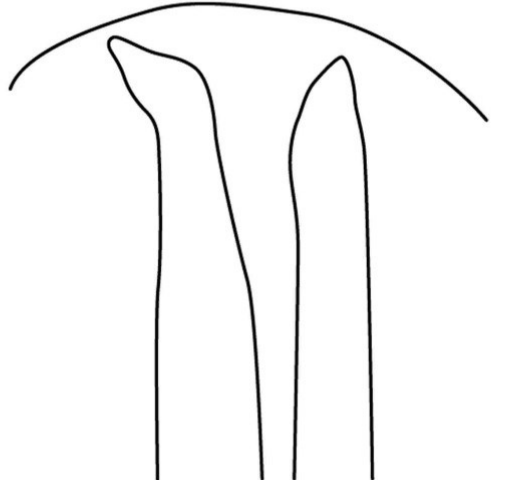

G

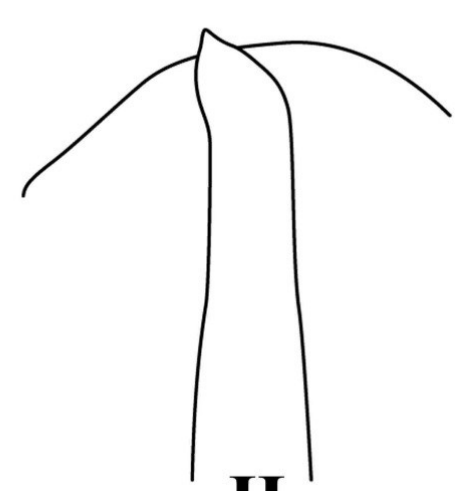

H

Figura 37 

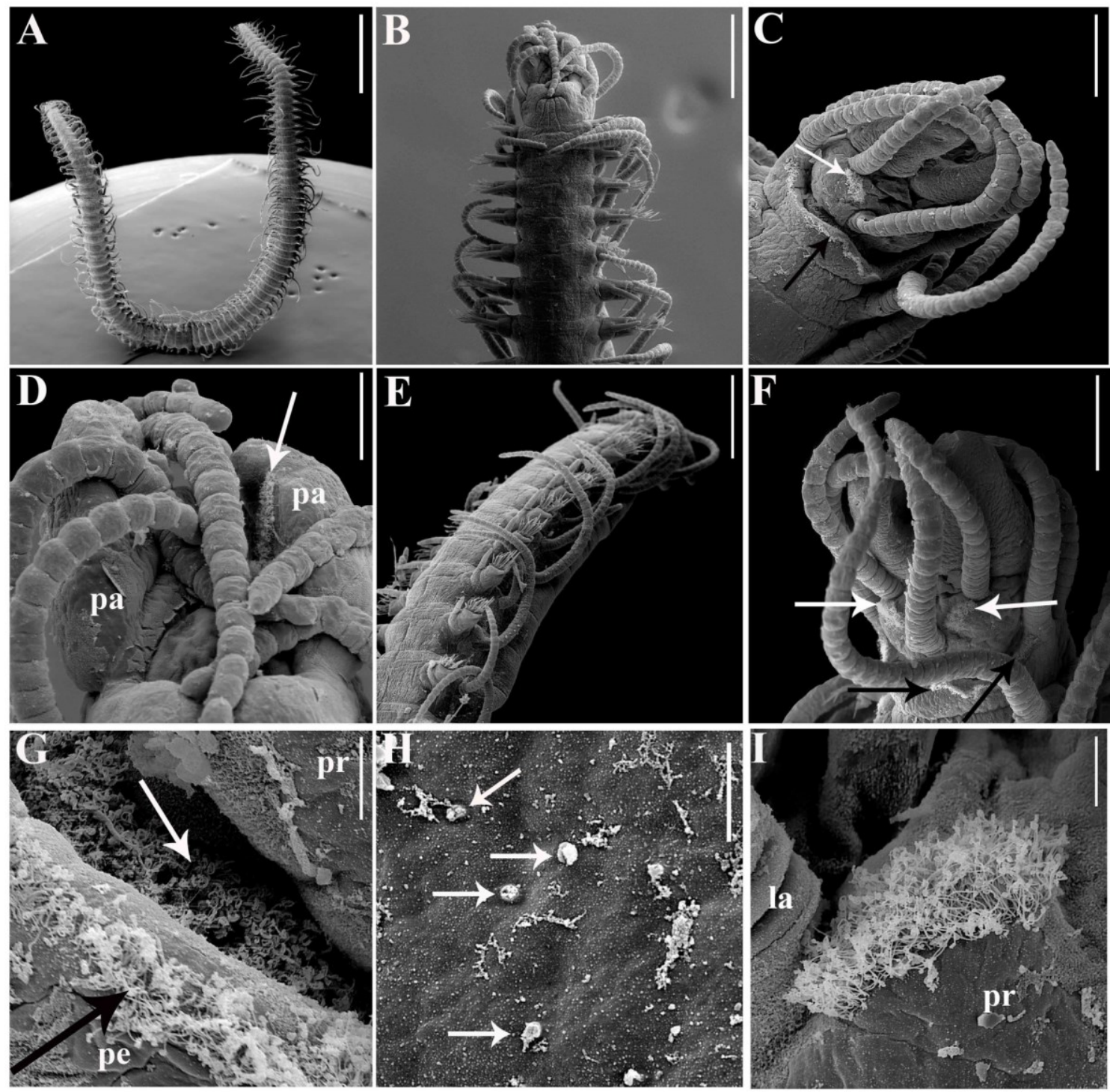

Figura 38 


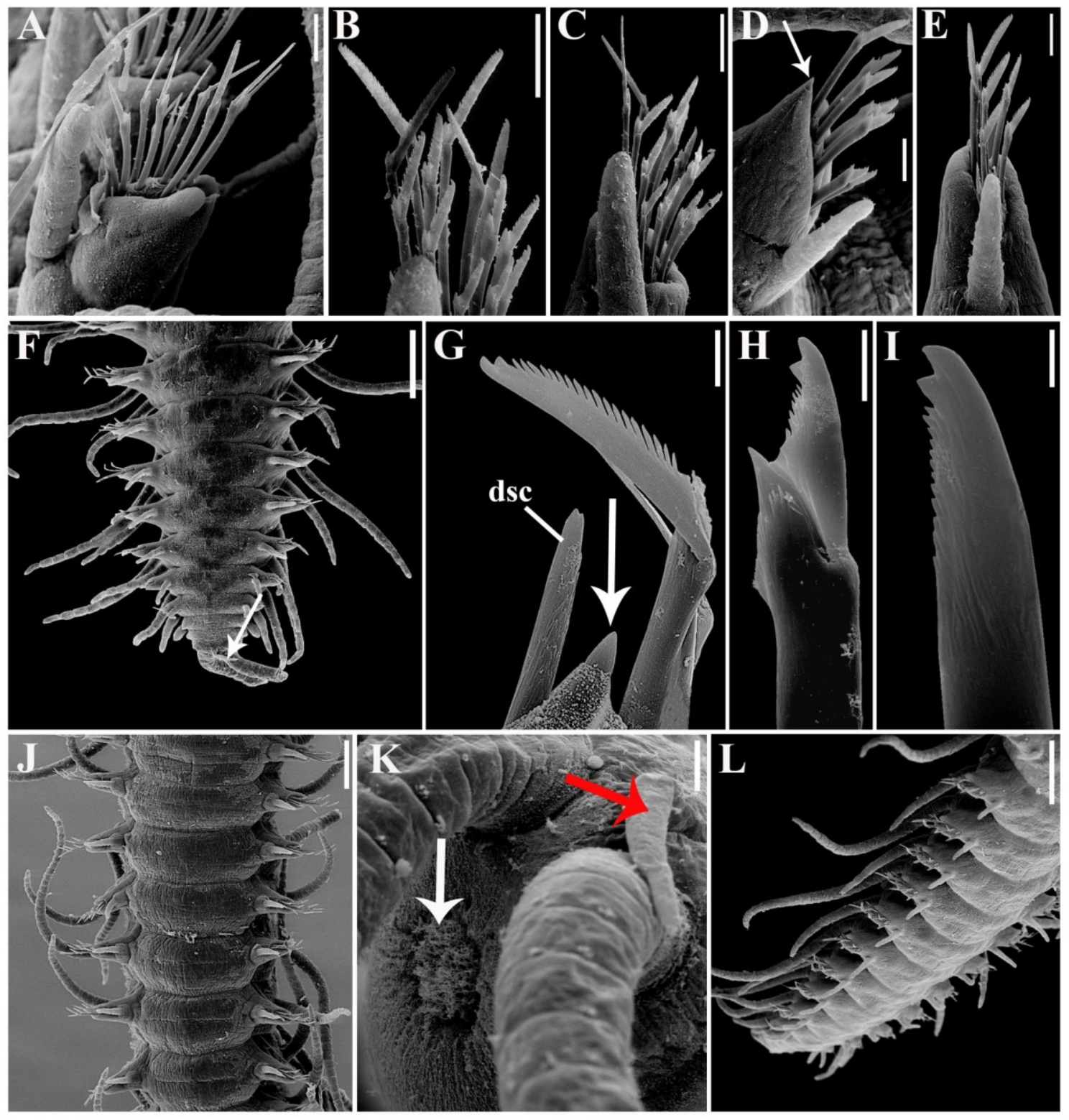

Figura 39 


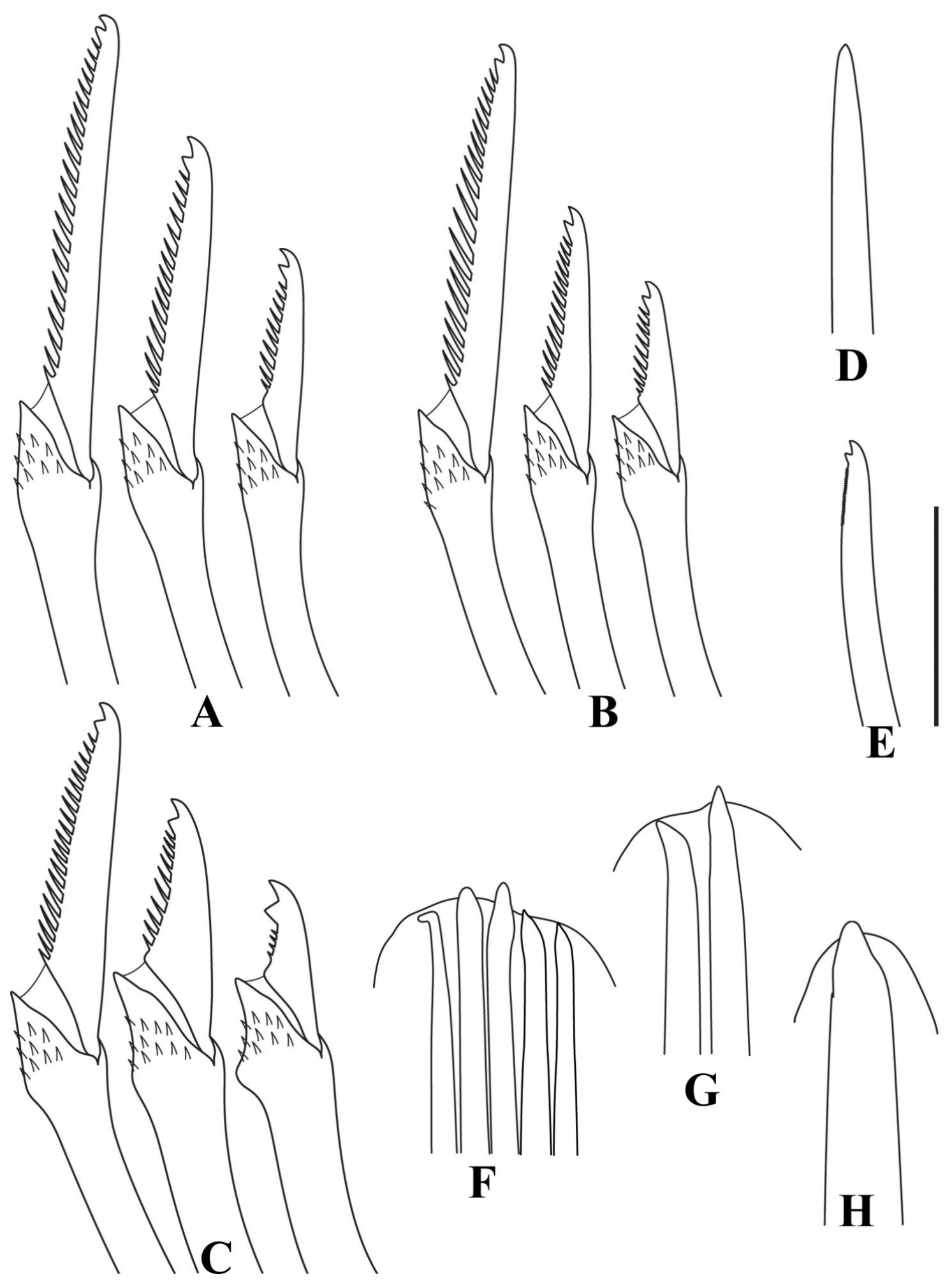

Figura 40 


\section{CAPÍTULO 4}

On some Exogoninae (Polychaeta: Syllidae) from off the northeastern Brazilian coast, with description of a new species 



\section{On some Exogoninae (Polychaeta: Syllidae) from off the northeastern Brazilian coast, with description of a new species}

\section{KARLA PARESQUE $^{1 *}$ MARCELO VERONESI FUKUDA ${ }^{1} \&$ JOÃO MIGUEL DE MATOS NOGUEIRA $^{1}$}

${ }^{1}$ Laboratório de Poliquetologia (LaPol), Departamento de Zoologia, Instituto de Biociências, Universidade de São Paulo, R. do Matão, travessa 14, n. 101, 05508-090, São Paulo, SP, Brazil

* corresponding author: kparesque@gmail.com

\section{Table of contents}

Abstract

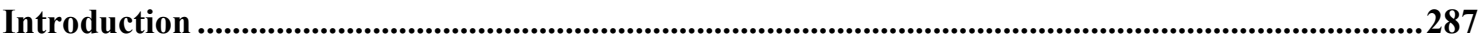

Material and methods …..............................................................................................................................288

Results

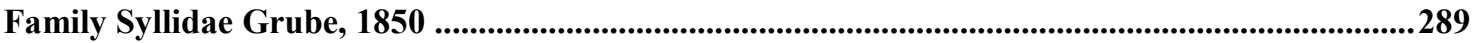

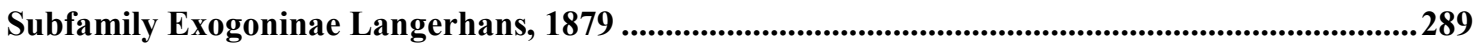

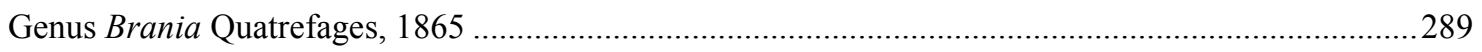

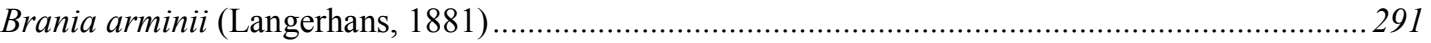

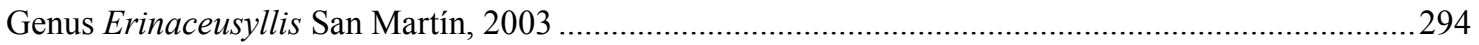

Erinaceusyllis centroamericana (Hartmann-Schröder, 1959) .......................................................297

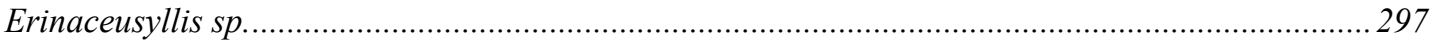

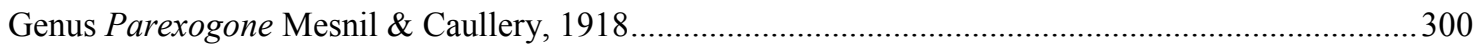

Parexogone anseforbansensis Böggemann \& Westheide, 2004 ................................................... 302

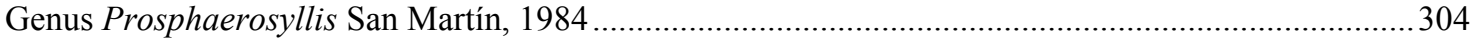

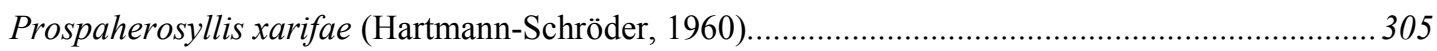

Prospaherosyllis isabellae (Nogueira, San Martín \& Amaral, 2001).......................................... 306

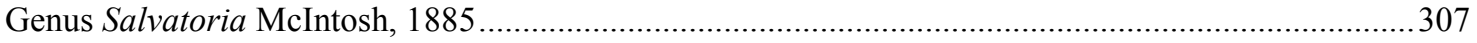

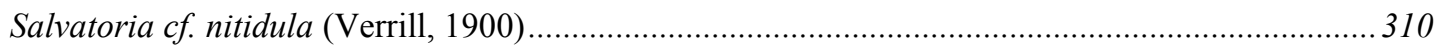

Salvatoria longiarticulata (Nogueira, San Martín \& Amaral, 2001) ........................................... 313

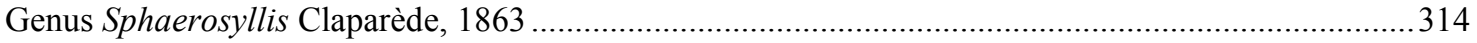

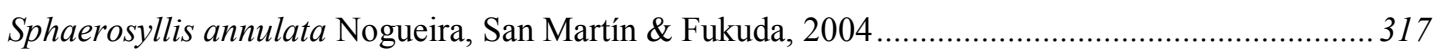




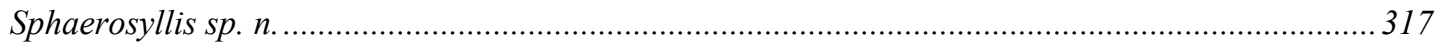

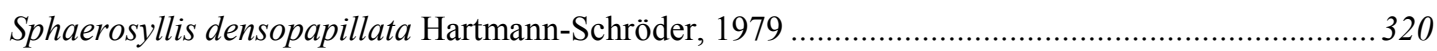

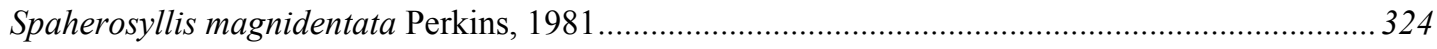

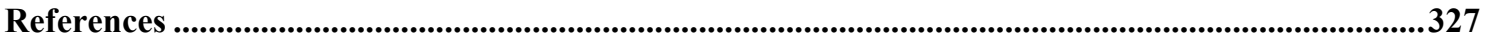

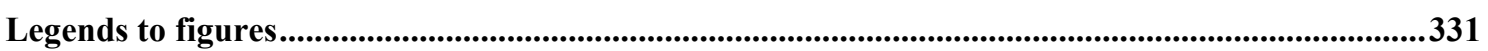

\section{Abstract}

A new species of Sphaerosyllis is described herein, together with descriptions of Erinaceusyllis sp., Salvatoria cf. nitidula, Sphaerosyllis densopapillata and $S$. magnidentata collected along off the states of Paraíba and Pernambuco, northeastern Brazil. The distributions of Brania arminii, Erinaceusyllis centroamericana, Parexogone anseforbansensis, Prosphaerosyllis isabellae, Prosphaerosyllis xarifae, Salvatoria longiarticulata and Sphaerosyllis annulata are expanded. Sphaerosyllis sp. n. is characterized by having median antenna inserted posteriorly to lateral antennae, between posteior pair of eyes; scattered papillae dorsal and ventrally, dorsally digitiform and ventrally rounded, shorter; blades of falcigers with marked dorso-ventral gradation in length on anterior parapodia only; and two aciculae per parapodium on anterior body, one with tip bent at right angle and another with straight, acute tip. The new species is compared to the morphologically most similar congeners. Also, for each genus, a Key for Identification of the species registered in the country is provided.

Keywords: Exogoninae, new species, taxonomy, Atlantic Ocean, sandstone reefs. 


\section{Introduction}

Syllidae Grube, 1850 is one of the most diverse families of polychaetes, with 72 valid genera and almost 700 species (San Martín 2003; Aguado \& San Martín 2009; Aguado et al. 2012). Currently, the family comprises five subfamilies: Syllinae Grube, 1850; Autolytinae Langerhans, 1879; Exogoninae Langerhans, 1879; Eusyllinae Malaquin, 1893; and Anoplosyllinae Aguado \& San Martín, 2009. These subfamilies are monophyletic, however, some genera are still considered of uncertain affinities (see Aguado et al. 2012 for details).

Exogoninae comprises 10 genera and about 240 species. As also happens in Eusyllinae and Anoplosyllinae, epigamy is the typical reproductive mode of Exogoninae (San Martín 2005). This latter group exhibits, besides some cases of viviparity, two different types of brooding eggs, dorsally (eggs usually attached to special notochaetae), and ventrally (eggs adhered to the nephridial pores). These different brooding methods are apparently associated with two different evolutionary lineages within Exogoninae (San Martín 2005; Aguado et al. 2012). The dorsal brooding is present in the genera Cicese Díaz-Castañeda \& San Martín, 2001, Erinaceusyllis San Martín, 2005, Nooralia San Martín, 2002, Prosphaerosyllis San Martín, 1984 and Salvatoria McIntosh, 1885, while the ventral brooding is found in Brania Quatrefages, 1866, Exogone Ørsted, 1845, Parapionosyllis Fauvel, 1923, Parexogone Mesnil \& Caullery, 1918, and Sphaerosyllis Claparède, 1863.

In one of the few phylogenetic analyses with a focus on the Syllidae, Aguado et al. (2012) showed the polyphyletism of Erinaceusyllis, with some species nested among Salvatoria, and suggested that Brania and Parapionosyllis might be synonymized. The difference between these genera is based merely on the number of pairs of peristomial 
cirri, one pair in Parapionosyllis and two pairs in Brania (San Martín 2005). In the present paper, we follow the traditional classification for the Exogoninae, considering the ten already mentioned genera as valid.

Up to the present, 8 genera and 52 species of the subfamily were recorded from Brazil (Amaral et al. 2013): 3 species of Brania, 5 species of Erinaceusyllis, 18 of Exogone, 2 of Parapionosyllis, 6 of Parexogone, 3 of Prosphaerosyllis, 7 of Salvatoria, and 8 of Sphaerosyllis. Most of these records, however, come from unpublished thesis and ecological studies, without a taxonomic approach (see Amaral et al. 2013).

Brazilian specimens of Erinaceusyllis sp., Salvatoria cf. nitidula, Salvatoria longiarticulata, Sphaerosyllis densopapillata, S. magnidentata and Sphaerosyllis sp. n. are described from recently collected material, and illustrated herein. The distributions of Brania arminii, Parexogone anseforbansensis, Prosphaerosyllis xarifae, P. isabellae, and Salvatoria longiarticulata are expanded from southeastern to the northeastern Brazilian coast. Additionally, we provided keys for identification of all currently known species of all genera recorded for the Brazilian coast, except for Exogone, and Prosphaerosyllis, which were treated elsewhere (Fukuda et al. 2009; Paresque et al. in press).

\section{Material and methods}

The material examined was collected by the project "Diversity of Polychaeta (Annelida) on hard substrates off the states of Paraíba and Pernambuco, northeastern Brazil". Collections were made at neap tide from the reefs off the states of Paraíba and Pernambuco. Algae, sponges, ascidians, mussel beds and similar substrates were scraped from the rocks, and examined under stereomicroscope; polychaetes were sorted, 
relaxed in menthol solution, preserved in $4 \%$ formalin solution, and later rinsed in fresh water and transferred to $70 \%$ ethanol. Several specimens were preserved directly in 98\% ethanol, for future molecular studies. Further analyses under stereo- and light microscopes were made of specimens preserved in ethanol, some of which were permanently mounted on slides in glycerin jelly. For examination under scanning electron microscope (SEM), at least one specimen of each species was dehydrated in a series of progressively increasing concentrations of ethanol solutions, critical point dried, covered with $25 \mathrm{~nm}$ of gold and photographed under the SEM at the Laboratório de Microscopia Eletrônica, IB/USP. Line drawings of slide-mounted specimens were made with the aid of a drawing tube attached to an Olympus BX-51 ${ }^{\circledR}$ microscope.

Type material and voucher specimens will be deposited at the Museu de Zoologia da Universidade Estadual de Campinas, Campinas, Brazil (ZUEC); Museu de Zoologia da Universidade de São Paulo, São Paulo, Brazil (MZUSP) and Museo Nacional de Ciencias Naturales, Madrid, Spain (MNCN). Comparative material was examined from specimens lodged at the MNCN and the Australian Museum, Sydney, Australia (AM).

\section{Results}

Family Syllidae Grube, 1850

Subfamily Exogoninae Langerhans, 1879

\section{Genus Brania Quatrefages, 1865}

Type species: Brania pusilla (Dujardin, 1839). 
Diagnosis. Body relatively small, slender. Palps fused basally for about $2 / 3$ of their length. Prostomium with two pairs of eyes and, sometimes, one pair of anterior eyespots; and three antennae. Two pairs of peristomial cirri. Antennae and peristomial cirri bowling-pin or spindle-shaped. Dorsal cirri present throughout, bowling-pin shaped or truncated. Ventral cirri digitiform. Parapodia conical, usually with distal, rounded, small papilla. Parapodial glands present. Compound chaetae as falcigers only, with unidentate to subbidentate blades. Dorsal simple chaetae usually subdistally serrated. Ventral simple chaetae sigmoid, usually unidentate. Aciculae with rounded, slightly hollow tips. Pharynx with tooth close to anterior border, opening surrounded by a crown of soft papillae. Reproduction by brooding eggs and juveniles ventrally (San Martín, 2003).

Remarks. Brania arminii (Langerhans, 1881) is the only species formally reported from Brazil, occurring along off the coast of the state of São Paulo (Nogueira et al. 2004; Nogueira 2006; Fukuda 2010). Two other species were recorded but not formally published, B. pusilla and B. furcelligera (Augener, 1913) (see Amaral et al. 2013 for details), both from the state of São Paulo. Fukuda (2010) provided a complete description of $B$. pusilla that agrees with that for material from the Iberian Peninsula (San Martín 2003). On the other hand, there are no descriptions for Brazilian specimens of $B$. furcelligera and we could not have access to this material, thus, we consider this as a doubtful record. Brania arminii was the unique species of the genus found in the present study, being the first occurrence of the genus in northeastern Brazil. 
Key for Identification of the species of Brania currently recorded for Brazilian waters

1a. Dorsal cirri distally truncate, with fibrillar inclusion... Brania pusilla

1b. Dorsal cirri bowling-pin shaped, without fibrillar inclusions...2

2a. (1b) Peristomium covering posterior part of prostomium; posterior body dorsal simple chaetae with about 4-5 short marginal serrations of different sizes, one of them much larger than remaining (San Martín 2005, Fig. 59F)...Brania furcelligera*

2b. (1b) Peristomium not covering posterior part of prostomium Posterior dorsal simple chaetae with two subdistal larger spines larger than remaining (San Martín 2003, Figs 75G, 76E)...Brania armini

*Species not analysed in the present study, data provided by San Martín 2005.

Brania arminii (Langerhans, 1881)

Grubea arminii Langerhans, 1881: 105.

Pionosyllis oculata Hartmann-Schröder, 1960: 93, Figs 83-85.

Brania oculata Hartmann-Schröder, 1971: 131, lam. XII, Figs 107-110; Westheide 1974b: 910, Abb. 5; San Martín 1984a: 176-181, lam. 36-37; Nuñez 1990: 267-270, Fig. 75.

Brania arminii. Nuñez et al. 1992: 44-45; Nogueira et al. 2004: 71-75, Figs 10-11; Fukuda 2010: 88-90, Fig. 23.

Material examined. State of Paraíba: Mataraca, Barra de Camaratuba $\left(6^{\circ} 36^{\prime} \mathrm{S}\right.$ 34 $\left.57^{\prime} \mathrm{W}\right)$, intertidal: 1 specimen, coll. 12 August 2010. Baía da Traição, Praia do Farol (6 $\left.{ }^{\circ} 41^{\prime} \mathrm{S} 34^{\circ} 55^{\prime} \mathrm{W}\right)$, intertidal: 1 specimen, coll. 09 August 2010. João Pessoa, Praia do 
Cabo Branco $\left(7^{\circ} 08^{\prime} \mathrm{S} 34^{\circ} 47^{\prime} \mathrm{W}\right)$, intertidal: 14 specimens, coll. 02 February 2010. Conde, Praia de Carapibus ( $\left.7^{\circ} 17^{\prime} \mathrm{S} 34^{\circ} 48^{\prime} \mathrm{W}\right)$, intertidal: 18 specimens, coll. 10 February 2009. State of Pernambuco: Goiana, Pontas de Pedra ( $\left.7^{\circ} 37^{\prime} \mathrm{S} 34^{\circ} 48^{\prime} \mathrm{W}\right), 3$ specimens,

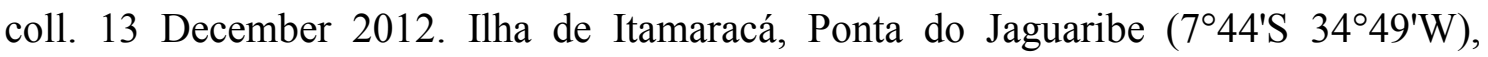
intertidal: 1 specimen, coll. 11 December 2012; recifes de Itamaracá, (7443.944'S 34²49.200'W), 1 m: 25 specimens, coll. 15 December 2012.

Additional material examined. Brania arminii. Brazil, state of São Paulo, Caraguatatuba, Martím de Sá (2337'34"S 45²2'31"W): 1 specimen (MNCN 16.01/8852), coll. 2001, coll. \& det. JMM Nogueira. Brania articulata HartmannSchröder, 1982. Australia, Western Australia, Beacon Island, northeast entrance to Goss

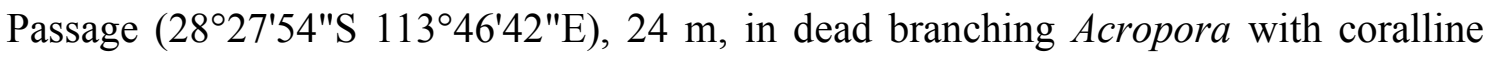
and brown algae: 1 specimen (AM W27102), coll. 25 May 1994, det. G. San Martín; Goss Passage, south east end of Long Island (28 $\left.28^{\prime} 48^{\prime \prime S} 113^{\circ} 46^{\prime} 30^{\prime \prime E}\right)$, dead coral embedded in calcareous substrate, 30 m: 1 specimen (AM W27101), coll. 22 May 1994,

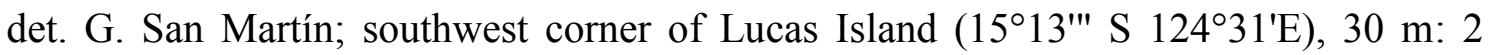
specimens (AM W27105), coll. 24 July 1988, det. G. San Martín; Exmouth Gulf, beach at north end of Bundegi Reef (21 $\left.{ }^{\circ} 49^{\prime \prime S} 114^{\circ} 11^{\prime \prime E}\right), 1-2$ m: 1 specimen (W27415), coll. 04 January 1984, coll. H.E. Stoddart, det. G. San Martín; Kalbarri, Red Bluff, rocky shore $\left(27^{\circ} 42^{\prime} \mathrm{S} 114^{\circ} 09^{\prime} \mathrm{E}\right)$, brown alga from surf zone on rocky shore, $0.5 \mathrm{~m}: 2$ specimens (W27421), coll. 09 Jan 1984, det. G. San Martín.

Remarks. Brania arminii is the only species of the genus found along the states of Paraíba and Pernambuco, with material in overall agreement with the descriptions provided by San Martín (2003), from Spanish specimens, and by Nogueira et al. (2004), who analysed specimens from São Paulo. Specimens from Paraíba and Pernambuco, as well those from São Paulo, have the dorsal simple chaetae on posterior body with two 
conspicuous spines (Nogueira et al. 2004, Fig. 11N), while the specimens examined by San Martín have a larger, single, triangular subdistal spine (San Martín 2003, Fig. 76E).

Brania furcelligera has antennae, peristomial, dorsal and anal cirri similar to those of $B$. arminii, as well as similar compound chaetae, aciculae, and length of pharynx and proventricle. According to San Martín (2005) the species can be differentiated from each other by the spinulation on the dorsal simple chaetae. The dorsal simple chaetae of $B$. furcelligera are unidentate, provided with about 4-5 short marginal serrations of different sizes, one of them much larger than the others (San Martín 2005), while B. arminii, Brazilian specimens included, has dorsal simple chaetae with two distal spines larger than the remaining.

Brania articulata is an Australian species morphologically similar to B. arminii, as both have falcigers with similar size and shape; unidentate ventral simple chaetae, with acute tips; aciculae with rounded tips, slightly hollow; pharynx and proventricle similar in length. Brania articulata is characterised by having biarticulated dorsal cirri throughout, and short spines on the dorsal simple chaetae. Our analysis of material from off northeastern Brazil showed specimens with articulated and non-articulated dorsal cirri, exactly as in Australian specimens, without a clear pattern of distribution. So, this is a variable character in Brazilian material and it seems likely to be due to different physyological conditions. In any case, $B$. arminii can be differentiated from $B$. articulata by having the dorsal simple chaetae with 1-2 longer subdistal spines, while B. articulata has short serrations only.

Type locality. Canary Islands (Atlantic Ocean).

Distribution. Circumtropical (San Martín 2003). First record of the genus from off the northeastern Brazilian coast. 


\section{Genus Erinaceusyllis San Martín, 2003}

Type species: Sphaerosyllis erinaceus Claparède, 1863 designed by San Martín (2003).

Diagnosis. Body relatively small, usually covered on papillae. Palps almost completely fused, short. Prostomium with three antennae, four eyes and two anterior eyespots. Peristomium usually large, frequently with paired dorsolateral, semi-circular lobes over prostomium and one pair of peristomial cirri. Dorsal cirri on chaetiger two only present on few species, usually absent, replaced by large papilla. Antennae, peristomial, dorsal cirri throughout and anal cirri spindle-shaped to pyriform, bases slightly more inflated than tips. Compound chaetae as falcigers and spiniger-like chaetae, usually with blades relatively long and slender, bidentate, bidentate and unidentate, or unidentate. Short pharynx, conical to rhomboidal tooth at anterior margin or slightly backwards; pharynx opening usually smooth, surrounded by papillae in few species. Proventricle long and wide (San Martín 2005).

Remarks. Erinaceusyllis, previously considered as a subgenus of Sphaerosyllis, was recently erected to the generic level because, among other differences to Sphaerosyllis s.s., it groups species which brood eggs dorsally, by means of special capillary chaetae, while Sphaerosyllis brood eggs ventrally, attached to nephridiopores.

Nogueira (2000) reported the genus for the first time in the country, although still as Sphaerosyllis, as occurring off the state of São Paulo, and registered three species, E. bilobata (Perkins, 1981) (as Sphaerosyllis bilobata), E. cf. erinaceus (as Sphaerosyllis cf. erinaceus) and E. mussismiliaicola (Nogueira, San Martín \& Amaral, 2001) (as Sphaerosyllis mussismiliaicola). Among those, only E. mussismiliaicola was formally published (Nogueira et al. 2001). Erinaceusyllis cf. erinaceus, according to the 
description provided by Nogueira (2000), probably corresponds to another species, maybe E. belizensis (Russell, 1989), as Brazilian specimens have bilobed peristomiumm covering posterior part of prostomium, and shorter, subbidentate blades of falcigers, similar to what is observed in species from Belize. Then, we consider the occurence of E. cf. erinaceus in Brazilian waters as doubtful.

Nogueira et al. (2004) presented the desciptions of Brazilian material of $E$. centroamericana (Hartmann-Schröder, 1959) and E. subterranea (Hartmann-Schröder, 1960), also occurring off the state of São Paulo. Finally, Fukuda (2010) in addition to $E$. bilobata, E. centroamericana and E subterranea, reported and provided descriptions for E. belizensis and E. perkinsi (Riser, 1991) occuring along off the coast of São Paulo. We found two species in this study, E. cetroamericana and Erinaceusyllis sp. being the first record of the genus for northeastern Brazil.

\section{Key for Identification of thespecies of Erinaceusyllis currently recorded for Brazilian waters}

1a. Eyes absent. Blades of falcigers elongated and unidentate, dorsalmost chaetae with blades up to $92 \mu \mathrm{m}$ long...Erinaceusyllis subterranea ${ }^{1}$

1b. Eyes present. Blades of falcigers unidentate, or bidentate, dorsalmost chaetae with blades up to $40 \mu \mathrm{m}$ long...2

2a. (1b) Blades of falcigers unidentate only...3

2b. (1b) Bidentate or subbidentate blades of falcigers present...4 
3a. (2a) Anterior eyes in line with eyespots; posterior eyes on level of peristomium; proventricle through 1.5-2 segments, with ca. 15 rows of muscle cells...Erinaceusyllis centroamericana ${ }^{1}$

3b. (2a) Anterior eyes near posterior ones, posterior to eyespots; all eyes on prostomium; proventricle through four segments, with ca. 20 rows of muscle cells...Erinaceusyllis perkinsi ${ }^{1}$

4a. (2b) Dorsum with short papillae; dorsalmost falcigers subbidentate, ventralmost falcigers subbidentate or unidentate...5

4b. (2b) Dorsum smooth, without papillae; all falcigers bidentate...6

5a. (4a) Two pairs of lensed eyes; ventralmost falcigers subbidentate; dorsal simple chaetae subdistally spinulated, with long and slender subdistal spine...Erinaceusyllis mussismiliaicola ${ }^{2}$

5b. (4a) Three pairs of lensed eyes; ventralmost falcigers unidentate; dorsal simple chaetae smooth... Erinaceusyllis belizensis ${ }^{1}$

6a. (4b) Blades of ventralmost falcigers smooth; dorsal simple chaetae subdistally spinulated; ventral simple chaetae unidentate... Erinaceusyllis bilobata ${ }^{1}$

6b. (4b) Blades of ventralmost falcigers with short spinulation; dorsal simple chaetae smooth; ventral simple chaetae bidentate...Erinaceusyllis $\mathbf{s p .}$

${ }^{1-2}$ Species not analysed in the present study, data provided by ${ }^{1}$ Fukuda 2010 and ${ }^{2}$ Nogueira et al. 2001 
Erinaceusyllis centroamericana (Hartmann-Schröder, 1959)

Sphaerosyllis centroamericana Hartmann-Schröder, 1959: 127, Figs 79-82; 1965: 117; 1990: 54; Westheide 1974: 293-295, Figs 45-46D-E.

Erinaceusyllis centroamericana. Nogueira et al. 2004: 54-58, Figs 2-3; San Martín 2005: 7879, Fig. 33.

Material examined. State of Paraíba: Baía da Traição, Praia do Farol (6 $\left.6^{\circ} 41^{\prime} \mathrm{S} 34^{\circ} 55^{\prime} \mathrm{W}\right)$, intertidal: 1 specimen, coll. 09 August 2010. State of Pernambuco: Goiana, Pontas de Pedra $\left(7^{\circ} 37^{\prime} \mathrm{S} 34^{\circ} 48^{\prime} \mathrm{W}\right), 2$ specimens, coll. 13 December 2012. Ilha de Itamaracá, Ponta do Jaguaribe $\left(7^{\circ} 44^{\prime} \mathrm{S} 34^{\circ} 49^{\prime} \mathrm{W}\right)$, intertidal: 1 specimen, coll. 11 December 2012.

Additional material examined. Erinaceusyllis centroamericana. Brazil, São Paulo, Caraguatatuba, Praia Martím de Sá $\left(23^{\circ} 57^{\prime} \mathrm{S} 45^{\circ} 28^{\prime} \mathrm{W}\right): 2$ specimens (MNCN 16.01/8848 and 16.01/8849), coll. 2001, det. Nogueira, Fukuda \& San Martín.

Remarks. The specimens from Paraíba match the description provided by Nogueira et al. (2004) for specimens from São Paulo.

Type locality. El Salvador (Pacific Ocean)

Distribution. Pacific Ocean: El Salvador. Atlantic Ocean: Brazil (states of Paraíba, Pernambuco and São Paulo).

\section{Erinaceusyllis sp.}

(Figures 1-2)

Material examined. State of Paraíba: Conde, Praia do Coqueirinho ( $\left.7^{\circ} 18^{\prime} \mathrm{S} 34^{\circ} 47^{\prime} \mathrm{W}\right)$, 2 specimens, coll. 28 August 2011. 
Additional material examined. Erinaceusyllis cryptica (Ben-Eliahu, 1977): Spain, Andalucía, Cala Mal Paso, Cuevas de Almanzora: 1 specimen (MNCN 16.01/10831), coll. June 2001, coll. Campaña Fauna II, det. G. San Martín.

Description. Small-sized body; longest specimens analysed ca. $1.1 \mathrm{~mm}$ long, 0.1 $\mathrm{mm}$ wide, with up to 15 chaetigers. Body covered on scattered small, oval papillae, more conspicuous laterally on anteriormost chaetigers. Palps oval, almost totally fused, with conspicuous line of fusion and distal notch. Prostomium oval, slightly shorter than palps, with two pairs of eyes in trapezoidal arrangement, anterior eyespots on anterior margin of prostomium; lateral antennae inserted on anterior margin of prostomium, near eyespots, reaching tip of palps or slightly shorter; median antenna inserted slightly anteriorly to eyes, as long as lateral antennae. Nuchal organs not observed. Peristomium as long as anterior chaetigers; peristomial cirri shorter than lateral antennae, with wider base. Dorsal cirri similar in size and shape to lateral antennae, absent on chaetiger 2, replaced by large papilla; dorsal cirri longer posteriorwards. Antennae, peristomial and dorsal cirri spindle-shaped. Ventral cirri digitiform, as long as parapodial lobes. Parapodial lobes bilobed. Anterior and midbody parapodia with 7-8 falcigers each; posterior parapodia with 3-4 falcigers each. Shafts of falcigers slightly spinulated subdistally; shafts straight, tapering distally (Fig. 2A). Blades bidentate; blades of dorsalmost falcigers with longer spines basally, directed upwards, progressively shorter, distal 2/3 of cutting edge smooth (Fig. 2A); blades of intermediate and ventralmost falcigers with shorter spinulation; blades with dorso-ventral gradation in length, 30-14 $\mu \mathrm{m}$ long on anterior parapodia, 26-12 $\mu \mathrm{m}$ long from midbody. Dorsal simple chaetae present from anterior parapodia, unidentate, smooth, thinner than shafts of falcigers (Fig. 2B); ventral simple chaetae only present on posteriormost parapodia, sigmoid, bidentate, smooth, thinner than shafts of falcigers (Fig. 2C). Parapodia with single 
acicula each, curved, with oblique tip (Fig. 2D-E). Semicircular pygidium, with four short papillae; anal cirri not observed. Pharynx through 3.5 segments; pharyngeal tooth near anterior margin of pharynx; proventricle extending for two chaetigers, with 23 rows of muscle cells (Fig. 1).

Biology. One of the specimens with reproductive material and natatory chaetae though chaetigers 9-12, and small eyes (Fig. 1).

Remarks. Erinaceusyllis sp. is characterized by having smooth body, without papillae; median antenna inserted slightly anteriorly to anterior pair of eyes; and blades of falcigers bidentate, spinulated, with dorso-ventral gradation in length, 30-14 $\mu \mathrm{m}$ long on anterior parapodia, 26-12 $\mu \mathrm{m}$ long from midbody. Other species with bidentate falcigers are E. belizensis (Russell, 1989), E. bidentata (Hartmann-Schröder, 1974), E. bilobata, E. cryptica, and E. parvoculata (Russell, 1989).

The most similar species to Erinaceusyllis sp. is E. bidentata, known from the Indian Ocean, from Mozambique (Hartmann-Schröder 1974) and Western Australia (San Martín 2005), also occurring in the Atlantic, off USA (Hartmann-Schröder 1992). Erinaceusyllis sp. has the blades of falcigers more conspicuously bidentate and spinulated, and shorter proventricle, than E. bidentata from Africa, as illustrated by Hartmann-Schröder (1974, Figs 116-119). Compared to E. bidentata from northern Atlantic, Erinaceusyllis sp. still has blades of dorsalmost falcigers more spinulated. Finally, specimens of E. bidentata analysed by San Martín (2005) have more strongly papillated bodies, and median antenna inserted more anteriorly. Also, all descriptions of E. bidentata report bigger eyes than those observed in Erinaceusyllis sp. and ventral simple chaetae unidentate, while Erinaceusyllis sp. has ventral simple chaetae bidentate. One of the Brazilian specimens analysed was in reproductive stage, nevertheless presenting small eyes. 
The other species with bidentate blades of falcigers mentioned above also present slight differences from Erinaceusyllis sp.. Erinaceusyllis belizensis has bilobed peristomium, covering posterior part of prostomium, blades of falcigers with short teeth, and unidentate ventral simple chaetae. E. bilobata has median antenna inserted more posteriorly, ventralmost falcigers with smooth blades and unidentate ventral simple chaetae (Perkins 1981, Russell 1991, Fukuda 2010). E. cryptica has blades of falcigers of posterior body chaetigers shorter and smooth, with shorter distal tooth (San Martín 2003). E. parvoculata and E. centroamericana have the posterior pair of eyes more posteriorly placed than Erinaceusyllis sp. and smooth dorsum, without papillae.

As showed above, the differences between these congeneres are very subtle and, except for E. cryptica, the comparisons were based on the literature. Furthermore, none of the descriptions provided images under the SEM, what makes careful comparisons much more difficult. Because of all the exposed, we prefer to identify this species as Erinaceusyllis sp. herein, instead of describing it as a new species.

Distribution. Atlantic Ocean: Brazil (state of Paraíba).

\section{Genus Parexogone Mesnil \& Caullery, 1918}

Type species: Paedophylax hebes Webster \& Benedict, 1884

Diagnosis. Relatively short, slender, and smooth body. Palps completely fused or with terminal notch. Prostomium with three antennae, four eyes and, sometimes, also two anterior eyespots. One pair of peristomial cirri. Compound chaetae as falcigers, sometimes with relatively elongate blades. Dorsal and ventral simple chaetae present, 
dorsal simple chaetae similar throughout, tips unidentate or bidentate, teeth of similar size. Paired, usually long anal cirri. Pharynx with anterior margin surrounded by soft papillae; tooth close to anterior margin. Reproduction by ventral brooding of eggs and juveniles (San Martín 2005), viviparity present sometimes.

Remarks. Parexogone, previously a subgenus of Exogone, was raised to the generic level by Böggemann \& Westheidei (2004). The genus have two species reported formally to Brazil, P. anseforbansensis Böggemann \& Westheide, 2004 and $P$. caribensis San Martín, 1991, by Nogueira et al. (2004). Besides these reports, Fukuda (2010) provided descriptions of Parexogone exmouthensis (Hartmann-Schröder, 1980), P. cf. gambiae (Lanera, Sordino \& San Martín, 1994) and P. wolfi (San Martín, 1991). Another species, $P$. hebes (Webster \& Benedict, 1884), was reported to Ubatuba, state of São Paulo, by Petti (1997) in an ecological study, identification considered as doubtful herein. Parexogone anseforbansensis was the unique species of the genus recorded in the present study, being the first report of the genus to northeastern Brazil.

\section{Key for Identification of the species of Parexogone currently recorded from Brazilian waters}

1a. Antennae inserted close to each other, between eyes; median antenna longer ...2

1b. Median antenna inserted posteriorly to lateral antennae; antennae all similar in length...5

2a. (1a) Dorsal and ventral simple chaetae unidentate...Parexogone caribensis $^{1}$

2b. (1a) Dorsal and ventral simple chaetae bidentate ...3 
3a. (2b) Adults with dorsal cirri on chaetiger 2; blades of compound chaetae and dorsal simple chaetae with long, thin subdistal spines ('aristae')...Parexogone wolfi ${ }^{1}$

3b. (2b) Adults without dorsal cirri on chaetiger 2; blades of compound chaetae and dorsal simple chaetae with short subdistal spines ...4

4a. (3b) Lateral antennae digitiform; median antenna elongated, reaching beyond tip of palps; each anterior parapodium with 1-2 dorsalmost falcigers with elongated, bidentate blades, distinctly longer than remaining ones within same fascicle...Parexogone gambiae ${ }^{1}$

4b. (3b) Lateral antennae minute, papiliform; median antenna not reaching tip of palps; all falcigers with short blades ... Parexogone hebe ${ }^{2}$

5a. (1b) Long proventricle, through 7-9 chaetigers; dorsal and ventral simple chaetae smooth...Parexogone exmouthensis ${ }^{1}$

5b. (1b) Short proventricle, through 2-5 chaetigers; dorsal and ventral simple chaetae subdistally spinulated ...Parexogone anseforbansensis

${ }^{1-3}$ Species not analysed in the present study, data provided by ${ }^{1}$ Fukuda $2010 ;{ }^{2}$ San Martín 2003; ${ }^{3}$ Nogueira et al. 2001

Parexogone anseforbansensis Böggemann \& Westheide, 2004

Parexogone anseforbansensis Böggeman \& Westheide, 2004: 431-433, Figs 4F, 8; Nogueira et al. 2004: 67-68, Fig. 8. Fukuda 2010: 158-159.

Exogone (Parexogone) exmouthensis. San Martín 1991: 726; Nogueira 2000: 31. 
Material examined. State of Paraíba: Baía da Traição, Praia do Farol (6º $\left.41^{\prime} \mathrm{S} 34^{\circ} 55^{\prime} \mathrm{W}\right)$, intertidal: 4 specimens, coll. 09 August 2010. João Pessoa, Paria do Cabo Branco ( $\left.7^{\circ} 08^{\prime} \mathrm{S} 34^{\circ} 47^{\prime} \mathrm{W}\right)$, intertidal: 4 specimens, coll. 09 February 2009; 15 specimens, coll. 02 February 2010; Recife do Picãozinho (7²4.243'S 3449.291'W), 1 m: 1 specimen, coll. 15 September 2012. Conde, Praia de Tabatinga ( $\left.7^{\circ} 19^{\prime} \mathrm{S} 34^{\circ} 47^{\prime} \mathrm{W}\right)$, intertidal: 1 specimen, coll. 17 September 2012. State of Pernambuco: Ilha de Itamaracá, recifes de Itamaracá, (743.944'S 3449.200'W), 1 m: 1 specimen, coll. 15 December 2012.

Remarks. Three specimens from Cabo Branco have the proventricle slightly shorter or longer than the known for the species, which is proventricle extending through 2.5-3.5 chaetigers, with ca. 40 rows of muscle cells. In one of those specimens, the proventricle is longer, occupying five chaetigers, while in both remaining, it occupies 2.5 chaetigers, with 30 rows of muscle cells.

Developing juveniles were found inside the bodies of these latter specimens with shorter proventricle. One specimen has 36 chaetigers and incubates five juveniles through chaetigers 16-30; juveniles have 7-9 chaetigers, proventricle extending for 1.5-3 chaetigers, and all of them have anal cirri; juveniles are positioned in different ways, first (in atero-posterior direction) and fourth with same antero-posterior orientation as parental form; second and fifth with opposite orientation; and third bent inside chaetiger 23 . The other specimen afore mentioned has 18 chaetigers and a single juvenile within chaetigers 14-16; juvenile with 4 chaetigers, proventricle extending for 1.5 chaetiger, with anal cirri, and positioned in opposite orientation to parental form.

Despite the differences in the size of the proventricle, the specimens from Paraíba and Pernambuco agree with the descriptions provided by Böggemann \& Westheide (2004) for specimens from Mahé (Seychelles, Indian Ocean), and by Nogueira et al. (2004), for specimens from São Paulo. 
Type locality. Anse Forbans, Mahé, Seychelles (Indian Ocean).

Distribution. Indian Ocean: Seychelles. Atlantic Ocean: Cuba, Brazil (states of Paraíba, Pernambuco and São Paulo).

\section{Genus Prosphaerosyllis San Martín, 1984}

Type species: Sphaerosyllis xarifae Hartmann-Schröder, 1960, designed by San Martín 1984.

Diagnosis. Body relatively small, provided with dorsal and ventral papillae, also present on palps, peristomial and dorsal cirri throughout, and on parapodia. Palps short, completely fused, usually slightly bent ventrally. Prostomium with three antennae, four eyes and, frequently, two anterior eyespots. Peristomium frequently covering at least posterior part of prostomium, with one pair of peristomial cirri. Ciliated nuchal organs between prostomium and peristomium, usually covered by peristomium. Dorsal cirri present on all chaetigers. Antennae, peristomial and dorsal cirri throughout short, pyriform to bulbous, with sphaerical bases and short tips, usually retractile inside bases. Ventral cirri digitiform. Parapodial glands absent. Compound chaetae as heterogomph falcigers only, with unidentate, usually short blades. Dorsal and ventral simple chaetae unidentate. Usually single acicula per parapodium, acuminate. Pharynx long and wide, usually without papillae surrounding opening; pharyngeal tooth rhomboidal to conical, located slightly away from anterior margin. Proventricle long and wide, similar in size to pharynx, with slender muscle cell rows. Reproduction by epigamy with dorsal incubation of eggs by means of capillary notochaetae. 
Remarks. Prosphaerosyllis is represented by three species reported to the Brazilian coast, two of which found in the state of São Paulo, P. isabellae (Nogueira, San Martín e Amaral, 2001) (Nogueira et al. 2001, as Sphaerosyllis isabellae; Fukuda et al. 2009) and P. xarifae (Fukuda et al. 2009), and a third species, P. brachycephala Fukuda, Yunda-Guarín \& Nogueira, 2009, described based on material from off the state of Ceará, Northeastern Brazil (Fukuda et al. 2009). Prosphaerosyllis longicauda (Webster \& Benedict, 1887) was recorded in the state of São Paulo, but as that record was not formally published (Amaral et al. 2013) and no voucher material is available, it is treated herein as a doubtful record. A key for the identification of all currently known species of Prosphaerosyllis in Brazilian waters can be found in Fukuda et al. (2009). In this study, we found two species already reported to Brazil previously, P. isabellae and P. xarifae.

\section{Prospaherosyllis xarifae (Hartmann-Schröder, 1960)}

Sphaerosyllis xarifae Hartmann-Schröder, 1960: 103, Figs 121-124; 1980: 56; 1985: 72; 1991: 41; San Martín 1984: 236, Fig. 54.

Prosphaerosyllis xarifae. San Martín 2005: 60-61, Figs 15-16; Fukuda et al. 2009: 1448-1450, Fig. 3.

Material examined. State of Paraíba: Baía da Traição, Praia do Farol (6 $\left.6^{\circ} 41^{\prime} \mathrm{S} 34^{\circ} 55^{\prime} \mathrm{W}\right)$, intertidal: 3 specimens, coll. 09 August 2010. Rio Tinto, Barra de Mamanguape (6 $6^{\circ} 45^{\prime} \mathrm{S}$ 34 $\left.55^{\prime} \mathrm{W}\right)$, intertidal: 1 specimen, coll. 11 August 2010. 
Additional material examined. Spain, Islas Baleares, Cabo Font, south of Isla de Menorca (39 49'40"N 04'12'25"E): 2 specimens (MNCN 16.01/6405), coll. 30 June 1994, det. G. San Martín.

Remarks. Spanish specimens examined differ from the Brazilian ones and from the redescription provided by San Martín (2003) in having longer blades of falcigers, with more conspicuous dorso-ventral gradation in length, with 25-13 $\mu \mathrm{m}$ long; and body papillate throughout, including prostomium, while in the Brazilian specimens papillae begin from chaetiger 1 . Brazil specimens has blades of falcigers with $18-12 \mu \mathrm{m}$ long; also differ in having shorter proventricle, through 2.5-3 chaetigers, and more rows of muscle cells, ca. 25, while Spanish material have proventricle through four chaetigers, with ca. 17 rows of muscle cells.

Type locality. Saudi Arabia, Sarso Islands (Red Sea).

Distribution. Pacific Ocean: Australia (Queensland). Atlantic Ocean: Mediterranean Sea (Spain), Brazil (Paraíba, São Paulo).

Prospaherosyllis isabellae (Nogueira, San Martín \& Amaral, 2001)

Sphaerosyllis isabellae Nogueira, San Martín \& Amaral, 2001: 1777-1779, Fig. 1; Nogueira 2000: 40-42, Fig. 8; 2006: 144.

Prosphaerosyllis isabellae. San Martín 2005: 68-69, Fig. 23; Fukuda et al. 2009: 1450-1453, Figs 4-5. Fukuda 2010: 173-176, Fig. 51.

? Sphaerosyllis sp. Temperini, 1981: 20, Figs 38-42.

Material examined. State of Paraíba: Conde, Praia de Tabatinga ( $\left.7^{\circ} 19^{\prime} \mathrm{S} 34^{\circ} 47^{\prime} \mathrm{W}\right)$, intertidal: 1 specimen, coll. 01 September 2011 
Remarks. The specimen from Paraíba matches the description provided by Fukuda et al. (2009).

Type locality. Ilha de Alcatrazes, São Paulo, Brazil (Atlantic Ocean).

Distribution. Atlantic Ocean: Brazil (states of Paraíba and São Paulo). Pacific Ocean: Australia (Tasmania). Indian Ocean: Australia (Western Australia).

\section{Genus Salvatoria McIntosh, 1885}

Type species: Salvatoria kerguelensis McIntosh, 1885.

Diagnosis. Small-sized body, without papillae. Palps fused along most of their length by dorsal membrane, usually leaving short distal notch. Prostomium with three antennae, four eyes and, usually, two eyespots. Two pairs of peristomial cirri. Dorsal cirri of segment 2 present or absent. Antennae, peristomial and dorsal cirri throughout usually spindle-shaped. Ventral cirri digitiform, usually shorter than parapodial lobes. Parapodial lobes conical, frequently with three distal, rounded, small papillae. Parapodial glands absent. Compound chaetae as heterogomph falcigers, blades uni- to bidentate. Dorsal and ventral simple chaetae present. Aciculae usually subdistally inflated, with long and filiform tip. Pharynx wide, usually with smooth opening, without papillae; tooth rhomboidal to ovate, usually slightly away from anterior margin of pharynx. Proventricle relatively long and wide, usually about as long as pharynx, with numerous, slender muscular rows. Reproduction by epigamy, females brooding eggs dorsally by means of special capillary notochaetae (San Martín 2005). 
Remarks. Salvatoria breviarticulata (Nogueira, San Martín \& Amaral, 2001) and S. longiarticulata were described from Brazilian material (Nogueira et al. 2001), collected off the state of São Paulo. Westheide (1974a) found S. neapolitana (Goodrich, 1930) (as Brania subterranea) in the state of São Paulo and, posteriorly, the same species was reported by Fukuda (2010), who also recorded and described Brazilian specimens of S. nitidula (Verrill, 1900), also from São Paulo. Salvatoria heterocirra (Rioja, 1941) was reported, as Grubeosyllis cf. heterocirra, by Nogueira (2000), however, the specimens analysed have several differences compared to specimens from others localities (Rioja 1941; Westheide 1974a) and that record might be doubtful. Three other species were reported from off the Brazilian coast, but not formally published, S. clavata (Claparède, 1863), S. euritmica (Sardá, 1984), and S. limbata (Claparède, 1868) (as Brania limbata) and are also treated herein as doubtful records. Salvatoria cf. nitidula was the unique species of the genus recorded in the present study, being the first report of the genus to northeastern Brazil.

\section{Key to species of Salvatoria currently recorded in Brazilian waters}

1a. Ventral simple chaetae unidentate ...2

1b. Ventral simple chaetae bidentate ...3

2a. (1a) Aciculae with rounded, apparently hollow tips...Salvatoria neapolitana ${ }^{1}$

2b. (1a) Aciculae with acute tip...Salvatoria limbata ${ }^{2}$

3a. (1b) Blades of falcigers relatively short, insconspicuous dorso-ventral gradation in length, 11-8 $\mu \mathrm{m}$ long throughout...Salvatoria breviarticulata ${ }^{3}$ 
3b. (1b) Blades of falcigers relatively long, marked dorso-ventral gradation in length, at least on anterior body parapodia...4

4a. (3b) Blades of falcigers with distal teeth of similar size, rounded space inbetween...Salvatoria euritmica ${ }^{2}$

4b. (3b) Blades of falcigers with distal tooth larger, at least on anterior parapodia, oblique space inbetween...5

5a. (4b) Blades of falcigers of posterior chaetigers all 12-11 $\mu \mathrm{m}$ long... Salvatoria clavata ${ }^{2}$

5b. (4b) Blades of falcigers gradation in length throughout...6

6a. (5b) Median antenna originating between anterior pair of eyes; blades of falcigers of posterior chaetigers with short basal spines on cutting edges; dorsal simple chaetae bidentate...Salvatoria cf. nitidula

6b. (5b) Median antenna originating between posterior pair of eyes; blades of falcigers of posterior chaetigers with long basal spines on cutting edges; dorsal simple chaetae unidentate... Salvatoria longiarticulata

${ }^{1-3}$ Species not analysed in the present study, data provided by ${ }^{1}$ Fukuda $2010 ;{ }^{2}$ San Martín 2003; ${ }^{3}$ Nogueira et al. 2001 


\section{Salvatoria cf. nitidula (Verrill, 1900)}

(Figures 3-6)

Material examined. State of Paraíba: Mataraca, Barra de Camaratuba (6 $366^{\circ} \mathrm{S}$ 34 57'W), intertidal: 15 specimens, coll. 12 August 2010. Baía da Traição, Praia do Farol (6 $\left.6^{\circ} 41^{\prime} \mathrm{S} 34^{\circ} 55^{\prime} \mathrm{W}\right)$, intertidal: 6 specimens, coll. 09 August 2010. Rio Tinto, Barra de Mamanguape $\left(6^{\circ} 45^{\prime} \mathrm{S} 34^{\circ} 55^{\prime} \mathrm{W}\right)$, intertidal: 24 specimens, coll. 11 August 2010. Cabedelo, Píer de Cabedelo (6 $\left.6^{\circ} 58^{\prime} \mathrm{S} 34^{\circ} 50^{\prime} \mathrm{W}\right)$, intertidal: 2 specimens, coll. 12 February 2009. João Pessoa, Praia do Cabo Branco ( $\left.7^{\circ} 08^{\prime} S 34^{\circ} 47^{\prime} \mathrm{W}\right)$, intertidal: 1 specimen, coll. 09 February 2009; 23 specimens, coll. 02 February 2010; Recife do Picãozinho (7².243'S 34²49.291'W), 1 m: 2 specimens, coll. 15 September 2012. Conde, Praia de Jacumã ( $\left.7^{\circ} 14^{\prime} \mathrm{S} 34^{\circ} 47^{\prime} \mathrm{W}\right)$, intertidal: 3 specimens, coll. 29 January 2010; Praia de Tabatinga ( $\left.7^{\circ} 19^{\prime} \mathrm{S} 34^{\circ} 47^{\prime} \mathrm{W}\right)$, intertidal: 15 specimens; coll. 17 September 2012; Praia do Coqueirinho ( $\left.7^{\circ} 18^{\prime} \mathrm{S} 34^{\circ} 47^{\prime} \mathrm{W}\right), 12$ specimens, coll. 28 August 2011; Praia de Tambaba ( $\left.7^{\circ} 21^{\prime} \mathrm{S} 34^{\circ} 47^{\prime} \mathrm{W}\right), 1$ specimen, coll. 30 August 2011. State of Pernambuco: Goiana, Pontas de Pedra $\left(7^{\circ} 37^{\prime} \mathrm{S} 34^{\circ} 48^{\prime} \mathrm{W}\right), 4$ specimens, coll. 13 December 2012. Ilha de Itamaracá, recifes de Itamaracá, (743.944'S 3449.200'W), 1m: 13 specimens, coll. 15 December 2012; Ponta do Jaguaribe (744'S 34²4'W), intertidal: 5 specimens, coll. 11 December 2012. Almirante Tamandaré, Praia dos Carneiros ( $\left.8^{\circ} 42.849^{\prime} \mathrm{S} 35^{\circ} 4.999^{\prime} \mathrm{W}\right)$, intertidal: 1 specimen, coll. 22 July 2013. Sirinhaém, Barra do Sirinhaém ( $8^{\circ} 36.707$ 'S $\left.35^{\circ} 2.450^{\prime} \mathrm{W}\right): 8$ specimens, coll. 23 July 2013.

Description. Small-sized body; longest specimens ca. $2.2 \mathrm{~mm}$ long and $0.2 \mathrm{~mm}$ wide, with up to 29 chaetigers. Palps triangular, distally rounded, almost totally fused, with conspicuous line of fusion and distal notch (Figs 3, 4A-C). Prostomium subrectangular, shorter than palps, with two pairs of eyes in open trapezoidal 
arrangement (Fig. 3), anterior eyespots usually present; lateral antennae inserted on anterior margin of prostomium, reaching beyond tips of palps (Figs 3; 4A-C); median antenna inserted between eyes, longer than lateral antennae. Ciliated nuchal organs between prostomium and peristomium (Fig. 4A, C-D). Peristomium as long as anterior chaetigers; dorsal peristomial cirri similar in size to median antenna; ventral peristomial cirri shorter (Figs 3, 4B). Dorsal cirri of chaetiger 1 slightly longer than median antennae, dorsal cirri of chaetigers 2 and 3 shorter (Fig. 3), dorsal cirri of chaetigers 4 and 5 as long as dorsal cirri of chaetiger 1 or slightly shorter (Fig. 3); following dorsal cirri irregularly alternating long, as long as body width or slightly shorter, and short, shorter than body width. Antennae, peristomial and dorsal cirri throughout fusiform. Ventral cirri digitiform, inserted at bases of parapodial lobes, not reaching their tips (Figs 4B, E-F; 5I). Parapodial lobes distally bilobate. Anterior and midbody parapodia with 7-9 falcigers each; posterior parapodia with 3-4 each. Shafts of falcigers slightly spinulated subdistally, straight, tapering distally (Figs 5A-E; 6A-B). Blades of falcigers spinulated, bidentate, distal tooth larger; within each fascicle, dorsalmost falcigers with relatively long spines throughout blades, intermediate and ventralmost falcigers with shorter spines (Figs 5A-E; 6A-B); blades of falcigers with dorso-ventral gradation in length (Figs 4E-F; 6A-B), 22-8 $\mu \mathrm{m}, 25-12 \mu \mathrm{m}$ and 24-11 $\mu \mathrm{m}$ long on anterior, midand posterior body parapodia, respectively. Dorsal simple chaetae present from anterior parapodia, thinner than shafts of falcigers, with short subdistal spines, distally bidentate, teeth of similar size, progressively more triangular posteriorwards (Figs 5F-G; 6C); ventral simple chaetae only present in posteriormost parapodia, sigmoid, thinner than shafts of falcigers, with short subdistal spines, distally bidentate, distal tooth larger (Figs $5 \mathrm{H} ; 6 \mathrm{D})$. Anterior parapodia with two aciculae each, one of which straight, with acute tip, another subdistally inflated, with long, thin, needle-like tip (Fig. 6E); from midbody 
onwards single acicula per parapodium, subdistally inflated, with a long, thin, needlelike tip, stouter posteriorly (Fig. 6F). Semicircular pygidium, with paired anal cirri, similar in shape to dorsal cirri, longer. Pharynx through 3-4 segments; tooth relatively long, rhomboidal to ovate, slightly away from anterior margin of pharynx; proventricle extending for 2-3 chaetigers, with 19-21 rows of muscle cells (Fig. 3).

Reproduction. Some specimens were found broodin eggs dorsally, ca. from chaetiger 10-18 dorsally, 2 per chaetiger (Fig. 3).

Remarks. Brazilian specimens of $S$. cf. nitidula are very similar to $S$. clavata from the Iberian Peninsula, according to the redescription provided by San Martín (2003). The author noticed different morphotypes of $S$. clavata and considered it beyond intraespecific variation, suggesting the occurrence of a species-complex. Salvatoria clavata is characterized by having dorsal cirri of chaetiger 1 longer than remainning ones, dorsal cirri alternating between long and short from midbody onwards; falcigers with bidentate blades, distal tooth larger on anterior body parapodia, also with short, straight spines and dorso-ventral gradation in length, 19-12 $\mu \mathrm{m}$ long; blades of falcigers of posterior body parapodia stouter, distal teeth similar in size, with short, straight spines, and no dorso-ventral gradation in length, blades 11-12 $\mu \mathrm{m}$ long; dorsal and ventral simple chaetae bidentate, with short subdistal spinulation; single acicula per parapodium, acuminate; pharynx and proventricle wide, similar in lengh, through 3-4 chaetigers; pharyngeal tooth on anterior third of pharynx, away from anterior margin; proventricle with 20-23 rows of muscle cells.

Specimens of $S$. cf. nitidula analysed herein, differ from the description of $S$. clavata from Iberian Peninsula by having longer blades of falcigers, with dorso-ventral gradation in length throughout, 22-8 $\mu \mathrm{m}, 25-12 \mu \mathrm{m}$ and 24-11 $\mu \mathrm{m}$ long on anterior, mid- and posterior body parapodia, respectively; longer spinulation on the cutting edges 
of the blades of dorsalmost falcigers; dorsal simple chaetae only present on posterior parapodia, with both teeth triangular, similar in length; and anterior parapodia with two aciculae with acute tip each, one of which straight, another subdistally inflated.

Salvatoria nitidula, reported by Fukuda (2010), differs from S. cf. nitidula by having blades of falcigers with subdistal tooth short on anterior chaetigers, larger posteriorwards; ventral simple chaetae subdistally smooth, although also bidentate. Specimens from São Paulo need to be examined to check this differences.

\section{Salvatoria longiarticulata (Nogueira, San Martín \& Amaral, 2001)}

Grubeosyllis longiarticulata Nogueira, San Martín \& Amaral, 2001: 1788-1791, Fig. 5.

Material examined. State of Paraíba: João Pessoa, Paria do Cabo Branco $\left(7^{\circ} 08^{\prime} \mathrm{S}\right.$ $\left.34^{\circ} 47^{\prime} \mathrm{W}\right)$, intertidal: 20 specimens, coll. 02 February 2010

Remarks. The description provided by Nogueira et al (2001) for material from São Paulo, matches the material analysed herein, except for details of distal teeth of blades of falcigers. Specimens from Paraíba have both teeth shorter and directed forwards, and proventricle with ca. 17 rows of muscle cells, while material from São Paulo has longer teeth of blades of falcigers directed slightly upwards, and 24 rows of proventricular muscle cells rows.

Type locality. Ilha dos Alcatrazes, Santos, São Paulo, Brazil (Atlantic Ocean).

Distribution. Atlantic Ocean: Brazil (states of Paraíba and São Paulo). 


\section{Genus Sphaerosyllis Claparède, 1863}

Type species: Sphaerosyllis hystrix Claparède, 1863.

Diagnosis. Body relatively small, usually covered dorsally and ventrally on papillae. Palps usually completely fused, sometimes leaving terminal notch. Prostomium with three antennae and four eyes, eyespots usually absent. Peristomium frequently covering prostomium for some extention; 1 pair of peristomial cirri. Dorsal cirri usually absent on chaetiger 2. Antennae, peristomial and dorsal cirri throughout short, pyriform to flask-shaped, with sphaerical bases and short, slender tips. Ventral cirri conical to digitiform. Parapodial glands usually present and distinct, with fibrillar, hyaline, or granular material, frequently with prominent papilla dorsally. Compound chaetae as heterogomph falcigers only, with unidentate, usually short blades. Dorsal and ventral simple chaetae unidentate. Usually single acicula per parapodium throughout, distally bent at right angle. Pharynx slender, provided with small, soft papillae surrounding opening; pharyngeal tooth conical, close to anterior margin. Proventricle short, provided with few, large muscle cell rows. Reproduction by epigamy with ventral incubation of eggs and juveniles (San Martín 2005).

Remarks. This genus is known in Brazil for two species formally registered, S.annulata Nogueira, San Martín \& Fukuda, 2004 and S. brasiliensis Nogueira, San Martín \& Amaral, 2001 (Nogueira et al. 2001; 2004). Sphaerosyllis capensis Day, 1953, S. densopapillata Hartmann-Schröder, 1979, S. hystrix, S. magnidentata Perkins, 1981, and S. piriferopsis Perkins, 1981 were reported, described and illustred by Fukuda (2010), but not formally published. In this study, we found three species already 
reported from Brazil, S.annulata, S. densopapillata, S. magnidentata and a new species, Sphaerosyllis sp. n..

Key for Identification of the species of Sphaerosyllis currently recorded for Brazilian waters

1a. Each chaetigers with several annulations throughout body...2

1b. Chaetigers not divided in annuli...3

2a. (1a) Dorsal surface of the body without papillae; antennae, peristomial, dorsal and anal cirri with bases distinctly globular to oval, with abrupt transition to cylindrical tips; aciculae distally oblique and rounded, tips protruding from parapodial lobes...Sphaerosyllis annulata

2b. (1a) Body papillate dorsally, especially posteriorly; antennae, peristomial, dorsal and anal cirri with globular bases gradually tapering to cylindrical tips; aciculae subdistally bent at right angle, not protruding from parapodial lobes...Sphaerosyllis $\mathbf{s p .} \mathbf{n}$.

3a. (1b) Median and lateral antennae transversely aligned...4

3b. (1b) Median antennae inserted posteriorly to lateral antennae...6

4a. (3a) Body densely papillate...Sphaerosyllis densopapillata

4b. (3a) Body with scattered papillae...5

5a. (4b) Parapodial glands with fibrilar inclusions; peristomium covering prostomium for most of its extention, including eyes; blades of dorsalmost falcigers $22 \mu \mathrm{m}$ long on anterior parapodia, $19 \mu \mathrm{m}$ long on midbody, and $17 \mu \mathrm{m}$ long on posterior parapodia...Sphaerosyllis capensis ${ }^{1}$ 
5b. (4b) Parapodial glands with granulous inclusions; peristomium not covering prostomium; blades of dorsalmost falcigers $48 \mu \mathrm{m}$ long on anterior and midbody parapodia, $29 \mu \mathrm{m}$ on posterior parapodia...Sphaerosyllis magnidentata

6a. (3b) Parapodial glands present, with fibrilar inclusions; blades of dorsalmost falcigers of anterior body chaetigers $35 \mu \mathrm{m}$ long...Sphaerosyllis hystrix ${ }^{2}$

6b. (3b) Parapodial glands absent; blades of dorsalmost falcigers of anterior body chaetigers $15-22 \mu \mathrm{m}$ long...7

7a. (6b) Blades of falcigers on anterior and midbody parapodia with dorso-ventral gradation in length, 15-8 $\mu \mathrm{m}$ long, all blades of similar length on posterior body parapodia, ca. $8 \mu \mathrm{m}$ long; anterior parapodia with single acicula each; pharynx surrounded by brown glandular tissue; proventricle with 13-14 rows of muscle cells...Sphaerosyllis piriferopsis ${ }^{1}$

7b. (6b) Blades of falcigers with dorso-ventral gradation in length throughout the body, 22-12 $\mu \mathrm{m}$ long on anterior parapodia, $22-14 \mu \mathrm{m}$ long on midbody, and $20-12 \mu \mathrm{m}$ long on posterior body chaetigers; anterior parapodia with two aciculae each; pharynx with yellowish glands on chaetiger 1; proventricle with ca. 20 rows of muscle cells...Sphaerosyllis brasiliensis ${ }^{3}$

${ }^{1-3}$ Species not found in the present study, data provided by ${ }^{1}$ Fukuda 2010, ${ }^{2}$ San Martín 2003; ${ }^{3}$ Nogueira et al. 2001. 


\section{Sphaerosyllis annulata Nogueira, San Martín \& Fukuda, 2004}

Sphaerosyllis annulata Nogueira, San Martín \& Fukuda, 2004: 50-54, Fig. 1. Fukuda 2010: 189-191.

Material examined. State of Pernambuco: Itamaracá, Ponta do Jaguaribe $\left(7^{\circ} 44^{\prime} \mathrm{S}\right.$ 3449'W), intertidal: 1 specimen, coll. 11 December 2012.

Remarks. The specimen analysed was incomplete, an anterior fragment with 14 chaetigers. It differs from the original description by having scattered papillae dorsally.

Type locality. Ubatuba, São Paulo, Brazil (Atlantic Ocean).

Distribution. Atlantic Ocean: Brazil (states of Pernambuco and São Paulo).

\section{Sphaerosyllis sp. $\mathbf{n}$.}

(Figures 7-10)

Material examined. State of Paraíba: João Pessoa, Recife do Picãozinho ( $7^{\circ} 4.243^{\prime}$ S 34ํำ.291'W), 1 m: 21 specimens, coll. 15 September 2012. Pitimbu, Farol de Pitimbu ( $\left.7^{\circ} 28.362^{\prime} \mathrm{S} 34^{\circ} 47^{\prime} \mathrm{W}\right)$, intertidal: 4 specimens, coll. 18 September 2012. State of Pernambuco: Ilha de Itamaracá, recifes de Itamaracá, (743.944'S 3449.200'W), $1 \mathrm{~m}: 1$ specimen, coll. 15 December 2012.

Description. Small-sized body; largest specimens analysed ca. $3.5 \mathrm{~mm}$ long, 0.2 $\mathrm{mm}$ wide, with up to 21 chaetigers. Body covered on papillae from peristomium, papillae more numerous and digitiform dorsally, shorter and oval ventrally (Figs 7A-D, F-H; 8A; 9). Palps triangular, distally rounded, almost completely fused, with conspicuous line of fusion and distal notch (Fig. 7A-B). Prostomium ovate, as long as 
palps, with two pairs of eyes in trapezoidal arrangement, anterior eyespots absent; antennae with bulbous bases and relatively short tips, all about same length, lateral antennae inserted on anterior margin of prostomium, shorter than palps, median antenna inserted between posterior eyes. Nuchal organs not observed. Peristomium shorter than following chaetigers, peristomial cirri shorter than antennae, with similar shape; tufts of cilia close to base of peristomial cirri ventrally (Fig. 7E). Anterior dorsal cirri with bulbous bases and relatively long tips as long as antennae and peristomial cirri; bases progressively more slender posteriorwards; dorsal cirri absent on chaetiger 2. Ventral cirri digitiform, shorter than parapodial lobes. Parapodial lobes conical; each midbody parapodium with pair of lateral, larger papillae, one anterior, inserted on distal half of parapodium, another posterior, near tip of parapodium, smaller, scattered papillae also present (Fig. 9); parapodial glands from chaetiger 6-7, with granular material. Anterior parapodia with 5-7 falcigers each, midbody with 3-5, posterior parapodia with 2-4 falcigers each. Shafts of falcigers subdistally spinulated and inflated, distally straight, with acute tip (Figs 8D, F-G, J-K; 10A-C). Blades of falcigers from anterior and midbody parapodia unidentate and spinulated, with progressively shorter spines directed upwards; blades of falcigers of posteriorbody parapodia unidentate, smooth (Figs 8D, $\mathrm{F}-\mathrm{G}, \mathrm{J}-\mathrm{K} ; 10 \mathrm{~A}-\mathrm{C}$ ); blades with dorso-ventral gradation in length, 24-10 $\mu \mathrm{m}$ long on anterior parapodia, 14-11 $\mu \mathrm{m}$ long from midbody. Dorsal simple chaetae present from anterior parapodia, sigmoid, thinner than shafts of falcigers, with short subdistal spines, distally unidentate (Figs 8E, H-I; 10D-E); ventral simple chaetae only present on posterior parapodia, sigmoid, thinner than shafts of falcigers, smooth under light microscopy, with short subdistal spines under SEM, distally unidentate (Figs 8L; 10F). Anterior parapodia with two aciculae each, one of which with tip bent at right angle, another straight, with acute tip, sometimes difficult to see (Fig. 10G); single acicula per 
parapodium from midbody, with tips bent at right angle (Fig. 10H). Semicircular pygidium, with paired anal cirri, similar to dorsal cirri but longer, and papillae inbetween. Pharynx through 2-3 segments; tooth near to anterior margin of pharynx; anterior margin of pharynx surrounded by 10 papillae (Figs 7A-B, 8A, C); proventricle extending for 1.5-2 chaetigers, with 13-15 rows of muscle cells.

Remarks. Sphaerosyllis sp. n. can be differentiated from the other species occurring in Brazilian waters by having median antenna inserted posteriorly to lateral antennae, between posteior pair of eyes; scattered papillae dorsal and ventrally, dorsal papillae digitiform, ventral papillae rounded, shorter; two aciculae per anterior chaetiger, one tip bent at right angle another straight, with acute tip; and blades of falcigers with marked gradation in length on anterior parapodia only, 24-10 $\mu \mathrm{m}$ long; blades of mid- and posterior falcigers 14-11 $\mu \mathrm{m}$. Sphaerosyllis densopapillata have the body more densely papilate; antennae transversely aligned; single acicula per parapodium throughout, with tip bent at right angle, and longer blades of falcigers, with gradation in length, 38-10 $\mu \mathrm{m}, 40-12 \mu \mathrm{m}$, and 35-12 $\mu \mathrm{m}$ long on anterior, mid- and posterior parapodia, respectively. Sphaerosyllis magnidentata also has antennae transversely aligned; single acicula per parapodium throughout, with tip bent at right angle, and longer blades of falcigers, 48-15 $\mu \mathrm{m}$ long on anterior and midbody parapodia, 29-15 $\mu \mathrm{m}$ on posterior parapodia. Sphaerosyllis brasiliensis has more densely papilate body and blades of falcigers with gradation in length throughout. Finally, S. annulata differs from Sphaerosyllis sp. n. by having annelated chaetigers, and different morphologies of dorsal cirri and aciculae.

Sphaerosyllis taylori Perkins, 1981, S. austriaca Banse, 1959 and S. pirifera Claparède, 1868 are similar to Shaerosyllis sp. n. by having papilate dorsum. However, S. taylori has parapodial glands usually present and distinct, with fibrillar material; 
blades of falcigers smooth, except for the dorsalmost anterior chaetae, with short spinulation, 10-8 $\mu \mathrm{m}$ thoughout; anterior parapodia with a single acicula each. Differently, Shaerosyllis sp. n. has parapodial glands with granular material; blades of anterior and midbody falcigers spinulated, 24-10 $\mu \mathrm{m}$ long on anterio body; anterior parapodia with two aciculae each.

Sphaerosyllis austriaca has the peristomium covering the prostomium, including the anterior pair of eyes; parapodial glands; blades of anterior falcigers subbidentate, with 30-12 $\mu \mathrm{m}$ long; and a single acicula thougout the body. Finally, S. pirifera has papilae from the palps, the parapodial glands absent and thinner blades of falcigers, whereas in Sphaerosyllis sp. n. the papilae begging from peristomium.

Distribution. States of Paraíba and Pernambuco (Atlantic Ocean).

\section{Sphaerosyllis densopapillata Hartmann-Schröder, 1979}

(Figure 11)

Sphaerosyllis capensis densopapillata Hartman-Schröder, 1979: 104-105, Abb. 141-143; 1980:54.

Sphaerosyllis densopapillata. San Martín 2005: 92-94, figs. 48-49A-B. Fukuda 2010: 195198, Fig. 5657.

Material examined. State of Paraíba: Mataraca, Barra de Camaratuba $\left(6^{\circ} 36^{\prime} \mathrm{S}\right.$ 34 $57^{\prime} \mathrm{W}$ ), intertidal: 2 specimens, coll. 12 August 2010. Baía da Traição, Praia do Farol (6 $\left.41^{\circ} \mathrm{S} 34^{\circ} 55^{\prime} \mathrm{W}\right)$, intertidal: 3 specimens, coll. 09 August 2010. João Pessoa, Recife do Picãozinho (74.243'S 3449.291'W), 1 m: 5 specimens, coll. 15 September 2012. State 
of Pernambuco: Itamaracá, Ponta do Jaguaribe $\left(7^{\circ} 44^{\prime} \mathrm{S} 34^{\circ} 49^{\prime} \mathrm{W}\right)$, intertidal: 6 specimens, coll. 11 December 2012.

Description. Small-sized body; longest specimens ca. $1.5 \mathrm{~mm}$ long and $0.1 \mathrm{~mm}$ wide, with up to 18 chaetigers. Body covered on transverse rows of oval papillae, more abundant dorsally, but also present ventrally, from peristomium. Palps triangular, distally rounded, almost totally fused, with conspicuous line of fusion and distal notch. Prostomium oval, shorter than palps, with two pairs of eyes in trapezoidal arrangement, anterior eyespots absent; antennae with bulbous bases and relatively short tips, inserted in line, close to each other, on anterior margin of prostomium, all about the same length, reaching tips of palps or slightly shorter. Nuchal organs not observed. Peristomium shorter than following chaetigers, sometimes covering posterior part of prostomium, including posterior eyes; peristomial cirri shorter than antennae, with similar shape. Dorsal cirri with bulbous bases and relatively short tips, slightly larger than peristomial cirri, absent on chaetiger 2. Anterior ventral cirri pyriform, as long as parapodial lobes; from midbody onwards, ventral cirri elongated, digitiform, longer than parapodial lobes. Parapodial lobes conical, with 1-2 papillae each; parapodial glands from chaetiger 4-5, with granular material. Anterior and midbody parapodia with 5-7 falcigers each; and posterior parapodia with $2-4$ falcigers each. Shafts of falcigers subdistally spinulated; shafts subdistally inflated, straight, distally tapering (Fig. 11A-B). Blades unidentate; blades of anterior and midbody falcigers densely spinulated, progressively shorter spines directed upwards; posterior falcigers with fewer spines, ventralmost ones smoother (Fig. 11A-B); blades with gradation in length, 38-10 $\mu \mathrm{m}, 40-12 \mu \mathrm{m}$, and 35$12 \mu \mathrm{m}$ long on anterior, mid- and posterior parapodia, respectively. Dorsal simple chaetae present from anterior parapodia, thinner than shafts of falcigers, sigmoid, with short subdistal spines, distally unidentate, with rounded tips (Fig. 11C) on anterior 
parapodia, acute tips from midbody (Fig. 11D); ventral simple chaetae only present on most posterior parapodia, thinner than shafts of falcigers, sigmoid, smooth, distally unidentate (Fig. 11E). Parapodia with single acicula bent at right angle throughout; anterior acicula with straight tips, sligtly upwardly directed posteriorly (Fig. 11F-G). Semicircular pygidium, with paired anal cirri similar to posterior dorsal cirri but longer, and papillae inbetween. Pharynx through 2-3 segments; tooth on anterior margin of pharynx; proventricle extending for 1.5-2 chaetigers, with 14-17 rows of muscle cells.

Remarks. This species is characterized by having antennae transversely aligned on anterior margin of prostomium; dorsal surface densely covered on rounded papillae; unidentate blades of falcigers, those from anterior and midbody parapodia with spinulated blades, blades smooth on posterior parapodia; and blades with gradation in length through. Sphaerosyllis magnidentata and Sphaerosyllis sp. n. (see description above) are sympatric and share several characters with $S$. densopapillata.

Sphaerosyllis magnidentata differs from $S$. densopapillata by having less papillated body; blades of falcigers with more conspicuous spines and larger pharyngeal tooth. Sphaerosyllis sp. n. also has fewer papillae; together with shorter blades of falcigers, dorsalmost blades of anterior parapodia with ca. $24 \mu \mathrm{m}$ long, against $38 \mu \mathrm{m}$ long in S. densopapillata; and blades of falcigers of posterior segments without conspicuous gradation in length.

Sphaerosyllis brasiliensis from the state of São Paulo is similar to $S$. densopapillata by having the body densely papilate; similar shape and size of appendages, pharynx and proventricle. These species can be differentiated by the length of the blades of falcigers, blades of $S$. densopapillata being 38-10 $\mu \mathrm{m}$ long on anterior parapodia, 40-12 $\mu \mathrm{m}$ on midbody, 35-12 $\mu \mathrm{m}$ long on posterior parapodia, while $S$. brasiliensis has blades $22.5-12 \mu \mathrm{m}$ long on anterior parapodia, 22-11 $\mu \mathrm{m}$ on midbody, 
and $20-9.5 \mu \mathrm{m}$ long on posterior parapodia; also, $S$. densopapillata has single acicula per parapodium throughout, bent at right angle, while $S$. brasiliensis has two aciculae on each anterior parapodium, one of which straigth, with acute tip, another bent at right angle.

Finally, S. annulata, also from state of São Paulo, differs from S. densopapillata by having annellated segments; dorsal cirri with remarkably abrubt transition from base to tip; and anterior parapodia with two aciculae each, one of wich thick, distally oblique, with pointed tip, another straight and slightly thinner; from midbody, single acicula per parapodium, distally oblique and rounded, tip protruding from parapodial lobe.

Specimens of $S$. densopapillata from the northeastern Brazilian coast agree with description provided by Fukuda (2010), for specimens from the state of São Paulo, except for the spinulation present on blades of posterior falcigers of northeastern specimens, not observed in material from São Paulo; and also in the morphology of posterior aciculae, with oblique tips in northeastern specimens, straight among those from São Paulo (Fukuda 2010, Fig. 56F).

Type locality. Broome, Western Australia, Australia (Indian Ocean).

Distribution. Pacific Ocean: Australia (Queensland); Indian Ocean: Australia (Western Australia); Atlantic Ocean: Brazil (states of Paraíba, Pernambuco and São Paulo). 


\section{Spaherosyllis magnidentata Perkins, 1981}

(Figures 12)

Sphaerosyllis magnidentata Perkins, 1981: 1130-1133, Fig. 22; Nuñez 1990: 301-302, Fig. 87

Material examined. State of Paraíba: João Pessoa, Paria do Cabo Branco $\left(7^{\circ} 08^{\prime} \mathrm{S}\right.$ 34 ${ }^{\circ} 47^{\prime} \mathrm{W}$ ), intertidal: 2 specimens, coll. 02 February 2010; Recife do Picãozinho $\left(7^{\circ} 4.243^{\prime} \mathrm{S} 34^{\circ} 49.291^{\prime} \mathrm{W}\right), 1 \mathrm{~m}: 4$ specimens, coll. 15 September 2012 . State of Pernambuco: Goiana, Pontas de Pedra $\left(7^{\circ} 37^{\prime} \mathrm{S} 34^{\circ} 48^{\prime} \mathrm{W}\right), 2$ specimens, coll. 13 December 2012. Almirante Tamandaré, Praia dos Carneiros ( $\left.8^{\circ} 42.849^{\prime} \mathrm{S} 35^{\circ} 4.999^{\prime} \mathrm{W}\right)$, intertidal: 1 specimen, coll. 22 July 2013.

Description. Small-sized body; longest specimens ca. $1.4 \mathrm{~mm}$ long and $0.1 \mathrm{~mm}$ wide, with up to 17 chaetigers. Body covered on small papillae, diffused, present from peristomium (Fig. 8). Palps triangular, distally rounded, almost totally fused, with conspicuous line of fusion and distal notch. Prostomium oval, shorter than palps, with 2 pairs of eyes in open trapezoidal arrangement, anterior eyespots absent; antennae with bulbous bases and relatively short tips, all about same length, reaching tip of palps or terminating slightly before that, inserted transversely aligned on anterior margin of prostomium, close to each other. Nuchal organs not visible. Peristomium shorter than following chaetigers; peristomial cirri shorter than antennae, with similar shape. Dorsal cirri with bulbous bases and relatively short digitiform tips, slightly larger than peristomial cirri, absent on chaetiger 2. Anterior ventral cirri digitiform, longer than parapodial lobes. Parapodial lobes conical, with 1-2 papillae each; parapodial glands from chaetiger 4-5, with granular material. Anterior and midbody parapodia with 5-7 falcigers each, posterior parapodia with 2-4 falcigers each. Shafts of falcigers subdistally spinulated and inflated, with straight, tapering tip (Fig. 12A-B). Blades of 
dorsal and intermediate falcigers spinulated, progressively shorter spines directed upwards, distally subbidentate; blades of ventralmost falcigers inconspicuously spinulated throughout, distally unidentate (Fig. 12A-B); blades with dorso-ventral gradation in length, 48-15 $\mu \mathrm{m}$ long on anterior and midbody parapodia, 29-15 $\mu \mathrm{m}$ long on posterior ones. Dorsal simple chaetae present from anterior parapodia, sigmoid, thinner than shafts of falcigers, subdistally spinulate, distally unidentate (Fig. 12C); ventral simple chaetae only present on posteriormost parapodia, sigmoid, thinner than falciger shafts, subdistally smooth, distally unidentate (Fig. 12D). Parapodia with single acicula each throughout, tip bent at right angle (Fig. 12E-F). Papilate pygidium with 2 anal cirr, slightly longer than posterior dorsal cirri. Pharynx through 2-3 segments; tooth relatively large, occupying most of pharynx openning; proventricle extending for 1.5-2 chaetigers, with $15-17$ rows of muscle cells.

Remarks. Specimens of $S$. magnidentata from off the northeastern Brazilian coast match the description provided by Fukuda (2010), for specimens from the state of São Paulo. This species can be easily differentiated from $S$. densopapillata, $S$. brasiliensis and Sphaerosyllis sp. $\mathbf{n}$. by having less papillae on the body and by the remarkably larger phryngeal tooth.

Sphaerosyllis annulata differs from $S$. magnidentata by having annelated chaetigers, and both dorsal cirri and aciculae throughout with different morphology.

Type locality. Monroe County, Florida, USA (Atlantic Ocean)

Distribution. Atlantic Ocean: Canary Islands, Bahamas, Cuba, Belize, Brazil (states of Paraíba, Pernambuco and São Paulo). 


\section{Acknowledgements}

The Project "Diversity of Polychaeta (Annelida) on hard substrates off the state of Paraíba and Pernambuco, northeastern Brazil" was funded by the Conselho Nacional de Desenvolvimento Cientifico e Tecnológico-CNPq (proc. 481510/2008-7) and Fundação de Amparo a Pesquisa do Estado de São Paulo - FAPESP (proc. 2010/52116-4). In addition, KP receives a Ph. D. fellowship from FAPESP (proc. 2009/17606-3), and MVF receives a post-doc fellowship from FAPESP (proc. 2010/19424-7). We are also thankful to Orlemir Carrerette, Rudá Amorin, Rafael Brito, Carmem Alonso Samiguel and all students of Laboratório de Invertebrados Paulo Yang for the help with the collections; Ênio Mattos and Phillip Lenktaitis for preparing the specimens and photographing them under the SEM. 


\section{References}

Aguado, M.T. \& San Martín, G. (2009) Phylogeny of the Syllidae (Polychaeta) based on morphological data. Zoologica Scripta 38, 379-402.

Aguado, M.T., San Martín, G. \& Siddall, M.E. (2012) Systematics and evolution of syllids (Annelida, Syllidae). Cladistics, 27, 1-17.

Amaral, A.C.Z., Nallin, S.A.H., Steiner, T.M., Forroni, T.O. \& Gomes-Filho, D. (2013) Catálogo das espécies de Annelida Polychaeta do Brasil. http://www.ib.unicamp.br/projbiota/bentos_marinho/prod_cien/texto_poli.pdf. (Acessed February 2014).

Augener, H. (1913) Polychaeta 1, Errantia. In: Michaelsen,W. \& Hartmeyer, R. (Eds) Die Fauna Südwest-Australiens. Ergebnisse der Hamburger südwest-australischen Forschungsreise 1905, vol 4, Lieferung 5. Gustav Fischer, Jena, 65-304.

Ben-Eliahu, M.N. (1977) Polychaete cryptofauna from rims of similar intertidial vermetid reefs onthe mediterranean coast of Israel and in the Gulf of Elat: Exogoninae and Autolytinae (Polychaeta errantia: Syllidae). Israel Journal of Zoology, 26, 59-99.

Böggemann M. \& Westheide W. (2004) Interstitial Syllidae (Annelida: Polychaeta) from Mahé (Seychelles). Journal of Natural History, 38, 403-446.

Claparède, E. (1863) Beobachtungen über Anatomie und Entwicklungsgeschichte wirbelloser Thiere an der Küste von Normandie angelstellt. Wilhelm Engelmann, Leipzig, 120 pp.

Claparède, E. (1868) Les annélides chétopodes du Golfe de Naples. Mémoires de la Société de physique et d'Histoire naturelle de Genève, 19, 313-584.

Day, J.H. (1953) The polychaet fauna of South Africa. Part 2. Errant species from Cape shores and estuaries. Annals of the Natal Museum, 12, 397-441.

Díaz-Castañeda, V. \& San Martín, G. (2001) Syllidae (Polychaeta) from San Quintin lagoon, Baja California, México, with the description of a new genus. Proceedings of the Biological Society of Washington, 114, 708-719.

Fauvel, P. (1923) Polychètes errantes. In: Faune de France, vol. 5. Le Chavalier. Paris. 486 pp.

Fukuda, M.V. (2010) Contribuição ao conhecimento taxonômico dos silídeos (Polychaeta: Syllidae) da região sudeste-sul do Brasil. Ph. D. Thesis, Instituto de Biociências da Universidade de São Paulo, São Paulo, 340 pp.

Fukuda, M.V., Yunda-Guarín, G. \& Nogueira, J.M.M. (2009) The genus Prosphaerosyllis (Polychaeta: Syllidae: Exogoninae) in Brazil, with description of a new species. Journal of the Marine Biological Association of the United Kingdom, 89, 1443-1454.

Goodrich, E.S. (1930) On a new hermaphroditic syllid. Quaterly Journal of Microscopical Science, 73, 651-666. 
Grube, A.E. (1850) Die Familien der Anneliden. Archiv für Naturgeschichte, 16, 249-364.

Hartmann-Schroder, G. (1959) Zur Okologie der Polychaeten des Mangrove-Estero-Gebietes von El Salvador. Beitraege zur Neotropischen Fauna, 1, 69-183.

Hartmann-Schröder, G. (1960) Polychaeten aus dem Roten Meer. Kieler Meeresforschungen, $16,69-125$.

Hartmann-Schröder, G. (1971) Annelida, Borstenwürmer, Polychaeta. Die Tierwelt Deutschlands, vol. 58. Jena: Gustav Fischer Veerlag, 594 pp.

Hartmann-Schröder, G. (1974) Zur Kenntnis des Eulitorals der afrikanischen Westkuste zwischen Angola und Kap der Guten Hoffnung und der afrikanischen Ostkuste von Sudafrika und Mocambique unter besonderer Berücksichtigung der Polychaeten und Ostracoden. Teil 2. Die Polychaeten des Untersuchungsgebietes. Mitteilungen aus dem Hamburgischen Zoologischen Museum und Institut, 68, 95-228.

Hartmann-Schröder, G. (1979) Teil 2. Die Polychaeten der tropischen Nordwestküste Australiens (Zwischen Port Samson in Norden und Port Hedland in Süden). Mitteilungen aus dem Hamburgischen Zoologischen Museum und Institut, 76, 75-218.

Hartmann-Schröder, G. (1980) Die Polychaeten der tropischen Nordwestküste Australiens (zwischen Port Samson im Norden und Exmouth im Süden). In: Hartmann-Schröder, G. \& Hartmann, G. Zur Kenntnis des Eulitorals der australischen Küsten unter besonderer Berücksichtigung der Polychaeten und Ostracoden. Teil 4. Mitteilungen aus dem Hamburgischen Zoologischen Museum und Institut, 77, 41-110

Hartmann-Schröder, G. (1982) Die Polychaeten der subtropisch-antiborealen Westküste Australiens (zwischen Cervantes im Norden und Cape Naturaliste im Süden). Teil 8. In: Hartmann-Schröder, G. \& Hartman, G. Zur Kenntnis des Eulitorals der australischen Küsten unter besonderer Berücksichtigung der Polychaeten und Ostracoden. Mitteilungen aus dem Hamburgischen Zoologischen Museum und Institut, 79, 51-118.

Lanera, P., Sordino, P. \& San Martín, G. (1994) Exogone (Parexogone) gambiae, a new species of Exogoninae (Polychaeta, Syllidae) from the Mediterranean Sea. Italian Journal of Zoology, 61, 235-240.

Langerhans, P. (1879) Die Wurmfauna von Madeira. Zeitschrift für wissenschaftliche Zoologie, $32,513-592$

Langerhans, P. (1881) Ueber einige canarische Anneliden. Nova Acta Leopoldina, 42, 93-124.

Malaquin, A. (1893) Recherches sur les Syllidiens, morphologie, anatomie, reproduction, développement. Mémoires de la Société des sciences, de l'agriculture et des arts de Lille, 18, 1-477.

McIntosh, W.C. (1885) Report on the Annelida Polychaeta collected by H.M.S. Challenger duringthe years 1873-76. Report on the Scientific Results of the voyage of H.M.S. Challenger during the years 1873-76, 12, 1-554. 
Mesnil, F.Y \& Caullery, M. (1918) Sur l'organisation et la biologie d'un Syllidien Exogone (Parexogone n. s.g.) hebes Webster et Benedict, var. hibernica Southern, habitant un sable compacte. Bulletin de la Société Zoologique de France, 42, 126-132.

Nogueira, J.M.M. (2000) Anelídeos poliquetas associados ao coral Mussismilia híspida (Verril, 1868) em ilhas do litoral do Estado de São Paulo. Phyllodocida, Amphinomida, Eunicida, Spionida, Terebellida, Sabellida. Tese de Doutorado - Instituto de Biociências, Universidade de São Paulo. 265 pp.

Nogueira, J.M.M. (2006) Família Syllidae. In: Amaral ACZ, Rizzo AE, Arruda, EP, editors. Manual de Identificação dos Invertebrados Marinhos da Região Sudeste-Sul do Brasil. São Paulo, SP: Editora da Universidade de São Paulo, 134-164.

Nogueira, J.M.M., San Martín, G. \& Amaral, A.C.Z. (2001) Description of five new species of Exogoninae (Polychaeta, Syllidae) associated with the stony coral Mussismilia hispida (Verrill, 1868) in São Paulo State, Brazil. Journal of Natural History 35, 1773-1794.

Nogueira, J.M.M., San Martín, G. \& Fukuda, M.V. (2004) On some exogonines (Polychaeta, Syllidae) from the northern coast of the State of São Paulo, southeastern Brazil Results of BIOTA/FAPESP/BentosMarinho Project. Meiofauna Marina 13, 45-78.

Nuñez, J. (1990) Anelidos Poliquetos de Canarias: Estudio Sistematico de los Ordenes Phyllodocida, Amphinomida y Eunicida. Tese de Doutorado - Departamento de Biologia Animal (Zoologia), Universidade de La Laguna. 620 pp.

Núñez, J., San Martín, G. \& Brito, M.C (1992) Exogoninae (Polychaeta, Syllidae) from the Canary Islands. Scientia Marina, 56 (1), 43-52.

Ørsted, A.E., (1845) Ueber die Entwicklung der Jungen bei einer Annelide und über änveren Untersuchiede zwischen beiden Geschlechtern. Archiv für Naturgeschichte Berlin, 11, $20-23$.

Perkins, T. H. (1981) Syllidae (Polychaeta), principally from Florida, with descriptions of a new genus and twenty-one new species. Proceedings of the Biological Society of Washington, 93, 1080-1172.

Quatrefages, A. (1866) Histoire naturelle des Annelés marins et d'eau douce. Annélides et Géphyriens. Librairie Encyclopédique de Roret, Paris.

Riser, N.W. (1991) An evaluation of taxonomic characters in the genus Sphaerosyllis (Polychaeta: Syllidae). Ophelia, 5, 209-217.

Russell, D.E. (1991) Exogoninae (Polychaeta: Syllidae) from the Belizean barrier reef with a key to species of Sphaerosyllis. Journal of Natural History, 25, 49-74.

San Martín, G. (1984) Estudio biogeográfico, faunístico y sistemático de los Poliquetos de la família Sílidos (Syllidae: Polychaeta) en Baleares. Publicaciones de la Universidad Complutense de Madrid, 187, Madrid. 581 pp. 
San Martín, G. (1991) Grubeosyllis and Exogone (Exogoninae, Syllidae, Polychaeta) from Cuba, the Gulf of Mexico, Florida and Puerto Rico, with a revision of Exogone. Bulletin of Marine Science, 49, 715-740.

San Martín, G. (2002) A new genus and species of Syllidae (Polychaeta) from Australia dorsally brooding eggs by means of compound notochaetae, with comments on external brooding in the family. Proceedings of the Biological Society of Washington, 115, 333340 .

San Martín, G. (2003) Annelida Polychaeta II: Syllidae. In: Ramos, M.A. et al. (eds.), Fauna Ibérica, vol. 21. Museo Nacional de Ciências Naturales, CSIC, Madrid. 544 pp.

San Martín, G. (2005) Exogoninae (Polychaeta, Syllidae) from Australia with the description of a new genus and twenty-two new species. Records of the Australian Museum, 57, 39152.

Sarda, R. (1984) La subfamilia Exogoninae (Polychaeta; Syllidae) de Gibraltar, con descripcion de Pseudobrania euritmica n. sp. Publicaciones del Departamento de Zoologia Universidad de Barcelona Facultad de Biologia, 10, 7-13.

Temperini, M.T. (1981). Sistemática e distribuição dos poliquetos errantes da plataforma

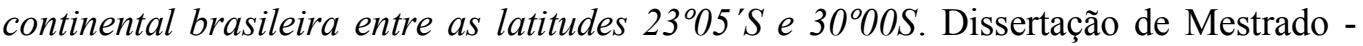
Instituto Oceanográfico, Universidade de São Paulo. 89 pp.

Webster, H.E. \& Benedict, J.E. (1884) The Annelida Chaetopoda from Provicentown and Wellfleet, Mass. Reports of the United States Commissioner of Fish and Fisheries for 1881, 699-747.

Westheide, W. (1974a) Interstitielle Polychaeten aus brasilianischen Sandstränden. Mikrofauna Meeresbodens, 31, 1-16.

Westheide, W. (1974b) Interstitielle Fauna von Galapagos 11. Pisionidae, Hesionidae, Pilargidae, Syllidae (Polychaeta). Mikrofauna Meeresbodens, 44, 1-146. 


\section{Legends to figures}

FIGURE 1. Erinaceusyllis sp.. Complete specimen, dorsal view. Scale bar: $100 \mu \mathrm{m}$.

FIGURE 2. Erinaceusyllis sp. (A) falcigers, anterior parapodia; (B) dorsal simple chaeta; (C) ventral simple chaeta; (D) (E) aciculae, anterior and posterior parapodia, respectively. Scale bar: $20 \mu \mathrm{m}$.

FIGURE 3. Salvatoria $\mathrm{cf}$. nitidula. Anterior body, dorsal view. Scale bar: $200 \mu \mathrm{m}$.

FIGURE 4. Salvatoria cf. nitidula, SEM. (A) (B) anterior body, dorsal and ventral views, respectively; (C) close up view of the anterior end, dorsal view; (D) ciliated nuchal organ; (E) parapodia 2-4, ventral view; (F) posterior parapodia, ventro-lateral view. Scale bars: A-B, $50 \mu \mathrm{m}$; C, E-F, $20 \mu \mathrm{m}$; D, $5 \mu \mathrm{m}$.

FIGURE 5. Salvatoria cf. nitidula, SEM. (A) (B) dorsalmost falcigers, anterior parapodium; (C) ventralmost falcigers, parapodium 2; (D) ventralmost falciger, midbody parapodium; (E) ventralmost falcigers, posterior parapodium; (F) (G) dorsal simple chaetae, posterior parapodium; $(\mathrm{H})$ ventral simple chaeta, posterior parapodium; (I) posterior parapodia, frontal view. Scale bars: A-B, D-F, $5 \mu \mathrm{m}$; C, G-I, $2 \mu \mathrm{m}$.

FIGURE 6. Salvatoria $\mathrm{cf}$. nitidula. (A) B) falcigers, anterior and posterior parapodia, respectively; (C) dorsal simple chaeta, posterior parapodium; (D) ventral simple chaeta, 
posterior parapodium; (E) (F) aciculae, anterior and posterior parapodia, respectively. Scale bar: $10 \mu \mathrm{m}$.

FIGURE 7. Sphaerosyllis sp. n., SEM. (A) (B) anterior end, dorsal and ventral views, respectively; (C) chaetigers 1-5, dorsal view; (D) close up view of the prostomium; (E) close up view of the ventral base of peristomial cirri; (F) midbody, dorso-lateral view; (G) midbody, dorsal view; $(\mathrm{H})$ posterior body, dorsal view. la-lateral antenna, mamedian antenna, pa-palps, pr-prostomium. Scale bars: A, $100 \mu \mathrm{m}$; B-C, F-H, 50 $\mu \mathrm{m} ; \mathrm{D}, 20 \mu \mathrm{m} ; \mathrm{E}, 5 \mu \mathrm{m}$.

FIGURE 8. Sphaerosyllis sp. n., SEM. (A) complete specimen; (B) chaetae, parapodia 1 and 2; (C) pharynx, frontal view; (D) falciger, parapodium 6; (E) dorsal simple chaeta, anterior parapodium; (F) dorsalmost falciger, anterior parapodium; (G) ventralmost falciger, anterior parapodium; (H) (I) dorsal simple chaetae, posterior parapodium; (J) falciger, midbody parapodium; (K) falciger, posterior parapodium; (L) ventral simple chaeta, posterior parapodium. Scale bars: A, $20 \mu \mathrm{m}$; B-C, E, I, $10 \mu \mathrm{m}$; D, G-H, $2 \mu \mathrm{m}$; F, J-L, $5 \mu \mathrm{m}$.

FIGURE 9. Sphaerosyllis sp. n. Midbody parapodium. Scale bar: $200 \mu \mathrm{m}$.

FIGURE 10. Sphaerosyllis sp. n. (A) (B) (C) falcigers, anterior, midbody and posterior, parapodia, respectively; (D) (E) dorsal simple chaetae, anterior and posterior parapodia, respectively; (F) ventral simple chaeta, posterior parapodium; (G) (H) aciculae, anterior and posterior parapodia, respectively. Scale bar: $20 \mu \mathrm{m}$. 
FIGURE 11. Sphaerosyllis densopapillata. (A) (B) falcigers, anterior and midbody parapodia, respectively; (C) (D) dorsal simple chaetae, anterior and posterior parapodia, respectively; (E) ventral simple chaeta, posterior parapodium; (F) (G) aciculae, anterior and posterior parapodia, respectively. Scale bar: $10 \mu \mathrm{m}$.

FIGURE 12. Sphaerosyllis magnidentata. (A) (B) falcigers, anterior and posterior parapodia, respectively; (C) dorsal simple chaeta, posterior parapodium; (D) ventral simple chaeta, posterior parapodium; (E) (F) aciculae, anterior and posterior parapodia, respectively. Scale bar: $20 \mu \mathrm{m}$. 


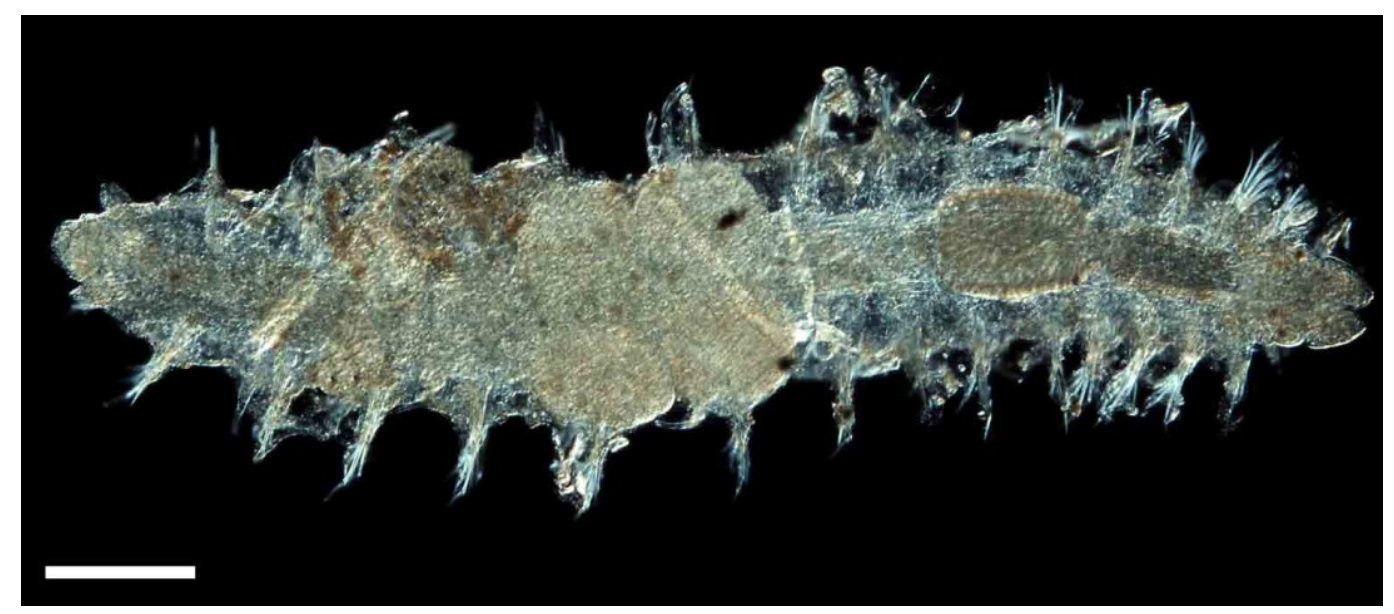

Figure 1

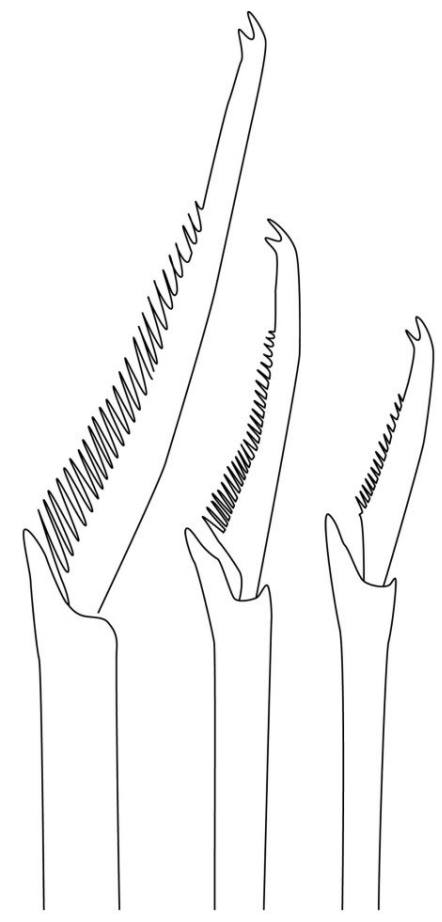

A

Figure 2

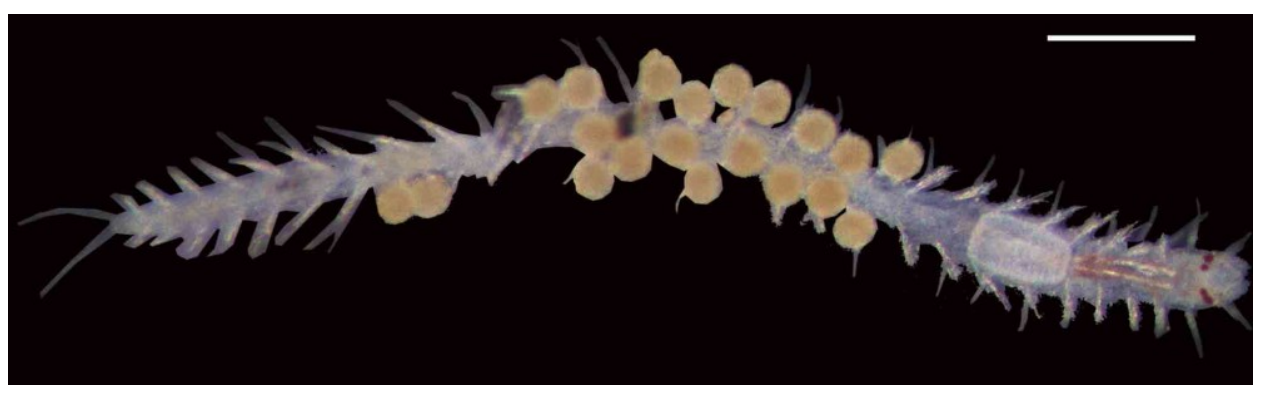

Figure 3 

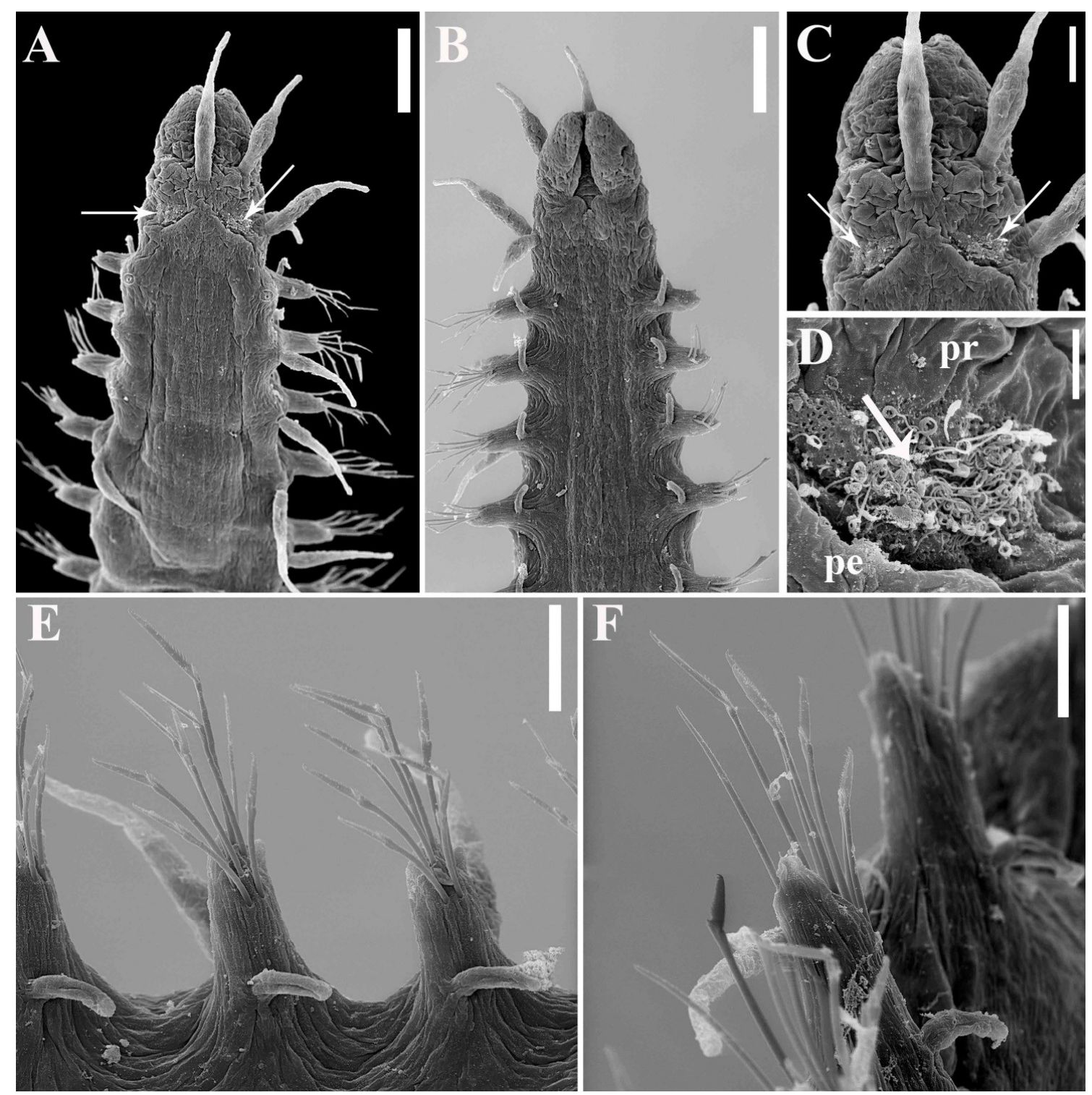

Figure 4 


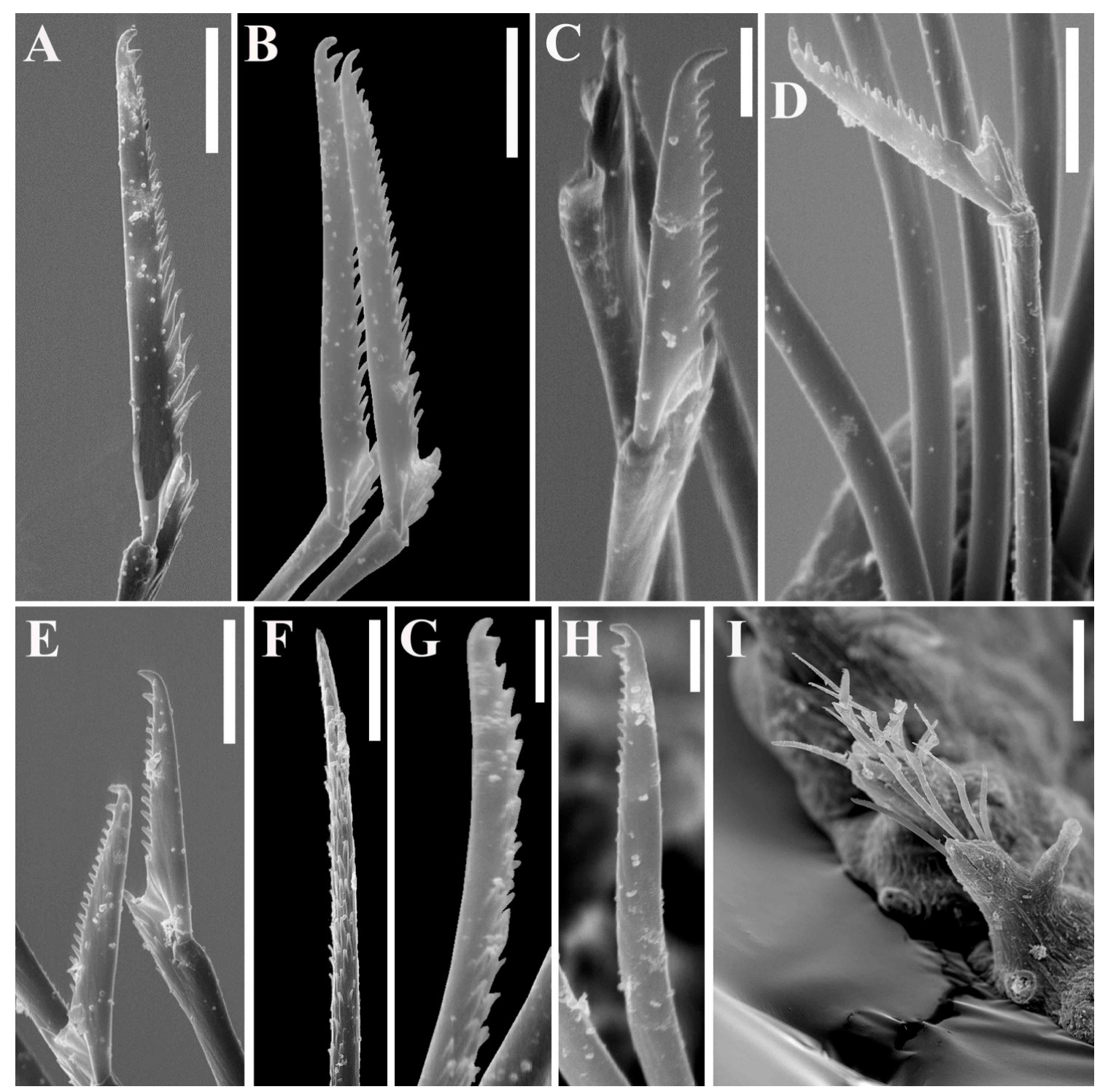

Figure 5 

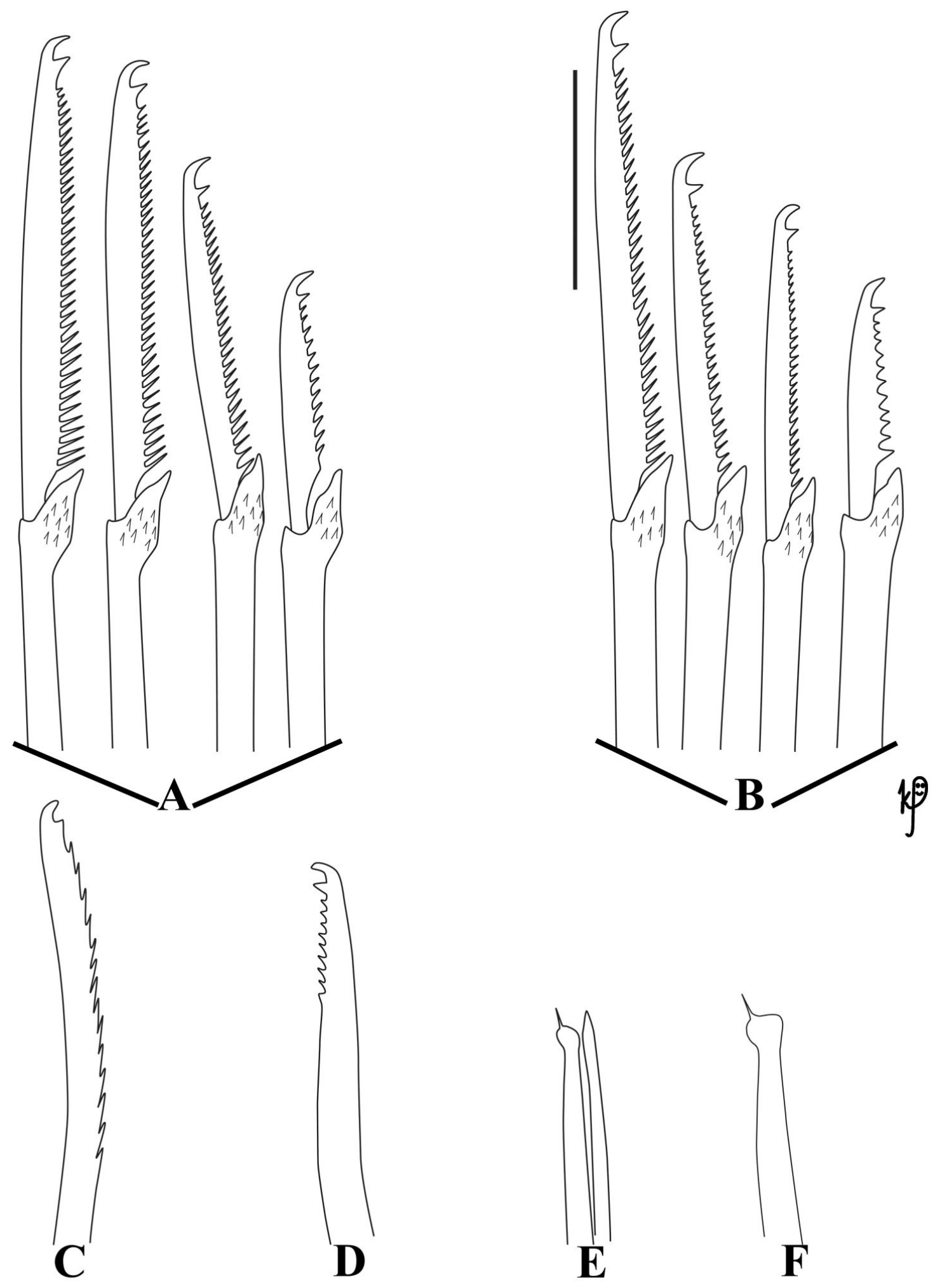

Figure 6 


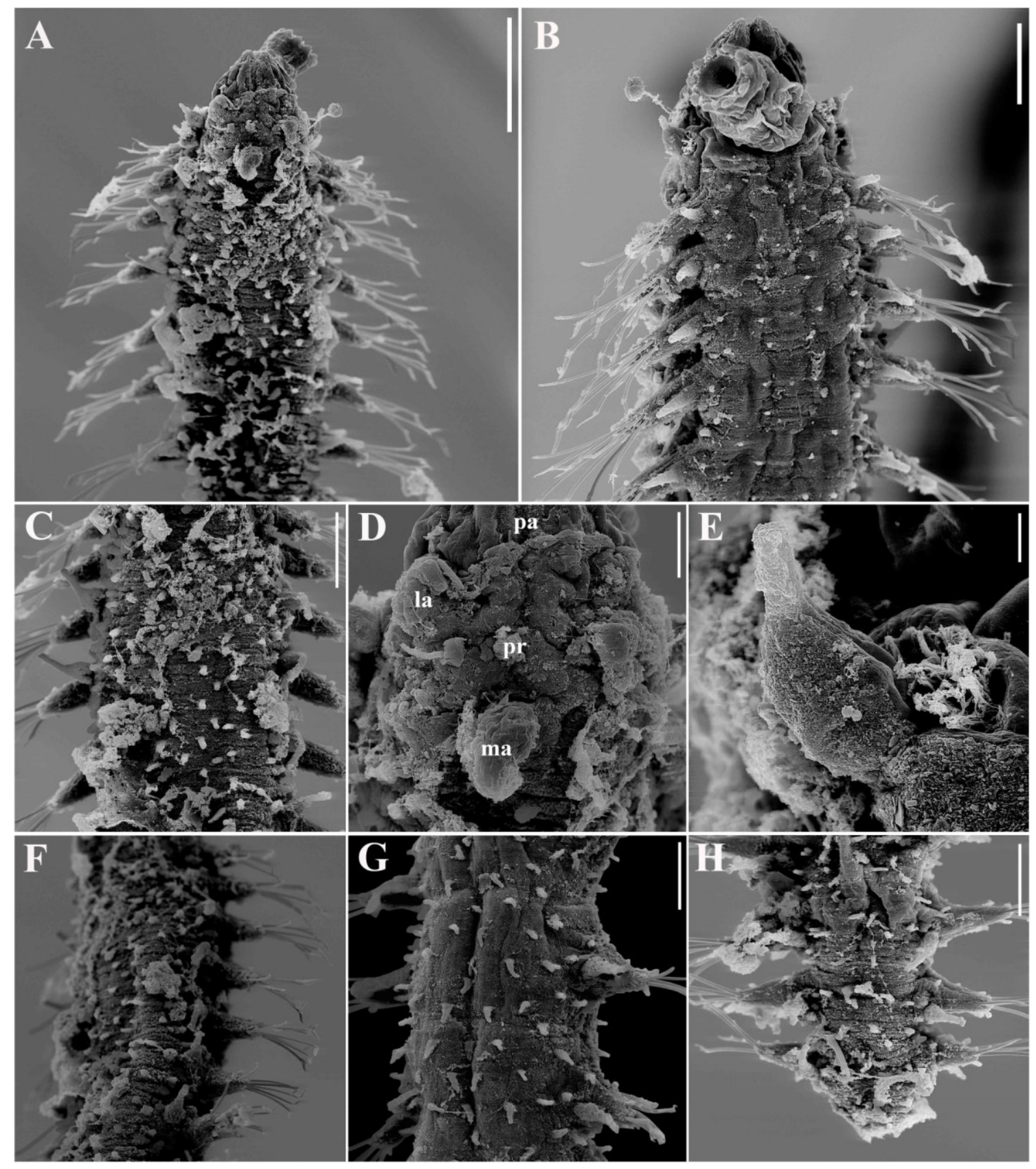

Figure 7 




Figure 8 


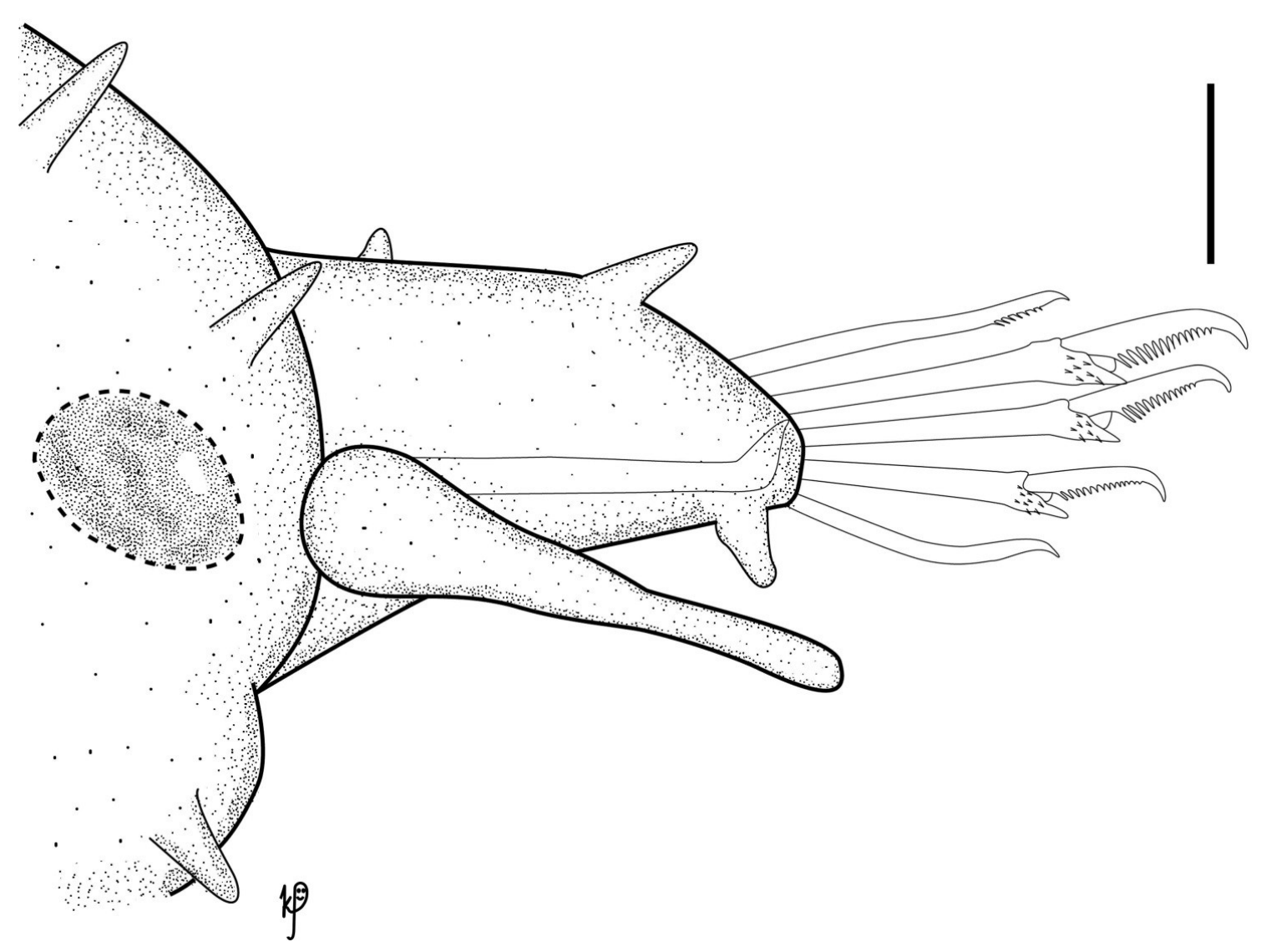

Figure 9 

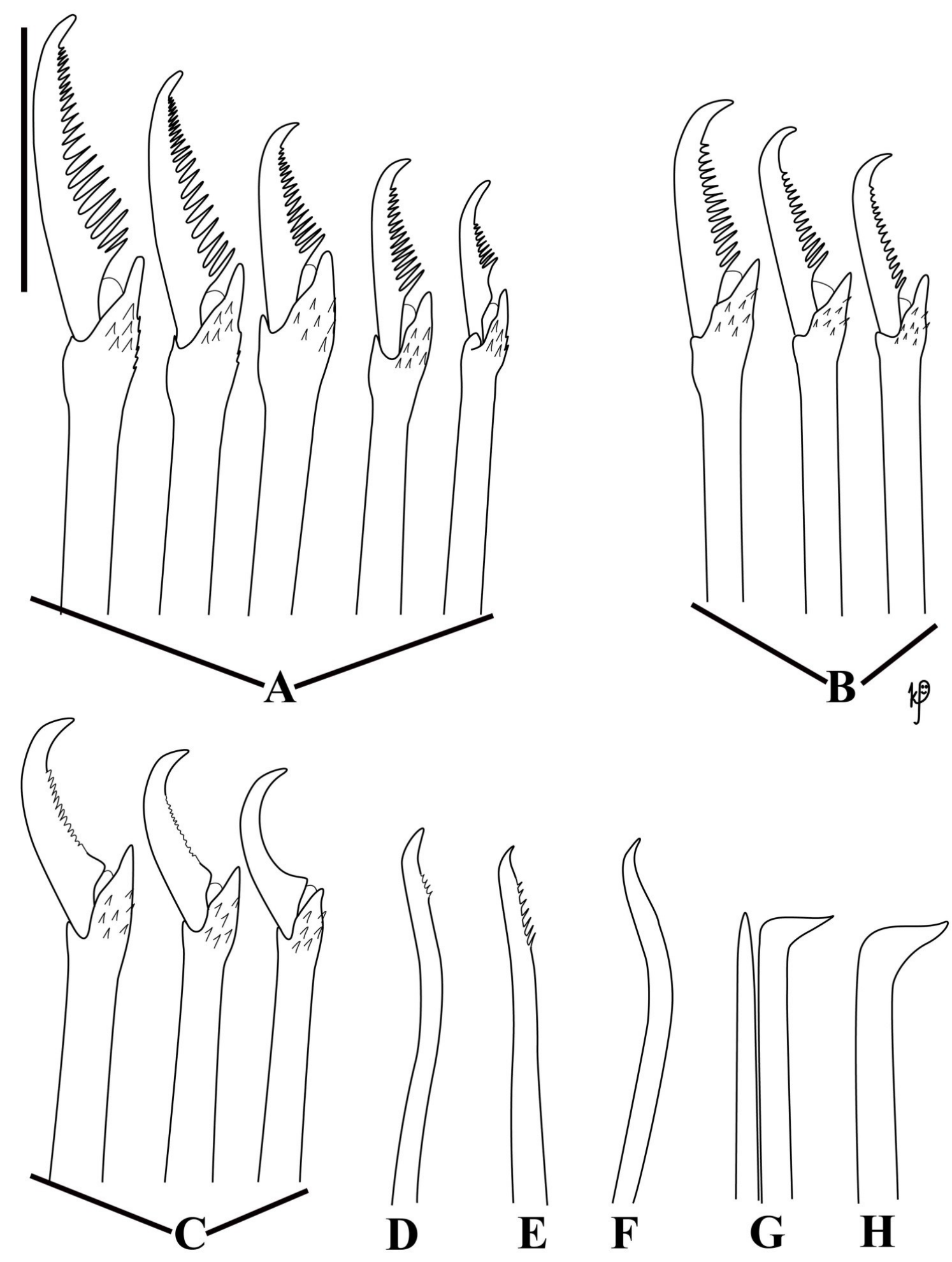

Figure 10 


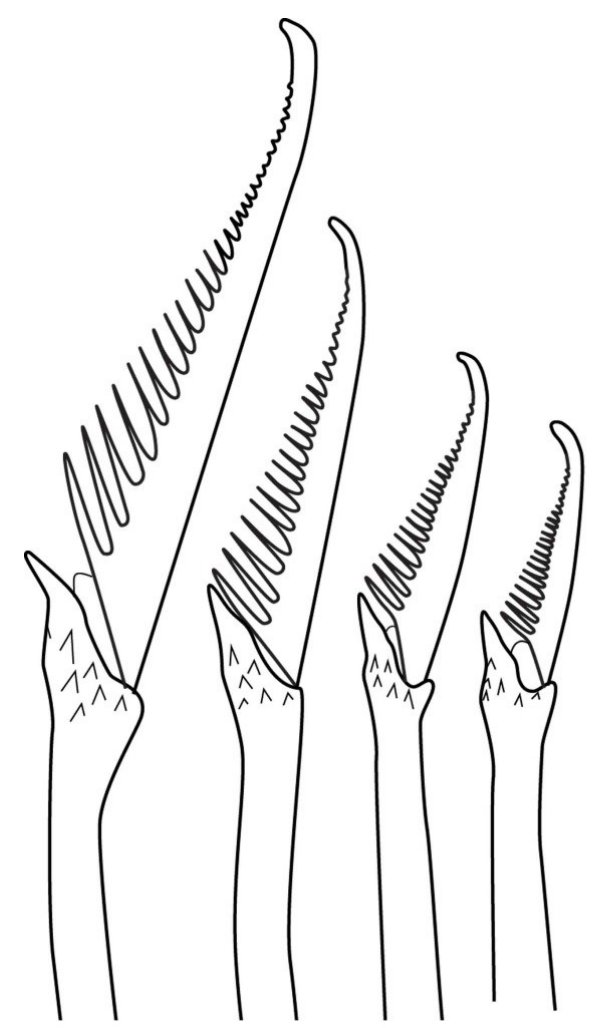

A
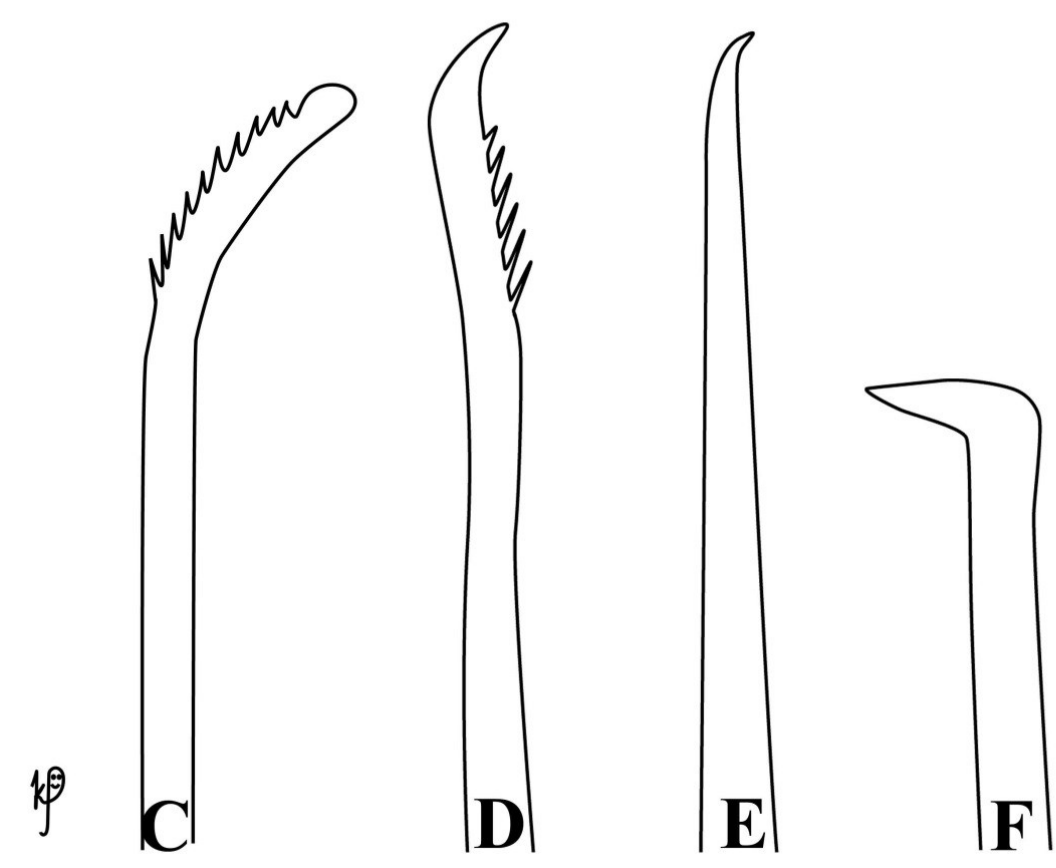

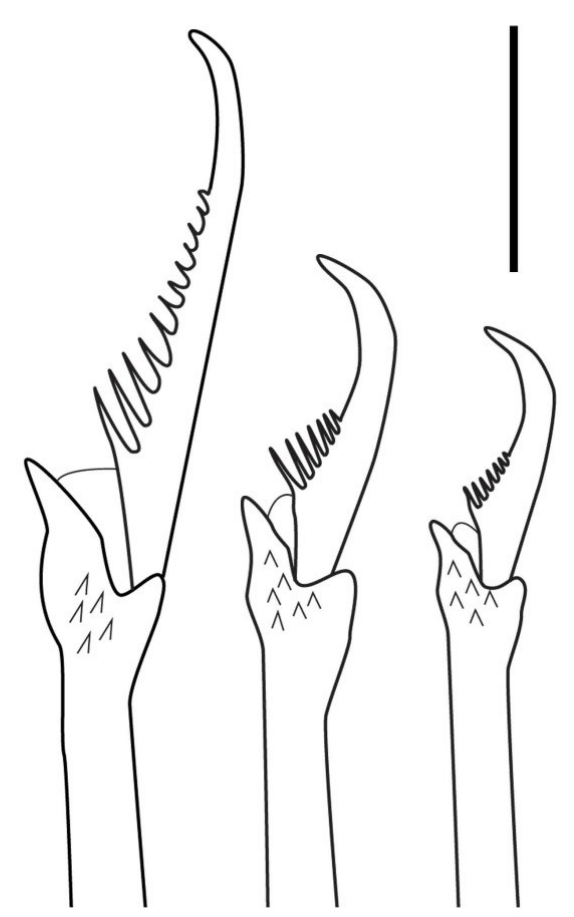

B

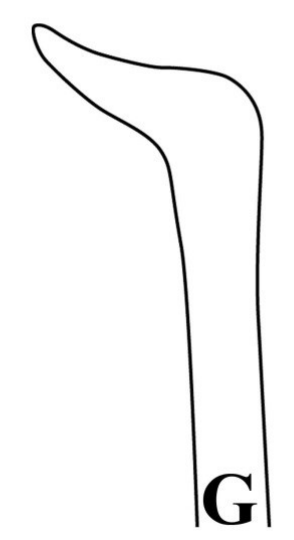

Figure 11 

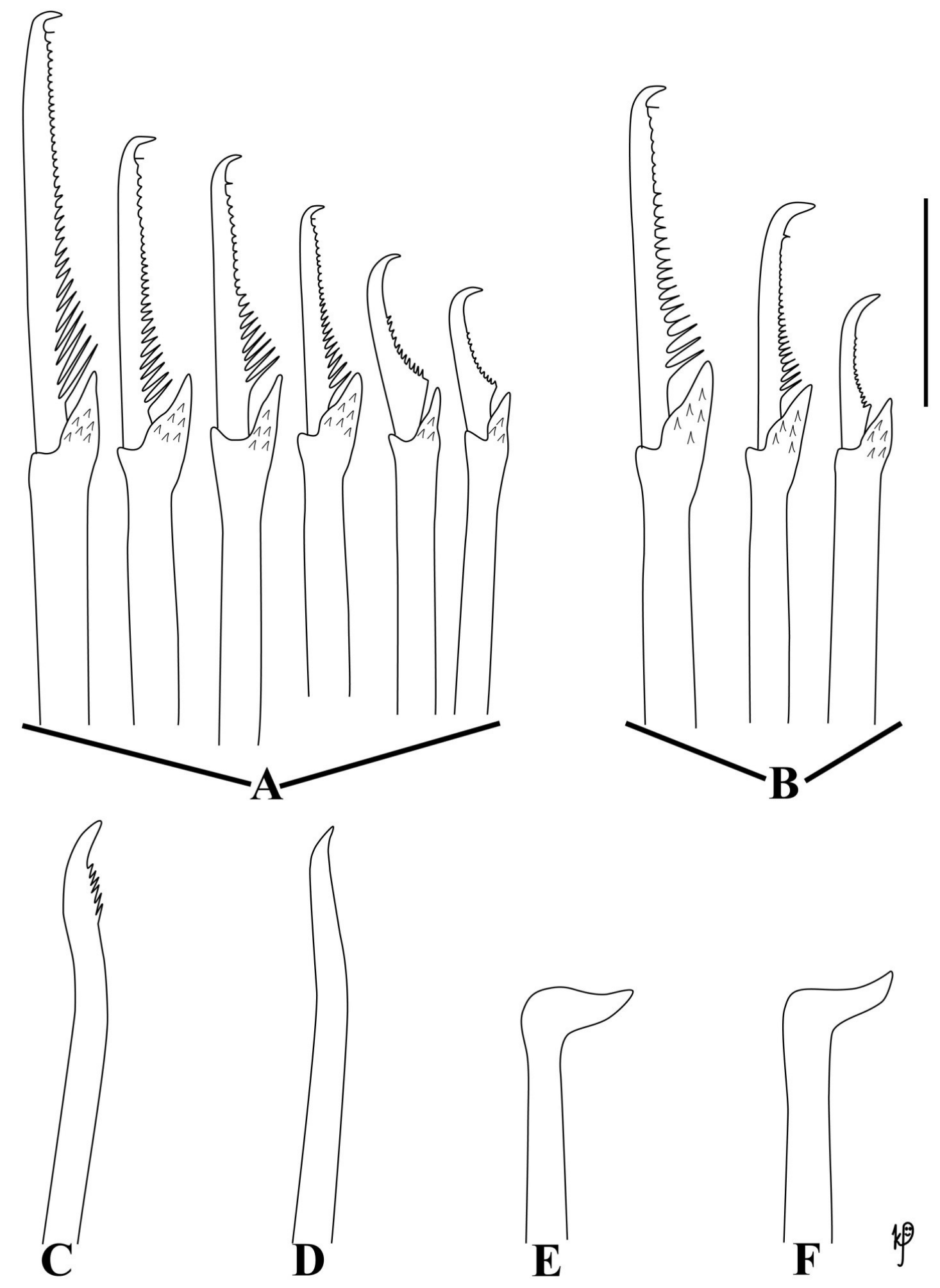

Figure 12 


\section{RESUMO}

Diversidade de Syllidae (Polychaeta: Annelida) em substratos consolidados ao longo dos estados da Paraíba e Pernambuco, nordeste do Brasil 



\section{RESUMO}

Poliquetas são anelídeos em sua maioria marinhos, apresentando grande diversidade de formas e hábitos de vida. Há tanto animais sedentários quanto errantes, incluindo alguns táxons planctônicos, mas a maioria vive em ambientes bentônicos. A família Syllidae Grube, 1850 é uma das mais complexas, diversificadas, abundantes e amplamente distribuídas famílias de poliqueta. É composta por poliquetas errantes, atualmente distribuídos em mais de 70 gêneros e aproximadamente 700 espécies, distribuídas em 5 subfamílias (Anoplosyllinae, Autolytinae, Eusyllinae, Exogoninae e Syllinae).

Os silídeos são facilmente reconhecidos por possuírem uma estrutura muscular geralmente robusta, posteriormente à faringe, denominada proventrículo. A família atualmente é considerada monofilética e a presença desse órgão tem sido considerada como uma sinapomorfia do grupo. Além do proventrículo, os silídeos caracterizam-se por apresentarem corpos relativamente pequenos, com segmentação homônoma e parapódios unirremes, excepcionalmente adquirindo condição birreme nas formas epítocas. Reproduzem-se principalmente por epitoquia, embora incubação externa de ovos, viviparidade, paternogênese e arquitomia também já tenham sido registradas no grupo.

O principal objetivo deste estudo foi realizar um levantamento taxonômico das espécies da família Syllidae presentes em substratos consolidados do litoral raso dos estados da Paraíba e de Pernambuco, fornecendo descrições e ilustrações detalhadas dos táxons encontrados. Amostragens foram realizadas no entremarés e infralitoral raso ao longo desses dois estados, totalizando 21 localidades amostradas.

Foram analisados morfologicamente 4.233 indivíduos, distribuídos em 20 gêneros e 57 espécies. Dessas, 19 espécies são novas para a ciência, duas são novas ocorrências de gêneros para o Atlântico Sul (Basidiosyllis e Amblyosyllis), e 14 e 18 são novas ocorrências de espécies para o Brasil e para o nordeste brasileiro, respectivamente. Dentre os táxons identificados, estão representadas as cinco subfamílias de Syllidae, assim como os gêneros independentes Amblyosyllis e Basidiosyllis. 



\section{ABSTRACT}

Diversity of Syllidae (Polychaeta: Annelida) on hard substrates off the State of Paraíba and Pernambuco, northeastern Brazil 



\section{ABSTRACT}

Polychaetes are usually marine annelids extremely variable in form and lifestyle. Among them, there are examples of sedentary and errant animals, most living in benthic environments, but also including some planktonic taxa. The Syllidae Grube, 1850 is one of the most complex, diverse, abundant and widespread families of polychaetes. It is represented by errant animals, currently comprising more than 70 genera and about 700 species, divided in 5 subfamilies (Anoplosyllinae, Autolytinae, Eusyllinae, Exogoninae e Syllinae).

Syllids are recognized by the presence of the proventricle, a muscular structure, generally strong, posteriorly to the pharynx. The family is considered monophyletic, the proventricle considered as a synapomorphy of the group. Besides the proventricle, syllids are also characterized by having relatively small-sized bodies, with homonomous segmentation and uniramous parapodia, exceptionally acquiring a biramous condition in epitokous forms. The reproduction is usually by epitoky, but external brooding of eggs, viviparity, parthenogenesis and architomy are all also found among syllids.

The aim of this study was to make a taxonomic inventory of the syllid species occurring on hard bottoms of shallow waters off the states of Paraíba and Pernambuco, providing descriptions and detailed illustrations of the taxa found. Samples were taken from the intertidal and shallow sublitoral zones of both states, totalizing 21 localities sampled.

In total, 4,233 individuals were morphologically analysed, belonging to 20 genera and 57 species; 19 of these species are new to science, two are new records for the genera to Brazil (Amblyosyllis and Basidiosyllis), and 14 and 18 are new records for the species to Brazil and to the northestern Brazilian coast, respectively. Among the taxa, all five subfamilies of Syllidae are represented, besides two independent genera, Amblyosyllis and Basidiosyllis. 

CONSIDERAÇÕES FINAIS 



\section{CONSIDERAÇÕES FINAIS}

O presente estudo revelou, conforme esperado, uma grande diversidade de silídeos desconhecida para a região entremarés dos estados da Paraíba e de Pernambuco. Utilizando-se apenas de identificações baseadas em caracteres morfológicos, foram registradas 19 espécies novas para a ciência, duas novas ocorrências de gêneros para o Atlântico Sul (Basidiosyllis e Amblyosyllis), 14 e 18 novas ocorrências de espécies para o Brasil e para o nordeste brasileiro, respectivamente.

Muitos destes novos registros de ocorrência de espécies para o Brasil expandem a distribuição das mesmas de forma disjunta. Nestes casos, as análises morfológicas realizadas não foram suficientes para distinguir os espécimes brasileiros daqueles de localidades até, em certos casos, de oceanos diferentes. Algumas destas espécies, consideradas cosmopolitas, também foram registradas pela primeira vez para o Brasil.

As análises exclusivamente baseadas em caracteres morfológicos muitas vezes subestimam a riqueza de espécies, já que frequentemente são incapazes de separar espécies com características convergentes, porém, de linhagens evolutivas distintas (Maltagliati et al., 2000). O criptismo em poliquetas já foi reconhecido e comprovado para diferentes grupos (Nygren, 2013), inclusive para espécies de Syllidae. Ao longo das últimas décadas, diversas espécies da família vêm sendo apontadas como sendo, na verdade, complexos de espécies, possivelmente englobando diferentes linhagens evolutivas e diferentes histórias de vida, ocorrendo tanto em casos de distribuição simpátrica quanto alopátrica (Lattig, 2009; Álvarez-Campos et al. 2012). Entretanto, somente recentemente esforços têm sido realizados para acessar este tipo de informação utilizando-se de ferramentas moleculares.

O Brasil, país com dimensões continentais, com mais de $8.000 \mathrm{~km}$ de costa, é uma área interessante para estudos biogeográficos e filogeográficos de tais complexos de espécies com distribuição ampla. Para outros grupos marinhos, algumas barreiras biogeográficas já foram registradas ao longo da costa, porém, as mesmas não foram testadas para os poliquetas. Uma abordagem interessante, a partir do conhecimento da distribuição das espécies proporcionada por esta Tese, seria testar se ao longo do litoral elas se apresentam como uma unidade evolutiva única, com fluxo gênico ao longo de 
toda sua distribuição, ou não. Complementarmente, outros questionamentos poderiam ser feitos considerando os aspectos reprodutivos das diferentes subfamílias. Os exogoníneos com incubação ventral, por exemplo, são epigâmicos e incubam os juvenis, não apresentando uma fase larval livre natante em seu ciclo de vida, diferente dos silíneos, esquizogâmicos, que podem se dispersar através de larvas (San Martín, 2003). Este diferente potencial de dispersão entre os grupos poderia se refletir em suas distribuições? Para algumas espécies meiofaunais, o cosmopolitismo já foi comprovado ("Paradoxo da Meiofauna", (Giere,1993)); será que para alguma espécie de silídeo meiofaunal ele também existe e as espécies incubadoras são amplamente distribuídas ao longo da costa? A estrutura genética em nível de população não é conhecida para nenhuma espécie de Syllidae na costa brasileira. Apesar de morfologicamente serem consideradas espécies únicas, estudos mais detalhados, com a utilização de ferramentas moleculares, podem representar o próximo passo para melhor compreensão e dimensionamento desta biodiversidade.

\section{Referências}

Giere, O., (1993) Meiobenthology, the Microscopic Fauna in Aquatic Sediments. Springer-Verlag, Berlin, 527 pp.

Maltagliati, F., Peru, A.P., Casu, M., Rossi, F., Lardicci, C., Curini-Galletti, M. \& Castelli, A. (2000) Is Syllis gracilis (Polychaeta: Syllidae) a species complex? An allozyme perspective. Marine Biology, 136, 871-879.

Nygren, A. (2013) Cryptic polychaete diversity: a review. Zoologica scripta, 43, 119216.

San Martín, G. (2003) Annelida Polychaeta II: Syllidae. In: Ramos, M.A. et al. (eds.), Fauna Ibérica, vol. 21. Museo Nacional de Ciências Naturales, CSIC, Madrid. 544 pp. 


\section{APÊNDICE 1}

Lista de material analisado provenientes das coleções do

Museo Nacional de Ciencias Naturales de Madrid e do

The Australian Museum 

APÊNDICE 1. Lista de material analisado provenientes das coleções do Museo Nacional de Ciencias Naturales de Madrid (MNCN) e do Australian Museum (AM).

\begin{tabular}{|c|c|c|c|c|c|}
\hline \multicolumn{2}{|r|}{ Museu } & Número de Tombo & Espécie & País & Tipo \\
\hline 1 & AM & W28943 & Amblyosyllis enigmatica & Austrália & Holótipo \\
\hline 2 & AM & W502.001 & Amblyosyllis multidenticulata & Australia & Holótipo \\
\hline 3 & AM & W25245.001 & Amblyosyllis multidenticulata & Australia & Parátipos \\
\hline 4 & AM & W28229 & Amblyosyllis multidenticulata & Australia & Parátipos \\
\hline 5 & AM & W28948 & Basidiosyllis kalimna & Australia & Holótipo \\
\hline 6 & AM & W26779 & Basidiosyllis kalimna & Australia & Parátipos \\
\hline 7 & AM & W30088 & Branchiosyllis baringaboorean & Australia & Holótipo \\
\hline 8 & AM & W30089 & Branchiosyllis baringaboorean & Australia & Parátipos \\
\hline 9 & AM & W30090 & Branchiosyllis baringaboorean & Australia & Parátipos \\
\hline 10 & AM & W26511 & Branchiosyllis baringaboorean & Austrália & Parátipos \\
\hline 11 & AM & W30118 & Branchiosyllis carmenroldanae & Australia & Holótipo \\
\hline 12 & $\mathrm{AM}$ & W30119 & Branchiosyllis carmenroldanae & Australia & Parátipos \\
\hline 13 & AM & W30115 & Branchiosyllis orbiniformis & Australia & Holótipo \\
\hline 14 & AM & W30116 & Branchiosyllis orbiniformis & Australia & Parátipos \\
\hline 15 & AM & W26512 & Branchiosyllis orbiniformis & Australia & Parátipos \\
\hline 16 & AM & W30120 & Branchiosyllis thylacine & Australia & Holótipo \\
\hline 17 & AM & W30121 & Branchiosyllis thylacine & Australia & Parátipos \\
\hline 18 & MNCN & $16.01 / 8852$ & Brania arminii & Brasil & \\
\hline 19 & $\mathrm{AM}$ & W27421 & Brania articulata & Australia & \\
\hline 20 & AM & W27102 & Brania articulata & Australia & \\
\hline 21 & AM & W27101 & Brania articulata & Australia & \\
\hline 22 & AM & W27415 & Brania articulata & Australia & \\
\hline 23 & AM & W27105 & Brania articulata & Australia & \\
\hline 24 & MNCN & $16.01 / 6761$ & Brania clavata & Espanha & \\
\hline 25 & MNCN & $16.01 / 8848$ & Erinaceusyllis centroamericana & Brasil & \\
\hline 26 & MNCN & $16.01 / 8849$ & Erinaceusyllis centroamericana & Brasil & \\
\hline 27 & MNCN & $16.01 / 10830$ & Erinaceusyllis cryptica & Espanha & \\
\hline 28 & MNCN & $16.01 / 10831$ & Erinaceusyllis cryptica & Espanha & \\
\hline 29 & MNCN & $16.01 / 10859$ & Erinaceusyllis cryptica & Espanha & \\
\hline 30 & MNCN & $16.01 / 10921$ & Erinaceusyllis cryptica & Espanha & \\
\hline 31 & MNCN & $16.01 / 6157$ & Erinaceusyllis cryptica & Espanha & \\
\hline 32 & $\mathrm{AM}$ & W26624 & Erinaceusyllis ettiennei & Australia & Holótipo \\
\hline 33 & AM & W18556 & Erinaceusyllis serratosetosa & Australia & Parátipos \\
\hline 34 & MNCN & $16.01 / 6764$ & Eusyllis kupfferi & Cuba & \\
\hline 35 & MNCN & $16.01 / 8680$ & Eusyllis lamelligera & Espanha & \\
\hline 36 & MNCN & $16.01 / 8684$ & Eusyllis lamelligera & Espanha & \\
\hline 37 & MNCN & $16.01 / 8694$ & Eusyllis lamelligera & Espanha & \\
\hline 38 & MNCN & $16.01 / 8697$ & Eusyllis lamelligera & Espanha & \\
\hline 39 & MNCN & $16.01 / 6739$ & Exogone (Parexogone) gambiae & Espanha & \\
\hline
\end{tabular}

continua 


\begin{tabular}{|c|c|c|c|c|c|}
\hline & Museu & Número de Tombo & Espécie & País & Tipo \\
\hline 41 & $\mathrm{MNCN}$ & $16.01 / 629$ & Exogone arenosa & Cuba & \\
\hline 42 & $\mathrm{MNCN}$ & $16.01 / 9902$ & Exogone breviantennata & Cuba & \\
\hline 43 & $\mathrm{MNCN}$ & $16.01 / 3536$ & Exogone heterosetoides & Antártica & \\
\hline 44 & $\mathrm{MNCN}$ & $16.01 / 1492$ & Exogone heterosetoides australis & Antártica & \\
\hline 45 & MNCN & $16.01 / 7656$ & Exogone naidina & Espanha & \\
\hline 46 & $\mathrm{MNCN}$ & $16.01 / 631$ & Exogone naidinoides & Cuba & \\
\hline 47 & $\mathrm{MNCN}$ & $16.01 / 6923$ & Exogone rostrata & Espanha & \\
\hline 48 & $\mathrm{MNCN}$ & $16.01 / 11242$ & Exogone verugera & Noruega & \\
\hline 49 & $\mathrm{MNCN}$ & $16.01 / 2948$ & Exogone wolfi & França & \\
\hline 50 & $\mathrm{MNCN}$ & $16.01 / 10606$ & Geminosyllis granulosa & Espanha & Holótipo \\
\hline 51 & MNCN & $16.01 / 10607$ & Geminosyllis granulosa & Espanha & Parátipo \\
\hline 52 & $\mathrm{MNCN}$ & $16.01 / 10971$ & Grubeosyllis clavata & Espanha & \\
\hline 53 & $\mathrm{MNCN}$ & $16.01 / 8545$ & Grubeosyllis clavata & Espanha & \\
\hline 54 & $\mathrm{MNCN}$ & $16.01 / 7047$ & Grubeosyllis nitidula & Cuba & \\
\hline 55 & $\mathrm{MNCN}$ & $16.01 / 7048$ & Grubeosyllis nitidula & Cuba & \\
\hline 56 & $\mathrm{MNCN}$ & $16.01 / 8808$ & Haplosyllides floridana & Estados Unidos & \\
\hline 57 & $\mathrm{MNCN}$ & $16.01 / 8439$ & Haplosyllis basticola & Estados Unidos & \\
\hline 58 & $\mathrm{MNCN}$ & $16.01 / 10645$ & Haplosyllis carmenbritoae & Espanha & Holótipo \\
\hline 59 & $\mathrm{MNCN}$ & $16.01 / 10646$ & Haplosyllis carmenbritoae & Espanha & Parátipo \\
\hline 60 & $\mathrm{MNCN}$ & $16.01 / 10127$ & Haplosyllis chamaeleon & Espanha & \\
\hline 61 & MNCN & $16.01 / 7834$ & Haplosyllis chamaeleon & Espanha & \\
\hline 62 & $\mathrm{MNCN}$ & $16.01 / 7835$ & Haplosyllis chamaeleon & Espanha & \\
\hline 63 & MNCN & $16.01 / 10647$ & Haplosyllis hamata & Espanha & \\
\hline 64 & AM & W14020 & Haplosyllis imajimai & Australia & Holótipo \\
\hline 65 & $\mathrm{AM}$ & W36593 & Haplosyllis imajimai & Australia & Parátipos \\
\hline 66 & AM & W28352 & Haplosyllis loboi & Argentina & Parátipos \\
\hline 67 & $\mathrm{AM}$ & W36622 & Haplosyllis sanchoi & Australia & Holótipo \\
\hline 68 & AM & W36623 & Haplosyllis sanchoi & Australia & Parátipos \\
\hline 69 & $\mathrm{AM}$ & W36580 & Haplosyllis sandii & Australia & Holótipo \\
\hline 70 & AM & W36588 & Haplosyllis sandii & Australia & Parátipos \\
\hline 71 & $\mathrm{MNCN}$ & $16.01 / 7833$ & Haplosyllis villogorgicola & Espanha & Parátipos \\
\hline 72 & $\mathrm{AM}$ & W35406 & Megasyllis mariandreworum & Austrália & Holótipo \\
\hline 73 & AM & W36503 & Megasyllis tigrina & Austrália & Holótipo \\
\hline 74 & AM & W36505 & Megasyllis tigrina & Austrália & Parátipos \\
\hline 75 & $\mathrm{AM}$ & W36504 & Megasyllis tigrina & Austrália & Parátipos \\
\hline 76 & AM & W28932 & Odontosyllis australiensis & Australia & \\
\hline 77 & AM & W198074 & Odontosyllis australiensis & Australia & \\
\hline 78 & $\mathrm{AM}$ & W28933 & Odontosyllis australiensis & Australia & \\
\hline 79 & MNCN & $16.01 / 7597$ & Odontosyllis fulgurans & Cabo Verde & \\
\hline 80 & $\mathrm{MNCN}$ & $16.01 / 4376$ & Odontosyllis fulgurans & Espanha & \\
\hline
\end{tabular}

continua 


\begin{tabular}{|c|c|c|c|c|c|}
\hline & Museu & Número de Tombo & Espécie & País & Tipo \\
\hline 81 & AM & W28393 & Opisthodonta hannelorae & Austrália & Holótipo \\
\hline 82 & AM & W28972 & Opisthodonta hannelorae & Austrália & Parátipos \\
\hline 83 & AM & W28951 & Opisthodonta hannelorae & Austrália & Parátipos \\
\hline 84 & $\mathrm{AM}$ & W28950 & Opisthodonta hannelorae & Austrália & Parátipos \\
\hline 85 & AM & W29230 & Opisthodonta rousei & Australia & Holótipo \\
\hline 86 & AM & W28840 & Opisthodonta rousei & Australia & Parátipos \\
\hline 87 & MNCN & $16.01 / 750$ & Opisthosyllis brunnea & Cuba & \\
\hline 88 & MNCN & $16.01 / 11025$ & Opisthosyllis brunnea & Venezuela & \\
\hline 89 & MNCN & $16.01 / 10264$ & Opisthosyllis leslieharrisae & Estados Unidos & Holótipo \\
\hline 90 & MNCN & $16.01 / 10266$ & Opisthosyllis leslieharrisae & Estados Unidos & Parátipos \\
\hline 91 & AM & W42805 & Paraopisthosyllis alternocirra & Austrália & \\
\hline 92 & AM & W28949 & Paraopisthosyllis ornaticirra & Australia & Holótipo \\
\hline 93 & AM & W37715 & Paraopisthosyllis phylocirra & Austrália & \\
\hline 94 & MNCN & $16.01 / 6822$ & Parapionosyllis brevicirra & Espanha & \\
\hline 95 & MNCN & $16.01 / 6823$ & Parapionosyllis brevicirra & Espanha & \\
\hline 96 & MNCN & $16.01 / 6714$ & Parapionosyllis elegans & Espanha & \\
\hline 97 & MNCN & $16.01 / 6711$ & Parapionosyllis elegans & Espanha & \\
\hline 98 & MNCN & $16.01 / 6712$ & Parapionosyllis elegans & Espanha & \\
\hline 99 & MNCN & $16.01 / 6713$ & Parapionosyllis elegans & Espanha & \\
\hline 100 & MNCN & $16.01 / 6832$ & Parapionosyllis labronica & Espanha & \\
\hline 101 & MNCN & $16.01 / 6841$ & Parapionosyllis minuta & Espanha & \\
\hline 102 & MNCN & $16.01 / 6844$ & Parapionosyllis minuta & Espanha & \\
\hline 103 & MNCN & $16.01 / 191$ & Parapionosyllis minuta & Espanha & \\
\hline 104 & MNCN & $16.01 / 6836$ & Parapionosyllis minuta & Espanha & \\
\hline 105 & MNCN & $16.01 / 741$ & Parasphaerosyllis indica & Cuba & \\
\hline 106 & MNCN & $16.01 / 6792$ & Pionosyllis procera & Cabo Verde & \\
\hline 107 & MNCN & $16.01 / 6782$ & Pionosyllis procera & Cuba & \\
\hline 108 & MNCN & $16.01 / 6153$ & Prosphaerosyllis brevicirra & Espanha & \\
\hline 109 & MNCN & $16.01 / 6405$ & Prosphaerosyllis xarifae & Espanha & \\
\hline 110 & MNCN & $16.01 / 10992$ & Salvatoria clavata & Espanha & \\
\hline 111 & AM & W22195 & Syllides mikeli & Estados Unidos & Parátipos \\
\hline 112 & AM & W28472 & Syllides tam & Australia & Holótipo \\
\hline 113 & $\mathrm{AM}$ & W28471 & Syllides tam & Australia & Parátipos \\
\hline 114 & AM & W24704 & Syllides tam & Australia & Parátipos \\
\hline 115 & $\mathrm{AM}$ & W28464 & Syllides tam & Australia & Parátipos \\
\hline 116 & MNCN & $16.01 / 10002$ & Syllis aciculata & México & \\
\hline 117 & MNCN & $16.01 / 6943$ & Syllis alternata & Cuba & \\
\hline 118 & MNCN & $16.01 / 772$ & Syllis alternata & Cuba & \\
\hline 119 & MNCN & $16.01 / 2475$ & Syllis alternata & Espanha & \\
\hline 120 & MNCN & $16.01 / 134$ & Syllis amica & Espanha & \\
\hline
\end{tabular}

continua 


\begin{tabular}{|c|c|c|c|c|c|}
\hline & Museu & Número de Tombo & Espécie & País & Tipo \\
\hline 121 & MNCN & $16.01 / 6974$ & Syllis amica & Espanha & \\
\hline 122 & MNCN & $16.01 / 6975$ & Syllis amica & Espanha & \\
\hline 123 & AM & W29246 & Syllis armillaris & Austrália & \\
\hline 124 & MNCN & $16.01 / 7909$ & Syllis armillaris & Espanha & \\
\hline 125 & MNCN & $16.01 / 8840$ & Syllis armillaris & Espanha & \\
\hline 126 & MNCN & $16.01 / 11223$ & Syllis armillaris & Noruega & \\
\hline 127 & MNCN & $16.01 / 6979$ & Syllis benelahui & Espanha & \\
\hline 128 & MNCN & $16.01 / 8725$ & Syllis beneliahuae & Brasil & \\
\hline 129 & $\mathrm{AM}$ & W202355 & Syllis botosaneanui & Australia & \\
\hline 130 & AM & W202353 & Syllis botosaneanui & Austrália & \\
\hline 131 & AM & W29544 & Syllis botosaneanui & Austrália & \\
\hline 132 & AM & W199368 & Syllis broomensis & Austrália & \\
\hline 133 & AM & W29388 & Syllis broomensis & Austrália & \\
\hline 134 & AM & W18557 & Syllis bulsseltonensis & Austrália & Parátipos \\
\hline 135 & MNCN & $16.01 / 6100$ & Syllis castroviejoi & Panamá & Holótipo \\
\hline 136 & MNCN & $16.01 / 9207$ & Syllis castroviejoi & Panamá & Parátipo \\
\hline 137 & MNCN & $16.01 / 9215$ & Syllis castroviejoi & Panamá & Parátipo \\
\hline 138 & AM & W29487 & Syllis cf. bella & Austrália & \\
\hline 139 & AM & W29499 & Syllis cf. gelarchi & Australia & \\
\hline 140 & MNCN & $16.01 / 8723$ & Syllis corallicola & Brasil & \\
\hline 141 & MNCN & $16.01 / 768$ & Syllis corallicola & Cuba & \\
\hline 142 & MNCN & $16.01 / 1196$ & Syllis corallicola & Espanha & \\
\hline 143 & MNCN & $16.01 / 6744$ & Syllis cruzi & Espanha & \\
\hline 144 & $\mathrm{MNCN}$ & $16.01 / 6745$ & Syllis cruzi & Espanha & \\
\hline 145 & AM & W17723 & Syllis erikae & Austrália & \\
\hline 146 & MNCN & $16.01 / 616$ & Syllis ferrani & Espanha & Parátipo \\
\hline 147 & $\mathrm{MNCN}$ & $16.01 / 7005$ & Syllis ferrani & Espanha & \\
\hline 148 & MNCN & $16.01 / 7011$ & Syllis ferrani & Espanha & \\
\hline 149 & MNCN & $16.01 / 7002$ & Syllis garciai & Espanha & \\
\hline 150 & MNCN & $16.01 / 8959$ & Syllis garciai & Espanha & \\
\hline 151 & MNCN & $16.01 / 8960$ & Syllis garciai & Espanha & \\
\hline 152 & AM & W29379 & Syllis gerhardi & Austrália & \\
\hline 153 & MNCN & $16.01 / 769$ & Syllis gerlachi & Cuba & \\
\hline 154 & MNCN & $16.01 / 7563$ & Syllis gerlachi & Espanha & \\
\hline 155 & MNCN & $16.01 / 8075$ & Syllis gracilis & Argentina & \\
\hline 156 & $\mathrm{AM}$ & W29511 & Syllis gracilis & Australia & \\
\hline 157 & MNCN & $16.01 / 683$ & Syllis gracilis & Cuba & \\
\hline 158 & MNCN & $16.01 / 8037$ & Syllis gracilis & Espanha & \\
\hline 159 & $\mathrm{MNCN}$ & $16.01 / 8044$ & Syllis gracilis & Espanha & \\
\hline 160 & MNCN & $16.01 / 8930$ & Syllis gracilis & Espanha & \\
\hline
\end{tabular}




\begin{tabular}{|c|c|c|c|c|c|}
\hline & Museu & Número de Tombo & Espécie & País & Tipo \\
\hline 161 & MNCN & $16.01 / 8940$ & Syllis gracilis & Espanha & \\
\hline 162 & MNCN & $16.01 / 8076$ & Syllis gracilis & Estados Unidos & \\
\hline 163 & AM & W29486 & Syllis gracilis australiensis & Australia & \\
\hline 164 & AM & W29514 & Syllis gracilis australiensis & Australia & \\
\hline 165 & AM & W29540 & Syllis gracilis australiensis & Australia & \\
\hline 166 & AM & W29549 & Syllis gracilis australiensis & Australia & \\
\hline 167 & AM & W29484 & Syllis gracilis australiensis & Australia & \\
\hline 168 & AM & W29543 & Syllis gracilis australiensis & Australia & \\
\hline 169 & AM & W29539 & Syllis gracilis australiensis & Australia & \\
\hline 170 & AM & W29548 & Syllis gracilis australiensis & Australia & \\
\hline 171 & AM & W29477 & Syllis gracilis australiensis & Australia & \\
\hline 172 & AM & W29488 & Syllis gracilis australiensis & Australia & \\
\hline 173 & AM & W29488 & Syllis gracilis australiensis & Australia & \\
\hline 174 & AM & W29506 & Syllis gracilis australiensis & Australia & \\
\hline 175 & AM & W29492 & Syllis gracilis group & Australia & \\
\hline 176 & AM & W28202 & Syllis krohnii & Austrália & \\
\hline 177 & MNCN & $16.01 / 10263$ & Syllis mayeri & Belize & Holótipo \\
\hline 178 & AM & W29383 & Syllis prolifera & Austrália & \\
\hline 179 & AM & W29380 & Syllis prolifera & Austrália & \\
\hline 180 & MNCN & $16.01 / 8376$ & Syllis prolifera & Cabo Verde & \\
\hline 181 & MNCN & $16.01 / 8347$ & Syllis prolifera & Cuba & \\
\hline 182 & MNCN & $16.01 / 8338$ & Syllis prolifera & Espanha & \\
\hline 183 & AM & W28359 & Syllis prolixa & Argentina & \\
\hline 184 & AM & W29391 & Syllis pseudoarmillaris & Austrália & \\
\hline 185 & MNCN & $16.01 / 8858$ & Syllis pseudoarmillaris & Brasil & Parátipo \\
\hline 186 & MNCN & $16.01 / 7020$ & Syllis rosea & Espanha & \\
\hline 187 & MNCN & $16.01 / 7025$ & Syllis rosea & Espanha & \\
\hline 188 & AM & W28355 & Syllis sclerolaema & Argentina & \\
\hline 189 & MNCN & $16.01 / 6753$ & Syllis torquata & Espanha & \\
\hline 190 & MNCN & $16.01 / 6754$ & Syllis torquata & Espanha & \\
\hline 191 & AM & W506 & Syllis truncata & Austrália & Síntipo \\
\hline 192 & MNCN & $16.01 / 8390$ & Syllis truncata cryptica & Espanha & \\
\hline 193 & MNCN & $16.01 / 8391$ & Syllis truncata cryptica & Espanha & \\
\hline 194 & MNCN & $16.01 / 6702$ & Syllis tyrrhena & Espanha & \\
\hline 195 & AM & W29384 & Syllis variegata & Austrália & \\
\hline 196 & MNCN & $16.01 / 8443$ & Syllis variegata & Espanha & \\
\hline 197 & MNCN & $16.01 / 8449$ & Syllis variegata & Espanha & \\
\hline 198 & MNCN & $16.01 / 8484$ & Syllis variegata & Espanha & \\
\hline 199 & MNCN & $16.01 / 6665$ & Syllis vittata & Espanha & \\
\hline 200 & MNCN & $16.01 / 7028$ & Syllis westheidei & Espanha & \\
\hline
\end{tabular}

continua 


\begin{tabular}{l|c|c|l|l|l}
\hline \multicolumn{2}{c|}{ Museu } & Número de Tombo & \multicolumn{1}{|c|}{ Espécie } & \multicolumn{1}{c}{ País } & Tipo \\
\hline 201 & MNCN & $16.01 / 7038$ & Syllis westheidei & Espanha & \\
\hline 202 & AM & W29509 & Syllis ypsiloides & Australia & \\
\hline 203 & MNCN & $16.01 / 6715$ & Trypanosyllis aeolis & Espanha & \\
\hline 204 & MNCN & $16.01 / 6718$ & Trypanosyllis aeolis & Espanha & \\
\hline 205 & MNCN & $16.01 / 6855$ & Trypanosyllis coeliaca & Espanha & \\
\hline 206 & MNCN & $16.01 / 6856$ & Trypanosyllis coeliaca & Espanha & \\
\hline 207 & MNCN & $16.01 / 7464$ & Trypanosyllis zebra & Espanha & \\
\hline 208 & MNCN & $16.01 / 7479$ & Trypanosyllis zebra & Espanha & \\
\hline
\end{tabular}




\section{APÊNDICE 2}

Lista de material examinado no âmbito da presente Tese 

APÊNDICE 2. Lista de material examinado no âmbito da presente Tese, discriminando o número de indivíduos encontrados por espécie em cada uma das localidades amostradas dos estados da Paraíba e de Pernambuco. Na coluna "Outros estados (BA/ES/RJ/SP/PR/SC)" encontra-se a somatória do número de espécimes analisados provenientes de outros estados do Brasil. Nas três últimas colunas estão marcadas com "x" as novas ocorrências assim como as espécies novas para a ciência. A coluna "Capítulo/Apêndice" mostra em qual Capítulo (C) ou Apêndice (A) a respectiva espécie é tratada.

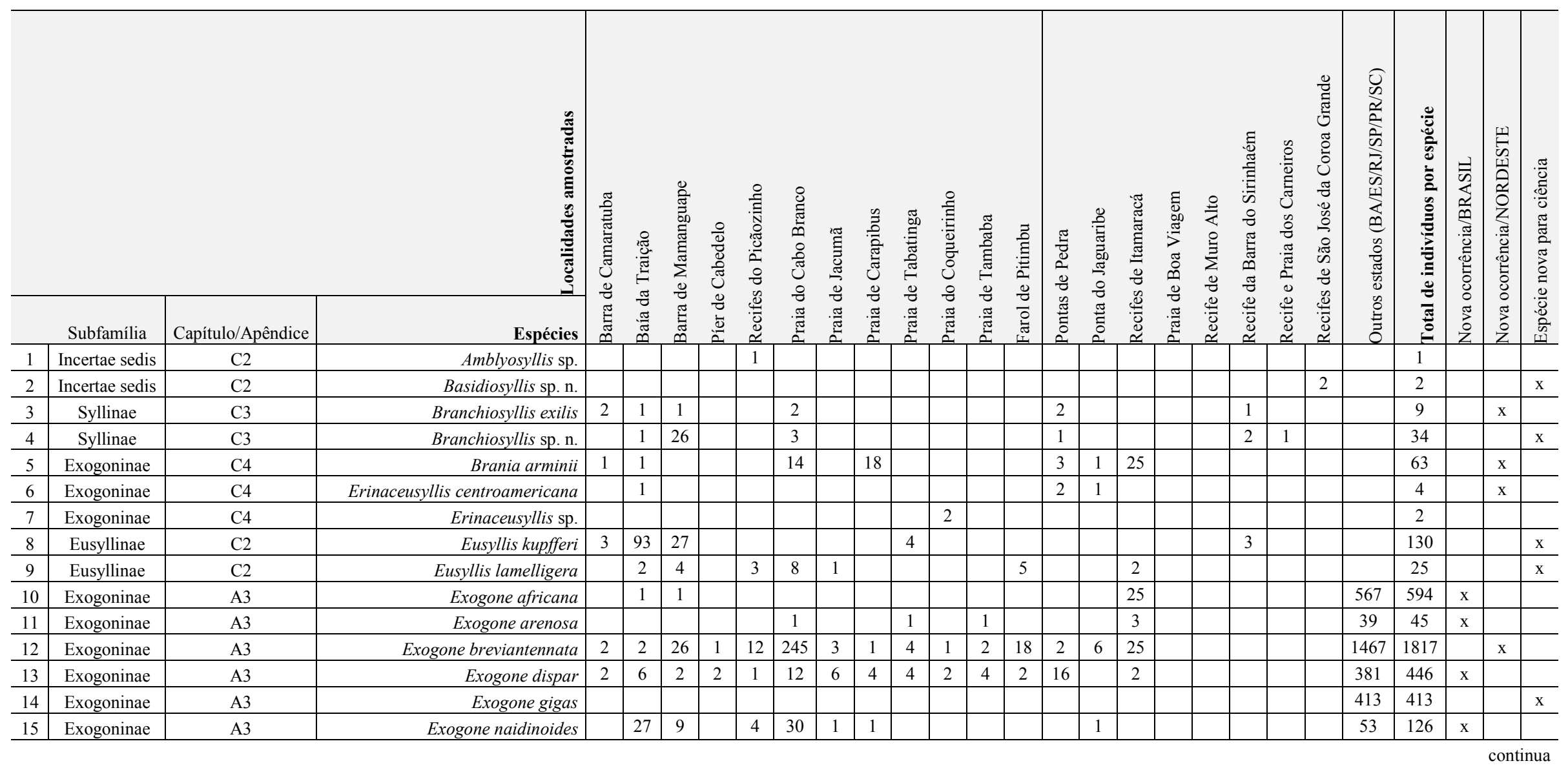




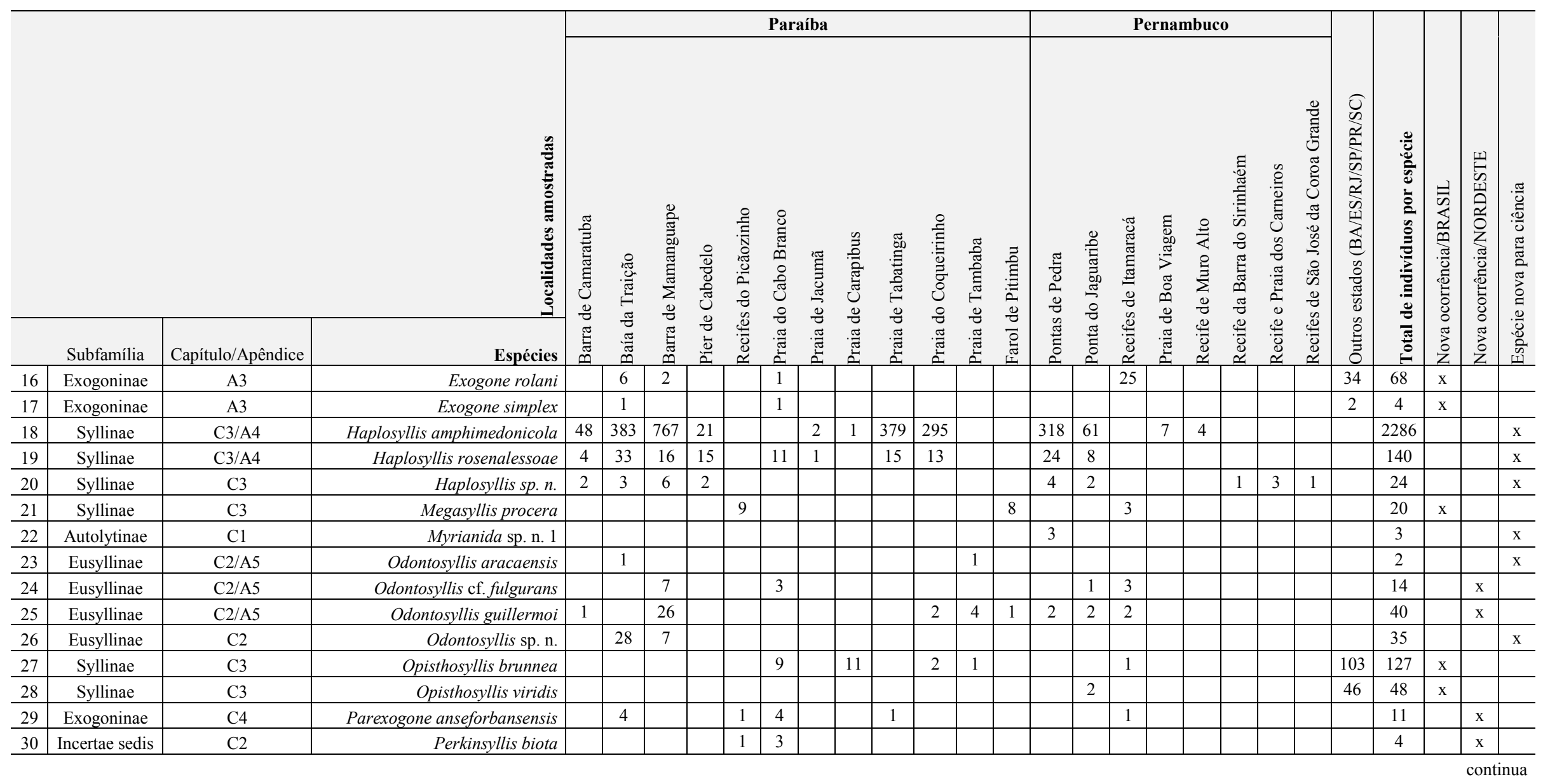




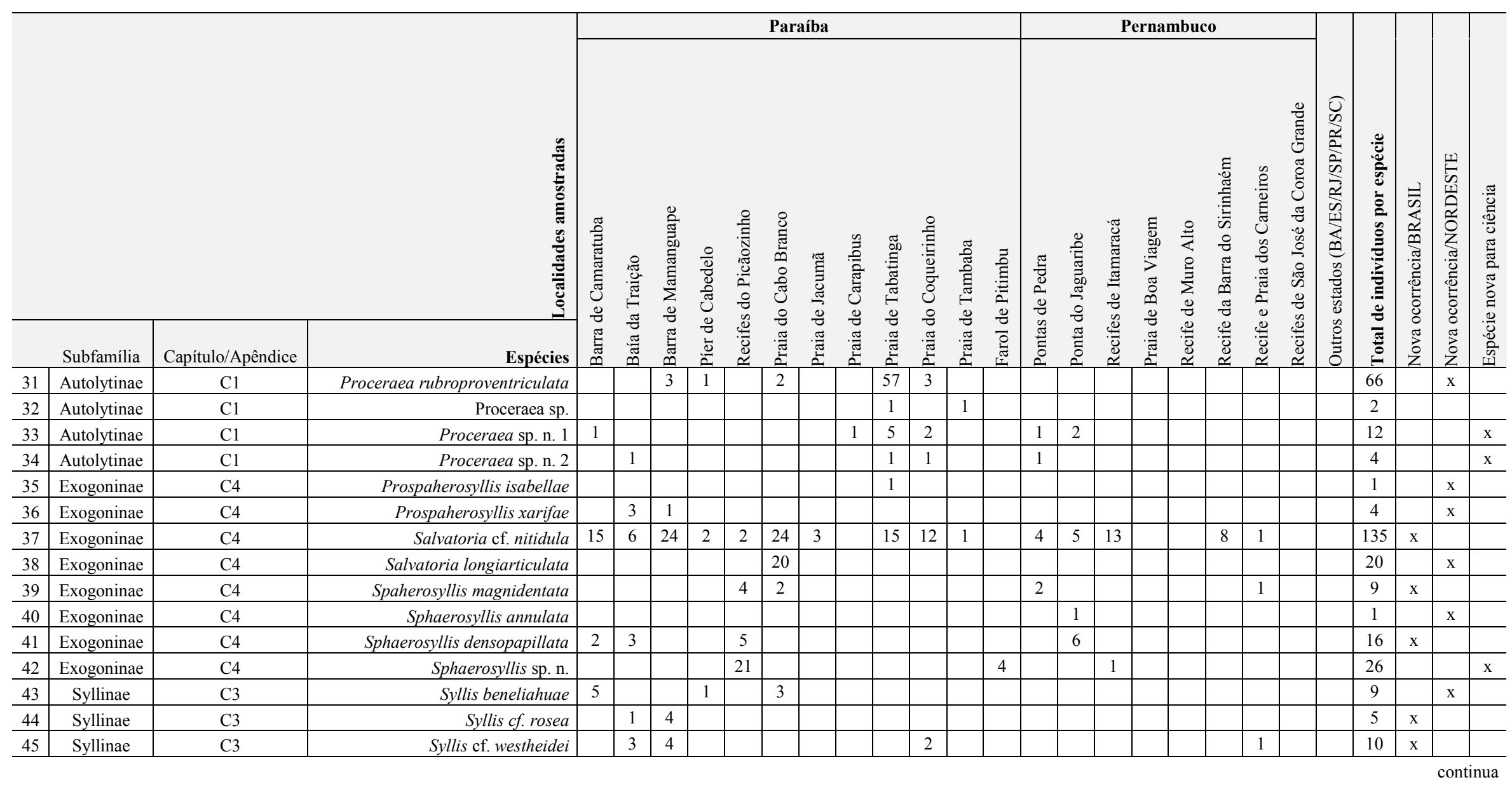




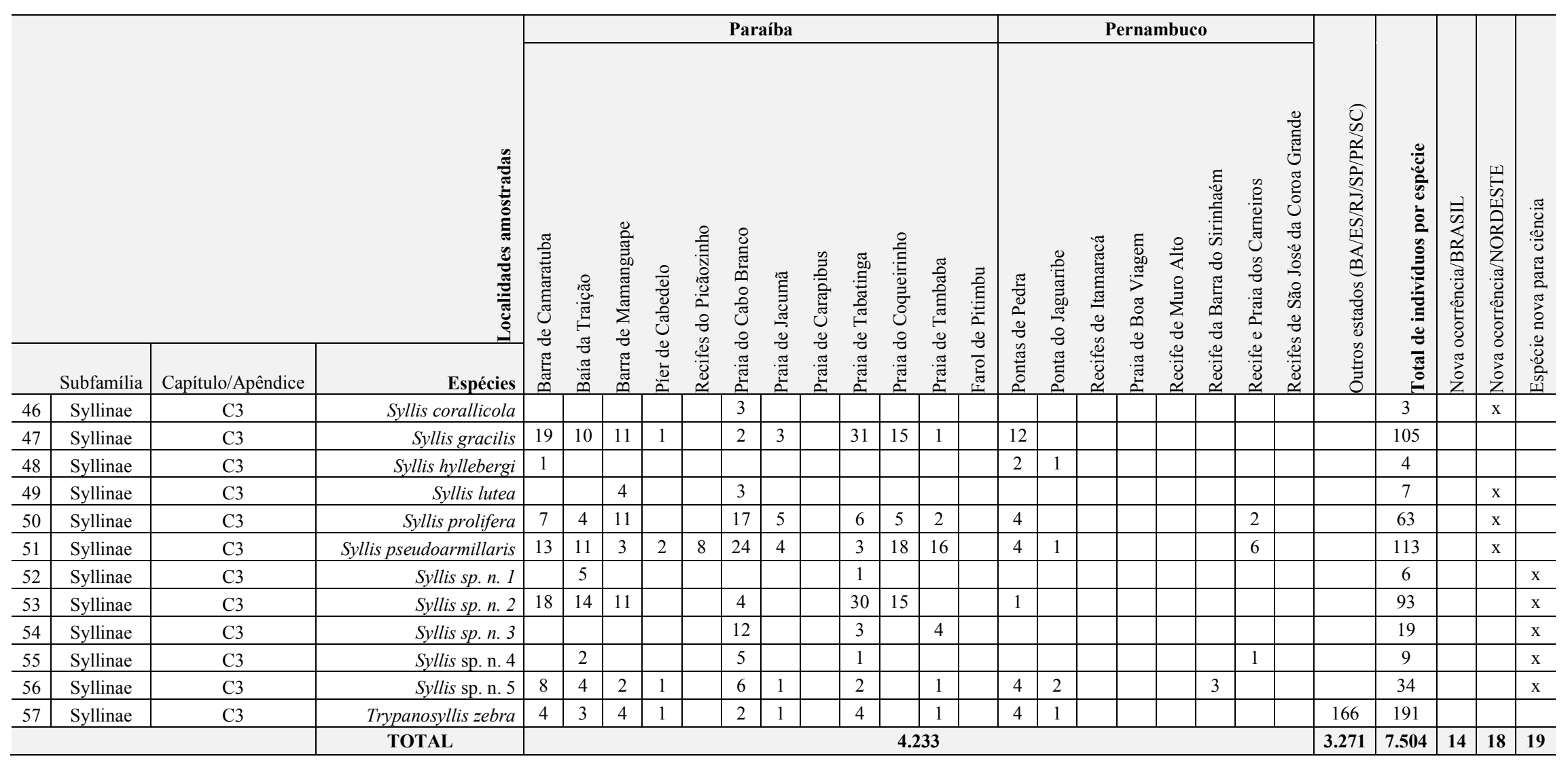




\begin{abstract}
APÊNDICE 3
Manuscrito aceito para publicação 27 de Janeiro de 2014
\end{abstract}

The genus Exogone (Polychaeta: Syllidae) from the Brazilian coast, with the description of a new species

Periódico Zootaxa 



\title{
The genus Exogone (Polychaeta: Syllidae) from the Brazilian coast, with the description of a new species
}

\section{KARLA PARESQUE $^{1 *}$ MARCELO VERONESI FUKUDA ${ }^{1} \&$ JOÃO MIGUEL DE MATOS NOGUEIRA $^{1}$}

${ }^{1}$ Laboratório de Poliquetologia (LaPol), Departamento de Zoologia, Instituto de Biociências, Universidade de São Paulo, R. do Matão, travessa 14, n. 101, 05508-090, São Paulo, SP, Brazil *corresponding author: kparesque@gmail.com

\section{Table of contents}

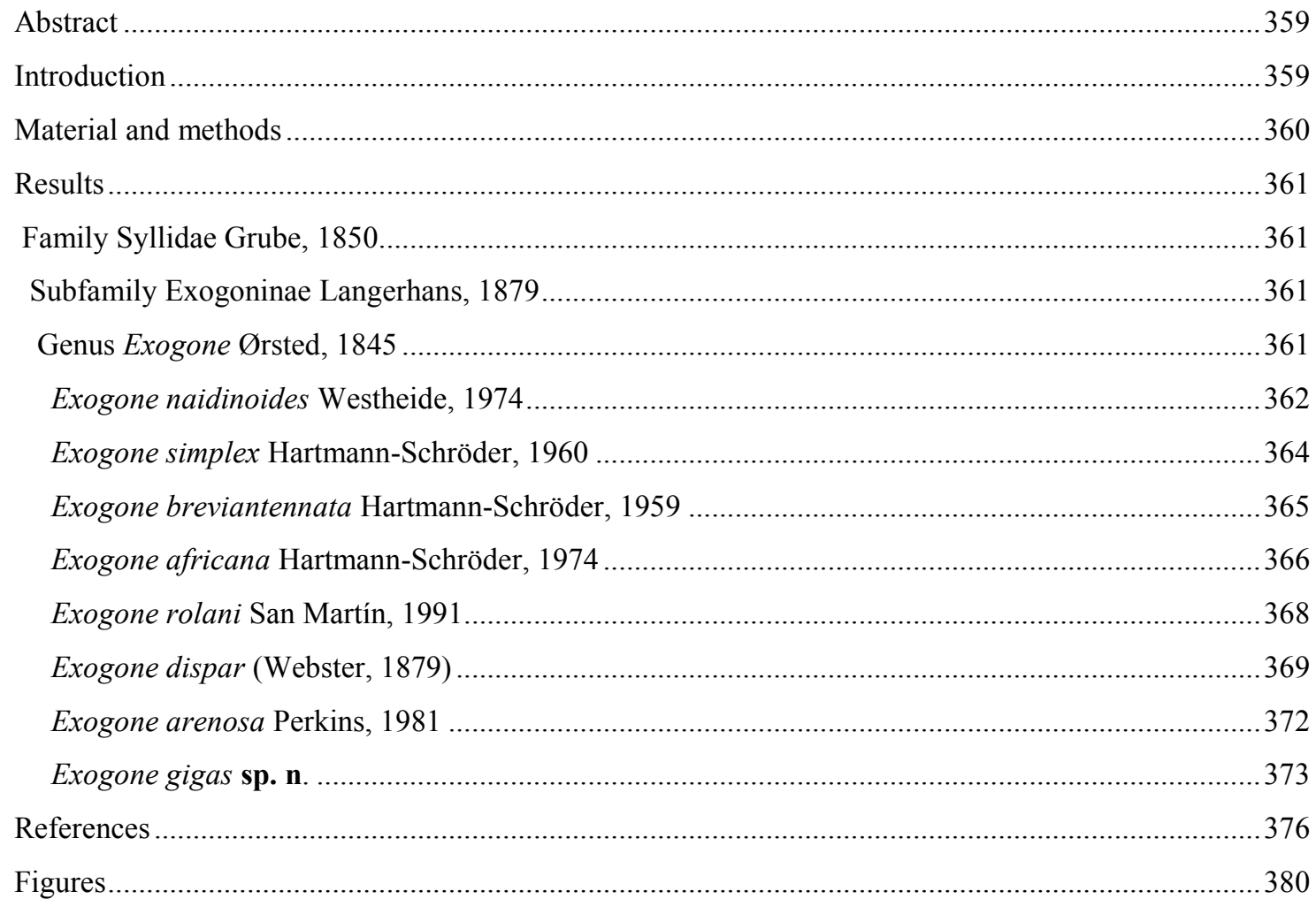

\begin{abstract}
A new species of Exogone, E. gigas sp. n., is described herein, together with $E$. africana, $E$. arenosa, E. dispar, E. naidinoides, E. rolani, and E. simplex, collected along the Brazilian coast, including new morphological details. The distribution of E. breviantennata is expanded to include the states of Espírito Santo, Paraíba and Pernambuco. Exogone gigas sp. n. is characterized by having a large median antenna, the absence of dorsal cirri on chaetiger 2 , and having a triangular process and minute spines on the shaft of the spiniger-like chaetae on chaetiger 2. The Brazilian specimens are compared to the morphologically most similar congeners. A key for the species described in this paper is provided.
\end{abstract}

Keywords: Exogoninae, new occurrence, taxonomy, Atlantic Ocean, phytal.

\section{Introduction}

Syllidae Grube, 1850 is one of the largest families of polychaetes, currently comprising around 700 species, with more than 70 genera (Aguado et al. 2007). The state of knowledge of the 
syllid fauna occurring off the Brazilian coast is still poor, considering the great extension of the Brazilian coast and the diversity of syllids in areas that have been more thoroughly studied (San Martín 2003, 2005; San Martín \& López 2003; San Martín \& Hutchings 2006; San Martín et al. 2008a, 2008b, 2010). Up to the present, about 140 species have been recorded from Brazil (Rullier \& Amoureux 1979; Morgado \& Amaral 1985; Nogueira 2000, 2006; Nogueira et al. 2001, 2004; Nygren \& Gidholm 2001; Nogueira \& San Martín 2002; Fukuda \& Nogueira 2006, 2013a, b; Paiva et al. 2007; Nogueira \& Fukuda 2008; Nogueira \& Yunda-Guarín 2008; Fukuda et al. 2009, 2012, 2013; Fukuda 2010; Berlandi et al. 2011; Amaral et al. 2012; Paresque \& Nogueira, in press).

Exogone Ørsted, 1845 is a cosmopolitan genus commonly found in samples collected off the Brazilian coast (Nogueira 2000; Nogueira et al. 2004; Berlandi et al. 2011). However, only eight species of this genus have been recorded from Brazil: E. aquadulcensis Pascual, Núñez \& San Martín, 1996, E. arenosa Perkins, 1980, E. breviantennata Hartmann-Schröder, 1959, E. dispar Webster, 1879, E. lourei (Berkeley \& Berkeley 1938), E. marisae Pascual, Núñez \& San Martín, 1996, E. naidina Ørsted, 1845 and E. verugera (Claparède, 1856) (see Amaral et al. 2012). A formal description of Brazilian populations was provided only for $E$. breviantennata (Nogueira et al. 2004), with the remaining records coming from identifications for ecological studies or unpublished theses and dissertations and frequently without voucher specimens available for examination. Therefore, only E. breviantennata and the species dealt with in this paper can be confirmed as occuring in Brazilian waters. Brazilian specimens of $E$. arenosa, E. africana, E. dispar, Exogone gigas sp. n., E. naidinoides, E. rolani, and E. simplex from recent collections are described and illustrated herein.

\section{Material and methods}

The material for the present study came from six independent studies (Figure 1). The first, the project 'Diversity of Polychaeta (Annelida) on sandstone reefs off northeastern Brazil, states of Paraíba and Pernambuco' ('BioPol-NE'), was conducted by the Laboratório de Poliquetologia (LaPol), Instituto de Biociências, Universidade de São Paulo (IB/USP). Collections were made at neap tide from eight sandstone reefs off the state of Paraíba and three off Pernambuco. Algae, sponges, ascidians, mussel beds, and similar substrates were scraped from the rocks and examined under a stereomicroscope; syllids were sorted, relaxed in a menthol solution, preserved in $4 \%$ formaldehyde, and later rinsed in fresh water and transferred to $70 \%$ ethanol. Similar methods were also adopted for the project 'Biodiversity of intertidal polychaetes (Annelida: Polychaeta) on rocky shores off the State of São Paulo' ('BioPol-SP') which was also carried out by LaPol.

The project 'BIOTA/FAPESP/Benthic marine biodiversity in the State of São Paulo' ('BIOTA') also studied the fauna occurring off São Paulo, but included more habitats, such as soft bottoms and deeper waters. For that study, material was preserved in $4 \%$ formaldehyde immediately after collection, and specimens were sorted later and transferred to $70 \%$ ethanol.

The project 'REVIZEE/South Score/Benthos' ('REVIZEE') investigated the fauna occurring in the Brazilian Economic Exclusive Zone. Material was collected from 60 to $800 \mathrm{~m}$ depths with dredges, box corers, and Van Veen grabs (see Amaral et al., 2004 for collection details).

The project 'Influence of the fractal dimension of marine macroalgae on the associated community' ('Poly-Phytal'), studied the fauna living on the algae Arthrocardia gardneri Manza, 1937, Hypnea musciformis (Wulfen) J. V. Lamouroux, 1813, Sargassum sp., Centroceras clavulatum (C. Agardh) Montagne, 1846, Colpomenia sinuosa (Mertens ex Roth) Derbès \& Solier, 1851, and Ulva fasciata Delile, 1813. Algae were scraped from the rocks of Vitória, state of Espírito Santo, and preserved in 4\% formaldehyde. The solution was later sieved through a $0.5-\mathrm{mm}$ mesh, syllids were sorted and then rinsed in fresh water and transferred to $70 \%$ ethanol (Paresque 2008).

The project 'HABITATS - Environmental heterogeneity in the Campos Basin' ('HABITATS') sampled the Campos Basin, State of Rio de Janeiro, in a survey coordinated by the Brazilian energy company PETROBRAS. Collections were made from 12 to $3301 \mathrm{~m}$ in 
2008 and 2009. Material was fixed in $4 \%$ formaldehyde and later rinsed in fresh water and transferred to $70 \%$ ethanol.

Further analyses under stereo- and light microscopes were made of specimens preserved in ethanol, some of which were permanently mounted on slides in glycerin jelly. For examination under scanning electron microscope (SEM), at least one specimen of each species was dehydrated in a series of progressively increasing concentrations of ethanol solutions, critical point dried, covered with $25 \mathrm{~nm}$ of gold and photographed under the SEM at the Laboratório de Microscopia Eletrônica, IB/USP. Line drawings of slide-mounted specimens were made with the aid of a drawing tube attached to an Olympus BX-51 ${ }^{\circledR}$ microscope.

Measurements were made from the type series, in the case of the new species, and from selected specimens, for the other taxa included herein. Data for the holotype of E. gigas sp.n.is shown in parentheses after the range of variation for each character. Length of the specimens was measured from the tip of the palps to the tip of the pygidium, excluding anal cirri; width was measured at the proventricular level, excluding parapodia.

Type material and voucher specimens are deposited at the Museu de Zoologia da Universidade Estadual de Campínas, Campinas, Brazil (ZUEC); Museu de Zoologia da Universidade de São Paulo, São Paulo, Brazil (MZUSP) and Museo Nacional de Ciencias Naturales, Madrid, Spain (MNCN). Comparative material was examined from specimens lodged at the MNCN, the Australian Museum, Sydney, Australia (AM), and the Zoological Museum Hamburg, Hamburg, Germany (ZMH).

\section{Results}

Family Syllidae Grube, 1850

Subfamily Exogoninae Langerhans, 1879

Genus Exogone Ørsted, 1845

Type species: Exogone naidina Ørsted, 1845.

Diagnosis. Relatively small forms, slender, with smooth, not papillate, body wall. Palps completely fused to each other or with terminal notch. Prostomium usually with three antennae and four eyes, sometimes also with two anterior eyespots; antennae and/or eyes occasionally absent. One pair of peristomial cirri. Dorsal cirri small, ovate, present on all segments or absent on chaetiger 2. Compound chaetae as falcigers and, frequently, spiniger-like chaetae; falcigers with bidentate blades, distal tooth shorter, sometimes resembling enlarged spine; some species with blades of falcigers fused to shafts or secondarily absent; dorsal and ventral simple chaetae present. Pair of anal cirri usually long. Pharynx with anterior margin surrounded by soft papillae, anterior tooth present. Reproduction by ventral brooding of eggs and juveniles (San Martín 2005).

Remarks. The genus was reorganized by San Martín (1991), who recognized three subgenera, Exogone (Parexogone) Mesnil \& Caullery, 1918, Exogone (Exogone) Ørsted, 1845, and Exogone (Sylline) Claparède, 1864. According to San Martin, E. (Parexogone) was characterized by having blades of falcigers more or less elongated, from distinctly short to spiniger-like, uni- or bidentate, the latter with both teeth similar or with distal tooth larger, while E. (Exogone) had falcigers with a minute distal tooth and a much larger subdistal one, and spiniger-like chaetae with thin and elongate blades. Finally, the compound chaetae of $E$. (Sylline) were even more specialized, with the blades secondarily lost, or partially to totally fused to the shafts. Also, antennae were inserted very close to each other, in a central position, in E. (Exogone) and E. (Sylline), while several species of E. (Parexogone) had well-separated antennae, with the lateral ones at the anterior margin of the prostomium or close to it, and the median antenna at the dorsal midline, in a central position or close to the anterior margin.

Böggemann \& Westheide (2004) raised Parexogone to the generic level; and, more recently, phylogenetic studies on the Syllidae have abandoned San Martin's subgenera classification, considering Exogone as monophyletic and not recognizing E. (Exogone) and E. (Sylline) as separate subgenera (Aguado \& San Martín 2009; Aguado et al. 2011). Although 
those studies did not specifically consider the Exogoninae and did not include any species of Parexogone, but were broad studies of the family, the proposed exclusion of subgenera is followed herein. Currently, Exogone comprises approximately 40 species.

\section{Identification key to species of Exogone treated in the present paper}

1. Compound chaetae bayonet-shaped by partial fusion of shafts and blades, or blades absent...2

- Compound chaetae on all chaetigers include both spiniger-like chaetae with fine, long, filiform blades and falcigers with bidentate blades, with subdistal tooth larger than distal tooth...3

2. Chaetae from anterior body usually with blades reduced to thick spine, fused to shafts; from proventricle level, each parapodium with one chaeta with slender, filiform blade partially fused to shaft, and two chaetae with blades reduced to thick, short spines fused to shafts. Dorsal simple chaetae ending in acute tip, with subdistal circle of elongate spines...Exogone naidinoides

- All chaetae distally spinulated, lacking blades. Anterior dorsal simple chaetae smooth, unidentate... Exogone simplex

3. Median and lateral antennae of similar size, short, papilliform...4

- Median antenna distinctly longer, lateral antennae papilliform...5

4. Body slender, filiform. Blades of anterior body falcigers with 3-4 relatively thick spines.

Proventricle short, through ca. 2 segments... Exogone breviantennata

- Body relatively stout. Blades of anterior body falcigers with thin spines, more numerous than above. Proventricle long, through more than three segments... Exogone africana

5. Shafts of spiniger-like chaetae of chaetiger 2 unmodified...6

- Shafts of spiniger-like chaetae of chaetiger 2 modified, with stout subdistal triangular process...7

6. Falcigers of chaetigers 1-5 modified, blades with subdistal tooth distinctly larger than those from chaetiger 6 onwards... Exogone rolani

- Falcigers with similar blades throughout body... Exogone dispar

7. Dorsal cirri on chaetiger 2 present... Exogone arenosa

- Dorsal cirri on chaetiger 2 absent... Exogone gigas sp. n.

Exogone naidinoides Westheide, 1974

(Figures 2-4)

Exogone naidinoides Westheide, 1974: 109-113, figs 50-51e-f; Russell 1991: 9-11, fig. 3; San Martín \& Bone 2001.

Exogone (Sylline) naidinoides. San Martín 1991: 737, fig. 7a-f; Capa et al. 2001: 623; Ruíz-

Ramírez \& Salazar-Vallejo 2001: 128, fig. 4 (66-76); San Martín 2005: 146-147, fig. 93; Fukuda 2010: 149-151, fig. 44.

Material examined. Project 'BIOTA': State of São Paulo: Ubatuba, Praia de Picinguaba $\left(23^{\circ} 22^{\prime} \mathrm{S} 44^{\circ} 50^{\prime} \mathrm{W}\right)$, on algae: 5 specimens (MZUSP 1015), coll. 08 June 2001. Caraguatatuba, Praia de Martím de Sá $\left(23^{\circ} 38^{\prime} \mathrm{S} 45^{\circ} 23^{\prime} \mathrm{W}\right)$, on Sargassum sp.: 43 specimens (MZUSP 1014),

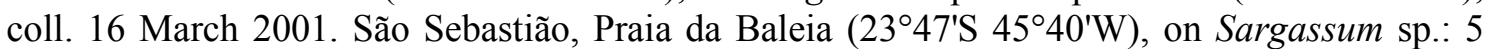
specimens (MZUSP 1012), coll. 10 April 2001. Project 'BioPol-NE': State of Paraíba, Baía da Traição, Praia do Farol $\left(06^{\circ} 41^{\prime} \mathrm{S} 34^{\circ} 55^{\prime} \mathrm{W}\right)$, intertidal: 27 specimens (MZUSP 1343), coll. 09 August 2010. Rio Tinto, Barra de Mamanguape $\left(06^{\circ} 45^{\prime} \mathrm{S} 34^{\circ} 55^{\prime} \mathrm{W}\right)$, intertidal: 9 specimens (MZUSP 1342), coll. 11 August 2010. João Pessoa, Cabo Branco (0708'S 3447'W), intertidal: 30 specimens (MZUSP 1339), coll. 02 February 2010; Recife do Picãozinho (0704.243'S 34 49.291'W), intertidal: 4 specimens (MZUSP 1341), coll. 15 September 2012. Conde, Praia de Jacumã $\left(07^{\circ} 14^{\prime} \mathrm{S} 34^{\circ} 47^{\prime} \mathrm{W}\right)$, intertidal: 1 specimen (MZUSP 2082), coll. 29 January 2010; Praia de Carapibus $\left(07^{\circ} 17^{\prime} \mathrm{S} 34^{\circ} 48^{\prime} \mathrm{W}\right)$, intertidal: 1 specimen, coll. 10 February 2009. State of 
Pernambuco, Itamaracá, Ponta do Jaguaribe $\left(7^{\circ} 44^{\prime} \mathrm{S} 34^{\circ} 49^{\prime} \mathrm{W}\right)$, intertidal: 1 specimen (MZUSP 2081), coll. 11 December 2012.

Additional material examined. Exogone naidinoides. Galápagos Islands, Santa Cruz holotype (ZMH P-13611), coll. \& det. W. Westheide, 1972. Cuba, Punta del Francés - Isla de Pinos, in dead coral, 1 m, coll. \& det. G. San Martín, 1 specimen (MNCN 16.01/631).

Description. Small species, longest specimens ca. $2.5 \mathrm{~mm}$ long and $0.1 \mathrm{~mm}$ wide, with up to 23 chaetigers. Palps narrower than anterior chaetigers, distally rounded, totally fused (Figs $2 \mathrm{~A}, 3 \mathrm{~A}-\mathrm{B}$ ) with conspicuous line of fusion (Fig. 2A). Prostomium pentagonal to ovate, slightly shorter than palps, with two pairs of eyes in trapezoidal arrangement, anterior eyespots absent; antennae inserted in nearly transverse row, close to each other, anterior to anteriormost eyes, median antenna slightly posterior to lateral antennae and slightly longer, reaching tip of palps (Figs 2A, 3A-C). Nuchal organs as pair of ventrolateral ciliated pits between prostomium and peristomium, close to peristomial cirri, visible only with SEM (Fig. 3B-C, H). Peristomium shorter than following chaetigers, sometimes covering posterior part of prostomium, including posterior eyes; peristomial cirri short, papilliform (Figs 2A, 3C, H). Dorsal cirri ovate (Figs 2A, 3A, C, 4C, F), slightly larger than peristomial cirri, absent on chaetiger 2 (Figs 2A, 3A). Ventral cirri similar to dorsal cirri but smaller (Fig. 3B). Parapodial lobes conical. Anterior parapodia with 3-7 bayonet chaetae each; chaetae subdistally spinulated, blades 4-10 $\mu \mathrm{m}$ long (Figs 2B, 3D-F); after chaetiger 4-5, only 1 bayonet chaeta per parapodium, blades 5-13 $\mu \mathrm{m}$ long, and 23 chaetae with short nail-like blades fused to shafts, with crown of spines surrounding tip of shafts (Figs 2C, 4A, D). Dorsal simple chaetae present on all chaetigers, with acute tip (Figs 2D-E, 3I, 4D), becoming progressively thicker toward posterior; ventral simple chaetae present only on mid- and posterior body chaetigers, sigmoid, bidentade, subdistal tooth larger (Figs 2F, 4E). Single acicula per parapodium throughout, thick, subdistally enlarged, with tip protruding from parapodial lobes on mid- and posterior body chaetigers (Figs 2G-H, 4A-B). Pygidium with thin, elongate pair of anal cirri (Fig. 4F). Pharynx through 2-3 segments, tooth at anterior border; proventricle extending for 1-2.5 chaetigers (Fig. 2A), with 13-16 rows of muscle-cells.

Remarks. The position of the nuchal organs and the presence of protruding acicula are recorded for the first time for this species. The nuchal organs are in an unusual ventrolateral position, rather than the dorsolateral position commonly observed in other syllids (Fig. 3A-C, $\mathrm{G}-\mathrm{H})$.

Exogone aquadulcensis Pascual, Nuñez \& San Martín, 1996, described from Tenerife, Canary Islands, Spain, is the species most similar to E. naidinoides. It differs by having antennae that are thicker but of about the same length; in addition, ventral simple chaetae are unidentate in E. aquadulcensis and bidentate in E. naidinoides. The sympatric species $E$. simplex is less common than E. naidinoides; both have palps that are distally rounded and totally fused with a conspicuous line of fusion, dorsal cirri absent on chaetiger 2 , solitary acicula per parapodium throughout the body, similar lengths of pharynx and proventricle, as well as a similar number of muscle cells. In contrast, E. simplex has chaetae that lack blades throughout, shorter antennae, and papilliform dorsal cirri, while E. naidinoides has 3-7 bayonet-shaped chaetae on anterior chaetigers and, after chaetigers $4-5$, a single bayonet chaeta per parapodium and 2-3 chaetae with short nail-like blades fused to the shafts, digitiform antennae almost reaching the tip of the palps, and dorsal cirri longer than those of E. simplex.

Brazilian specimens have lateral antennae that are proportionally longer than those from Australia (San Martín 2005) and Galápagos (Westheide 1974), and the bayonet chaetae of chaetigers 1-3 are longer. The specimen from Cuba has up to six bayonet chaetae in each parapodium of chaetigers 1-3, with blades ca. $4 \mu \mathrm{m}$ long; from chaetiger 4 onwards, each parapodium bears a single bayonet chaeta with a blade 5-8 $\mu \mathrm{m}$ long and 2-3 chaetae with blades fused to shafts; that specimen has blades of the bayonet chaetae relatively shorter than those of Brazilian specimens.

Although specimens from Brazil do not match perfectly the available descriptions for this species, the differences are very subtle and include characters that are visible only under SEM and therefore cannot be compared with populations from other localities, as they have not 
been studied under SEM. Future molecular studies may reveal whether this is one of a complex of sibling species.

Type locality. Ecuador, Galápagos Islands (Pacific Ocean).

Distribution. Atlantic Ocean: Canary Islands, Cuba, Mexico, Belize, Panamá, Venezuela, and Brazil (Paraíba and São Paulo). Pacific Ocean: Galápagos Islands. Indian Ocean: Australia (Western Australia). From the intertidal zone to ca. $12 \mathrm{~m}$ deep.

\section{Exogone simplex Hartmann-Schröder, 1960}

(Figure 5)

Exogone simplex Hartmann-Schröder, 1960: 107-108, figs 134-136, Taf. 15.

Exogone (Sylline) simplex. San Martín 2005: 146, fig. 92; Fukuda 2010: 152-153, fig. 45.

Material examined. Project 'BioPol-SP': Guarujá, Praia de Pernambuco (235' $\left.58^{\circ} 46^{\circ} 11^{\prime} \mathrm{W}\right)$, intertidal: 2 specimens, coll. 04 October 2005. Project 'BioPol-NE': State of Paraíba, Baía da Traição, Ponta da Prainha (06 $\left.41^{\circ} \mathrm{S} 34^{\circ} 55^{\prime} \mathrm{W}\right)$, intertidal: 1 specimen (MZUSP 1337), coll. 09 August 2010. João Pessoa, Cabo Branco $\left(07^{\circ} 08^{\prime} \mathrm{S} 34^{\circ} 47^{\prime} \mathrm{W}\right)$, on rock shore, intertidal: 1 specimen (MZUSP 1338), coll. 02 February 2010.

Additional material examined. Exogone simplex. Egypt, Ghardaqa - holotype (ZHM P-14704), coll. Remane \& Schulz, 29 March 1956.

Description. Small species, longest specimens ca. $1.6 \mathrm{~mm}$ long and $0.1 \mathrm{~mm}$ wide, with up to 18 chaetigers. Palps narrower than anterior chaetigers, distally rounded, totally fused with conspicuous line of fusion (Fig. 5A). Prostomium ovate, slightly shorter than palps, with two pairs of eyes in trapezoidal arrangement; anterior eyespots absent; antennae inserted in nearly transverse row, close to each other, anterior to anterior pair of eyes; median antenna digitiform, slightly longer than lateral antennae; lateral antennae papilliform, inserted slightly anterior to median antenna (Fig. 5A). Peristomium shorter than following chaetigers, sometimes covering posterior part of prostomium, including posterior eyes; peristomial cirri short, papilliform (Fig. 5A). Dorsal cirri ovate, slightly larger than peristomial cirri, absent on chaetiger 2 (Fig. 5A). Ventral cirri similar to dorsal cirri but shorter. Parapodial lobes conical, short; anterior parapodia with 3-5 chaetae each, midbody parapodia with 3 chaetae each, posterior parapodia with 2-3 chaetae each; chaetae lacking blades, distally spinose, one spine larger than others, chaetae distally inflated and bent ventralwards (Fig. 5D). Dorsal simple chaetae present on all segments, subdistally inflated, with acute tip, stouter posteriorwards (Fig. 5C). Ventral simple chaetae present on all chaetigers, thinner than other chaetae of the same parapodium, sigmoid, bidentate, subdistal tooth larger than apical tooth (Fig. 5G). Single acicula per parapodium throughout, subdistally inflated, with acute tip, thicker in posterior chaetigers (Fig. 5F). Pygidium with thin, elongate pair of anal cirri (Fig. 5B). Pharynx through two segments; tooth at anterior border; proventricle extending for one chaetiger, with ca.14 rows of muscle cells (Fig. 5A).

Remarks. Exogone simplex is similar to E. aquadulcensis in the length of the palps, antennae, peristomial and dorsal cirri, pharynx, and proventricle, including the number of muscle-cells and number of acicula per parapodium, as well as in the absence of dorsal cirri on chaetiger 2 . However, E. simplex has chaetae lacking blades throughout the body, acicula that are subdistally inflated with an acute tip, and bidentate ventral simple chaetae, while $E$. aquadulcensis has bayonet chaetae on chaetigers 1-3 and chaetae with slender blades dorsalmost in the remaining parapodia, distally thickened and asymmetrical acicula with a short tip, and unidentate and slightly serrated ventral simple chaetae (Pascual et al. 1996).

Specimens from Paraíba differ from the Australian ones described by San Martín (2005), in that the latter have only three chaetae per parapodium and the proventricle extends for two chaetigers, whereas those from Paraíba have up to five chaetae per parapodium and a shorter proventricle that extends only through one chaetiger.

Type locality. Egypt, Ghardaka (Indian Ocean). 
Distribution. Atlantic Ocean: Angola, Brazil (Paraíba and São Paulo). Pacific Ocean: Australia (New South Wales). Indian Ocean: Australia (Western Australia); Red Sea: Egypt. Found in the intertidal zone.

\section{Exogone breviantennata Hartmann-Schröder, 1959}

Exogone breviantennata Hartmann-Schröder, 1959: 125, figs 75-78; Nuñez 1990: 283-285, fig.80; Zottoli \& Long 2000: 502-511, figs 1-5; Aguado \& San Martín 2007: 209-210.

Exogone (Exogone) breviantennata. San Martín 1991: 730, fig.8; 2005: 141-142, fig. 81E, 89; Nuñez et al. 1992: 47, fig.3; Nogueira 2000: 32, fig. 6F-I; Nogueira et al. 2004: 63-66, figs 67; Fukuda 2010: 121, figs 33-34.

Exogone ovalis Hartmann-Schröder, 1960: 106, figs 131-133.

Exogone occidentalis Westheide, 1974b: 305-309, pl. 52a-1; Morgado \& Amaral 1985: 220, fig. 1.

Exogone verugera non Claparède, 1868. Imajima 1966: 399, fig. 3; Day 1967: 272, fig. 12 g-1; Gardiner 1975: 132, fig. 11 a-e.

Material examined. Project 'BioPol-SP': State of São Paulo: Ubatuba, Praia do Perequê-Mirim $\left(23^{\circ} 29^{\prime} 20^{\prime \prime S} 45^{\circ} 06^{\prime} 25^{\prime \prime} \mathrm{W}\right): 13$ specimens, coll. 5 January 2003. Caraguatatuba, Praia Martim de Sá $\left(23^{\circ} 37^{\prime} 34^{\prime \prime S} 45^{\circ} 22^{\prime} 31^{\prime \prime W}\right): 8$ specimens, coll. 22 July 2005. São Sebastião, Praia de São

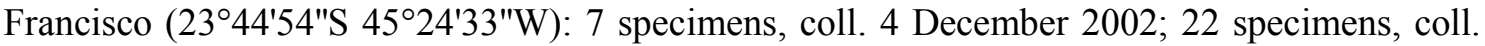
19 April 2003; 29 specimens, coll. 27 September 2003; 24 specimens, coll. 24 July 2005; Praia

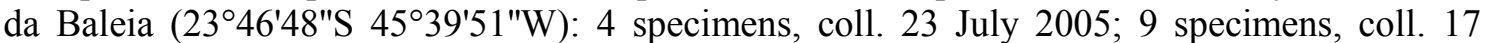

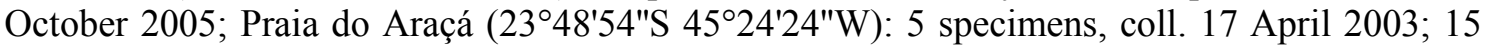
specimens, coll. 15 July 2003; 2 specimens, coll. 25 September 2003; 59 specimens, coll. 20

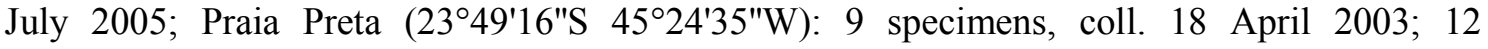

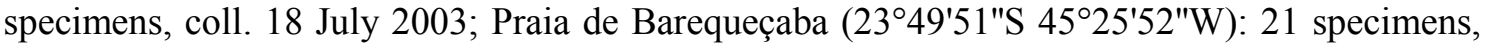
coll. 20 April 2003; Praia de Guaecá $\left(23^{\circ} 49^{\prime} \mathrm{S} 45^{\circ} 28^{\prime} 08^{\prime \prime} \mathrm{W}\right): 19$ specimens, coll. 17 July 2003; Praia de Toque-Toque Grande $\left(23^{\circ} 50^{\prime} 12^{\prime \prime S} 45^{\circ} 30^{\prime} 40^{\prime \prime} \mathrm{W}\right): 3$ specimens, coll. 21 July 2005. Guarujá, Praia Branca $\left(23^{\circ} 52^{\prime} \mathrm{S} 46^{\circ} 08^{\prime} \mathrm{W}\right)$ : 1 specimen, coll. 25 June 2002; Praia de Pernambuco $\left(23^{\circ} 58^{\prime} 20^{\prime \prime S} 46^{\circ} 11^{\prime} 02^{\prime \prime} \mathrm{W}\right): 6$ specimens, coll. 22 June 2005; 76 specimens, coll. 04 October 2005. Santos, Ilha das Palmas $\left(24^{\circ} 00^{\prime} 34^{\prime \prime} \mathrm{S} 46^{\circ} 19^{\prime} 25^{\prime \prime W}\right): 8$ specimens, coll. 05 October 2005. São Vicente, Ilha Porchat $\left(23^{\circ} 58^{\prime} 39^{\prime \prime} \mathrm{S} 46^{\circ} 22^{\prime} 08^{\prime \prime} \mathrm{W}\right)$ : 1 specimen, coll. 17 November $2002 ; 2$ specimens, coll. 16 March 2003; 4 specimens, coll. 15 June 2003; Praia das Vacas (23⒌'55"S 46 22'48"W): 1 specimen, coll. 19 November 2002; 3 specimens, coll. 16 May 2003. Peruíbe, Praia do Guaraú $\left(24^{\circ} 22^{\prime} 01^{\prime \prime S} 47^{\circ} 00^{\prime} 31^{\prime \prime W}\right)$ : 6 specimens, coll. 05 March 2007. Project 'BIOTA': Ubatuba, Praia da Fazenda ( $\left.23^{\circ} 21^{\prime} 25^{\prime \prime} \mathrm{S} 44^{\circ} 51^{\prime} 55^{\prime \prime}\right)$, on rocky shore, intertidal: 14 specimens,

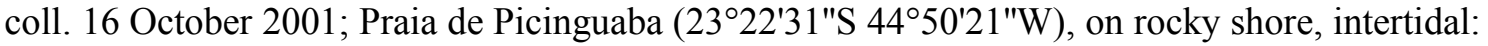
29 specimens, coll. 9 May 2001; 2 specimens, coll. 10 May 2001; 51 specimens, coll. 17 October 2001; on Sargassum sp.: 26 specimens, coll. 18 October 2001; on assemblage of algae: 5 specimens, coll. 08 June 2001; 10 specimens, coll. 08 October 2001; 15 specimens, coll. 18 October 2001. Caraguatatuba ( $\left.23^{\circ} 33^{\prime} 954^{\prime \prime S} 45^{\circ} 12^{\prime} 277^{\prime} \mathrm{W}\right), 9.4 \mathrm{~m}$ : 1 specimen, coll. 22 August 2001; Praia Martim de Sá $\left(23^{\circ} 37^{\prime} 34^{\prime \prime S} 45^{\circ} 22^{\prime} 31^{\prime \prime W}\right)$, on rocky shore, intertidal: 3 specimens, coll. 13 March 2001; 6 specimens, coll. 16 March 2001; 26 specimens, coll. 19 September 2001; 9 specimens, coll. 21 September 2001; on Dyctiota sp.: 42 specimens, coll. 16 March 2001; on Sargassum sp.: 197 specimens, 16 March 2001; on assemblage of algae: 4 specimens, coll. 16 March 2001; Ponta do Cambiri $\left(23^{\circ} 37^{\prime} \mathrm{S} 45^{\circ} 24 ' 31\right.$ 'W), on rocky shore, intertidal: 47 specimens, coll. 15 March 2001; 6 specimens, coll. 20 September 2001. São Sebastião, Praia de São Francisco $\left(23^{\circ} 44^{\prime} 54^{\prime \prime S} 4^{\circ} 24^{\prime} 33^{\prime \prime W}\right)$, on sand: 5 specimens, coll. 01 June 2003; 2 specimens, coll. 17 June 2003; Praia da Baleia $\left(23^{\circ} 46^{\prime} 48^{\prime \prime} \mathrm{S} 45^{\circ} 39^{\prime} 51^{\prime \prime} \mathrm{W}\right)$, on rocky shore, intertidal: 229 specimens, coll. 08 April 2001; 11 specimens, coll. 09 April 2001; 5 specimens, coll. 10 April 2001; 12 specimens, coll. 12 December 2001; 13 specimens, coll. 13 December 2001; on Sargassum sp.: 174 specimens, coll. 10 April 2001; 13 specimens, coll. 14 November 


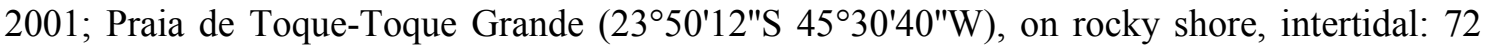
specimens, coll. 10 April 2001. Project 'Poly-Phytal': State of Espírito Santo, Vitória, Ilha do Boi. Praia da Direita $\left(20^{\circ} 18^{\prime} \mathrm{S} 40^{\circ} 17^{\prime} \mathrm{W}\right)$, rocky shore, intertidal: on Arthrocardia gardnerii: 3 specimens (MZUSP 1316), coll. 26 May 2005; 5 specimens (MZUSP 1306), coll. 21 July 2005; 21 specimens (MZUSP 1307 and 1314), coll. 01 November 2005; 21 specimens (MZUSP 1309), coll. 01 March 2006; on Centroceras clavulatum: 8 specimens (MZUSP 1308), coll. 01 November 2005; 1 specimen (MZUSP 1311), coll. 01 March 2006; on Hypnea musciformis: 3 specimens (MZUSP 1310), coll. 26 May 2005; on Colpomenia sinuosa: 2 specimens (MZUSP 1315), coll. 01 November 2005; 3 specimens (MZUSP 1313), coll. 01 March 2006; on Sargassum sp.: 1 specimen (MZUSP 1312), coll. 21 July 2005; 1 m: on Arthrocardia gardnerii: 1 specimen (MZUSP 2071), coll. 01 March 2006 . Project 'BioPol-NE': State of Paraíba, Mataraca, Barra de Camaratuba (06 $\left.36^{\circ} \mathrm{S} 34^{\circ} 57^{\prime} \mathrm{W}\right)$, intertidal: 2 specimens (MZUSP 2066), coll. 12 August 2010. Baía da Traição, Praia do Farol (06 $\left.06^{\circ} 1^{\prime} \mathrm{S} 34^{\circ} 55^{\prime} \mathrm{W}\right)$, intertidal: 2 specimens (MZUSP 1319), coll. 09 August 2010. Rio Tinto, Barra de Mamanguape (06 $\left.45^{\circ} \mathrm{S} 34^{\circ} 55^{\prime} \mathrm{W}\right)$, intertidal: 26 specimens, coll. 02 February 2010. Cabedelo, Píer de Cabedelo (06 58'S $\left.34^{\circ} 50^{\prime} \mathrm{W}\right)$, intertidal: 1 specimen coll. 12 February 2009. João Pessoa, Cabo Branco $\left(07^{\circ} 08^{\prime} \mathrm{S}\right.$ $34^{\circ} 47^{\prime} \mathrm{W}$ ), intertidal: 4 specimens (MZUSP 1318), coll. 09 February 2009; 241 specimens, coll. 02 February 2010; Recife do Picãozinho (07²4.243'S 3449.291'W), intertidal: 12 specimens (MZUSP 1317), coll. 15 September 2012. Conde, Praia de Jacumã $\left(07^{\circ} 14^{\prime} \mathrm{S} 34^{\circ} 47^{\prime} \mathrm{W}\right)$, intertidal: 3 specimens (MZUSP 2074), coll. 29 January 2010; Praia de Carapibus $\left(07^{\circ} 17^{\prime} \mathrm{S}\right.$ $34^{\circ} 48^{\prime} \mathrm{W}$ ), intertidal: 1 specimen (MZUSP 2072), coll. 10 February 2009; Praia de Coqueirinho $\left(07^{\circ} 18^{\prime} \mathrm{S} 34^{\circ} 47^{\prime} \mathrm{W}\right), 1$ specimen (MZUSP 2073), coll. 28 August 2011; Praia de Tabatinga $\left(07^{\circ} 19^{\prime} \mathrm{S} 34^{\circ} 47^{\prime} \mathrm{W}\right)$, intertidal: 2 specimens (MZUSP 2075), coll. 01 September 2011; 2 specimens (MZUSP 2076), coll. 17 September 2012; Praia de Tambaba (07²1'S 34²4'W), 2 specimens (MZUSP 2077), coll. 30 August 2011, Pitimbú, Farol de Pitimbú (7²8.362'S $34^{\circ} 47^{\prime} \mathrm{W}$ ), 1m: 18 specimens (MZUSP 2068), coll. 18 September 2012. State of Pernambuco,

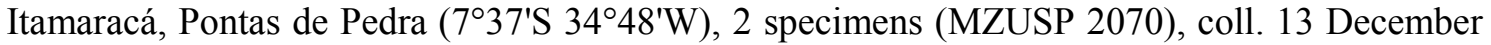
2012; Ponta do Jaguaribe ( $\left.7^{\circ} 44^{\prime} \mathrm{S} 34^{\circ} 49^{\prime} \mathrm{W}\right)$, intertidal: 6 specimens (MZUSP 2069), coll. 11

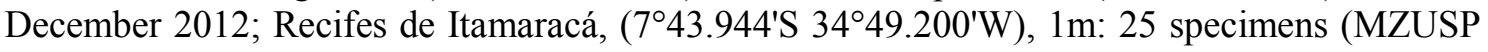
2078), coll. 15 December 2012.

Additional material examined. Exogone breviantennata. El Salvador - holotype (ZMH P-14589), det. G. Hartmann-Schröder. Cuba - Manglar Boca Grande, 1 specimen (MNCN 16.01/9902), coll. 16 June 1996.

Type locality. El Salvador, Estero Jaltepeque (Pacific Ocean).

Distribution. Atlantic Ocean: USA (Florida), Madeira Island, Canary Islands, Brazil (Paraíba, Espírito Santo, Rio de Janeiro and São Paulo); Mediterranean Sea: Lebanon; Caribbean Sea: Bahamas, Belize, Cuba and Venezuela. Pacific Ocean: China, Australia (Queensland), Galápagos Islands, El Salvador. Indian Ocean: Tanzania, Mozambique, Australia (Western Australia). From the intertidal zone to ca. $40 \mathrm{~m}$ deep.

Remarks. This species was reported from Brazil for the first time from the coast off São Paulo (see Nogueira et al. 2004 for more details). In the present paper, its distribution is expanded to Espírito Santo and northeastern Brazil.

\section{Exogone africana Hartmann-Schröder, 1974}

(Figure 6)

Exogone verugera africana Hartmann-Schröder, 1974: 137, figs 164-168.

Exogone (Exogone) africana. San Martín 2005: 143-145, figs 90-91; Fukuda 2010: 112-115, fig. 30 .

Exogone africana. Abd Elnaby \& San Martín 2010: 135-136, fig. a-i.

Material examined. Project 'BioPol-SP': State of São Paulo: Guarujá, Praia de Pernambuco

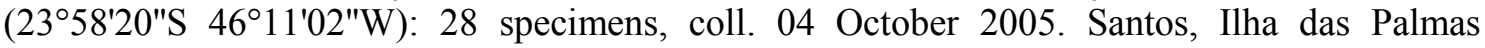

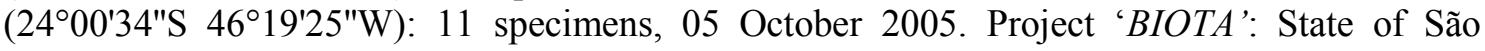


Paulo: Ubatuba, Praia de Picinguaba $\left(23^{\circ} 22^{\prime} 31^{\prime \prime S} 44^{\circ} 50^{\prime} 21^{\prime \prime W}\right)$, on rocky shore, intertidal: 2 specimens, coll. 10 May 2001; 5 specimens, coll. 17 October 2001; on Sargassum sp.: 12 specimens, coll. 18 October 2001; on assemblage of algae: 7 specimens, coll. 08 June 2001; 3 specimens, coll. 08 October 2001; 2 specimens, coll. 18 October 2001. Caraguatatuba, Praia Martim de Sá $\left(23^{\circ} 37^{\prime} 34^{\prime \prime S} 45^{\circ} 22^{\prime} 31^{\prime \prime W}\right)$, on rocky shore, intertidal: 128 specimens, coll. 19 September 2001; 27 specimens, coll. 21 September 2001; on Sargassum sp.: 1 specimen, coll. 16 March 2001; 3 specimens, coll. 27 September 2001; Ponta do Cambiri, on rocky shore, intertidal: 13 specimens, coll. 15 March 2001; 8 specimens, coll. 20 September 2001. São

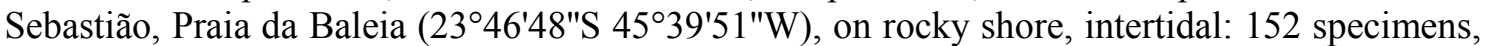
coll. 08 April 2001; 4 specimens, coll. 09 April 2001; 2 specimens, coll. 10 April 2001; 3 specimens, coll. 12 December 2001; 2 specimens, coll. 13 December 2001; on Sargassum sp.: 91 specimens, coll. 10 April 2001; 28 specimens, coll. 14 November 2001. Praia de ToqueToque Grande ( $\left.23^{\circ} 50^{\prime} 12^{\prime \prime} \mathrm{S} 45^{\circ} 30^{\prime} 40^{\prime \prime} \mathrm{W}\right)$, on rocky shore, intertidal: 26 specimens, coll. 10 April 2001. Project 'Poly-Phytal': State of Espírito Santo, Vitória, Ilha do Boi, Praia da Direita (20 18'S 40 $\left.17^{\prime} \mathrm{W}\right)$, rocky shore, intertidal: on Arthrocardia gardnerii: 1 specimen (MZUSP 1331), coll. 26 May 2005; 6 specimens (MZUSP 1333), coll. 01 March 2006; on Colpomenia sinuosa: 1 specimen (MZUSP 1332), coll. 21 July 2005; on Sargassum sp.: 1 specimen (MZUSP 1334), coll. 01 March 2006. Project 'BioPol-NE': State of Paraíba, Rio Tinto, Barra de Mamanguape $\left(06^{\circ} 45^{\prime} \mathrm{S} 34^{\circ} 55^{\prime} \mathrm{W}\right)$, intertidal: 1 specimen (MZUSP 1329), coll. 11 August 2010; Baía da Traição, Praia do Farol $\left(06^{\circ} 41.331^{\prime} \mathrm{S} 34^{\circ} 55.803^{\prime} \mathrm{W}\right)$, intertidal: 1 specimen (MZUSP 1330), coll. 09 August 2010. State of Pernambuco, Itamaracá, Recifes de Itamaracá, ( $7^{\circ} 43.944$ 'S 3449.200'W), 1m: 25 specimens (MZUSP 2060), coll. 15 December 2012.

Description. Body thin, elongated, longest specimens ca. $3 \mathrm{~mm}$ long and $0.3 \mathrm{~mm}$ wide, with up to 40 chaetigers. Palps triangular, distally rounded, totally fused, with a line of fusion (Fig. 6A). Prostomium pentagonal to ovate, shorter than palps, with two pairs of eyes in trapezoidal arrangement, anterior eyespots absent; antennae inserted close to each other, in transverse row between anterior pair of eyes, antennae papilliform, median antenna slightly longer (Fig. 6A). Peristomium shorter than following chaetigers, usually covering posterior part of prostomium; peristomial cirri similar to lateral antennae but smaller (Fig. 6A). Dorsal cirri ovate, similar in length to median antenna, present on all chaetigers (Fig. 6A). Ventral cirri similar to dorsal cirri but smaller, shorter than parapodial lobes. Parapodial lobes conical; anterior parapodia with 1-2 spiniger-like chaetae and 3-5 falcigers each, midbody and posterior parapodia with single spiniger-like chaeta and 2-3 falcigers each; shafts of spiniger-like chaetae subdistally inflated and spinulated; blades of spiniger-like chaetae distally bifid, with minute teeth, spinulated, blades ca. $28 \mu \mathrm{m}$ long on anterior, $45-50 \mu \mathrm{m}$ long on midbody, and 20-24 $\mu \mathrm{m}$ long on posterior parapodia (Fig. 6B-D); shafts of falcigers subdistally inflated, spinulated; blades of falcigers spinulated, bidentate; blades with slight anterior-posterior gradation in length, $7-10 \mu \mathrm{m}$ long on anterior, ca. $8 \mu \mathrm{m}$ on midbody, and ca. $7 \mu \mathrm{m}$ long on posterior parapodia (Fig. 6B-D). Dorsal simple chaetae present on all chaetigers, sigmoid, subdistally spinulated, with acute tip, stouter posteriorwards (Fig. 6E-F); ventral simple chaetae present only in posterior, sigmoid, bidentate, subdistal tooth larger (Fig. 6G). Anterior parapodia with up to two aciculae each, both slightly curved subdistally, with inflated, rounded tip (Fig. 6H); midbody and posterior parapodia with single acicula each, of same shape (Fig. 6I), stouter posteriorwards. Pygidium with thin, elongate pair of anal cirri (Fig. 6J). Pharynx through three segments; tooth at anterior border; anterior margin of pharynx surrounded by papillae; proventricle extending for four chaetigers, with ca. 22 rows of muscle cells (Fig. 6A).

Remarks. Exogone africana is very similar to E. breviantennata, E. dispar, and E. verugera (Claparède, 1868). Exogone breviantennata is the most similar species, as both species share papilliform antennae and peristomial, dorsal, and ventral cirri; the same number of aciculae, spiniger-like and falciger chaetae per parapodium; similar morphology of aciculae, dorsal and ventral simple chaetae,; pharynx of similar length; and proventricle with approximate number of muscle-cell rows. However, E. breviantennata is proportionally more slender, also differing from E. africana by having blades on anterior falcigers with fewer, but somewhat stouter spines, and shorter proventricle. Studying the fauna of Australia, San Martín (2005) 
pointed out that young specimens of these species can be easily mixed up, noticing that $E$. breviantennata was found only in tropical areas, where E. africana was less abundant. In the present study, E. breviantennata was more abundant than E. africana, thus supporting the pattern noticed by San Martín (2005).

Exogone dispar also has papilliform lateral antennae, peristomial, dorsal and ventral cirri; a similar number of aciculae, spiniger-like and falciger chaetae per parapodium; acicula, dorsal and ventral simple chaetae with similar morphology; pharynx of similar length; and proventricle with approximately the same number of muscle-cells rows as in E. africana. The differences between E. africana and E. dispar include the shorter proventricle of the latter species, as well as E. dispar having falciger blades that are more spinulated, and a median antenna distinctly longer than the lateral antennae.

The Brazilian specimens agree with the original description and that provided for an Australian specimen by San Martín (2005).

Type locality. Republic of Namibia, Luderitz (Atlantic Ocean).

Distribution. Atlantic Ocean: Namibia; Angola; Brazil (Paraíba, Espírito Santo, São Paulo); Mediterranean Sea (Egypit and Turkey). Pacific Ocean: USA (Hawaii); Japan; Australia (Queensland, New South Wales). Indian Ocean: Australia (Western Australia). From the intertidal zone to ca. $81 \mathrm{~m}$ deep.

\section{Exogone rolani San Martín, 1991}

(Figures 7-8)

Exogone rolani San Martín, 1991: 731, fig. 09.

Material examined. Project 'HABITATS': All collections off the state of Rio de Janeiro (Campos Basin), Van Veen grab; 21 221'21"S 4052'9"W, 20 m: 1 specimen, coll. 23 July 2009; $21^{\circ} 22^{\prime} 58^{\prime \prime S} 40^{\circ} 19^{\prime} 41^{\prime \prime W}, 52 \mathrm{~m}: 18$ specimens, coll. 05 March 2009; 9 specimens, coll. 21 July $2009 ; 21^{\circ} 28^{\prime} 2^{\prime \prime} \mathrm{S} 40^{\circ} 56^{\prime} 22^{\prime \prime} \mathrm{W}, 15 \mathrm{~m}: 3$ specimens, coll. 20 July 2009; $22^{\circ} 3^{\prime} 45^{\prime \prime} \mathrm{S} 40^{\circ} 9^{\prime} 59^{\prime \prime} \mathrm{W}, 75$

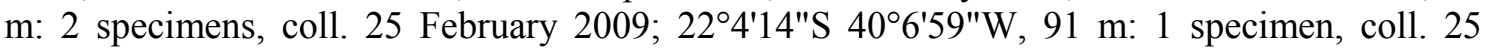
February 2009. Project 'BioPol-NE': State of Paraíba: Baía da Traição, Praia doFarol (06\%41'S $34^{\circ} 55^{\prime} \mathrm{W}$ ), intertidal: 6 specimens ), coll. 09 August 2010. Rio Tinto, Barra de Mamanguape $\left(06^{\circ} 45^{\prime} \mathrm{S} 34^{\circ} 55^{\prime} \mathrm{W}\right)$, intertidal: 2 specimens, coll. 02 February 2010. João Pessoa, Cabo Branco $\left(07^{\circ} 08^{\prime} \mathrm{S} 34^{\circ} 47^{\prime} \mathrm{W}\right)$, intertidal: 1 specimen (MZUSP 2078), coll. 02 February 2010. State of Pernambuco, Itamaracá, Recifes de Itamaracá, (743.944'S 3449.200'W), $1 \mathrm{~m}: 25$ specimens (MZUSP 2080), coll. 15 December 2012.

Description. Body thin, elongated, longest specimens ca. $5.6 \mathrm{~mm}$ long and $0.17 \mathrm{~mm}$ wide, with up to 32 chaetigers. Palps triangular, distally rounded, almost totally fused, with conspicuous line of fusion and distal notch (Fig. 7A). Prostomium pentagonal, slightly shorter than palps (Figs 7A, 8A), with two pairs of eyes in trapezoidal arrangement, eyespots absent; antennae in transverse row, inserted close to each other; median antenna inserted between anterior pair of eyes, elongated, reaching beyond tip of palps, abruptly tapering distally (Fig. 7A); lateral antennae ovate (Figs 7A, 8A). Ciliated nuchal organs placed dorsolaterally between prostomium and peristomium, close to peristomial cirri, visible only under SEM (Fig. 8A-C). Peristomium shorter than following chaetigers, sometimes covering posterior part of prostomium, including posterior pair of eyes; peristomial cirri similar to lateral antennae but smaller (Fig. 7A). Dorsal cirri ovate, slightly larger than peristomial cirri, present on all chaetigers (Fig. 7A, 8B).Ventral cirri similar to dorsal cirri but smaller, about $2 / 3$ as long as parapodial lobes (Fig. 8K). Parapodial lobes conical; anterior parapodia with 1-2 spiniger-like chaetae and 8-10 falcigers each (Fig. 8F), midbody parapodia with single spiniger-like chaeta and three falcigers each (Fig. 8K), posterior parapodia with single spiniger-like chaeta and two falcigers each; shafts of spiniger-like chaetae subdistally spinulated; blades of spiniger-like chaetae unidentate, with fine marginal spines, spines close to base of blade longer, diminishing in length towards tip; blades $25-12 \mu \mathrm{m}$ long on anterior body, $25-15 \mu \mathrm{m}$ on midbody, and 8-12 
$\mu \mathrm{m}$ on posterior body (Figs 7D, H, M, 8D); shafts of falcigers on chaetigers 1-5 modified, with large, pointed, oblique tip, reaching half length of blades (Figs $7 \mathrm{E}, 8 \mathrm{~F}-\mathrm{H}$ ); from chaetiger 6 onwards shafts subdistally inflated, spinulated, with acute tip (Figs 7I, N, 8I-L); blades of falcigers on chaetigers 1-5 bidentate, subdistal tooth long, pronounced, about as long as blade, distal tooth thin, shorter, spinulation on cutting edge inconspicuous (Figs 7E, 8F-H); from chaetiger 6 onwards blades spinulated, subdistal tooth distinctly shorter than on anteriormost chaetigers, but longer than distal tooth (Figs 7I, N, 8I-K); blades 9-10 $\mu \mathrm{m}$ long on anterior parapodia, ca. $7 \mu \mathrm{m}$ long on midbody and $5 \mu \mathrm{m}$ long on posterior body chaetigers. Dorsal simple chaetae present on all chaetigers, subdistally spinulated, with rounded tip (Figs 7C, G, K, 8I, L), thicker posteriorwards; ventral simple chaetae present only on posterior chaetigers, sigmoid, bidentate, with subdistal tooth larger than distal tooth (Figs 7L, 8L). Anterior parapodia with up to two aciculae each, one straight, with acute tip, second slightly bent subdistally, with inflated, rounded tip (Fig. 7B); midbody and posterior chaetigers with single acicula each, of the second type, stouter posteriorwards (Fig. 7F, J). Pygidium with thin, elongate pair of anal cirri (Fig. 8M). Pharynx through 3.5-5 segments; tooth set slightly back from anterior border (Fig. 7A); anterior margin of pharynx smooth, without papillae, surrounded by fringe of cilia (Fig. 8E); proventricle extending for 5-7 chaetigers, with ca. 29 rows of muscle-cells.

Remarks. Exogone rolani was described based on specimens from Cuba and is characterized by having a median antenna longer than the lateral ones and longer than the prostomium and peristomium together, dorsal cirri present on all chaetigers, shafts of spinigerlike chaetae on chaetigers 1 and 2 without a triangular process, and falcigers of anteriormost chaetigers with a subdistal tooth distinctly longer than in the other species of this genus. This latter character is found only in E. rolani and is the most diagnostic feature to distinguish this species from the others in the genus.

Exogone arenosa, E. dispar, E. gigas sp. n. and E. lourei are the other species of Exogone with a median antennae longer than the lateral ones that occur off the Brazilian coast. All these species differ from E. rolani by having bidentate blades of falcigers with a subdistal tooth that is not remarkably longer than the distal one, even on anteriormost chaetigers. Moreover, E. arenosa, E. gigas sp. n., and E. lourei have a triangular process on the shafts of the spiniger-like chaetae of chaetiger 2 that is lacking in $E$. rolani.

Brazilian specimens match the description based on Cuban material (San Martín 1991), except for having longer palps and a longer proventricle, the latter extending through 5-7 chaetigers, with 27-29 rows of muscle cells, while Cuban specimens have a proventricle extending for 3-5 segments, with up to 25 muscle cells row. Future molecular studies may reveal if this is one more complex of sibling species.

Type locality. Cuba, Archipelago de los Canarreos (Atlantic Ocean).

Distribution. Atlantic Ocean: USA (East coast), Cuba, Brazil (Paraíba, Rio de Janeiro). From the intertidal zone to ca. $91 \mathrm{~m}$ deep.

\title{
Exogone dispar (Webster, 1879)
}

\author{
(Figures 9-11)
}

Paedophyllax dispar Webster, 1879: 23, pl. 4, fig. 49, pl. 5, figs 50-55

Exogone dispar. Westheide 1974b: 298-301, figs 48-49; Perkins 1981: 1090-1091; Uebelacker 1984: 30-43, fig. 30-35-30-36; Campoy 1982: 290, pl. 21; San Martín 1984: 221, pl. 52.

Exogone (Exogone) dispar. San Martín 1991: 729; 2003: 274-276, figs 149-150; 2005: 137138, figs 81F, 85; Ruíz-Ramírez \& Salazar-Vallejo 2001: 127, fig. 3 (45-54); Fukuda 2010: 126, fig. 35 .

Material examined. Project 'REVIZEE': State of Rio de Janeiro: $21^{\circ} 51^{\prime} \mathrm{S} 40^{\circ} 07^{\prime} \mathrm{W}, 110 \mathrm{~m}: 2$

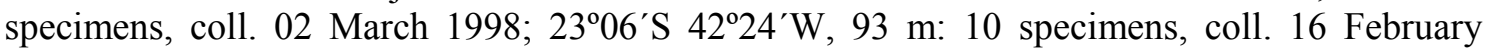
1998 ; $23^{\circ} 20^{\prime} \mathrm{S} 41^{\circ} 22^{\prime} \mathrm{W}, 110 \mathrm{~m}$ : 12 specimens, coll. 28 February $1998 ; 23^{\circ} 26^{\prime} \mathrm{S} 41^{\circ} 15^{\prime} \mathrm{W}, 145$ 


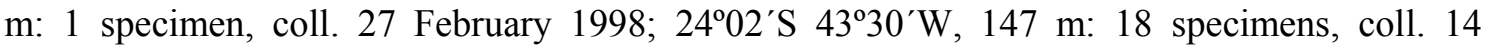
February 1998. State of São Paulo: $24^{\circ} 07^{\prime} \mathrm{S} 45^{\circ} 51^{\prime} \mathrm{W}, 147 \mathrm{~m}$ : 70 specimens, coll. 09 January

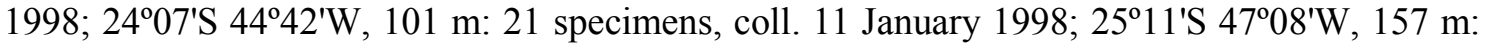

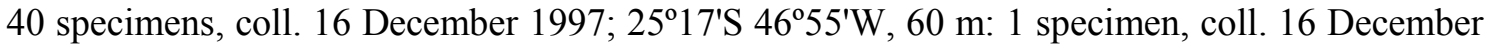

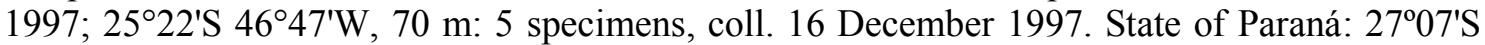
$47^{\circ} 44^{\prime} \mathrm{W}, 102 \mathrm{~m}$ : 1 specimen, coll. 13 March 1998. State of Santa Catarina: $28^{\circ} 41^{\prime} \mathrm{S} 48^{\circ} 18^{\prime} \mathrm{W}$, 104 m: 1 specimen, coll. 22.Mar.1998. Project 'BIOTA': State of São Paulo: Ubatuba,

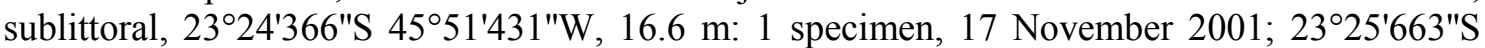

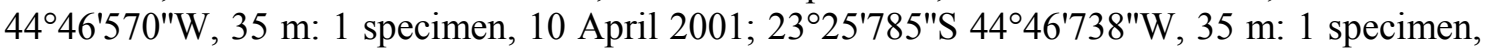

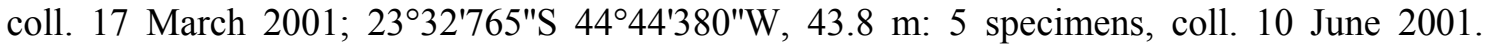
Caraguatatuba, Praia de Martim de Sá $\left(23^{\circ} 37^{\prime} 34^{\prime \prime S} 45^{\circ} 22^{\prime} 31^{\prime \prime W}\right)$, on rocky shore, intertidal: 1 specimen, coll. 13 March 2001; on Dyctiota sp.: 1 specimen, coll. 16 March 2001. São Sebastião, sublittoral, 234' $844^{\prime \prime S} 45^{\circ} 02^{\prime} 451^{\prime \prime W}, 45$ m: 2 specimens, coll. 13 February 2001; $23^{\circ} 56^{\prime} 373^{\prime \prime S} 45^{\circ} 27^{\prime} 080^{\prime \prime} \mathrm{W}, 44.6 \mathrm{~m}: 4$ specimens, coll. 15 December 2001; 2356 $497^{\prime \prime} \mathrm{S}$ 45²8'339"W, $45.1 \mathrm{~m}: 2$ specimens, coll. 16 May 2001. Project 'Poly-Phytal': State of Espírito Santo: Vitória, Praia da Direita, Ilha do Boi $\left(20^{\circ} 18^{\prime} \mathrm{S} 40^{\circ} 17^{\prime} \mathrm{W}\right)$, rocky shore, intertidal, on Arthrocardia gardnerii: 2 specimens (MZUSP 1321), coll. 26 May 2005; 2 specimens (MZUSP 1322), coll. 01 November 2005; on Centroceras clavulatum: 2 specimens (MZUSP 1320), coll. 01 November 2005; on Hypnea musciformis: 1 specimen (MZUSP 1323), coll. 01 November 2005. Project 'HABITATS' All collections off state of Rio de Janeiro (Campos Basin), Van Veen grab; $21^{\circ} 22^{\prime} 58^{\prime \prime S} 40^{\circ} 19^{\prime} 41^{\prime \prime} \mathrm{W}, 53 \mathrm{~m}: 2$ specimens, coll. 05 March 2009, 3 specimens, coll. 06 March 2009, 4 specimens, coll. 21 July 2009; 21 ${ }^{\circ} 23^{\prime} 2^{\prime \prime} \mathrm{S} 40^{\circ} 15^{\prime} 9^{\prime \prime} \mathrm{W}, 145 \mathrm{~m}: 1$ specimen,

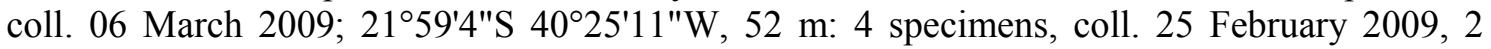
specimens, coll. 06 July 2009; 22 ${ }^{\circ} 1^{\prime} 9^{\prime \prime} \mathrm{S} 40^{\circ} 31^{\prime} 55^{\prime \prime} \mathrm{W}, 49 \mathrm{~m}$ : 2 specimens, coll. 24 July 2009; $22^{\circ} 3^{\prime} 41^{\prime \prime S} 40^{\circ} 24^{\prime} 9^{\prime \prime} \mathrm{W}, 55 \mathrm{~m}: 27$ specimens, coll. 25 February 2009, 1 specimen, coll. 06 July

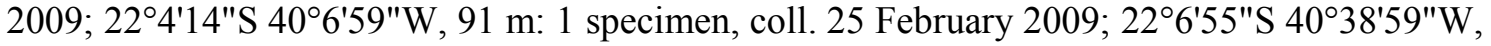
53 m: 42 specimens, coll. 26 February 2009, 12 specimens, coll. 17 July 2009; 22 ${ }^{\circ} 43^{\prime \prime} \mathrm{S}$

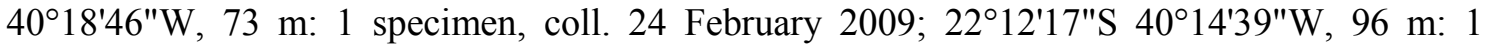
specimen, coll. 15 March 2009, 2 specimens, coll. 24 July 2009; 22 ${ }^{\circ} 12^{\prime} 53^{\prime \prime S ~ 40} 51^{\prime} 13^{\prime \prime W}, 52 \mathrm{~m}$ : 23 specimens, coll. 26 February 2009, 2 specimens, coll. 17 July 2009; 22 $17^{\prime} 42^{\prime \prime} \mathrm{S} 40^{\circ} 26^{\prime} 59^{\prime \prime} \mathrm{W}$,

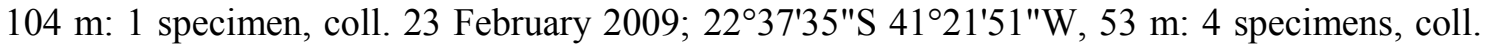
27 February 2009; 22 $41^{\prime} 46^{\prime \prime} \mathrm{S} 41^{\circ} 53^{\prime} 45^{\prime \prime} \mathrm{W}, 29 \mathrm{~m}$ : 1 specimen, coll. 16 March 2009, 1 specimen, coll. 12 July $2009 ; 22^{\circ} 45^{\prime} 49^{\prime \prime} \mathrm{S} 41^{\circ} 45^{\prime} 33^{\prime \prime} \mathrm{W}, 53 \mathrm{~m}: 3$ specimens, coll. 16 July 2009;

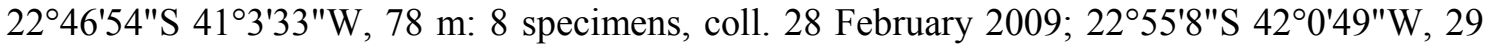
m: 6 specimens, coll. 28 February 2009, 5 specimens, coll. 15 July 2009; 22 59'47"S

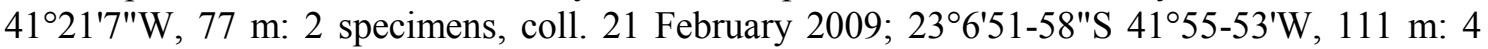
specimens, coll. 01 March 2009, 9 specimens, coll. 16 March 2009. Project 'BioPol-NE': State of Paraíba: Mataraca, Barra de Camaratuba $\left(06^{\circ} 36^{\prime} \mathrm{S} 34^{\circ} 57^{\prime} \mathrm{W}\right)$, intertidal: 2 specimens (MZUSP 2095), coll. 12 August 2010. Baía da Traição, Praia do Farol (06²41'S $\left.34^{\circ} 55^{\prime} \mathrm{W}\right)$, intertidal: 6 specimens (MZUSP 2086), coll. 09 August 2010. Rio Tinto, Barra de Mamanguape (06 $45^{\prime}$ S 34 $55^{\prime} \mathrm{W}$ ), intertidal: 2 specimens (MZUSP 1327), coll. 11 August 2010. Cabedelo, Píer de

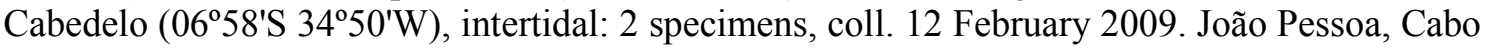
Branco $\left(07^{\circ} 08^{\prime} \mathrm{S} 34^{\circ} 47^{\prime} \mathrm{W}\right)$, intertidal: 4 specimens (MZUSP 1326), coll. 09 February 2009, 7 specimens (MZUSP 1328), coll. 02 February 2010; in Tedania sp.: 1 specimen, coll 09 February 2009; Recife do Picãozinho $\left(07^{\circ} 4.243^{\prime} \mathrm{S} 34^{\circ} 49.291^{\prime} \mathrm{W}\right)$, intertidal: 1 specimen (MZUSP 1325), coll. 15 September 2009. Conde, Praia de Carapibus $\left(07^{\circ} 17^{\prime} \mathrm{S} 34^{\circ} 48^{\prime} \mathrm{W}\right)$, intertidal, in rhodolithes: 1 specimen (MZUSP 2092); on algae: 3 specimens coll. 09 February 2009; Praia de Coqueirinho $\left(07^{\circ} 18^{\prime} \mathrm{S} 34^{\circ} 47^{\prime} \mathrm{W}\right.$ ), intertidal: 2 specimen (MZUSP 2087), coll. 28 August 2011; Praia de Jacumã $\left(07^{\circ} 14^{\prime} \mathrm{S} 34^{\circ} 47^{\prime} \mathrm{W}\right)$, intertidal: 6 specimens (MZUSP 2094), coll. 29 January 2010; Praia de Tabatinga $\left(07^{\circ} 19.297\right.$ 'S $\left.34^{\circ} 47.862^{\prime} \mathrm{W}\right)$, intertidal: 2 specimens (MZUSP 2088), coll. 17 September 2012, 2 specimens (MZUSP 2093), coll. 01 September

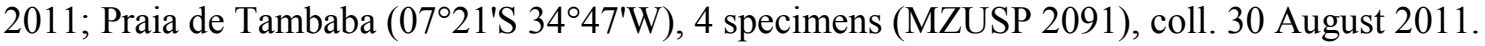
Pitimbú, Farol de Pitimbú ( $\left.7^{\circ} 28.362^{\prime} \mathrm{S} 34^{\circ} 47^{\prime} \mathrm{W}\right), 1 \mathrm{~m}$ : 2 specimens (MZUSP 2090), coll. 18 September 2012. State of Pernambuco, Itamaracá, Pontas de Pedra $\left(7^{\circ} 37^{\prime} \mathrm{S} 34^{\circ} 48^{\prime} \mathrm{W}\right), 16$ 
specimens (MZUSP 2085), coll. 13 December 2012; Recifes de Itamaracá, (7²43.944'S 3449.200'W), 1 m: 2 specimens (MZUSP 2089), coll. 15 December 2012.

Description. Body thin, elongated, longest specimens ca. $5.6 \mathrm{~mm}$ long and $0.2 \mathrm{~mm}$ wide, with up to 45 chaetigers. Palps triangular, distally rounded (Figs 9A, 10A-C), almost totally fused, with conspicuous line of fusion and distal notch (Fig. 9A). Prostomium pentagonal to ovate, slightly shorter than palps, with two pairs of eyes in trapezoidal arrangement (Fig. 9A); anterior eyespots absent; antennae inserted close to each other in nearly transverse row, median antenna inserted above and between anterior pair of eyes, elongated, shorter than palps, subdistally inflated with tapered tip (Figs 9A, 10A); lateral antennae inserted slightly anterior to median antenna, ovate to papilliform, ca. 1/4-1/2 length of median antenna (Figs 9A, 10A). Ciliated nuchal organs located dorsolaterally between prostomium and peristomium. Peristomium similar in length to following chaetigers, sometimes covering posterior part of prostomium, including posterior pair of eyes; peristomial cirri similar to lateral antennae but smaller (Figs 9A, 10A, B). Dorsal cirri ovate, slightly larger than peristomial cirri, becoming progressively longer, present on all chaetigers (Figs 9A, 10A). Ventral cirri similar to dorsal cirri but shorter, ca. 2/3 length of parapodial lobes (Fig. 10B). Parapodial lobes blunt (Fig. 10D); anterior parapodia with 1-3 spiniger-like chaetae and 6-8 falcigers each, middle parapodia with single spiniger-like chaeta and 3-4 falcigers each (Fig. 11D), posterior parapodia with single spiniger-like chaeta and 2-3 falcigers each (Fig. 11F). Shafts of anterior spinigerlike chaetae with conspicuous spines, posterior spines shorter (Figs 9B, 11C); shafts of spinigerlike chaetae in midbody with distal longitudinal lines forming grooves (Figs 9C-D, 11D); all blades with short spines (Figs 9B, 11C), anterior blades 22-45 $\mu \mathrm{m}$ long, 25-50 $\mu \mathrm{m}$ in midbody, and $15-32 \mu \mathrm{m}$ in posterior. Shafts of anterior falcigers subdistally enlarged and spinulated (Figs 9B, 11A-B), shafts of posterior falcigers also subdistally enlarged, but with few spines, shafts of falcigers in mid- and posterior body with distal longitudinal lines forming grooves (Figs 9CD, 11D-E);. Blades of falcigers spinulated and bidentate, subdistal tooth larger (Figs 9B-D, $11 \mathrm{~A}-\mathrm{F}$ ); blades with dorsoventral gradation in length, 3-10 $\mu \mathrm{m}$ long in anterior, 3-8 $\mu \mathrm{m}$ long midbody, and $2-5 \mu \mathrm{m}$ long in posterior. Dorsal simple chaetae present on all chaetigers, sigmoid, subdistaly spinulated, with acute tip, stouter posteriorwards (Figs 9E-F, 11D, F, H); ventral simple chaetae present only on posterior chaetigers, sigmoid, bidentate, subdistal tooth larger (Figs 9G, 11G). Anterior parapodia with up to two aciculae each, one straight, with acute tip, other slightly bent subdistally, with inflated, rounded tip (Fig. 9H); middle and posterior parapodia with single acicula each, of the second type, stouter posteriorwards. Ciliated pygidium with a pair of thin, elongate anal cirri (Fig. 10E-F). Pharynx through 4-5 segments, tooth at anterior border (Figs 9A, 10B-C); anterior margin of pharynx surrounded by papillae and fringe of cilia (Fig. 10B-C); proventricle extending for 2-3 chaetigers (Fig. 9A), with ca. 22 rows of muscle-cells.

Remarks. Exogone dispar is similar to the sympatric species E. breviantennata and E. africana but differs from both in having an elongated median antenna. Exogone africana and $E$. rolani also share some characters with E. dispar (see 'Remarks' of the former species). Exogone arenosa, E. gigas sp. n. and E. lourei, which also occur along off the Brazillian coast, all have a triangular process on the shafts of the spiniger-like chaetae of chaetiger 2, which is absent in $E$. dispar. More detailed comparisons between E. dispar and other species in this genus are provided by Perkins (1981) and San Martín (1991, 2003, 2005), among several others.

Brazilian specimens of $E$. dispar differ from Australian ones by having longer blades on the spiniger-like chaetae, 22-50 $\mu \mathrm{m}$ vs. 28-29 $\mu \mathrm{m}$, as in Australian material (San Martín 2005).

Type locality. Northampton, Virginia (USA, Atlantic Ocean).

Distribution. Atlantic Ocean: USA (New England, North Carolina, Virginia, and Florida), Mexico, Panamá, Brazil (Paraíba, Bahia: Abrolhos, Espírito Santo, São Paulo), South Africa; North Sea: Skagerrak; Mediterranean Sea: Iberian Peninsula, Italy; Caribbean Sea: Cuba, Trinidad y Tobag . Pacific Ocean: Mexico (Baja California), Galápagos Islands, China, Japan. Indian Ocean: Australia (Western Australia). From the intertidal zone to ca. $157 \mathrm{~m}$ deep. 


\section{Exogone arenosa Perkins, 1981}

(Figures 12-13)

Exogone arenosa Perkins, 1981: 1094-1097, figs 5g-j, 6; Lana 1984: 66-67, figs 55-56; Sovierzoski 1999: 61-62, fig. 11.

? Exogone dispar. Temperini 1981: 20-21. San Martín \& Bone 2001.

Exogone (Exogone) arenosa. Fukuda 2010: 118-121, fig. 32.

Material examined. Project 'REVIZEE': State of Rio de Janeiro: $23^{\circ} 08.07$ 'S $41^{\circ} 00.84^{\prime} \mathrm{W}, 110$ m: 1 specimen, coll. 28 February 1998; $23^{\circ} 20.0^{\prime} \mathrm{S} 41^{\circ} 22.0^{\prime} \mathrm{W}, 110 \mathrm{~m}: 5$ specimens, coll. 28 February 1998. Project 'BIOTA': State of São Paulo: São Sebastião, sublittoral, 2356'373"S 45 27'080"W, $44.6 \mathrm{~m}: 3$ specimens, coll. 15 December 2001. Project 'HABITATS': All collections off state of Rio de Janeiro (Campos Basin), Van Veen grab; 21 $22^{\prime} 58^{\prime \prime S}$ 40 $19^{\prime} 41 " \mathrm{~W}, 53 \mathrm{~m}$ : 7 specimens, coll. 05 March 2009, 1 specimen, coll. 21 July 2009;

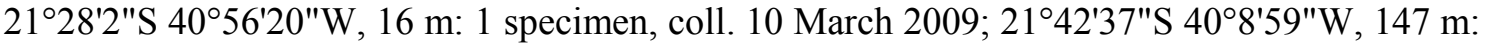

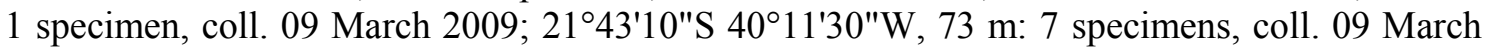

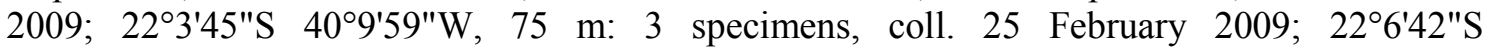

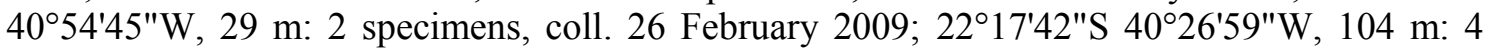
specimens, coll. 23 February 2009; 22 $19^{\prime} 32.134^{\prime \prime S} 40^{\circ} 37^{\prime} 19.109^{\prime \prime} \mathrm{W}, 75 \mathrm{~m}: 1$ specimen

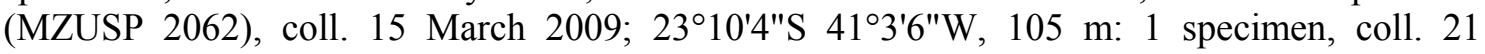
February 2009; $23^{\circ} 11^{\prime} 30^{\prime \prime S} 41^{\circ} 0^{\prime} 48^{\prime \prime} \mathrm{W}, 150 \mathrm{~m}: 2$ specimens, coll. 21 February 2009. Project 'BioPol-NE': State of Paraíba: Conde, Praia de Tabatinga $\left(07^{\circ} 19^{\prime} \mathrm{S} 34^{\circ} 47^{\prime} \mathrm{W}\right)$, intertidal: 1

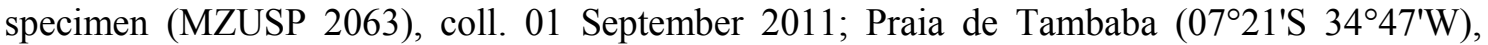
intertidal: 1 specimen (MZUSP 2064), coll. 30 August 2011. João Pessoa, Praia de Cabo Branco $\left(07^{\circ} 08^{\prime} \mathrm{S} 34^{\circ} 47^{\prime} \mathrm{W}\right)$, intertidal: 1 specimen (MZUSP 1335), coll. 09 February 2009, 5 specimens (MZUSP 1336), coll. 02 February 2010. State of Pernambuco, Itamaracá, Recifes de Itamaracá (743.944'S 3449.200'W), 1 m: 3 specimens (MZUSP 2065), coll. 15 December 2012.

Additional material examined. Exogone arenosa. USA, Florida, St. Lucile County, Hutchinson Island $\left(27^{\circ} 22.08^{\prime} \mathrm{N} 80^{\circ} 13.48^{\prime} \mathrm{W}\right), 10 \mathrm{~m}$ : paratype (ZMH P-16389), leg. \& det. T. Perkins.

Description. Body thin, elongated, longest specimens ca. $7.7 \mathrm{~mm}$ long and $0.7 \mathrm{~mm}$ wide, with up to 48 chaetigers. Palps triangular, distally rounded (Figs 12A, 13A), almost totally fused, with conspicuous line of fusion and distal notch (Fig. 13A). Prostomium pentagonal to ovate, about half length of palps, with two pairs of eyes in trapezoidal arrangement, anterior eyespots absent; median antenna inserted between anterior pair of eyes, elongated, usually reaching tip of palps or slightly shorter, subdistally inflated, with thin tip (Fig. 13A); lateral antennae digitiform, inserted slightly anterior to median antenna, ovate to papilliform, ca. 1/4 length of median antenna (Fig. 13A). Peristomium shorter than following chaetigers; peristomial cirri similar to lateral antennae but smaller, about half length of lateral antennae (Fig. 13A). Dorsal cirri ovate, slightly larger than peristomial cirri, present on all chaetigers (Fig. 13A, D).Ventral cirri similar to dorsal cirri but smaller, ca. $3 / 4$ length of parapodial lobes. Parapodial lobes conical (Fig. 13A, D); anterior parapodia with 1-2 spiniger-like chaetae and 48 falcigers each, midbody with single spiniger-like chaeta and 4-8 falcigers each, posterior parapodia with single spiniger-like chaeta and 2-3 falcigers each. Spiniger-like chaetae of chaetiger 2 with thick shafts subdistally provided with triangular process (Figs 12D, 13E-F); shafts of remaining parapodia enlarged, subdistally spinulated (Fig. 12F, I, N); blades of spiniger-like chaetae spinulated, with short spines, blades distally bifid, with minute, inconspicuous teeth (Fig. 12D, F, I, N); blades ca. 25-60 $\mu \mathrm{m}$ long in anterior parapodia, 25-56 $\mu \mathrm{m}$ long in midbody and 15-25 $\mu \mathrm{m}$ long in posterior. Shafts of falcigers subdistally enlarged and spinulated; blades of anterior falcigers more spinulated, spinulation inconspicuous in posterior; blades bidentate, subdistal tooth larger (Figs 12E, J, O, 13E-G, I),7-15 $\mu \mathrm{m}$ long in anterior, 5-10 $\mu \mathrm{m}$ in midbody and 3-7 $\mu \mathrm{m}$ long in posterior parapodia. Dorsal simple chaetae usually present on all chaetigers, sigmoid, subdistally spinulated, with acute tip (Figs 12C, H, L, $13 \mathrm{E}, \mathrm{G}, \mathrm{J}-\mathrm{K})$, becoming stouter in posterior. Ventral simple chaetae present only on posterior 
chaetigers, sigmoid, bidentate, subdistal tooth larger (Figs 12M, 13L). Anterior parapodia with up to three aciculae each, two straight with acute tip, remaining one slightly bent subdistally, with inflated tip (Fig. 12B); each midbody parapodium with two aciculae, one of each type (Fig. $12 \mathrm{G}$ ), posterior parapodia with one acicula each, of the second type (Fig. 12K). Pygidium with thin, elongate pair of anal cirri. Pharynx through seven segments; tooth at anterior border; anterior margin of pharynx surrounded by 10 papillae with fringe of cilia (Fig. 13B-C); proventricle extending for 3.5-7 chaetigers, with 27-36 rows of muscle cells.

Remarks. Exogone arenosa is similar to E. longicornis Westheide, 1974 and E. lourei by having the median antenna longer than the lateral ones, dorsal cirri present on all chaetigers, and the triangular process on the shafts of spiniger-like chaetae of chaetiger 2.

Exogone longicornis differs from E. arenosa by having triangular processes on the shafts of spiniger-like chaetae of chaetigers 1 and 2, and of different morphology, with larger and stouter tips; spiniger-like chaetae and falcigers with shorter blades, blades of spiniger-like chaetae ca. $26 \mu \mathrm{m}$ long on anterior and midbody parapodia and $20 \mu \mathrm{m}$ on posterior chaetigers, vs. 25-60 $\mu \mathrm{m}, 25-56 \mu \mathrm{m}$, and 15-25 $\mu \mathrm{m}$ on anterior, mid- and posterior chaetigers of $E$. arenosa, respectively; falciger blades $4-5 \mu \mathrm{m}$ long in $E$. longicornis, while falcigers of $E$. arenosa are 7-15 $\mu \mathrm{m}, 5-10 \mu \mathrm{m}$ and 3-7 $\mu \mathrm{m}$ long on anterior, mid- and posterior body chaetigers (San Martín 2005), respectively. Exogone lourei also differs from E. arenosa by having triangular processes on the shafts of the spiniger-like chaetae of chaetigers 1 and 2, and a proventricle with ca. 23 rows of muscle cells (27-36 in E. arenosa) (San Martín 2005). Exogone arenosa shares some characters with E. rolani and E. dispar, as discussed above (see 'Remarks' for these species).

The Brazilian specimens examined match the original description (Perkins 1981), except that the pronounced spine on the dorsal simple chaetae carefully described by Perkins (1981) was not visible in our material, even under SEM.

Type locality. USA, Florida, Hutchingson Island (Atlantic Ocean).

Distribution. Atlantic Ocean: USA (Florida), Brazil (Paraíba, São Paulo, Paraná); Caribbean Sea: Cuba, Panamá, and Venezuela. From the intertidal zone to ca. $150 \mathrm{~m}$.

\section{Exogone gigas sp. $n$.}

(Figures 14-15, Table 1)

Material examined. Type series. (Morphological features of specimens from type-series provided in Table 1). Holotype: Project 'HABITATS', State of Rio de Janeiro, $22^{\circ} 11^{\prime} 56^{\prime \prime S}$ 4032'15"W, $68 \mathrm{~m}$, soft bottom (MZUSP 1271), coll. 15 March 2009. Paratypes: Project 'HABITATS', State of Rio de Janeiro, 22 $2^{\circ} 11^{\prime} 56^{\prime S} \mathrm{~S} 40^{\circ} 32^{\prime} 15^{\prime \prime} \mathrm{W}, 68 \mathrm{~m}$, unconsolidated substrate, 15 March 2009. Paratype 1 (MZUSP 1272), paratype 2 (MZUSP 1273), paratype 3 (MZUSP 1274), paratype 4 (ZUEC 13534), paratype 5 (ZUEC 13533), paratype 6 (ZUEC 13532), paratype 7 (MZUSP 2083), paratype 8 (MZUSP 2084), paratype 9 (MNCN 16.01/14629), paratype 10 (MNCN 16.01/14630). "Project 'HABITATS': All collections off the State of Rio de Janeiro, Campos Basin, Van Veen grab; 21 ${ }^{\circ} 9^{\prime} 9.813^{\prime \prime S} 40^{\circ} 16^{\prime} 7.837^{\prime \prime} \mathrm{W}, 103 \mathrm{~m}$ : 2 specimens

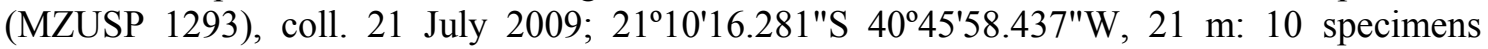
(MZUSP 1299), coll. 22 July 2009; 21 $11^{\circ} 0.342 " \mathrm{~S} 40^{\circ} 28^{\prime} 28.313^{\prime \prime} \mathrm{W}, 26 \mathrm{~m}: 9$ specimens

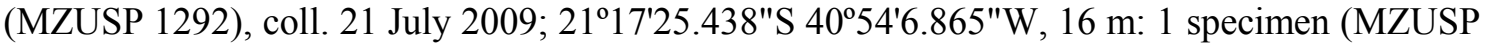

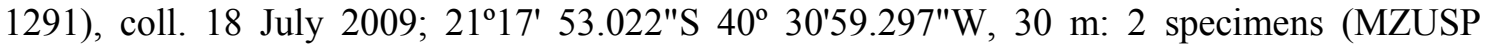
1303), coll. 22 July 2009; 2121'21.471"S 40 52'9.225"W, 20 m: 2 specimens (MZUSP 1295), coll. 23 July 2009; $21^{\circ} 24^{\prime} 43.527^{\prime \prime S ~} 40^{\circ} 25^{\prime} 20.695^{\prime \prime W}, 32 \mathrm{~m}: 1$ specimen (MZUSP 1304), coll. 20 July 2009; 21 $28^{\prime} 2.200^{\prime \prime S} 40^{\circ} 56^{\prime} 21.516^{\prime \prime} \mathrm{W}, 17 \mathrm{~m}: 7$ specimens (MZUSP 1294), coll. 20 July

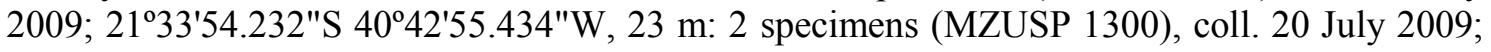
$21^{\circ} 34^{\prime} 13.655^{\prime \prime S} 40^{\circ} 25^{\prime} 31.571 " \mathrm{~W}, 28 \mathrm{~m}: 12$ specimens (MZUSP 1305), coll. 23 July 2009; $21^{\circ} 40^{\prime 2} 23.730^{\prime \prime S} 40^{\circ} 58^{\prime} 23.765^{\prime \prime} \mathrm{W}, 18 \mathrm{~m}: 3$ specimens (MZUSP 1296), coll. 19 July 2009; $21^{\circ} 47^{\prime} 15.563 " \mathrm{~S} 40^{\circ} 57^{\prime} 34.882^{\prime \prime} \mathrm{W}, 16 \mathrm{~m}: 2$ specimens (MZUSP 1297), coll. 18 July 2009; 21 ${ }^{\circ} 50^{\prime}$ 21.049"S 40 31'37.376"W, $28 \mathrm{~m}: 1$ specimen (MZUSP 1302), coll. 23 July 2009; 
21 $1^{\circ} 57^{\prime} 16.013 " \mathrm{~S} 40^{\circ} 37^{\prime} 59.948^{\prime \prime} \mathrm{W}, 27 \mathrm{~m}: 9$ specimens (MZUSP 1283), coll. 26 February 2009; $22^{\circ} 17.705^{\prime \prime S ~ 4031 ' 53.782 " W, ~} 49 \mathrm{~m}: 1$ specimen (MZUSP 1301), coll. 24 July 2009; $22^{\circ} 3^{\prime} 41.155^{\prime \prime S} 40^{\circ} 24^{\prime} 9.910^{\prime \prime} \mathrm{W}, 56 \mathrm{~m}: 42$ specimens (MZUSP 1284), coll. 25 February 2009; $22^{\circ} 6^{\prime} 40.471 " \mathrm{~S}$ 40 $54^{\prime} 46.350^{\prime \prime} \mathrm{W}, 30 \mathrm{~m}$ : 9 specimens (MZUSP 1288), coll. 17 July 2009; $22^{\circ} 6^{\prime} 42.052^{\prime \prime S ~ 40} 54^{\prime} 44.607 " \mathrm{~W}, 29 \mathrm{~m}: 34$ specimens (MZUSP 1278), coll. 26 February 2009; $22^{\circ} 6^{\prime} 55.679 " \mathrm{~S} 40^{\circ} 38^{\prime} 58.325^{\prime \prime} \mathrm{W}, 53 \mathrm{~m}$ : 93 specimens (MZUSP 1282), coll. 26 February 2009; $22^{\circ} 6^{\prime} 55.873 " \mathrm{~S} 40^{\circ} 38^{\prime} 59.945^{\prime \prime} \mathrm{W}, 53 \mathrm{~m}$ : 20 specimens (MZUSP 1290), coll. 17 July 2009; $22^{\circ} 7{ }^{\prime} 43.309^{\prime \prime S ~} 40^{\circ} 18^{\prime} 46.483 " \mathrm{~W}, 73 \mathrm{~m}: 3$ specimens (MZUSP 1285), coll. 24 February 2009; $22^{\circ} 11^{\prime} 30.609 " \mathrm{~S} 40^{\circ} 55^{\prime} 24.468^{\prime \prime} \mathrm{W}, 44 \mathrm{~m}: 2$ specimens (MZUSP 1298), coll. 17 July 2009; $22^{\circ} 12^{\prime} 37.087 " \mathrm{~S} 40^{\circ} 13^{\prime} 18.731 \mathrm{lW}, 99 \mathrm{~m}: 2$ specimens (MZUSP 1286), coll. 24 February 2009; $22^{\circ} 12^{\prime} 52.897 " \mathrm{~S} 40^{\circ} 51^{\prime} 12.067 \mathrm{lW}, 52 \mathrm{~m}: 82$ specimens (MZUSP 1280), coll. 26 February 2009; $22^{\circ} 12^{\prime} 52.906 " \mathrm{~S} 40^{\circ} 51^{\prime} 13.559^{\prime \prime} \mathrm{W}, 52 \mathrm{~m}: 14$ specimens (MZUSP 1289), coll. 17 July 2009; $22^{\circ} 17^{\prime} 25.519 " \mathrm{~S} 40^{\circ} 6^{\prime} 36.262^{\prime \prime} \mathrm{W}, 143 \mathrm{~m}: 2$ specimens (MZUSP 1287), coll. 24 February 2009; $22^{\circ} 18^{\prime} 50.070 " \mathrm{~S} 41^{\circ} 21^{\prime} 35.068^{\prime \prime} \mathrm{W}, 28 \mathrm{~m}: 18$ specimens (MZUSP 1277), coll. 27 February 2009;

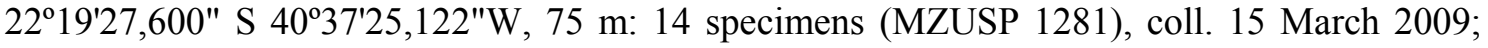

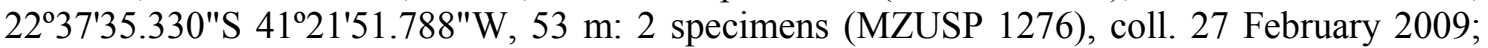
22 $2^{\circ} 2^{\prime} 1.951 " \mathrm{~S} 40^{\circ} 57^{\prime} 28.983 \mathrm{lW}, 92 \mathrm{~m}$ : 1 specimen (MZUSP 1279), coll. 22 February 2009; 2310'4.258"S 41'3'6.679"W, $105 \mathrm{~m}$ : 1 specimen (MZUSP 1275), coll. 21 February 2009. Project 'BioPol-NE': State of Paraíba: João Pessoa, Praia de Cabo Branco (06 57.761 'S 34 50.556'W), intertidal: 7 specimens (MZUSP 1346), coll. 02 February 2010. Conde, Praia de Tabatinga $\left(07^{\circ} 19.297^{\prime} \mathrm{S} 34^{\circ} 47.862^{\prime} \mathrm{W}\right)$, intertidal: 1 specimen (MZUSP 1347), coll. 01 September 2011.

Additional material examined. Exogone multisetosa. Peru, Lima- holotype (ZMH P15371), 2 paratypes (ZMH P-15372), coll. 22 June 1952, det. Friedrich, 1956.

Description. Body thin, elongated, 8-11 (10) $\mathrm{mm}$ long and $0.20-0.35(0.27) \mathrm{mm}$ wide, with up to 80 (78) chaetigers. Palps triangular, distally rounded, totally fused, with a conspicuous line of fusion and distal notch (Figs 14A, 15A). Prostomium ovate, shorter than palps, two pairs of eyes in trapezoidal arrangement; anterior eyespots absent; median antenna inserted between anterior pair of eyes, elongated, almost reaching tip of palps (Fig. 14A); lateral antennae small, digitiform, inserted slightly anterior to median antenna (Figs 14A, 15A). Ciliated nuchal organs dorsolateral between prostomium and peristomium (Fig. 15A, C). Peristomium shorter than following chaetigers; peristomial cirri ovate, similar to lateral antennae but smaller, about $2 / 3$ as long as lateral antennae (Fig. 14A). Dorsal cirri with shape similar to lateral antennae but slightly smaller, absent on chaetiger 2 . Ventral cirri inserted at bases of parapodia, shorter than parapodial lobes. Parapodial lobes conical; anterior parapodia with 1-3 (1-2) spiniger-like chaetae and 4-10 (6-9) falcigers each, midbody parapodia with 12 (1) spiniger-like chaetae and 2-4 (3-4) falcigers, posterior parapodia with single spiniger-like chaeta and 2-3 (2) falcigers each; spiniger-like chaetae of chaetiger 2 with thick shafts, subdistally provided with triangular process (Figs 14B, 15D-E); shafts of spiniger-like chaetae of remaining chaetigers without triangular process, subdistally spinulated (Figs 14C-E, 15F, I, L, P); blades of spiniger-like chaetae unidentate (Figs 14E, 15G, K) to indistinctly bifid (Fig. 14B-D), 30-50 (42-47) $\mu \mathrm{m}$ long in anterior, 22-45 (25-45) $\mu \mathrm{m}$ long in midbody, 17-35 (17$25)$ in posterior. Shafts of falcigers subdistally enlarged and spinulated; blades of falcigers spinulated and bidentate (Figs 14C-E, 15E-F, H-I, P), spinulation of blades and difference of size between teeth more evident on anterior parapodia; blades 6-11 (7-10) $\mu \mathrm{m}$ long in anterior parapodia, 4-9 (4-8) $\mu \mathrm{m}$ in midbody, and 3-6 (4-6) $\mu \mathrm{m}$ long in posterior. Dorsal simple chaetae usually beginning from chaetiger 6-11 (11), sigmoid, subdistally spinulated, with acute tip (Figs 14F, 15J), stouter in posterior (Fig. 14G). Ventral simple chaetae present only on posterior chaetigers, chaetae sigmoid, bidentate, subdistal tooth larger than distal tooth (Figs $14 \mathrm{H}, 15 \mathrm{M}, \mathrm{O})$. Anterior parapodia with up to three aciculae each, two slightly bent subdistally, with inflated, apparently hollow tip, third acicula distally bent at almost $90^{\circ}$ (Fig. 14I); from midbody onwards, single acicula per parapodium, of the first type (Fig. 14J). Pygidium semicircular with pair of thin, elongate anal cirri. Pharynx through 3.5-5.5 (5.5) segments, tooth at anterior border; anterior margin of pharynx surrounded by papillae and fringe of cilia (Fig. 
15B); proventricle extending for 3.5-5 (3.5) chaetigers, 44-55 (55) $\mu \mathrm{m}$ long, 11-18 (16) $\mu \mathrm{m}$ wide, with 25-27 (26) rows of muscle cells.

Remarks. This species is characterized by having a triangular process with minute spines on the shafts of the spiniger-like chaetae on chaetiger 2, a large median antenna, and by lacking dorsal cirri on chaetiger 2. Exogone lourei, E. rostrata, E. longicornis, E. multisetosa Friedrich, 1956 and E. arenosa are the species most similar to E. gigas sp. n., sharing with it the presence of a triangular process on the shafts of the spiniger-like chaetae in certain anterior chaetigers.

Exogone lourei differs from E. gigas sp. n. by having dorsal cirri on chaetiger 2, a triangular process on the shafts of spiniger-like chaetae on chaetiger 1 as well as chaetiger 2, a pharynx through 6-7 segments, and a proventricle extending for ca. 3 segments with 23 rows of muscle cells, while E. gigas sp. n. lacks dorsal cirri on chaetiger 2, has a triangular process on the shafts of spiniger-like chaetae only on chaetiger 2, a pharynx extending through 3.5-5.5 segments, and a proventricle through 3.5-5 segments, with 25-27 rows of muscle-cells.

Exogone rostrata is similar to E. gigas $\mathbf{s p}$. $\mathbf{n}$. by having median antenna longer than lateral ones, subdistal tooth of the falcigers larger than distal tooth, and pharynx through about 5 chaetigers. However, E. rostrata differs from E. gigas sp. n. by being a shorter species, with up to $7 \mathrm{~mm}$ and 47 chaetigers vs. $1-10 \mathrm{~mm}$ and 80 chaetiger as in E. gigas sp. n.. Furthermore, $E$. rostrata has dorsal cirri on chaetiger 2 ; spiniger-like chaetae with spinulated triangular process, on chaetiger 1 only, and shorter, distally bifid blades, ca. $20 \mu \mathrm{m}$ long; two aciculae per parapodium on anterior body; and proventricule shorter, through about 3 segments. On the other hand, E. gigas sp. n. has spiniger-like chaetae with smooth triangular process, on chaetiger 2 only, and longer, unidentate to indistinctly bifid blades, $17-50 \mu \mathrm{m}$ long; three aciculae per parapodium on anterior body; and proventricle through 3.5-5 segments.

Exogone longicornis also has dorsal cirri on chaetiger 2 and a triangular process is present on the shafts of spiniger-like chaetae of chaetigers 1 and 2 (San Martín 2005). In addition, E. longicornis has shorter blades on the spiniger-like chaetae throughout, $26 \mu \mathrm{m}, 26$ $\mu \mathrm{m}$, and $20 \mu \mathrm{m}$ long on anterior, mid- and posterior body chaetigers, respectively, and a proventricle with 33-38 rows of muscle cells. In contrast, E. gigas sp. n. has blades of spinigerlike chaetae 30-50 $\mu \mathrm{m}, 22-45 \mu \mathrm{m}$, and 17-35 $\mu \mathrm{m}$ long on anterior, mid- and posterior parapodia, and a proventricle with 25-27 rows of muscle-cells.

Exogone multisetosa is a smaller species, the holotype, with 41 chaetigers, was described from the Pacific Ocean (Lima, Peru) and can be differentiated from E. gigas sp. n. by having a shorter, square triangular process on spiniger-like chaetae of chaetiger 2, ventral simple chaetae with acute tip, and shorter proventricle, through 2.5-3segments. Exogone arenosa differs from E. gigas sp. n. by having dorsal cirri on chaetiger 2, distal teeth of dorsal simple chaetae relatively larger, pharynx through 7 segments, and proventricle with 27-36 rows of muscle cells.

Etymology. The epithet gigas is derived from Latin, meaning "giant", and refers to the length of this species, which is the longest known for this genus.

Distribution. Atlantic Ocean: Brazil (Rio de Janeiro and São Paulo). From the intertidal zone to ca. $143 \mathrm{~m}$.

\section{Acknowledgements}

We are thankful to Petrobras, namely Ana Paula Falcão (CENPES/PETROBRAS) and Prof. Dr Helena Lavrado (Universidade Federal do Rio de Janeiro), of the 'Habitats' Project. The Project 'Diversity of Polychaeta (Annelida) on sandstone reefs off northeastern Brazil, states of Paraíba and Pernambucoi' was funded by the Conselho Nacional de Desenvolvimento Cientifico e Tecnológico - CNPq (proc. 481510/2008-7) and is presently funded by Fundação de Amparo a Pesquisa do Estado de São Paulo - FAPESP (proc. 2010/52116-4). In addition, KP receives a $\mathrm{Ph}$. D. fellowship from FAPESP (proc. 2009/17606-3), MVF receives a post-doc fellowship from FAPESP (proc. 2010/19424-7), and JMMN receives a productivity grant from CNPq. We are also thankful to Orlemir Carrerette, Rudá Amorin, Rafael Brito, Carmem Alonso Samiguel, 
and all students of Laboratório de Invertebrados Paulo Yang (Universidade Federal da Paraíba UFPB) for help with the collections; to Enio Mattos and Phillip Lenktaitis for preparing the specimens and photographing them under the SEM; to the team of 'BIOTA', 'REVIZEE', and 'HABITATS' projects for collecting part of the material analysed in this study. We are grateful to Javier Sánchez Almazán (MNCN), Tatiana M. Steiner (ZUEC), and Aline Benetti (MZUSP) for providing museum numbers, and to Dr Angelika Brandt and the staff of the ZMH for all the support during a visit of one of us (MVF) to that collection.

\section{References}

Abd-Elnaby, F.A. \& San Martin, G. (2010) Eusyllinae, Anoplosyllinae, and Exogoninae (Polychaeta: Syllidae) for the Mediterranean Coasts of Egypt, together the description of one new species. Life Science Journal, 7(4), 132-139.

Aguado, M.T. \& San Martín, G. (2009) Phylogeny of the Syllidae (Polychaeta) based on morphological data. Zoologica Scripta 38, 379-402.

Aguado, M.T., Nygren, A. \& Siddall, M.E. (2007) Phylogeny of Syllidae (Polychaeta) based on combined molecular analysis of nuclear and mitochondrial genes. Cladistics, 23(6), 552564.

Aguado, M.T., Nygren, A. \& Siddall, M.E. (2007) Phylogeny of Syllidae (Polychaeta) based on combined molecular analysis of nuclear and mitochondrial genes. Cladistics, 23, 552564.

Aguado, M.T., San Martín, G. \& Siddall, M.E. (2011) Systematics and evolution of syllids (Annelida, Syllidae). Cladistics, 27, 1-17.

Amaral, A.C.Z., Nallin, S.A.H., Steiner, T.M., Forroni, T.O. \& Gomes-Filho, D. (2012) Catálogo das espécies de Annelida Polychaeta do Brasil. http://www.ib.unicamp.br/projbiota/bentos_marinho/prod_cien/texto_poli.pdf. (Acessed June 2013).

Amaral, A.C.Z., Lana, P.C. Fernandes, F.C. \& Coimbra, J.C. (2004) Parte I - Caracterização do ambiente e da macrofauna bentônica. In: Amaral, A.C.Z. and Rossi-Wongtschowski, C.L.B. (eds.), Biodiversidade Bentônica da Região Sudeste-Sul do Brasil - Plataforma Externa e Talude Superior. (Série Documentos REVIZEE-Score Sul). Instituto Oceanográfico, São Paulo. pp. 11-46.

Berlandi, R.M., Figueiredo, M.A.O. \& Paiva, P.C. (2011) Rhodolith morphology and the diversity of polychaetes off the Southeastern Brazilian coast. Journal of Coastal Research, 28, 280-287.

Böggemann M. and Westheide W. (2004) Interstitial Syllidae (Annelida: Polychaeta) from Mahé (Seychelles). Journal of Natural History, 38, 403-446.

Campoy, A. (1982) Fauna de España. Fauna de Anélidos Poliquetos de la Península Ibérica. Publicaciones de Biología de la Universidad de Navarra, Série Zoológica, 7(1). EUNSA (Ediciones de la Universidad de Navarra), Pamplona. 781p.

Capa, M., San Martín, G. \& López, E. (2001) Autolytinae, Eusyllinae and Exogoninae (Syllidae: Polychaeta) from Coiba National Park, Panamá. Revista De Biologia Tropical, 49(2), 621-627.

Day, J.H. (1967) A Monograph on the Polychaeta of Southern Africa, 1. Errantia, 2. Sedentaria. Brit Mus (Nat Hist) London Publ, (656), 1-458, 459-878. 
Fukuda, M.V. (2010) Contribuição ao conhecimento taxonômico dos silídeos (Polychaeta: Syllidae) da região sudeste-sul do Brasil. Ph. D. Thesis, Instituto de Biociências da Universidade de São Paulo, São Paulo, 340 pp.

Fukuda, M.V. \& Nogueira, J.M.M. (2006) A new species of Odontosyllis Claparède, 1863 (Polychaeta: Syllidae: Eusyllinae), and description of Brazilian material of Odontosyllis cf. fulgurans (Audouin and Milne Edwards, 1834). Zoological Studies, 45, 223-233.

Fukuda, M.V. \& Nogueira, J.M.M. (2013a) On a new species of Nuchalosyllis (Polychaeta: Syllidae), a rare syllid genus only known from Brazilian waters. Journal of the Marine Biological Association of the United Kingdom, 93, 963-966.

Fukuda, M.V. \& Nogueira, J.M.M. (2013b) First occurrence of Perkinsyllis San Martín, López \& Aguado, 2009 (Polychaeta: Syllidae) in Brazil, with descriptions of two new species. Marine Biology Research 9: 972-989.

Fukuda, M.V., Centurion, R., Nogueira, J.M.D. \& San Martin, G. (2012) Two new species of Paraehlersia San Martin, 2003 (Polychaeta, Syllidae) from the Atlantic Coast of South America. Zootaxa, 3264, 38-52.

Fukuda, M.V., Nogueira, J.M.M., Paresque, K. \& San Martín, G. (2013) Species of Odontosyllis Claparède, 1863 (Annelida: Polychaeta: Syllidae) occurring along the Brazilian coast. Zootaxa, 3609, 142-162.

Fukuda, M.V., Yunda-Guarín, G. \& Nogueira, J.M.M. (2009) The genus Prosphaerosyllis (Polychaeta: Syllidae: Exogoninae) in Brazil, with description of a new species. Journal of the Marine Biological Association of the United Kingdom, 89, 1443-1454.

Gardiner, S.L. (1975) Errant polychaete annelids from North Carolina. Journal Elisha Mitchell Scient Soc, 91(3), 77-220.

Hartmann-Schroder, G. (1959) Zur Okologie der Polychaeten des Mangrove-Estero-Gebietes von El Salvador. Beitraege zur Neotropischen Fauna, 1, 69-183.

Hartmann-Schröder, G. (1960) Polychaeten aus dem Roten Meer. Kieler Meeresforschungen, $16,69-125$.

Hartmann-Schröder, G. (1974) Zur Kenntnis des Eulitorals der afrikanischen Westkuste zwischen Angola und Kap der Guten Hoffnung und der afrikanischen Ostkuste von Sudafrika und Mocambique unter besonderer Berücksichtigung der Polychaeten und Ostracoden. Teil 2. Die Polychaeten des Untersuchungsgebietes. Mitteilungen aus dem Hamburgischen Zoologischen Museum und Institut, , 68, 95-228.

Imajima, M. (1966) The Syllidae (polychaetous annelids) from Japan. I. Exogoninae. Publications of the Seto Marine Biological Laboratory, 13, 385-404.

Lana, P.C. (1984) Anelídeos poliquetas errantes do litoral do estado do Paraná. Tese de Doutorado - Instituto Oceanográfico, Universidade de São Paulo. 275 pp.

Morgado, E.H. \& Amaral, A.C.Z. (1985) Anelídeos poliquetos associados ao briozoário Schizoporella unicornis (Johnston). V. Syllidae. Revista Brasileira de Zoologia, 3, 219 227.

Nogueira, J.M.M. (2000) Anelídeos poliquetas associados ao coral Mussismilia hispida (Verril, 1868) em ilhas do litoral do Estado de São Paulo. Phyllodocida, Amphinomida, Eunicida, Spionida, Terebellida, Sabellida. Tese de Doutorado - Instituto de Biociências, Universidade de São Paulo. 265 pp.

Nogueira, J.M.M. (2006) Família Syllidae. In: Amaral ACZ, Rizzo AE, Arruda, EP, editors. Manual de Identificação dos Invertebrados Marinhos da Região Sudeste-Sul do Brasil. São Paulo, SP: Editora da Universidade de São Paulo, 134-164. 
Nogueira, J.M.M. \& Fukuda, M.V. (2008) A new species of Trypanosyllis Claparède, 1864 (Polychaeta: Syllidae) from Brazil, with a redescription of Brazilian material of Trypanosyllis zebra. Journal of the Marine Biological Association of the United Kingdom, 88, 913-924.

Nogueira, J.M.M. \& San Martín, G. (2002) Species of Syllis Savigny in Lamarck, 1818 (Polychaeta: Syllidae) living in corals in the state of São Paulo, southeastern Brazil. Beaufortia, 52, 57-93.

Nogueira, J.M.M. \& Yunda-Guarín, G. (2008) A new species of Syllis (Polychaeta: Syllidae: Syllinae) from off Fortaleza, north-eastern Brazil. Journal of the Marine Biological Association of the United Kingdom, 88, 1391-1399.

Nogueira, J.M.M., San Martín, G. \& Amaral, A.C.Z. (2001) Description of five new species of Exogoninae (Polychaeta, Syllidae) associated with the stony coral Mussismilia hispida (Verrill, 1868) in São Paulo State, Brazil. Journal of Natural History 35, 1773-1794.

Nogueira, J.M.M., San Martín, G. \& Fukuda, M.V. (2004) On some exogonines (Polychaeta, Syllidae) from the northern coast of the State of São Paulo, southeastern Brazil - Results of BIOTA/FAPESP/BentosMarinho Project. Meiofauna Marina 13, 45-78.

Núñez, J., San Martín, G. \& Brito, M.C (1992) Exogoninae (Polychaeta, Syllidae) from the Canary Islands. Scientia Marina, 56 (1): 43-52.

Nygren, A. \& Gidholm, L. (2001) Three new species of Proceraea (Polychaeta: Syllidae: Autolytinae) from Brazil and the United States, with a synopsis of all Proceraea-like taxa. Ophelia, 54, 177-191.

Paiva, P.C., Young, P.S. \& Echeverría, C.A. (2007) The Rocas Atoll, Brazil: a preliminary survey of the crustacea and polychaete fauna. Arquivos do Museu Nacional, Rio de Janeiro 65, 241-250.

Paresque, K. \& Nogueira, J.M.M. (in press) The genus Haplosyllis Langerhans, 1879 (Polychaeta: Syllidae) from off northeastern Brazil, with descriptions of two new species. Marine Biology Research.

Paresque, K. 2008. Influência das características do hábitat na comunidade macrobentônica associada a diferentes fitais no entre-marés da Ilha do Boi, Vitória, Espírito Santo. Dissertação de Mestrado, Universidade Federal do Espírito Santo. 47 pp.

Pascual, M., Núñez, J. \& SanMartín, G. (1996) Exogone (Polychaeta: Syllidae: Exogoninae) endobiontics of sponges from the Canary and Madeira Islands with description of two new species. Ophelia, 45(1), 67-80.

Perkins, T. H. (1981) Syllidae (Polychaeta), principally from Florida, with descriptions of a new genus and twenty-one new species. Proceedings of the Biological Society of Washington, 93, 1080-1172.

Ruiz-Ramírez, J.D. \& Salazar-Vallejo, S. (2001) Exogoninae (Polychaeta: Syllidae) from the Mexican Caribbean with a key to the Great Caribbean species. Revista De Biologia Tropical, 49(1), 117-140.

Rullier, F. \& Amoureux, L. (1979) Annélides Polychàetes. Annales de l'Institute Oceanographique, 55, 145-206.

Russell, D.E. (1991) Exogoninae (Polychaeta: Syllidae) from the Belizean barrier reef with a key to species of Sphaerosyllis. Journal of Natural History, 25, 49-74.

San Martín, G. (1984) Estudio biogeográfico, faunístico y sistemático de los Poliquetos de la família Sílidos (Syllidae: Polychaeta) en Baleares. Publicaciones de la Universidad Complutense de Madrid, 187, Madrid. 581 pp. 
San Martín, G. (1991) Grubeosyllis and Exogone (Exogoninae, Syllidae, Polychaeta) from Cuba, the Gulf of Mexico, Florida and Puerto Rico, with a revision of Exogone. Bulletin of Marine Science, 49, 715-740.

San Martín, G. (2003) Annelida Polychaeta II: Syllidae. In: Ramos, M.A. et al. (eds.), Fauna Ibérica, vol. 21. Museo Nacional de Ciências Naturales, CSIC, Madrid. 544 pp.

San Martín, G. (2005) Exogoninae (Polychaeta, Syllidae) from Australia with the description of a new genus and twenty-two new species. Records of the Australian Museum, 57, 39-152.

San Martín, G. \& Hutchings, P. (2006) Eusyllinae (Polychaeta: Syllidae) from Australia with the description of a new genus and fifteen new species. Records of the Australian Museum, 58, 257-370.

San Martín, G. \& López, E. (2003) A new genus of Syllidae (Polychaeta) from Western Australia. Hydrobiologia 496, 191-197.

San Martín, G., Hutchings, P. \& Aguado, M.T. (2008a) Syllinae (Polychaeta, Syllidae) from Australia. Part. 2. Genera Inermosyllis, Megasyllis n. gen., Opisthosyllis, and Trypanosyllis. Zootaxa, 1840, 1-53.

San Martín, G., Hutchings, P. \& Aguado, M.T. (2008b) Syllinae (Polychaeta, Syllidae) from Australia. Part 1. Genera Branchiosyllis, Eurysyllis, Karroonsyllis, Parasphaerosyllis, Plakosyllis, Rhopalosyllis, Tetrapalpia n. gen., and Xenosyllis. Records of the Australian Museum, 60, 19-160.

San Martín, G., Hutchings, P. \& Aguado, M.T. (2010) Syllinae (Polychaeta: Syllidae) from Australia. Part 3. Genera Alcyonosyllis, Parahaplosyllis, and Trypanosyllis (Trypanobia). Zootaxa, 2493, 35-48.

Sovierzoski, H.H. (1999) Anelídeos poliquetas do litoral de Alagoas, Brasil. Tese de Doutorado - Instituto de Biociências, Universidade de São Paulo. 208 pp.

Temperini, M.T. (1981). Sistemática e distribuição dos poliquetos errantes da plataforma continental brasileira entre as latitudes $23^{\circ} 05^{\prime} \mathrm{S}$ e $30^{\circ} 00 \mathrm{~S}$. Dissertação de Mestrado Instituto Oceanográfico, Universidade de São Paulo. 89 pp.

Uebelacker, J.M. (1984) Family Syllidae Grube, 1850. In: Uebelacker, J.M. \& Johnson, P.G. (eds.), Taxonomic Guide to the Polychaetes of the Northern Gulf of Mexico. Volume IV. Barry A. Vittor \& Associates, Metairie. pp. 30-1-30-151.

Webster, H.E. (1879) On the Annelida Chaetopoda of the Virginian coast. Transactions Albany Inst, ix, 202-272.

Westheide, W. (1974) Interstitielle Fauna von Galapagos 11. Pisionidae, Hesionidae, Pilargidae, Syllidae (Polychaeta). Mikrofauna Meeresbodens, 44, 1-146.

Westheide, W. (1974) Interstitielle Fauna von Galapagos. XI. Pisionidae, Hesionidae, Pilargidae, Syllidae (Polychaeta). Mikrofauna Meersbodens, 44, 195-338.

Zottoli, R. \& Long, C.D. (2000) Exogone breviantennata Hartmann-Schroder, 1959 (characters emended) (Annelida: Polychaeta: Syllidae), a new record for the Bahamas with a key to selected Exogone species. Proceedings of the Biological Society of Washington, 113(2), $500-513$ 


\section{Legends to figures}

FIGURE 1. Map of distribution of the six different projects which collected the material used for the present paper: A. Northeastern Brazilian coast $(\bullet=$ collection sites from Project 'Diversity of Polychaeta (Annelida) on sandstone reefs off northeastern Brazil, states of Paraíba and Pernambuco'); B. Southeastern Brazilian coast ( = 'Influence of the fractal dimension of marine macroalgae on the associated community'; $\star$ ='HABITATS Project - Campos Basin Environmental Heterogeneity by CENPES/PETROBRAS'; $O=$ 'REVIZEE/Southern Score/Benthos'; - = 'Biodiversity of Intertidal Polychaetes (Annelida:Polychaeta) on Rocky Shores off the State of São Paulo'; $\diamond=$ 'BIOTA/FAPESP/Benthic Marine Diversity in the State of São Paulo').

FIGURE 2. Exogone naidinoides. (A) Anterior end, dorsal view; (B) compound chaetae, anterior body; (C) compound chaetae, mid- and posterior body; (D) dorsal simple chaeta, anterior body; (E) dorsal simple chaeta, posterior body; (F) ventral simple chaeta, posterior body; (G) acicula, anterior body; $(\mathrm{H})$ acicula, posterior body. Scale bars: A, $50 \mu \mathrm{m}$; B-H, 10 $\mu \mathrm{m}$.

FIGURE 3. Exogone naidinoides, SEM. (A) (B) (C) Anterior end, dorsal, ventral and lateral view, respectively; (D) parapodia, chaetigers 1-2; (E) chaetae, chaetiger 1; (F) detail of one chaeta from chaetiger $1 ;(\mathrm{G})$ region between prostomium and peristomium, dorsal view; $(\mathrm{H})$ nuchal organ, lateral view; (I) dorsal simple chaeta, chaetiger 2. dc1-dorsal cirri 1, no-nuchal organ, vc1 - ventral cirri 1, pc - peristomial cirri. Scale bars: A-C, $20 \mu \mathrm{m} ; \mathrm{D}, 10 \mu \mathrm{m} ; \mathrm{E}, \mathrm{G}-\mathrm{H}, 5$ $\mu \mathrm{m} ; \mathrm{F}, \mathrm{I}, 2 \mu \mathrm{m}$.

FIGURE 4. Exogone naidinoides, SEM. (A) Chaetae, midbody chaetiger; (B) detail of protruding acicula, midbody chaetiger; (C) midbody chaetigers, dorsal view; (D) chaetae, posterior body; (E) ventral simple chaeta, posterior body; $(\mathrm{F})$ posterior end, dorsal view. Arrows point to protruding acicula. Scale bars: A, D, $5 \mu \mathrm{m}$; B, E, $2 \mu \mathrm{m} ; \mathrm{C}, 50 \mu \mathrm{m} ; \mathrm{F}, 20 \mu \mathrm{m}$.

FIGURE 5. Exogone simplex. (A) Anterior end, dorsal view; (B) posterior end, dorsal view; (C) dorsal simple chaeta, anterior body; (D) chaetae; (E) dorsal simple chaeta, mid- and posterior body; (F) acicula; (G) ventral simple chaeta, posterior body. Scale bars: A-B, $50 \mu \mathrm{m}$; C-G: $10 \mu \mathrm{m}$.

FIGURE 6. Exogone africana. (A) Anterior end, dorsal view; (B) compound chaetae, anterior body; (C) compound chaetae, midbody; (D) compound chaetae, posterior body; (E) dorsal simple chaeta, anterior body; (F) dorsal simple chaeta, posterior body; $(\mathrm{G})$ ventral simple chaeta, posterior body; (H) aciculae, anterior body; (I) acicula, posterior body; (J) posterior end, dorsal view. Scale bars: A, $200 \mu \mathrm{m}$; B-I, $10 \mu \mathrm{m}, \mathrm{J}=25 \mu \mathrm{m}$.

FIGURE 7. Exogone rolani. (A) Anterior body, dorsal view; (B) acicula, anterior body; (C) dorsal simple chaeta, anterior body; (D) spiniger-like chaetae, anterior body; (E) falcigers, anterior body; (F) acicula, midbody; (G) dorsal simple chaeta, midbody; (H) spiniger-like chaeta, midbody; (I) falcigers, midbody; (J) acicula, posterior body; (K) dorsal simple chaeta, posterior body; (L) ventral simple chaeta, posterior body; (M) spiniger-like chaeta, posterior body; (N) falcigers, posterior body. Scale bars: A, $0.20 \mathrm{~mm}$; B-N, $10 \mu \mathrm{m}$.

FIGURE 8. Exogone rolani, SEM. (A) (B) Anterior end, dorsal view; (C) detail of ciliated nuchal organ; (D) spiniger-like chaeta, chaetiger 2; (E) pharynx opening, frontal view; (F) chaetae, chaetiger 2; (G) falciger, chaetiger 3; (H) falcigers, chaetiger 3; (I) chaetae, chaetiger 6; (J) ventral-most falciger, midbody parapodium; (K) chaetae, midbody parapodium; (L) chaetae, posterior body parapodium; (M) posterior end, frontal view. The arrows indicating the ciliated nuchal organ.Scale bars: A-B = 50 $\mu \mathrm{m}$; C, E, F, I, L, $10 \mu \mathrm{m} ; \mathrm{D}, \mathrm{J}, 5 \mu \mathrm{m} ; \mathrm{G}-\mathrm{H}, 2 \mu \mathrm{m} ; \mathrm{K}, \mathrm{M}, 20$ $\mu \mathrm{m}$. 
FIGURE 9. Exogone dispar. (A) Anterior end, dorsal view; (B) compound chaetae, anterior body; (C) compound chaetae, midbody; (D) compound chaetae, posterior body; (E) dorsal simple chaeta, anterior body; (F) dorsal simple chaeta, posterior body; $(\mathrm{G})$ ventral simple chaeta, posterior body; $(\mathrm{H})$ aciculae, anterior body; (I) acicula, posterior body. Scale bars: A, $200 \mu \mathrm{m} ; \mathrm{B}-\mathrm{I}, 10 \mu \mathrm{m}$.

FIGURE 10. Exogone dispar, SEM. (A) (B) anterior end, dorsal and ventral view, respectively; (C) detail of pharynx, frontal view; (D) midbody chaetigers, dorsal view; (E) posterior end, dorsal view; $(F)$ posterior end, frontal view; $(\mathrm{G})$ anterior end, lateral view; $(\mathrm{H})$ nuchal organ, lateral view . Scale bars: A-B, D, G, $50 \mu \mathrm{m} ; \mathrm{C}, \mathrm{F}, 20 \mu \mathrm{m}$; E, H, $100 \mu \mathrm{m}$.

FIGURE 11. Exogone dispar, SEM. (A) (B) falcigers, anterior body; (C) compound chaetae, chaetiger 3; (D) chaetae, midbody parapodium (E) falcigers, midbody parapodium; (F) chaetae, posterior body parapodium; $(\mathrm{G})$ ventral simple chaeta, posterior body; $(\mathrm{H})$ dorsal simple chaeta, posterior body. Scale bars: A-H, $2 \mu \mathrm{m} ; \mathrm{B}, \mathrm{E}, \mathrm{G}, 5 \mu \mathrm{m} ; \mathrm{C}, 10 \mu \mathrm{m} ; \mathrm{D}, \mathrm{F}, 20 \mu \mathrm{m}$.

FIGURE 12. Exogone arenosa. . (A) Anterior body, dorsal view; (B) aciculae, anterior body; (C) dorsal simple chaeta, anterior body; (D) spiniger-like chaeta, chaetiger 2; (E) falcigers, anterior body; (F) spiniger-like chaeta, anterior body; $(\mathrm{G})$ aciculae, midbody; $(\mathrm{H})$ dorsal simple chaeta, midbody; (I) spiniger-like chaeta, midbody; (J) falcigers, midbody; (K) acicula, posterior body; (L) dorsal simple chaeta, posterior body; (M) ventral simple chaeta, posterior body; $(\mathrm{N})$ spiniger-like chaeta, posterior body; $(\mathrm{O})$ falcigers, posterior body. Scale bars: A, 0.3 $\mathrm{mm} ; \mathrm{B}, 10 \mu \mathrm{m}$.

FIGURE 13. Exogone arenosa, SEM. (A) Anterior end, dorsal view; (B) pharynx, frontal view; (C) detail of pharynx, showing the ciliated border; (D) midbody chaetigers, dorsal view; (E) chaetae, anterior parapodium; (F) falciger and detail of triangular process of spiniger-like chaeta of chaetiger 2; (G) chaetae, midbody parapodium; (H) spiniger-like chaeta, midbody parapodium; (I) falciger, posterior body; (J) (K) dorsal simple chaetae, anterior and posterior body, respectively; (L) ventral simple chaeta, posterior body. pha - pharynx; pa - palp; mamedian antenna; la-lateral antennae; pr-prostomium. Scale bars: A, D, $50 \mu \mathrm{m} ; \mathrm{B}, 20 \mu \mathrm{m} ; \mathrm{C}$, $\mathrm{K}, 5 \mu \mathrm{m} ; \mathrm{E}, \mathrm{G}, \mathrm{H}, 10 \mu \mathrm{m} ; \mathrm{F}, \mathrm{I}, \mathrm{J}, \mathrm{L}, 2 \mu \mathrm{m}$.

FIGURE 14. Exogone gigas sp. n. (A) Anterior end, left dorso-lateral view; (B) spiniger-like chaeta, chaetiger 2; (C) compound chaetae, anterior body; (D) compound chaetae, midbody; (E) compound chaetae, posterior body; (F) dorsal simple chaeta, anterior body; (G) dorsal simple chaeta, posterior body; $(\mathrm{H})$ ventral simple chaeta, posterior body; (I) aciculae, anterior body; (J) acicula, posterior body. Scale bars: A, $200 \mu \mathrm{m}$; B-J, $10 \mu \mathrm{m}$.

FIGURE 15. Exogone gigas sp. n., SEM. (A) Anterior end, dorsal view; (B) pharynx, frontal view; (C) detail of one nuchal organ; (D) shaft of spiniger-like chaeta, chaetiger 2; (E) compound chaetae, chaetiger 2; (F) chaetae, chaetiger 3; (G) tip of spiniger-like chaeta, chaetiger 2; $(\mathrm{H})$ falciger, chaetiger 2; (I) compound chaetae, midbody; (J) dorsal simple chaeta, midbody; (K) tip of spiniger-like chaeta, midbody; (L) spiniger-like chaeta, midbody; (M) ventral simple chaeta, midbody; $(\mathrm{N})$ tip of spiniger-like chaeta, posterior body; $(\mathrm{O})$ ventral simple chaeta, posterior body; $(\mathrm{P})$ compound chaetae, posterior body. no-nuchal organ. Scale bars: A, $100 \mu \mathrm{m}$; B, $50 \mu \mathrm{m}$; C, $20 \mu \mathrm{m}$; D, H, $5 \mu \mathrm{m}$; E, G, N, $2 \mu \mathrm{m}$; F, I, J, L, M, O, P, $10 \mu \mathrm{m}$; K, $1 \mu \mathrm{m}$. 
TABLE 1. Morphological features of the type series of Exogone gigas sp. n.

\begin{tabular}{|c|c|c|c|c|c|c|c|c|c|c|c|}
\hline & $\begin{array}{c}\text { Holotype } \\
\text { MZUSP } \\
1271 \\
\end{array}$ & $\begin{array}{c}\text { Paratype } 1 \\
\text { MZUSP } \\
1272 \\
\end{array}$ & $\begin{array}{c}\text { Paratype } 2 \\
\text { MZUSP } \\
1273 \\
\end{array}$ & $\begin{array}{c}\text { Paratype } 3 \\
\text { MZUSP } \\
1274 \\
\end{array}$ & $\begin{array}{c}\text { Paratype } 4 \\
\text { ZUEC } \\
13534 \\
\end{array}$ & $\begin{array}{c}\text { Paratype } 5 \\
\text { ZUEC } \\
13533 \\
\end{array}$ & $\begin{array}{c}\text { Paratype } 6 \\
\text { ZUEC } \\
13532 \\
\end{array}$ & $\begin{array}{c}\text { Paratype } 7 \\
\text { MZUSP } \\
\mathbf{2 0 8 3} \\
\end{array}$ & $\begin{array}{c}\text { Paratype } 8 \\
\text { MZUSP } \\
\mathbf{2 0 8 4} \\
\end{array}$ & $\begin{array}{c}\text { Paratype } 9 \\
\text { MNCN } \\
16.01 / 14629 \\
\end{array}$ & $\begin{array}{c}\text { Paratype } 10 \\
\text { MNCN } \\
\mathbf{1 6 . 0 1 / 1 4 6 3 0} \\
\end{array}$ \\
\hline Body length / width (mm) & $10 / 0.27$ & $9.5 / 0.23$ & $2.5 / 0.22$ & $9 / 0.28$ & $9 / 0.33$ & $10 / 0.32$ & $9.5 / 0.31$ & $8.5 / 0.35$ & $10 / 0.30$ & $8 / 0.31$ & $9 / 0.28$ \\
\hline Number of chaetigers & 78 & 68 & 35 & 75 & 75 & 78 & 73 & 72 & 72 & 65 & 71 \\
\hline $\begin{array}{c}\text { Length of median antenna / } \\
\text { lateral }(\mu \mathrm{m})\end{array}$ & $150 / 31-36$ & $95 / 20-22$ & $132 / 25-32$ & $120 / 45-45$ & $150 / 35-40$ & 77 / 37-42 & $160 / 45-50$ & $220 / 42-44$ & $192 / 45-50$ & $88 / 40-43$ & $125 / 35-37$ \\
\hline $\begin{array}{l}\text { Proventricle length /width } \\
\text { (mm) }\end{array}$ & $0.55 / 0.16$ & $0.44 / 0.14$ & $0.27 / 0.07$ & $0.49 / 0.11$ & $0.48 / 0.18$ & $0.47 / 0.15$ & $0.50 / 0.13$ & $0.52 / 0.15$ & $0.50 / 0.14$ & $0.48 / 0.17$ & $0.46 / 0.14$ \\
\hline $\begin{array}{l}\text { Number of chaetigers / } \\
\text { Number of rows of muscle- } \\
\text { cells }\end{array}$ & $3.5 / 26$ & $4.5 / 27$ & $4 / 27$ & $4.5 / 25$ & $4.5 / 26$ & $4 / 26$ & $5 / 27$ & $5 / 25$ & $4.5 / 25$ & $4 / 26$ & $4.5 / 28$ \\
\hline $\begin{array}{l}\text { Number of chaetigers of the } \\
\text { pharynx }\end{array}$ & 5.5 & $4.5 \mathrm{ev}$ & $3 \mathrm{ev}$ & 4.5 & 5 & 3.5 & 4 & 5 & $4.5 \mathrm{ev}$ & 5 & 4 \\
\hline \multicolumn{12}{|l|}{$\begin{array}{l}\text { Number of spiniger-like } \\
\text { chaetae /falcigers per } \\
\text { parapodium }\end{array}$} \\
\hline Anterior body & $1-2 / 6-9$ & $1-2 / 6-10$ & $1-2 / 3-6$ & $1-2 / 4-10$ & $1-2 / 5-8$ & $1-2 / 6-9$ & $1-2 / 7-9$ & $1-2 / 7-10$ & $1-2 / 7-9$ & $1-2 / 5-8$ & $1-2 / 6-8$ \\
\hline Midbody & $1 / 3-4$ & $1 / 2-4$ & $1 / 2-3$ & $1-2 / 2-3$ & $1 / 3-4$ & $1 / 3-4$ & $1 / 3-4$ & $1-2 / 2-3$ & $1-2 / 3$ & $1 / 3$ & $1 / 3$ \\
\hline Posterior body & $1 / 2$ & $1 / 2-3$ & $0-1 / 2$ & $1 / 2$ & $1 / 2$ & $1 / 2-3$ & $1 / 2-3$ & $1 / 2-3$ & $1 / 2-3$ & $1 / 2$ & $1 / 2-3$ \\
\hline \multicolumn{12}{|l|}{$\begin{array}{l}\text { Length of spiniger-like } \\
\text { chaetae / falcigers chaetiger } \\
\qquad(\mu \mathrm{m})\end{array}$} \\
\hline Anterior body & $42-47 / 7-10$ & $30-50 / 6-9$ & $25-33 / 4-8$ & $30-48 / 7-9$ & $30-40 / 6-10$ & $40-50 / 7-10$ & $40-45 / 8-11$ & $40-50 / 7-10$ & $36-45 / 8-9$ & $37-45 / 7-10$ & $40-50 / 7-11$ \\
\hline Midbody & $25-45 / 4-8$ & $30-43 / 4-8$ & $12-18 / 3-5$ & $22-32 / 4-6$ & $30-40 / 4-9$ & $27-45 / 4-9$ & $34-38 / 4-8$ & $31-41 / 4-9$ & $30-40 / 6-8$ & $38-34 / 6-8$ & $32-38 / 5-8$ \\
\hline Posterior body & $17-25 / 4-6$ & $22-28 / 4-6$ & $18-22 / 3-5$ & $20-23 / 4-6$ & $19-24 / 3-5$ & $18-22 / 3-6$ & $27-35 / 3-6$ & $20-24 / 4-5$ & $23-29 / 4-6$ & $20-22 / 4-5$ & $20-26 / 4-6$ \\
\hline $\begin{array}{l}\text { Chaetiger on which } \\
\text { dorsal/ventral simple chaetae } \\
\text { first appear }\end{array}$ & $11 / 75$ & $6 / 54$ & $3 / 12$ & $6 / 64$ & $6 / 62$ & $7 / 70$ & $10 / 61$ & $11 ? / 61$ & $9 ? / 59$ & $7 / 47$ & $7 ? / 60$ \\
\hline
\end{tabular}

ev. $=$ everted 

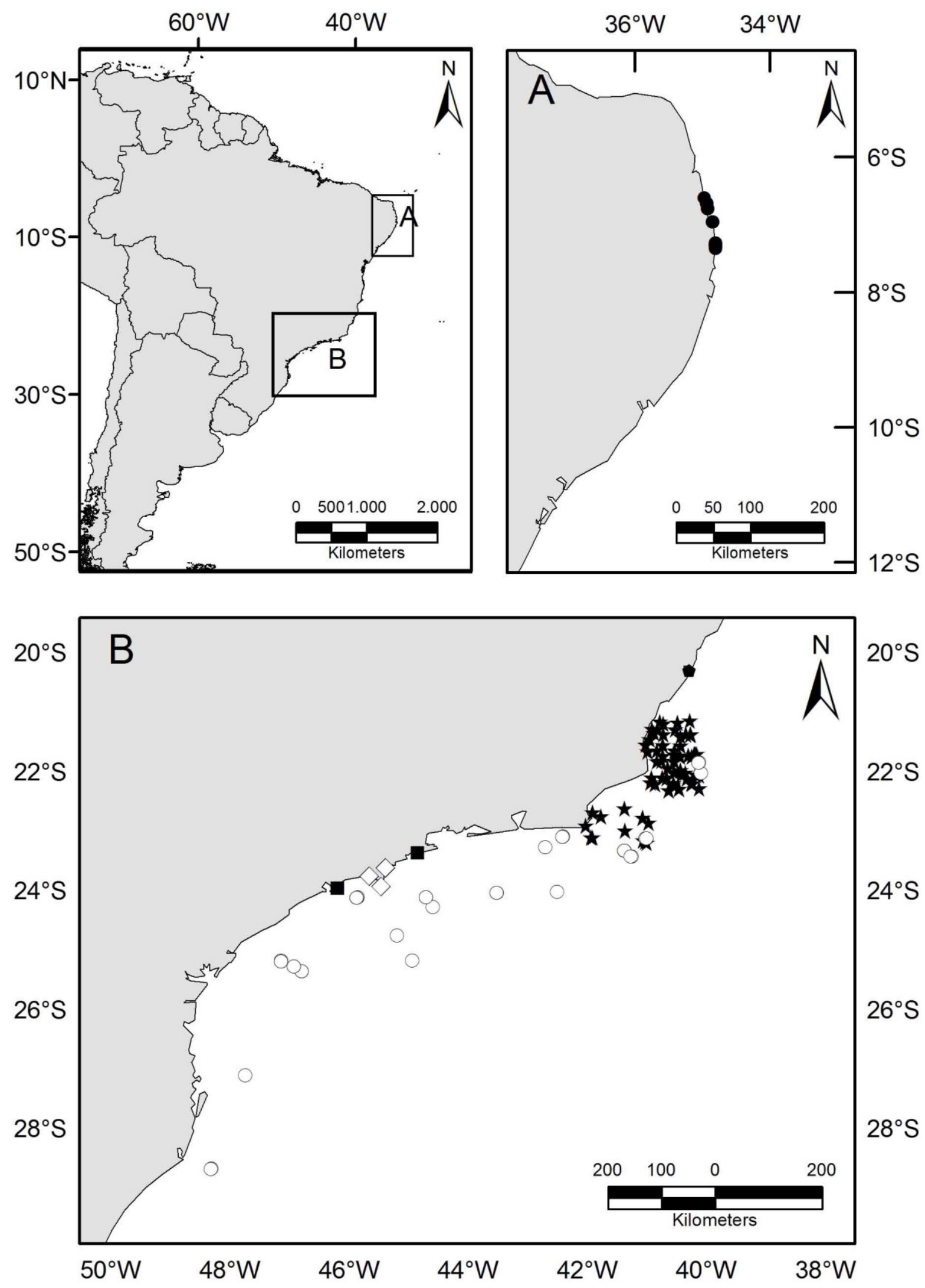

FIGURE 1 

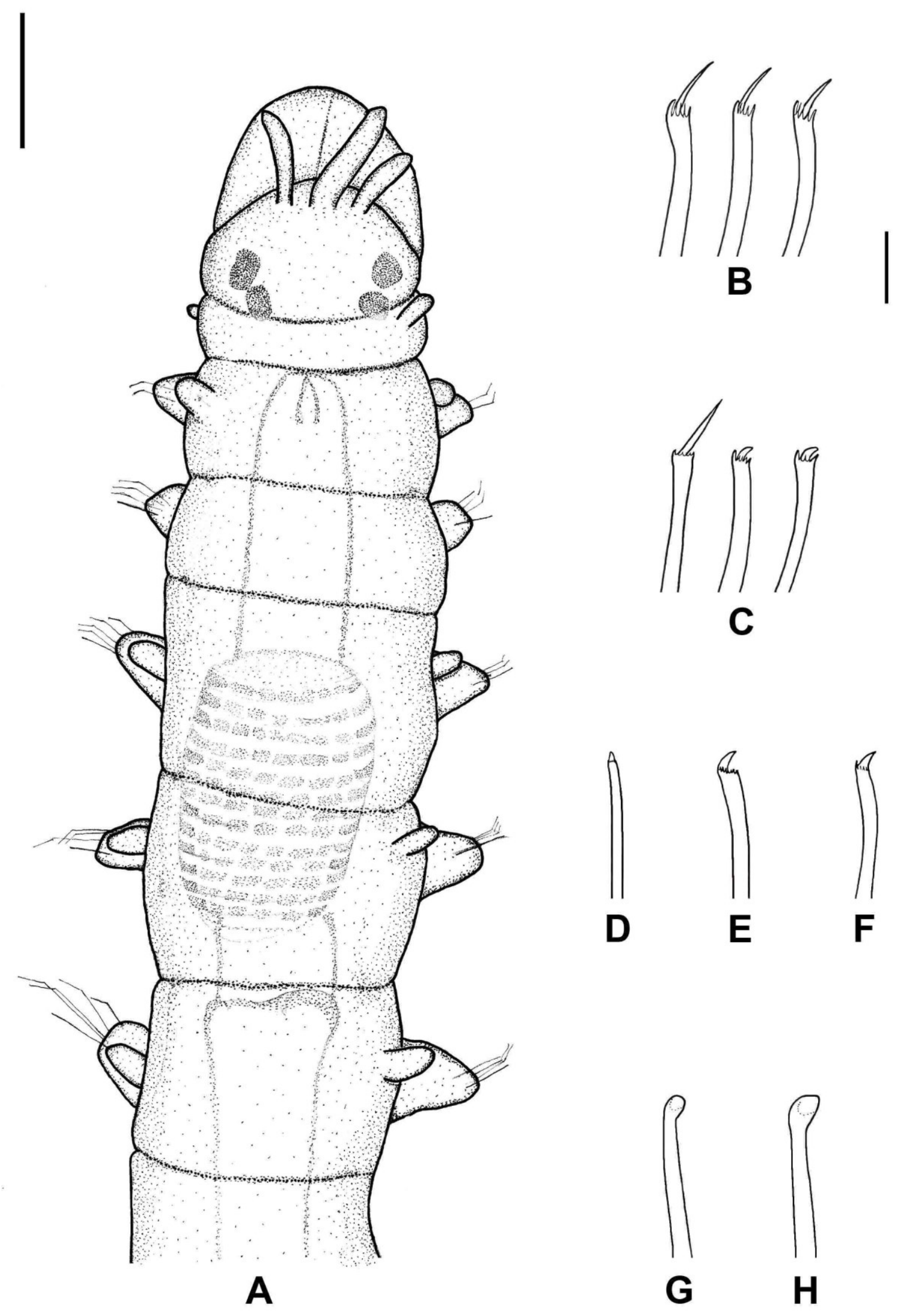

FIGURE 2 

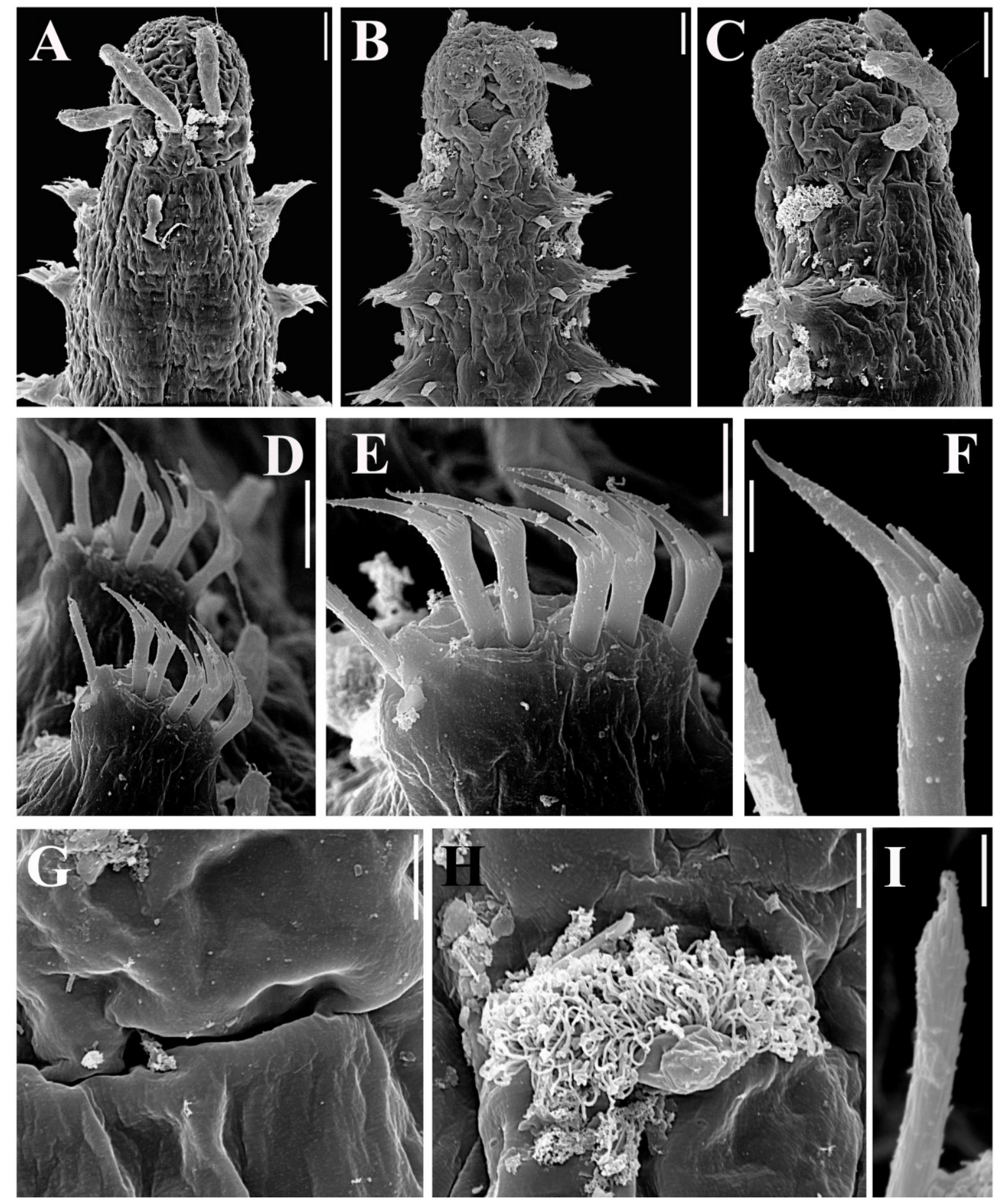

FIGURE 3 

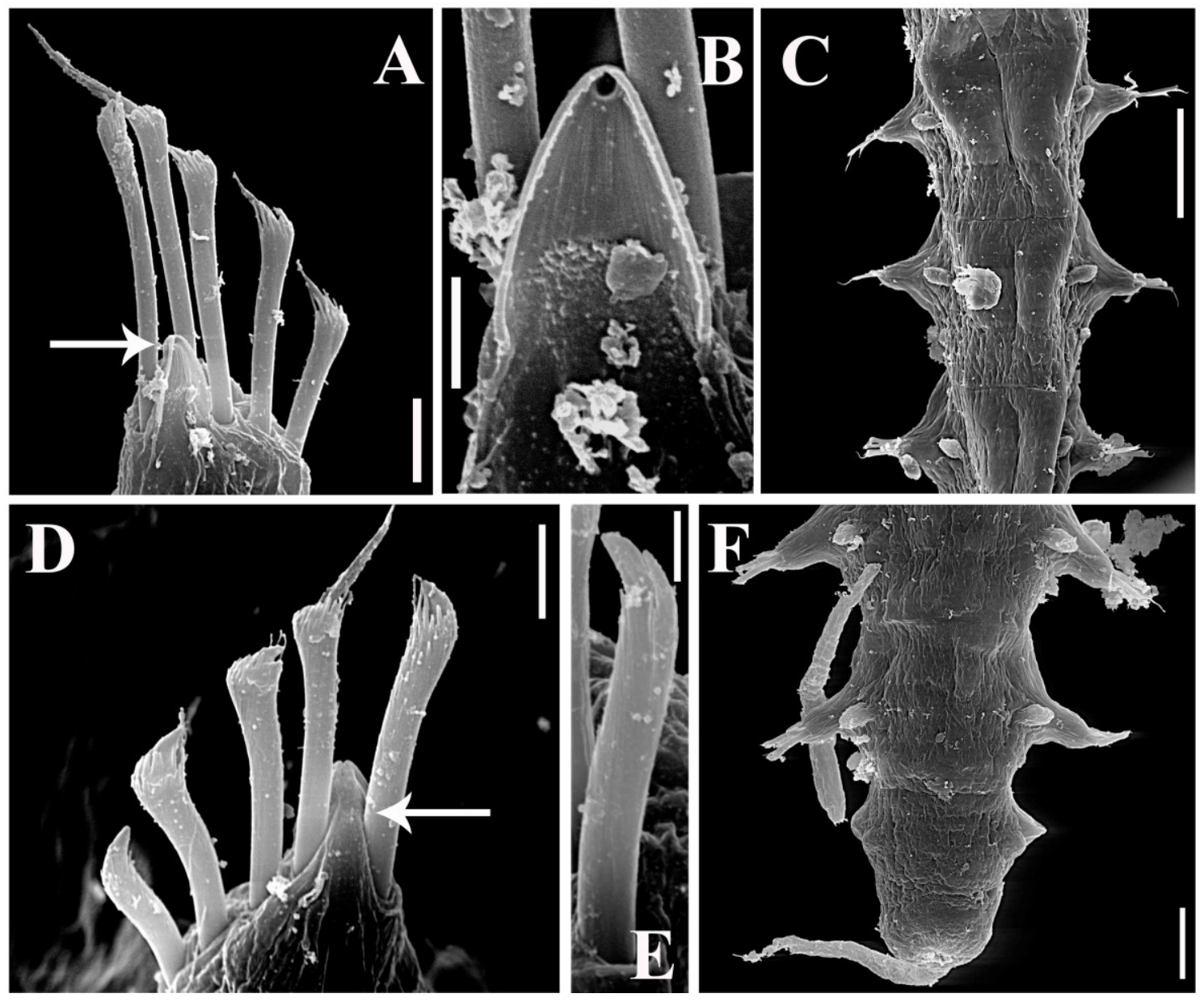

FIGURE 4 


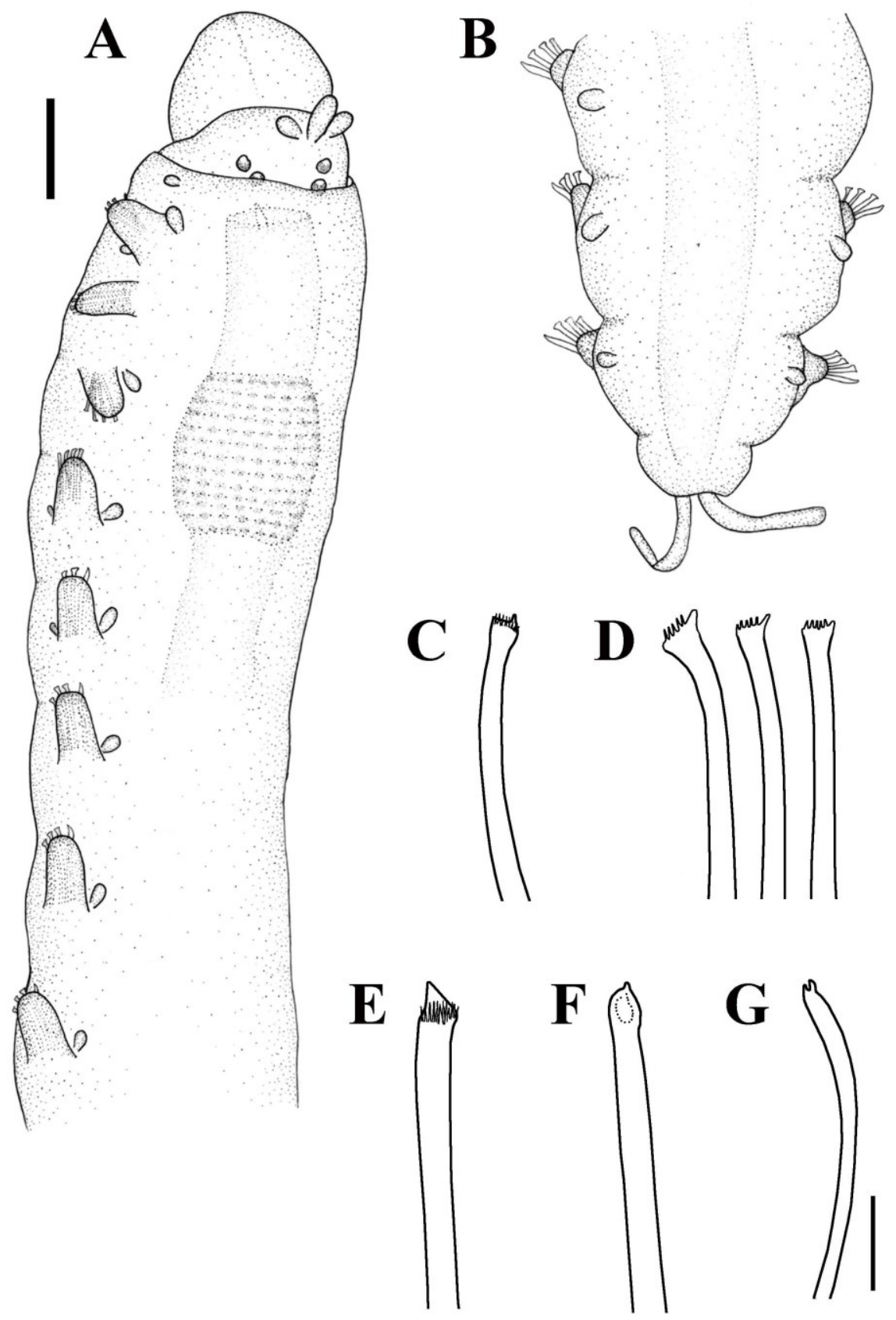

FIGURE 5 

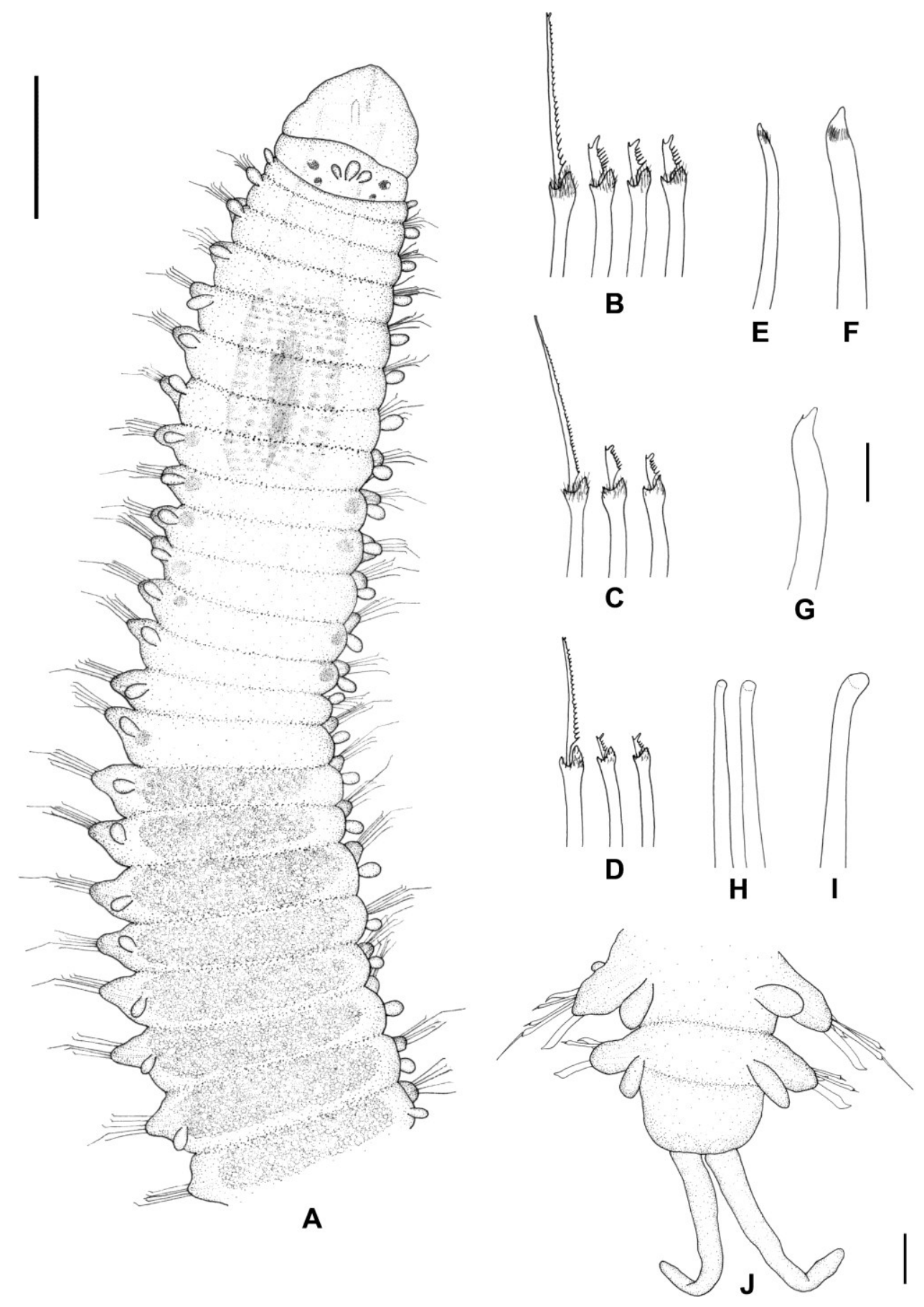

FIGURE 6 


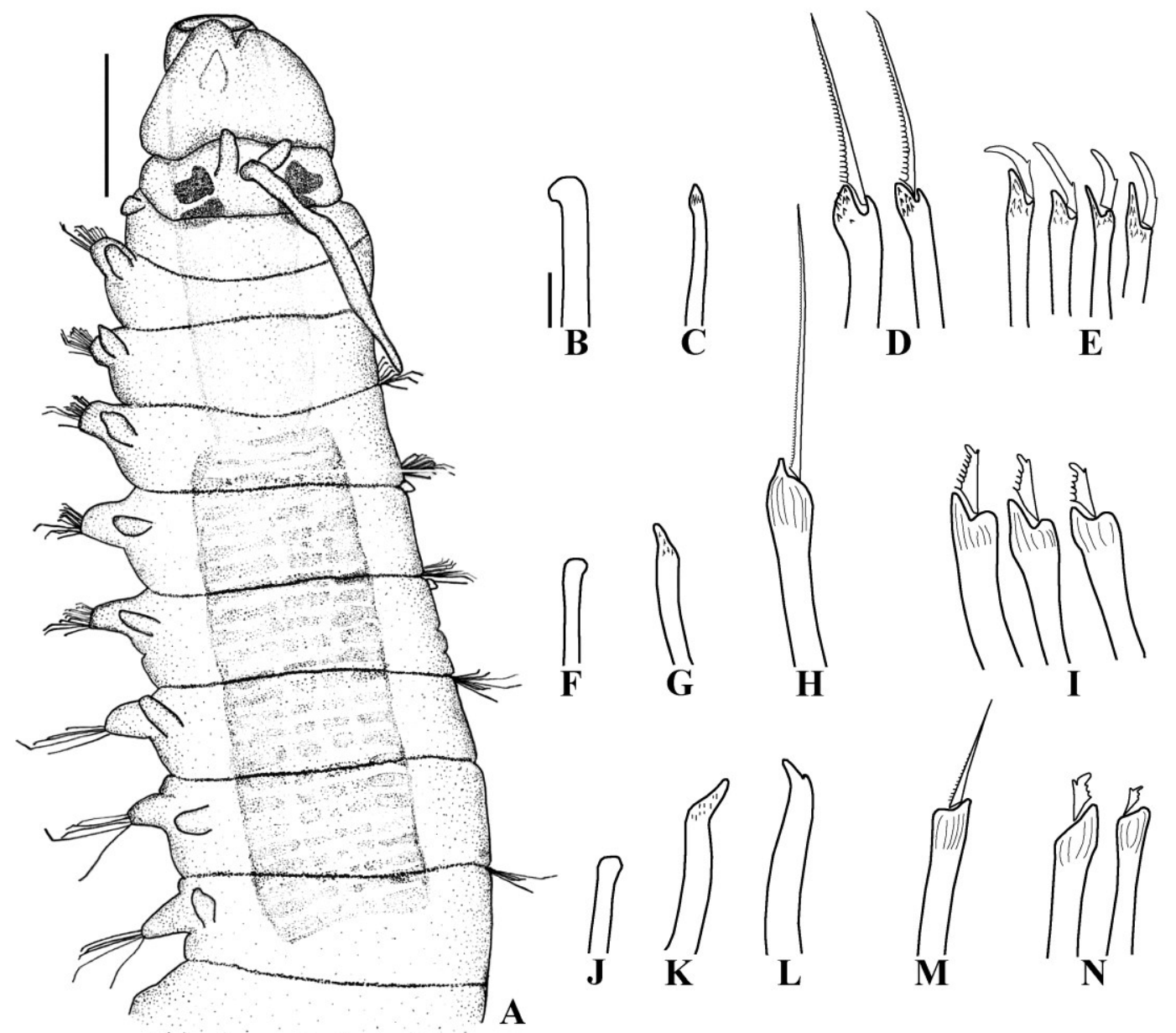

FIGURE 7 


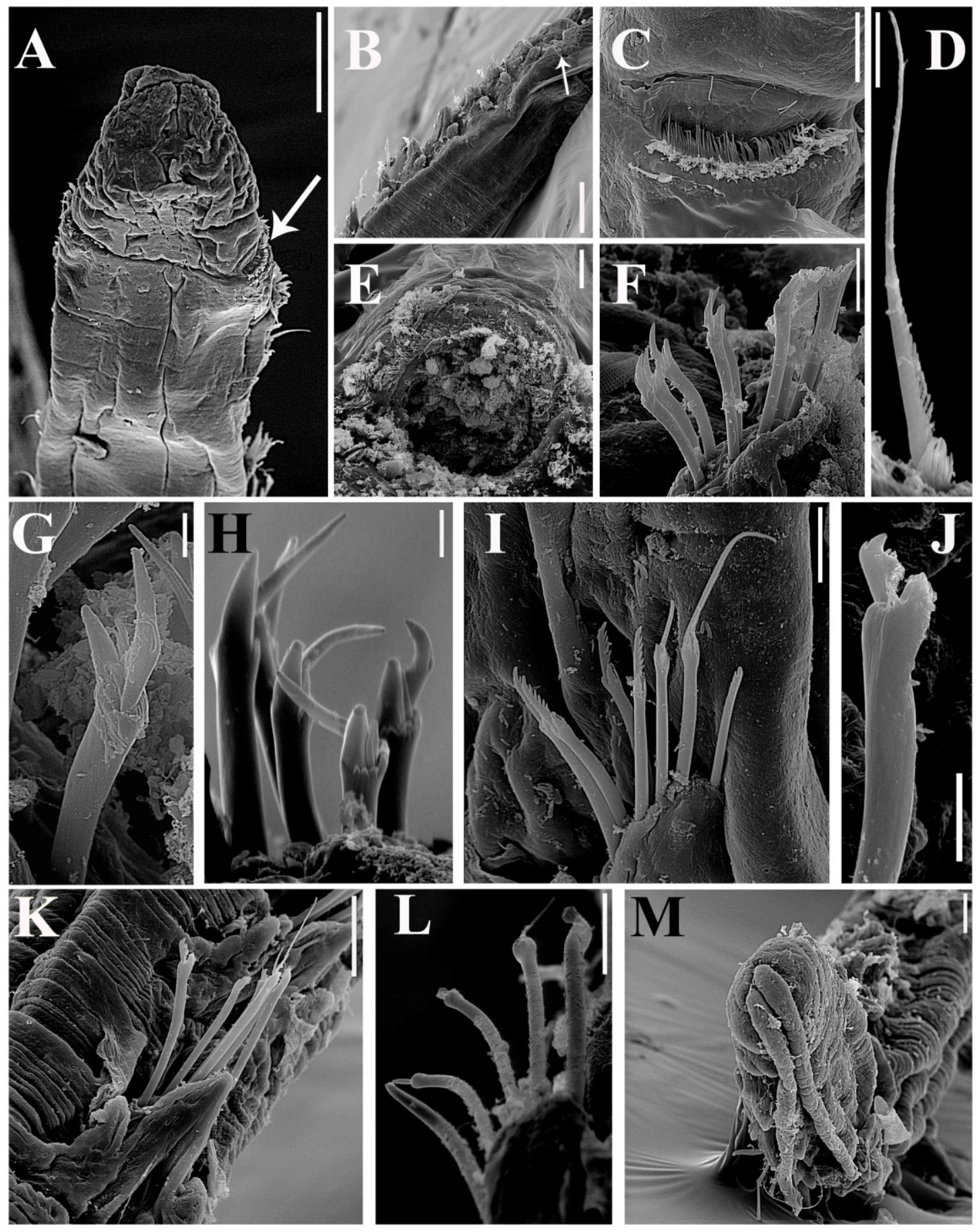

FIGURE 8 


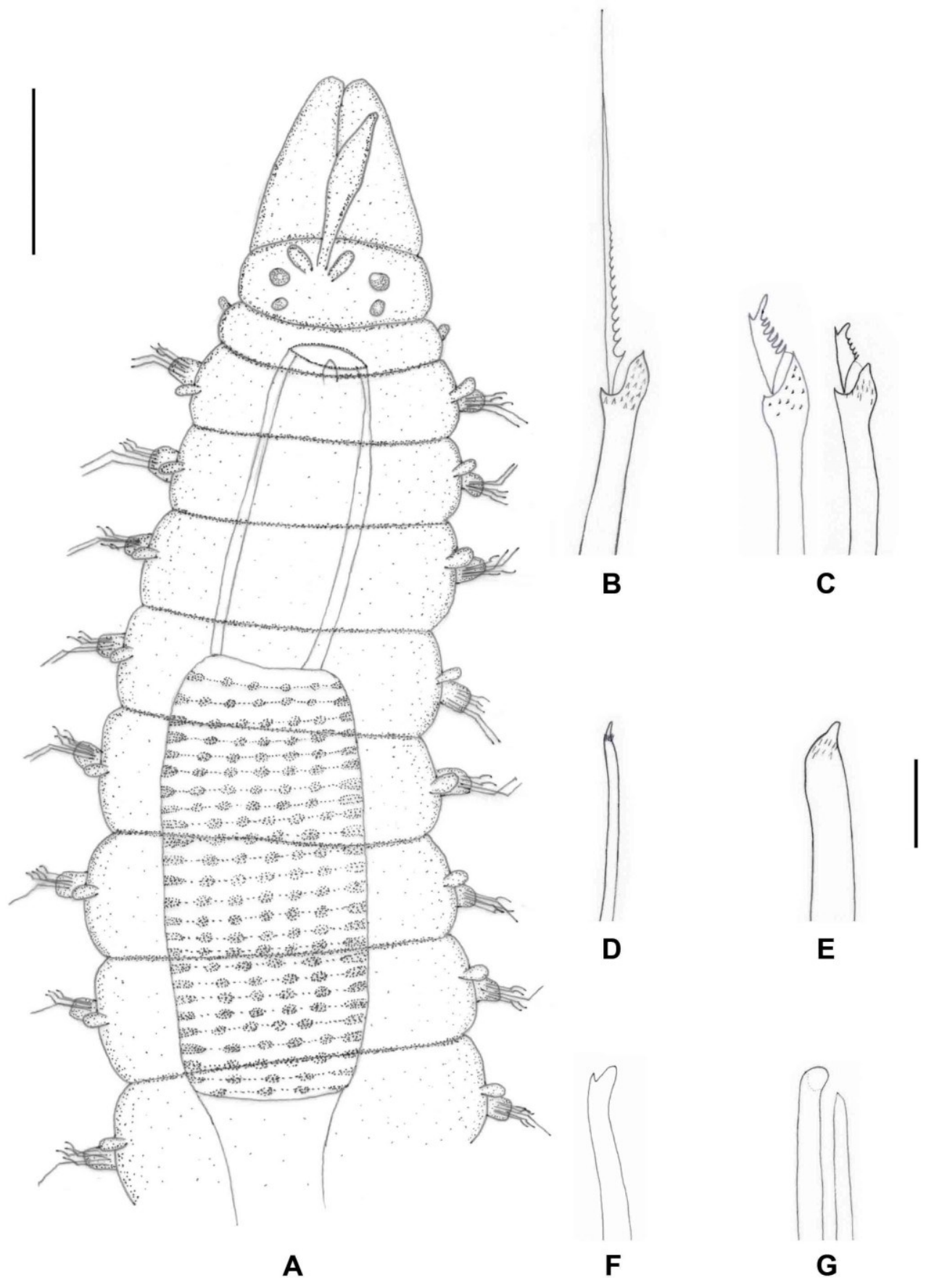

FIGURE 9 

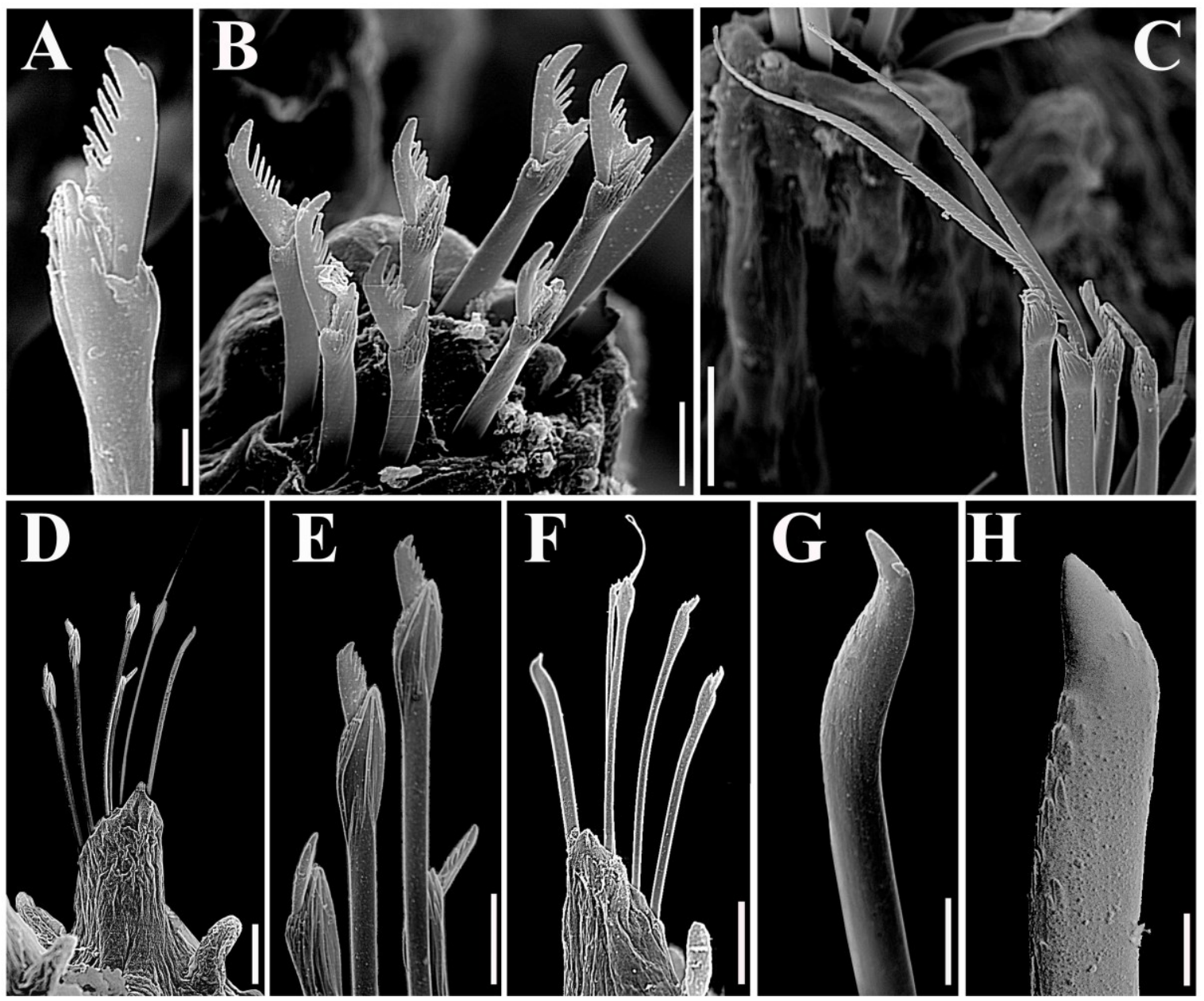

FIGURE 10 


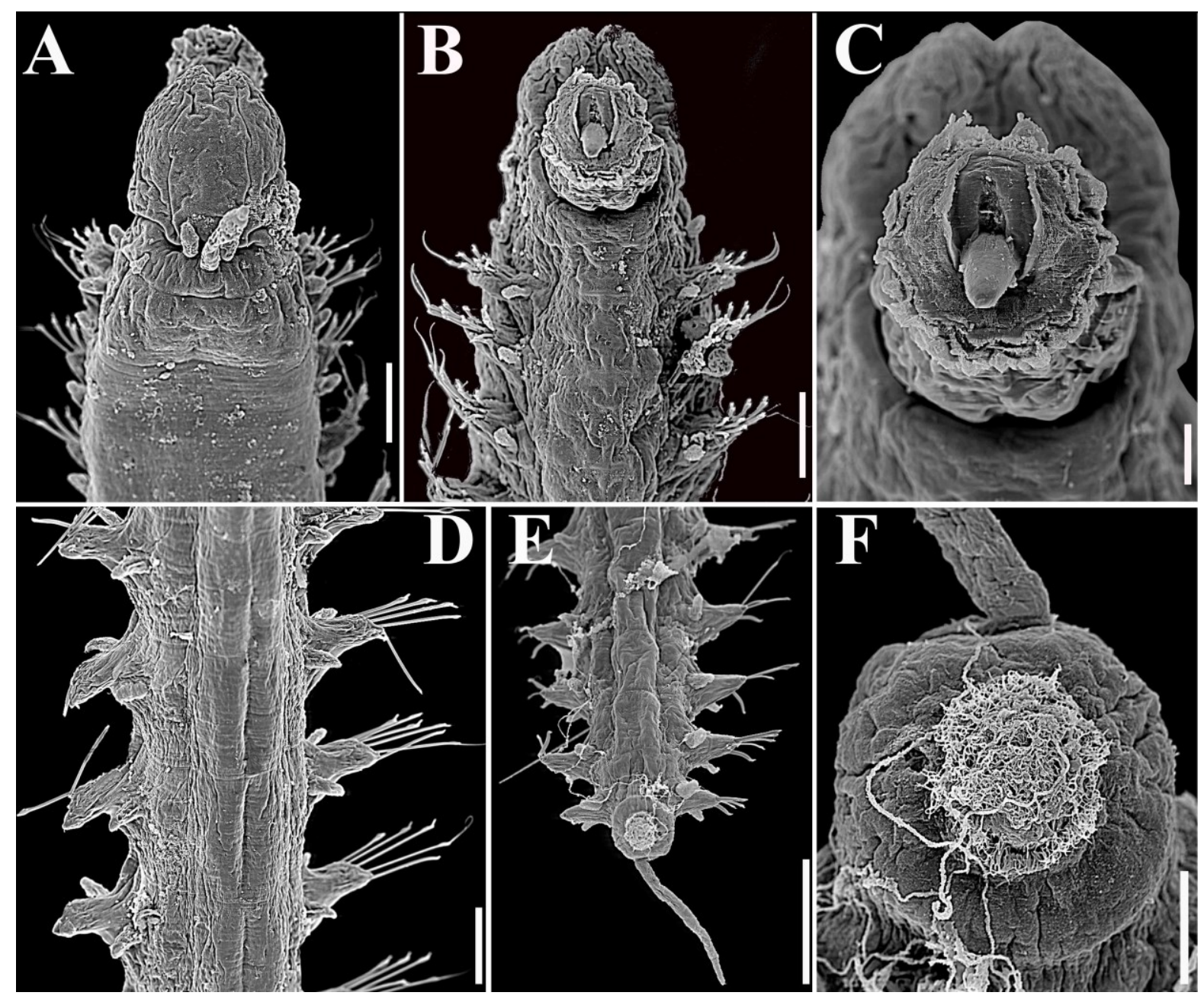

FIGURE 11 


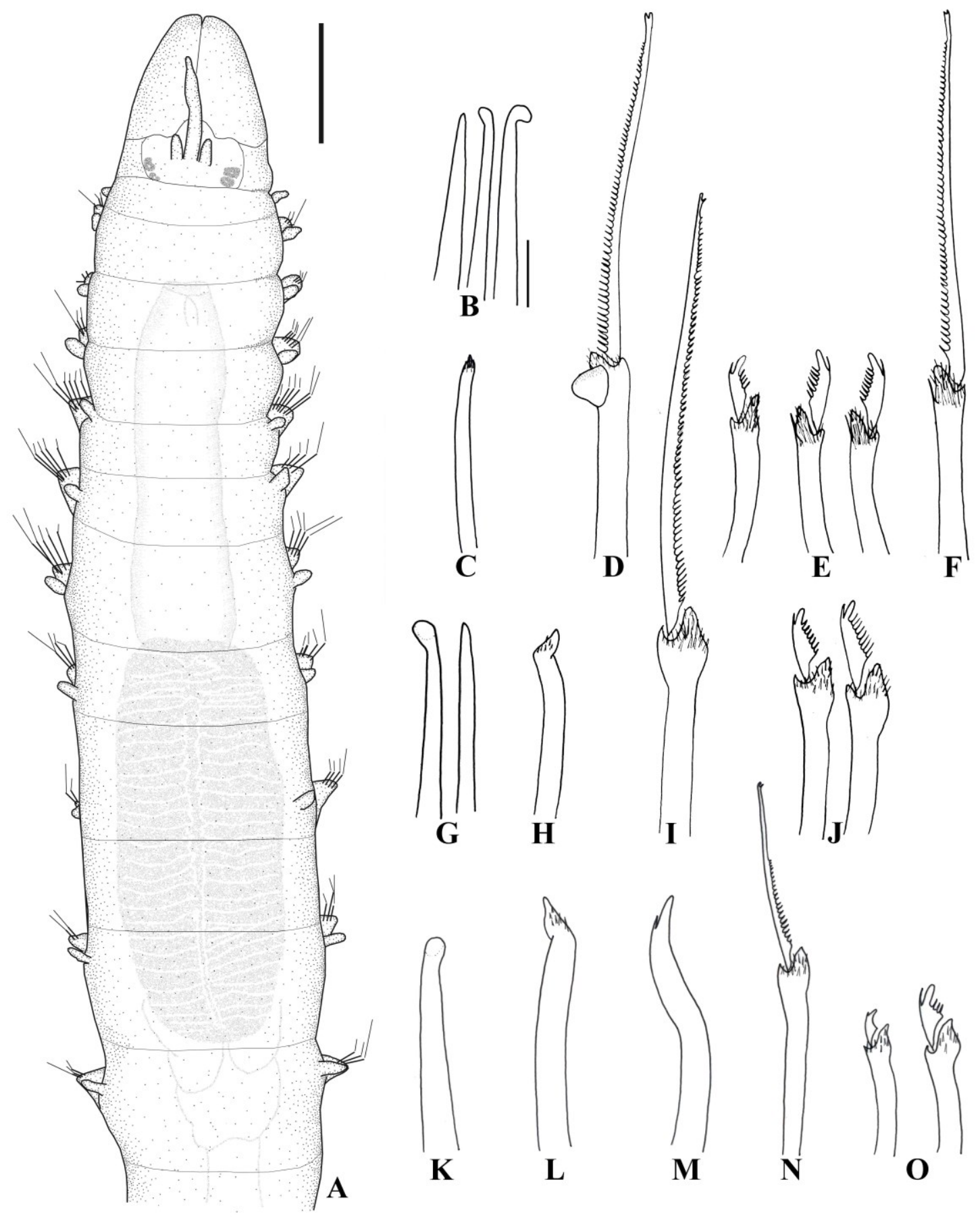

FIGURE 12 

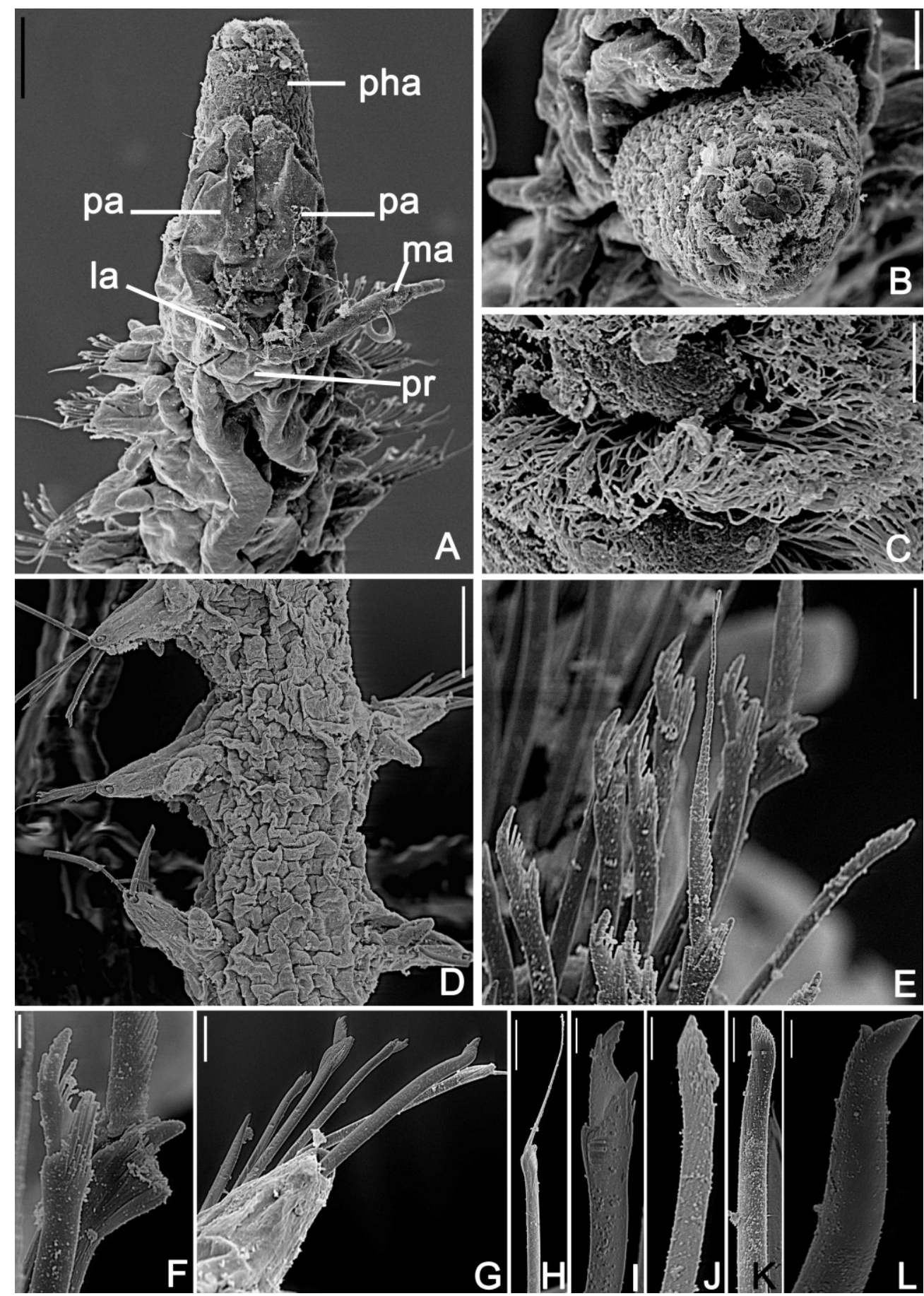

FIGURE 13 


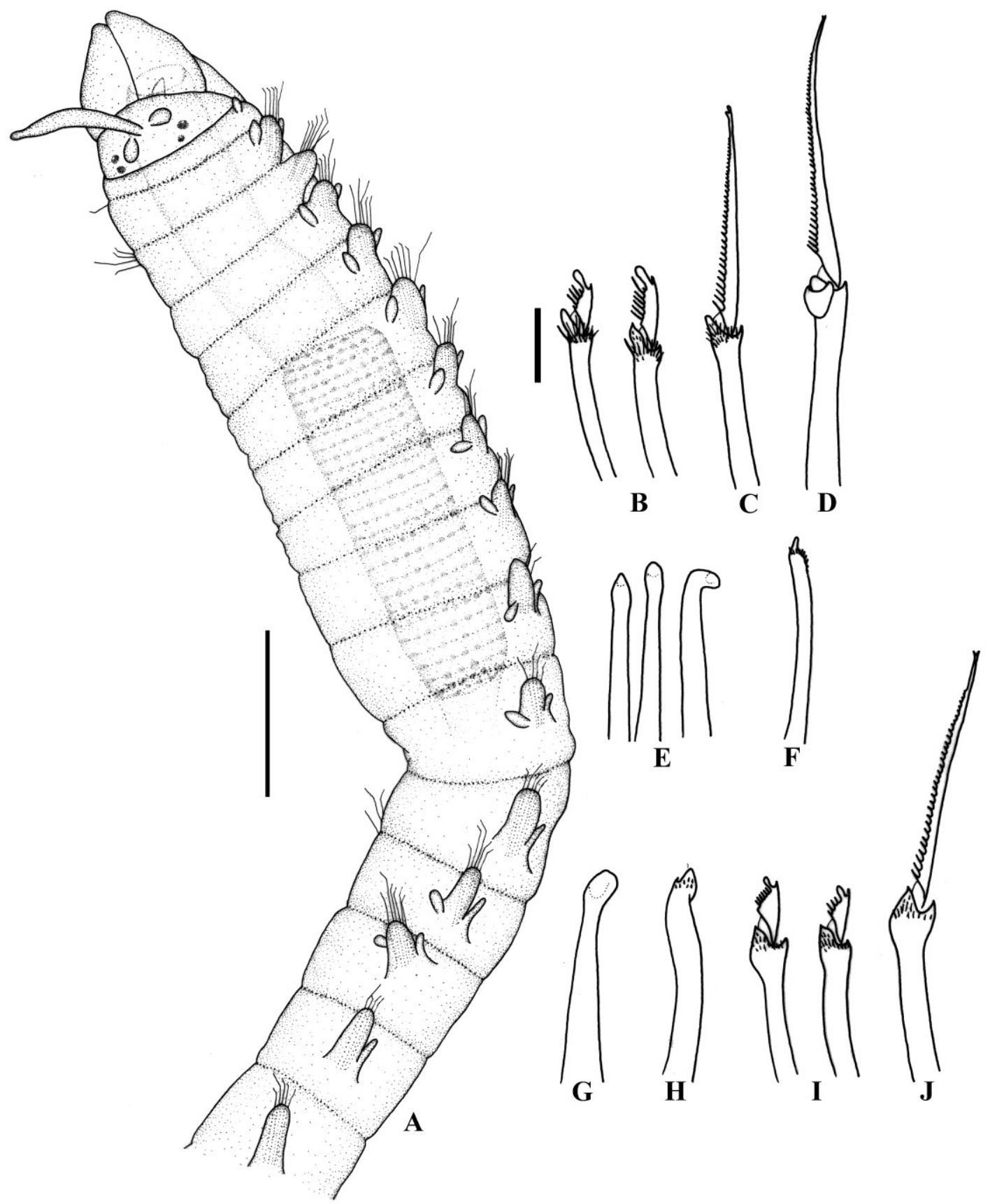

FIGURE 14 

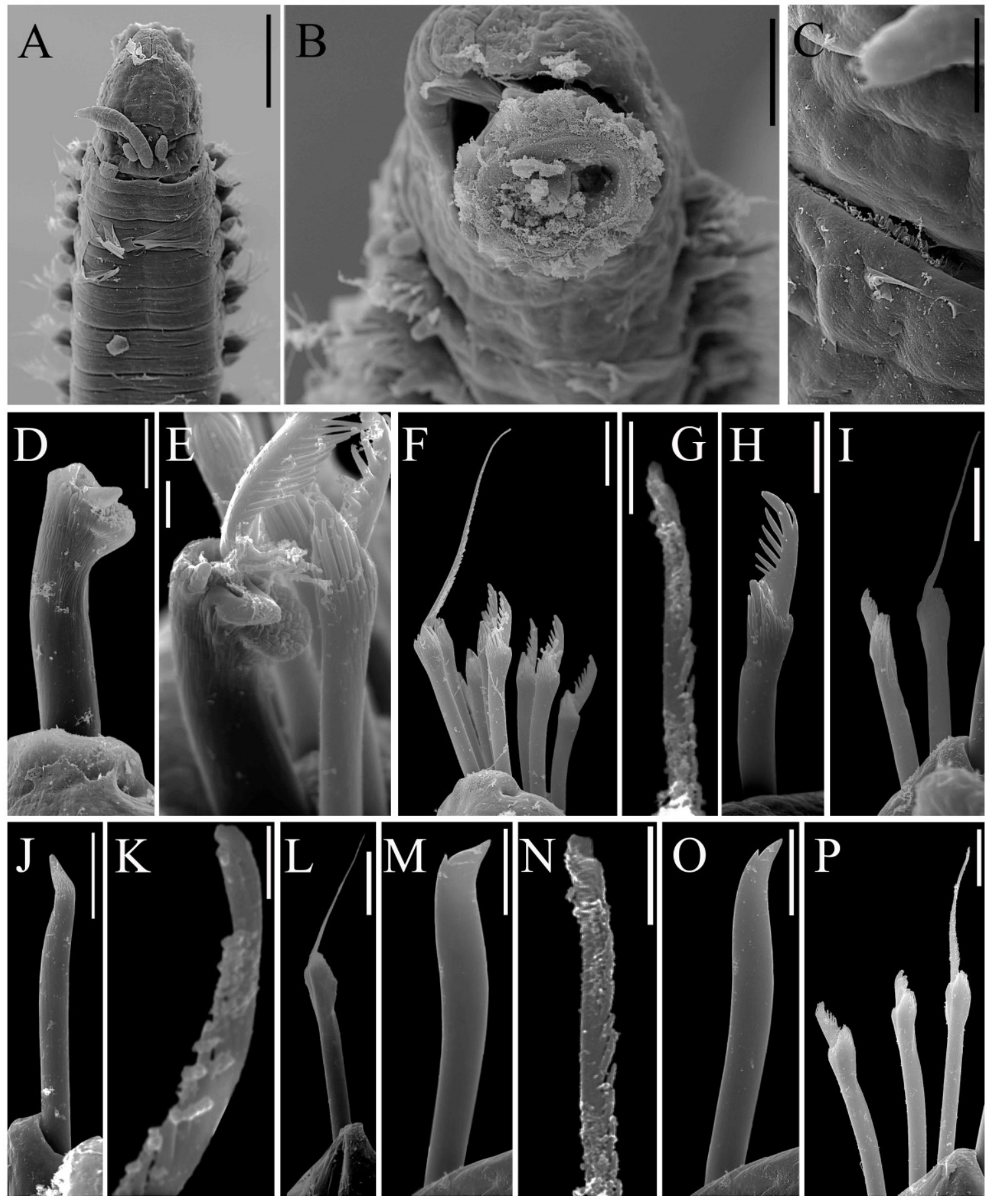

FIGURE 15 


\begin{abstract}
APÊNDICE 4
The genus Haplosyllis Langerhans, 1879 (Polychaeta:

Syllidae) from northeastern Brazil, with descriptions of two new species

Periódico Marine Biology Research
\end{abstract}

Paresque, K. \& Nogueira, J.M.M. (2014) The genus Haplosyllis Langerhans, 1879 (Polychaeta: Syllidae) from off northeastern Brazil, with descriptions of two new species. Marine Biology Research, 10, 554-576.

Manuscrito aceito para publicação 02 de Setembro de 2013

Publicado 03 de Março de 2014 

This article was downloaded by: [Karla Paresque]

On: 05 March 2014, At: 14:33

Publisher: Taylor \& Francis

Informa Ltd Registered in England and Wales Registered Number: 1072954 Registered office: Mortimer House, 37-41 Mortimer Street, London W1T 3J H, UK

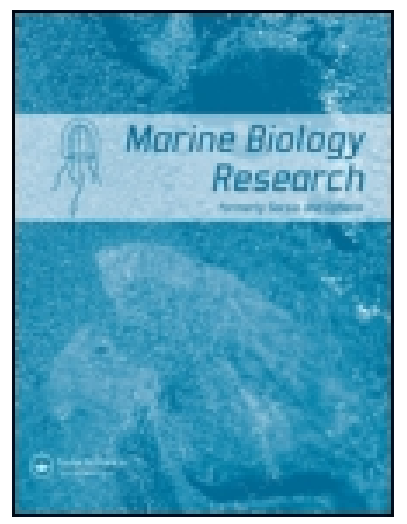

\title{
Marine Biology Research
}

Publication details, including instructions for authors and subscription information: http:// www. tandfonline.com/loi/ smar20

\section{The genus Haplosyllis Langerhans, 1879 (Polychaeta: Syllidae) from northeastern Brazil, with descriptions of two new species}

\author{
Karla Paresque ${ }^{a} \&$ J oão Miguel de Matos Nogueira ${ }^{a}$ \\ a Departamento de Zoologia, Instituto de Biociências, Universidade de São Paulo, São \\ Paulo, Brazil \\ Published online: 03 Mar 2014.
}

To cite this article: Karla Paresque \& J oão Miguel de Matos Nogueira (2014) The genus Haplosyllis Langerhans, 1879 (Polychaeta: Syllidae) from northeastern Brazil, with descriptions of two new species, Marine Biology Research, 10:6, 554-576, DOI: 10.1080/17451000.2013.841941

To link to this article: http:// dx. doi.org/ 10.1080/17451000.2013.841941

\section{PLEASE SCROLL DOWN FOR ARTICLE}

Taylor \& Francis makes every effort to ensure the accuracy of all the information (the "Content") contained in the publications on our platform. However, Taylor \& Francis, our agents, and our licensors make no representations or warranties whatsoever as to the accuracy, completeness, or suitability for any purpose of the Content. Any opinions and views expressed in this publication are the opinions and views of the authors, and are not the views of or endorsed by Taylor \& Francis. The accuracy of the Content should not be relied upon and should be independently verified with primary sources of information. Taylor and Francis shall not be liable for any losses, actions, claims, proceedings, demands, costs, expenses, damages, and other liabilities whatsoever or howsoever caused arising directly or indirectly in connection with, in relation to or arising out of the use of the Content.

This article may be used for research, teaching, and private study purposes. Any substantial or systematic reproduction, redistribution, reselling, loan, sub-licensing, systematic supply, or distribution in any form to anyone is expressly forbidden. Terms \& Conditions of access and use can be found at http:// www.tandfonline.com/page/terms-and-conditions 


\title{
The genus Haplosyllis Langerhans, 1879 (Polychaeta: Syllidae) from northeastern Brazil, with descriptions of two new species
}

\author{
KARLA PARESQUE^ \& JOÃO MIGUEL DE MATOS NOGUEIRA \\ Departamento de Zoologia, Instituto de Biociências, Universidade de São Paulo, São Paulo, Brazil
}

\begin{abstract}
Two new species of Haplosyllis collected along the coast off northeastern Brazil are described. Haplosyllis amphimedonicola sp. nov. lives in close association with the sponge Amphimedon viridis and is characterized by having midbody dorsal cirri alternating long (with 3-7 articles) and short (with 1-3 articles), with long cirri not reaching half the body width. Ciliated anus dorsally and pair of smooth to irregularly articulated anal cirri; chaetae bidentate, often with eroded tips, main fang about same length or shorter than shaft width, mid-joining point straight and long, upper side of main fang with few, short denticles. Haplosyllis rosenalessoae sp. nov. is characterized by having body wall of midbody to posterior chaetigers with internal iridescent and granulose inclusions, arranged in continuous transverse rows across chaetigers, broader laterally, at base of parapodia, progressively narrower towards dorsal mid-line. Bidentate chaetae, with long and pointed main fang, about same width as shaft, slightly stouter posteriorly. Chaetae on posterior parapodia with apical teeth very close to each other, nearly unidentate at first glance, upper side of main fang smooth; 2-3 aciculae in each midbody parapodium. A table comparing all valid species of Haplosyllis is provided.
\end{abstract}

Key words: New species, taxonomy, southwestern Atlantic, sponge symbionts

\section{Introduction}

Syllidae Grube, 1850 is one of the largest families of polychaetes, currently comprising around 700 species and more than 70 genera (Aguado et al. 2007). The knowledge of the syllid fauna occurring off the Brazilian coast is still poor. Up to the present, only 139 species have been registered for the country (Rullier \& Amoureux 1979; Morgado \& Amaral 1985; Nogueira 2000, 2006; Nogueira et al. 2001, 2004; Nygren \& Gidholm 2001; Nogueira \& San Martín 2002; Fukuda \& Nogueira 2006, 2013; Paiva et al. 2007; Nogueira \& Fukuda 2008; Nogueira \& Yunda-Guarín 2008; Fukuda et al. 2009, 2012, 2013; Fukuda 2010; Amaral et al. 2010; Berlandi et al. 2012). However, this number is still low for the family, considering the diversity of syllids found in other areas which have been studied more thoroughly (San Martín 2003, 2005; San Martín \& López 2003; San Martín \& Hutchings 2006; San Martín et al. 2008, 2010). In addition, most
Brazilian reports have been from the southern/ southeastern coast of the country and the taxa occurring in the other areas off the Brazilian coast are virtually unknown. The northeastern Brazilian coast, for instance, has been very poorly studied so far, with only 17 species of syllids reported (Rullier \& Amoureux 1979; Nogueira \& Yunda-Guarín 2008; Fukuda et al. 2009, 2013).

Haplosyllis Langerhans, 1879 is an easily identifiable genus of syllids, characterized by having simple chaetae throughout, which are uni- and/or bidentate. Haplosyllis spongicola (Grube, 1855), the type species, was first described as a species of Syllis Savigny, 1818 and considered as cosmopolitan, possibly because the original description is very brief and does not mention several characters currently considered important for the taxonomy of the group. Currently, $H$. spongicola is considered a species restricted to the Mediterranean Sea (Lattig \& Martin 2009; Lattig et al. 2010b).

^Correspondence: Karla Paresque, Laboratório de Poliquetologia, Departamento de Zoologia - Instituto de Biociências, Universidade de São Paulo, Rua do Matão, 101 - Travessa 14 CEP: 05508-900, São Paulo, Brazil. E-mail: kparesque@gmail.com

Published in collaboration with the Institute of Marine Research, Norway 
Some species of this genus live in soft bottoms (Granados-Barba et al. 2003; Paiva 2006), but most species of Haplosyllis have been described as living in close association with other marine organisms, on which they frequently feed (Martin \& Britayev 1998). The most common hosts for species of Haplosyllis are sponges (Duarte \& Nalesso 1996; Martin \& Britayev 1998; López et al. 2001; Çinar 2003; Martin et al. 2003; Neves \& Omena 2003), gorgonians (López et al. 1996; Martin et al. 2003), bryozoans (Morgado \& Tanaka 2001), intertidal and sublittoral algae (Çinar 2003; Giangrande et al. 2003; Antoniadou et al. 2004), and seagrasses (Bone \& San Martín 2003; Çinar 2003; Lattig et al. 2007).

Up to the end of the twentieth century, Haplosyllis was considered to consist of 12 species, most of them only known from a few reports, frequently just the original descriptions, while $H$. spongicola was synonymous with about 13 other forms and more than 350 reports worldwide (Licher 1999). At that time, Martin et al. (2003) studied material of $H$. spongicola from 28 different localities all around the world and concluded that it was in fact a 'pseudo-sibling species-complex'. Later, Lattig et al. (2007) redescribed $H$. spongicola based on morphometric and taxonomic data, and Lattig \& Martin (2009) revised the genus through the study of those species which had type material available. Since then, more species have been described from different localities: four from Indonesia (Lattig et al. 2010a), three from Australia (Lattig et al. 2010b), four from the Caribbean (Lattig \& Martin 2011a), and two from the Red Sea and Indian Ocean (Lattig \& Martin 2011b). Haplosyllis is currently represented by 32 valid species.

The differences between species of Haplosyllis, however, are very subtle. Several of those new species recently described were previously identified as $H$. spongicola, and thus it is highly desirable that material from all localities at which $H$. spongicola has been registered be reviewed.

Haplosyllis spongicola is the only species formally registered from off the Brazilian coast. Rullier \& Amoureux (1979) recorded this species as occurring in Atol das Rocas $\left(03^{\circ} 51^{\prime} \mathrm{S}, 33^{\circ} 48^{\prime} \mathrm{W}\right)$ and from off the southern part of the state of Paraíba $\left(07^{\circ} 29^{\prime} \mathrm{S}\right.$, $\left.34^{\circ} 29^{\prime} \mathrm{W}\right)$ to the northern part of Espírito Santo $\left(18^{\circ}\right.$ $\left.51^{\prime} \mathrm{S}, 39^{\circ} 08^{\prime} \mathrm{W}\right)$. Neves \& Omena (2003) studied the fauna occurring on 13 species of sponges (Demospongiae) in Atol das Rocas and found H. spongicola on $65 \%$ of the sponges examined, representing $98 \%$ of the total polychaete fauna associated with those sponges. In southeastern Brazil, this species was found associated with the sponges Mycale (Zygomycale) parishii (Bowerbank, 1875) (Duarte \& Nalesso 1996), Cliona varians (Duchassaing \& Michelotti,
1864) (Stofel et al. 2008), and Mycale (Carmia) microsigmatosa Arndt, 1927 (Ribeiro et al. 2003), the scleractinian coral Mussismilia hispida (Verrill, 1868) (Nogueira 2000), the bryozoan Schizoporella errata (Waters, 1878) (Morgado \& Tanaka 2001) and species of Sargassum (Agardh, 1820) (Fukuda 2010). Finally, Fukuda (2010) studied the syllids from off southeastern Brazil and identified two species of Haplosyllis, one of them new to science and not formally described yet.

In our study of the polychaetes occurring off the state of Paraíba, northeastern Brazil, two new species of Haplosyllis were found, both described here.

\section{Material and methods}

The material examined was collected by the project 'Diversity of Polychaeta (Annelida) on hard substrates off northeastern Brazil states of Paraíba and Pernambuco'. Collections were made at neap tide from reefs off Mataraca (Barra de Camaratuba, $06^{\circ}$ $36^{\prime} \mathrm{S} 34^{\circ} 57^{\prime} \mathrm{W}$ ), Rio Tinto (Barra de Mamanguape, $06^{\circ} 45^{\prime} \mathrm{S}, 34^{\circ} 55^{\prime} \mathrm{W}$ ), Baía da Traição (Ponta da Prainha, $06^{\circ} 41^{\prime} \mathrm{S}, 34^{\circ} 55^{\prime} \mathrm{W}$ ), Cabedelo (Píer de Cabedelo, $06^{\circ} 58^{\prime} \mathrm{S}, 34^{\circ} 50^{\prime} \mathrm{W}$ ), João Pessoa (Praia de Cabo Branco, $07^{\circ} 08^{\prime} \mathrm{S}, 34^{\circ} 47^{\prime} \mathrm{W}$ ), and Conde (Praia de Jacumã, $07^{\circ} 14^{\prime} \mathrm{S}, 34^{\circ} 47^{\prime} \mathrm{W}$, Praia de Carapibus, $07^{\circ} 17^{\prime} \mathrm{S}, 34^{\circ} 48^{\prime} \mathrm{W}$, Praia de Coqueirinho, $07^{\circ} 18^{\prime} \mathrm{S}$, $34^{\circ} 47^{\prime} \mathrm{W}$, and Praia de Tabatinga, $07^{\circ} 19^{\prime} \mathrm{S}, 34^{\circ} 47^{\prime} \mathrm{W}$ ). Algae, sponges, ascidians, mussel beds and similar substrates were scraped from the rocks and examined under a stereo microscope; syllids were sorted, relaxed in menthol solution, preserved in $4 \%$ formalin solution, and later rinsed in fresh water and transferred to $70 \%$ ethanol. Several specimens were preserved directly in $98 \%$ ethanol for future molecular studies.

Further analyses under stereo and compound light microscopes were made from specimens preserved in ethanol, some of which were permanently mounted on slides in glycerine jelly. For examinations in the scanning electron microscope (SEM), at least one specimen of each species was dehydrated in a series of progressively increasing concentrations of ethanol, then critical point-dried, coated with $25 \mathrm{~nm}$ of gold and examined and photographed under SEM at Laboratório de Microscopia Eletrônica, Instituto de Biociências, Universidade de São Paulo (IB/USP). Line drawings were made with the aid of a drawing tube, from slide-mounted specimens.

The nomenclature used for chaetal morphology follows that suggested by Martin et al. (2003) and Lattig \& Martin (2009). The chaetal characters used in descriptions and Tables I and II are: 
Table I. Morphological features of the type series of Haplosyllis amphimedonicola sp. $\mathrm{n}$.

\begin{tabular}{|c|c|c|c|c|c|c|c|c|c|c|c|}
\hline & $\begin{array}{c}\text { Holotype } \\
\text { ZUEC-POL } \\
10099\end{array}$ & $\begin{array}{c}\text { Paratype } 1 \\
\text { ZUEC-POL } \\
10100\end{array}$ & $\begin{array}{c}\text { Paratype } 2 \\
\text { ZUEC-POL } \\
10101\end{array}$ & $\begin{array}{c}\text { Paratype } 3 \\
\text { ZUEC-POL } \\
10102\end{array}$ & $\begin{array}{c}\text { Paratype } 4 \\
\text { MNCN 16.01/ } \\
14625\end{array}$ & $\begin{array}{c}\text { Paratype } 5 \\
\text { MNCN } 16.01 / \\
14626\end{array}$ & $\begin{array}{c}\text { Paratype } 6 \\
\text { MZUSP } \\
1372\end{array}$ & $\begin{array}{c}\text { Paratype } 7 \\
\text { MZUSP } \\
1373\end{array}$ & $\begin{array}{c}\text { Paratype } 8 \\
\text { MZUSP } \\
1253\end{array}$ & $\begin{array}{c}\text { Paratype } 9 \\
\text { MZUSP } \\
1254\end{array}$ & $\begin{array}{c}\text { Paratype } 10 \\
\text { MZUSP } \\
1255\end{array}$ \\
\hline Body length (mm) & 4.3 & 5.2 & 4.1 & 4.8 & 3.7 & 4.2 & 6.7 & 4.0 & 4.6 & 3.4 & 3.9 \\
\hline $\begin{array}{l}\text { Body length until } \\
\text { chaetiger } 10(\mathrm{~mm})\end{array}$ & 1.1 & 1.0 & 1.3 & 1.2 & 1.2 & 0.9 & 1.3 & 1.1 & 1.0 & 1.0 & 1.2 \\
\hline Body width (mm) & 0.3 & 0.3 & 0.4 & 0.3 & 0.4 & 0.4 & 0.3 & 0.3 & 0.3 & 0.3 & 0.3 \\
\hline $\begin{array}{l}\text { Number of } \\
\text { chaetigers }\end{array}$ & 40 & 48 & 37 & 45 & 41 & 44 & 53 & 40 & 45 & 36 & 39 \\
\hline \multicolumn{12}{|l|}{ Proventricle } \\
\hline Length (mm) & 0.61 & 0.63 & 0.62 & 0.64 & 0.55 & 0.51 & 0.58 & 0.57 & 0.53 & 0.44 & 0.55 \\
\hline $\begin{array}{l}\text { Number of } \\
\text { chaetigers }\end{array}$ & 6 & 6 & 5.5 & 5.5 & 5 & 5 & 4.5 & 5.5 & 5 & 4.0 & 4.5 \\
\hline $\begin{array}{l}\text { Number of rows } \\
\text { of muscle cells }\end{array}$ & 41 & 43 & 46 & 42 & 44 & 38 & 41 & 44 & 40 & 39 & 40 \\
\hline \multicolumn{12}{|l|}{ Pharynx length } \\
\hline $\begin{array}{l}\text { Number of } \\
\text { chaetigers }\end{array}$ & 7 & 9 & 8 & 8 & 7 & 8 & 7.5 & 7 & 5 & 6 & 7 \\
\hline \multicolumn{12}{|l|}{ Number of articles } \\
\hline Median antenna & 18 & 14 & 14 & 15 & 18 & 14 & 11 & 15 & 16 & 13 & 16 \\
\hline Lateral antennae & 11,8 & 10,11 & 11,11 & 11,10 & 11,11 & 11,9 & 13,12 & 11,12 & 11,10 & 11,11 & 11,11 \\
\hline $\begin{array}{l}\text { Peristomial dorsal } \\
\text { cirri }\end{array}$ & $15, ?$ & ?, ? & $15, ?$ & $15, ?$ & 15,16 & 10,8 & 16,14 & 14,12 & 15,15 & 13,14 & 15 \\
\hline $\begin{array}{l}\text { Peristomial } \\
\text { ventral cirri }\end{array}$ & $9, ?$ & 9 , ? & 9 , ? & $8, ?$ & $?$ & 8 , ? & 9,9 & ?, 9 & 8,8 & 8,8 & 9 , ? \\
\hline Dorsal cirri 1 & 19 , ? & 14 , ? & 19 , ? & 18 , ? & 18,16 & 19 , ? & 19,14 & 17,17 & 18,18 & 14,16 & 16,18 \\
\hline Dorsal cirri 2 & $8, ?$ & 7,9 & $8, ?$ & $8, ?$ & 8,7 & $8, ?$ & 8,7 & 7,8 & 8,9 & 6 , ? & 9,7 \\
\hline Dorsal cirri 3 & 11 , ? & 10 , ? & 9 , ? & 10 ? & 10,10 & 8 , ? & 10,11 & 9,9 & 8,9 & 8,8 & 8,10 \\
\hline Dorsal cirri 4 & 12 , ? & $11, ?$ & $10, ?$ & $8, ?$ & 12,5 & 11 , ? & 11,12 & 12,11 & 9,12 & 9,11 & 12,10 \\
\hline Dorsal cirri 5 & $8, ?$ & $6, ?$ & $7, ?$ & 7 , ? & 6,5 & $6, ?$ & 10,7 & 7,7 & 6,7 & $5, ?$ & 7,7 \\
\hline Dorsal cirri 6 & 12,11 & 8,10 & 10 , ? & 10 , & 11,9 & 10 , ? & 10,10 & 11,11 & 10,11 & 9 , ? & 10,10 \\
\hline Dorsal cirri 7 & 6,7 & $5, ?$ & $6, ?$ & $6, ?$ & 5,4 & $6, ?$ & 7,6 & 5,11 & 6,6 & 6,4 & 6,6 \\
\hline Dorsal cirri 8 & 5,5 & $5, ?$ & 5 , ? & 6 , ? & 3, ? & 5 , ? & 7,6 & 5,6 & 4,4 & 4,4 & 5,6 \\
\hline $\begin{array}{l}\text { Long cirri, } \\
\text { midbody }\end{array}$ & $3-5$ & $4-6$ & $5-7$ & $4-6$ & $5-7$ & $4-6$ & $4-6$ & $4-6$ & $4-6$ & $4-7$ & $4-6$ \\
\hline $\begin{array}{l}\text { Short cirri, } \\
\text { midbody }\end{array}$ & $1-3$ & 2 & $1-3$ & $1-3$ & $2-3$ & $2-3$ & $2-3$ & $2-3$ & $1-3$ & $1-3$ & $1-3$ \\
\hline
\end{tabular}

? Missing data. 
Table II. Morphological features of the type series of Haplosyllis rosenalessoae sp. nov.

\begin{tabular}{|c|c|c|c|c|c|c|c|c|c|c|c|}
\hline & $\begin{array}{c}\text { Holotype } \\
\text { ZUEC-POL } \\
10094\end{array}$ & $\begin{array}{c}\text { Paratype } 1 \\
\text { ZUEC-POL } \\
10095\end{array}$ & $\begin{array}{c}\text { Paratype } 2 \\
\text { ZUEC-POL } \\
10096\end{array}$ & $\begin{array}{c}\text { Paratype } 3 \\
\text { ZUEC-POL } \\
10097\end{array}$ & $\begin{array}{c}\text { Paratype } 4 \\
\text { MNCN 16.01/ } \\
14627\end{array}$ & $\begin{array}{c}\text { Paratype } 5 \\
\text { MNCN 16.01/ } \\
14628\end{array}$ & $\begin{array}{c}\text { Paratype } 6 \\
\text { MZUSP } \\
1374\end{array}$ & $\begin{array}{c}\text { Paratype } 7 \\
\text { MZUSP } \\
1375\end{array}$ & $\begin{array}{c}\text { Paratype } 8 \\
\text { MZUSP } \\
1268\end{array}$ & $\begin{array}{c}\text { Paratype } 9 \\
\text { MZUSP } \\
1269\end{array}$ & $\begin{array}{c}\text { Paratype } 10 \\
\text { MZUSP } \\
1270\end{array}$ \\
\hline Body length (mm) & 7.4 & 8.4 & 6.4 & 9.0 & 6.9 & 4.7 & 9.7 & 7.9 & 7.4 & 6.4 & 7.0 \\
\hline $\begin{array}{l}\text { Body length until } \\
\text { chaetiger } 10(\mathrm{~mm})\end{array}$ & 1.5 & 1.6 & 1.5 & 1.6 & 1.5 & 1.6 & 1.8 & 1.6 & 1.5 & 1.6 & 1.6 \\
\hline Body width (mm) & 0.4 & 0.3 & $?$ & 0.4 & 0.4 & 0.3 & 0.3 & 0.3 & 0.3 & 0.4 & 0.4 \\
\hline $\begin{array}{l}\text { Number of } \\
\text { chaetigers }\end{array}$ & 50 & 61 & 45 & 58 & 40 inc. & 25 inc. & 52 & 43 & 41 inc. & 34 inc. & 36 inc. \\
\hline \multicolumn{12}{|l|}{ Proventricle } \\
\hline Length (mm) & 0.88 & 0.83 & 0.60 & 0.80 & 0.85 & 0.91 & 0.70 & 0.94 & 0.85 & 0.78 & 0.90 \\
\hline $\begin{array}{l}\text { Number of } \\
\text { chaetigers }\end{array}$ & 6 & 5 & 4.5 & 4 & 5.5 & 5.5 & 4 & 5 & 5 & 5 & 4 \\
\hline $\begin{array}{l}\text { Number of rows } \\
\text { of muscle cells }\end{array}$ & 48 & 45 & 46 & 42 & 42 & 43 & $?$ & 47 & 44 & 40 & 43 \\
\hline \multicolumn{12}{|l|}{ Pharynx length } \\
\hline $\begin{array}{l}\text { Number of } \\
\text { chaetigers }\end{array}$ & 9 & 9 & 6 & 8 & 8 & 6 & 7 & 7 & 8.5 & 7.5 & 8 \\
\hline \multicolumn{12}{|l|}{ Number of articles } \\
\hline Median antenna & 20 & ? & 18 & 17 & 21 & ? & 16 & 21 & ? & 19 & 22 \\
\hline Lateral antennae & 13,13 & $13, ?$ & $12, ?$ & 12,12 & 12,12 & 14,14 & 13 & $14, ?$ & 13,13 & 14,15 & 15,13 \\
\hline $\begin{array}{l}\text { Peristomial dorsal } \\
\text { cirri }\end{array}$ & 19,17 & 16 , ? & $16, ?$ & 16,18 & 18,17 & 21,17 & 11,14 & ?, ? & 17 , ? & 18,17 & 18,19 \\
\hline $\begin{array}{l}\text { Peristomial } \\
\text { ventral cirri }\end{array}$ & $10, ?$ & 10 , ? & 8 , ? & 9 , ? & $10, ?$ & $12, ?$ & 10,9 & $11, ?$ & ?, ? & 9,11 & 11,10 \\
\hline Dorsal cirri 1 & 25,21 & 18,16 & 20 , ? & 23,20 & 22,21 & 24,25 & 18,18 & $25, ?$ & ?, ? & 20,19 & 25,22 \\
\hline Dorsal cirri 2 & 11,11 & 10,10 & $8, ?$ & 11,12 & 11,10 & 11,11 & 10,8 & 12,11 & ?, ? & 11,12 & 13,13 \\
\hline Dorsal cirri 3 & 12,13 & 13,13 & 12 , ? & $13, ?$ & 16,15 & 21,16 & 13,10 & $16, ?$ & ?, ? & 14,12 & 16,16 \\
\hline Dorsal cirri 4 & 17,16 & 14,13 & 14 , ? & 16,14 & 18,18 & 18,20 & 14,14 & 19,17 & 14,15 & 15,18 & 20,20 \\
\hline Dorsal cirri 5 & 10,10 & 11,8 & 10 , ? & 12,9 & 11,10 & 10,11 & 11,11 & 13,12 & 11,11 & 10,11 & 12,13 \\
\hline Dorsal cirri 6 & 12,8 & 12,13 & $12, ?$ & 15,15 & 17,12 & 18 , ? & 13,13 & 17,15 & $15, ?$ & 13,15 & 16,18 \\
\hline Dorsal cirri 7 & 8,7 & 6,10 & $8, ?$ & 11,11 & 8,10 & $10, ?$ & 8,9 & 11,11 & 11,12 & 11,11 & 12,12 \\
\hline Dorsal cirri 8 & 8,8 & 8,5 & 6 , ? & 10,9 & $9, ?$ & 9,11 & 7,6 & 11,11 & 11,10 & 10,10 & 12,12 \\
\hline $\begin{array}{l}\text { Long cirri, } \\
\text { midbody }\end{array}$ & $9-10$ & $8-11$ & $8-8$ & $9-13$ & $11-13$ & $11-13$ & $8-11$ & $10-13$ & $9-11$ & $9-11$ & $10-13$ \\
\hline $\begin{array}{l}\text { Short cirri, } \\
\text { midbody }\end{array}$ & $5-6$ & $5-6$ & $4-5$ & $6-8$ & $5-8$ & $6-7$ & $4-7$ & $7-8$ & $6-7$ & $5-8$ & $7-8$ \\
\hline
\end{tabular}

? Missing data, inc. $=$ incomplete. 
- length of main fang, similar in length or longer than chaetal width;

- upper side of main fang with or without denticles;

- mid-joining point between apical teeth and main fang curved (usually short) or straight (at right angle with main fang, short or long); and

- proximal and distal apical teeth equal in size or one of them larger than the other.

Along with the descriptions, measurements were made from the entire type series and comparative tables are provided. Data on holotypes are shown between parentheses after the range of variation for each character; when two measurements are provided, they refer to differences between left and right sides of the body, as for number of articles of dorsal cirri, for instance.

A comparative table between all currently known species of Haplosyllis is also provided (Table III).

Type material is deposited at the Museu de História Natural (ZUEC), IB-UNICAMP, Brazil; Museu de Zoologia da Universidade de São Paulo (MZUSP), Brazil; Museo Nacional de Ciéncias Naturales (MNCN), Spain.

\section{Taxonomy}

Family Syllidae Grube, 1850

Subfamily Syllinae Grube, 1850

Genus Haplosyllis Langerhans, 1887

Haplosyllis amphimedonicola sp. nov.

(Figures 1-4; Table I)

\section{Holotype}

ZUEC-POL 10099, State of Paraíba, Rio Tinto, Barra de Mamanguape $\left(06^{\circ} 45^{\prime} \mathrm{S}, 34^{\circ} 55^{\prime} \mathrm{W}\right)$, intertidal, within Amphimedon viridis Duchassaing \& Michelotti, 1864, coll. 11 Aug 2010.

\section{Paratypes}

ZUEC-POL 10100, ZUEC-POL 10101, ZUECPOL 10102, MZUSP 1253, MZUSP 1254, MZUSP 1255, MZUSP 1372, MZUSP 1373, MNCN 16.01/ 14625 and MNCN 16.01/14626: State of Paraíba, Rio Tinto, Barra de Mamanguape $\left(06^{\circ} 45^{\prime} \mathrm{S}\right.$, $34^{\circ} 55^{\prime}$ W), intertidal, within $A$. viridis, coll. 11 Aug 2010 .

\section{Additional material examined}

State of Paraíba, on sandstone reefs, intertidal: Mataraca, Barra de Camaratuba $\left(06^{\circ} 36^{\prime} \mathrm{S}\right.$, $34^{\circ} 57^{\prime}$ W): 30 specs, coll. 12 Aug 2010 (MZUSP 1256). Rio Tinto, Barra de Mamanguape $\left(06^{\circ} 45^{\prime} \mathrm{S}\right.$, $34^{\circ} 55^{\prime}$ W): 36 specs, coll. 11 Aug 2010 (MZUSP 1257); 70 specs, within $A$. viridis, coll. 11 Aug 2010 (MZUSP
1258). Conde, Praia de Jacumã $\left(07^{\circ} 14^{\prime} \mathrm{S}, 34^{\circ} 47^{\prime} \mathrm{W}\right)$ : 2 specs, coll. 29 Jan 2010 (MZUSP 1259); Praia de Carapibus $\left(07^{\circ} 17^{\prime} \mathrm{S}, 34^{\circ} 48^{\prime} \mathrm{W}\right): 1$ spec., coll. 10 Feb 2009 (MZUSP 1260); Praia de Coqueirinho $\left(07^{\circ} 18^{\prime} \mathrm{S}, 34^{\circ} 47^{\prime} \mathrm{W}\right): 1$ spec., within $A$. viridis, coll. 28 Aug 2011 (MZUSP 1261); Praia de Tabatinga $\left(07^{\circ} 19^{\prime} \mathrm{S}, 34^{\circ} 47^{\prime} \mathrm{W}\right)$ : 18 specs, within $A$. viridis, coll. 1 Sep 2011 (MZUSP 1262).

\section{Comparative material examined}

Haplosyllis niphatesicola Lattig \& Martin, 2011: 10 specs (MNCN 16.01/13201), Belize, $15 \mathrm{~m}$, coll. 27 Dec 1999 by E. Ballesteros.

\section{Description}

Small to medium-sized syllines, 3-7 (4.3) $\mathrm{mm}$ long, 0.3-0.4 (0.3) $\mathrm{mm}$ wide at proventricle, excluding parapodia, with 36-53 (40) segments (Table I), translucent, slender. Diffused, irregularly distributed dark brown pigmentation, faint in mounted specimens, more conspicuous on prostomium and at base of dorsal cirri; pigmentation absent in some specimens. Dorsal and ventral surfaces with irregularly distributed pores, possibly glandular openings, only visible under SEM (Figure 3A-C). Triangular, distally rounded palps, fused at their bases (Figures $1 \mathrm{~A}, 2 \mathrm{~A}, \mathrm{~B})$; palps with paired ciliated organ ventrally, right above mouth, possibly sensorial (Figure 2D,E). Sub-pentagonal prostomium, shorter than palps, with two pairs of eyes in trapezoidal arrangement; anterior ocular spots absent; antennae longer than palps; median antenna inserted between posterior eyes or slightly anteriorly, with 11-18 (17) articles; lateral antennae inserted at anterior margin of prostomium, 8-13 (12) articles, shorter than median antenna (Figures 1A, 2A; Table III). Ciliated nuchal organs between prostomium and peristomium, only visible under SEM (Figures 2F, 4D). Peristomium shorter than following chaetigers, dorsally inconspicuous; dorsal peristomial cirri with 8-16 (15) articles, shorter than median antenna; ventral peristomial cirri with 8-9 (9) articles (Table I). Dorsal cirri of chaetiger 1 longer than following cirri, with 14-19 (19) articles; shortest dorsal cirri on chaetigers 2 and 5, with 5-9 (8, 8) articles; dorsal cirri of chaetigers 3, 4 and 6 of intermediate size, with $5-12(11,8,8$, respectively) articles; following cirri alternating long, with 3-7 (35) articles, and short, with 1-3 (1-3) articles, long cirri distinctly shorter than half body width at corresponding chaetiger (Figure 3A,B); posterior dorsal cirri short, with 1-2 (1-2) articles (Figure 3C; Table I). Oval ventral cirri, inserted at bases of parapodia, slightly longer than parapodial lobes on anterior body, posteriorly shorter. Conical parapodial 


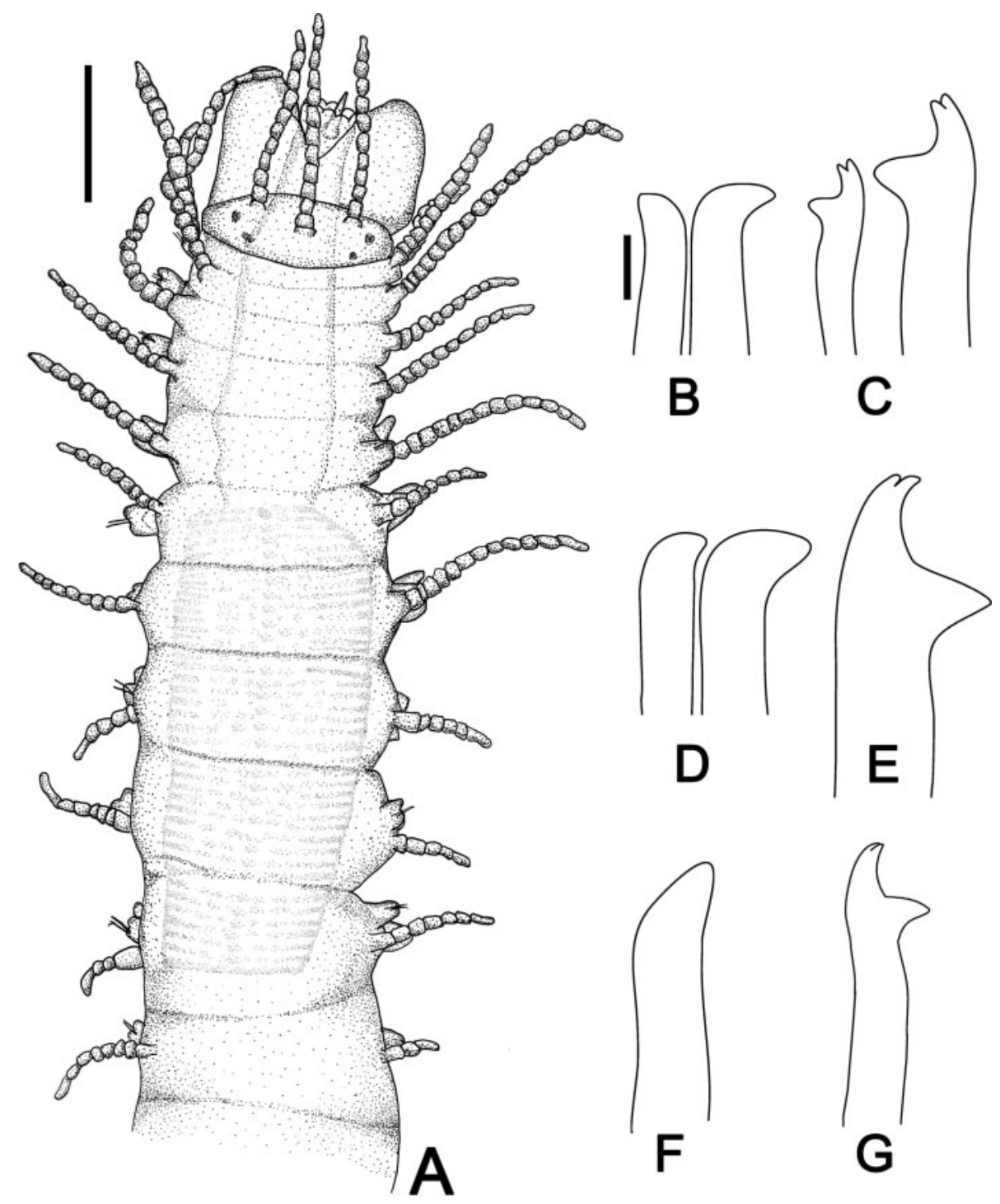

Figure 1. Haplosyllis amphimedonicola sp. nov. A: anterior end, dorsal view; B,D,F: anterior, mid- and posterior body aciculae, respectively; C,E,G: anterior, mid- and posterior body chaetae, respectively. Scale bars: A $=200 \mu \mathrm{m}$; B-G $=5 \mu \mathrm{m}$.

lobes (Figure 3C), with 1-2 chaetae each throughout body; chaetae on same parapodium of similar shape, but different sizes. Anterior parapodia with bidentate chaetae, apical teeth about same size, with oblique, upwardly directed tip (Figures 1C, 3E), main fang about same length as shaft width, mid-joining point straight and long, upper side of main fang with few, short denticles, only visible under SEM (Figure 3E); mid- (Figures 1E, 3F) and posterior body chaetae (Figures 1G, 3G) stouter, bidentate, proximal tooth shorter, teeth often with eroded tips, inconspicuous under optical microscope; main fang shorter than shaft width, longest on midbody, then progressively shorter, mid-joining point straight and relatively long, upper side of main fang with few, short denticles, only visible under SEM, frequently eroded (Figure 3F, G).
Two aciculae per parapodium in anterior and midbody chaetigers (Figure 1B,D), single acicula per parapodium in proventricular and posterior chaetigers; aciculae subdistally curved almost at right angle, with oblique tip; aciculae progressively stouter posteriorwards (Figure 1F), thicker than chaetae of same parapodium. Semicircular pygidium, with ciliated anus dorsally and pair of smooth to irregularly articulated anal cirri of variable length, up to 5 times as long as posterior dorsal cirri (Figure 3D). Pharynx extending for 5-9 (7) chaetigers (Figure 1A; Table I), tooth at anterior border; anterior margin of pharynx surrounded by crown of 10 papillae with fringe of cilia (Figure 2B,C); proventricle 0.44-0.64 (0.61) $\mathrm{mm}$ long, extending for 4-6 (6) chaetigers, with 38-46 (41) rows of muscle cells (Table I). 

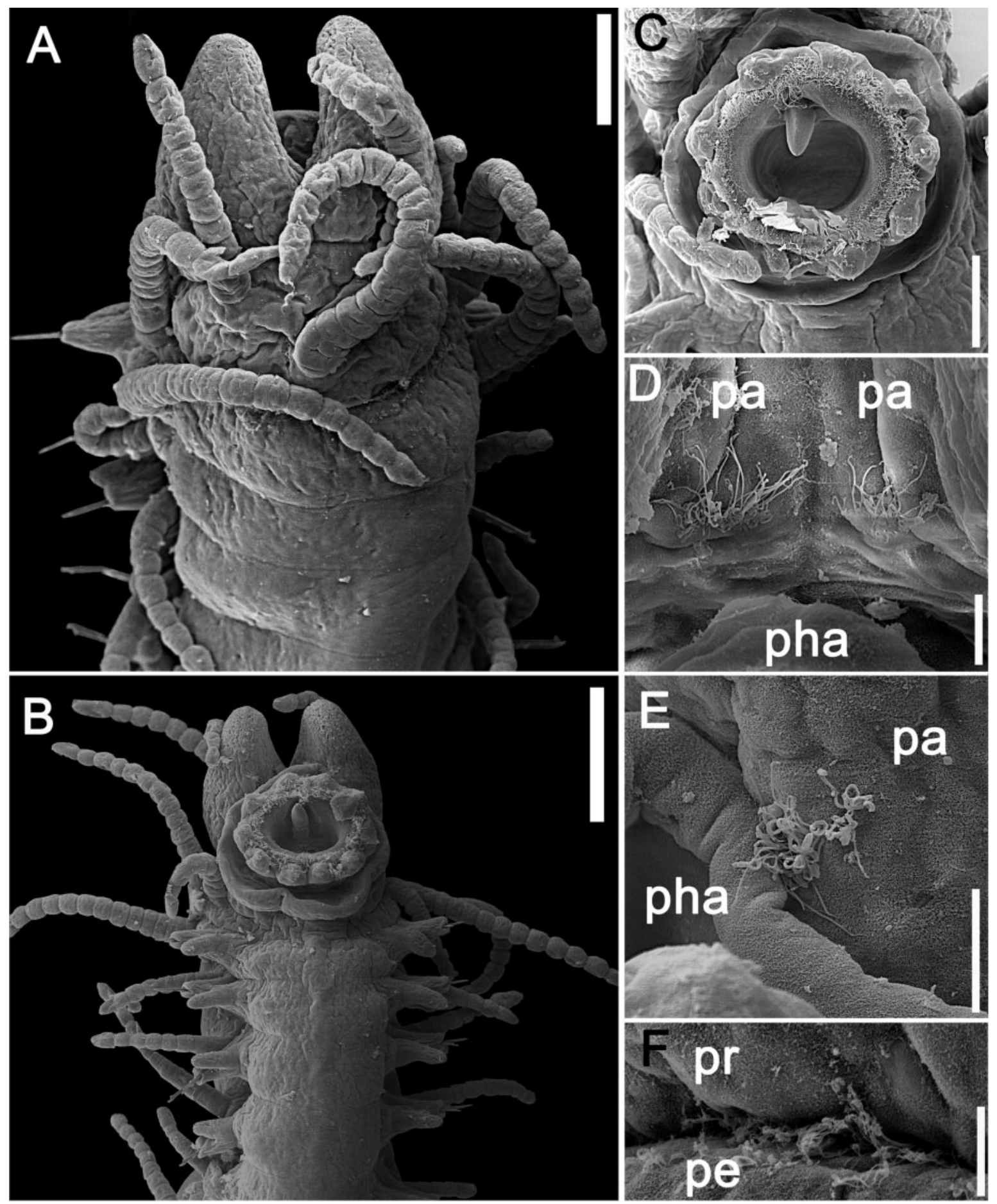

Figure 2. Haplosyllis amphimedonicola sp. nov. A: anterior end, dorsal view; B: anterior end, ventral view; C: detail of pharynx, showing the ciliated border, papillae and tooth; D,E: ventral ciliated sensory organ; F: nuchal organ. pa, palp; pe, peristomium; pha, pharynx; pr, prostomium. Scale bars: A,C $=50 \mu \mathrm{m} ; \mathrm{B}: 100 \mu \mathrm{m} ; \mathrm{D}-\mathrm{F}=10 \mu \mathrm{m}$.

Host. A great number of specimens were found within the sponge Amphimedon viridis (Figure $4 \mathrm{~A}-\mathrm{D})$.

Reproduction. Some specimens were developing stolons on the $9-12$ posteriormost chaetigers and so it was possible to observe that $H$. amphi- medonicola sp. nov. reproduces by acephalous stolons, with one pair of blackish ocular spots per parapodium.

\section{Distribution}

State of Paraíba, northeastern Brazilian coast. 

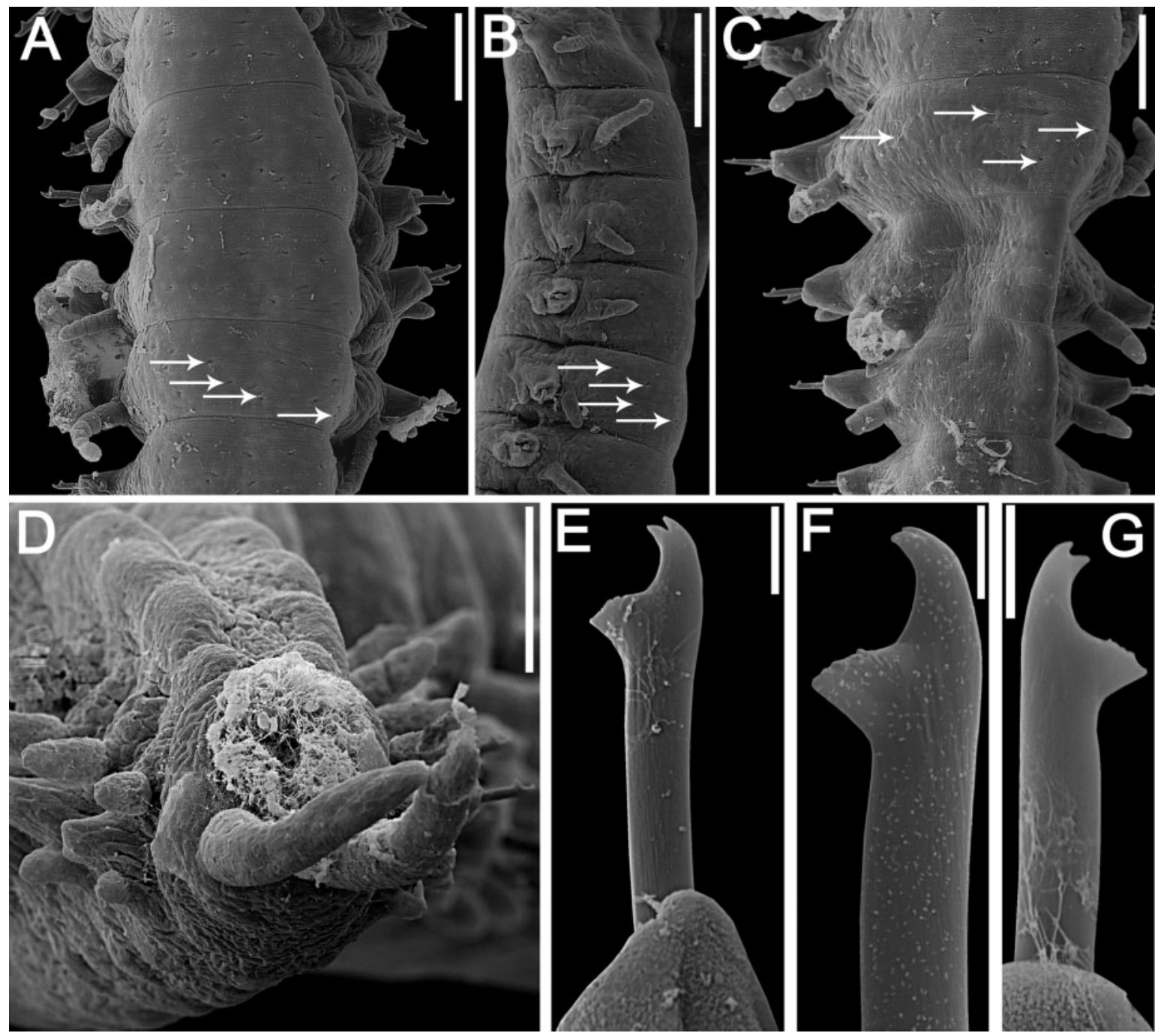

Figure 3. Haplosyllis amphimedonicola sp. nov. A,B: midbody, dorsal and lateral views, respectively, white arrows indicating some pores in each view; C: posterior body, dorsal view; D: posterior end, showing ciliated anus and smooth anal cirri; E-G: anterior, mid- and posterior body chaetae, respectively. Scale bars: $A, C, D=50 \mu \mathrm{m} ; \mathrm{B}=100 \mu \mathrm{m} ; \mathrm{E}-\mathrm{G}=5 \mu \mathrm{m}$.

\section{Etymology}

The specific name refers to the genus of the sponge within which most specimens of $H$. amphimedonicola sp. nov. were collected, followed by the Latin suffix '-cola', which means 'dweller, inhabitant'.

\section{Remarks}

This is one more species of Haplosyllis which lives in close association with sponges. The sponge $A$. viridis is abundant in the studied area and we could observe large numbers of specimens of $H$. amphimedonicola sp. nov. as the 'tissues' of the sponge were torn apart in live material, to extract the polychaetes. However, our methodology does not allow us to state that this species lives exclusively within $A$. viridis, rather than also being present in other types of substrates, including other species of sponges, found close to A. viridis.
The most important characters to distinguish $H$. amphimedonicola sp. nov. from other species of Haplosyllis are the length of antennae, peristomial and dorsal cirri, and the morphology of anal cirri, chaetae and aciculae.

The Caribbean species $H$. niphatesicola Lattig \& Martin, 2011a is, morphologicaly, the most similar taxon to $H$. amphimedonicola sp. nov. (Table III) and lives in association with Niphates erecta Duchassaing \& Michelotti, 1864, a sponge belonging to the same family as $A$. viridis, the Niphatidae. The differences between these species are subtle: the dorsal granules are only present in the Caribbean species; the main fang of the chaetae of $H$. niphatesicola is thinner in mid- and posterior body chaetigers (see Lattig \& Martin 2011a, figures 16g,h, 17f) and the midjoining point is longer than in the Brazilian species; besides, dorsal cirri of midbody parapodia are clearly different in size and form, being longer in 

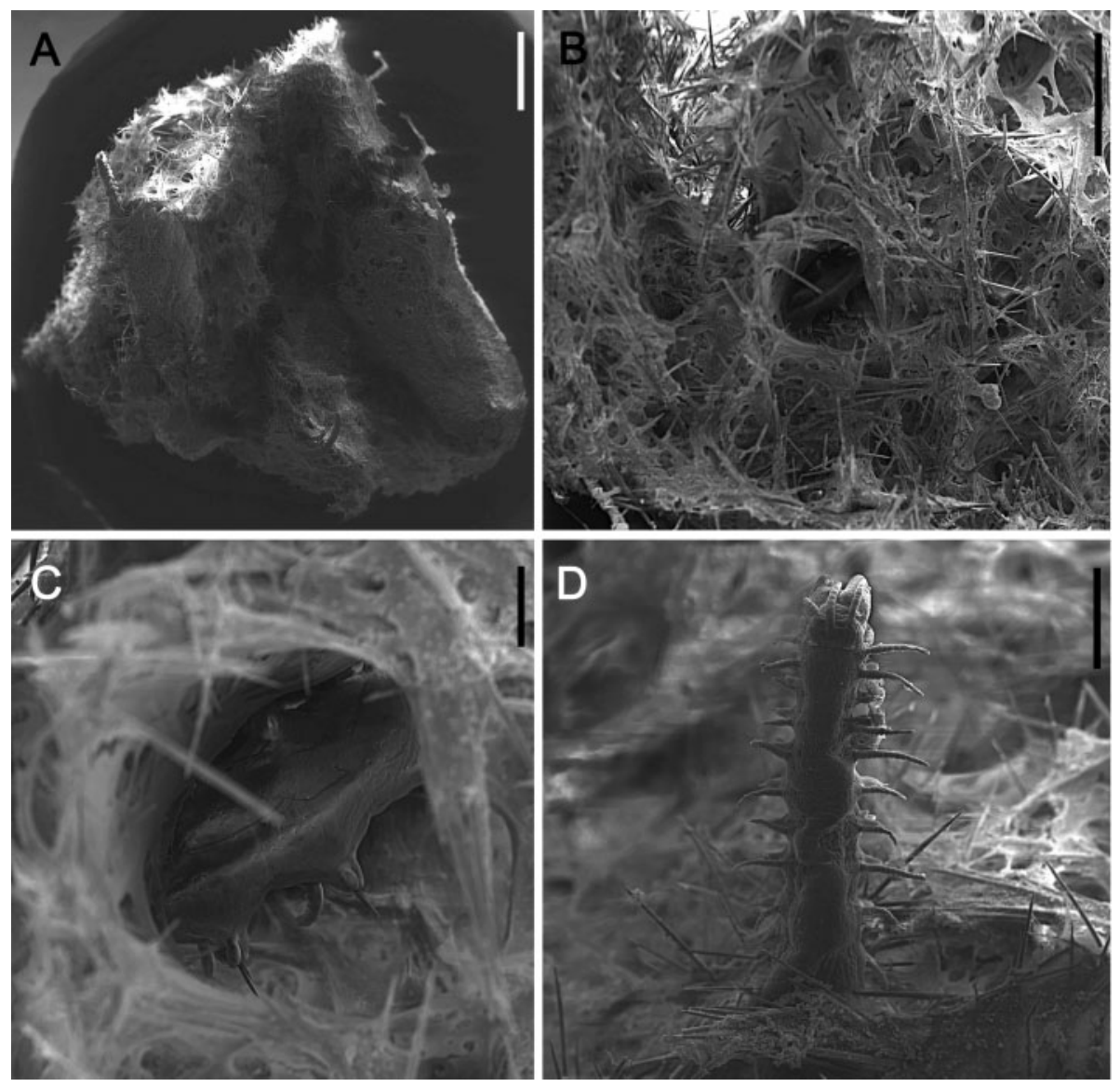

Figure 4. Haplosyllis amphimedonicola sp. nov. A: fragment of the host sponge Amphimedon viridis; B: view of galleries; C: detail of gallery with $H$. amphimedonicola sp. nov. $\mathrm{D}$, anterior end of the symbiont protruding from the host. Scale bars: $\mathrm{A}=1 \mathrm{~mm} ; \mathrm{B}=500 \mu \mathrm{m} ; \mathrm{C}=100$ $\mu \mathrm{m} ; \mathrm{D}=200 \mu \mathrm{m}$.

H. niphatesicola (see Lattig \& Martin 2011a, figures 15c, 16e) than in H. amphimedonicola sp. nov. (Figure 3A-C). Moreover, the anal cirri of $H$. niphatesicola have 6-11 articles, whereas in $H$. amphimedonicola sp. nov. anal cirri are smooth and not articulated.

Lattig \& Martin (2011a) found some specimens of Haplosyllis associated with Niphates digitalis (Lamarck, 1814) slightly different from $H$. niphatesicola and sharing some characters with Haplosyllis chaetofusorata Lattig \& Martin, 2011, but the small number of specimens prevented the authors from describing them as a new species. Therefore, it seems likely that several known and unknown species of Haplosyllis belong to a complex of sibling species which evolved within different species of sponges. Molecular studies will probably be helpful to elucidate these questions.

Haplosyllis chaetofusorata differs from $H$. amphimedonicola sp. nov. in having appendages with more articles throughout (Table III), more pronounced in midbody dorsal cirri; on midbody parapodia, the longest cirri have 11-18 articles and the shortest 4-8. In addition, the chaetae of anterior and midbody parapodia of $H$. chaetofusorata show traces of fusion between blade and shaft, 3-4 aciculae are present in each anterior parapodium, small, with curved tips, and $2-3$ in midbody parapodia, some straight, others with small, curved tips. In contrast, $H$. amphimedonicola sp. nov. has distinctly shorter dorsal cirri on midbody parapodia (Figure 3A-C), longest cirri with 4-7 articles, shortest with 1-3, no traces of fusion are visible on chaetae of any part of the body, and there are 2,2 , and 1 aciculae per parapodium, respectively, in anterior, mid- and posterior body chaetigers.

With regard to the length patterns of anterior dorsal cirri, $H$. amphimedonicola sp. nov. is similar to $H$. navasi (Lattig \& Martin, 2011a; Table III). However, the latter is a shorter species, with up to 24 chaetigers, with dorsal projections on the body wall throughout, two types of chaetae and a single acicula per parapodium throughout, aciculae straight on anterior and midbody chaetigers, and pharynx and proventricle shorter than those of $H$. amphimedonicola sp. nov., extending for 3-4 and 2-3 chaetigers, respectively, with 20-25 rows of proventricular muscle cells (Lattig \& Martin 2011a). Haplosyllis amphimedonicola sp. nov., on 
Table III. Morphological comparison between all valid species of Haplosyllis.

\begin{tabular}{|c|c|c|c|c|c|c|}
\hline & $\begin{array}{l}\text { H. aciculata Lattig, } \\
\text { Martin \& Aguado, } 2010\end{array}$ & $\begin{array}{l}\text { H. agelas } \\
\text { Uebelacker, } 1879\end{array}$ & $\begin{array}{l}\text { H. aplysinicola Lattig \& } \\
\text { Martin, } 2011\end{array}$ & $\begin{array}{l}\text { H. anthogorgicola } \\
\text { Utinomi, } 1956\end{array}$ & $\begin{array}{l}\text { H. amphimedonicola } \\
\text { sp. } \mathbf{n} .\end{array}$ & $\begin{array}{l}\text { H. basticola Sardá, Ávila } \\
\text { \& Paul, } 2002\end{array}$ \\
\hline $\begin{array}{l}\text { Total length, length to chaetiger } \\
10(\mathrm{~mm}) / \mathrm{chaetigers}\end{array}$ & $3-9, ? / 30-52$ & $10-20, ? / 88-117$ & $2-5, ? / 23-32$ & 3 , ? / 38-42 & $3-7,0.9-1 . / 36-56$ & $1-4, ? / 8-25$ \\
\hline Pharynx (chaetigers) & $4-5$ & 8 & $5-6$ & 3 & $5-9$ & 4 \\
\hline \multicolumn{7}{|l|}{$\begin{array}{l}\text { Proventricle } \\
\text { Pros }\end{array}$} \\
\hline $\begin{array}{l}\text { Length }(\mathrm{mm}) \text {, chaetigers/number } \\
\text { of muscle cell rows }\end{array}$ & $\sim 0.6,5-7$ / 32-38 & $1.1,9 / 46$ & $\sim 0.45,2-5 / 27-33$ & $?, 4$ / ? & $\begin{array}{l}0.44-0.64,4-6 / \\
38-46\end{array}$ & $0.3-0.45,2-3 / 23-30$ \\
\hline \multicolumn{7}{|l|}{ Number of articles } \\
\hline Central, lateral antennae & $15-34,8-20$ & 19,12 & $13-27,9-18$ & $25-28,10$ & $11-18,8-13$ & $9-17,6-10$ \\
\hline Dorsal, ventral peristomial cirri & $15-32$, half of dorsal ones & 14,7 & $11-23,4-13$ & 15,8 & $8-16,8-9$ & $6-13,2-5$ \\
\hline Dorsal cirri segs $1-6$ & $\begin{array}{l}19-53,4-24,10-29 \\
12-40,3-17,19-40\end{array}$ & $\begin{array}{c}14-20,6-10,9-13 \\
8-18,6-8, ?\end{array}$ & $\begin{array}{c}15-30,6-12,9-17,8-28 \\
5-13, ?\end{array}$ & $\begin{array}{c}30-35,7-8,5-7,10-15,3-6 \\
5-10\end{array}$ & $\begin{array}{c}14-19,5-9,5-12, \\
5-12\end{array}$ & $\begin{array}{c}10-15,2-5,3-7,4-10 \\
2-4, ?\end{array}$ \\
\hline Midbody long, short dorsal cirri & $18-37,9-22$ & $5-10,5-10$ & $6-11,2-7$ & $3-4,2-6$ & $3-7,1-3$ & $2-5,2-5$ \\
\hline Anal cirri & $\sim 8-10$ & 10 & $1-8$ & ? & Smooth & $?$ \\
\hline \multicolumn{7}{|l|}{ Chaetae } \\
\hline $\begin{array}{l}\text { Number per parapodium } \\
\text { (anterior, midbody, } \\
\text { posterior body) }\end{array}$ & $2-3,2-3,2-3$ & $1-2,1-2,1-2$ & $2-3,2-3,2-3$ & $1-2,1-2,1-2$ & $1-2,1-2,1-2$ & $1,1,2-3$ \\
\hline $\begin{array}{l}\text { Main fang size (in relation to shaft } \\
\text { width) }\end{array}$ & $\begin{array}{l}\text { Progressively longer. On } \\
\text { midbody chaetae: longer } \\
\text { than shaft width }\end{array}$ & Shorter & Similar & $\begin{array}{l}\text { Anterior: shorter; midbody: } \\
\text { similar (Martin et al. 2002, fig. } \\
12 \mathrm{~g}-\mathrm{i})\end{array}$ & Similar or shorter & Similar \\
\hline Main fang upper side & $\begin{array}{l}\text { With denticles, mostly in } \\
\text { anterior parapodia }\end{array}$ & Smooth & With denticles & Smooth & $\begin{array}{l}\text { With denticles, mostly } \\
\text { in anterior parapodia }\end{array}$ & Smooth \\
\hline Mid-joining point & Straight, relatively small & Curved, short & Curved, short & $\begin{array}{l}\text { Anterior chaetae: straight, long; } \\
\text { mid- and posterior body: straight, } \\
\text { shorter }\end{array}$ & Straight, long & Curved, short \\
\hline Apical teeth & $\begin{array}{l}\text { Distal slightly shorter, } \\
\text { clearly separated }\end{array}$ & Same size, wide angle & $\begin{array}{l}\text { Same size, clearly } \\
\text { separated }\end{array}$ & $\begin{array}{l}\text { Proximal shorter (Martin et al. } \\
\text { 2002, fig. 12g,i), clearly separated }\end{array}$ & $\begin{array}{l}\text { Same size, narrow } \\
\text { angle }\end{array}$ & $\begin{array}{l}\text { Distal tooth slightly } \\
\text { shorter, narrow angle } \\
\text { between teeth }\end{array}$ \\
\hline \multicolumn{7}{|l|}{ Aciculae } \\
\hline $\begin{array}{l}\text { Number per parapodium } \\
\text { (anterior, midbody, } \\
\text { posterior body) }\end{array}$ & $1,1,1$ & $2,2,2$ & $2,2,2$ & $1,1,1$ & $2,2,1$ & $1,1,1$ \\
\hline Morphology & $\begin{array}{l}\text { Broad, with long, } \\
\text { pointed, curved tip } \\
\text { directed upwards or } 90^{\circ} \\
\text { bent, protruding off } \\
\text { parapodial lobes }\end{array}$ & $\begin{array}{l}\text { One straight and } \\
\text { another subdistally } \\
\text { oblique }\end{array}$ & $\begin{array}{l}\text { One subdistally oblique } \\
\text { and another with curved } \\
\text { tip, directed upwards }\end{array}$ & $\begin{array}{l}\text { Anterior and midbody: broad, } \\
\text { slightly curved tip, directed } \\
\text { upwards; posterior: } 90^{\circ} \text { bent }\end{array}$ & $\begin{array}{l}\text { Anterior and } \\
\text { midbody: one oblique } \\
\text { and another } 90^{\circ} \text { bent; } \\
\text { posterior: subdistally } \\
\text { curved with } \\
\text { oblique tip }\end{array}$ & $\begin{array}{l}\text { Stout, with slightly } \\
\text { curved tip, directed } \\
\text { upwards }\end{array}$ \\
\hline Source & Lattig et al. 2010a & Lattig \& Martin 2009 & Lattig \& Martin 2011a & Martin et al. 2002 & Present paper & Lattig \& Martin 2009 \\
\hline
\end{tabular}


Table III. (Continued)

\begin{tabular}{|c|c|c|c|c|c|c|}
\hline & $\begin{array}{l}\text { H. basticola Sardá, Ávila } \\
\text { \& Paul, } 2002\end{array}$ & $\begin{array}{l}\text { H. carmenbritoae } \\
\text { Lattig, San Martín \& } \\
\text { Martin, } 2007\end{array}$ & H. cephalata Verrill, 1900 & H. chamaleon (Laubier, 1960) & $\begin{array}{l}\text { H. chaetafusorata } \\
\text { Lattig \& Martin, } 2011\end{array}$ & $\begin{array}{l}\text { H. crassicirrata Aguado, } \\
\text { San Martín \& } \\
\text { Nishi, } 2006\end{array}$ \\
\hline $\begin{array}{l}\text { Total length, length to chaetiger } \\
10(\mathrm{~mm}) / \text { chaetigers }\end{array}$ & $2.5-4.5, ? / 15-33$ & ?, $1.25-1.65 /(25)$ & $3.5-6, ? / 25-30$ & $3.8-13.25, ? / 38-104$ & $3-8, ? / 25-54$ & $1.6-2.4, ? / 14-16$ \\
\hline Pharynx (chaetigers) & 4 & $4-5$ & $6-7$ & ? & $4-6$ & $2-3$ \\
\hline \multicolumn{7}{|l|}{ Proventricle } \\
\hline $\begin{array}{l}\text { Length }(\mathrm{mm}) \text {, chaetigers/number } \\
\text { of muscle cell rows }\end{array}$ & ?, 2-4 / 30-35 & $0.42-1.09,4-5 / \sim 40$ & $0.7,4-6 / 42-52$ & $0.3-0.96,6.5 / 28$ & $0.3-0.4,2-5 / 31-37$ & $?, 2 / ?$ \\
\hline \multicolumn{7}{|l|}{ Number of articles } \\
\hline Central, lateral antennae & $8-28,6-14$ & $14-24,11-17$ & $6-7,6-7$ & $14-28,5-16$ & $7-38,9-21$ & $23-25,8-12$ \\
\hline Dorsal, ventral peristomial cirri & $10-18,2-8$ & $16-20,(7)$ & $7, ?$ & $16-36,3-18$ & $17-27,7-13$ & $11-15,5$ \\
\hline Dorsal cirri segs $1-6$ & $\begin{array}{c}10-28,3-14,4-14,5-19 \\
2-10, ?\end{array}$ & $\begin{array}{l}20-23,10-15,8-24, \\
8-24,6-15, ?\end{array}$ & $\begin{array}{c}14,5-7,5-7,5-7,1-4, \\
1-4\end{array}$ & $?$ & $\begin{array}{l}16-40,9-16,14-20 \\
20-28,8-13,20-28\end{array}$ & $20-27,6,6,6,6,6$ \\
\hline Midbody long, short dorsal cirri & ?,? & $(5-8),(3-5)$ & $1-4,1-4$ & $17-49,8-28$ & $11-18,4-8$ & 6,6 \\
\hline Anal cirri & $?$ & ? & ? & 30 & $2-4$ & Smooth, pyriform \\
\hline \multicolumn{7}{|l|}{ Chaetae } \\
\hline $\begin{array}{l}\text { Number per parapodium } \\
\text { (anterior, midbody, } \\
\text { posterior body) }\end{array}$ & $1-3,1-3,1-3$ & $\begin{array}{c}1-3(1-2), 1-3(1-2) \\
1-3(1-2)\end{array}$ & $1-2,1-2,1-2$ & $3-5,3-5,3-5$ & $2-3,2-3,2-3$ & $2,2,2$ \\
\hline $\begin{array}{l}\text { Main fang size (in relation to shaft } \\
\text { width) }\end{array}$ & $\begin{array}{l}\text { Shorter (Lattig \& Martin } \\
\quad 2010 \text { b, fig. 2c,d) }\end{array}$ & Shorter & Similar & Shorter & $\begin{array}{l}\text { Shorter (Lattig \& } \\
\text { Martin 2011a, fig. } 10 \\
\text { c-f) }\end{array}$ & Shorter \\
\hline Main fang upper side & Smooth & $\begin{array}{l}\text { With } 4 \text { to } 6 \text { long } \\
\text { denticles, followed by } \\
\text { several smaller near tip }\end{array}$ & Smooth & Smooth & With denticles & Smooth \\
\hline Mid-joining point & Curved, short & $\begin{array}{l}\text { Anterior and } \\
\text { midbody: straight, } \\
\text { long; posterior: } \\
\text { straight, short }\end{array}$ & Straight, short & Straight, long & Straight, short? & $?$ \\
\hline Apical teeth & $\begin{array}{l}\text { Same size, narrow angle } \\
\text { between teeth }\end{array}$ & $\begin{array}{l}\text { Same size, clearly } \\
\text { separated }\end{array}$ & $\begin{array}{l}\text { Same size, narrow angle } \\
\text { between teeth }\end{array}$ & $\begin{array}{l}\text { Distal tooth shorter; anterior and } \\
\text { midbody: unidentate appearence; } \\
\text { posterior body: clearly bidentate }\end{array}$ & $\begin{array}{l}\text { Distal tooth shorter, } \\
\text { clearly separated }\end{array}$ & $\begin{array}{l}\text { Longer chaetae: distal } \\
\text { tooth shorter; shorter } \\
\text { chaetae: same size; both } \\
\text { with narrow angle } \\
\text { between teeth }\end{array}$ \\
\hline \multicolumn{7}{|l|}{ Aciculae } \\
\hline $\begin{array}{l}\text { Number per parapodium } \\
\text { (anterior, midbody, } \\
\text { posterior body) }\end{array}$ & $1,1,1$ & $1-6, ?, 1$ & $2,1,2$ & $?$ & $3-4,2-3,2-3$ & $1,1,1$ \\
\hline Morphology & $\begin{array}{l}\text { Stout, with slightly } \\
\text { curved tip, directed } \\
\text { upwards }\end{array}$ & $\begin{array}{l}\text { Rounded tip or with a } \\
\text { hooked, pointed tip, } \\
\text { directed upwards }\end{array}$ & $\begin{array}{l}\text { Anterior and posterior: } \\
\text { one straight and another } \\
\text { with curved tip directed } \\
\text { upwards; midbody: } \\
\text { broad, with curved tip }\end{array}$ & $?$ & $\begin{array}{l}\text { One straight, other } \\
\text { subdistally oblique, } \\
\text { curved }\end{array}$ & $\begin{array}{l}\text { Curved tips, directed } \\
\text { upwards }\end{array}$ \\
\hline Source & Lattig et al. $2010 \mathrm{~b}$ & $\begin{array}{l}\text { Lattig et al. } 2007 \text { (in } \\
\text { brackets are holotype } \\
\text { complementary data, } \\
\text { persnonal observation) }\end{array}$ & Lattig \& Martin 2009 & Martin et al. 2002 & $\begin{array}{l}\text { Lattig \& Martin } \\
\quad 2011 \mathrm{a}\end{array}$ & Aguado et al. 2006 \\
\hline
\end{tabular}


Table III. (Continued)

\begin{tabular}{|c|c|c|c|c|c|c|}
\hline & $\begin{array}{l}\text { H. crassicirrata Aguado, } \\
\text { San Martín \& } \\
\text { Nishi, } 2006\end{array}$ & $\begin{array}{c}\text { H. cratericola } \\
\text { Buzhinskaja, } 1990\end{array}$ & $\begin{array}{l}\text { H. djiboutiensis } \\
\text { Gravier, } 1900\end{array}$ & H. djiboutiensis Gravier, 1900 & $\begin{array}{l}\text { H. eldagainoae Lattig } \\
\text { \& Martin, } 2011\end{array}$ & $\begin{array}{l}\text { H. granulosa (Lattig, } \\
\text { Martin \& San } \\
\text { Martín, 2007) }\end{array}$ \\
\hline $\begin{array}{l}\text { Total length, length to chaetiger } \\
10(\mathrm{~mm}) / \text { chaetigers }\end{array}$ & $2-3, ?$ / $20-26$ & $44, ? / 60$ & $8, ? / 38$ & $3-17, ?$ / 30-92 & $2-4, ? / 16-30$ & (10), $0.82-2.08 /(50)$ \\
\hline $\begin{array}{l}\text { Pharynx (chaetigers) } \\
\text { Proventricle }\end{array}$ & $3-4$ & 10 & 5 & $4-6$ & $3-5$ & $\sim 5$ \\
\hline $\begin{array}{l}\text { Length }(\mathrm{mm}) \text {, chaetigers/number } \\
\text { of muscle cell rows }\end{array}$ & $0.25-0.32,2-4 / 22-26$ & ?, $11 /$ ? & $0.45,4 / 36$ & ?, 3-9 / 30-50 & ?, 3-5 / 25-26 & $(0.9), 4-8 / 40-57$ \\
\hline \multicolumn{7}{|l|}{ Number of articles } \\
\hline Central, lateral antennae & $9-21,6-13$ & 40,27 & 22,14 & $11-30,7-16$ & $8-18,5-9$ & $9-30,6-17$ \\
\hline Dorsal, ventral peristomial cirri & 10-13, ? & 40,22 & $13-15,7-11$ & 13-24, ? & $7-16, ?$ & $17-22,(12)$ \\
\hline Dorsal cirri segs $1-6$ & $\begin{array}{c}12-20,4-9,5-12,7-13 \\
3-12,7-12\end{array}$ & $\sim 50$ in anterior body & $23,12,15,19,10,15$ & $\begin{array}{c}11-30,5-16,7-20,10-29,4-16, \\
6-24\end{array}$ & $\begin{array}{c}5-16,1-2,1-4,2-7 \\
1-2,2-5\end{array}$ & $\begin{array}{l}18-30,8-16,8-16 \\
7-25,5-14,(17)\end{array}$ \\
\hline $\begin{array}{l}\text { Midbody long, short dorsal cirri } \\
\text { Anal cirri }\end{array}$ & $\begin{array}{c}6-14,6-14 \\
?\end{array}$ & $\begin{array}{c}\sim 30-35 \text { in midbody } \\
? ?\end{array}$ & $\begin{array}{c}7-9,4-5 \\
?\end{array}$ & $\begin{array}{c}7-16,3-11 \\
8-10\end{array}$ & $\begin{array}{c}1-3,1-3 \\
1-2\end{array}$ & $\begin{array}{l}11-17,4-13 \\
\text { (Smooth) }\end{array}$ \\
\hline \multicolumn{7}{|l|}{ Chaetae } \\
\hline $\begin{array}{l}\text { Number per parapodium } \\
\text { (anterior, midbody, } \\
\text { posterior body) }\end{array}$ & $2-4,2-4,2-4$ & $\sim 20, \sim 14, ?$ & ?, 2, ? & ?, $2-3,2-3$ & $2-3,2-3,2-3$ & $\begin{array}{l}2-3 \text { or } 3-7(2-3 \\
\text { anteriorly and midbody } \\
\text { and } 3-4 \text { posteriorly) }\end{array}$ \\
\hline $\begin{array}{l}\text { Main fang size (in relation to shaft } \\
\text { width) }\end{array}$ & $\begin{array}{l}\text { Shorter (Lattig \& Martin } \\
2010 \mathrm{~b} \text {, figs } 4 \mathrm{f}, 5 \mathrm{e}, \mathrm{f})\end{array}$ & Shorter & Shorter or similar & Shorter or similar & Similar & Shorter \\
\hline Main fang upper side & Smooth & Smooth & $\begin{array}{l}\text { Longer chaeta: with } \\
\text { denticles; shorter } \\
\text { chaetae: smooth }\end{array}$ & $\begin{array}{l}\text { Longer chaeta: with denticles; } \\
\text { shorter chaetae: smooth }\end{array}$ & Smooth & $\begin{array}{l}\text { With } 2-3 \text { rows of } \\
\text { denticles }\end{array}$ \\
\hline Mid-joining point & Short, curved & Straight, long & $\begin{array}{l}\text { Longer chaeta: straight, } \\
\text { long; shorter chaetae: } \\
\text { straight, short }\end{array}$ & $\begin{array}{l}\text { Longer chaeta: straight, long; } \\
\text { shorter chaetae: curved, short }\end{array}$ & Curved, very short & Straight, long \\
\hline Apical teeth & $\begin{array}{l}\text { Same size, clearly } \\
\text { separated }\end{array}$ & $\begin{array}{l}\text { Same size, narrow } \\
\text { angle between teeth }\end{array}$ & $\begin{array}{l}\text { Longer chaeta: distal } \\
\text { tooth slightly shorter, } \\
\text { narrow angle between } \\
\text { teeth; shorter chaetae: } \\
\text { proximal tooth shorter, } \\
\text { clearly separated }\end{array}$ & $\begin{array}{c}\text { Longer chaeta: distal tooth } \\
\text { slightly shorter, narrow angle } \\
\text { between teeth; shorter chaetae: } \\
\text { proximal tooth shorter, clearly } \\
\text { separated }\end{array}$ & $\begin{array}{l}\text { Same size, wide angle } \\
\text { between teeth }\end{array}$ & $\begin{array}{l}\text { Same size, narrow angle } \\
\text { between teeth }\end{array}$ \\
\hline \multicolumn{7}{|l|}{ Aciculae } \\
\hline & & & & & & \\
\hline Morphology & $\begin{array}{l}\text { Curved tips, directed } \\
\text { upwards }\end{array}$ & $\begin{array}{l}\text { Straight, broad, with } \\
\text { rounded tips }\end{array}$ & $\begin{array}{l}\text { Stout, curved tips, } \\
\text { directed upwards }\end{array}$ & $\begin{array}{l}\text { Anterior and midbody: one } \\
\text { straight and another with curved } \\
\text { tip; posterior: curved tips, } \\
\text { directed upwards }\end{array}$ & $\begin{array}{l}\text { Curved tips, directed } \\
\text { upwards }\end{array}$ & $\begin{array}{l}\text { Some subdistally } \\
\text { oblique and pointed tip, } \\
\text { directed upwards and } \\
\text { others straight. } \\
\text { Specimens from Cape } \\
\text { of Palos and holotype: } \\
90^{\circ} \text { bent, rounded tip }\end{array}$ \\
\hline Source & Lattig et al. $2010 \mathrm{~b}$ & Lattig \& Martin 2009 & Lattig \& Martin 2009 & Lattig \& Martin 2010b & $\begin{array}{l}\text { Lattig \& Martín } \\
\quad 2011 \text { b }\end{array}$ & $\begin{array}{l}\text { Lattig et al. } 2007 \text { (in } \\
\text { brackets are holotype } \\
\text { complementary data, } \\
\text { personal observation) }\end{array}$ \\
\hline
\end{tabular}

Anterior and midbody: one ight and another with curved posterior: curved tip
directed upwards

upwards
ups, directed direct and pointed tip, directed upwards and pecimens from Cape of Palos and holotype: attig et al. 2007 (in compls holotype personal observation) 
Table III. (Continued)

\begin{tabular}{|c|c|c|c|c|c|c|}
\hline & $\begin{array}{l}\text { H. giuseppemagninoi } \\
\text { Lattig \& Martin, } 2011\end{array}$ & $\begin{array}{l}\text { H. gula } \\
\text { Treadwell, } 1924\end{array}$ & $\begin{array}{l}\text { H. imäimai Lattig, } \\
\text { Martin \& San } \\
\text { Martín, } 2010\end{array}$ & $\begin{array}{l}\text { H. ingensicola Lattig, Martin \& } \\
\text { Aguado, } 2010\end{array}$ & $\begin{array}{l}\text { H. ingensicola Lattig, } \\
\text { Martin \& } \\
\text { Aguado, } 2010\end{array}$ & $\begin{array}{l}\text { H. loboi Paola, San } \\
\text { Martín \& Martin, } 2006\end{array}$ \\
\hline $\begin{array}{l}\text { Total length, length to chaetiger } \\
10(\mathrm{~mm}) / \text { chaetigers }\end{array}$ & $2-5, ? / 28-40$ & $2.5-3.8, ?$, / 26-31 & $14-28, ? / 46-126$ & $4-15, ? / 45-72$ & $7-13, ? / 37-53$ & $\sim 6.05-7.84, ?$ / 38-64 \\
\hline \multicolumn{4}{|l|}{ Proventricle } & $6-8$ & $6-8$ & 9 \\
\hline $\begin{array}{l}\text { Proventricle } \\
\text { Length }(\mathrm{mm}) \text {, chaetigers/number } \\
\text { of muscle cell rows }\end{array}$ & ?, 3-7 / 25-28 & $0.3-0.4,3-4 / 23-27$ & ?, 9-16 / ? & ?, 5-6 / ? & ?, 3-6 / 33-43 & ?, 8 / 36 \\
\hline \multicolumn{7}{|l|}{ Number of articles } \\
\hline Central, lateral antennae & $\begin{array}{c}14-23,7-12 \\
9-19 ?\end{array}$ & $\begin{array}{c}12-27,8-11 \\
8-18 ?\end{array}$ & $30,20-25$ & $17-54,11-23$ & $29-58,13-23$ & $16-38,15-34$ \\
\hline Dorsal, ventral peristomial cirri & 9-19,? & $8-18, ?$ & $25-35, ?$ & $11-38, ?$ & 21-33,? & $23-33,17-28$ \\
\hline Dorsal cirri segs $1-6$ & $\begin{array}{c}10-21,3-9,3-11,4-14, \\
2-6,2-10\end{array}$ & $\begin{array}{l}19-29,7-13,12-14 \\
21-26,6-11,16-18\end{array}$ & $\begin{array}{l}30-33,19-30,19-30 \\
19-30,19-30,19-30\end{array}$ & $\begin{array}{c}28-59,4-23,12-28,20-54,6- \\
25,17-40\end{array}$ & $\begin{array}{l}32-63,12-20,19-24 \\
32-42,14-24,24-42\end{array}$ & $\begin{array}{c}48,15-20,15-20,15- \\
20,15-20, ?\end{array}$ \\
\hline Midbody long, short dorsal cirri & $1-8,1-8$ & $15-19,5-7$ & $19-30,19-30$ & $18-47,9-20$ & $17-41,11-18$ & $14-17,10-12$ \\
\hline Anal cirri & $3-10$ & ? & $?$ & $14-15$ & $13-15$ & $14-17$ \\
\hline \multicolumn{7}{|l|}{ Chaetae } \\
\hline $\begin{array}{l}\text { Number per parapodium } \\
\text { (anterior, midbody, } \\
\text { posterior body) }\end{array}$ & $2,1,2-4$ & $2,2,2$ & $3-5,3-5,3-5$ & $2-3,2-3,1-3$ & $2-3,2-3,2-3$ & $2,2,2$ \\
\hline $\begin{array}{l}\text { Main fang size (in relation to shaft } \\
\text { width) }\end{array}$ & Similar & Shorter & Longer or similar & Similar or longer & Similar or longer & Shorter \\
\hline Main fang upper side & Smooth & With denticles & With denticles & With 2-3 rows of denticles & $\begin{array}{l}\text { With } 2-3 \text { rows of } \\
\text { denticles, eroded in } \\
\text { mid- and } \\
\text { posterior body }\end{array}$ & With denticles \\
\hline Mid-joining point & $\begin{array}{l}\text { Anterior and posterior } \\
\text { body: straight, long; } \\
\text { midbody: short, curved }\end{array}$ & $\begin{array}{l}\text { Anterior and midbody } \\
\text { longer chaeta: straight, } \\
\text { long; midbody shorter } \\
\text { chaetae: curved, short }\end{array}$ & $\begin{array}{l}\text { Anterior body: ?; mid- } \\
\text { and posterior body: } \\
\text { straight, long }\end{array}$ & Curved, short & $\begin{array}{l}\text { Anterior: curved, } \\
\text { short; mid- and } \\
\text { posterior body: } \\
\text { straight }\end{array}$ & $\begin{array}{l}\text { Anterior: straight, long; } \\
\text { mid- and posterior } \\
\text { body: curved, short }\end{array}$ \\
\hline Apical teeth & $\begin{array}{l}\text { Same size, wide angle } \\
\text { between teeth }\end{array}$ & $\begin{array}{l}\text { Distal tooth slightly } \\
\text { shorter, narrow angle } \\
\text { between teeth }\end{array}$ & $\begin{array}{l}\text { Same size, narrow angle } \\
\text { between teeth }\end{array}$ & $\begin{array}{l}\text { Distal tooth slightly shorter, } \\
\text { narrow angle between teeth }\end{array}$ & $\begin{array}{l}\text { Distal tooth slightly } \\
\text { shorter, narrow angle } \\
\text { between teeth }\end{array}$ & $\begin{array}{l}\text { Distal tooth slightly } \\
\text { shorter, wide angle } \\
\text { between teeth }\end{array}$ \\
\hline \multicolumn{7}{|l|}{ Aciculae } \\
\hline $\begin{array}{l}\text { Number per parapodium } \\
\text { (anterior, midbody, } \\
\text { posterior body) }\end{array}$ & $2,1,1$ & 2,1, ? & $4-5,4-5,2-3$ & $1-2,1,1$ & $1-2,1,1$ & $2,2 ?, 1$ \\
\hline Morphology & $\begin{array}{l}\text { Anterior body: one } \\
\text { straight, another } 90^{\circ} \\
\text { bent; mid- and posterior } \\
\text { body: } 90^{\circ} \text { bent }\end{array}$ & Stout, $90^{\circ}$ bent & $\begin{array}{l}\text { Most aciculae straight, } \\
\text { some } 90^{\circ} \text { bent }\end{array}$ & $\begin{array}{l}\text { Anterior body: one enlarged with } \\
\text { pointed tip, another with curved } \\
\text { tip, almost } 90^{\circ} \text { bent; mid- and } \\
\text { posterior body: broad, almost } \\
90^{\circ} \text { bent }\end{array}$ & $\begin{array}{l}\text { Anterior body: } \\
\text { straight and with } \\
\text { curved tip bent at } 90^{\circ} \text {; } \\
\text { mid- and posterior } \\
\text { body: broader than } \\
\text { chaetae, } 90^{\circ} \text { bent }\end{array}$ & $\begin{array}{l}\text { Straight with } \\
\text { pointed tip }\end{array}$ \\
\hline Source & Lattig \& Martín 2010b & Lattig \& Martin 2009 & Lattig et al. $2010 \mathrm{~b}$ & Lattig et al. 2010a & Lattig et al. $2010 \mathrm{~b}$ & Paola et al. 2006 \\
\hline
\end{tabular}


Table III. (Continued)

\begin{tabular}{|c|c|c|c|c|c|c|}
\hline & $\begin{array}{l}\text { H. navasi Lattig \& } \\
\text { Martin, } 2011\end{array}$ & $\begin{array}{l}\text { H. nicoleae Lattig, } \\
\text { Martin \& } \\
\text { Aguado, } 2010\end{array}$ & $\begin{array}{l}\text { H. niphatesicola Lattig \& } \\
\text { Martin, } 2011\end{array}$ & $\begin{array}{l}\text { H. ohma (Imajima \& } \\
\text { Hartman, 1964) }\end{array}$ & H. rosenalessoae sp. n. & $\begin{array}{l}\text { H. sanchoi Lattig, } \\
\text { Martin \& San } \\
\text { Martín, } 2010\end{array}$ \\
\hline $\begin{array}{l}\text { Total length, length to chaetiger } \\
10(\mathrm{~mm}) / \mathrm{chaetigers}\end{array}$ & $3-4, ? / 17-24$ & $2-7, ? / 30-41$ & $3-5, ? / 26-37$ & $25-32$, , / 65-82 & $4-10,1.5-1.8 / 25-61$ & $4-5.5, ? / 35-42$ \\
\hline Pharynx (chaetigers) & $3-4$ & $4-6$ & $3-6$ & 12 & $6-9$ & $6-7$ \\
\hline \multicolumn{7}{|l|}{ Proventricle } \\
\hline $\begin{array}{l}\text { Length }(\mathrm{mm}) \text {, chaetigers/number } \\
\text { of muscle cell rows }\end{array}$ & $0.3-0.5,2-3 / 20-25$ & ?, 4-6 / 27-39 & $0.3-0.6,5-8 / 32-42$ & ?, 12 / 35-39 & $0.6-0.9,4.5-6 / 40-48$ & ?, 7-9 / 35-39 \\
\hline \multicolumn{7}{|l|}{ Number of articles } \\
\hline Central, lateral antennae & $16-21,6-10$ & $10-25,4-17$ & $15-23,9-15$ & 30,25 & $16-21,12-15$ & $15-21,12-14$ \\
\hline Dorsal, ventral peristomial cirri & $8-14,4-6$ & $10-22, ?$ & $13-18,6-15$ & 30,12 & $11-21,8-12$ & $14-17, ?$ \\
\hline Dorsal cirri segs $1-6$ & $\begin{array}{c}17-23,5-10,5-10,11- \\
19,5-9,5-9\end{array}$ & $\begin{array}{l}13-26,2-15,5-15 \\
9-26,2-11,10-20\end{array}$ & $\begin{array}{l}18-28,6-13,9-16 \\
11-18,4-11,10-14\end{array}$ & $\begin{array}{c}31-36,16-18,24-29,24-29, \\
24-29,32\end{array}$ & $\begin{array}{l}16-25,8-13,10-21 \\
13-20,8-13,8-18\end{array}$ & $\begin{array}{l}15-22,7-10,6-13 \\
9-14,3-7,5-6\end{array}$ \\
\hline Midbody long, short dorsal cirri & $5-9,5-9$ & $7-18,2-8$ & $5-9,1-4$ & $28-35,28-35$ & $8-13,4-8$ & $2-6,2-6$ \\
\hline Anal cirri & $?$ & $?$ & $6-11$ & $?$ & $4-8$ & 7 \\
\hline \multicolumn{7}{|l|}{ Chaetae } \\
\hline $\begin{array}{l}\text { Number per parapodium } \\
\text { (anterior, midbody, } \\
\text { posterior body) }\end{array}$ & $2-3,2-3,2-3$ & $2-3,2,2$ & $1,1-3,1-3$ & $4-6,5-8, ?$ & $1-2,1-2,1-2$ & $1-2,1-2,1-2$ \\
\hline $\begin{array}{l}\text { Main fang size (in relation to shaft } \\
\text { width) }\end{array}$ & Shorter or similar & $\begin{array}{l}\text { Anterior: short; mid- } \\
\text { and posterior body: } \\
\text { similar }\end{array}$ & Longer & Shorter & Similar or shorter & $\begin{array}{l}\text { Anterior: similar; mid- } \\
\text { and posterior body: } \\
\text { longer }\end{array}$ \\
\hline Main fang upper side & With denticles & With denticles & With denticles & With denticles & $\begin{array}{l}\text { Anterior: with } \\
\text { denticles; mid- and } \\
\text { posterior: smooth }\end{array}$ & Smooth \\
\hline Mid-joining point & $\begin{array}{l}\text { Longer chaetae: straight, } \\
\text { short; shorter chaetae: } \\
\text { curved, short }\end{array}$ & $\begin{array}{l}\text { Anterior and midbody } \\
\text { longer chaetae: } \\
\text { straight, long; } \\
\text { midbody shorter } \\
\text { chaetae: straight, short }\end{array}$ & Straight, long & Straight, long & Straight, long & $\begin{array}{l}\text { Anterior chaetae: } \\
\text { straight, long; mid- and } \\
\text { posterior chaetae: } \\
\text { curved, short }\end{array}$ \\
\hline Apical teeth & $\begin{array}{l}\text { Same size, clearly } \\
\text { separated }\end{array}$ & $\begin{array}{l}\text { Same size, clearly } \\
\text { separated }\end{array}$ & $\begin{array}{l}\text { Distal tooth slightly } \\
\text { shorter, narrow angle } \\
\text { between teeth }\end{array}$ & Same size, clearly separated & $\begin{array}{l}\text { Anterior: same size, } \\
\text { clearly separated; } \\
\text { mid- and posterior } \\
\text { body: distal tooth } \\
\text { shorter, narrow angle } \\
\text { between teeth } \\
\text { (unidentate } \\
\text { appearence) }\end{array}$ & $\begin{array}{l}\text { Distal tooth slightly } \\
\text { shorter, narrow angle } \\
\text { between teeth }\end{array}$ \\
\hline \multicolumn{7}{|l|}{ Aciculae } \\
\hline $\begin{array}{l}\text { Number per parapodium } \\
\text { (anterior, midbody, } \\
\text { posterior body) }\end{array}$ & $1,1,1$ & $2,2,1$ & $2,1,1$ & $\begin{array}{l}3 \text { or more per parapodium } \\
\text { throughout the body }\end{array}$ & $2,2-3,1$ & $2,2,1$ \\
\hline Morphology & $\begin{array}{l}\text { Curved tips, directed } \\
\text { upwards }\end{array}$ & $\begin{array}{l}\text { Curved tips, more or } \\
\text { less directed upwards }\end{array}$ & $\begin{array}{l}\text { Anterior body: one } \\
\text { straight, and another with } \\
\text { curved tip, directed } \\
\text { upwards; mid- and } \\
\text { posterior body: broader } \\
\text { than chaeta, with curved } \\
\text { tip, directed upwards }\end{array}$ & Enlarged, with rounded tip & $\begin{array}{l}\text { Curved tip or } \\
90^{\circ} \text { bent }\end{array}$ & $\begin{array}{l}\text { Anterior and midbody: } \\
\text { one straight and another } \\
\text { with curved tip, } \\
\text { directed upwards; } \\
\text { posterior: curved tip, } \\
\text { directed upwards }\end{array}$ \\
\hline Source & Lattig \& Martin 2011a & Lattig \& Martin 2010a & Lattig \& Martin 2011a & Lattig \& Martin 2009 & Present paper & Lattig \& Martin 2010b \\
\hline
\end{tabular}


Table III. (Continued)

\begin{tabular}{|c|c|c|c|c|c|c|}
\hline & $\begin{array}{l}\text { H. sandii Lattig, Martin \& } \\
\text { San Martín, } 2010\end{array}$ & $\begin{array}{l}\text { H. spongicola } \\
\text { (Grube, 1855) }\end{array}$ & $\begin{array}{l}\text { H. cf. spongicola } \\
\text { (Grube, 1855) }\end{array}$ & H. spongiphila (Verrill, 1885) & $\begin{array}{l}\text { H. streptocephala } \\
\text { (Grube, 1857) }\end{array}$ & $\begin{array}{l}\text { H. tenhovei Lattig, } \\
\text { Martin \& Aguado, } 2010\end{array}$ \\
\hline $\begin{array}{l}\text { Total length, length to chaetiger } \\
10(\mathrm{~mm}) / \text { chaetigers }\end{array}$ & $4-6.5, ?$ ? / 25-42 & Up to $65, ? / 52-77$ & $5-12, ? / 46-80$ & $10-20, ? / 60-80$ & $20, ? / 133$ & $3.5-4.2, ? / 29-31$ \\
\hline Pharynx (chaetigers) & $5-7$ & $\sim 9-12$ & $7-10$ & $14-21$ & 11 & $5-7$ \\
\hline \multicolumn{7}{|l|}{ Proventricle } \\
\hline $\begin{array}{l}\text { Length }(\mathrm{mm}) \text {, chaetigers/number } \\
\text { of muscle cell rows }\end{array}$ & ?, 3-6.5 / 28-36 & ?, 6-13 / 46-56 & ?, 7-14 / 33-61 & ?, 7-13 / 56-69 & ?, $11 / 90$ & $0.78,7-8 / ?$ \\
\hline \multicolumn{7}{|l|}{ Number of articles } \\
\hline Central, lateral antennae & $20-36,11-21$ & $40,13-23$ & $13-24,10-21$ & $43-55,21-31$ & $17-19,17-19$ & 30,19 \\
\hline Dorsal, ventral peristomial cirri & $14-24, ?$ & $16-30, ?$ & $17-26, ?$ & $28-45, ?$ & $17-21, ?$ & $22-30,11-18$ \\
\hline Dorsal cirri segs $1-6$ & $\begin{array}{l}20-36,7-15,10-14 \\
14-30,6-12,12-20\end{array}$ & $\begin{array}{l}24-40,8-26,13-32 \\
19-47,11-28, ?\end{array}$ & $\begin{array}{l}18-35,9-15,11-16 \\
12-17,9-12,14-24\end{array}$ & $\begin{array}{c}41-50,24-30,38-48,50-72, \\
27-35,48-59\end{array}$ & $28,14,20,24,15,19$ & $\begin{array}{l}37-42,16-19,21-24 \\
21-24,15-21,20-26\end{array}$ \\
\hline Midbody long, short dorsal cirri & $10-20,4-12$ & ?, ? & $10-20,4-14$ & $46-61,18-42$ & $13-21,13-21$ & $19-24,12-15$ \\
\hline Anal cirri & $?$ & 20 & 10 & $?$ & ? & $?$ \\
\hline \multicolumn{7}{|l|}{ Chaetae } \\
\hline $\begin{array}{l}\text { Number per parapodium } \\
\text { (anterior, midbody, } \\
\text { posterior body) }\end{array}$ & $2-3,2-3,2-3$ & $1-2,1-2,1-2$ & $2-3$ & $4-6,2-3, ?$ & $3-5,3-5,3-5$ & $2-3,2-3,2-3$ \\
\hline $\begin{array}{l}\text { Main fang size (in relation to shaft } \\
\text { width) }\end{array}$ & Similar & Shorter & $\begin{array}{l}\text { Anterior: similar; } \\
\text { midbody and posterior: } \\
\text { longer }\end{array}$ & Shorter & Shorter or similar & $\begin{array}{l}\text { Anterior: similar; mid- } \\
\text { and posterior body: } \\
\text { longer }\end{array}$ \\
\hline Main fang upper side & $\begin{array}{l}\text { With deep crevice and } \\
\text { denticles }\end{array}$ & With denticles & $\begin{array}{l}\text { With denticles, mostly in } \\
\text { anterior parapodia }\end{array}$ & $\begin{array}{l}\text { Anterior and midbody: with } \\
\text { denticles; posterior: with a long } \\
\text { denticle followed by several } \\
\text { smaller near tip }\end{array}$ & Smooth & $\begin{array}{c}\text { With denticles (Lattig \& } \\
\text { Martin 2010a, fig. 8b, } \\
\text { d,e) }\end{array}$ \\
\hline Mid-joining point & Curved, short & ?Curved, short & $\begin{array}{l}\text { Anterior chaetae: ?; } \\
\text { midbody and posterior } \\
\text { chaetae: curved, short }\end{array}$ & Straight, long & Straight, long & Curved, short \\
\hline Apical teeth & $\begin{array}{l}\text { Distal tooth slightly } \\
\text { shorter, clearly separated }\end{array}$ & $\begin{array}{l}\text { Same size, clearly } \\
\text { separated (Lattig et al. } \\
\text { 2007: fig. 2) }\end{array}$ & $\begin{array}{l}\text { Same size, clearly } \\
\text { separated }\end{array}$ & Same size, clearly separated & $\begin{array}{l}\text { Same size, narrow } \\
\text { angle between teeth } \\
\text { (unidentate } \\
\text { appearence) }\end{array}$ & $\begin{array}{l}\text { Same size, clearly } \\
\text { separated }\end{array}$ \\
\hline \multicolumn{7}{|l|}{ Aciculae } \\
\hline $\begin{array}{l}\text { Number per parapodium } \\
\text { (anterior, midbody, } \\
\text { posterior body) }\end{array}$ & $2,1,1$ & $1-6, ?, 1$ & $2,2,1$ & $2-3,2-3,2-3$ & ? & $2-3,2,1-2$ \\
\hline Morphology & $\begin{array}{l}\text { Curved tips, directed } \\
\text { upwards }\end{array}$ & $\begin{array}{l}\text { Hooked tip, directed } \\
\text { upwards or } 90^{\circ} \text { bent, } \\
\text { rounded tip }\end{array}$ & $\begin{array}{l}\text { Anterior body: one } \\
\text { straight and another } \\
\text { almost } 90^{\circ} \text { bent; mid- } \\
\text { and posterior body: } \\
\text { curved tips, directed } \\
\text { upwards }\end{array}$ & Straight and broad & $?$ & $\begin{array}{l}\text { Straight, broad, with } \\
\text { rounded tips }\end{array}$ \\
\hline Source & Lattig \& Martin 2010b & Lattig et al. 2007 & Lattig \& Martin 2010b & Lattig \& Martin 2009 & Lattig \& Martin 2009 & Lattig \& Martin 2010a \\
\hline
\end{tabular}

$18-35,9-15,11-16$

$8-26,13-32$

Midbody long, short dorsal cir

Number per parapodium

(anterior, midbody,

ain fang size (in relation to shat

(anterior, midbody,

posterior body)

tip, directe ds or $90^{\circ}$ ben straight and another nd posterior body: curved tips, directed

Anterior and midbody: with maller near tip me size, clearly separate

me size, narrow (unidentate ight, broad, with rounded tips 
Table III. (Continued)

\begin{tabular}{|c|c|c|c|c|c|}
\hline & $\begin{array}{l}\text { H. tenhovei Lattig, Martin } \\
\text { \& Aguado, } 2010\end{array}$ & $\begin{array}{l}\text { H. trifalcata } \\
\text { (Day, 1960) }\end{array}$ & $\begin{array}{l}\text { H. uncinigera } \\
\text { (Grube, 1878) }\end{array}$ & H. uncinigera (Grube, 1878) & $\begin{array}{l}\text { H. villogorgicola } \\
\text { Martin, Núñez, Riera } \\
\text { \& Gil, } 2002\end{array}$ \\
\hline $\begin{array}{l}\text { Total length, length to chaetiger } \\
10(\mathrm{~mm}) / \text { chaetigers }\end{array}$ & $3-6, ? / 25-42$ & $1-3, ? / 89$ & $32, ? / 115$ & $18-20, ? / 100$ & $3.87-13.25$, ? / 30-79 \\
\hline Pharynx (chaetigers) & $5-7$ & $8-9$ & 18 & 12 & 4 \\
\hline \multicolumn{6}{|l|}{ Proventricle } \\
\hline $\begin{array}{l}\text { Length }(\mathrm{mm}) \text {, chaetigers/number } \\
\text { of muscle cell rows }\end{array}$ & ?, 6-10 / 35-40 & $0.28,5-6 / 35$ & $4,10-11 / ?$ & ?, $11 / 58-84$ & $0.3-0.87,4-6 / 34$ \\
\hline \multicolumn{6}{|l|}{ Number of articles } \\
\hline Central, lateral antennae & $16-29,10-16$ & 14,10 & $24,23-24$ & $16-21,11-15$ & $13-30,9-16$ \\
\hline Dorsal, ventral peristomial cirri & $15-24,7-18$ & 12,9 & 26,13 & $18-20, ?$ & $16-47,10-33$ \\
\hline Dorsal cirri segs $1-6$ & $\begin{array}{l}21-29,9-13,11-19 \\
15-26,9-15,14-23\end{array}$ & $13,11, ?, 13,10, ?$ & $36,20,30,40,>25, ?$ & $\begin{array}{c}24-28,8-16,23,22-28, \\
14-21,20-25\end{array}$ & $?$ \\
\hline Midbody long, short dorsal cirri & $13-24,6-15$ & $7-13,7-13$ & $29-33,16-23$ & $20-29,10-18$ & $14-44,15-21$ \\
\hline Anal cirri & ? & $12-13$ & 13 & $?$ & 27 \\
\hline \multicolumn{6}{|l|}{ Chaetae } \\
\hline $\begin{array}{l}\text { Number per parapodium } \\
\text { (anterior, midbody, } \\
\text { posterior body) }\end{array}$ & $2-3,2-3,2-3$ & $3-6,3-6,3-6$ & $?, 2-3, ?$ & $2-3,1-3,1-3$ & $3-4,3-5,3-5$ \\
\hline $\begin{array}{l}\text { Main fang size (in relation to shaft } \\
\text { width) }\end{array}$ & Similar & Shorter & Similar & $\begin{array}{l}\text { Anterior: shorter; mid- and } \\
\text { posterior body: similar }\end{array}$ & Shorter \\
\hline Main fang upper side & $\begin{array}{l}\text { With a long denticle } \\
\text { followed by several } \\
\text { smaller near tip }\end{array}$ & Smooth & $?$ & $\begin{array}{l}\text { Anterior: with denticles; mid- } \\
\text { and posterior body: smooth } \\
\text { (Lattig \& Martin } 2010 \mathrm{~b} \text {, figs } 22 \mathrm{~h} \text {, } \\
23 \mathrm{e}, \mathrm{f} \text { ) }\end{array}$ & Smooth \\
\hline Mid-joining point & Curved, long & Curved, very short & Straight, long & $\begin{array}{l}\text { Anterior: ?straight, long; mid- } \\
\text { and posterior body: longer } \\
\text { chaetae: straight, long, shorter } \\
\text { chaetae: ?straight, short }\end{array}$ & $\begin{array}{l}\text { Longer chaeta: } \\
\text { straight, long; shorter } \\
\text { chaetae: straight, } \\
\text { short }\end{array}$ \\
\hline Apical teeth & $\begin{array}{l}\text { Same size, clearly } \\
\text { separated }\end{array}$ & $\begin{array}{l}\text { Same size; posterior: } \\
\text { tridentate appearence } \\
\text { (Lattig \& Martin } \\
\text { 2009, fig. 22e-h) }\end{array}$ & $\begin{array}{l}\text { Longer chaeta: distal } \\
\text { tooth shorter, narrow } \\
\text { angle between teeth, } \\
\text { unidentate appearence; } \\
\text { shorter chaeta: proximal } \\
\text { tooth shorter, clearly } \\
\text { separated }\end{array}$ & $\begin{array}{l}\text { Anterior body: same size, clearly } \\
\text { separated; mid- and posterior } \\
\text { body: longer chaeta with distal } \\
\text { tooth shorter, narrow angle } \\
\text { between teeth (unidentate } \\
\text { appearence), shorter chaeta: with } \\
\text { proximal tooth shorter, clearly } \\
\text { separated }\end{array}$ & $\begin{array}{l}\text { Distal tooth shorter, } \\
\text { narrow angle between } \\
\text { teeth }\end{array}$ \\
\hline \multicolumn{6}{|c|}{ - } \\
\hline $\begin{array}{l}\text { Number per parapodium } \\
\text { (anterior, midbody, } \\
\text { posterior body) }\end{array}$ & $2-3,2-3,1$ & $2,1,1$ & $4-6,4-6,4-6$ & $4-5,3-4,3-4$ & $3-5,3-5,1$ \\
\hline Morphology & $\begin{array}{l}\text { Straight, broad, with } \\
\text { rounded tips }\end{array}$ & $\begin{array}{l}\text { Anterior body: one } \\
\text { with straight rounded } \\
\text { tip, another with } \\
\text { oblique tip; midbody: } \\
\text { tip directed } \\
\text { downwards; posterior: } \\
\text { with slightly curved tip }\end{array}$ & $\begin{array}{c}\text { Two types, straight or } \\
\text { with curved tip directed } \\
\text { upwards }\end{array}$ & $\begin{array}{l}\text { Three types: straight, with curved } \\
\text { tip directed upwards, and (more } \\
\text { rarely) with curved tip bent at } 90^{\circ}\end{array}$ & Slightly curved tip \\
\hline Source & Lattig \& Martin 2010b & Lattig \& Martin 2009 & Lattig \& Martin 2009 & Lattig \& Martin 2010b & Martin et al. 2002 \\
\hline
\end{tabular}


the other hand, has up to 53 chaetigers, with smooth body wall throughout, lacking dorsal projections, chaetae of same parapodium are similar in shape, two aciculae per parapodium in anterior and midbody chaetigers, with tip subdistally curved nearly at right angle, pharynx extending for 5-9 chaetigers, and proventricle for 4-6 segments, with 38-46 rows of muscle cells.

\section{Haplosyllis rosenalessoae sp. nov.}

(Figures 5-7; Table II)

\section{Holotype}

ZUEC-POL 10094, State of Paraíba, João Pessoa, Praia de Cabo Branco $\left(7^{\circ} 8.815^{\prime} \mathrm{S}, 34^{\circ} 47.773^{\prime} \mathrm{W}\right)$, intertidal, coll. 11 Aug 2010.

\section{Paratypes}

ZUEC-POL 10095, ZUEC-POL 10096, ZUECPOL 10097, MZUSP 1268, MZUSP 1269, MZUSP 1270, MZUSP 1374, MZUSP 1375, MNCN 16.01/14627 and MNCN 16.01/14628: State of Paraíba, João Pessoa, Praia de Cabo Branco $\left(7^{\circ}\right.$ $\left.8.815^{\prime} \mathrm{S}, \quad 34^{\circ} 47.773^{\prime} \mathrm{W}\right)$, intertidal, coll. 11 Aug 2010.

\section{Additional material examined}

State of Paraíba, on sandstone reefs, intertidal: Baía da Traição, Praia do Farol $\left(06^{\circ} 41^{\prime} \mathrm{S}, 34^{\circ} 55^{\prime} \mathrm{W}\right)$ : 1 spec., coll. 9 Aug 2010 (MZUSP 1263). Rio Tinto, Barra de Mamanguape $\left(06^{\circ} 45^{\prime} \mathrm{S}, 34^{\circ} 55^{\prime} \mathrm{W}\right)$ : 7 specs, coll. 2 Feb 2010 (MZUSP 1264). Cabedelo, Píer de Cabedelo $\left(06^{\circ} 58^{\prime} \mathrm{S}, 34^{\circ} 50^{\prime} \mathrm{W}\right)$ : 2 specs, coll. 12 Feb 2009 (MZUSP 1265). Conde, Praia de Jacumã $\left(07^{\circ} 14^{\prime} \mathrm{S}, 34^{\circ} 47^{\prime} \mathrm{W}\right): 1$ spec., coll. 29 Jan 2010 (MZUSP 1266); Praia de Coqueirinho (07 $18^{\circ}$ S, $\left.34^{\circ} 47^{\prime} \mathrm{W}\right): 2$ specs, coll. 28 Aug 2011 (MZUSP 1267).

\section{Comparative material examined}

Haplosyllis carmenbritoae Lattig, San Martín \& Martin, 2007: holotype (MNCN 16.01/10645), Tabaiba, Santa Cruz de Tenerife, Canarias, Spain, $100 \mathrm{~m}$, coll. 1990; 6 paratypes (MNCN 16.01/ 10646), Tabaiba, Santa Cruz de Tenerife, Canarias, Spain, $100 \mathrm{~m}$, coll. 1990. Haplosyllis granulosa (Lattig, Martin \& San Martín, 2007): holotype (MNCN 16.01/10606), Nerja, Málaga, Andalucía, Spain, 3-4.5 m, coll. 24 Feb 1983 by G. San Martín; 5 paratypes (MNCN 16.01/10607), Nerja, Málaga, Andalucía, Spain, 3-4.5 m, coll. 24 Feb 1983 by G. San Martín.

\section{Description}

Small to medium-sized syllines, slender, opaque, 4-10 (7.4) mm long, 0.3-0.4 (0.3) $\mathrm{mm}$ wide at proventricle, excluding parapodia, with 25-61 (50) segments (Table II). Pigmentation absent, beige to light yellow body after preservation. Body wall of mid- to posterior body chaetigers with dorsal granulation, as internal iridescent and granulose inclusions, arranged in continuous transverse rows across chaetigers, broader laterally, at base of parapodia, progressively narrowing towards dorsal midline (Figure 5B). Dorsal and ventral surfaces with irregularly distributed pores, possibly glandular openings (Figure $6 \mathrm{H}-\mathrm{J}$ ), more abundant on midbody chaetigers. Triangular, distally rounded palps, fused at their bases (Figures 5A, 6A). Sub-pentagonal prostomium, shorter than palps (Figure 6A), with two pairs of red eyes in trapezoidal arrangement; ocular spots absent (Figure 5A); antennae longer than palps (Figure 6A); median antenna inserted between posterior eyes or slightly anteriorly, with 16-21 (20) articles; lateral antennae inserted at anterior margin of prostomium, 12-15 (13) articles, shorter than median antenna (Figures 5A, 6A; Table II). Ciliated nuchal organs between prostomium and peristomium, only visible under SEM (Figure 6A,F, G). Peristomium shorter than following chaetigers; peristomial dorsal cirri with 11-21 $(19,17)$ articles, shorter than median antenna; peristomial ventral cirri with 8-12 (10) articles. Dorsal cirri of chaetiger 1 longer than following cirri, with 16-25 $(21,25)$ articles; shorter dorsal cirri on chaetigers 2 and 5 with 8-13 (11,10, respectively) articles; dorsal cirri of chaetiger 3 of intermediate size, with 10-21 (13, 12) articles; dorsal cirri of chaetiger 4 longer, with 13-20 $(16,17)$ articles; dorsal cirri of chaetiger 6 with 8-18 $(12,8)$ articles; dorsal cirri of chaetigers 7 and 8 similar to each other, shorter, with $6-12(8,7$ and 8, respectively) articles; following cirri alternating long, with 8-13 (9-10) articles, and short, with 4-8 (5-6) articles, longest cirri longer than half of body width (Figure 6H,I); posterior dorsal cirri short, with 1-4 (1-4) articles. Oval ventral cirri inserted at bases of parapodia, similar in length to parapodial lobes on anterior body (Figure 6E), posteriorly digitiform, slightly longer than parapodial lobes (Figure $6 \mathrm{H}$ ). Conical parapodial lobes, with 12 chaetae each on anterior and midbody chaetigers, 1 chaeta per parapodium on posterior chaetigers; chaetae protruding from parapodial lobes for short extension; chaetae on same parapodium of similar shape, but different sizes (Figure 5C,D, 6E, 7C,F). Anterior parapodia with bidentate chaetae, apical teeth short, about same size, with oblique, upwardly directed tip; long and pointed main fang, about same width as shaft, mid-joining point straight and long, 

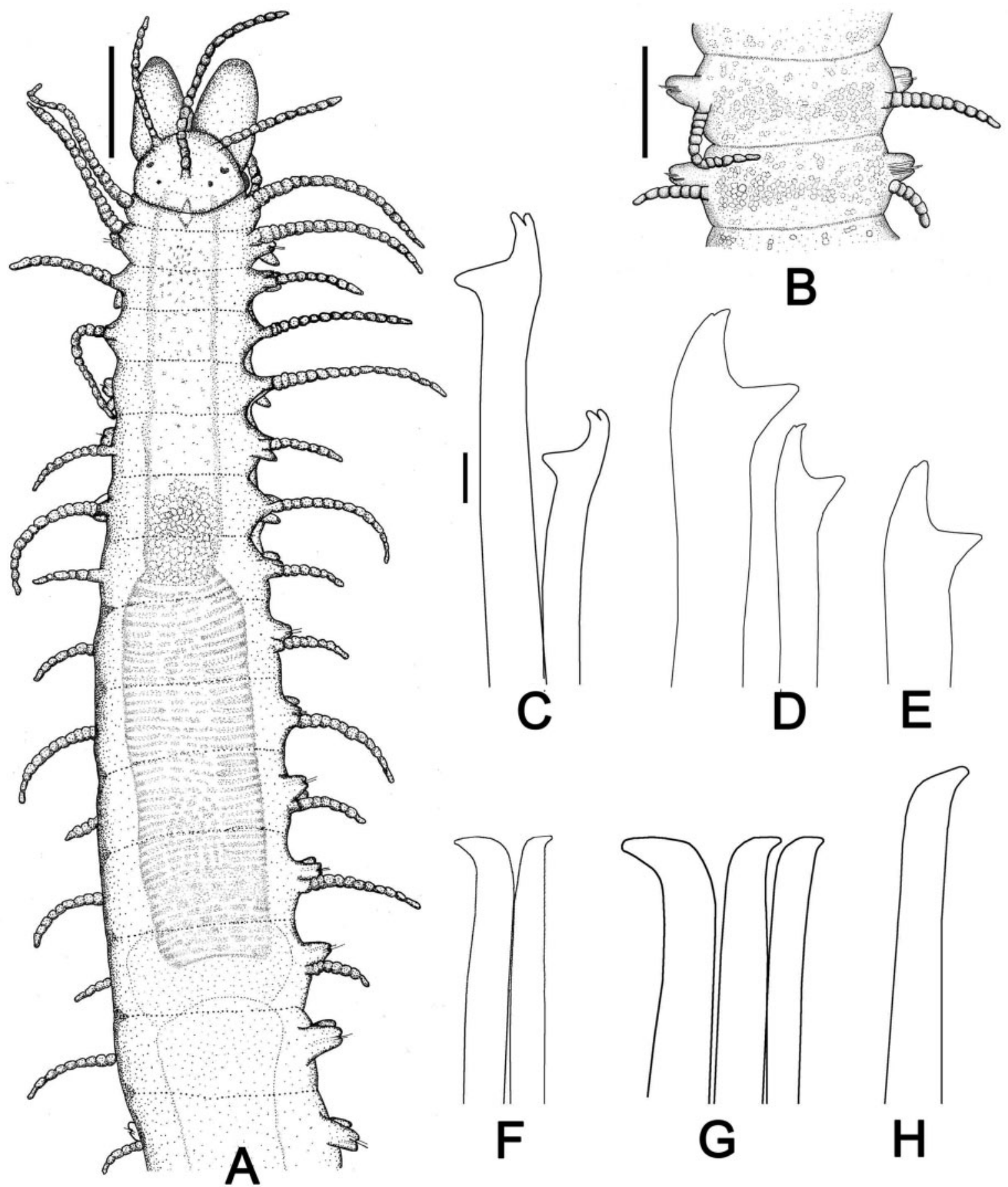

Figure 5. Haplosyllis rosenalessoae sp. nov. A: anterior end, dorsal view; B: midbody, showing dorsal internal granules; C-E: anterior, mid- and posterior body chaetae, respectively; F-H: anterior, mid- and posterior body aciculae, respectively. Scale bars: A,B $=200 \mu \mathrm{m}$; C-H $=5 \mu \mathrm{m}$.

upper side of main fang with few, short denticles, only visible under SEM (Figures 5C, 7C,D); chaetae on midbody parapodia similar to those on anterior body, but slightly stouter, with smooth upper side of main fang (Figures 5D, 7E); chaetae of posterior parapodia with apical teeth very close to each other, nearly unidentate at first glance, and smooth upper side of main fang (Figures 5E, 7F). Two aciculae per parapodium in anterior chaetigers,
2-3 aciculae in each midbody parapodium, single acicula per parapodium in posterior chaetigers; aciculae subdistally curved almost at right angle, with oblique tips (Figure $5 \mathrm{~F}-\mathrm{H}$ ); progressively stouter posteriorwards, about as thick as chaetae of same parapodium. Semicircular pygidium, with ciliated anus dorsally and pair of anal cirri with $4-8(6,8)$ articles (Figure 7A,B), up to 3 times as long as posterior dorsal cirri. Pharynx extending for 6-9 (9) 

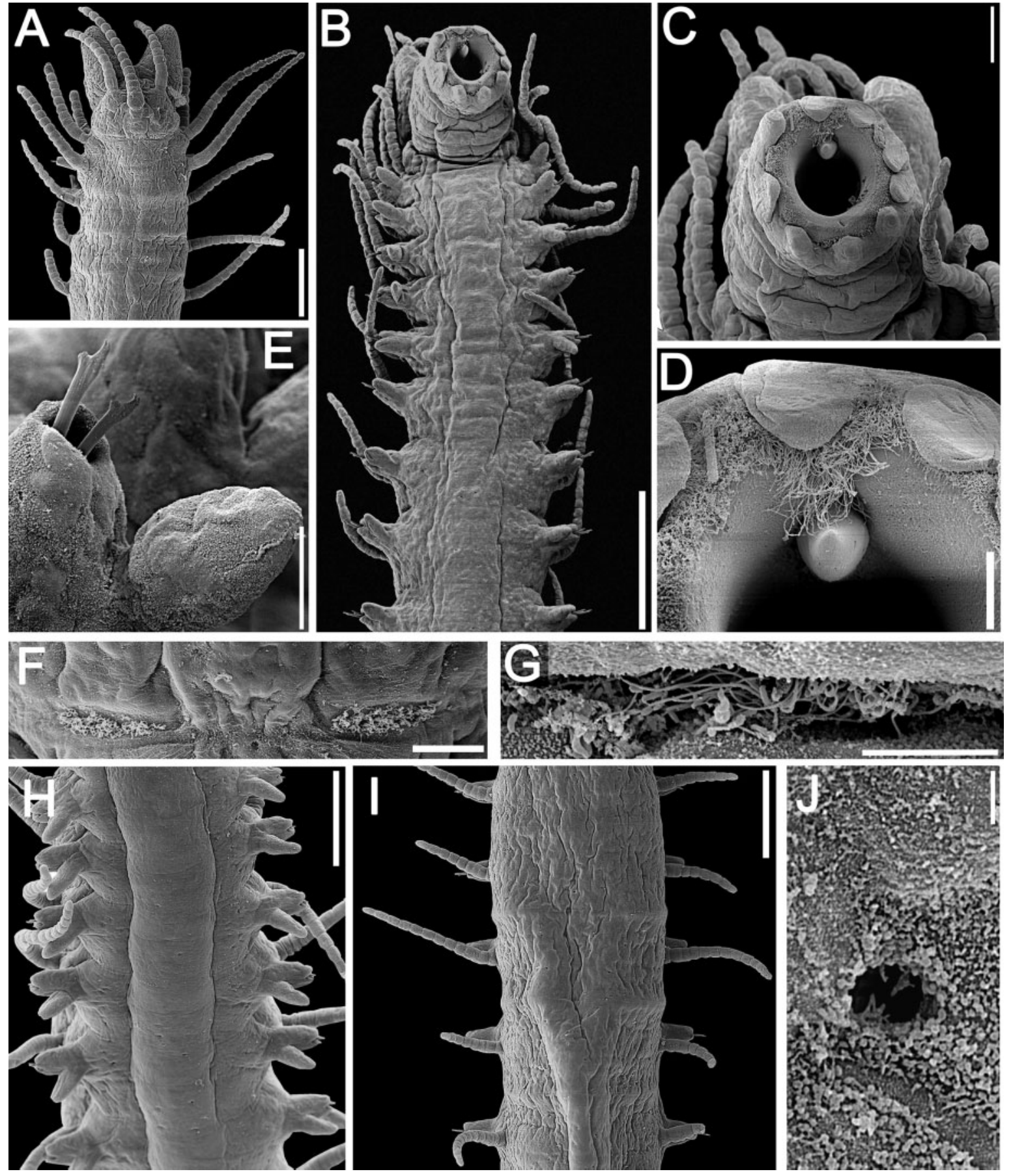

Figure 6. Haplosyllis rosenalessoae sp. nov. A: anterior end, dorsal view; B: anterior end, ventral view; C: anterior end, frontal view; D: detail of pharynx, showing the ciliated border, papillae and tooth; E: chaetiger 1, parapodial lobe and ventral cirrus; F: border between prostomium and peristomium, dorsal view, showing nuchal organs; G: detail, nuchal organ; H: midbody, ventral view; I: midbody, dorsal view; J: detail of a dorsal pore. Scale bars: A,H,I $=100 \mu \mathrm{m} ; \mathrm{B}: 200 \mu \mathrm{m} ; \mathrm{C}=50 \mu \mathrm{m} ; \mathrm{D}-\mathrm{F}=20 \mu \mathrm{m} ; \mathrm{G}=10 \mu \mathrm{m} ; \mathrm{J}=2 \mu \mathrm{m}$.

chaetigers, with tooth at anterior border; anterior margin of pharynx surrounded by crown of $9-11$ papillae with fringe of cilia all around; longer cilia right above pharyngeal tooth (Figure $6 \mathrm{~B}-\mathrm{D}$ ); proventricle $0.60-0.91(0.88) \mathrm{mm}$ long, extending for 4.5-6 (6) chaetigers, with 40-48 (48) rows of muscle cells (Figure 5A).

\section{Distribution}

State of Paraíba, northeastern Brazilian coast.

\section{Etymology}

This species is dedicated to Rosebel Cunha Nalesso, 'Rose', who presented the beauties of the benthos to 

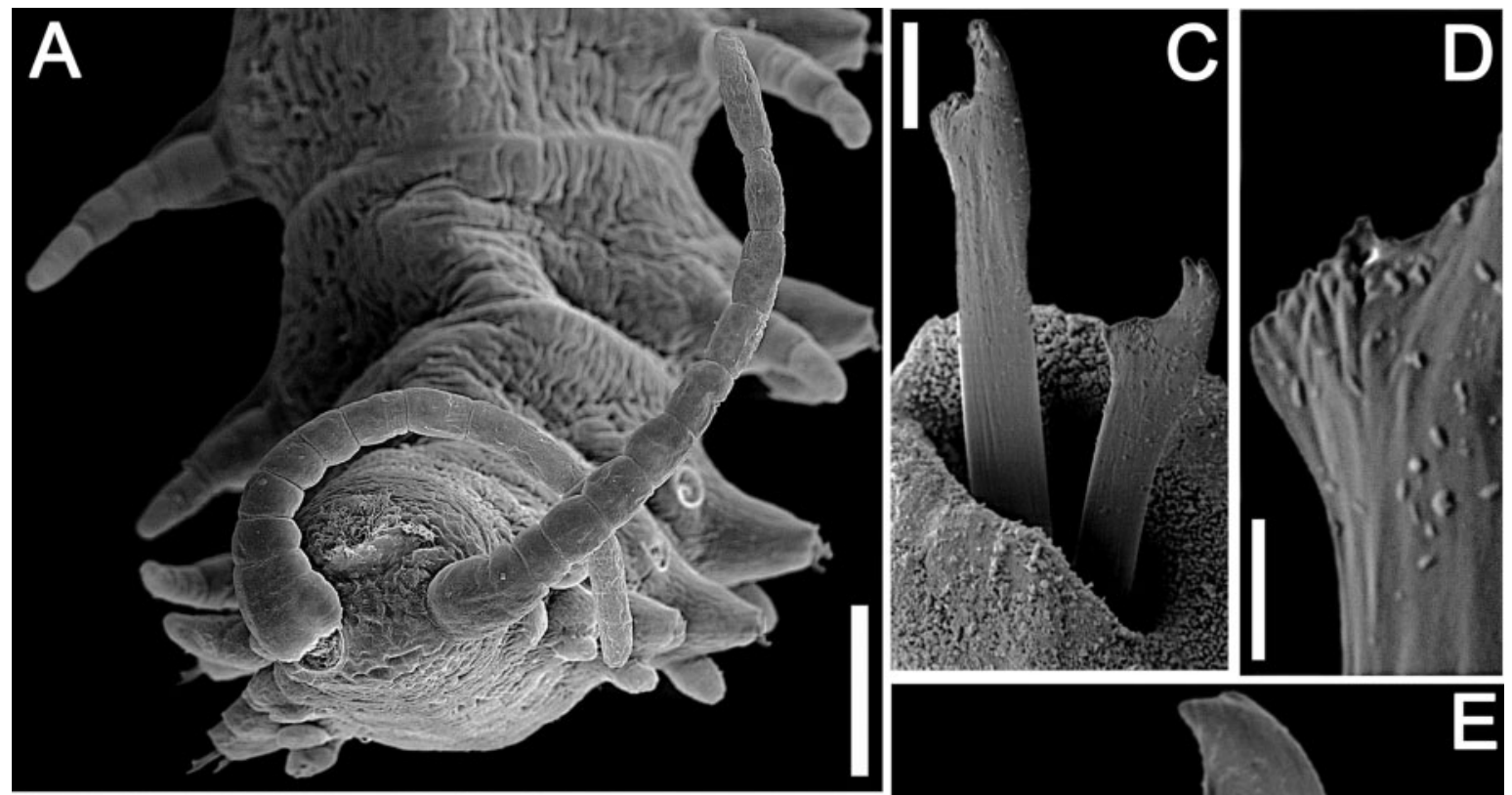

\section{B}
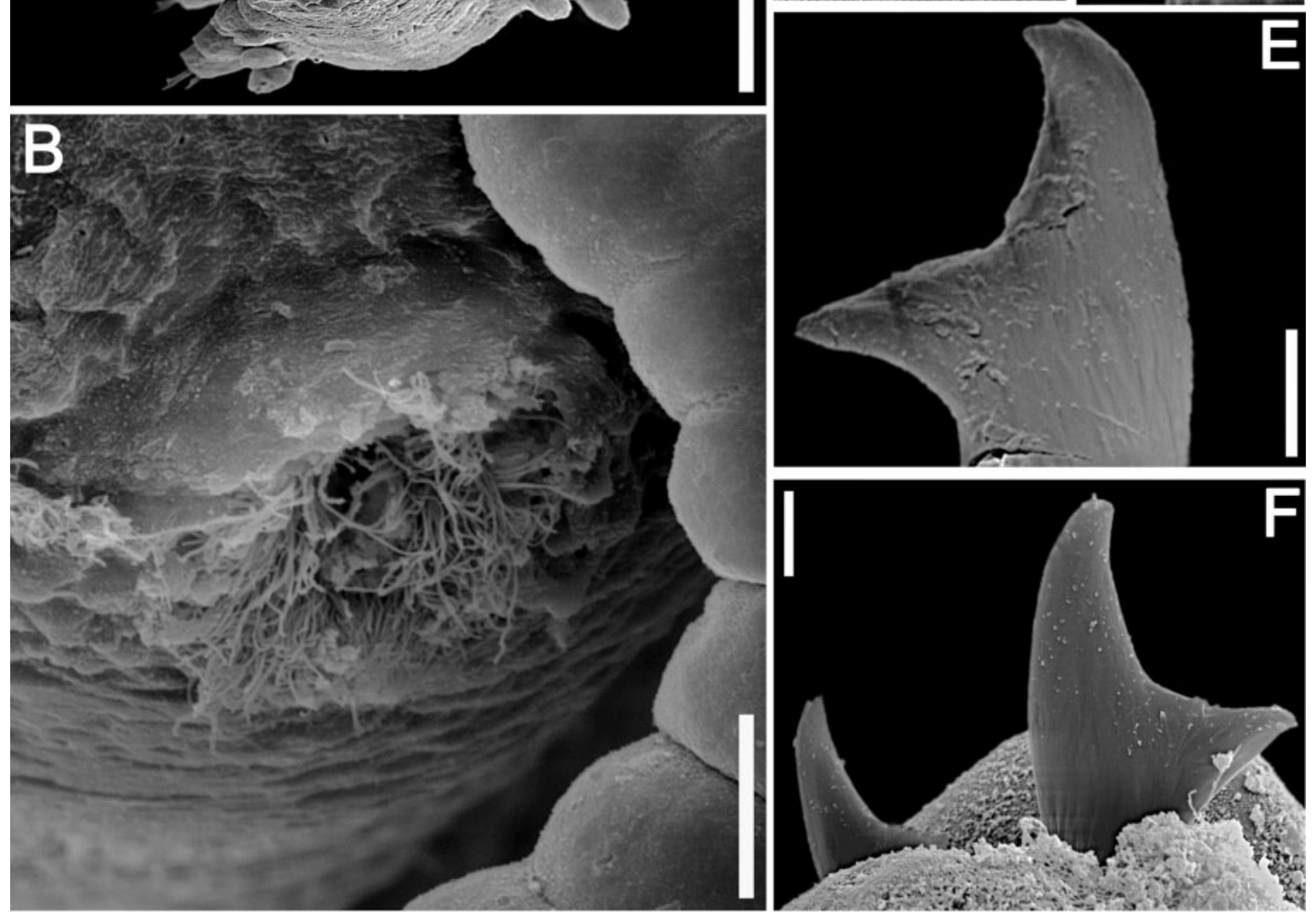

Figure 7. Haplosyllis rosenalessoae sp. nov. A: posterior end, dorsal view; B: ciliated anus; C: anterior body chaetae; D: detail of denticles on upper side of main fang of an anterior chaeta; E: midbody chaeta; F: posterior body chaetae. Scale bars: $A=50 \mu \mathrm{m} ; \mathrm{B}=20 \mu \mathrm{m} ; \mathrm{C}, \mathrm{E}, \mathrm{F}=5 \mu \mathrm{m}$; $\mathrm{D}=2 \mu \mathrm{m}$.

the first author and was the main supporter for KP to start working on the systematics of Syllidae under JMMN's supervision.

\section{Remarks}

Haplosyllis rosenalessoae sp. nov. is similar to Haplosyllis spongicola (Grube, 1855) in general dimensions of the body and number of articles of antennae and anterior cirri (Table III), but this latter species is currently considered as a sibling-species complex (Martin et al. 2003). Lattig et al. (2010b) noticed that Australian material of $H$. spongicola differed from specimens from the Mediterranean by having the body wall with dorsal granulation and shorter midbody dorsal cirri, alternating long and short cirri. Therefore, Lattig et al. (2010b) preferred to identify the Australian material as $H$. cf. spongicola and suggested the aid of molecular studies to check the status of that taxon. Haplosyllis rosenalessoae sp. nov. 
is more similar to Australian specimens of $H$. cf. spongicola (Table III) than to those from the Mediterranean, as it has similar general dimensions of the body, antennae and cirri throughout and the body wall has dorsal granulation. However, the Australian specimens have chaetae of a different morphology from those of $H$. rosenalessoae sp. nov., with a short mid-joining point, curved on chaetae from midbody and posterior body chaetigers, and apical teeth separated from each other by a gap at a greater angle. In addition, $H$. cf. spongicola has two aciculae per parapodium throughout, one of which is straight, while $H$. rosenalessoae sp. nov. has $2-3$ aciculae per parapodium in midbody chaetigers and a single acicula per parapodium in posterior chaetigers, and all aciculae are distally curved.

Haplosyllis rosenalessoae sp. nov. differs from $H$. niphatesicola, $H$. cephalata and $H$. chaetafusorata, all of them known from the Caribbean, mainly in the morphology of chaetae (Table III). In H. niphatesicola the main fang of midbody chaetae is longer than the shaft width and the apical teeth are of about the same size, clearly bidentate, whereas in $H$. rosenalessoae sp. nov. the main fang is shorter than the shaft width and the apical teeth are close to each other, nearly unidentate at first glance. In addition, $H$. niphatesicola has a transluscent body and straight aciculae in anterior chaetigers, while $H$. rosenalessoae sp. nov. has an opaque body and aciculae with curved tips.

Haplosyllis cephalata has a short mid-joining point, different from that of $H$. rosenalessoae sp. nov., which is longer. The Caribbean species has granules in all dorsal surfaces of the body and on the dorsal and ventral cirri (see Lattig \& Martin 2011a, figure 6a,e), while $H$. rosenalessoae sp. nov. only has granules dorsally on the midbody; furthermore, this species has a different width of dorsal cirri throughout the body, considerably shorter in $H$. cephalata. Haplosyllis chaetofusorata has visible traces of fusion between blade and shaft, which does not occur in $H$. rosenalessoae sp. nov.

Haplosyllis granulosa, from the Mediterranean Sea, has a body with dorsal granulation, with internal iridescent and granulose inclusions arranged in continuous transverse rows across chaetigers, like $H$. rosenalessoae sp. nov.; it differs from that species because it has $2-3$ or 3-7 chaetae per parapodium throughout, 2-3 rows of larger denticles on the upper side of the main fang and longer distal teeth, more aciculae per parapodium throughout, and its pharynx has a trepan (Lattig et al. 2007). In contrast, $H$. rosenalessoae sp. nov. has 1-2 chaetae per parapodium on anterior and midbody chaetigers, and a single chaeta on each posterior parapodium, without larger denticles on the main fang surface and inconspicuous distal teeth.

Haplosyllis carmenbritoae lives in deeper waters than $H$. rosenalessoae sp. nov., around $100 \mathrm{~m}$ deep, on Dendrophyllia ramea Linnaeus, 1758 bottoms (Lattig et al. 2007) off the eastern coast of Tenerife, Atlantic Ocean. According to the authors, the brown pigmentation on the body depends on the presence and amount of dorsal granular inclusions, but the authors did not specify the arrangement of these granular inclusions within the body wall. In addition, $H$. carmenbritoae differs from $H$. rosenalessoae sp. nov. in having chaetae with longer and more numerous denticles on the main fang, distal teeth with sharper tips, separated from each other by a gap at a greater angle than in Haplosyllis rosenalessoae sp. nov. and it has paired sensorial organs ventrally on the palps, which are not present in $H$. rosenalessoae sp. nov.

Finally, it is worth comparing $H$. rosenalessoae sp. nov. with $H$. amphimedonicola, described above, as both taxa live in the same area, although $H$. rosenalessoae sp. nov. has not been found within Amphimedon viridis. Haplosyllis rosenalessoae sp. nov. is a longer species, with up to 61 chaetigers and 4-10 $\mathrm{mm}$ in length, and it has up to 3 aciculae in each midbody parapodium, a body wall with dorsal granulation throughout, longer dorsal cirri on midbody chaetigers than those of $H$. amphimedonicola, the longest cirri with 8-13 articles each, exceeding half of body width, the shortest cirri with 4-8 articles each, the aciculae of these species are different (compare Figures $1 \mathrm{~B}, \mathrm{D}, \mathrm{F}$ and $5 \mathrm{~F}-\mathrm{H}$; see Table III), and $H$. rosenalessoae sp. nov. has moniliform anal cirri.

\section{Acknowledgements}

We are thankful to Marcelo Veronesi Fukuda, Orlemir Carrerette, Rudá Amorin, Rafael Brito, Carmem Alonso Samiguel and all the students of Laboratório de Invertebrados Paulo Young for their help with the collections. Special thanks to Javier Sanchez Almazan (Museo Nacional de Ciencias Naturales de Madrid, MNCN) for loaned material; Ênio Mattos and Phillip Lenktaitis for preparing the specimens and photographing them under the SEM; Marcelo Veronesi Fukuda (Universidade de São Paulo), Guilherme Henrique Pereira Filho (Universidade Federal Rural do Rio de Janeiro), Patricia Lattig (MNCN) and another anonymous referee for reading the manuscript and providing valuable comments and suggestions.

\section{Funding}

The Project 'Diversity of Polychaeta (Annelida) on hard substrates off the State of Paraíba, northeastern Brazil' was 
funded by the Conselho Nacional de Desenvolvimento Cientifico e Tecnológico - CNPq (proc. 481510/2008-7) and is presently funded by Fundação de Amparo a Pesquisa do Estado de São Paulo - FAPESP (proc. 2010/52116-4), under the name 'Diversity of Polychaeta (Annelida) on hard substrates off northeastern Brazil, states of Paraíba and Pernambuco'. In addition, $\mathrm{KP}$ received a $\mathrm{PhD}$ fellowship from FAPESP (proc. 2009/17606-3) and JMMN received a productivity grant from $\mathrm{CNPq}$.

\section{References}

Aguado MT, San Martín G, Nishi E. 2006. Two new species of Syllidae (Polychaeta) from Japan. Scientia Marina 70(S3): $9-16$.

Aguado MT, Nygren A, Siddall ME. 2007. Phylogeny of Syllidae (Polychaeta) based on combined molecular analysis of nuclear and mitochondrial genes. Cladistics 23:552-64.

Amaral ACZ, Nallin SAH, Steiner TM, Forroni TO, GomesFilho D. 2012. Catálogo das espécies de Annelida Polychaeta do Brasil. http://www.ib.unicamp.br/projbiota/bentos_marinho/ prod_cien/texto_poli.pdf (acessed August 2013)

Antoniadou C, Nicolaidou A, Chintiroglou C. 2004. Polychaetes associated with the sciaphilic alga community in the northern Aegean Sea: Spatial and temporal variability. Helgoland Marine Research 58:168-82.

Berlandi RM, Figueiredo MAO, Paiva PC. 2012. Rhodolith morphology and the diversity of polychaetes off the southeastern Brazilian coast. Journal of Coastal Research 28:280-87.

Bone D, San Martín G. 2003. Ecological aspects of syllids (Annelida: Polychaeta: Syllidae) on Thalassia testudinum beds in Venezuela. Hydrobiologia 496:289-98.

Çinar ME. 2003. Ecological features of Syllidae (Polychaeta) from shallow-water benthic environments of the Aegean Sea, eastern Mediterranean. Journal of the Marine Biological Association of the United Kingdom 83:737-45.

Duarte LFL, Nalesso RC. 1996. The sponge Zygomycale parishii (Bowerbank) and its endobiotic fauna. Estuarine, Coastal and Shelf Science 42:139-51.

Fukuda MV. 2010. Contribuição ao conhecimento taxonômico dos silídeos (Polychaeta: Syllidae) da região sudeste-sul do Brasil. PhD Thesis. Instituto de Biociências da Universidade de São Paulo, São Paulo. 340 pages.

Fukuda MV, Nogueira JMM. 2006. A new species of Odontosyllis Claparède, 1863 (Polychaeta: Syllidae: Eusyllinae), and description of Brazilian material of Odontosyllis cf. fulgurans (Audouin \& Milne Edwards, 1834). Zoological Studies 45:223-33.

Fukuda MV, Nogueira JMM. 2013. On a new species of Nuchalosyllis (Polychaeta: Syllidae), a rare syllid genus only known from Brazilian waters. Journal of the Marine Biological Association of the United Kingdom 93:963-66.

Fukuda MV, Yunda-Guarín G, Nogueira JMM. 2009. The genus Prosphaerosyllis (Polychaeta: Syllidae: Exogoninae) in Brazil, with description of a new species. Journal of the Marine Biological Association of the United Kingdom 89:1443-54.

Fukuda MV, Centurión R, Nogueira JMM, San Martín G. 2012. Two new species of Paraehlersia San Martín, 2003 (Polychaeta, Syllidae, Eusyllinae) from the Atlantic Coast off South America. Zootaxa 3264:38-52.

Fukuda MV, Nogueira JMM, Paresque K, San Martín G. 2013. Species of Odontosyllis Claparède, 1863 (Annelida: Polychaeta: Syllidae) occurring along the Brazilian coast. Zootaxa 3609:142-62.

Giangrande A, Delos AL, Fraschetti S, Musco L, Licciano M, Terlizzi A. 2003. Polychaete assemblages along a rocky shore on the South Adriatic coast (Mediterranean Sea): Patterns of spatial distribution. Marine Biology 143:1109-16.

Granados-Barba A, Solís-Weiss V, Tovar-Hernández M, OchoaRivera V. 2003. Distribution and diversity of the Syllidae (Annelida: Polychaeta) from the Mexican Gulf of Mexico and Caribbean. Hydrobiologia 496:337-45.

Lattig P, Martin D. 2009. A taxonomic revision of the genus Haplosyllis Langerhans, 1887 (Polychaeta: Syllidae: Syllinae). Zootaxa 2220:1-40.

Lattig P, Martin D. 2011a. Sponge-associated Haplosyllis (Polychaeta: Syllidae: Syllinae) from the Caribbean Sea, with the description of four new species. Scientia Marina 75:733-58.

Lattig P, Martin D. 2011b. Two new endosymbiotic species of Haplosyllis (Polychaeta: Syllidae) from the Indian Ocean and Red Sea, with new data on $H$. djiboutiensis from the Persian Gulf. Italian Journal of Zoology 78:112-23.

Lattig P, San Martín G, Martin D. 2007. Taxonomic and morphometric analyses of the Haplosyllis spongicola complex (Polychaeta: Syllidae: Syllinae) from Spanish seas, with redescription of the type species and descriptions of two new species. Scientia Marina 71:551-70.

Lattig P, Martin D, Aguado MT. 2010a. Four new species of Haplosyllis (Polychaeta: Syllidae: Syllinae) from Indonesia. Journal of the Marine Biological Association of the United Kingdom 90:789-98.

Lattig P, Martin D, San Martín G. 2010b. Syllinae (Syllidae: Polychaeta) from Australia. Part 4. The genus Haplosyllis Langerhans, 1879. Zootaxa 2552:1-36.

Licher F. 1999. Revision der Gattung Typosyllis Langerhans, 1879 (Polychaeta: Syllidae). Morphologie, Taxonomie und Phylogenie. Abhandlungen der Senckenbergischen Naturforschenden Gesellschaft 551:1-336.

López E, San Martín G, Jiménez M. 1996. Syllinae (Syllidae, Annelida, Polychaeta) from Chafarinas Islands (Alborán Sea, W. Mediterranean). Miscellània Zoològica 19:105-18.

López E, Britayev TA, Martin D, San Martín G. 2001. New symbiotic associations involving Syllidae (Annelida: Polychaeta), with taxonomic and biological remarks on Pionosyllis magnifica and Syllis cf. armillaris. Journal of Marine Biological Association of the United Kingdom 81:399-409.

Martin D, Britayev TA. 1998. Symbiotic polychaetes: Review of known species. Oceanography and Marine Biology: An Annual Review 36:217-340.

Martin D, Britayev TA, San Martín G, Gil J. 2003. Interpopulation variability and character description in the spongeassociated Haplosyllis spongicola complex (Polychaeta: Syllidae). Hydrobiologia 496:145-62.

Morgado EH, Amaral ACZ. 1985. Anelídeos poliquetos associados ao briozoário Schizoporella unicomis (Johnston). V. Syllidae. Revista Brasileira de Zoologia 3:219-27.

Morgado EH, Tanaka MO. 2001. The macrofauna associated with the bryozoan Schizoporella errata (Walters) in southeastern Brazil. Scientia Marina 65:173-81.

Neves G, Omena E. 2003. Influence of sponge morphology on the composition of the polychaete associated fauna from Rocas Atoll, northeast Brazil. Coral Reefs 22:123-29.

Nogueira JMM. 2000. Anelídeos poliquetas associados ao coral Mussismilia hispida (Verrill, 1868) em ilhas do litoral do Estado de São Paulo. Phyllodocida, Amphinomida, Eunicida, Spionida, Terebellida, Sabellida. PhD Thesis. Instituto de Biociências da Universidade de São Paulo, São Paulo. 265 pages.

Nogueira JMM. 2006. Família Syllidae. In: Amaral ACZ, Rizzo AE, Arruda EP, editors. Manual de Identificação dos Invertebrados Marinhos da Região Sudeste-Sul do Brasil. São Paulo: Editora da Universidade de São Paulo, p 134-64. 
Nogueira JMM, Fukuda MV. 2008. A new species of Trypanosyllis Claparède, 1864 (Polychaeta: Syllidae) from Brazil, with a redescription of Brazilian material of Trypanosyllis zebra. Journal of the Marine Biological Association of the United Kingdom 88:913-24.

Nogueira JMM, San Martín G. 2002. Species of Syllis Savigny in Lamarck, 1818 (Polychaeta: Syllidae) living in corals in the state of São Paulo, southeastern Brazil. Beaufortia 52:57-93.

Nogueira JMM, Yunda-Guarín G. 2008. A new species of Syllis (Polychaeta: Syllidae: Syllinae) from off Fortaleza, northeastern Brazil. Journal of the Marine Biological Association of the United Kingdom 88:1391-99.

Nogueira JMM, San Martín G, Amaral ACZ. 2001. Description of five new species of Exogoninae (Polychaeta, Syllidae) associated with the stony coral Mussismilia hispida (Verrill, 1868 ) in São Paulo State, Brazil. Journal of Natural History 35:1773-94.

Nogueira JMM, San Martín G, Fukuda MV. 2004. On some exogonines (Polychaeta, Syllidae) from the northern coast of the State of São Paulo, southeastern Brazil - Results of BIOTA/FAPESP/Bentos Marinho Project. Meiofauna Marina 13:45-78.

Nygren A, Gidholm L. 2001. Three new species of Proceraea (Polychaeta: Syllidae: Autolytinae) from Brazil and the United States, with a synopsis of all Proceraea-like taxa. Ophelia 54:177-91.

Paiva PC. 2006. Filo Annelida. Classe Polychaeta. In: Lavrado $\mathrm{HP}$, Ignacio BL, editors. Biodiversidade Bentônica da Região Central da Zona Econômica Exclusiva Brasileira. Série Livros no. 18. Rio de Janeiro: Museu Nacional, p 261-98.

Paiva PC, Young PS, Echeverría CA. 2007. The Rocas Atoll, Brazil: A preliminary survey of the crustacea and polychaete fauna. Arquivos do Museu Nacional, Rio de Janeiro 65:241-50

Paola A, San Martín G, Martin, D. 2006. A new species of Haplosyllis Langerhans, 1879 (Annelida: Polychaeta: Syllidae: Syllinae) from Argentina. Proceedings of the Biological Society of Washington 119:346-54.
Ribeiro SM, Omena EP, Muricy G. 2003. Macrofauna associated to Mycale microsigmatosa (Porifera, Demospongiae) in Rio de Janeiro State, SE Brazil. Estuarine, Coastal and Shelf Science 57:951-59.

Rullier F, Amoureux L. 1979. Annélides Polychètes. Annales de l'Institute Oceanographique 55:145-206.

San Martín G. 2003. Annelida Polychaeta II: Syllidae. In: Ramos MA, et al., editors. Fauna Ibérica, volume 21. Madrid: Museo Nacional de Ciências Naturales, CSIC. 544 pages.

San Martín G. 2005. Exogoninae (Polychaeta: Syllidae) from Australia with the description of a new genus and twenty-two new species. Records of the Australian Museum 57:39-152.

San Martín G, Hutchings P. 2006. Eusyllinae (Polychaeta: Syllidae) from Australia with the description of a new genus and fifteen new species. Records of the Australian Museum 58:257-370.

San Martín G, López E. 2003. A new genus of Syllidae (Polychaeta) from Western Australia. Hydrobiologia 496:191-97.

San Martín G, Hutchings P, Aguado MT. 2008. Syllinae (Polychaeta, Syllidae) from Australia. Part 2. Genera Inermosyllis, Megasyllis n. gen., Opisthosyllis, and Trypanosyllis. Zootaxa 1840:1-53.

San Martín G, Hutchings P, Aguado MT. 2010. Syllinae (Polychaeta, Syllidae) from Australia. Part 3. Genera Alcyonosyllis, Genus A, Parahaplosyllis, and Trypanosyllis (Trypanobia). Zootaxa 2493:35-48.

Stofel CB, Canton GC, Antunes LAS, Eutrópio FJ. 2008. Fauna associated with the sponge Cliona varians (Porifera, Desmoespongiae). Natureza on line 6:16-18.

Utinomi H. 1956. On the so-called 'Umi-utiwa', a peculiar flabellate gorgonacean, with notes on a syllidean polychaete commensal. Publications of the Seto Marine Biological Laboratory $2: 243-50$.

Editorial responsibility: Danny Eibye-facobsen 


\begin{abstract}
APÊNDICE 5
Species of Odontosyllis Claparède, 1863 (Annelida:

Polychaeta: Syllidae) occurring along the Brazilian coast

Periódico Zootaxa
\end{abstract}

Fukuda, M.V., Nogueira, J.M.M., Paresque, K. \& San Martín, G. (2013) Species of Odontosyllis Claparède, 1863 (Annelida: Polychaeta: Syllidae) occurring along the Brazilian coast. Zootaxa, 3609, 142-162.

Manuscrito aceito para publicação 05 de Dezembro de 2012

Publicado 29 de Janeiro de 2013. 



\title{
Species of Odontosyllis Claparède, 1863 (Annelida: Polychaeta: Syllidae) occurring along the Brazilian coast
}

\author{
MARCELO VERONESI FUKUDA ${ }^{1}$, JOÃO MIGUEL DE MATOS NOGUEIRA ${ }^{1}$, \\ KARLA PARESQUE ${ }^{1} \&$ GUILLERMO SAN MARTÍN ${ }^{2}$ \\ ${ }^{1}$ Laboratório de Poliquetologia (LaPol), Departamento de Zoologia, Instituto de Biociências, Universidade de São Paulo, Rua do \\ Matão, travessa 14,n. 101,05508-900,São Paulo,SP,Brazil.E-mail:fukuda@ib.usp.br; mvfukuda@gmail.com \\ ${ }^{2}$ Departamento de Biología (Zoología), Facultad de Ciencias, Universidad Autónoma de Madrid, Madrid, Spain
}

\begin{abstract}
Two new species of Odontosyllis were found in samples collected mainly on rocky shores off the states of São Paulo (SE Brazil) and Paraíba (NE Brazil). Odontosyllis aracaensis sp. nov., and O. guarauensis sp. nov., are herein described and compared to their most similar congeners. A key for the species found in Brazil is provided, and relevant morphological characters of similar species of the genus, based on falcigers morphology, are summarized and compared with those of the newly described species. The current state of knowledge on the genus is briefly discussed.
\end{abstract}

Key words: Eusyllinae, taxonomy, new species, Brazil

\section{Introduction}

The Brazilian syllids have seldom been the subject of specific taxonomic surveys, so that most of the species known until recently were reported in ecological studies (see Amaral et al. 2012). In the past decade, an increase in the efforts addressed to assess the diversity of the family in the country (Nogueira et al. 2001, 2004; Nogueira \& San Martín 2002; Nogueira 2006; Fukuda \& Nogueira 2006, 2012; Nogueira \& Fukuda 2008; Nogueira \& YundaGuarin 2008; Fukuda et al. 2009, 2012) resulted in numerous new occurrences and/or new species to science.

The present study is part of a series of papers reporting on the syllids from southeastern-southern Brazilian coast (Nogueira et al. 2004; Fukuda \& Nogueira 2006, 2012; Nogueira \& Fukuda 2008; Fukuda et al. 2009, 2012). We herein describe two new species of the genus Odontosyllis Claparède, 1863, O. aracaensis sp. nov., and $O$. guarauensis sp. nov. Prior to the present study, there were four species of the genus registered in Brazilian waters: O. fulgurans (Audouin \& Milne Edwards, 1833) (Sovierzoski 1991; Nogueira 2000, 2006; as O. cf. fulgurans: Fukuda \& Nogueira 2006, Fukuda 2010), O. polycera (Schmarda, 1861) (see Amaral et al. 2012), O. guillermoi Fukuda \& Nogueira, 2006 (Fukuda \& Nogueira 2006; Fukuda 2010), and Odontosyllis heterofalchaeta Temperini, 1981. However, the latter was informally described in a M. Sc. dissertation, without assignment of type material and a formal description was never published, so it must be considered nomen nudum; O. polycera was reported only in ecological studies (see Amaral et al. 2012) and there is no material available for examination. Therefore, only four species of the genus (including the two newly described in this paper) are formally recognized as present in Brazilian waters.

\section{Material and methods}

The material analysed for the present paper came from three independent projects:

1) 'BIOTA/FAPESP/Benthic Marine Biodiversity in the State of São Paulo' ('BIOTA'), with focus on rocky shores and soft bottoms (intertidal to $\sim 80 \mathrm{~m}$ deep) off the northern coast of the state of São Paulo (Fransozo \& Fransozo 2011), which provided us with material sorted at family level and preserved in $70 \%$ ethanol. 
2) 'Biodiversity of Intertidal Polychaetes on Rocky Shores off the State of São Paulo' ('BioPol-SP'); in this project, collections were made by scraping from rocky shores, at neap tide, tufts of algae, mussel beds, colonies of sponges and ascidians, small pieces of sabellariid reefs, and similar substrates, along beaches off the state of São Paulo. The samples were sorted alive under stereomicroscope; polychaetes were sorted, relaxed in a menthol solution (a few crystals in seawater), fixed in $4 \%$ formaldehyde - seawater solution and, a few weeks later, rinsed in fresh water and preserved in $70 \%$ ethanol.

3) 'Diversity of Polychaeta (Annelida) on Hard Substrates off the states of Paraíba and Pernambuco, Northeastern Brazil' ('BioPol-NE'), an ongoing project in which we are using the same procedures as in the previous project. Identifications were based exclusively on morphological characters. Illustrations were done with the aid of a drawing tube attached to an Olympus BX-51 ${ }^{\oplus}$ microscope. Length was measured from the tip of the prostomium (excluding antennae) to the tip of the pygidium (excluding anal cirri), or of the available fragments; width was measured at proventricular level, excluding parapodia. Blade lengths for compound chaetae are given in dorsoventral sequence. For the study under scanning electron microscope (SEM), specimens were dehydrated in a series of ethanol solutions with progressively increasing concentrations (75-100\%), critical-point-dried, covered with a layer of 10-20 nm of gold, and observed under the SEM at Laboratório de Microscopia Eletrônica, Instituto de Biociências, Universidade de São Paulo, and Laboratório de Microscopia Eletrônica, Museu de Zoologia, Universidade de São Paulo.

Collection sites are listed in a N-S and E-W arrangement.

Abbreviations for museum names are:

MNCN Museo Nacional de Ciencias Naturales, Madrid, Spain

MZUSP Museu de Zoologia, Universidade de São Paulo, São Paulo, Brazil

ZUEC Museu de Zoologia da Universidade Estadual de Campinas, Campinas, Brazil

ZMH Zoological Museum Hamburg, Hamburg, Germany

\section{Results}

\section{Taxonomy}

\section{Family Syllidae Grube, 1850}

\section{Subfamily Eusyllinae Malaquin, 1893}

\section{Genus Odontosyllis Claparède, 1863}

Type species: Syllis fulgurans Audouin \& Milne Edwards, 1833, designated by Hartman (1959).

Diagnosis. Medium to large sized body. Prostomium with two pairs of eyes and three antennae; palps fused only at bases or free, close to each other. Nuchal organs as one pair of ciliated rows extending along posterior border of prostomium. Peristomium with two pairs of cirri; rounded occipital flap usually present, frequently well developed, extending over posterior part of prostomium, covering dorsal end of nuchal organs. Antennae, peristomial and dorsal cirri throughout smooth to irregularly wrinkled, usually distally tapering. Compound chaetae as uni- or bidentate falcigers, elongated in some species. Pharynx usually short; trepan with teeth directed backwards and, frequently, two lateral plates; pharyngeal central tooth absent. Reproduction by epigamy; epitokes frequently bioluminescent.

Remarks. Odontosyllis is a relatively large genus of syllids, currently with about 49 valid species (Verdes et al. 2011), relatively easily recognized by the morphology of the trepan, with backwards directed teeth, and by the usual presence of an occipital flap extending over the posterior part of prostomium.

In many species of this genus (including all the Brazilian ones), the dorso-ventral gradation in length of the falciger blades is opposite to that usually found in syllids (i.e., the dorsalmost falciger blades are shorter than the ventralmost ones). This feature was misinterpreted in Fukuda \& Nogueira (2006) and is usually not mentioned in species descriptions. 


\section{Identification key to the currently known Brazilian species of Odontosyllis}

1a. "Regular" shafts of falcigers (subdistally inflated, distally straight, with short subdistal spines; Fig. 1A-B) throughout body.

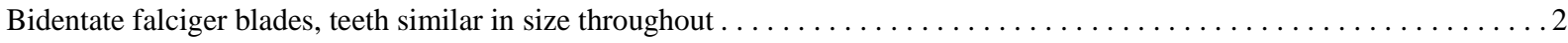

1b. Shafts of falcigers different from above at least on posterior body. Bidentate falciger blades, distal tooth larger than subdistal

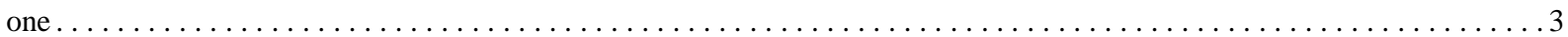

2a. Body without pigmentation patterns. All falcigers with bidentate blades, both teeth similar in size........ O. cf. fulgurans

2b. Body with one dark, large, transverse stripe on dorsum of each chaetiger. Falciger blades with teeth about same size on anterior body and in dorsalmost chaetae throughout; ventralmost chaetae from midbody onwards with distal tooth larger than subdistal

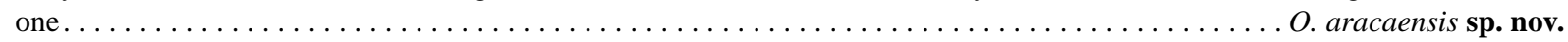

3a. Two black, transverse, dorsal stripes per chaetiger throughout; prostomial mask as one stripe around posterior border, one stripe between eyes of anterior pair and another stripe behind eyes of posterior pair. Shafts of posterior body falcigers, especially in dorsalmost chaetae, distally sigmoid. Trepan with six teeth and two lateral plates ............. guillermoi

3b. One roughly triangular patch on prostomium, beneath occipital flap, and one large, dorsal transverse stripe per chaetiger. Shafts of posterior body falcigers, especially in dorsalmost chaetae, with subdistal enlargement, nearly triangular in shape. Tre-

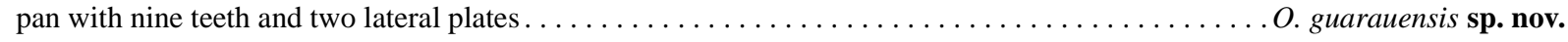

\section{Odontosyllis cf. fulgurans (Audouin \& Milne Edwards, 1833)}

Figure 1B

? Syllis fulgurans Audouin \& Milne Edwards, 1833: 229-232.

Odontosyllis cf. fulgurans. Fukuda \& Nogueira 2006: 229-232, figs 3-4; Fukuda 2010: 48-52, figs 11-12.

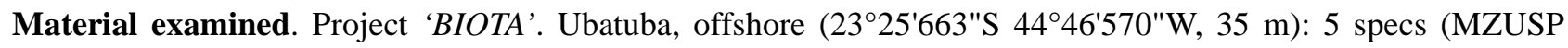

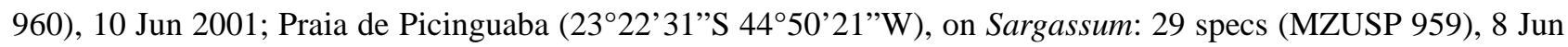

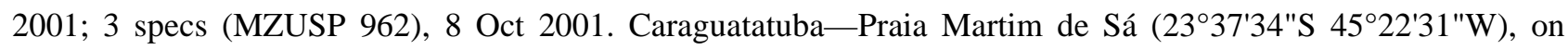
Sargassum: 9 specs (ZUEC-POL 11290), 16 Mar 2001; on rocky shore: 43 specs (MZUSP 961), 27 Sep 2001. São Sebastião-Praia da Baleia $\left(23^{\circ} 46^{\prime} \mathrm{S} 45^{\circ} 39^{\prime} \mathrm{W}\right)$, on rocky shore: 5 specs (MZUSP 958), 8 Apr 2001; 41 specs (ZUEC-POL 11291), 10 Apr 2001; 12 specs (MZUSP 963), 14 Oct 2001.

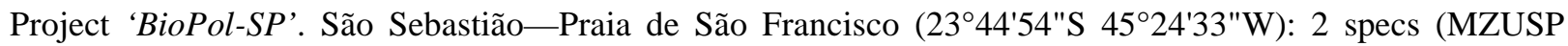
964), 19 Apr 2003; 5 specs (ZUEC-POL 11295), 16 Jul 2003; 2 specs (MZUSP 965), 27 Sep 2003; Praia da Baleia

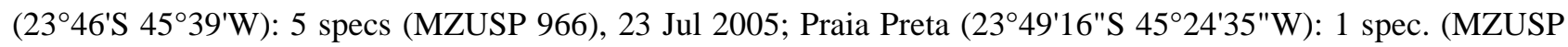
968), 18 Apr 2003. São Vicente-Praia das Vacas (2358'55"S 46²2'48"W): 1 spec. (MZUSP 969), 27 Aug 2003.

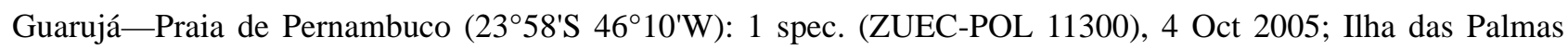
$\left(24^{\circ} 00^{\prime} \mathrm{S} 46^{\circ} 19^{\prime} \mathrm{W}\right): 4$ specs (MZUSP 967), 5 Oct 2005.

Project 'BioPol-NE'. Baía da Traição-Praia do Farol (6 $6^{\circ} 41^{\prime} 20^{\prime}$ 'S $34^{\circ} 55^{\prime} 48^{\prime \prime}$ W): 9 specs (MZUSP 1223), 9 Aug 2010. Rio Tinto-Barra de Mamanguape (6 $6^{\circ} 6^{\prime} 9^{\prime \prime} S$ 34 $\left.4^{\circ} 55^{\prime} 2^{\prime \prime} \mathrm{W}\right): 5$ specs (MZUSP 1224), 11 Aug 2010. João

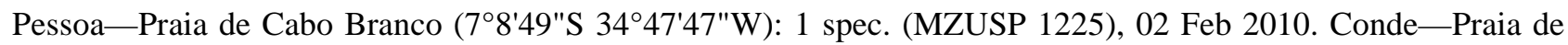
Jacumã (7¹6’40”S 3447'54”'W): 2 specs (MZUSP 1226), 20 Jan 2010.

Remarks. The specimens agree well with the description provided by Fukuda \& Nogueira (2006), except for the inverted dorso-ventral gradation in length of the falciger blades, which was misinterpreted in that study.

\section{Odontosyllis aracaensis sp. nov.}

Figures 1A; 2-3; Table 1

Material examined. Project 'BioPol-SP'. São Sebastião-Praia do Araçá (2348'54”'S 4524'24”'W): 7 specs (MZUSP 1017, holotype; ZUEC-POL 11891, paratype 1; MNCN 16.01/14458, paratype 4; MZUSP 1018,

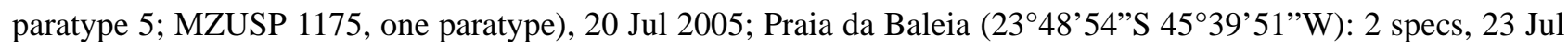

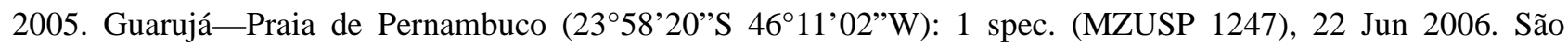
Vicente-Ilha Porchat (23⒌'39'S 46²2'08'W): 6 specs (MNCN 16.01/14457, paratype 2; ZUEC-POL 11892, paratype 3; MZUSP 1019, four paratypes), 18 Apr 2008. 


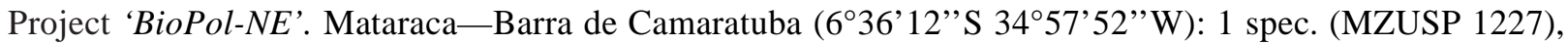
12 Aug 2010. Baía da Traição-Praia do Farol (641'20”'S 3455'48”'W): 16 specs (MZUSP 1228), 9 Aug

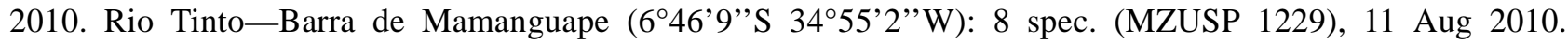
Conde-Praia de Jacumã ( $7^{\circ} 16^{\prime} 40^{\prime}$ 'S 3447'54”W): 1 spec. (MZUSP 1230), 20 Jan 2010; Praia de Coqueirinho

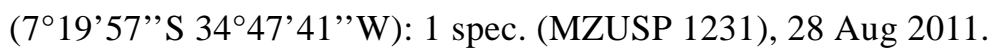

Type series. Data of selected specimens of the type series are provided in Table 1.

Additional material examined. Odontosyllis fulgurans (Audouin \& Milne Edwards, 1833). North Sea $\left(59^{\circ} 05^{\prime} \mathrm{N} 2^{\circ} 21^{\prime} \mathrm{W}, 76 \mathrm{~m}\right): 3$ specs (ZMH-P13322), coll. Institute für Meeresforschung Bremerhaven, det. G. Hartmann-Schröder, 1972. Odontosyllis fulgurans dolerens Westheide, 1974. Pacific Ocean, Galápagos, Santa Cruz: 1 spec. (holotype, ZMH P-13609), coll. \& det. W. Westheide, 1972.

Description. Medium-sized body, holotype largest specimen analysed, $13 \mathrm{~mm}$ long, $0.69 \mathrm{~mm}$ wide, with 84 segments (Table 1). Conspicuous pigmentation on living animals, dorsally with dark line on anterior border of prostomium, short longitudinal stripe between posterior eyes, beneath occipital flap, one large transverse stripe dorsally on each chaetiger, and additional longitudinal lines dorso-laterally in some specimens; ventrally, pigmentation as one pair of large, round spots at midline of each chaetiger. Palps irregularly rounded to subpentagonal, basally fused (Figs 2A; 3A-B). Prostomium ovate with two pairs of eyes in rectangular to trapezoidal arrangement and, sometimes, one pair of small anterior eyespots; lateral antennae inserted on anterior margin of prostomium, almost twice as long as palps; median antenna inserted on middle of prostomium, between anterior eyes, almost twice as long as lateral antennae (Figs 2A; 3A); nuchal organs as one pair of broad semi-circular rows of cilia posterior to eyes of posterior pair, extending dorsally until near base of central antenna and laterally around prostomium, until close to base of palps (Fig. 3A, D). Peristomium dorsally shorter than subsequent segments, with rounded occipital flap covering central area of posterior margin of prostomium, partially including posterior pair of eyes (Figs. 2A; 3A, D); dorsal peristomial cirri slightly longer than median antenna, ventral peristomial cirri approximately same size as lateral antennae, inserted in ventrolateral position, close to mouth (Fig. 3B). Dorsal cirri of chaetiger 1 longer than dorsal peristomial cirri; remaining dorsal cirri alternating longer cirri, as long as dorsal peristomial cirri, and shorter cirri, as long as lateral antennae (Figs 2A; 3A). Antennae, peristomial and dorsal cirri with short cirrophores (Figs 2A; 3F); cirrostyles with scattered tufts of cilia, arranged in irregular longitudinal rows (Fig. 3A-B, D-E). Ventral cirri round to ovate, slightly shorter than parapodial lobes (Fig. 3B, E). Parapodial lobes distally bilobed, with rounded lobes, posterior lobe slightly larger (Fig. 3B, E). Anterior parapodia with 15-20 falcigers each, midbody with 10-18, posterior parapodia with 6-10 falcigers each (Table 1); shafts of falcigers subdistally spinulated, with straight tips (Figs 1A; 2B-D; 3C, G); connective between shafts and blades spinulated in dorsalmost chaetae, especially on mid- and posterior body chaetigers (Fig. 2C-D); blades of falcigers spinulated and bidentate, teeth about same size on anterior chaetigers and in dorsalmost chaetae of mid- and posterior chaetigers (Figs 2B-D; 3G), distal tooth larger than subdistal one in ventralmost chaetae of mid- and posterior body chaetigers (Figs 2C-D; 3C); blades of falcigers within each parapodium with subdistal tooth progressively more separate from distal tooth ventralwards (Figs 2B-D; 3F); blades with inverted dorso-ventral gradation in length, 11-22 $\mu \mathrm{m}$ long on anterior chaetigers, 10-22 $\mu \mathrm{m}$ long on midbody, 9-17 $\mu \mathrm{m}$ long on posterior chaetigers (Table 1). Dorsal simple chaetae only present on posterior chaetigers (Table 1), thin, $\sim 1 / 3$ as thick as shafts of falcigers, slightly sigmoid, subdistally spinulated (Fig. 2E); ventral simple chaetae only present on posteriormost chaetigers (Table 1), sigmoid, bidentate, tips resembling those of blades of falcigers, slightly spinulated subdistally, about half as thick as shafts of falcigers (Fig. 2F). Anterior parapodia with up to 3 aciculae each, midbody with 1-2, posterior parapodia with 1 acicula each; aciculae subdistally enlarged and slightly spinulated, sometimes with short, acute tip (Fig. 2G-H). Pygidium with thin, elongate pair of anal cirri, almost twice as long as posterior dorsal cirri, sometimes wrinkled to pseudoarticulated. Pharynx through 3-4 segments (Table 1), trepan with six teeth and two lateral plates; proventricle through 5-9.5 segments (Table 1), with numerous transverse and oblique muscle cell rows (Fig. 2A). 


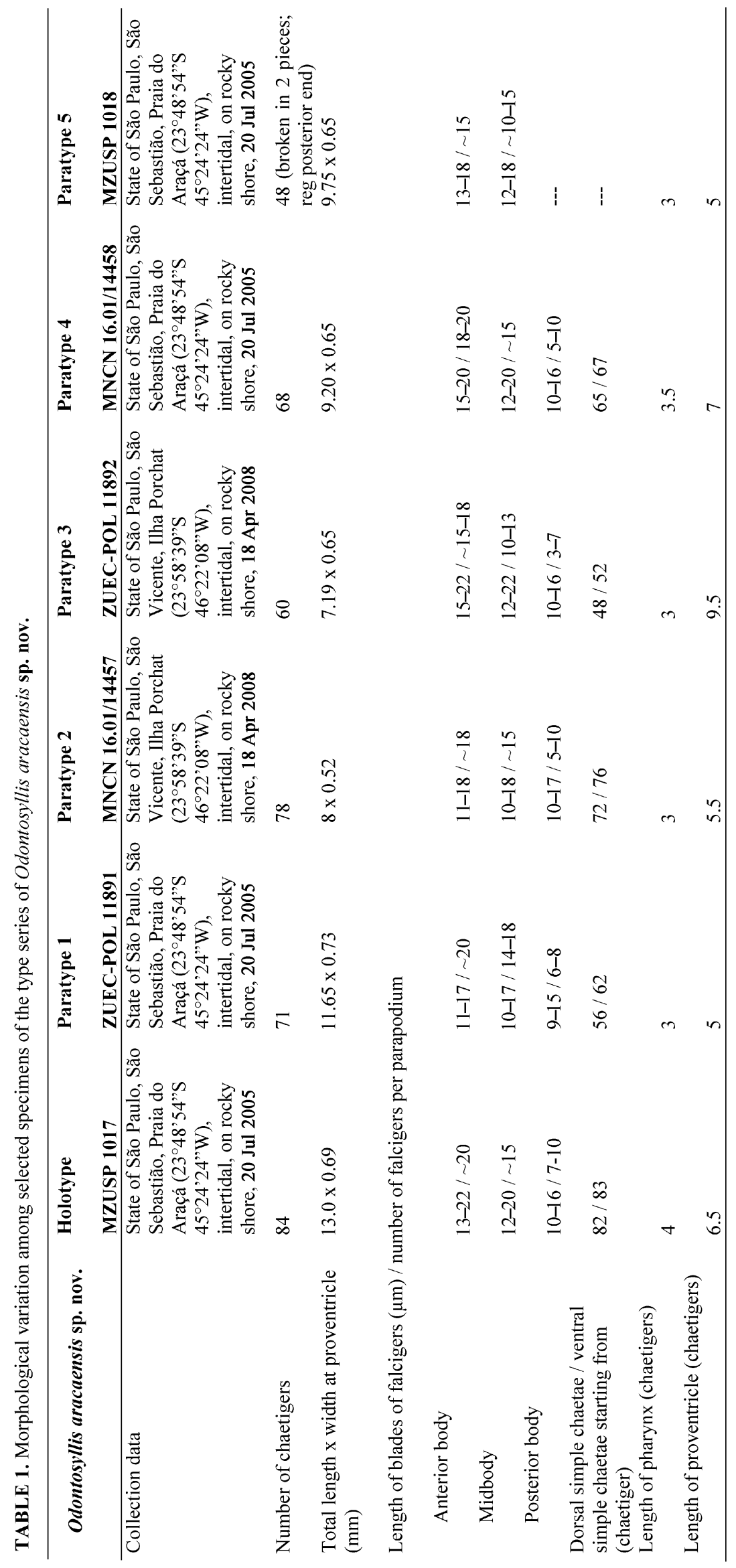




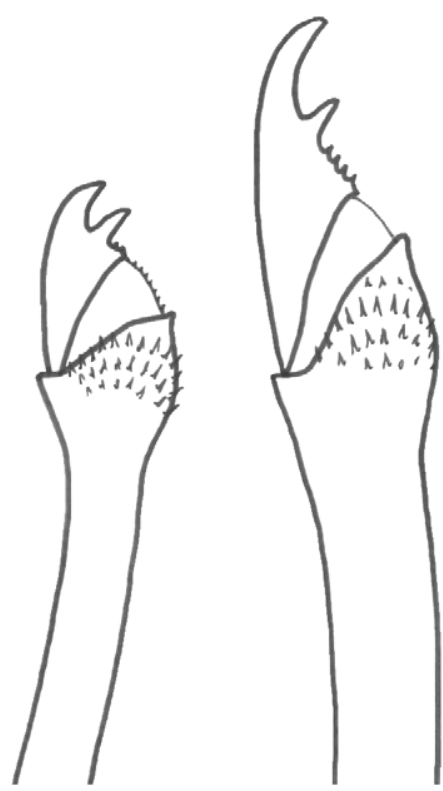

A

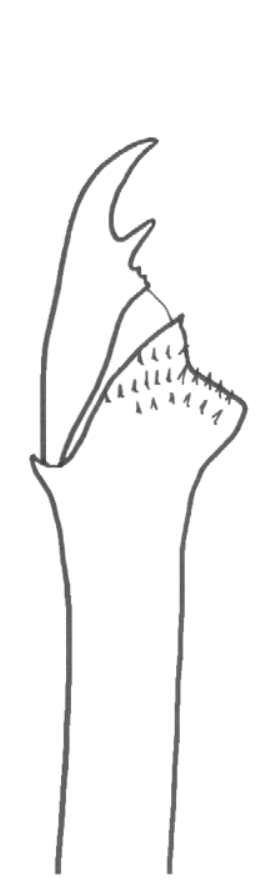

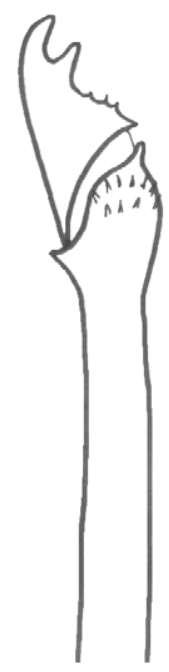

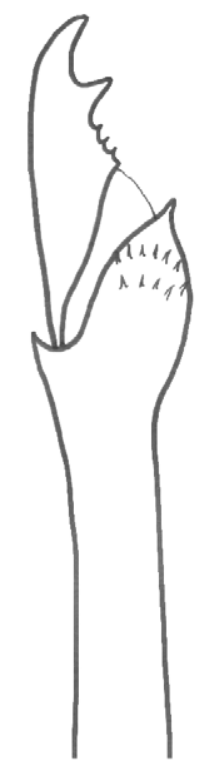

B
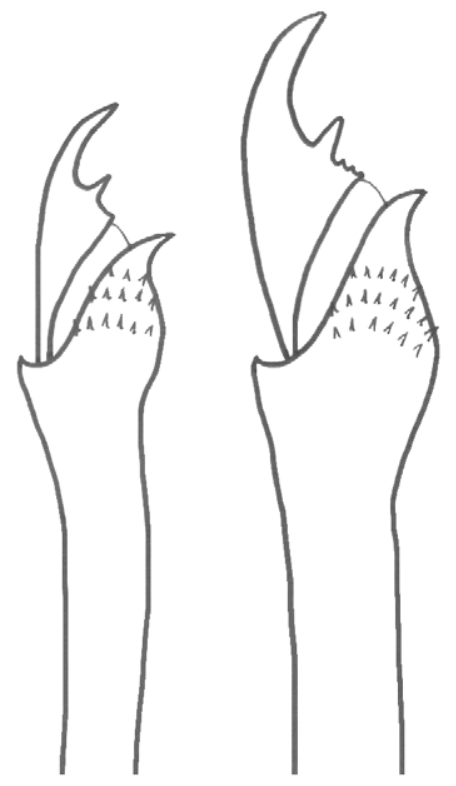

D

FIGURE 1. Dorsalmost (left hand) and ventralmost (right hand) falcigers of posterior chaetigers of the species of Odontosyllis treated in the present paper. (A) O. aracaensis sp. nov.; (B) O. cf. fulgurans; (C) O. guarauensis sp. nov.; (D) O. guillermoi. Scale bar $=10 \mu \mathrm{m}$. 

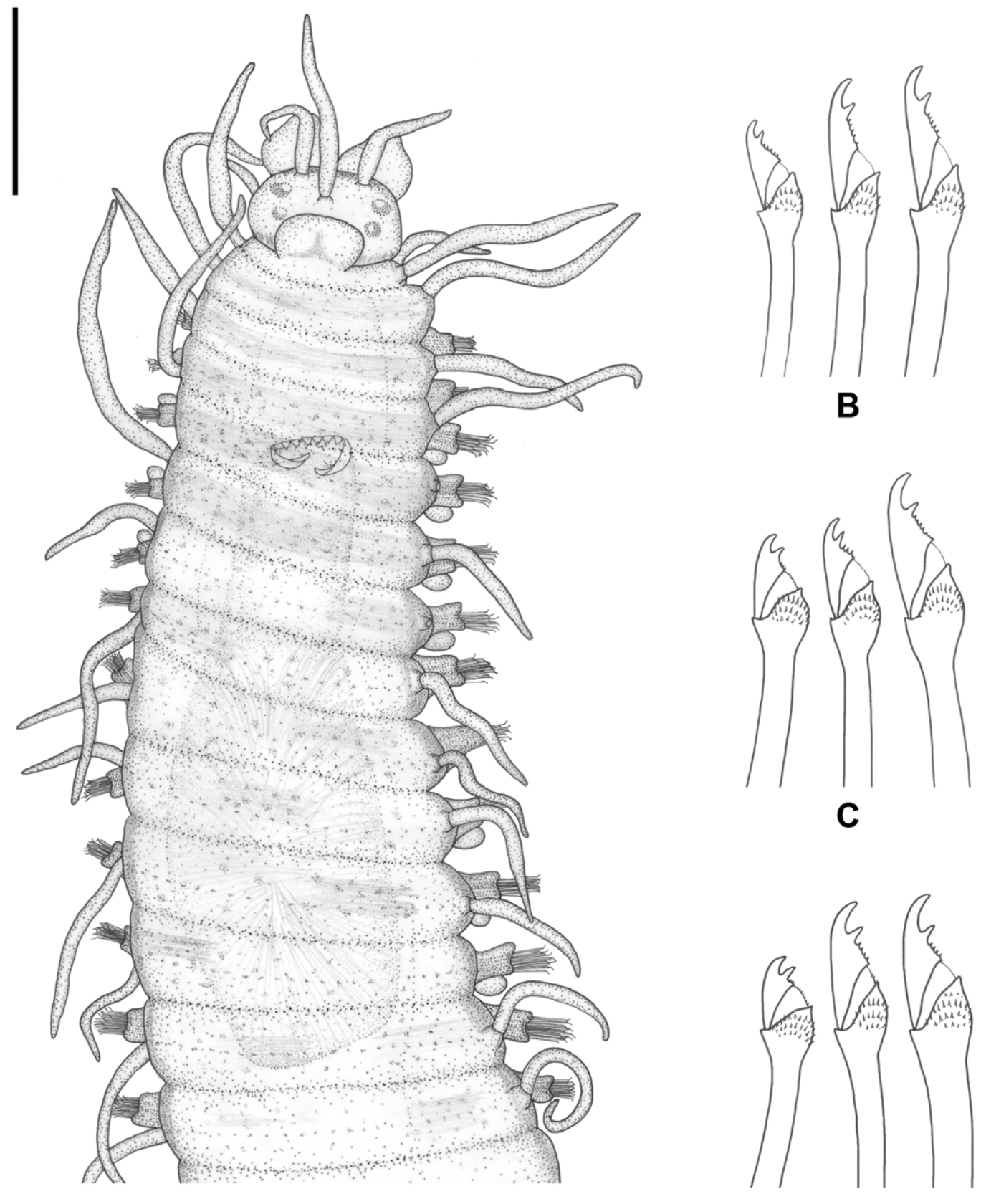

A

D

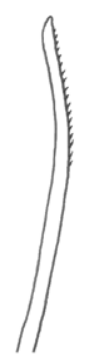

E

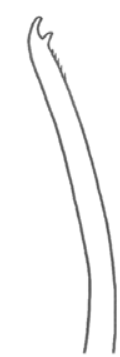

$\mathbf{F}$

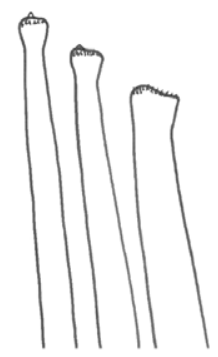

G

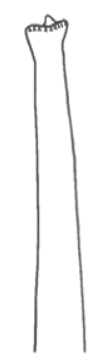

H

FIGURE 2. Odontosyllis aracaensis sp. nov. (Paratype 1, ZUEC-Pol 11891). (A) anterior end, dorsal view; (B) falcigers, anterior chaetiger; (C) falcigers, midbody chaetiger; (D) falcigers, posterior chaetiger; (E) dorsal simple chaeta, posterior chaetiger; $(\mathrm{F})$ ventral simple chaeta, posterior chaetiger; $(\mathrm{G})$ aciculae, anterior chaetiger; $(\mathrm{H})$ acicula, posterior chaetiger. Scale bars: $\mathrm{A}=375 \mu \mathrm{m} ; \mathrm{B}-\mathrm{H}=10 \mu \mathrm{m}$. 

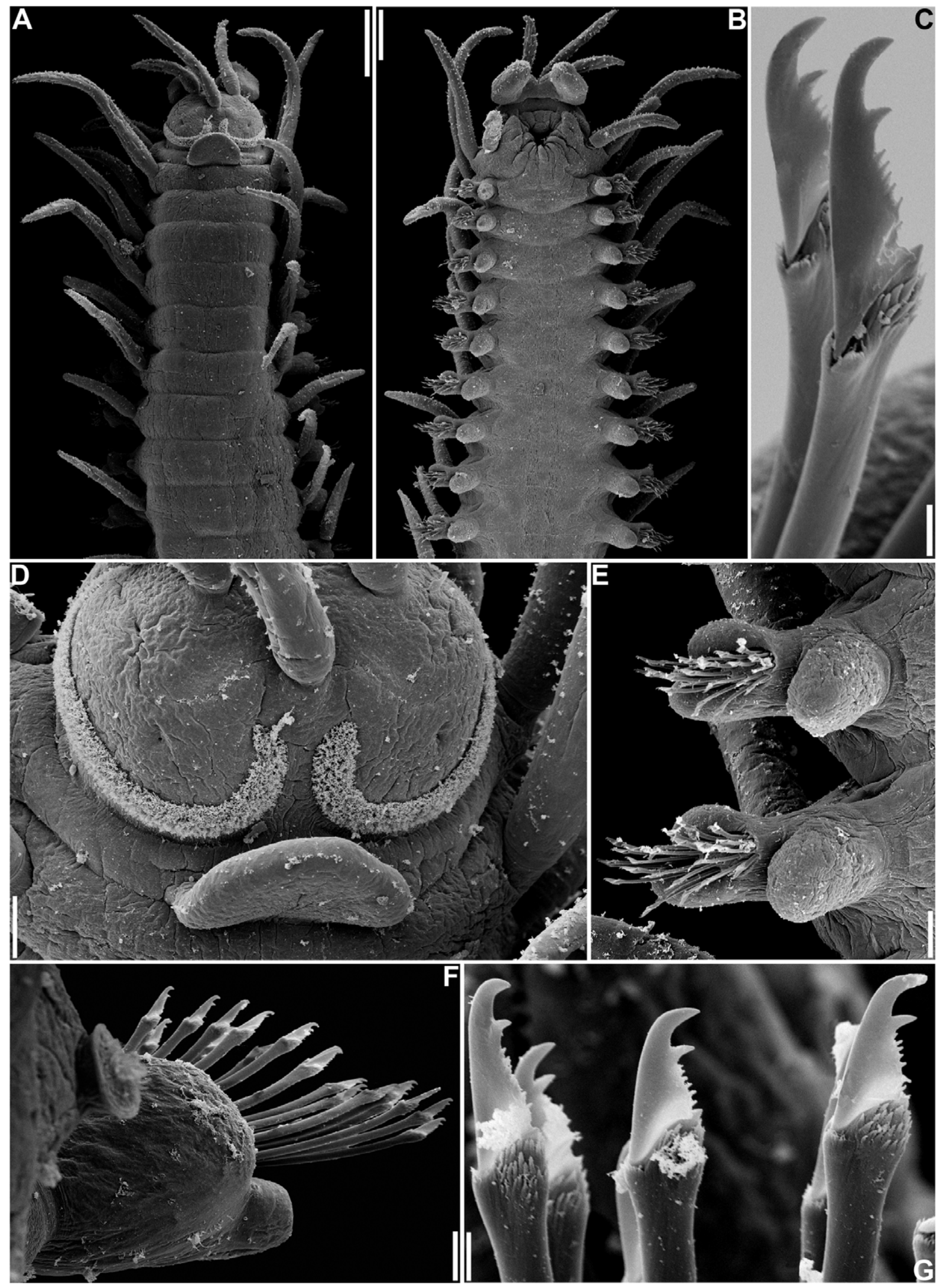

FIGURE 3. Odontosyllis aracaensis sp. nov., SEM. (A) anterior end, dorsal view; (B) anterior end, ventral view; (C) ventralmost falcigers, mid- to posterior body chaetiger; (D) prostomium and peristomium, dorsal view; (E) midbody parapodia, ventral view; $(\mathrm{F})$ anterior parapodia, dorsal view; $(\mathrm{G})$ intermediate falcigers, mid- to posterior body chaetiger. Scale bars: $\mathrm{A}=$ $200 \mu \mathrm{m} ; \mathrm{B}=140 \mu \mathrm{m} ; \mathrm{C}=2.4 \mu \mathrm{m} ; \mathrm{D}=40 \mu \mathrm{m} ; \mathrm{E}=32 \mu \mathrm{m} ; \mathrm{F}=16 \mu \mathrm{m} ; \mathrm{G}=3.2 \mu \mathrm{m}$. 
Remarks. Odontosyllis aracaensis sp. nov., belongs to a group of species with relatively short, bidentate falciger blades, which includes $O$. fulgurans (Audouin \& Milne Edwards, 1833), O. polycera (Schmarda, 1861), O. dugesiana Claparède, 1864, O. hyalina Grube, 1878, O. polyodonta Saint-Joseph, 1887, O. enopla Verrill, 1900, O. phosphorea Moore, 1909, O. octodentata Treadwell, 1917, O. undecimdonta Imajima \& Hartman, 1964, O. magnanuchalata Hartmann-Schröder, 1965, O. fulgurans japonica Imajima, 1966, O. setoensis Imajima, 1966, O. fulgurans dolerens Westheide, 1974, O. australiensis Hartmann-Schröder, 1979, O. luminosa San Martín, 1990, O. fragilis Kudenov \& Harris, 1995, O. trilineata Imajima, 2003, O. guillermoi Fukuda \& Nogueira, 2006, $O$. pentalineata Verdes, Pleijel \& Aguado, 2011, and O. guarauensis sp. nov. A comparison between all these species is provided in Table 2. Except for three of these species, discussed below, O. aracaensis sp. nov., is easily distinguished by the morphology of the pharynx, especially in regards to the trepan, and proventricle, and/or by the pigmentation pattern (see Table 2).

In addition to being sympatric, $O$. aracaensis sp. nov., shares many features with $O$. guillermoi, such as the size and shape of the body, trepan, proventricle and aciculae. These species differ, however, on the pigmentation: in $O$. guillermoi there are two narrow stripes per segment, while in $O$. aracaensis $\mathbf{s p . ~ n o v . , ~ t h e r e ~ i s ~ o n l y ~ o n e ~ b r o a d ~}$ stripe; the prostomial mask is more complex in $O$. guillermoi, with stripes along the anterior border and between the eyes, while $O$. aracaensis sp. nov., has only one stripe along the anterior border of prostomium and below the occipital flap. The falcigers of these species are also similar, but in $O$. guillermoi the subdistal tooth is distinctly smaller than the distal one and the teeth are more separated from each other, contrary to that seen in $O$. aracaensis sp. nov.; furthermore, the shafts of falcigers are distally sigmoid in $O$. guillermoi and distally straight in $O$. aracaensis sp. nov. (Fig. 1A, D).

Odontosyllis aracaensis sp. nov., also resembles $O$. fulgurans (and $O$. cf. fulgurans, sensu Fukuda \& Nogueira 2006) in the morphology of trepan and proventricle, shape of the aciculae, and falcigers with distally straight shafts and bidentate blades. However, $O$. fulgurans lacks body pigmentation patterns and has falciger blades with teeth of about same size and triangular subdistal tooth (Fig. 1B), while in O. aracaensis sp. nov., the teeth are about same size on anterior chaetigers and in the dorsalmost falcigers of mid- and posterior body chaetigers, but the subdistal tooth is distinctly smaller than the distal one in ventralmost falcigers of mid- and posterior body chaetigers (Figs 1A; 2B-D).

Odontosyllis fulgurans dolerens Westheide, 1974 also resembles $O$. aracaensis sp. nov., in all the characters discussed above for $O$. fulgurans. Furthermore, the falciger blades in this subspecies differ from those in European $O$. fulgurans in that the subdistal tooth is clearly smaller than the distal one, especially on posterior chaetigers. However, $O$. fulgurans dolerens can be differentiated from $O$. aracaensis sp. nov., by possessing a longitudinal grey to black dorsal line, instead of the transverse black stripes on each chaetiger of $O$. aracaensis sp. nov., and in having nearly all falciger blades with the distal tooth larger than the subdistal one and more falcate than those of $O$. aracaensis sp. nov. In addition, the new species only has the distal tooth clearly larger than the subdistal one in the ventralmost falcigers of mid- and posterior chaetigers.

Etymology. This species is named after the Araçá (São Sebastião, state of São Paulo), one of the last mangrove spots in that city, a locality constantly threatened by the expansion plans of the neighbouring port of São Sebastião. Most type specimens, including the holotype, were found in the area.

\section{Odontosyllis guillermoi Fukuda \& Nogueira, 2006}

Figure 1D

Odontosyllis guillermoi Fukuda \& Nogueira, 2006: 225-229, figs 1-2; Fukuda 2010: 52-56, figs 14-15.

Material examined. Project 'BIOTA'. Ubatuba—Praia da Fazenda (232 $\left.21^{\prime} 25^{\prime \prime} \mathrm{S} 44^{\circ} 51^{\prime} 55^{\prime \prime} \mathrm{W}\right)$, on rocky shore: 32

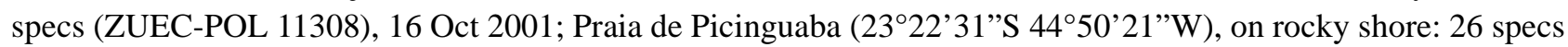
(MZUSP 995), 9 May 2001; on Sargassum: 46 specs (MZUSP 996), 18 Oct 2001. Caraguatatuba-Praia Martim

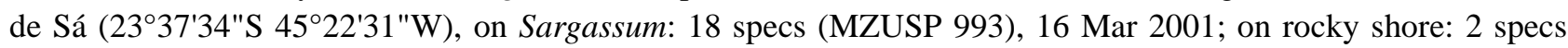

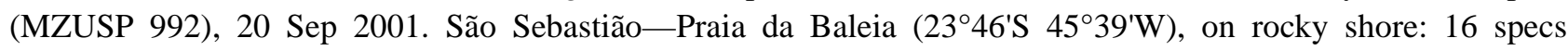
(MZUSP 983), 8 Apr 2001; 3 specs (MZUSP 984), 13 Dec 2001; on Sargassum: 1 spec. (MZUSP 986), 14 Nov 2001. 


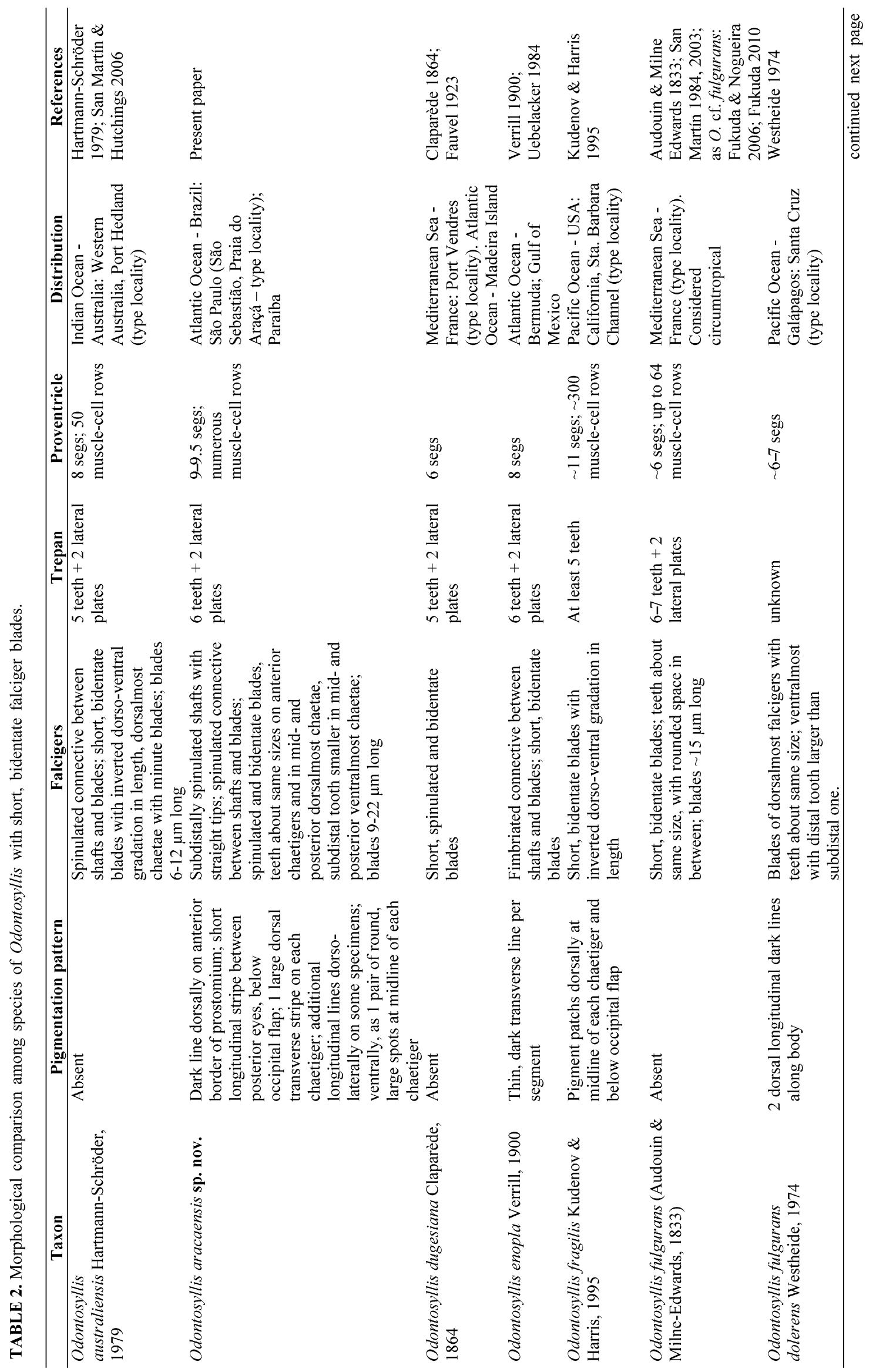




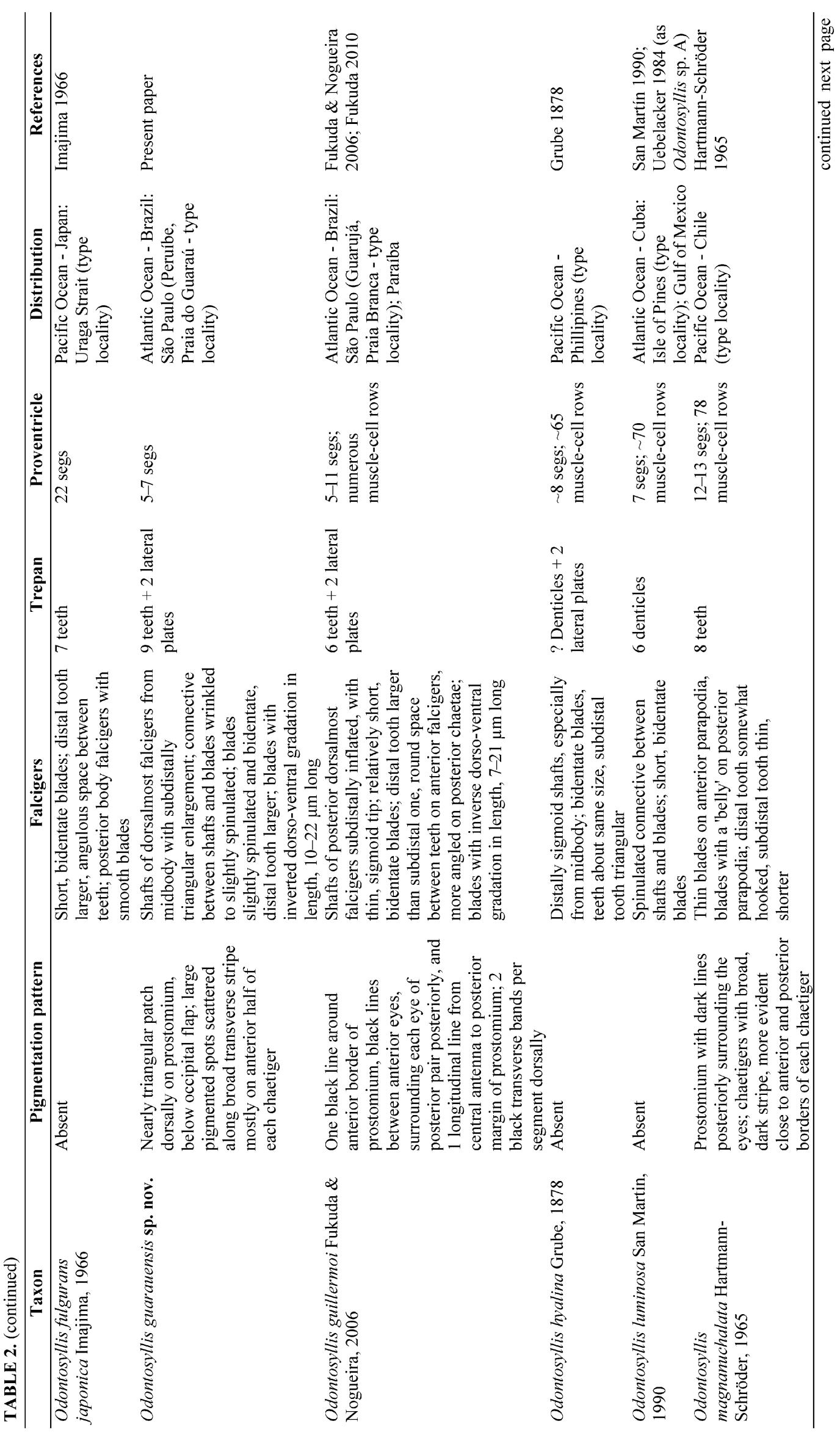




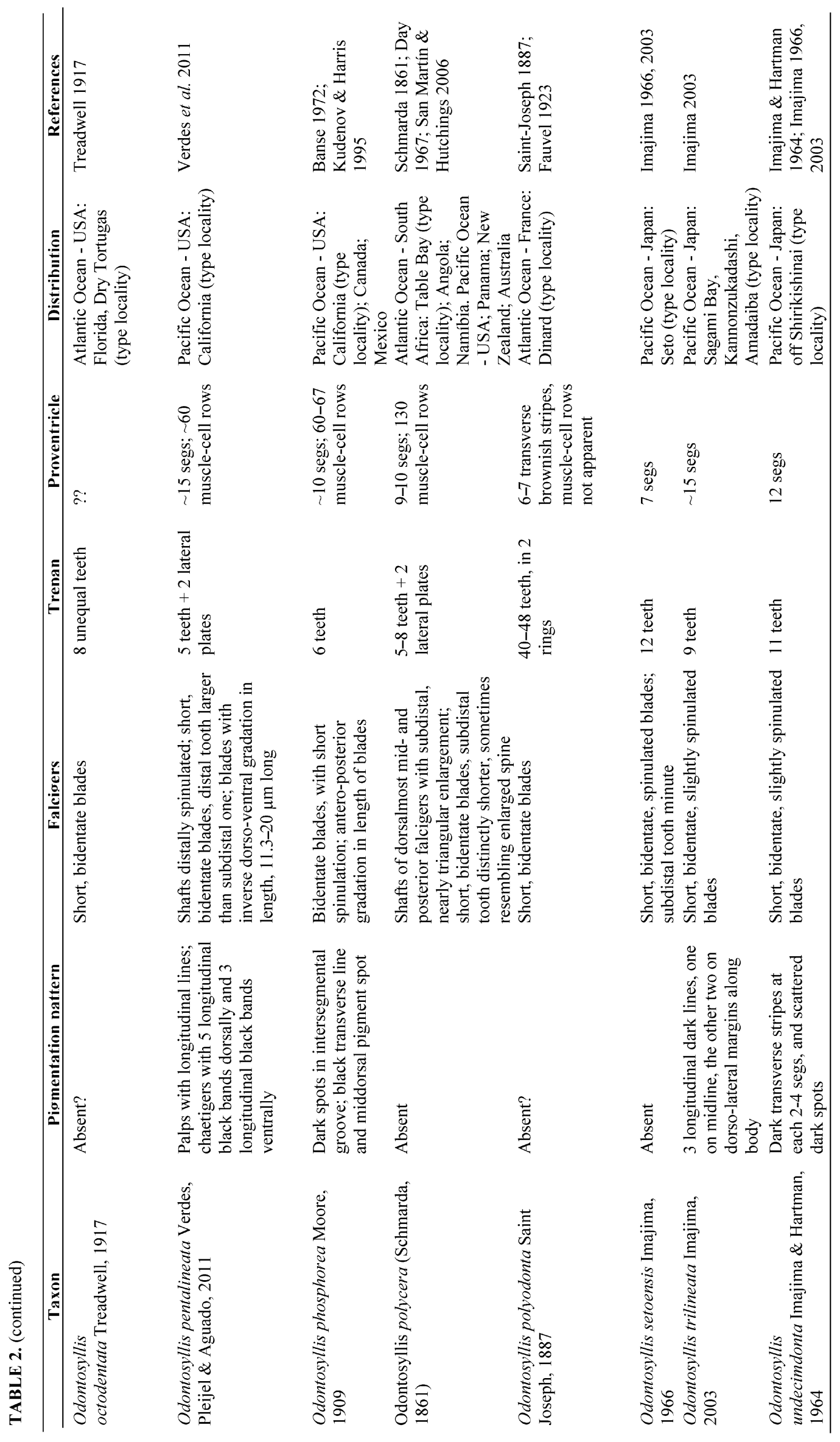


Project 'BioPol-SP'. Ubatuba-Praia do Félix $\left(23^{\circ} 23^{\prime} \mathrm{S} 44^{\circ} 58^{\prime} \mathrm{W}\right)$ : 3 specs (MZUSP 989), 4 Nov 2002.

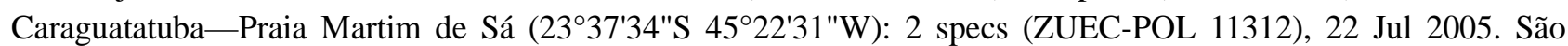
Sebastião-Praia de São Francisco (234' $\left.54^{\prime \prime S} 4^{\circ} 24^{\prime} 33^{\prime \prime W}\right)$ : 1 spec. (MZUSP 1000), 19 Apr 2003; Praia da Baleia

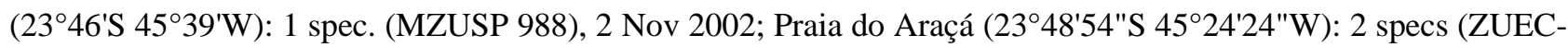

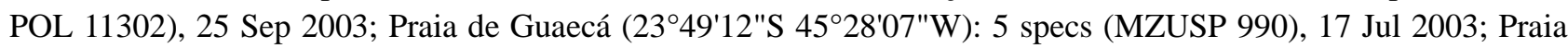

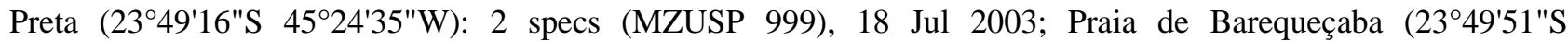

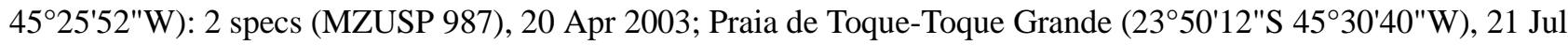

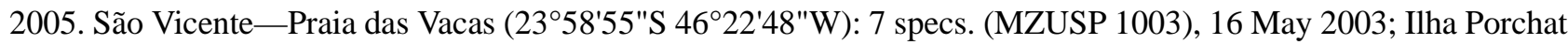

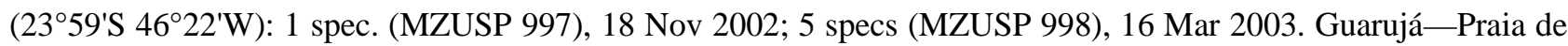
Pernambuco (23 $\left.58^{\prime} \mathrm{S} 46^{\circ} 10^{\prime} \mathrm{W}\right): 3$ specs (ZUEC-POL 11314), 4 Oct 2005; Ilha das Palmas ( $\left.24^{\circ} 00^{\prime} \mathrm{S} 46^{\circ} 19^{\prime} \mathrm{W}\right): 2$

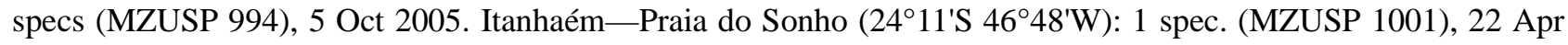

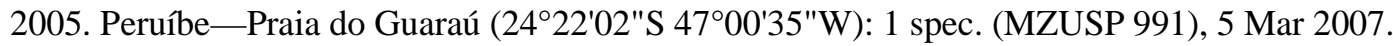

Project 'BioPol-NE'. Mataraca-Barra de Camaratuba (6³6'12'’S 3457'52' W): 4 specs (MZUSP 1233), 12 Aug 2010. Baía da Traição-Praia do Farol (641'20”S 3455'48”'W): 8 specs (MZUSP 1232), 9 Aug 2010; Rio Tinto-Barra de Mamanguape (646'9"S 345' 2"W): 34 specs (MZUSP 1234), 11 Aug 2010. Conde-Praia de

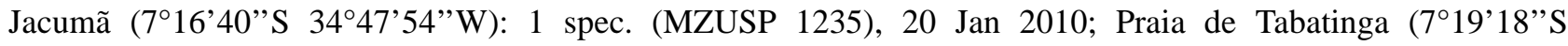

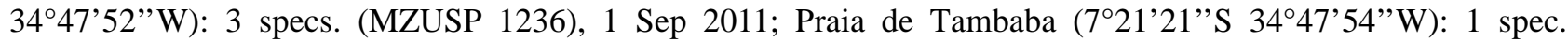
(MZUSP 1237), 30 Aug 2011.

Remarks. The specimens agree with the description provided by Fukuda \& Nogueira (2006), except for the inverted dorso-ventral gradation in length of the falciger blades, which was misinterpreted in that study.

\section{Odontosyllis guarauensis sp. nov.}

Figures 1C; 4-7; Table 3

Material examined. Project 'BIOTA'. Ubatuba-Praia de Picinguaba ( $23^{\circ} 22^{\prime} 31^{\prime}$ 'S $44^{\circ} 50^{\prime} 21^{\prime}$ 'W), on rocky shore: 1 spec. (MZUSP 1239), 10 May 2001; 4 specs (MZUSP 1025), 17 Oct 2001; 1 spec. (MZUSP 1240), 18 Oct 2001. São Sebastião-Praia da Baleia (2348'54”'S 45³9'51'W), on Sargassum: 4 specs (MZUSP 1222), 14 Nov 2001.

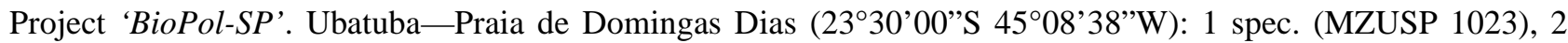

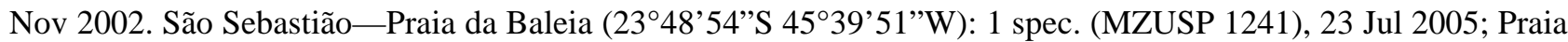

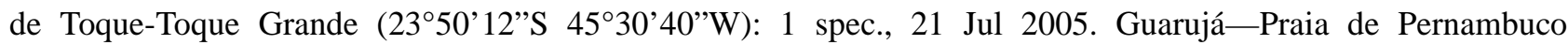

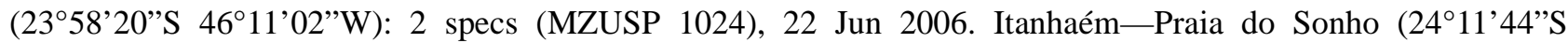
$\left.46^{\circ} 48^{\prime} 05^{\prime \prime} \mathrm{W}\right): 3$ specs, 26 Aug 2003. Peruíbe-Praia do Guaraú $\left(24^{\circ} 22^{\prime} 02^{\prime \prime} \mathrm{S} 47^{\circ} 00^{\prime} 35^{\prime \prime W}\right)$, intertidal, in Bostrychia sp.: 97 specs (MZUSP 1020, holotype; MZUSP 1021, paratype 1; ZUEC-POL 11893, paratype 2; MNCN 16.01/14459, paratype 3; ZUEC-POL 11894, paratype 4; MNCN 16.01/14460, paratype 5; MZUSP 1022, thirty paratypes; ZUEC-POL 11895-11897, thirty paratypes; MNCN 16.01/14461, twenty paratypes), 19 May 2008.

Type series. Data of selected specimens of the type series are provided in Table 3.

Additional material examined. Odontosyllis polycera (Schmarda, 1861). Indian Ocean, Australia: Western Australia, Albany, Frenchman Bay, Goode Beach: 1 spec. (ZMH P-18131), coll. \& det. G. Hartmann-Schröder, 21 Nov 1975; South Australia, Port Lincoln: 2 specs (ZMH P-18550), coll. \& det. G. Hartmann-Schröder, 3 Dec 1975; South Australia, Port MacDonnel, Cape Northumberland: 1 spec. (ZMH P-18772), coll. \& det. G. HartmannSchröder, 18 Dec 1975.

Description. Medium-sized body, holotype largest specimen collected, $9 \mathrm{~mm}$ long, $0.70 \mathrm{~mm}$ wide, with 81 segments (Table 3). Conspicuous pigmentation on living animals, as nearly triangular patch on prostomium, below occipital flap, and large dark spots scattered across dorsum, roughly arranged in one broad transverse stripe mostly on anterior half of each chaetiger (Fig. 5A); pigmentation slightly fading after preservation (Fig. 4A). Palps rounded to kidney-shaped, basally fused, each with two rows of cilia, one close to posterior border, another at midlength, present dorsally and ventrally, additional tufts of cilia on internal side of each palp dorsally, from midlength to tip (Figs 5C-F; 6A-C). Prostomium ovate with two pairs of eyes in rectangular to trapezoidal arrangement and one pair of small anterior eyespots; lateral antennae inserted on anterior margin of prostomium, as long as palps or slightly longer; median antenna inserted slightly anteriorly to middle of prostomium, $\sim 1.5$ times as long as lateral antennae (Figs 4A; 5A-F; 6A-C); nuchal organs as one pair of broad semi-circular rows of cilia 


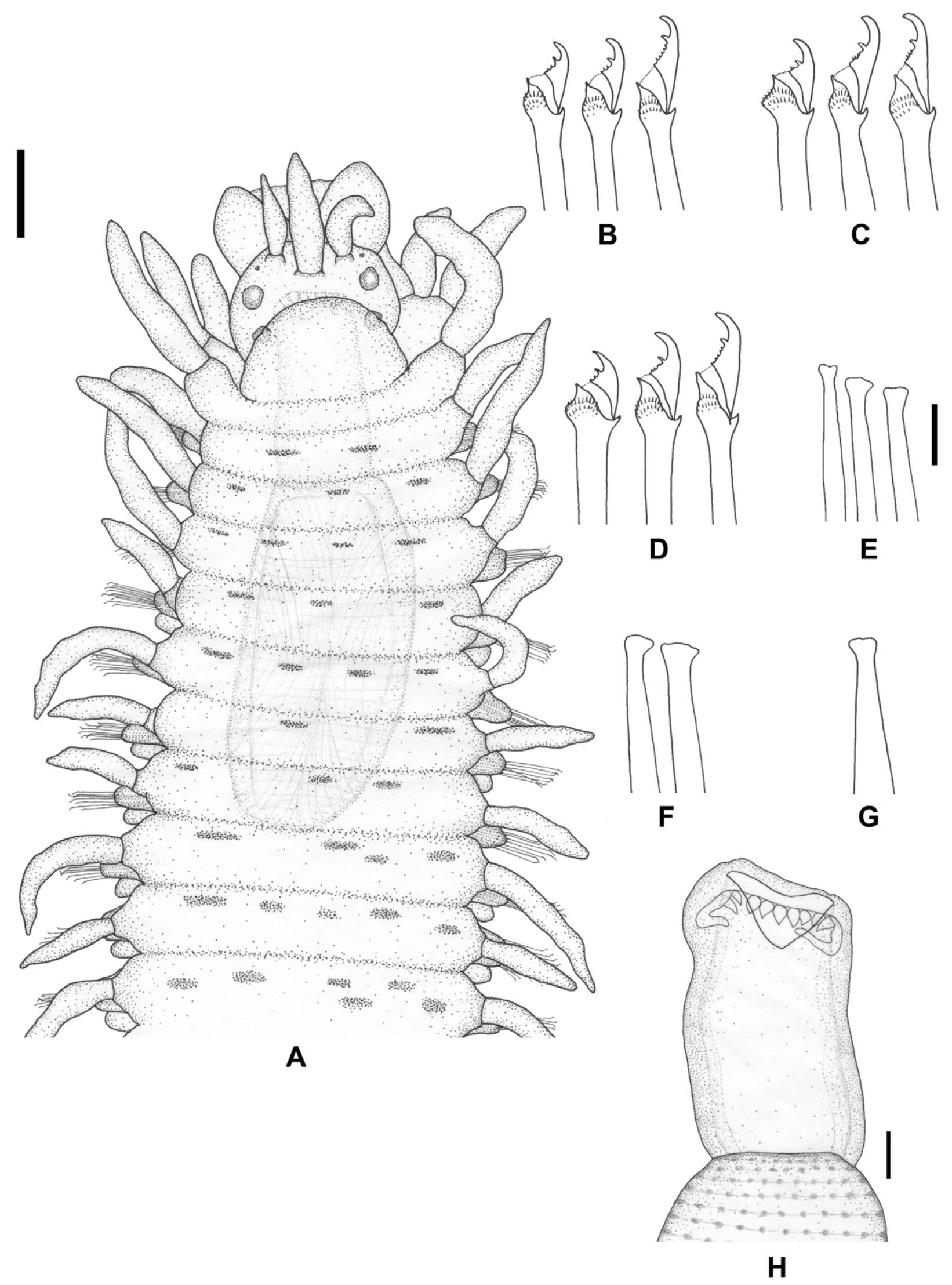

FIGURE 4. Odontosyllis guarauensis sp. nov. (A) anterior end, dorsal view; (B) falcigers, anterior chaetiger; (C) falcigers, midbody chaetiger; (D) falcigers, posterior chaetiger; (E) aciculae, anterior chaetiger; (F) aciculae, midbody chaetiger; $(\mathrm{G})$ acicula, posterior chaetiger; $(\mathrm{H})$ detail of the pharynx, showing trepan. Scale bars: $A=150 \mu \mathrm{m} ; \mathrm{B}-\mathrm{G}=10 \mu \mathrm{m} ; \mathrm{H}=50 \mu \mathrm{m}$. 

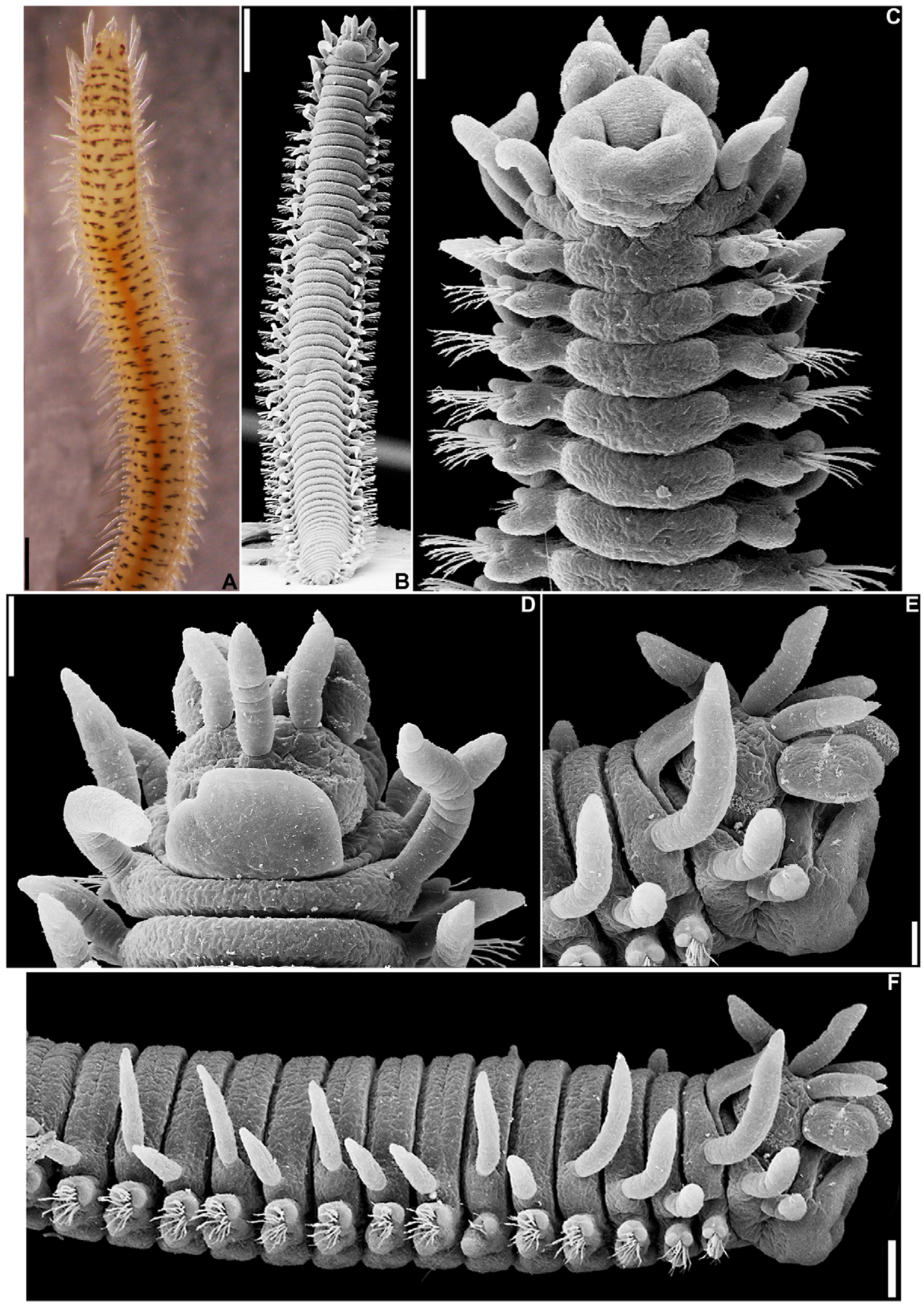

FIGURE 5. Odontosyllis guarauensis sp. nov. (A) holotype (MZUSP 1020) alive, dorsal view; (B) entire worm, dorsal view; (C) anterior end, ventral view; (D) anterior end, dorsal view; (E) detail of prostomium, peristomium and first chaetigers, right lateral view; (F) anterior end, right lateral view. Scale bars: $A=500 \mu \mathrm{m} ; \mathrm{B}=400 \mu \mathrm{m} ; \mathrm{C}, \mathrm{F}=100 \mu \mathrm{m} ; \mathrm{D}=90 \mu \mathrm{m} ; \mathrm{E}=60 \mu \mathrm{m}$. 

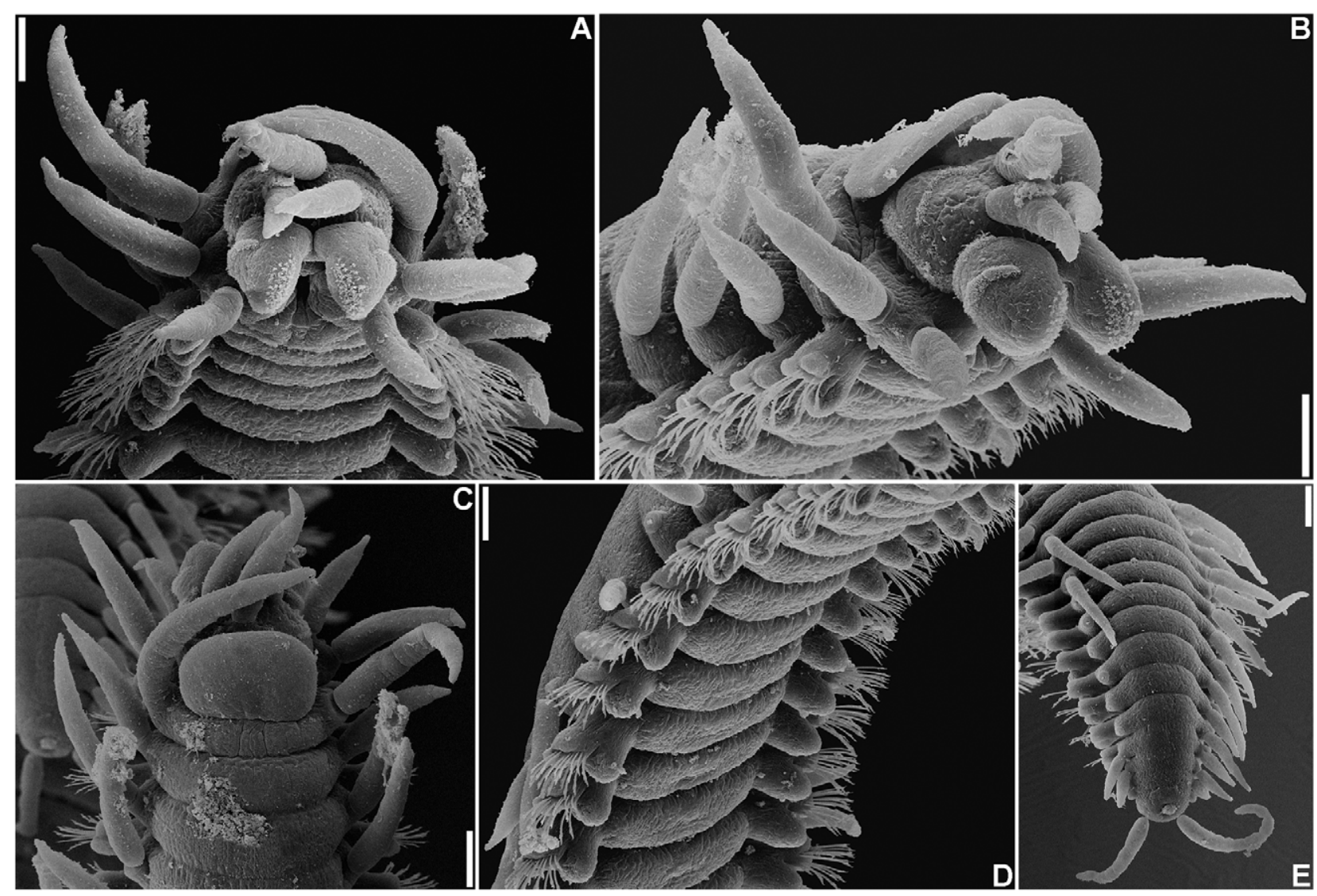

FIGURE 6. Odontosyllis guarauensis sp. nov. (A) anterior end, frontal view; (B) anterior end, fronto-lateral view; (C) anterior end, dorsal view; (D) anterior to midbody chaetigers, ventro-lateral view; (E) posterior end, dorsal view. Scale bars: $\mathrm{A}-\mathrm{E}=90 \mu \mathrm{m}$.

posterior to eyes of posterior pair, extending dorsally below occipital flap and laterally around prostomium, until close to base of palps (Figs 5D-F; 6B); prostomium with additional pair of rows of cilia between anterior and posterior pairs of eyes (Figs 5D; 6B-C). Peristomium dorsally short, with large, roughly rectangular occipital flap almost as wide as prostomium, covering posterior and, sometimes, anterior pairs of eyes (Figs 4A; 5A-B, D-F; 6B-C); dorsal peristomial cirri slightly longer than median antenna, ventral peristomial cirri about as long as median antenna, in ventro-lateral position, laterally to mouth (Figs 4A; 5C-F; 6A-C). Dorsal cirri of chaetiger 1 inserted dorsally to following cirri, 1.5-2 times as long as median antenna, dorsal cirri throughout about as long as median antenna, alternating longer and shorter cirri, longer cirri directed upwards and inserted dorsally to shorter cirri (Fig. 5F). Antennae, peristomial and anterior dorsal cirri with minute tufts of cilia (Figs 5D-F; 6A-E); peristomial and dorsal cirri with short cirrophores (Figs 5D-F; 6A-E). Ventral cirri short, ovate, not extending beyond parapodial lobes (Figs 5C; 6A-B, D). Parapodia distally bilobed (Figs 5C, F; 6A-B, D), lobes about same size or posterior lobe slightly larger. Anterior parapodia with 12-18 falcigers each, midbody with 9-15, posterior parapodia with 4-9 falcigers each (Table 3); falcigers with subdistally spinulated shafts; from midbody, shafts of dorsalmost falcigers with subdistal, nearly triangular enlargement and thin, straight tip (Figs 1C; 4C-D; 7E, G); connective between shafts and blades wrinkled to slightly spinulated; falcigers with blades slightly spinulated and bidentate, distal tooth larger than subdistal one (Figs 4B-D; 7A-H); blades with inverted dorso-ventral gradation in length, 12-22 $\mu \mathrm{m}$ long on anterior chaetigers, 12-21 $\mu \mathrm{m}$ long on midbody, $10-17 \mu \mathrm{m}$ long on posterior chaetigers (Table 3). Dorsal simple chaetae only present on posterior chaetigers (Table 3), thin, $\sim 1 / 5$ as thick as shafts of falcigers, poorly spinulated subdistally, distally rounded (Fig. 7G); ventral simple chaetae, if present, only on last chaetigers (Table 3), sigmoid, bidentate, tips resembling those of blades of falcigers, about half as thick as shafts of falcigers (Fig. 7H). Anterior parapodia with up to three aciculae each, midbody with two, posterior parapodia with one acicula each; aciculae irregularly enlarged distally, with slight progressively increasing thickness towards posterior parapodia (Fig. 4E-G). Pharynx through $\sim 4-4.5$ segments (Table 3), trepan with 9 teeth and two lateral plates (Fig. 4H); proventricle through 5-7.5 segments (Table 3), with numerous packed transverse and oblique muscle cell rows (Fig. 4A). 

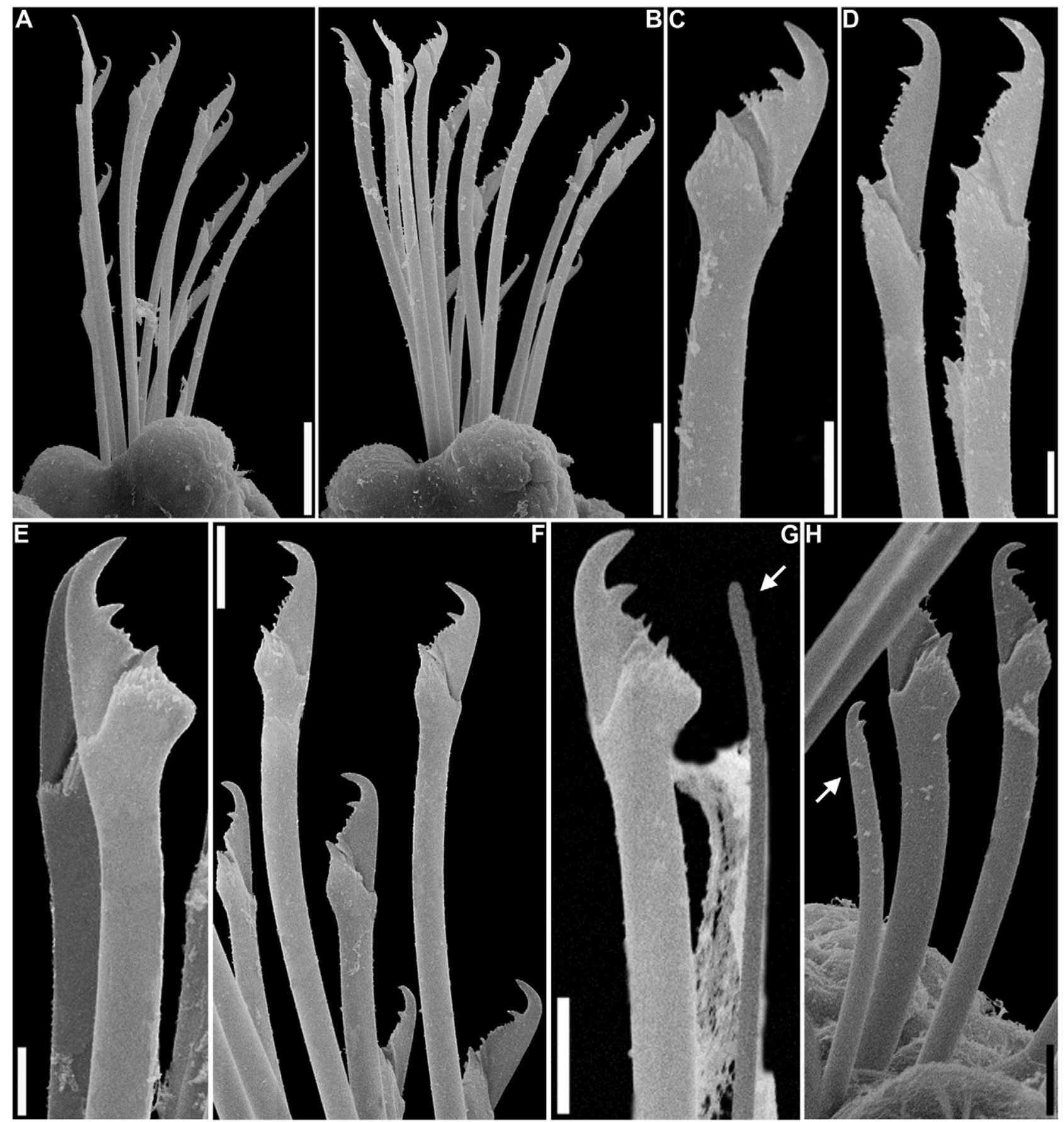

FIGURE 7. Odontosyllis guarauensis sp. nov. (A) falcigers, anterior chaetiger; (B) falcigers, midbody chaetiger; (C) dorsalmost falciger, midbody chaetiger; (D) ventralmost falcigers, midbody chaetiger; (E) dorsalmost falciger, posterior chaetiger; (F) ventralmost falcigers, posterior chaetiger; $(\mathrm{G})$ dorsalmost falciger and dorsal simple chaeta, posterior chaetiger (arrow pointing to dorsal simple chaeta); $(\mathrm{H})$ ventralmost falcigers and ventral simple chaeta, posterior chaetiger (arrow pointing to ventral simple chaeta). Scale bars: A-B $=20 \mu \mathrm{m} ; \mathrm{C}=5 \mu \mathrm{m} ; \mathrm{D}-\mathrm{E}=4 \mu \mathrm{m} ; \mathrm{F}=9 \mu \mathrm{m} ; \mathrm{G}-\mathrm{H}=6 \mu \mathrm{m}$.

Remarks. Odontosyllis guarauensis sp. nov., belongs to the same group of species as $O$. aracaensis $\mathbf{s p .}$ nov., with short, bidentate falciger blades. However, Odontosyllis guarauensis sp. nov., can be distinguished from most of those species by the morphology of chaetae and trepan, besides the pigmentation pattern (Table 2). 


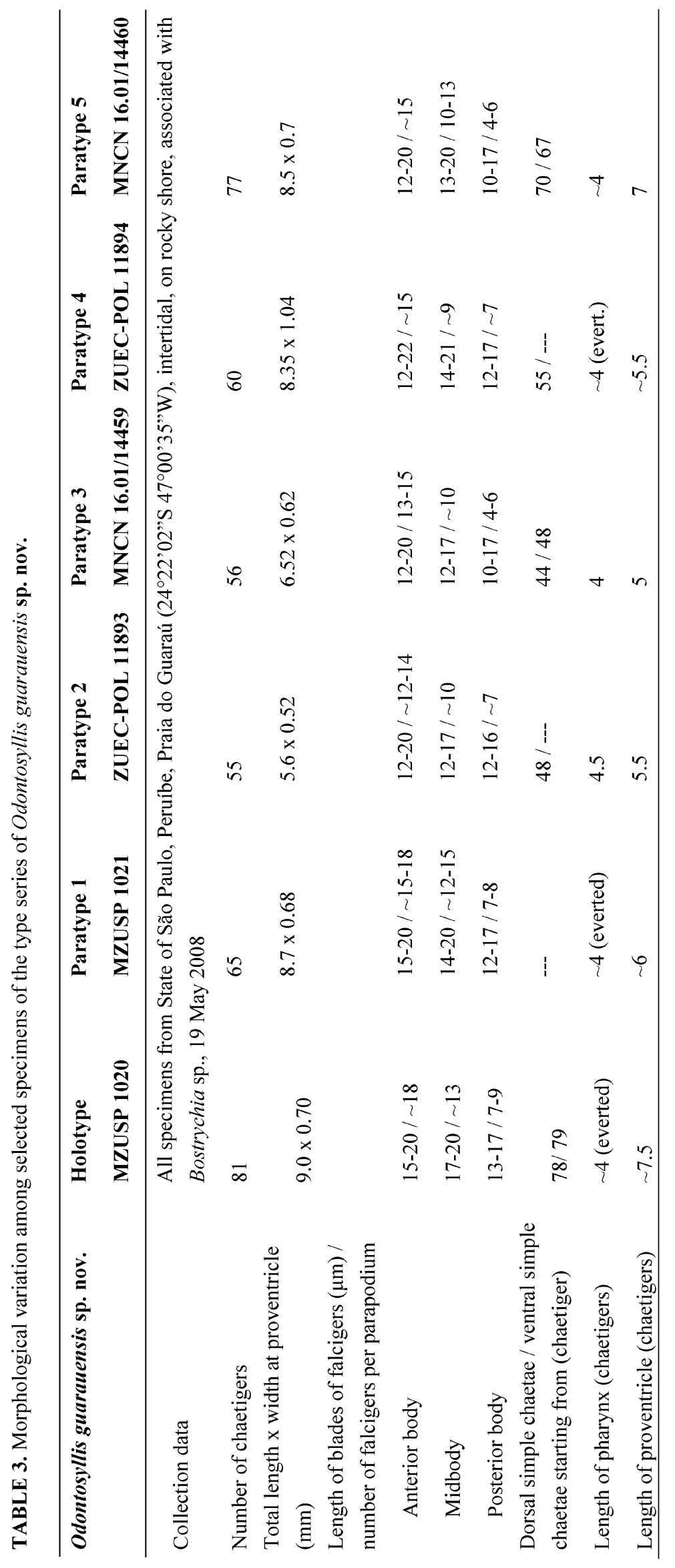


The nearly triangular subdistal enlargement of the shafts of posterior body dorsalmost falcigers of $O$. guarauensis sp. nov., has never been referred to in other descriptions of species of Odontosyllis, but a similar configuration is present in $O$. polycera (MVF, pers. obs.). In addition, O. polycera resembles $O$. guarauensis $\mathbf{s p .}$ nov., in the overall body shape, size of the occipital flap, and in the occurrence of falcigers with inverted dorsoventral gradation in lengths of the blades. However, O. polycera differs from $O$. guarauensis sp. nov., in having falciger blades with a much smaller subdistal tooth, sometimes reduced to an enlarged spine or even absent, while in $O$. guarauensis sp. nov., the subdistal tooth is always conspicuous, though smaller than the distal one. These differences also apply to the ventral simple chaetae, which have tips similar to those of falcigers. Furthermore, $O$. polycera has two types of aciculae, one subdistally enlarged, with crown of subdistal spines and short acuminate tip, and another thicker, subdistally oblique and distally rounded, slightly protrudring from parapodial lobes sometimes, while the aciculae of $O$. guarauensis sp. nov., are all irregularly enlarged distally (Fig. 4E-G). Finally, the trepan of $O$. polycera has 5-8 teeth and 2 lateral plates, while in $O$. guarauensis sp. nov., it has 9 teeth and 2 lateral plates (Fig. 4H).

Etymology. The species is named after the Praia do Guaraú (Guaraú beach, in Peruíbe, State of São Paulo) where it was found in the greatest abundance, frequently crawling over the algae Bostrychia sp.

\section{Conclusions}

We herein describe two new species of Odontosyllis, a widespread genus of Syllidae, which is recognized by the usual presence of a peristomial occipital flap covering the posterior part of the prostomium, and by the characteristic trepan with teeth pointing backwards. Identification to species level, however, is considerably more difficult, since many species are defined by different combination of characters, some of them with tenuous morphological variations. Many of the $\sim 49$ described species (Verdes et al. 2011) correspond to single reports and some lack informative taxonomic characters (especially the older descriptions). We provide here a list of characters (Table 2) as a first step to encourage a much needed revision of this group.

In our paper we also pay special attention to the morphology of the falciger shafts, which is usually disregarded. In the species of Odontosyllis so far investigated, we noticed three different morphologies for the shafts of posterior body dorsalmost falcigers, which are more evident when comparing the dorsalmost and ventralmost chaetae (Fig. 1A-D):

1) subdistally inflated shafts with thin, straight tip ('regular' syllid type) (Fig. 1A-B);

2) shafts of dorsalmost chaetae with nearly triangular subdistal enlargement, with thin, straight tip (Fig. 1C);

3) shafts of dorsalmost chaetae subdistally inflated with thin, sigmoid tip (Fig. 1D).

We suggest that this character should be investigated in other species of Odontosyllis, to check if it could provide useful information to resolve relationships within the genus.

\section{Acknowledgements}

We are grateful to the team of the project 'BIOTA' for collecting part of the material analysed in this study. We also thank the technicians Enio Matos and Phillip Lenktaitis (IB/USP) and Lara Guimarães (MZUSP) for preparing specimens to the SEM studies and for operating the SEM equipment, and Prof. Dr. Guilherme Henrique Pereira Filho (Universidade Federal Rural do Rio de Janeiro) for identifying the algae on which O. guarauensis sp. nov., was found. We are grateful to Prof. Dr. Angelika Brandt and the staff of the ZMH, for all the support in a visit of MVF to that institution, and to Javier Sánchez Almazán (MNCN), Aline Benetti (MZUSP) and Tatiana M. Steiner (ZUEC) for providing museum numbers. MVF received a Ph. D. fellowship from FAPESP_Fundação de Amparo à Pesquisa do Estado de São Paulo (FAPESP proc. 07/53040-9) and currently receives a post-doc fellowship from the same institution (FAPESP proc. 10/19424-7). JMMN receives a productivity fellowship from CNPq - Conselho Nacional de Desenvolvimento Científico e Tecnológico. KP receives a Ph. D. fellowship from FAPESP (proc. 09/17606-3). Thanks are due to the 'Biodiversity Heritage Library' (www.biodiversitylibrary.org, accessed 15 Nov 2012), without which help many of the references herein used would not have been found. Finally, we thank Dr Markus Böggemann, Dr Pat Hutchings and an anonymous referee for invaluable suggestions that greatly improved the final version of this paper. 


\section{References}

Amaral, A.C.Z., Nallin, S.A.H., Steiner, T.M., Forroni, T.O. \& Gomes-Filho, D. (2012) Catálogo das espécies de Annelida Polychaeta do Brasil. Available from: http://www.ib.unicamp.br/museu_zoologia/files/lab_museu_zoologia/ Catalogo_Polychaeta_Amaral_et_al_2012_0.pdf (Acessed 06 Jan 2013).

Audouin, J.V. \& Milne Edwards, H. (1833) Classification des Annélides, et description de celles qui habitent les côtes de la France. Annales des Sciences Naturelles, ser. 1, 29, 195-269.

Banse, K. (1972) On some species of Phyllodocidae, Syllidae, Nephtyidae, Goniadidae, Apistobranchidae, and Spionidae (Polychaeta) from the Northeast Pacific Ocean. Pacific Science, 26 (2), 191-222.

Claparède, E. (1863) Beobachtungen über Anatomie und Entwicklungsgeschichte wirbelloser Thiere an der Küste von Normandie angestellt. Wilhelm Engelmann, Leipzig, 120 pp. http://dx.doi.org/10.5962/bhl.title.10030

Claparède, E. (1864) Glanures zootomiques parmi les Annélides de Port-Vendres (Pyrenés Orientales). Mémoires de la Société de Physique et Sciences Naturelles de Genève, 17 (2), 463-600.

Day, J.H. (1967) A Monograph on the Polychaeta of Southern Africa. Part.1. Errant. Trustees of the British Museum (Natural History), London, $458 \mathrm{pp}$.

Fauvel, P. (1923) Polychètes Errantes. In: Faune de France, vol. 5. LeChevallier, Paris, 488 pp.

Fransozo, M.L.N \& Fransozo, A. (2011) Sublitoral não consolidado. In: Amaral, A.C.Z. \& Nallin, S.A.H. (Eds), Biodiversidade e ecossistemas bentônicos marinhos do litoral norte de São Paulo, Sudeste do Brasil. IB/UNICAMP, Campinas, pp. 38-42.

Fukuda, M.V. (2010) Contribuição ao conhecimento taxonômico dos silídeos (Polychaeta: Syllidae) da região sudeste-sul do Brasil. Ph. D. Thesis, Instituto de Biociências/USP, São Paulo, 340 pp.

Fukuda, M.V., Centurión, R., Nogueira, J.M.M. \& San Martín, G. (2012) Two new species of Paraehlersia San Martín, 2003 (Polychaeta, Syllidae, Eusyllinae) from the Atlantic Coast off South America. Zootaxa, 3264, 38-52.

Fukuda, M.V. \& Nogueira, J.M.M. (2006) A new species of Odontosyllis Claparède, 1863 (Polychaeta: Syllidae: Eusyllinae), and description of Brazilian material of Odontosyllis cf. fulgurans (Audouin \& Milne Edwards, 1834). Zoological Studies, 45 (2), 223-233.

Fukuda, M.V. \& Nogueira, J.M.M. (2012) On a new species of Nuchalosyllis (Polychaeta: Syllidae), a rare syllid genus only known from Brazilian waters. Journal of the Marine Biological Association of the United Kingdom, 1-4. http://dx.doi.org/ 10.1017/S0025315412000069

Fukuda, M.V., Yunda-Guarin, G. \& Nogueira, J.M.M. (2009) The genus Prosphaerosyllis (Polychaeta: Syllidae: Exogoninae) in Brazil, with description of a new species. Journal of the Marine Biological Association of the United Kingdom, 89 (7), 1443-1454. http://dx.doi.org/10.1017/S0025315409000095

Grube, A.E. (1850) Die Familien der Anneliden. Archiv für Naturgeschichte, 16, 249-364.

Grube, A.E. (1878) Annulata Semperiana. Beiträge zur Kenntnis der Annelidenfauna der Philippinen. Memoires de L'Academie Imperiale des Sciences de St.Petersbourg, Ser. 7, 25 (8), 1-300.

Hartman, O. (1959) Catalogue of the polychaetous annelids of the world. Part I. Occasional Papers of the Allan Hancock Foundation, 23, 1-353.

Hartmann-Schröder, G. (1965) Die Polychaeten des Sublitorals. In: Hartmann-Schröder, G. \& Hartmann, G. (Eds). Zur Kenntnis des Sublitorals der chilenischen Küste unter besonderer Berücksichtigung der Polychaeten und Ostracoden. Mitteilungen aus dem Hamburgischen zoologischen Museum und Institut, 62, 59-305.

Hartmann-Schröder, G. (1979) Teil 2. Die Polychaeten der tropischen Nordwestküste Australiens (zwischen Derby im Norden und Port Hedland im Süden). In: Hartmann-Schröder, G. \& Hartmann, G. (Eds). Zur Kenntnis des Eulitorals der australischen Küsten unter besonderer Berücksichtigung der Polychaeten und Ostracoden. Mitteilungen aus dem Hamburgischen Zoologischen Museum und Institut, 76, 75-218.

Imajima, M. (1966) The Syllidae (Polychaetous Annelids) from Japan. (III) Eusyllinae. Publications of the Seto Marine Biological Laboratory, 14, 85-116.

Imajima, M. (2003) Polychaetous Annelids from Sagami Bay and Sagami Sea collected by the Emperor Showa of Japan and deposited at the Showa Memorial Institute, National Science Museum, Tokyo (II). Orders included within the Phyllodocida, Amphinomida, Spintherida and Eunicida. National Science Museum Monographs, 23, 1-221.

Imajima, M. \& Hartman, O. (1964) The polychaetous annelids of Japan. Occasional Papers of the Allan Hancock Foundation, $26,1-452$.

Kudenov, J.D. \& Harris, L.H. (1995) Family Syllidae Grube, 1850. In: Blake, J., Hilbig, B. \& Scott, P.H. (Eds). Taxonomic atlas of the benthic fauna of the Santa Maria Basin and western Santa Barbara Channel, vol. 5. Santa Barbara Museum of Natural History, Santa Barbara, 97 pp.

Malaquin, A. (1893) Recherches sur les syllidiens. Morphologie, Anatomie, Reproduction, Développement. Mémoires de la Société des Sciences, de l'Agriculture et des Arts de Lille, 4ème série, 18, 1-477.

Moore, J.P. (1909) The polychaetous annelids dredged by the U.S.S. 'Albatross' off the coast of southern California in 1904 . I. Syllidae, Sphaerodoridae, Hesionidae and Phyllodocidae. Proceedings of the Academy of Natural Sciences, Philadelphia, 1909, 321-351.

Nogueira, J.M.M. (2000) Anelídeos poliquetas associados ao coral Mussismilia hispida (Verrill, 1868) em ilhas do litoral do Estado de São Paulo. Phyllodocida, Amphinomida, Eunicida, Spionida, Terebellida, Sabellida. Ph. D. Thesis. Instituto de 
Biociências/USP, São Paulo, 265 pp.

Nogueira, J.M.M. (2006) Família Syllidae. In: Amaral, A.C.Z., Rizzo, A.E. \& Arruda, E.P. (Eds), Manual de Identificação dos Invertebrados Marinhos da Região Sudeste-Sul do Brasil, volume 1. Edusp, São Paulo, 134-164.

Nogueira, J.M.M. \& Fukuda, M.V. (2008) A new species of Trypanosyllis Claparède, 1864 (Polychaeta: Syllidae) from Brazil, with a redescription of Brazilian material of Trypanosyllis zebra. Journal of the Marine Biological Association of the United Kingdom, 88 (5), 913-924. http://dx.doi.org/10.1017/S0025315408001707

Nogueira, J.M.M. \& San Martín, G. (2002) Species of Syllis Savigny in Lamarck, 1818 (Polychaeta: Syllidae) living in corals in the state of São Paulo, southeastern Brazil. Beaufortia, 52 (7), 57-93.

Nogueira, J.M.M., San Martín, G. \& Amaral, A.C.Z. (2001) Description of five new species of Exogoninae Rioja, 1925 (Polychaeta, Syllidae) associated with the stony coral Mussismilia hispida (Verrill, 1868) in São Paulo State, Brazil. Journal of Natural History, 35 (12), 1773-1794. http://dx.doi.org/10.1080/00222930152667096

Nogueira, J.M.M., San Martín, G. \& Fukuda, M.V. (2004) On some exogonines (Polychaeta, Syllidae) from the northern coast of the State of São Paulo, southeastern Brazil—Results of BIOTA/FAPESP/Bentos Marinho Project. Meiofauna Marina, $13,45-78$.

Nogueira, J.M.M. \& Yunda-Guarin, G. (2008) A new species of Syllis (Polychaeta: Syllidae: Syllinae) from off Fortaleza, north-eastern Brazil. Journal of the Marine Biological Association of the United Kingdom, 88 (7), 1391-1399. http:// dx.doi.org/10.1017/S0025315408002099

Saint-Joseph, A. de (1887) Les Annélides polychètes des côtes de Dinard, pt. 1. Annales des Sciences Naturelles, Paris, 1, 127-270.

San Martín, G. (1984) Estudio biogeográfico, faunístico y sistemático de los Poliquetos de la família Sílidos (Syllidae: Polychaeta) en Baleares. Publicaciones de la Universidad Complutense de Madrid, 187, 1-581.

San Martín, G. (1990) Eusyllinae (Syllidae, Polychaeta) from Cuba and Gulf of Mexico. Bulletin of Marine Science, 46 (3), 590-619.

San Martín, G. (2003) Annelida Polychaeta II: Syllidae. In: Ramos, M.A. et al. (Eds). Fauna Ibérica, vol. 21. Museo Nacional de Ciências Naturales, CSIC, Madrid, 544 pp.

San Martín, G. \& Hutchings, P. (2006) Eusyllinae (Polychaeta: Syllidae) from Australia with the description of a new genus and fifteen new species. Records of the Australian Museum, 58, 257-370. http://dx.doi.org/10.3853/j.0067-1975.58.2006.1466

Schmarda, L.K. (1861) Neue wirbellose Thiere beobachtet und gesammelt auf einer Reise um die Erde 1853 bis 1857. Erster Band. Turbellarian, Rotatorien und Anneliden. Verlag von Wilhelm Engelmann, Leipzig, 164 pp. + 37 pl.

Sovierzoski, H.H. (1991) Estrutura temporal da comunidade macrobentônica da foz do Rio Maciel, Baía de Paranaguá, Paraná. M. Sc. Dissertation. Universidade Federal do Paraná, Curitiba, 89 pp.

Temperini, M.T. (1981) Sistemática e distribuição dos poliquetos errantes da plataforma continental brasileira entre as latitudes $23^{\circ} 05^{\prime} S$ e $30^{\circ} 00^{\prime}$ S. M. Sc. Dissertation, Instituto Oceanográfico/USP, São Paulo, 89 pp.

Treadwell, A.L. (1917) Polychaetous annelids from Florida, Porto Rico, Bermuda and the Bahamas. Carnegie Institute of Washington Publication, 251, 255-272.

Uebelacker, J.M. (1984) Family Syllidae Grube, 1850. In: Uebelacker, J.M. \& Johnson, P.G. (Eds). Taxonomic Guide to the Polychaetes of the Northern Gulf of Mexico. Volume IV. Barry A. Vittor \& Associates, Mobile, 30-1-30-151.

Verdes, A., Pleijel, F. \& Aguado, M.T. (2011) A new species of Odontosyllis Claparède, 1863 (Annelida, Syllidae) with redescriptions of O. liniata Hartmann-Schröder, 1962 and O. gymnocephala Hartmann-Schröder, 1965. Zootaxa, 3095, 27-38.

Verrill, A.E. (1900) Additions to the Turbellaria, Nemertina and Annelida of the Bermudas with revisions of some New England genera and species. Transactions of the Connecticut Academy of Arts and Sciences, 10, 595-671.

Westheide, W. (1974) Interstitielle Fauna von Galapagos. XI. Pisionidae, Hesionidae, Pilargidae, Syllidae (Polychaeta). Mikrofauna des Meeresbodens, 44, 1-146. 